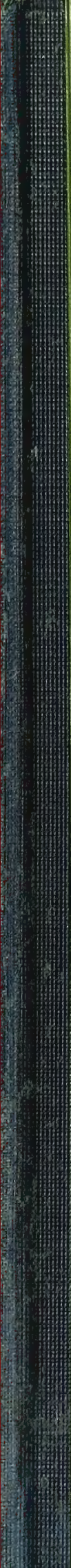




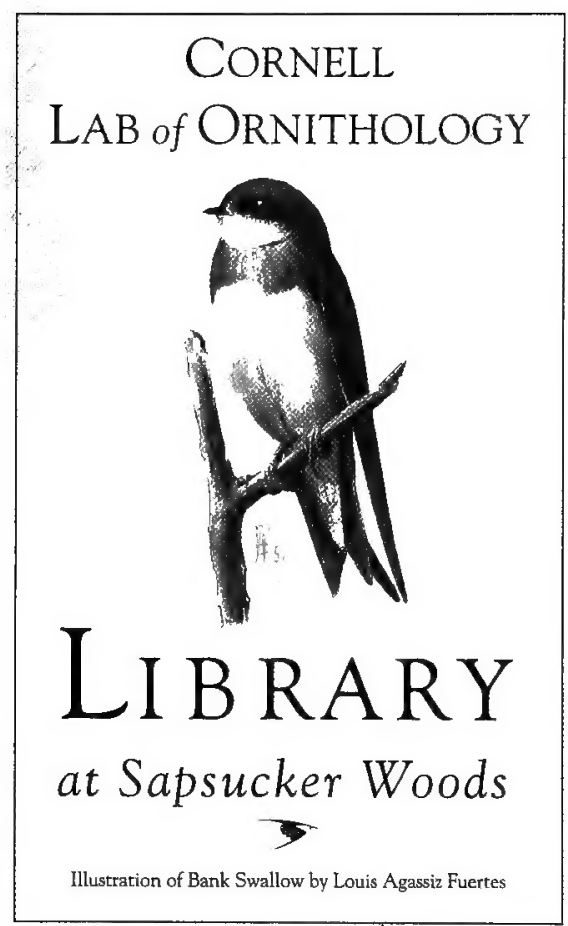


DATE DUE

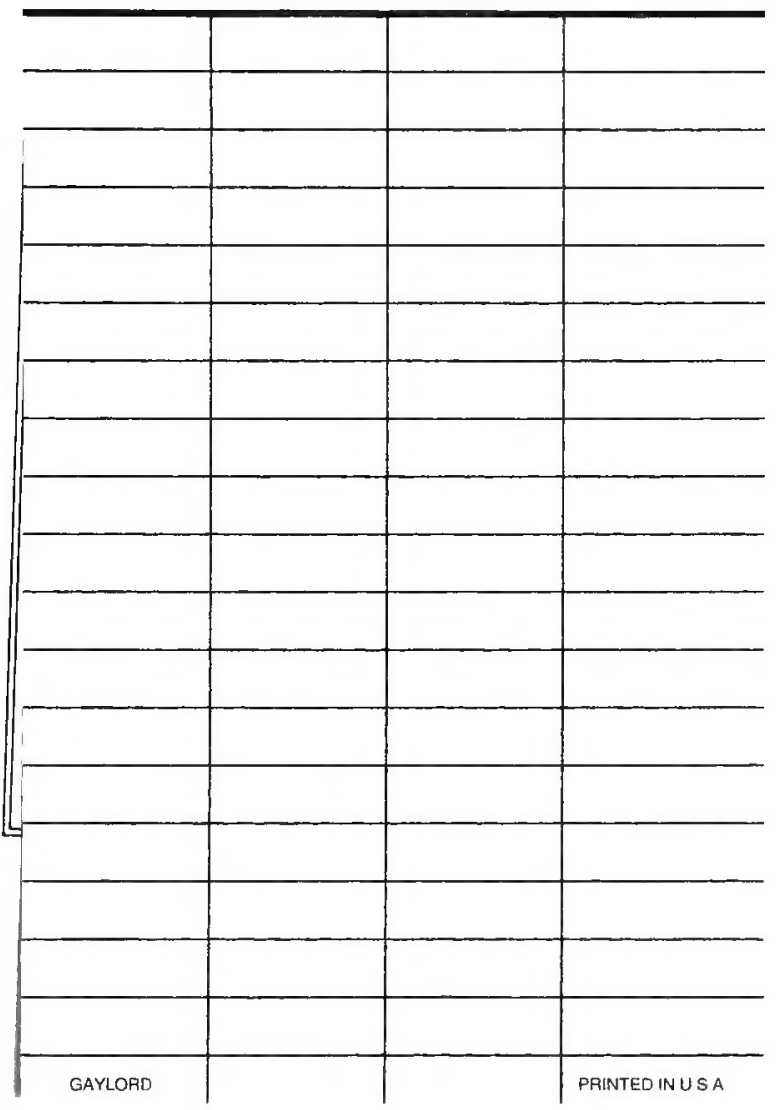




\section{Cornell University Library}

The original of this book is in the Cornell University Library.

There are no known copyright restrictions in the United States on the use of the text.

http://www.archive.org/details/cu31924090297411 


THE AGRICULTURAL EXPERIMENT STATION OF THE

COLORADO AGRICULTURAL COLLEGE

\section{FLORA OF COLORADO}

BY

P. A. RYDBERG, PH.D.

PUBLISHED BY THE EXPERIMENT STATION FORT COLLINS, COLORADO 1906 


$$
\begin{aligned}
& \text { ornith } \\
& \text { or } \\
& 150 \\
& \text { R99 }
\end{aligned}
$$

Preas of

THE New ERA PRINTING COMPANY Lancaster, Pa. 


\section{The Agricultural Experiment Station}

\section{FORT COLLINS, COLORADO}

THE STATE BOARD OF AGRICULTURE

HoN. P. F. SHARP, President ............ Denver ........... I907

HoN. HARLAN THOMAS ............. Denver ............ I907

Hon. JAMES L. CHATFIELD ........... Gypsum ........... I909

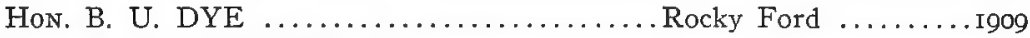

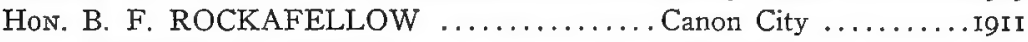

HoN. EUGENE H. GRUBB ..................... Carbondale .......

Hon. A. A. EDWARDS ................ Fort Collins . .......1913

Hon. R. W. CORWIN ................ Pueblo ........... I9I3

$\left.\begin{array}{l}\text { Governor JESSE F. McDONALD, } \\ \text { President BARTON O. AYLESWORTH, }\end{array}\right\}$ ex-officio.

A. M. HAWLEY, Secretary

EDGAR AVERY, Treasurer

\section{EXECUTIVE COMMITTEE IN CHARGE}

P. F. SHARP, Chatrman. B. F. ROCKAFELL

\section{STATION STAFF}

L. G. CARPENTER, M.S., Director............ Irrigation Engineer

C. P. GILLETTE, M.S. ..................... ENTOMOLOGIST

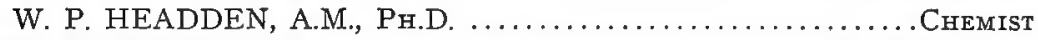

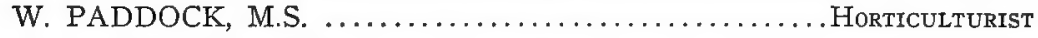

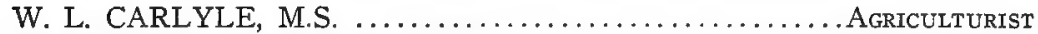

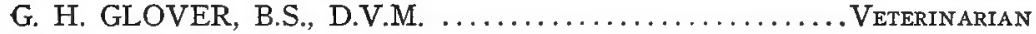

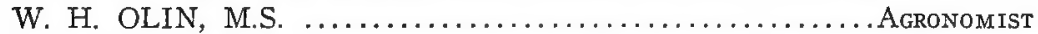

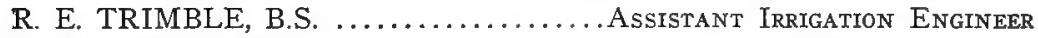

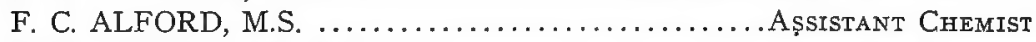

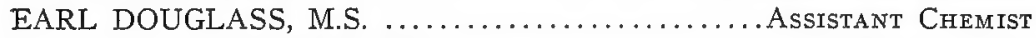

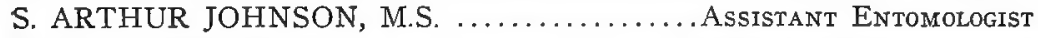

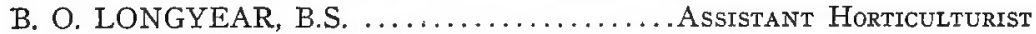

J. A. McLEAN, A.B., B.S.A. ................ Animal Husbandman

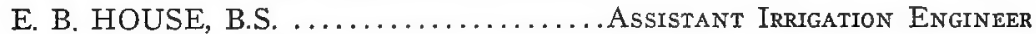

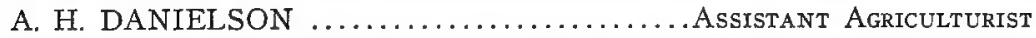

P. K. BLINN, B.S. ..........Field Agent, Arkansas Valley, Rocky Ford

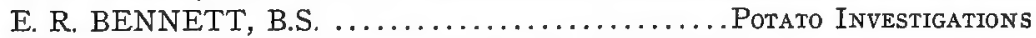

Western Slope Fruit Investigations, Grand Junction:

O. B. WHIPPLE, B.A. ................. Field HortTculturist

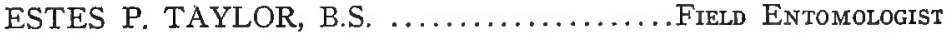

\section{OFFICERS}

PRESIDENT BARTON O. AYLESWORTH, A.M., LL.D.

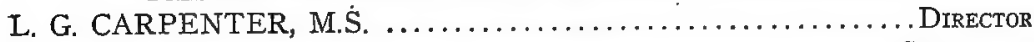

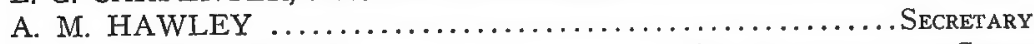
MARGARET MURRAY .................... STENOGRAPHER AND ClERK 



\section{CONTENTS.}

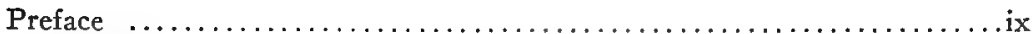

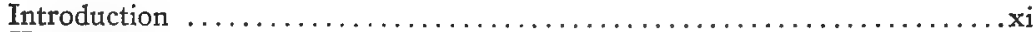

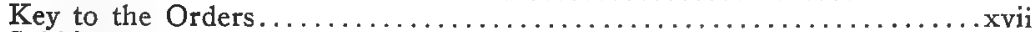

Subkingdom Pteridophyta............................ I

Order I. Ophioglossales .......................... I

Family I. Ophioglossaceae $\ldots \ldots \ldots \ldots \ldots \ldots \ldots \ldots \ldots \ldots \ldots \ldots \ldots \ldots$ I

Order 2. Filicales ................................ I

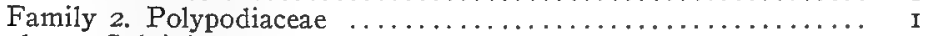

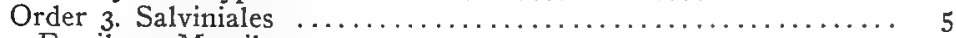

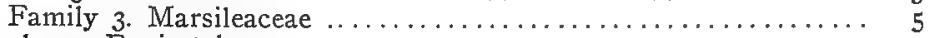

Order 4 . Equisetales ................................. 5

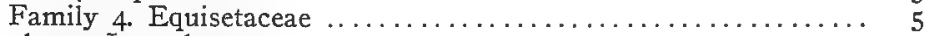

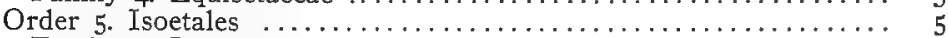

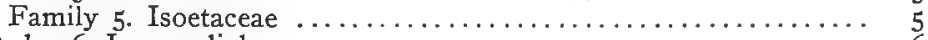

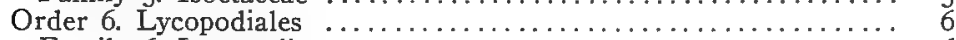

Family 6. Lycopodiaceae ............................. 6

7. Selaginellaceae ........................... 6

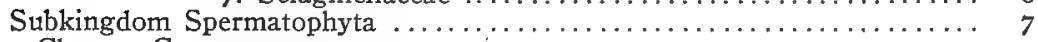

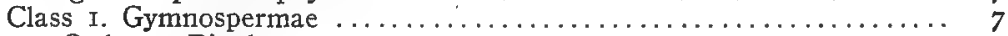

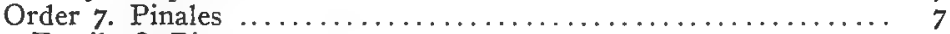

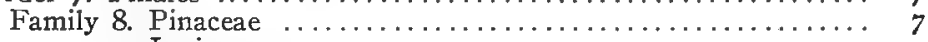

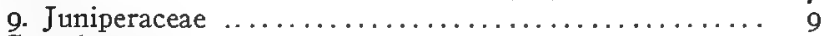

Order 8. Gnetales ............................................. Io

Family Io. Ephedraceae .......................... Io

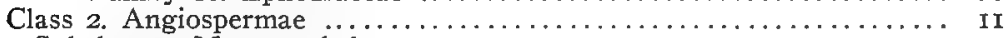

Subclass I. Monocotyledones ......................... II

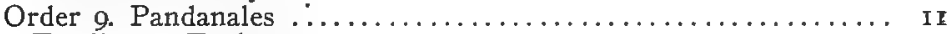

Family II. Typhaceae ......................... I

I2. Sparganiaceae $\ldots \ldots \ldots \ldots \ldots \ldots \ldots \ldots \ldots \ldots \ldots \ldots \ldots \ldots$ II

Order Io. Naiadales ................................ I2

Family I3. Zanichelliaceae ........................ I2

I4. Naiadaceae .......................... I3 $_{3}$

Order II. Alismales ............................. I3

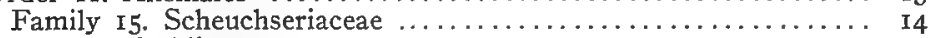

I6. Alismaceae $\ldots \ldots \ldots \ldots \ldots \ldots \ldots \ldots \ldots \ldots \ldots \ldots \ldots \ldots \ldots \ldots \ldots$ I4

Order 12. Hydrocharitales $\ldots \ldots \ldots \ldots \ldots \ldots \ldots \ldots \ldots \ldots \ldots$ I5

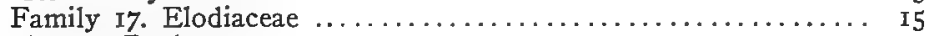

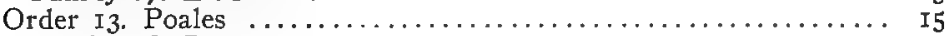

Family I8. Poaceae ........................... I5

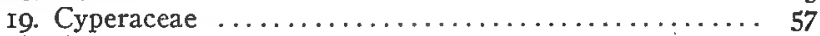

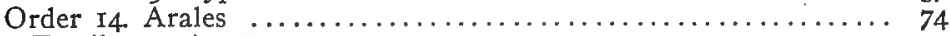

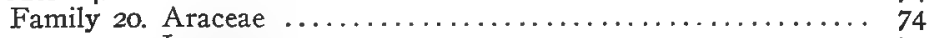

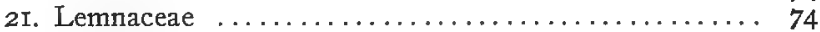

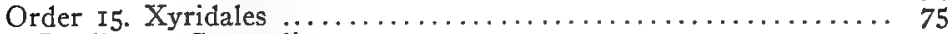

Family 22. Commelinaceae $\ldots \ldots \ldots \ldots \ldots \ldots \ldots \ldots \ldots \ldots \ldots \ldots \ldots$

23. Pontederiaceae $\ldots \ldots \ldots \ldots \ldots \ldots \ldots \ldots \ldots \ldots \ldots \ldots, 75$

Order 16. Liliales ............................... 76

Family 24. Melanthaceae .......................... 76

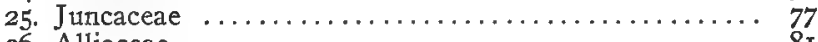

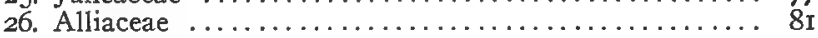




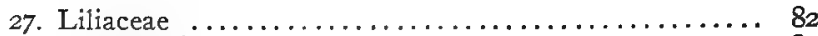

28. Convaliariaceae $\ldots \ldots \ldots \ldots \ldots \ldots \ldots \ldots \ldots \ldots, 83$

29. Dracaenaceae ......................... 85

30. Calochortaceae ....................... 85

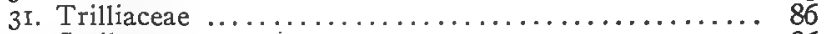

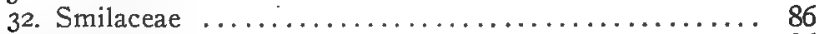

Order 17. Amaryllidales ............................ 86

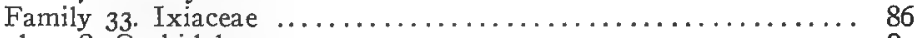

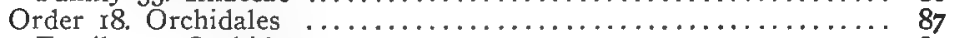

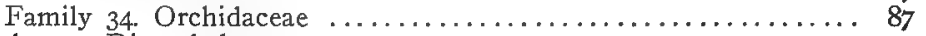

Subclass 2. Dicotyledones ......................... 9I

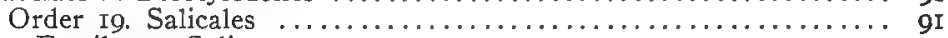

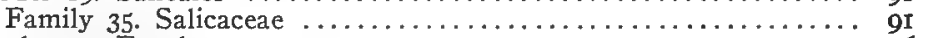

Order 20. Fagales ............................... 96

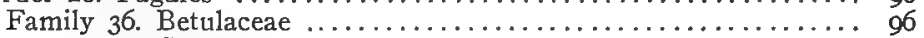

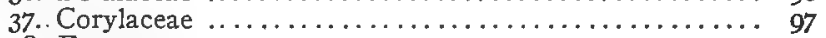

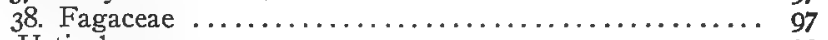

Order 2r. Urticales ........................... 99

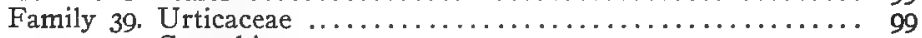

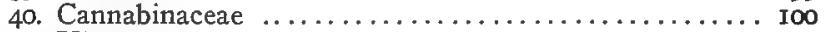

4I. Ulmaceae ................................ 100

Order 22. Santalales .............................. I00

Family 42. Loranthaceae ........................ I00

43. Santalaceae $\ldots \ldots \ldots \ldots \ldots \ldots \ldots \ldots \ldots \ldots \ldots$ ror

Order 23. Polygonales ............................... Ior

Family 44. Polygonaceae .......................... Ior

Order 24. Chenopodiales ........................ II 3

Family 45 . Chenopodiaceae $\ldots \ldots \ldots \ldots \ldots \ldots \ldots \ldots \ldots \ldots \ldots$ II3

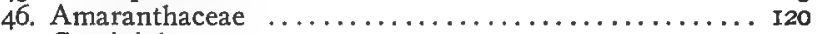

47. Corrigiolaceae $\ldots \ldots \ldots \ldots \ldots \ldots \ldots \ldots \ldots \ldots \ldots$ 121

48. Allioniaceae .......................... I22

49. Tetragoniaceae ........................ 124

50. Portulacaceae ......................... I25

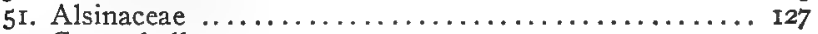

52. Caryophyllaceae ...................... I32

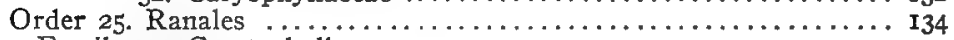

Family 53. Ceratophyllaceae $\ldots \ldots \ldots \ldots \ldots \ldots \ldots \ldots \ldots \ldots \ldots$. 34

54. Ranunculaceae $\ldots \ldots \ldots \ldots \ldots \ldots \ldots \ldots \ldots \ldots \ldots \ldots \ldots \ldots \ldots$

55. Nymphaeaceae $\ldots \ldots \ldots \ldots \ldots \ldots \ldots \ldots \ldots \ldots \ldots$ I47

56. Berberidaceae ................................. 148

Order 26. Papaverales ................................ I48

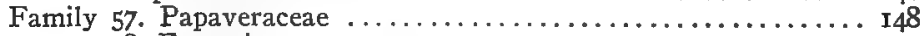

58. Fumariaceae ......................... 149

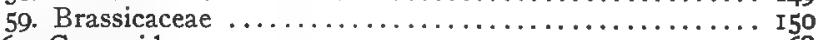

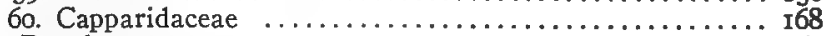

Order 27. Rosales .............................. I69

Family 6r. Crassulaceae ............................ 169

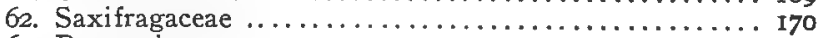

63. Parnassiaceae .......................... I75

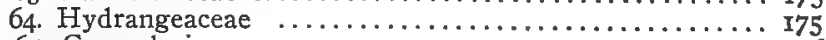

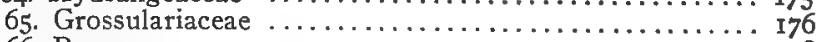

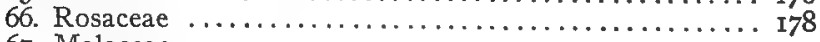

67. Malaceae..$\ldots \ldots \ldots \ldots \ldots \ldots \ldots \ldots \ldots \ldots \ldots \ldots$ I9I

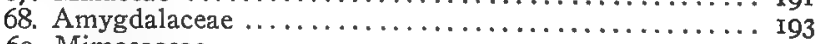

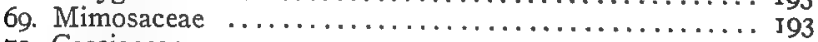

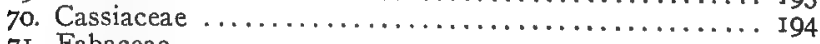

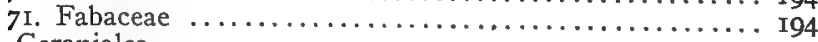

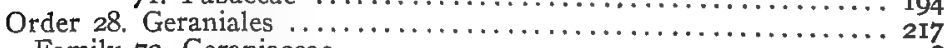

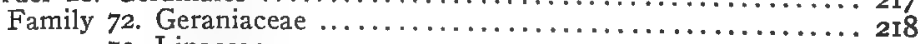

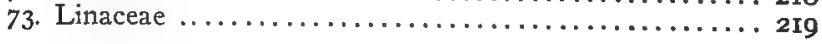


74. Oxalidaceae ........................ 220

75. Zygophyllaceae ....................... 220

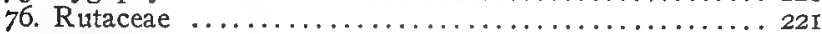

Order 29. Polygalales ........................... 22 I

Family 77. Polygalaceae ....................... 22I

Order 30. Euphorbiales ........................... 22 I

Family 78. Euphorbiaceae ..................... 222

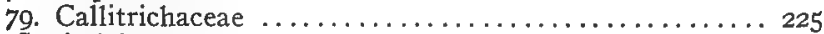

Order 31 . Sapindales ............................ 225

Family 80. Limnanthaceae ........................ 225

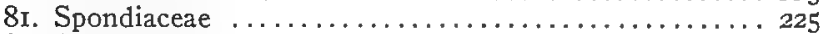

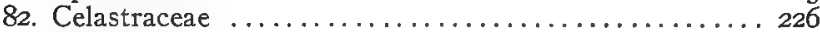

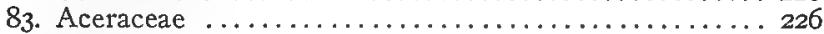

Order 32. Rhamnales .......................... 227

Family 84. Frangulaceae ....................... 227

85. Vitaceae .......................... 228

Order 33. Malvales ................................ 229

Family 86. Malvaceae ............................ 229

Order 34. Hypericales ........................... 231

Family 87. Elatinaceae ............................

88. Frankeniaceae ..................... 23I

89. Hypericaceae ........................ 23 I

90. Cistaceae ......................... 232

9I. Violaceae ........................... 232

Order 35. Opuntiales ................................ 234

Family 92 . Loasaceae $\ldots \ldots \ldots \ldots \ldots \ldots \ldots \ldots \ldots \ldots \ldots \ldots \ldots \ldots \ldots \ldots$

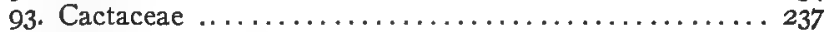

Order 36 . Thymeliales .............................. 239

Family 94. Elaeagnaceae ........................... 239

Order 37. Myrtales ................................. 240

Family 95. Lythraceae ............................ 240

96. Epilobiaceae ......................... 240

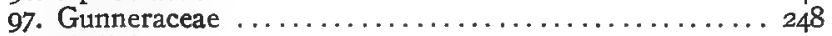

Order 38. Umbellales . . . . . . . . . . . . . . . . . . . . . . . . . 249

Family 98 . Hederaceae .............................. 249

99. Cornaceae ........................... 249

Ioo. Ammiaceae ........................... 250

Order 39. Ericales ................................ 258

Family ror. Monotropaceae ...................... 258

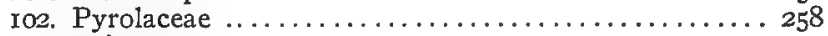

I03. Ericaceae .......................... 259

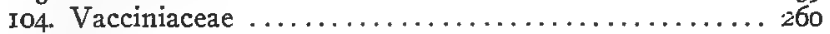

Order 40. Prinulales ........................... 26r

Family 105. Primulaceae ....................... 26I

Order 4r. Oleales ............................... 264

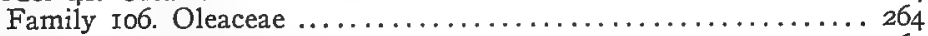

Order 42. Gentianales ............................ 264

Family ro7. Gentianaceae ........................ 264

108. Menyanthaceae ...................... 268

Order 43. Asclepiadales .............................. 269

Family rog. Apocynaceae ... . . . . . . . . . . . . . . . . . . . . 269

I Io. Asclepiadaceae ........................ 270

Order 44. Polemoniales .......................... 27 I

Family ı ı. Cuscutaceae ........................ 272

II2. Convolvulaceae ..................... 273

II3. Polemoniaceae .......................... 274

II4. Hydroleaceae ... . . . . . . . . . . . . . . . . . 28I

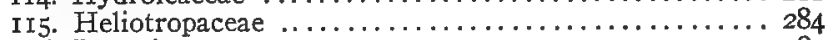

I 6. Boraginaceae .......................... 284 
II7. Verbenaceae. . . . . . . . . . . . . . . 294

I 8. Lamiaceae . . . . . . . . . . . . . . . . . . . . 294

I I9. Solanaceae .......................... 300

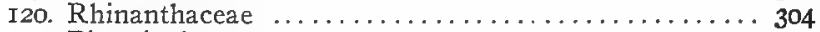

I2r. Pinguiculaceae $\ldots \ldots \ldots \ldots \ldots \ldots \ldots \ldots \ldots \ldots \ldots \ldots$ 319

I22. Orobanchaceae $\ldots \ldots \ldots \ldots \ldots \ldots \ldots \ldots \ldots \ldots \ldots \ldots \ldots \ldots \ldots \ldots$ 319

123. Martyniaceae ........................... 320

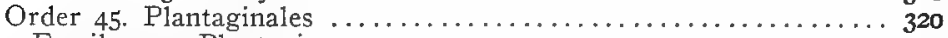

Family I24. Plantaginaceae ......................... 320

Order 46. Rubiales ............................

Family I25. Rubiaceae ..........................

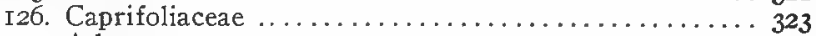

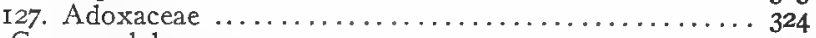

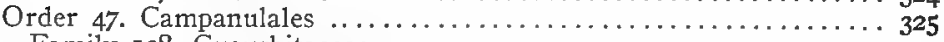

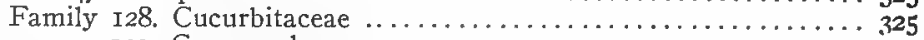

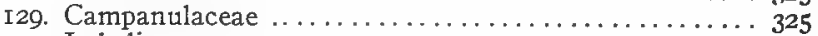

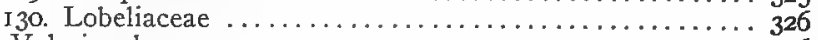

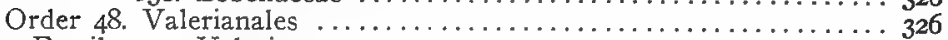

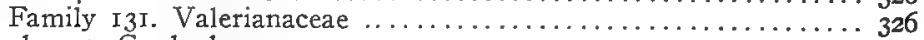

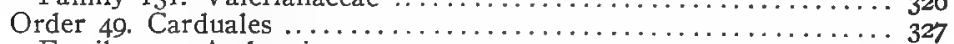

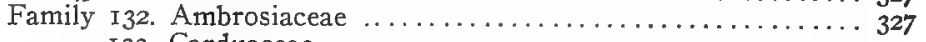

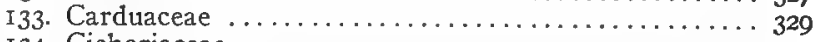

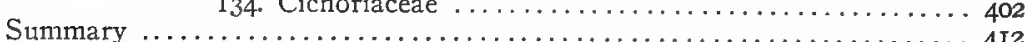

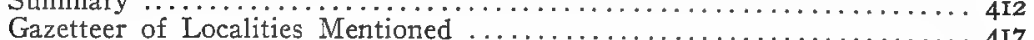

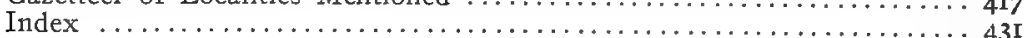




\section{PREFACE}

It was not the original intention of the Experiment Station to prepare and publish a work on the Flora of Colorado. The conditions of the State, the character of the flora, which is so different from that of the east, forced the necessity of collections and the study of local flora by the botanists of the Agricultural College and Experiment Station from the very first. The economic study of Colorado plants, especially the search for those which might be adapted to arid conditions, increased this necessity. Opportunity was furnished by collections of grasses and forest products for the World's Fair, and occasion was always taken when trips were made for any purpose, to obtain additional specimens. In the course of time the collection became so extensive that unless put in form for publication the time and expense involved would be lost, and the work which had been done would be of little service to us, and of none to the public in general.

Some systematic collection was done by Professor James Cassidy, Professor of Botany (I88I-I889), in the intervals of his many duties, up to the time of his death in 1889 . His successor, Professor C. S. Crandall, gave much time to the work, especially after the establishment of the experimental grass station in cooperation with the U. S. Department of Agriculture. This afforded occasion and opportunity for trips in search of promising species of native grasses. Subsequent collections, especially of forest products and grasses for the World's Fair in I893, gave rise to further collecting trips to various parts of the State. Enthusiastic aid was given by Mr. J. H. Cowan, an energetic and promising student, who became Professor of Horticulture and Botany upon the resignation of Professor Crandall, but whose promising career was terminated by death before he had entered upon the active duties of the position. By this time the collection was of considerable size, had been increased by exchanges, and represented much time and expense. A great many calls came for information, and it was at first thought to publish only a list of the plants which were represented in our own collection. The pressing demands and many duties, as well as the lack of facilities, made it difficult for Professor Paddock 
to undertake the completion of the work, and this was rendered unnecessary by the fortunate arrangement with the New York Botanical Garden, by which Dr. Rydberg took our collection for naming, and undertook the preparation of the Flora for publication. With the facilities of the Garden and the cordial aid given by Dr. Britton and Dr. Rydberg, and the special knowledge of Rocky Mountain Botany of Dr. Rydberg, it became possible to make this include much more than our own collection, which had been the original idea. The unrivaled and almost exhaustive collections accessible to them, the completeness of the knowledge of Dr. Rydberg, have made this a much more extensive and consequently much more valuable work than was originally designed. It therefore includes the work of nearly all collectors from the earliest times, and may be considered an exhaustive list of the plants at present known in Colorado. The extent of the service may be recognized when it is stated that while our own collection numbered about $I, 400$ plants, this Flora includes 2,9I2, a number greater than is known for any other State except California. The amount of work involved in its preparation, supplying keys to the genera and families, and the completeness of the work speak for themselves.

Acknowledgment should also be gratefully given to the State Board of Agriculture, and especially to Hon. P. F. Sharp, President of the Board, without whose assistance, encouragement and financial aid it would not have been possible for the Station to consider the completion and publication of a work of such magnitude. At one time it was proposed to lessen the expense by issuing a part of the edition as a College bulletin at a fixed price, but the Board took the liberal view that the saving would not compensate for the other disadvantages and that the generous friendliness of the State would justify the special effort in putting this at the service of those needing it, and thus the Station is enabled to issue the Flora as one of its bulletin series. It is believed that the publication will be of use to all systematic botanists, to the schools of the State, to those interested in the economic study of Colorado plants, as well as to all those interested in the fascinating Flora of the Plains and Mountains of Colorado. It is a necessary step in the systematic and economic study of our plants.

The preparation of the copy, keys and index has all been assumed by Dr. Rydberg, and also the laborious task of reading the proof. In addition the proof has been read by Professor Paddock and by the undersigned, but in the latter case attention was directed principally to the places and elevations.

L. G. Carpenter. 


\section{INTRODUCTION.}

In I90I, Professor L. G. Carpenter wrote to Dr. N. L. Britton, director-in-chief of the New York Botanical Garden, inquiring if anybody connected with the Garden would be willing and had time to complete the determinations of the botanical collections accumulated at the Agricultural College at Fort Collins, especially during. the time Professor C. S. Crandall was professor of Botany at that institution. As the author was well acquainted with the flora of the Rocky Mountain region, Dr. Britton referred the matter to him and at the same time gave him permission to undertake the work provided proper arrangements were made. After some correspondence with Professor Carpenter and Professor W. Paddock, such agreements were made as to make it possible not only to undertake this work but also to prepare a catalogue for publication.

The work has taken more time than was expected at first, partly because it had to be done mostly in the spare time from the author's official duties at the museum of the Botanical Garden, and partly because the author could not always secure the help he expected in the more mechanical work of recording the localities. The printing has also been delayed a good deal, and has been interrupted a few times for various reasons, so the work appears in print about a year later than was expected.

The catalogue is mainly based on the collections of the Agricultural College at Fort Collins, mentioned above, and the herbaria at the New York Botanical Garden. Some additional records have been secured from other sources, as for instance, the National Herbarium at Washington, the Gray Herbarium at Harvard University and the herbarium of the College of Pharmacy of the City of New York. The author has also consulted the various publications on the flora of Colorado. The most important of these are:

T. C. Porter and J.M. Coulter, Synopsis of the Flora of Colorado; J.M. Coulter, Manual of the Botany of the Rocky Mountain Region; T. S. Brandegee, Flora of South-western Colorado; Alice Eastwood, Flora of Denver and Vicinity; John Torrey's report on E. James' collection in Long's Expedition; Asa Gray's reports on the collections of C. C. Parry, E. Hall and Harbour; Professor E. L. Greene's various publications in Pittonia, Plantae Bakerianae and Leaflets 
and the publications of Professors T. S. Brandegee, Aven Nelson and M. E. Jones, Mr. G. E. Osterhout and Miss Alice Eastwood in the Botanical Gazette, Bulletin of the Torrey Botanical Club, Zoe, Erythea and the Proceedings of the California Academy of Sciences.

The author has tried to verify the records referring to Colorado plants given in these publications. Some of these records have been proven erroneous. In some cases the specimens were wrongly determined, in others the stations at which they were collcted are not within the present boundaries of the state of Colorado. Of course, all such species have been excluded from this catalogue. The author has also excluded a few more, which he thought should be included in the same category, although he has not been able to prove them erroneously referred to the flora of Colorado, as for instance Californian, Mexican, or Alleghanian species, accredited to Colorado but not to the intervening states. He has also been forced by circumstances to exclude a score or so species recently described from Colorado, but wholly unknown to the author. Not being able to include them in his "keys" and being uncertain whether the descriptions really characterize new and valid species or merely represent redescriptions of old ones, he thought it best to leave them out until more information could be had.

At first it was suggested that a catalogue should be prepared similar to the author's Catalogue of the Flora of Montana and the Yellowstone National Park. After some consultation with Professor Carpenter, it was agreed that the publication would be of more value to the plant lovers of Colorado, if some characterization of the plants could be given. A descriptive botany or so-called manual was out of question. The author would not have time to prepare such a one within a reasonable time and the College did not have funds available to pay for the cost of preparing it. The author had already begun the work on a botany of the whole Rocky Mountain region. He was preparing the "keys" first, leaving the main descriptive work to be done later. Some of these keys were already made, and he hoped to have most of them ready by the time the catalogue was ready to go to print. It would not take much more work to abstract from these keys the parts referring to the Colorado genera and species, than to cite a number of references to descriptions as was done in the Flora of Montana and the Yellowstone National Park. The author showed Professor Carpenter a catalogue prepared in this way, viz., Dr. T. C. Porter's Flora of Pennsylvania. This was taken as a model, except that the locali- 
ties as given on the labels should be recorded instead of merely the counties. A gazetteer explaining the localities is given as an appendix. This was partly prepared by the author, but completed, corrected and revised at Fort Collins, principally by M.rs. L. G. Carpenter.

As stated before, the keys were mainly abstracted from those of the author's larger work in preparation, $i$. e., as far as these were made. As the Manual will be a purely scientific work, the keys are perhaps drawn in a more technical style than desirable in a catalogue to be used principally by the local and the amateur botanists of Colorado and by tourists. To reconstruct the keys would involve too much extra labor. Besides it is hard or rather impossible to use only plain English without losing the fine shades of distinctions which can be expressed by more technical words. For example, the only purely English word for the technical words: "villous," "floccose," "pannose," " tomentose," " tomentulose," etc., is "woolly."

The measurements in the keys are given in the metric system, a system now used by nearly all the scientific departments of the United States Government and of most colleges and universities of this country. In the English system formerly used in descriptive botany, etc., the inch was divided into I2 lines. It is very hard to find a ruler now-a-days with this division, while rulers with the metric system are to be had nearly everywhere. For those unfamiliar with this system, the following comparative table is given. The equivalents are near enough for all practical purposes:

$\mathrm{I} \mathrm{mm} .=\frac{1}{25}$ inch.

$3 \mathrm{~mm} .=1 / 8$ inch.

I $\mathrm{cm} .=2 / 5$ inch.

$5 \mathrm{~cm}$. $=2$ inches.

I dm. $=4$ inches.

I $\mathrm{m}$. $=40$ inches (nearly) or $3^{\mathrm{T} / 3}$ foot.
I line $=2 \mathrm{~mm}$.

$\mathrm{r} / 8$ inch $=3 \mathrm{~mm}$.

$\mathrm{I}_{\mathrm{i}}$ inch $=25 \mathrm{~mm}$. or $2 \mathrm{I} / 2 \mathrm{~cm}$.

I $\mathrm{span}=\mathrm{I} \mathrm{dm}$.

I foot $=3 \mathrm{dm}$.

I yard $=9 \mathrm{dm}$.

$\mathrm{I}, 000 \mathrm{ft} .=300 \mathrm{~m}$.

The altitudes were also given in meters, but they were changed into feet by the request of Professor Carpenter, who claimed that the people of Colorado, for whom principally the work is prepared, as a rule think of altitudes in feet only. As the United States LandOffice has not as yet adopted the metric system as their standard, the altitudes may just as well be given in feet. This statement is 
made to explain why two different standards are used in the same work. The altitudes are those at which the different species grow within the state of Colorado, so far as records show. Many of the plants which grow at an altitude of 14,000 feet in Colorado, grow at sea-level along the arctic coast.

The nomenclature used is in principle agreeing with the so-called American Code adopted at a meeting in Philadelphia, printed in the Bulletin of the Torrey Botanical Club in May, I904, and submitted to the International Botanical Congress at Vienna last summer, with a few modifications resulting from a compromise with the European botanists. This code as modified is now followed by a majority of the leading systematic botanists in this country. The fundamental principle underlying is that the selection of generic as well as specific names should always be governed by the priority of publication. The European botanists have adopted this principle as far as specific names are concerned, but most of them are not yet willing to apply the same rules to generic names. In the older publications on the Rocky Mountain flora the so-called Kew Rules were adhered to, which after all gave very little consideration to priority. Many of the names in this catalogue will be unfamiliar to some of its users, but in most cases the old names are given as synonyms in italic and also in the index. In the index there has been inserted also a few common names not given in the text followed by the equivalent latin generic name in parenthesis. Most of these are local names unknown to the author before they appeared in a recent publication on western botany.

With regard to generic limitations, the author belongs to that radical school which believes in small genera with closely related species rather than in larger ones with a heterogeneous mass of different groups of plants having relatively little relationship to each other. Many of the older genera have therefore been divided. The division of genera as well as species has gone perhaps a little further than many would think advisable, but the author has tried to be consistent in his work.

The author has not published"any new species or genera in this work. He has also tried to avoid the publishing of new names or new combinations of names. Anything that had not been published before, the author has endeavored to publish in the Bulletin of the Torrey Botanical Club while the catalogue was being set in type. The reasons for so doing are the following: (I) The publication of technical descriptions should be limited to technical books and peri- 
odicals; (2) in this catalogue there could not very well be given a fuller synonymy with citations of places of publication, nor fuller discussions, which are always desirable and often necessary for clearness sake; (3) if the diagnoses of new species had been interpolated here and there, the uniformity of the catalogue would have suffered.

As it is, the Flora is the result of much labor and stands as a brief index of the present knowledge of the flora of the state. In its present form, the author hopes that it will be valuable for the purpose for which it was prepared, viz., as a record of the higher vegetation of the state of Colorado as far as known to-day and as a guide and help to those interested in its flora. Whatever shortcomings there may be, the author hopes will be forgiven. The technical systematist will undoubtedly find many facts omitted which he would expect to find in a "Flora of Colorado."

From the summary given after the catalogue it can be seen that the higher vegetation (fernworts and flowering plants) of Colorado comprises over 700 genera and 2,900 species, a number surpassed only by California and perhaps by Florida out of all states in the Union. The largest families are Carduacece or the Composites proper, with 568 species or about $191 / 2 \%$ of the flora; Poacea or grasses, 267 species or $9 \%$; Fabacece or Pea Family, I8 5 or $61 / 3 \%$; Brassicace I44, Rhinanthacece I06, Cyperacece IoI, Polygonacece 94, Ranunculacea 92 , and Rosacece 89 species, or between $3 \%$ and $4 \%$, etc. Just as remarkable as the large number of species of Composites (about $1 / 5$ of the whole flora), is the small number of Pteridophytes. The ferns proper are only 25 , to which are to be added I 5 other fernworts. The same may be said of the Gymnosperms, only 20 in number.

The author has had the help of sevetal specialists in certain groups. Professor L. M. Underwood has prepared the manuscript of the Pteridophyta, and Mr. H. D. House that of the family Violacece. Mr. G. V. Nash has given valuable assistance in the grasses. The account of the Polygonacece was written in conjunction with Dr. J. K. Small. Dr. Theodor Hom has characterized the groups and species of Carex and listed the specimens of that genus, while the author prepared the key to the groups. Mr. S. H. Burnham, Mr. H. D. House and Mr. W. W. Eggleston have assisted in listing the localities and Mrs. William Mitchell in copying the keys.

\section{P. A. RYdBerg.}

New York Botanical Garden, NEW YoRK, March, Igo6. 



\section{KEY TO THE ORDERS.}

\section{Subkingdom PTERIDOPHYTA.}

Plants without flowers or seeds, but producing spores each of which, on germination, develops into a flat or an irregular prothallium. The prothallia bear the reproductive organs (antheridia and archegonia). As a result of the fertilization of an egg in the archegonium by a sperm produced in the antheridium a fern or an allied plant is developed.

Leaves broad entire or dissected. (Fern-like plants.)

PAGE.

Spores of one kind, minute, borne in sporangia.

Vernation straight or inclined; eusporangiate, the sporangia ringless, leathery, opening by a transverse slit, arranged in spikes or panicles.

Order i. Ophioglossales.

Vernation circinate; leptosporangiate, the sporangia membranous, provided with a ring which opens elastically. Order 2. Filicales.

Spores of two kinds, minute microspores and larger macrospores, borne

in sporocarps; leaves filiform or quadrifoliate. Order 3. Salviniales. Leaves scale-like or awl-like. (Moss-like or rush-like plants.)

Sporangia in an apical cone, borne under peltate scales: stems hollow, rush-like.

Order 4. EQuisetales.

Sporangia in the axils of small or leaf-like bracts: stems solid.

Leaves awl-like, often much elongated, borne on a short corm-like caudex: aquatic plants.

Order 5. Isoetales.

Leaves narrow or scale-like, flat, borne on erect or creeping stems : terrestrial plants.

Order 6. LyCOPODIALES.

\section{Subkingdom SPERMATOPHYTA.}

Plants with flowers which produce seeds. Microspores (pollen-grains) borne in microsporangia (anther-sacs) develop each into a tubular prothallium; a macrospore (embryo-sac) develops a minute prothallium, and together with the macrosporangium (ovule) in which it is contained, ripens into a seed.

Ovules and seeds borne on the face of a bract or a scale: stigmas wanting. Ovules and seeds in a closed cavity (ovary): stigmas present.

Class 1. Gymnosperm $x$.

\section{Gymnospermæ.}

Class 2. Angrosperm $\approx$. II

Staminate and pistillate flowers both in aments; perianth none; trees or shrubs with needle- or scale-like leaves.

Order 7. Pinales.

Staminate flowers in aments; pistillate ones single or in pairs; perianth present, urnshaped; ours horsetail-like shrubs with jointed branches and leaves reduced to sheathing scales.

Order 8. Gnetales. 


\section{Angiospermæ.}

Cotyledon I : stem endogenous.

Subclass I. Monocotyledones. II

Cotyledons normally 2 : stem exogenous (with rare exceptions).

Subclass 2. Dicotyledones. $9 \mathrm{I}$

1. Monocotyledones.

Perianth rudimentary or degenerate, its members often bristles or mere scales, not corolla-like, or wanting.

Flowers not in the axils of dry or chaffy bracts (scales or glumes).

Perianth of bristles or chaffy scales.

Order 9. Pandanales. II

Perianth fieshy or herbaceous, or wanting.

Fruit baccate; endosperm present.

Otder I4. Arales. 74

Fruit drupaceous; endosperm wanting.

Order ro. NaIADALES. I 2

Flowers in the axils of dry or chaffy, usually imbricated, bracts (scales or glumes).

Order I3. Poales. I5

Perianth of 2 distinct series, the inner series usually corolloid.

Gynocium of distinct carpels.

Order i i. Alismales. I3

Gynœcium of united carpels.

Endosperm mealy.

Endosperm fleshy, horny or cartilaginous.

Ovary and fruit superior.

Ovary and fruit wholly inferior or half-inferior.

Endosperm present and usually copious; flowers regular; andrœcium not reduced.

Order I7. Amaryllidales.

Endosperm wanting.

Flowers regular, monœecious or diøecious: aquatic plants.

Order I2. HydRocharitales.

Flowers irregular, perfect: terrestrial or epiphytic plants.

Order 18. ORChidAles. 87

z. Dicotyledones.

A. Corolla wanting.

I. Calyx wanting, at least in the staminate flowers.

Herbs.

Trees or shrubs.

Order 30. Euphorbiales. 221

Fruit I-seeded: seeds without tufts of hairs.

Fruit a nut or an achene. Corylaceæ in Order 20. Fagales. 96

Fruit a drupe or a samara. Oleaceæ in Order 4I. Oleat_es. 264

Fruit many-seeded: seeds each with a tuft of hairs.

Order 19. Salicales. 9I

II. Calyx present at least in the staminate or in the perfect flowers.

1. Flowers, at least the staminate, in aments, or ament-like spikes; fruit a nut or an achene.

Order 20. Fagales.

2. Flowers, at least the staminate, not in aments.

a. Ovary superior.

Gynocium of I or several and distinct carpels: stigma and style of each solitary.

Carpel solitary.

Ovary neither enclosed nor seated in a hypanthium or a calyxtube.

Flowers not solitary in the axils of the leaves; land plants.

Urticaceæ in Order $2 \mathrm{I}$. URTICALES.

Flowers solitary in the axils of the leaves; aquatic plants.

Ceratophyllaceæ in Otder 25. Ranales. I 34

Ovary enclosed in or seated in a hypanthium or a calyx-tube. Stamens borne under the gynœcium,

Allioniacere in Order 24. Chenopodiales. I 22

Stamens borne on the hypanthium or adnate to the calyxtube.

Carpels several.

Order 36. THYMELEALES. 239 
Stamens inserted below the ovary.

Families in Order 25. Ranales. I 34

Stamens inserted on the edge of a cup-shaped hypanthium.

Families in Order 27. Rosales. I69

Gynœcium of 2 or several united carpels; stigmas or styles ? or several.

Ovary, by abortion, I-celled and I-ovuled.

Leaves with sheathing stipules (ocrex).

Order 23. Polygonales. IoI

Leaves estipulate, or if stipules are present they are not sheathing.

Trees or shrubs; ovary not seated in a hypanthium.

Herbs or vines.

Ulmacex in Order 21. URTICALES. I00

Stipules herbaceous: inflorescence spicate or racemose: leaf-blades palmately veined.

Cannabinaceæ in Order 21. URTICALES. Ioo

Stipules scarious or hyaline or none; inflorescence cymose: leaf-blades pinnately veined.

Families in Order 24. Chenopodiales. II3

Ovary several-celled, or with several placentæe, several-ovuled.

Stamens hypogynous, inserted under the gynocium in the perfect flowers, not on a disk in the pistillate flowers.

Flowers perfect.

Stamens not tetradynamous.

Stamens 2; inflorescence spicate.

Besseya in Order 44. Polemoniales. 3I 3

Stamens 3-10; inflorescence cymose.

Stamens tetradynamous.

Order 24. Chenopodiales. II 3

Brassicaceæ in Order 26. Papaverales. I50

Flowers monœcious or diœcious.

Euphorbiaceæ in Order 30. Euphorbiales. 222

Stamens perigynous or epigynous, inserted on the margin of a hypanthium or a disk.

Fruit a samara. Aceraceæ in Order 3 I. Sapindales. 226

Fruit drupe-like or berry-like. Order 32. RHamnales. 227

b. Ovary inferior.

Flowers not in involucrate heads.

Fruit a berry or a drupe, or nut-like.

Stamens as many as the perianth-members and alternate with them, or fewer.

Tetragoniaceæ in Order 24. Chenopodiales. I 24

Stamens as many as the perianth-members and opposite them, or twice as many.

Families in Order 37. Myrtales. 240

Fruit a capsule.

Sepals as many as the ovary-cavities or one-half as many.

Order 37. Myrtales. 240

Sepals (4-5) at least twice as many as the ovary-cavities.

Styles $2-3$; leaves alternate.

Styles solitary; leaves opposite.

Saxifragaceæ in Order 27. Rosales. 170

Glaux in Order 40. Primulales. 264

Flowers, at least the staminate, in involucrate heads.

Ambrosiaceæ in Order 49. Carduales. 327

B. Corolla present.

I. Petals distinct, at least at the base.

1. Carpels solitary, or several and distinct, or united only at the base.

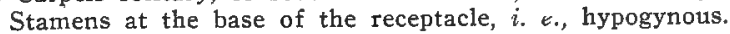


Plants with relatively firm stems and leaves, not succulent.

Plants with succulent stems and leaves.

Order 25. Ranales. I 34

Crassulacex in Order 27. Rosales. $\quad 169$

Stamens on the margin of a hypanthium (the hypanthium very small

in some Saxifragacex).

Order 27. Rosales. 169

2. Carpels several and united.

a. Ovary superior.

\# Stamens inserted at the base of the ovary or receptacle.

$\S$ Stamens numerous.

Sepals imbricated.

Calyx deciduous.

Calyx persistent.

Order 26. Papayerales. 148

Styles or stigmas distinct or united, but not discoid; land plants. Capparidacez in Order 26. Papaverales.

Styles or stigmas united into a disk; aquatic plants; petals and sepals numerous.

Nymphæaceæ in Order 25. Ranales. I47

Sepals valvate; stamens with united filaments.

Order 33. Malvales. 229

\$\$ Stamens few, not over twice as many as the petals.

Stamens as many as the petals and opposite them.

Anther-sacs opening by hinged valves.

Anther-sacs opening by slits.

Berberidacex in Order 25. Ranales. 148

Flowers monœcious.

Order 30. Euphorbiales. 22I

Flowers perfect.

Portulacaceæ in Order 24. Chenopodiales. - I25

Stamens as many as the petals and alternate with them, or more, sometimes twice as many.

Stamens 6: petals 4 : sepals 2 or 4 .

Families in Order 26. Papaverales. I 48

Stamens, petals and sepals of the same number, or stamens more, usually twice as many as the sepals or petals.

Ovary I-celled.

Ovules, or seeds, on basal or central placentz.

Families in Order 24. Chenopodiales. II 3

Ovules, or seeds, on parietal placentæ.

Stamens with united filaments and no staminodia.

Stamens with distinct filaments.

Order 33. Malvales. 229

Staminodia present.

Staminodia wanting.

Parnassiaceæ in Order 27. Rosales. I75

Families in Order 34. Hypericales. 231

Ovary several-celled.

Stamens adnate to the gynocium.

Asclepiadacer in Order 43. Asclepiadales, 270

Stamens not adnate to the gynœcium.

Stamens with wholly or partly united filaments.

Anthers opening lengthwise.

Families in Order 28. Geraniales. 217

Anthers opening by pores.

Order 29. Polygalales. 22I

Stamens with distinct filaments.

Anthers opening by pores.

Anthers opening by slits.

Families in Order 39. ERICales. 258

Stigmas or styles distinct and cleft, or foliaceous, or united by pairs. Order 30 . Euphorbiales.

Stigmas or styles all distinct or all united, neither cleft nor foliaceous. 


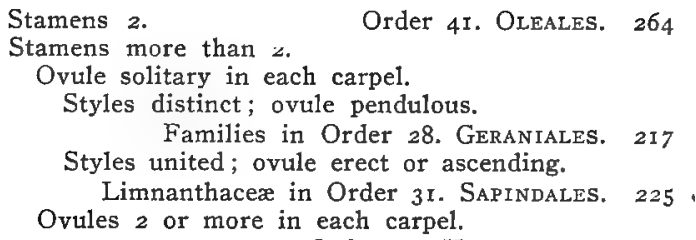

\$ Stamens inserted on the margin of a disk or hypanthium (perigynous or hypogynous).

Stamens as many as the petals and opposite them.

Styles and upper part of the ovaries distinct; ovules and seeds many. Saxifragaceæ in Order 27. Rosales. 170 Styles united, ovules and seeds solitary or $z$.

Order 32. Rhamnales.

Stamens as many as the petals and alternate with them, or more.

Styles distinct; upper part of the ovaries distinct, at least at maturity.

Styles united.

Saxifragaceæ in Order 27. Rosales. I70

Hypanthium flat or obsolete: disk fleshy.

Plants without secreting glands in the bark.

Plants with secreting glands in the bark.

Order 31. Sapindales. 225

Rutaceæ in Order 28. Geraniales. 221

Hypanthium cup-shaped or campanulate: disk obsolete or in-

b. Ovary inferior.

conspicuous.

Order 37. Myrtales. 240

Stamens numerous.

Hypanthium not produced beyond the ovary.

Ovary partly inferior. Hydrangiaceæ in Order 27. Rosales. 170

Ovary wholly inferior.

Order 35. Opuntiales. 234

Hypanthium produced beyond the ovary.

Families in Order 37. Myrtales. 240

Stamens not more than twice as many as the petals.

Styles wanting; stigmas sessile.

Styles present.

Gunneraceæ in Order 37. Myrtales. 248

Styles distinct.

Ovules several in each cavity of the ovary; fruit a capsule or a fleshy many-seeded berry.

Fruit, if dehiscent, valvate.

Fruit circumscissile.

Families in Order 27. Rosales. 169

Portulacacex in Order 24. Chenopodtales. I25

Ovules solitary in each cavity of the ovary; fruit a drupe or

2-5 more or less united achenes. Order 38. Umbellales. 249

Styles united, or single.

Plants without tendrils.

Ovary enclosed in or surpassed by the hypanthium or adnate to it.

Ovules solitary in each cavity of the ovary.

Ovules several in each cavity.

Order 38. UmbelLales. 249

Ovary with parietal placentr.

Loasacea in Order 35. Opuntiales. 234

Ovary with central or basal placentæ.

Families in Order 37. Myrtales. 240

Ovary exceeding the hypanthium, the top free.

Hydrangiaceæ in Order 27. Rosales. I75 
Plants with tendrils; fruit a pepo; leaf-blades palmately

veined. Cucurbitace in Order 47. Campanulales. 325

II. Petals more or less united.

Ovary superior.

Stamens free from the corolla.

Gyncecium of a single carpel. Families in Order 27. Rosales. I69 Gyncecium of several united carpels.

Filaments united.

Stamens diadelphous. Fumariacex in Order 26. Papaverales. 149

Stamens monadelphous.

Anther-sacs opening by slits.

Oxalidaceæ in Order 28. Geraniales. 220

Anther-sacs opening by pores.

Calyx and corolla very irregular.

Calyx and corolla regular.

Order 29. Polygalales. 22I

Filaments distinct.

Stamens partially adnate to the corolla.

Families in Order 39. Ericales. 258

Stamens as many as the lobes of the corolla and opposite them, or

twice as many or more; ovary I-celled; placentx central or basal.

Order 40. Primulales. 26I

Stamens as many as the lobes of the corolla and alternate with them, or fewer.

Corolla not scarious, veiny; fruit various, but not a pyxis.

Carpels distinct, except sometimes at the apex.

Carpels united.

Order 43. Ascleptadales. 269

Ovary I-celled, with central placentæ.

Order 42. Gentinnales. 264

Ovary 2-3-celled, or falsely 4-celled, or if I-celled with parietal placentæ.

Corolla scarious, veinless; fruit a pyxis.

Order 44. Polemoniales. 271

Order 45. Plantaginales. 320

Ovary inferior.

Stamens with the filaments free from the corolla.

Stamens Io; anther-sacs opening by terminal pores or chinks.

Vacciniaceæ in Order 39. ERICALES. 260

Stamens 5 or fewer; anther-sacs opening by longitudinal slits.

Stamens adnate to the corolla.

Order 47. Campantlales. 325

Ovary with $2-$ many fertile cavities and 2 -many ovules; calyx unmodified, at least not a pappus.

Plants tendril-bearing.

Plants not tendril-bearing.

Cucurbitacer in Order 47. Campanulales. 325

Ovules mostly on basal placentr; plants parasitic.

Order 22. Santalales. ioo

Ovules variously borne, but not on a basal placenta; plants not parasitic.

Ovary with one fertile cavity.

Order 46. Rubiales. 321

Flowers not in heads, often in head-like spikes or racemes.

Flowers in involucrate heads.

Order 48. VAleRianales. 326 Order 49. Carduales. 327 


\title{
FLORA OF COLORADO.
}

\section{Subkingdom PTERIDOPHYTA. FERN-WORTS.}

\author{
Order I. OPHIOGLOSSALES.
}

Family i. OPHIOGLOSSACEAE Presl. Adder's-Tongue Family.

I. BOTRYCHIUM Sw. MOONWORT.

Plant large, the sterile leaf ternately decompound, sessile at the middle of the stem.

Plant small; the leaf under $5 \mathrm{~cm}$. long.

Leaf triangular, sessile near the top of the stem.

Leaf oval, slightly stalked from near the middle of the stem or lower.

1. B. virginianum.

2. B. lanceolatum.

3. B. Lunaria.

1. Botrychium virginianum (L.) Sw. Rich woods, N. S. to Labr., B. C. and Wash. to Texas and Fla.-Arkansas Cañon (Brandegee).

2. Botrychium lanceolatum (S. G. Gmel.) Angs. In woods, N. J. and N. S. to Alaska and Wash.- "Colorado."

3. Botrychium Lunaria (L.) Sw. In open places, Newf. to Alaska and Utah: rare--Alt, about I2,000 ft.-Gray's Peak.

\section{Order 2. FILICALES.}

Family 2. POLYPODIACEAE R. Br. FERn Family.

Sori round, or at least less than twice as long as broad.

Sori naked.

Leaves jointed to the rootstock, simply pinnate.

Leaves continuous with the rootstock, ternately compound.

Sori covered with a membranous indusium when young.

2. Phegopteris.

Indusium superior.

Indusium circular fixed by the center. 3. Polystichum.

Indusium heart-shaped or reniform fixed by the sinus. 4. Dryopteris.

Indusium inferior or lateral.

Indusium inferior, breaking at maturity into stellate lobes.

5. Woonsia.

Indusium lateral, thrown back at maturity like a delicate hood. 
Sori linear or oblong, at least twice as long as broad.

Sori marginal.

Indusium present formed of the recurved leaf margin.

Indusium double, the inner membranous one opening outwardly; leaves large, scattered.

7. Pteridium.

Indusium single.

Leaves dimorphous, the sporophyls contracted and more or less pod-

like.

8. Cryptogramma.

Leaves uniform or nearly so.

Leaves chaffy or tomentose, the ultimate segments small and beadlike.

9. Cheilanthes.

Leaves smooth with dark polished stalks; segments broader.

io. Peliaka.

Indusium wanting; under surface (in the Colorado species) with white powder; rachises zigzag.

i I. Northolaena.

Sori dorsal, oblique to the midribs or rachises, covered with a special indusium.

Leaves pinnate or pinnately compound.

Sori straight.

12. Asplenium.

Sori curved, often crossing the veins; indusia occasionally horseshoeshaped.

r. Athyrium.

Leaves dichotomous, the divisions few and narrow; small rock-loving plants of the mountains.

I4. Belvista.

I. POLYPODIUM L. POLYPODY.

I. Polypodium hesperium Maxon. [P. vulgare of western botanists.] On rocks, Mont. to B. C., Wash., Colo. and Ariz.-Alt. about $8500 \mathrm{ft}$.-Red Mountain road, south of Ouray.

\section{PHEgOPTERIS Fee. BEECH-FERN.}

I. Phegopteris Dryopteris (L.) Fee. In moist-rocky places; Newf. to Alaska, Ore, Colo. and Va.-Alt. about $8000 \mathrm{ft}$--Green Mountain Falls.

\section{POLYSTICHUM Roth. Holly-Fern.}

x. Polystichum Lonchitis (L.) Roth. On rocks, Arctic America to N. S., Calif. and Colo.-Alt. 8500-10,000 ft.-Ruby; Red Motıntain road, south of Ouray; Fish Creek Falls, Routt Co.

\section{DRYOPteris Adans. Male-Fern, Wood-Fern.}

I. Dryopteris Filix-mas (L.) Schott. On rocks, N. S. to northern Mich., Alaska, Calif., Ariz. and Colo.-Alt. $6000-8500 \mathrm{ft}$-Red Mountain road, south of Ouray; Horsetooth Mountain; Cañon City; Rist Cañon.

\section{WOODSIA R. Br.}

Teeth of young leaves coarse, not ciliate.

Stalks and pinnules covered with minute flattened hairs.

Stalks and pinnules smooth.

Teeth of young leaves fine, ciliate at the tips.

1. W. scopulina.

2. W. oregana.

3. W. mexicana.

I. Woodsia scopulina D. C. Eaton. On exposed rocks, Mich. to B. C., Calif., Ariz. and Colo.-Alt. 5000-7000 ft.-North Cheyenne Cañon; vicinity of Arthur's Rock; Boulder; Horsetooth Gulch; gulch west of Soldier Cañon; foot-hills, Larimer Co.; South Boulder Cañon. 
z. Woodsia oregana D. C. Eaton. On exposed rocks, northern Mich. to B. C., Calif., Ariz. and Neb.-Alt. 4000-II,500 ft.-Hills about Box Cañon, west of Ouray; Red Mountain road, south of Ouray; Cheyenne Cañon; Horsetooth Mountain; North Cheyenne Cañon; hills south of La Veta; Parlin, Gunnison Co.; Alpine Tunnel.

3. Woodsia mexicana Fee. Foot-hills from Colo. and Ariz. to Mex.-Alt. 7500-9500 ft.-Manitou; South Cheyenne Cañon; Colorado Springs; Cheyenne Mountain; Ouray.

\section{FILIX Adans. Bladder-FERn.}

Leaves ovate-lanceolate, 2-3-pinnate.

Leaves broadly triangular, 3-4-pinnate.

1. F. fragilis.

2. F. montana.

1. Filix fragilis (L.) Underw. [Cystopteris fragilis Bernh.] On moist rocks, Newf. and Labr. to Alaska, Calif., Ariz. and Ga.-Alt. 5000-I3,000 ft.Horsetooth Mountain; Crystal Creek; near Ouray; Red Mountain, south of Ouray; Upper La Plata River; near Pagosa Peak; Cheyenne Cañon; Steamboat Springs; Minnehaha; Sierra Blanca; gulch west of Bear River; Parlin, Gunnison Co.; Lake City; Pike's Peak; Rist Cañon; Horsetooth Gulch; Michigan; Leroux Creek; Howe's Gulch; Silverton; Mount Garfield.

2. Filix montana (Lam.) Underw. On rocks, Lab. and Que. to B. C. and Colo.-Alt. about Io,500 ft.-Mt. Antero, Saguache Range.

\section{PTERIdIUM Scopoli. Bracken.}

I. Pteridium aquilinum pubescens Underw. [Pteris aquilina of western botanists.] On poor soil in open places, Mont. to Calif., Colo. and Ariz.Alt. 8500-I0,000 ft.-Red Mountain road, south of Ouray; near Pagosa Peak; Bosworth's ranch; Rabbit-Ear Range.

\section{CRYPTOGRAMMA R. Br. PARLley-Fern.}

Leaves 3-4-pinnatifid, densely cespitose; texture firm. Leaves 2-3-pinnatifid, scattered; texture flaccid.

1. C. acrostichoides.

2. C. Stelleri.

I. Cryptogramma acrostichoides $\mathrm{R}$. Br. On loose rocks, Lake Superior to Alaska, Colo. and Calif.-Alt. 8500-II,500 ft.-Near Pagosa Peak; Mt. Hesperus; Estes Park, Larimer Co.; West Spanish Peak; Twin Lakes; Red Mountain road, south of Ouray; Clear Creek; Fish Creek Falls, Routt Co.

z. Cryptogramma Stelleri (S. C. Gmel.) Prantl. [Pellaea gracilis Hook.] On moist rocks, Labr. and $\mathrm{Pa}$. to Colo. and Alaska.-Alt. 7500-9500 ft.Cañons west of Ouray.

\section{ChEILANTHES Sw. LIP-FERN.}

Leaves hairy or tomentose, not scaly.

Stalks covered with woolly hairs when young, at length nearly smooth.

Stalks and rachises with narrow lanceolate scales.

Leaves covered beneath with imbricated scales, not tomentose.

1. C. Feei.

2. C. Eatoni.

3. C. Fendleri. 
I. Cheilanthes Feei Moore. [C. lanuginosa Nutt.] On dryish rocks, Ill. and Minn. to B. C., Ariz. and Tex.-Alt. 4000-900o ft.-Trail Glen; Ute Pass; West Indian Creek; North Cheyenne Cañon; Colorado Springs; Cañon City. 2. Cheilanthes Eatoni Baker. On rocks, Ariz. to Colo. and Texas.-Alt. about $5800 \mathrm{ft}$.-Arkansas Cañon.

3. Cheilanthes Fendleri Hook. On dry rocks, Texas to Colo. and Calif.Alt. 5000-8500 ft.-Horsetooth Mountain; Cheyenne Cañon; Green Mountain Falls; Glen Eyrie; Boulder; Arkansas Cañon; Manitou.

Io. PELlaEA Link. Rock-Brake.

Simply pinnate; texture thin; pinnae obtuse, narrower when fertile.

Bi-tri-pinnate; texture coriaceous.

Pinnae obtuse or barely acute.

Pinnae mucronulate.

I. P. Breweri.

z. P. atropurpurea.

3. P. Wrightiana.

I. Pellaea Breweri D. C. Eaton. On rocks, Mont., Ore. and Calif.-Reported from Colorado, but exact locality not given.

2. Pellaea atropurpurea (L.) Link. On rocks, New England to B. C., southward to Ga., Texas and Ariz.-Alt. about $7500 \mathrm{ft}$-Box Cañon, Ouray.

3. Pellaea Wrightiana Hook. On rocks, Kans. to Texas and Calif-Cañon City.

\section{NOTHOLAENA R. Br. ClOAK-Fern.}

I. Notholaena Fendleri Kunze. On exposed rocks, Wyo. to N. M. and Ariz. -Alt. 6000-9500 ft.-Cheyenne Cañon, base of Pike's Peak; Queen's and William's Cañons; Arkansas Cañon; Colorado Springs; Ute Pass; Clear Creek Cañon, at Dumont; South Cheyenne Cañon; between La Veta and Gardner; La Veta; Bergen Park.

\section{ASPLENIUM L. SPLeen wort.}

Leaves simply pinnate.

Rachis chestnut brown or blackish.

Pinnae 2-3 cm. long, auriculate on the upper side at base.

Pinnae I $\mathrm{cm}$. long, obliquely oval, not auriculate at base.

1. A. platyneuron.

Rachis green; pinnae ovate-rhomboidal, oblique at base. Leaves bipinnate.

2. A. Trichomanes.

3. $A$. viride.

4. A. Andrewsii.

I. Asplenium platyneuron (L.) Oakes. [A. ebeneum Aiton] On rocks, Me. to Fla., Tex., N. M. and Colo.-Green Horn Mountains (Greene).

2. Asplenium Trichomanes L. On limestone rocks, quite generally east of the Rocky Mountains.-Alt. 5000-7000 ft.-South Boulder Cañon; Horsetooth Mountain; Horsetooth Gulch.

3. Asplenium viride Huds. On rocks, N. Br. and Vt. to Alaska, Ore. and Wyo.-Reported from Colorado, but exact locality not given.

4. Asplenium Andrewsii A. Nelson. Sandstone cliff, in Colo.-Boulder Creek.

I3. ATHYRIUM Roth. LADY-FERN.

I. Athyrium Filix-foemina (L.) Roth. In moist, shady places, Newf. to B. C., Calif. and Fla.-Alt. about $9000 \mathrm{ft}$--Near Pagosa Peak; Fish Creek Falls, Routt Co. 
14. BELVISIA Mirb.

I. Belvisia septentrionalis (L.) Mirb. (Asplenium septentrionale Hoffm.) On rocks, S. D. to Mont., N. M. and Ariz.-Alt. 6000-6500 ft.-Horsetooth Mountain; South Boulder Cañon; Arkansas Cañon.

\section{Order 3. SALVINIALES.}

Family 3. MARSileaceaE R. Br. Marsilia Family.

I. MARSILEA L.

I. Marsilea vestita Hook. \& Grev. Wet, sandy soil, Ark. and Tex. to Calif., B. C. and S. D.-Saguache (Wolf).

\section{Order 4. EQUISETALES.}

Family 4. EQUISETACEAE Michx. Horsetail Family.

I. EQUisetum L. Horsetail.

Stems annual, copiously branching.

Spike-bearing stems pale, soon withering; sheaths of branches 4-toothed.

I. E. arvense.

Spike-bearing stems withering at apex, producing branches below; sheaths of branches 3 -toothed.

Stems perennial, evergreen; branches few.

Stems smoothish, $14-30$-furrowed.

Stems roughened, 5-10-furrowed.

2. E. pratense.

3. E. laevigatum.

4. E. variegatum.

1. Equisetum arvense L. In sandy places, Greenl. and Va. to Calif. and Alaska.-Alt. 5000-I0,000 ft.-Fort Collins; Ouray; West Indian Creek; Mancos; Bob Creek, west of Mt. Hesperus; Hotchkiss.

2. Equisetum pratense Ehrh. Along streams, N. Sc. to N. J., Colo. and Neb.-Alt. up to 10,500 ft.-Bob Creek, west of Mt. Hesperus.

3. Equisetum laevigatum A. Br. Moist places, N. J. to Tex., B. C. and Calif.-Alt. 4000-12,500 ft.-Gunnison; Parlin; Ft. Collins; West Spanish Peak; Cucharas River, below La Veta; Wahatoya Creek; Trimble Springs; Mancos; Grand Junction.

4. Equisetum variegatum Schleich. In sandy soil, Arctic America to N. Y. and Nev.-Clear Creek, near Denver (Coulter).

\section{Order 5. ISOETALES.}

\section{Family 5. ISOETACEAE Horan. Quillwort Family.}

I. ISOETES L. QUILLWORT.

Stomata wanting; leaves $4^{0-60}$, rigid; microspores whitish, papillose.

I. I. paupercula.

Stomata present; leaves 5-25, soft; microspores deep brown, spinulose.

2. I. Bolanderi.

1. Isoetes paupercula (Engelm.) A. A. Eaton. [I. occidentalis Henderson, I. lacustris paupercula Engelm.] In lakes, always submerged; Colo. to Calif., Wash. and Ida.-Grand Lake, Middle Park. 
2. Isoetes Bolanderi Engelm. In ponds, Mont. to Wash., Colo. and Calif. - Western Colorado."

\section{Order 6. LYCOPODIALES.}

Spores uniform, minute.

Family 6. Lycopodiaceae.

Spores of two sorts, minute microspores and larger macrospores.

Family 7. Selagineilaceae.

Family 6. LYCOPODIACEAE Michx. Clubmoss Family.

1. Lycopodium L. Club-Moss, Running Pine.

I. Lycopodium annotinum L. In open places in forest, Mass. and Newf. to Colo., Wash. and Alaska.-Alt. 9000-I0,500 ft.-Beaver Creek; Estes Park; Front Range, Larimer Co.; Notch Mountain.

Family 7. SELAGINELlaCEAE Underw. Selaginella Family.

I. Selaginella Beauv. Little Club-Moss.

Stems rooting at base only; spikes thick, with lax bracts; macrospores spinulose.

Stems rooting their entire length; bracts rigid.

I. S. selaginoides.

Leaves without bristles at the ends; stems slender, wiry. z. S. mutica.

Leaves with distinct terminal bristles.

Stems short, compact; leaves light green, crowded, with long terminal bristles. 3. S. densa.

Stems long, loosely spreading; leaves dark green, lax, with short terminal bristles. 4. S. Underwoodii.

I. Selaginella selaginoides (L.) Link. In open places in high mountains, Labr. and northern N. Y. to Alaska and Colo. Exact locality not given.

2. Selaginella mutica D. C. Eaton. On rocks, N. M. to Colo. and Calif. -Alt. 6000-6500 ft.-Idaho Springs; South Cheyenne Cañon; North Cheyenne Cañon; Royal Gorge.

3. Selaginella densa Rydb. (S. Engelmanni Hieron.) On exposed rocks, S. D. and western Neb. to Mont. and Colo.-Alt. about $7000 \mathrm{ft}$-The Rustic, Larimer Co.

4. Selaginella Underwoodii Hieron. ( $S$. rupestris Fendleri Underw.) On exposed rocks, N. Mex. and Colo.-Alt. 5000-7500 ft.--North Cheyenne Cañon; Minnehaha; Pike's Peak; South Cheyenne Cañon; Boulder; foothills near Ft. Collins; Manitou. 


\section{Subkingdom SPERMATOPHYTA SeEd-bearing Plants.}

\section{Class 1. GYMNOSPERMAE.}

\section{Order 7. PINALES.}

Carpellary scales with bracts, never peltate; ovules inverted; buds scaly; wing accompanying the seed a portion of the carpellary scale; cones dry. Fam. 8. Pinaceae.

Carpellary scales without bracts, in ours fleshy and peltate; ovules erect; buds naked; wings of the seed (if present) a portion of the testa; cones in ours berrylike.

Fam. 9. JuniperaceaE.

\section{Family 8. PINACEAE Lindl. Prne Family.}

Leaves usually several together, surrounded by a sheath at the base: cones maturing the second year.

Cone-scales with dorsal, (in ours) spine-armed appendages.

Seeds with elongated wings, these free from the scales and attached to the seeds when these fall.

1. Pinus.

Seeds with rudimentary wings, these adnate to the scales when the seeds fall.

4. CARYOPITYS.

Cone-scales with inconspicuous terminal, unarmed appendages; wing of the seed rudimentary.

Leaves solitary, without sheath; cones maturing the first year.

Branchlets rough from the prominent, persistent leaf-bases (sterigmata); leaves in ours quadrangular in cross-section; cones pendulous with persistent scales. 4. Picen.

Branchlets smooth, the leaf-scars scarcely raised; leaves flat.

Cones pendulous; their scales persistent on the axis; leaves petioled, with transversely oval scars.

5. Pseudotsuga. Cones erect; their scales deciduous from the axis; leaves sessile with circular scars.

6. ABIES.

\section{PINUS L. Pines.}

Leaves in fascicles of 4 or 5 ; spines of the cone-scales long and slender.

I. P. aristata.

Leaves in fascicles of 2 or 3 ; spines of the cone-scales short and stout. Cones $6-9 \mathrm{~cm}$. long and $5-6 \mathrm{~cm}$. in diameter; leaves $8-15 \mathrm{~cm}$. long.

Cones 3-5 cm. long and $3 \mathrm{~cm}$. in diameter; leaves $3-6 \mathrm{~cm}$. long.

4. P. scopulorum.

3. P. Murrayana.

i. Pinus aristata Engelm. Foxtail Pine, Hickory Pine. Rocky and gravelly mountains from Colo. to Nev., southern Calif. and Ariz.-Alt. 8500I2,500 ft.-Mt. Garfield; Seven Lakes;.Como; Veta Pass; Pike's Peak; Middle Park; Gray's Peak.

2. Pinus scopulorum (Engelm.) Lemmon. Bull Pine, Rocky Mountain Yellow Pine. Hills and mountains from Nebr. to Mont., Ariz. and N. M.- 
Alt. 5000-10,000 ft.-Mountains, Veta Pass; Mancos; Ouray; Minnehaha; Georgetown; Horsetooth Mountain.

3. Pinus Murrayana Oreg. Com. Lodge Pole Prne, Black Pine. Hills and mountains from Mont. to Alaska, Colo. and Calif.-Alt. 5000-10,000 ft.Mountains near Veta Pass; Pallas and Sydney; Dillon; Mount Ouray; Breckenridge; Cipango; Baxter's ranch; North Park; Como.

\section{CARYOPITyS Small. Prñons, Nut Pines.}

Cones about $3 \mathrm{~cm}$; leaves usually in pairs, seldom in threes. 1. C. edulis. Cones 4-5 cm. ; leaves singly or rarely in pairs.

z. C. monophylla.

r. Caryopitys edulis (Engelm.) Small. (Pinus edulis Engelm.) Dry foothills and table-lands from southern Wyo. to western Texas, northern Mex., Ariz, and Utah.-Alt. 4000-9000 ft.-Glen Eyrie; Cedar Creek; Red Rock Cañon; Mancos; Salida; Florence; Manitou; Buena Vista; Grand Junction. 2. Caryopitys monophylla (Torr. and Frem.) Rydb. (Pinus monophylla Torr. and Frem.) Dry hills and mountain slopes from Utah to Calif., Lower California and Ariz. One specimen from Colorado seems to belong here.Manitou.

\section{APINUS Necker. Cembra Pines.}

^. Apinus flexilis (James) Rydb. (Pinus flexilis James) Rocky Mourtain White Pine. Mountains from Alb. to western Texas and southern Calif.-Alt. 7500-II,000 ft.-Clear Creek, Middle Park; Ojo; Graham's Park; North Park; Minnehaha; Beaver Creek; Chambers Lake; Manitou.

\section{PICEA Link. Spruces.}

Branchlets pubescent; cones $3-5 \mathrm{~cm}$. long. Branchlets glabrous; cones $5-9 \mathrm{~cm}$. long.

1. P. Engelmannii. ¿. P. Parryana.

I. Picea Engelmanni (Parry). Engelm. Engelmann Spruce, White Spruce. Mountains, especially on the north sides, from Alb. to B. C., Ore., Ariz. and N. M.-Alt. 8500-12,500 ft.-Empire; Buffalo Pass, Park Range; Mount Baldy; Wahatoya Cañon; Bob Creek, La Plata Mountains; Grand Lake; Cameron Pass.

2. Picea Parryana (Andree) Sarg. (Picea pungens Engelm.) BLuE Spruce, Colorado Spruce. Mountains especially along streams from Wyo. to Utah and N. M.-Alt. 6500-10,000 ft.-Empire; near Pagosa Peak; Crystal Park; Wahatoya Cañon; Cameron Pass.

\section{PSeUdotsuga Carr. Douglas Spruce, Red Fir.}

r. Pseudotsuga mucronata (Raf.) Sudw. Douglas Spruce, Red Fir. Hills and mountains from Alb. to B. C., Calif., northern Mexico and western Texas. -Alt. 6000-II,500 ft.-Pagosa Peak; South Cheyenne Cañon; Colorado Springs; Como; State Bridge, Grand River; Boulder; Manitou ; Minnehaha; Mancos; Placer; hills about Ouray; Cameron Pass; Pingree Hill; Stove Prairie. 


\section{ABIES Miller. Balsams, Firs.}

Resin ducts of the leaves within the soft tissue, remote from the epidermis.

Resin ducts of the leaves close to the epidermis on the lower side.

I. A. lasiocarpa.

2. A. concolor.

1. Abies lasiocarpa (Hook.) Nutt. Balsam FIR. Subalpine mountains from Alb. to Alaska, Ariz. and N. M.-Alt. 9500-I2,500 ft.-West Spanish Peak; Grand Lakes; Empire; Andrew's ranch; Mt. Richtofen; Cameron Pass.

2. Abies concolor Lindl. WhITE FIR. Along streams in the mountains from Colo, to Ore., Calif. and N. M.-Alt. 8000-ro,00o ft.-Wahatoya Cañon; Manitou; Veta Mountain; Bob Creek, west of La Plata; Ouray.

\section{Family 9. JUNIPERACEAE Horan. Juniper FAMIly.}

Leaves subulate on the mature branches; aments axillary, the pistillate with smaller scales at the top.

I. JUNIPERUS.

Leaves scalelike and appressed on the mature branches; aments terminal, the pistillate with larger scales at the top.

2. Sabina.

\section{JUNIPERUS L. JUNIPERS.}

Low shrub with depressed branches; leaves abruptly bent at the base, deeply channelled, abruptly acute.

I. J. sibirica.

Tree or erect shrub; leaves straight or nearly so, shallowly channelled, gradually acuminate.

2. J. communis.

I. Juniperus sibirica Burgsd. MountaIn or Low JunIPER. Exposed rocky mountains and hills from Labr. to Alaska, Utah and N. Y.-Alt. 6500-Io,000 ft.-Pike's Peak; Colorado Springs; Empire; Marshall Pass; Golden; Little Beaver; near Veta Pass; Bob Creek, west of La Plata Mountains; Ouray; Grand Lake; between Sunshine and Ward; Ojo; Beaver Creek; Baxter's ranch; Trapper's Lake; Rist Cañon.

«. Juniperus communis L. JUNIPER. Rocky hills and stony places from Lab. to Mont., N. M. and Ga.-Alt. 5000-8500 ft.-Minnehaha; Colorado Springs.

\section{SABINA Haller. Red Cedars, Savins, Junipers.}

Fruit reddish-brown or bluish by a bloom, with dry-fibrous sweet flesh. I. S. utahensis.

Fruit blue or blue-black, rarely copper-colored, with juicy resinous flesh. Trees or erect shrubs; fruit on straight peduncle.

Leaves minutely denticulate at the apex; fruit $5-7 \mathrm{~mm}$. in diameter, usually I-seeded.

2. S. monosperma.

Leaves entire; fruit 4-5 $\mathrm{mm}$. in diameter, usually several-seeded.

Prostrate shrub; fruit on recurved peduncle.

3. S. scopulorum.

4. S. prostrata.

I. Sabina utahensis (Engelm.) Rydb. (Juniperus californica 'utahensis Engelm.) On dry mountain slopes and table-lands from western Colo. to Nev., southeastern Calif. and Ariz.-Alt. 5000-Io,000 ft.-State Bridge; Glenwood Springs; Grand River Valley. 
z. Sabina monosperma (Engelm.) Rydb. (Juniperus occidentalis monosperma Engelm.) Dry foot-hills and mesas from Colo. to Utah, Ariz., N. M. and northern Mexico.-Alt. 5500-7500 ft.-McCoy; Cedar Creek; La Veta; Mancos; Owl Cañon; Rustic.

3. Sabina scopulorum (Sarg.) Rydb. (Juniperus scopulorum Sarg.) Rocky Mountain Red Cedar. On foot-hills and river bluffs from Alb. to B. C., Ore., Ariz. and Texas.-Alt. 4000-8500 ft.-Colorado Springs; Golden; Garden of the Gods; Ouray; Durango; McCoy; State Bridge, Grand River; Kremmling; Eagle River, Walcott; Boulder; Manitou; New Castle; Salida; Andrew's ranch; Soldier Cañon; Rist Cañon; Trinidad; Owl Cañon.

4. Sabina prostrata (Pers.) Antoine. Creeping Juniper, Trailing Savin. Exposed hills and slopes from N. S. to B. C., Colo. and N. Y.-Alt. 4000$8500 \mathrm{ft}$--North Cheyenne Cañon; Parlin; Owl Cañon.

\section{Order 8. GNETALES.}

Family io. EPHEDRACEAE Dumort. JoInt-fir FAMiLy.

x. EPHEDRA Tourn. JoINT-FIRS.

Scales and branches opposite; bracts opposite and connate, scarious only on the margins.

I. E. antisyphylitica.

Scales, branches and bracts in threes; the latter scarcely connate; those of the pistillate cones mostly scarious and more or less clawed.

Scales $2-3 \mathrm{~mm}$. long, not becoming shreddy; fruit scabrous.

2. E. Torreyana.

Scales 6-12 mm. long, becoming shreddy; fruit smooth. 3. E. trifurca.

I. Ephedra antisyphylitica E. A. Mey. On desert land from Colo. to Texas and Mex.-Mancos.

2. Ephedra Torreyana S. Wats. On desert lands to an altitude of $5500 \mathrm{ft}$. from Colo. and Utah to N. M. and Calif.-Deer Run.

3. Ephedra trifurca Torr. On desert lands from southwestern Colo. and Utah to Texas and Ariz.-Mesa Verde; Las Animas Valley (Brandegee). 


\section{Class 2. ANGIOSPERMAE.}

\section{Subclass 1. MONOCOTYLEDONES.}

\section{Order 9. PANDANALES.}

Flowers in elongated terminal spikes; fruit hidden among bristles.

Fam. II. TYPHACEAE.

Flowers in globose lateral spikes; fruit not hidden among bristles.

Fam. i 2 . Sparganiaceat.

\section{Family i I. TYPHACEAE J. St. Hil. Cat-tail Family.}

\section{TYPHa L. Cat-tails.}

I. Typha latifolia L. In marshes, lakes and streams from Newf. to Wash., Fla. and Calif.; also Mex., Asia and Europe-Ait. 400o-600o ft.-Pagosa Springs; Ft. Collins; common in swamps formed by irrigation.

\section{Family I 2. SPARGANIACEAE Agard. Bur-ReEd Family.}

\section{SPARGANIUM L. BUR-REED.}

\section{Leaves triangular-keeled at the base.}

Mature achenes truncate at the apex, stalked; stigmas often $z$.

I. S. eurocarpum.

Mature achenes acuminate at the apex, sessile; stigma always solitary; lower heads peduncled.

Leaves flat throughout, mostly floating.

Mature heads $12-15 \mathrm{~mm}$. in diameter; style and stigma of about the same length as the achenes.

3. S. angustifolium.

Mature heads $7-10 \mathrm{~mm}$. in diameter; style and stigma shorter than the achenes. 4. S. minimum.

1. Sparganium eurocarpum Engelm. In marshes and slow streams from Newf. to Wash., Fla. and Calif.-Alt. 4000-5500 ft.-Along Platte River, Denver.

2. Sparganium multipedunculatum (Morong) Rydb. (S. simplex multipedunculatum Morong) In marshes, slow streams and lakes, from the Mackenzie River to Wash. and Colo.-Alt. 6500-10,500 ft.-Gunnison; Cottonwood Lake; Kremmling; West Cliff; margin of lake, Buffalo Pass, Park Range; Estes Park; eight miles west of Hebron.

3. Sparganium angustifolium Michx. In lakes and streams from Newf. to Ore., N. Y. and Calif.-Alt. 8500-I I,500 ft.-Near Pagosa Peak; Seven Lakes; Trapper's Lake; Estes Park. 
4. Sparganium minimum Fries. In ponds and streams from N. B. to Alaska, N. Y. and Utah.-Grand Lake; Estes Park.

\section{Order Io. NAIADALES.}

Gynoecium of distinct carpels; stigmas disk-like or cup-like.

Gynoecium of united carpels; stigmas $2-4$, slender.

Fam. I3. Zanichelliaceae.

Fam. I 4. NaiAdaceae.

\section{Family 13. ZANICHELLIACEAE Dumort. Pond-Weed Family.}

Flowers perfect in peduncled spikes; ovaries sessile; stamens 4; connective appendaged.

I. Potamogeton.

Flowers monoecious, axillary; anthers I ; connective not appendaged.

2. ZANICHELIIA.

1. POTAMOgeton L. Pond-Weed.

With both floating and submerged leaves.

Submerged leaves bladeless.

I. P. natans.

Submerged leaves with proper blade.

Submerged leaf-blades lanceolate.

Submerged leaves all petioled.

Submerged leaves sessile or the uppermost short-petioled.

Peduncles of the same thickness as the stem. 3. P. alpinus.

Peduncles thicker than the stem.

Submerged leaves linear.

5. P. heterophyllus.

With submerged leaves only.

Leaves with broad blades, lanceolate or oval, many-nerved.

Leaves short-petioled or sessile, not clasping.

Leaves clasping.

6. P. lucens.

7. P. Richardsonii.

Leaves narrowly linear or capillary.

Stipules free from the leaves.

Glands at the base of the leaves absent. 8 . P. foliosus.

Glands at the base of the leaves present. 9. P. pusillus.

Stipules adnate to the base of the leaves.

Stigma broad, sessile.

Leaves filiform, $I / 4-T / 2 \mathrm{~mm}$. wide; stipular sheath $3-8 \mathrm{~mm}$. long.

Leaves about I $\mathrm{mm}$. wide; stipular sheath $\mathrm{I}-2 \mathrm{~cm}$. long.

10. P. filiformis.

Stigma capitate; style evident.

I. P. interior.

12. $P$. pectinatus.

1. Potamogeton natans L. In lakes and ponds from N. S. to Alaska, Fla. and Calif.; also Mex., Europe and Asia.-Alt. 4000-8000 ft.-Rio Grande, Alamosa; Lee's Lake, Ft. Collins; Laramie River near state line.

2. Potamogeton lonchites Tuckerm. In ponds and slow streams from N. B. to Wash., Fla. and Calif.-Alt. $4000-8000 \mathrm{ft}$--Alamosa.

3. Potamogeton alpinus Balbis. (P. rufescens Schrad.) In ponds from N. S. to Alaska, N. J. and Calif.-Alt. 8000-1 I,500 ft.-Georgetown; Tomichi River; Seven Lakes; Trapper's Lake. 
4. Potamogeton Zizii M. \& K. In lakes and streams from Que. to Ida., Fla. and Texas.-Cerro Summit.

5. Potamogeton heterophyllus Schreb. In still or flowing water from Lab. to B. C., Fla. and Calif.-Alt. 5000-6000 ft.-Near Boulder.

6. Potamogeton lucens $\mathrm{L}$. In ponds and lakes, from N. Sc. to Fla. and Calif.-Cottonwood Lake.

7. Potamogeton Richardsonii (Bennett) Rydb. ( $P$. perfoliatus lanceolatus Robbins) In lakes, ponds and slow streams from Newf. to Alaska, Del, and Calif.-Alt. about $8000 \mathrm{ft}$--Tomichi River.

8. Potamogeton foliosus Raf. In streams and ponds from N. B. to B. C., Fla. and Calif.-Alt. 4000-9000 ft.-North Platte River, below Hebron; Grand River, Sulphur Springs; Platte River, Denver.

9. Potamogeton pusillus L. In slow streams and ponds from N. B. to B. C., N. C. and Calif.-Alt. 4000-8000 ft.-Base of Pike's Peak; Brantly Cañon, Las Animas Co.; Alamosa.

I0. Potamogeton filiformis Pers. In ponds and lakes from Anticosti to B. C., N. Y. and Colo.-Alt. 4000-9000 ft.-Twin Lakes; Walsenburg; Grand Lake.

Ir. Potamogeton interior Rydb. (P. marinus occidentalis Robbins) In lakes and slow streams from Alb. to Colo. and Nev.-Alt. 6500-10,00o ft.San Luis Valley; Ironton Park, nine miles south of Ouray; Tomichi River; Gunnison; Hamor's Lake, Durango.

12. Potamogeton pectinatus L. In fresh, alkaline or salt water from N. B. to Alaska, Fla. and Low. Calif.-Alt. 4000-10,000 ft.-Twin Lakes; New Windsor; lake near Ft. Collins; Grizzly Creek; Trapper's Lake; Lee's Lake, Ft. Collins.

\section{ZANICHELLIA L. ZANICHELLIA.}

I. Zanichellia palustris $L$. In fresh and alkaline ponds and streams especially with sandy bottoms from Mass. to Wash., Fla. and Calif.; also in the Old World.-Alt. 4000-9000 ft.-Ft. Collins; Platte River, Denver; stream twelve miles below Grand Lake; swamp along Poudre River.

\section{Family 14. NAIADACEAE Lindl. NaIAS Family.}

r. NAIAS L. NaIAS.

I. Naias guadalupensis (Spreng.) Morong. In brackish and alkaline water from Kans., Nebr. to Ore., Fla. and Texas; Tropical America.-Lee's Lake, Ft. Collins.

\section{Order II. ALISMALES.}

Petals similar to the sepals; anthers long and narrow; carpels coherent.

Fam. 15. Scheuch Seriaceas.

Petals different from the sepals, in ours white; anthers short and thick; carpels not coherent.

Fam. 16. Alismaceae. 
Family i 5. SCHEUCHSERIACEAE Agardh. Arrow-Grass Family.

1. TRIGLOCHIN L. ARrow-GRASS.

Carpels 3 ; fruit linear-clavate, tapering to an awl-shaped base. 1. T. palustris. Carpels 6 ; fruit oblong or ovoid, obtuse at the base. $2 . T$. maritima.

I. Triglochin palustris L. In marshes from N. B. to Alaska, N. Y. and Colo.; also in Europe and Asia.-Alt. 6500-10,000 ft.-Lake John, North Park; Iola; Hamor's Lake, north of Durango; Grizzly Creek; Como; South Park.

2. Triglochin maritima L. In marshes, especially those that are more or less alkaline or saline, from Lab. to Alaska, N. J. and Calif.-Alt. 6500-I0,000 ft.-Parlin, Gunnison Co.; Doyle's; Trimble Springs, north of Durango; Gypsum, Eagle Co.; Tobe Miller's ranch; Steamboat Springs.

\section{Family i6. ALISMACEAE DC. Water-plaintain Family.}

Carpels in a ring on a flat receptacle.

I. Alisma.

Carpels spirally arranged in several series on a convex or globose receptacle.

2. Sagittaria.

\section{ALISMA L. Water-plantain.}

1. Alisma Plantago L. (A. brevipes Greene) In water from Que. to Wash., Colo, and Low. Calif, ; also in Europe--Alt. 4000-9000 ft.-Cerro Summit; La Porte, Larimer Co.; La Plata River; Piedra; near the river, Ft. Collins; Hubbard Creek, Delta Co.

\section{SAGITTARIA L. ARROW-HEAD.}

Basal lobes of the leaf-blades not longer than the blade proper.

Beak of the achenes at a right angle to the body and of $1 / 4$ its length or more; bracts ovate.

Beak of the achenes erect, very short.

Bracts lanceolate, $8-20 \mathrm{~mm}$. long; petiole comparatively short; blade seldom floating. $\quad 2 . S$ arifolia.

Bracts ovate-lanceolate, 4-6 mm. long; petioles very long; blades floating or none. 3. S. cuneata.

Basal lobes of the leaf-blades $2-3$ times as long as the blades proper.

4. S. longiloba.

I. Sagittaria latifolia Willd. In marshes and shallow water from N. B. to B. C., Fla. and Tex.-Lee's Lake, near Ft. Collins; along the river near Ft. Collins.

z. Sagittaria arifolia J. G. Smith. In shallow water and mud from Me., Sask., B. C. and Mich. to N. M. and Calif.-Alt. $4000-8500 \mathrm{ft}$-Near Boulder; New Windsor, Weld Co.; North Cheyenne Cañon; Alamosa; Kremmling; La Porte road, near Ft. Collins.

3. Sagittaria cuneata Sheldon. In lakes from Minn. to Sask., B. C. and Colo.-." Colorado."

4. Sagittaria longiloba Engelm. In shallow ponds from Kans. to Colo., Tex. and Sonora.-Exact locality not given. 


\section{Order I2. HYDROCHARITALES.}

\section{Family i 7. ELODIACEAE Dumort. Tape-grass Family.}

1. PHILOTRIA Raf. WATER-WeEd.

Calyx over $2.5 \mathrm{~mm}$. broad.

Calyx less than $2 \mathrm{~mm}$. broad.

I. $P$. angustifolia.

Ł. P. minor.

r. Philotria angustifolia (Muh1.) Britton. In ponds and slow-flowing water from N. Y. to Sask., Ky, and Nev.-Alt. 4000-6500 ft.-Lee's Lake, Ft. Collins.

z. Philotria minor (Engelm.) Small. In ponds and slow-flowing streams from Me. to Minn., Wyo., Tenn. and Colo.-Alt. 4000-6000 ft.-Rio Grande; Alamosa; Lee's Lake.

\section{Order I3. POALES.}

Leaves 2-ranked; their sheath with their margins not united; stem mostly hollow; fruit a grain.

Fam. I8. POACEAE.

Leaves 3-ranked; their sheath with united margins; stem solid; fruit an achene.

Fam. I9. CYPERACEAE.

\section{Family I8. POACEAE R. Br. Grass Family.}

Spikelets falling from the pedicles entire, naked or enclosed in bristles or burlike involucres, I-flowered, or if 2 -flowered the lower flower staminate; no upper empty glumes; rachilla not extending above the upper glume.

Spikelets round or somewhat compressed dorsally; empty glumes manifest; hilum punctiform.

Flowering glume and palet hyaline, thin, much more delicate in texture than the empty glumes.

Spikelets in pairs, one sessile and the other pedicellate.

Spikelets not in pairs (Alopecurus, Polypogon, Cinna, etc.).

Tribe I. ANDROPOGONEAE.

Tribe 6. Agrostideae.

Flowering glume, at least that of the perfect flower, similar in texture to the empty glumes, or thicker and firmer, never hyaline and thin.

Flowering glume and palet membranous; the first glume usually larger than the rest.

Tribe 2. ZOYSIEAE.

Flowering glume and palet chartaceous to coriaceous, very different in color and appearance from the remaining glumes. Tribe 3. PanicEaE.

Spikelets much compressed laterally; empty glumes none or rudimentary; hilum linear.

Tribe 4. ORYzeAE.

Spikelets with the empty glumes persistent, the rachilla articulated above them, I-many-flowered; frequently the upper glumes are empty; rachilla often produced beyond the upper glume.

Spikelets borne in an open or spike-like panicle or raceme, usually upon distinct pedicels.

Spikelets I-flowered.

Empty glumes 4; palet I-nerved. Tribe 5. Phalarideae.

Empty glumes 2, rarely $\mathrm{I}$; palet 2 -nerved (except in Cinna).

Spikelets 2-many-flowered.

Tribe 6. Agrostideae.

Flowering glumes usually shorter than the empty glumes; the awn dorsal and usually bent.

Tribe 7. Aveneas.

Flowering glumes usually longer than the empty ones; the awn terminal and straight (rarely dorsal in Bromus) or none.

Tribe 9. Festuceae. 
Spikelets in two rows sessile or nearly so.

Spikelets on one side of the continuous axis, forming one-sided spikes. Tribe 8. Chlorideaz.

Spikelets alternately on opposite sides of the axis, which is often articulated. Tribe Io. Hordeaz.

\section{TRIBE 1. ANDROPOGONEAE.}

Racemes singly disposed; apex of the rachis-internodes a translucent cup-shaped appendage.

I. SCHIZACH YRIUM.

Racemes disposed in pairs or more; apex of the rachis-internodes not appendaged. Rachis-internodes and pedicels sulcate, the median portion translucent, the margins thickened.

2. AMPHILOPHIS.

Rachis-internodes not sulcate.

Some or all of the racemes sessile.

3. Andropogon.

All of the racemes more or less peduncled.

Pedicellate spikelets wanting.

4. Sorghastrum.

Pedicellate spikelets present and usually staminate.

5. SORGHUM.

Only one genus represented.

TRIBE ¿. ZOYSIEAE.

TRIBE 3. PANICEAE.

Spikelets naked, not involucrate.

Empty glumes 2 .

Rachis produced beyond the upper spikelet; spikelets narrow.

- Rachis not so produced; spikelets globose.

37. Spartina.

mpty glumes 3 .

38. BeCKMANNIA.

Empty glumes not awned.

Spikelets in very slender I-sided racemes, which are usually whorled or approximate.

Spikelets in panicles or panicled racemes.

Spikeles lanceolate, acuminate, long-hairy.

7. SYNTHERISMA.

Spikelets orbicular or lanceolate; if the latter, then glabrous.

Empty glumes awned or awn-pointed.

9. Panicum.

ikelets involucrate.

Involucre of numerous bristles.

Involucre of two spine-bearing valves.

I0. ECHinOCHLOA.

II. Chaetochloa.

12. Cenchrus.

TrIBE 4. ORYZEAE.

Spikelets perfect; empty glumes wanting or rarely rudimentary.

13. Homalocenchrus.

Tribe 5. PHALARIDEAE.

Third and fourth glumes empty, awnless.

Third and fourth glumes enclosing staminate flowers.

I4. Phalaris.

I5. Savastana.

Tribe 6. AGROSTIDEAE.

Flowering glumes indurate when mature and very closely embracing the grain, or at least firmer than the empty glumes.

Spikelets all perfect not in pairs.

Flowering glume 3 -awned.

Flowering glume $\mathrm{x}$-awned.

Awn twisted and bent.

Awn not twisted.

r6. ARISTIDA.

I 7. StIPA. 
Flowering glumes broad; awn deciduous.

Flowering glumes glabrous, or pubescent with short appressed hairs.

I8. ORYZOPSIS.

Flowering glumes pubescent with long, silky hairs much exceeding the glume.

I9. ERIOCOMA.

Flowering glumes narrow; glabrous or with short, appressed hairs; the awn persistent. 20. MuHLen Bergia.

Spikelets in pairs, one perfect and the other staminate or sterile, in a spikelike panicle.

2I. LyCURUS.

Flowering glumes usually hyaline or membranaceous at maturity; at least more delicate than the empty ones; grains loosely enclosed.

Stigma, sub-plumose ( $i$. e., with short hairs all around), projecting from the apex of the nearly closed glumes.

Inflorescence spike-like.

Rachilla of the spikelets articulated above the empty glumes, which are therefore persistent. 22. PHLEUM.

Rachilla of the spikelets articulated below the empty glumes, hence the spikelets deciduous entire.

Inflorescence an open small panicle; dwarf arctic-alpine plant.

24. PHIPPSIA.

Stigma plumose, profecting from the sides of the spikelets; inflorescence an open or spike-like panicle.

Grain not permanently enclosed in the flowering scale and palet; pericarp opening readily at maturity.

Flowering glumes long-hairy on the veins.

Flowering glumes not long-hairy on the veins.

25. BlepharineURON.

26. Sporobulus.

Grain permanently enclosed in the flowering glume and the palet; pericarp adherent.

Spikelets readily falling off entire when mature.

Spikelets with the empty scaies at least persistent.

Palet $\mathrm{I}$-nerved and I-keeled; stamen I.

27. Polypogon.

Palet 2-nerved and 2-keeled or sometimes wanting; stamen 3 .

Flowering glumes naked at the base. 29. Agrostis.

Flowering glumes with long hairs at the base.

Flowering glume and palet thin-membranous. 30. Calamagrostis.

Flowering glume and palet chartaceous. 3I. Calamovilfa.

Tribe 7. AVENEAE.

Awn of the flowering glumes inserted dorsally below the teeth.

Grain free, unfurrowed; spikelets less than I cm. long.

Flowering glumes erose-toothed or shortly z-lobed at the apex.

32. Deschampsia.

Flowering glumes 2-cleft or deeply 2-toothed at the apex; teeth awn-pointed. Awn twisted and bent. 33 . Trisetum.

Awn if present not twisted, straight.

34. GRAPHEPHORUM.

Grain furrowed, adherent to the glumes; spikelets exceeding $\mathrm{I} \mathrm{cm}$. in length.

Ovary not crowned by a villous appendage. 35. Avena.

Ovary crowned by a villous appendage (awned species of)

Awn of the flowering glumes inserted between the teeth. 36. DantHonIA.

TRIBE 8. CHLORIDEAE.

Spikelets with perfect flowers.

Spikelets with I (rarely 2 ) perfect flowers.

Spikelets deciduous as a whole; rachis articulated below the empty glumes. Rhachis produced above the upper spikelet; spikelets narrow.

37. Spartina.

Rhachis not produced beyond the upper spikelet; spikelets globose.

38. BECKMANNIA. 
Spikelets with at least the empty glumes persistent.

Glumes above the perfect flower none; spikes digitate, very slender.

Glumes above the perfect flower I-several; spikes scattered.

39. Schedonardus.

Spikes $\mathrm{I}-4$, rarely more; spikelets 25 or more.

40. Bouteloua.

Spikes numerous, Iz or more; spikelets few, less than 12.

Spikelets with $2-3$ perfect flowers; spikelets alternate.

4I. Atheropogon.

Spikelets dioecious; those of the two sexes very unlike.

42. LeptochloA.

43. Bulbilis.

Tribe 9. FESTUCEAE.

Flowering glumes, at least of the pistillate spikelets, 3 -lobed and 3 -awned; plant dioecious.

Flowering glumes entire or at most 2-lobed.

44. Scleropogon.

Hairs on the rachilla or flowering glume very long and enclosing the latter.

45. Phragmites.

Hairs, if any, on the rachilla and the flowering glume shorter than the glume.

Stigmas barbellate on elongated styles; spikelets in threes in the axils of spinescent leaves.

Stigmas plumose, sessile or on short styles.

46. Munroa.

Flowering glumes I--3-nerved.

Lateral nerves of the flowering glumes hairy.

Flowering glumes deeply 2 -lobed.

Internodes of the rachilla long, often half as long as the flowering glume; plants without stolons.

47. Triplasis.

Internodes of the rachilla short, many times shorter than the glumes; plants with long, arching stolons.

48. Dasyochloa.

Flowering glume entire or slightly 2 -lobed; internodes of the rachilla short.

Inflorescence a short congested raceme; leaf-blades with thick cartilaginous margins.

49. ERIONEURON.

Inflorescence a panicle; leaf-blades not with cartilaginous margins. Panicle simple or compound; the spikelets on pedicels of varying length. 50. Tridens.

Panicles composed of long branches, along which the appressed spikelets are arranged on short pedicels. 5I. DipLachLE.

Lateral nerves of the flowering giumes glabrous.

Callus of the flowering glumes copiously pubescent with long hairs; panicle open.

Callus of the flowering glumes glabrous. 52. REDFIELDIA.

Second empty glume similar to the first or nearly so.

Panicle narrow, dense and spike-like, shining; its branches erect.

Panicle open; its branches spreading.

53. KOELERIA.

Rachilla continuous (except in E. major); flowering glume deciduous; palet persistent; plants of dry soil.

54. ERagrostis.

Rachilla articulated; flowering giumes and palet both deciduous with the rachilla-internodes; water plants with 2-flowered spikelets.

55. Catabrosa.

Second empty glume very unlike the first one, broad at the summit.

Flowering glumes 5 -many-nerved. 56. EATONIA.

Spikelets with two or more of the upper glumes empty, broad and enfolding each other.

57. Melica.

Spikelets with upper glumes flower-bearing or narrow and abortive.

Stigmas placed at or near the apex of the ovary.

Spikelets borne in one-sided fascicles which are arranged in a glomerate or interrupted panicle; flowering glumes herbaceous.

58. Dactylis. 
Spikelets borne in panicles of racemes.

Glumes more or less compressed and keeled.

Spikelets cordate, large.

Spikelets not cordate.

59. Briza,

Plants dioecious; flowering glume of the pistillate spikelets coriaceous; palet strongly 2 -keeled and serrate on the margin.

6o. Distichlis.

Plants with perfect flowers or in some species of Poa dioecious; spikelets all alike; flowering glume thin; palet ciliate or smooth on the margin

Flowering glumes scarious-margined; rachis glabrous or with webby hairs.

6I. Poa.

Flowering glumes membranous, not scarious-margined; rachis with stiff hairs, extending into a hairy appendage.

Glumes rounded on the back, at least below.

34. GRAPHEPHORUM.

Flowering glumes obtuse or acutish and scarious at the apex, usually toothed.

Flowering glumes distinctly $5-7$-nerved; style present.

Flowering glumes obscurely 5-nerved; style none.

62. Panicularia.

63. Puccinellia.

Flowering glumes acute, pointed or more commonly awned at the apex.

64. Festuca.

Stigmas plainly arising below the apex of the ovary which is tipped by a hairy cushion.

65. Bromus.

\section{TRIBE IO. HORDEAE.}

Spikelets usually single at the nodes of the rachis.

Empty scales broad, with their sides turned towards the rachis.

Empty glumes with their back turned to the rachis.

66. AgROPYRON. 70. Lolium.

Spikelets 2-6 at each joint of the rachis, or if solitary the empty glumes arranged obliquely to the rachis.

Spikelets I-flowered or with a rudimentary second flower. 67. Hordeum.

Spikelets 2-many-flowered.

Rachis of the spikes articulated, readily breaking up into joints.

Rachis of the spikes continuous, not breaking up into joints.

68. Sitanion.

69. Elymus.

\section{Tribe I. ANDROPOGONEAE.}

1. SCHIZACHYRIUM Nees. Bunch-GRAss, Broom-grass.

I. Schizachyrium scoparium (Michx.) Nash. (Andopogon scoparium Michx.) On sandy or dry gravelly hills from N. B. to Sask., Fla. and Tex.Alt. 4000-7500 ft.-Near Boulder; Cheyenne Mountain; Engelmann Cañon; New Windsor, Weld Co.; Royal Gorge; La Porte, Tobe Miller's ranch; Poudre Cañon; Ft. Collins.

\section{AMPHILOPHIS Nash.}

1. Amphilophis Torreyanus (Steud.) Nash. (Andropogon saccharoides of Coult. Man.; not Sw.) In dry soil from Mo. to Colo., Tex. and Ariz.; also in Mex.-Alt. 4000-5500 ft.-Cañon City. 


\section{ANDROPOGON L. BeARD-grass, Blue-Stem.}

Fourth glume of the sessile spikelet with a long geniculate awn, more or less spiral at the base.

Outer two glumes of the sessile spikelet more or less hispidulous all over; hairs on the rachis-internodes usually $2 \mathrm{~mm}$. or less long. 1. A. furcatus.

Outer two glumes of the sessile spikelet smooth or nearly so, except on the nerves; hairs of the rachis-internodes $3-4 \mathrm{~mm}$. long. 2. A. chrysocomus.

Fourth glume of the sessile spikelet awnless or with a short, straight, untwisted awn. 3. A. Hallii.

1. Andropogon furcatus Muhl. In meadows from Me. to Sask., Fla. and Tex.-Alt. 4000-8000 ft.-Near Boulder; La Veta; Golden; West Dry Creek, Larimer Co.; Manitou; Colorado Springs; Tobe Miller's ranch, near La Porte; Ft. Collins.

2. Andropogon chrysocomus Nash. In dry meadows from Neb. to Colo, Kans. and Tex.-Alt. $4000-8000 \mathrm{ft}$.-La Veta; on the plains.

3. Andropogon Hallii Hack. In sandy soil from Neb. to Mont., Kans. and Mex.-Exact locality not given.

\section{SORGHASTRUM Nash. Indian Grass.}

I. Sorghastrum nutans (L.) Nash. (Chrysopogon nutans Benth.) In dry soil from Ont. to Man., Fla. and Ariz.-Alt. 4000-6000 ft.-Near Boulder; New Windsor, Weld Co.; Cañon City; Tobe Miller's ranch, near La Porte; Ft. Collins.

\section{SORghum Pers. Johnson Grass, Sugar Corn.}

1. Sorghum halapense (L.) Pers. Cultivated for fodder and occasionally escaped.-Rocky Ford.

\section{Tribe 2. ZOYSIEAE.}

\section{6. hilaria H. B. K. Mesquite, Black Grama.}

Outer glumes of the spikelets euneate, awnless; the nerves strongly diverging.

Outer glumes linear or oblong, awned; the nerves parallel.

I. H. mutica.

2. H. Jamesii.

I. Hilaria mutica (Buckl.) Benth. On dry plains from southern Colo. to Tex. and Ariz.-Reported from Colorado, but doubtful.

2. Hilaria Jämesii (Torr.) Benth. Hillsides and gulches of the mesas from Wyo. to Nev., Tex, and N. Mex.-Alt. 4000-6000 ft.-Deer Run; mesas near Pueblo; Arboles; Mancos; Hotchkiss, Delta Co.

\section{Tribe 3. PANICEAE.}

\section{SYNTHERISMA Walt. Crab-grass.}

Pedicels terete or nearly so, sparingly if at all hispidulous; lower sheath glabrous. Pedicels sharply 3 -angled; the angles strongly hispidulous; as are also the sheaths. 2. S. sanguinale. 
I. Syntherisma humifusum (Pers.) Rydb. On roadsides, in old fields and waste places, introduced from the Old World and established from N. S. to Mont. and Colo. and Fla.-Alt. 4000-9000 ft.-Georgetown; Ft. Collins.

2. Syntherisma sanguinale (L.) Dulac. (Panicum sanguinale L.) In lawns, cultivated ground and waste places; introduced from the Old World and established from Mass. to Neb., Fla. and Calif.-Alt. about $5000 \mathrm{ft.}-$ Boulder; Cañon City; Ft. Collins.

\section{TRICHACHNE Nees.}

I. Trichachne saccharatum (Buckley) Nash. On dry hillsides from Colo, to western Tex., Ariz. and Mex.-Alt. up to 8500 ft.-Cañon City; Fremont Co.

9. Panicum L. Panic-grass, Witch-grass, Switch-grass, Millet.

Basal leaf-blades long and narrow; spikelets lanceolate to ovate, acute to acuminate.

Annual.

Perennial with long, scaly root-stock.

r. P. capillare.

z. $P$. virgatum.

Basal leaf-blades ovate to lanceolate; spikelets elliptic to ovate or obovate, obtuse.

Spikelets less than $2 \mathrm{~mm}$. long.

Spikelets more than $2 \mathrm{~mm}$. long.

3. P. unciphyllum.

4. P. Scribnerianum,

I. Panicum capillare L. In sandy soil and waste places from S. Dak. to B. C., N. M. and Calif.-Alt. 4000-9500 ft.-Black Cañon; Ft. Collins; Pike's Peak; Grand Junction; near Boulder; Cañon City; Colorado Springs; Graymont.

2. Panicum virgatum $\mathrm{L}$. In meadows and on river-banks from $\mathrm{Me}$. to Ass., Fla. and Ariz.-Alt. $4000-7500$ ft.-Ft. Collins; Golden; Trimble Springs; New Windsor, Weld Co.; near Boulder; La Veta; Tobe Miller's ranch.

3. Panicum unciphyllum Trin. ( $P$. pubescens and $P$. dichotomum of Coult. Man.) In dry or sandy soil from Me. to B. C., Ga. and Ariz.-Exact locality not given.

4. Panicum Scribnerianum Nash. ( $P$. scoparium of Coult. Man.; not Lam.) In meadows from Me. to B. C., Va., Ariz. and Ore.-Alt. 4000-6000 ft.-Foot-hills, Larimer Co.; Palmer Lake; Brantly Cañon, Las Animas Co.; Boulder.

10. ECHINOChLOA Beauv. Barnyard-Grass, Cockspur-grass.

I. Echinochloa Crus-galli (L.) Beauv. (Panicum Crus-galli L.) In sandy or alkaline soil, waste places and old fields.-Alt. $4000-5500$ ft.-Golden; Grand Junction; Dry Creek, Larimer Co.; Cañon City.

Echinochloa Crus-galli mutica is a variety with short awn.-Golden; Tobe Miller's ranch, near La Porte; Ft. Collins.

11. Chaetochloa Scribn. Fox-tail Grass, Italian Millet, Hungarian Grass.

Inflorescence with the spikelets racemosely arranged; bristles $5^{-16}$ at the base of each spikelet, involucrate, tawny-orange. $\quad$ r. C. glauca.

Inflorescence with the spikelets in clusters or on branches; bristles $I-3$ at the base of each spikelet, not involucrate. 
Second glume of the spikelet as long as the flowering glume or very nearly so ; annuals.

Panicle usually I cm. thick or less; bristles commonly green; spikelets about $2 \mathrm{~mm}$. long. 2. C. viridis.

Panicle usually $\mathrm{I}-3 \mathrm{~cm}$. thick; bristles usually purple; spikelets $2.5-3 \mathrm{~mm}$. long.

3. C. italica.

Second glume manifestly shorter than the flowering glume; perennial.

4. C. composita.

x. Chaetochloa glauca (L.) Scribn. (Setaria glanca Beauv.) YeLLow Fox-rAIL. In waste places and cultivated grounds from Vt. to Man., Fla. and Tex.-Alt. up to $5000 \mathrm{ft}$ - - Ft. Collins.

2. Chaetochloa viridis (L.) Scribn. (Setaria viridis Beauv.) Green FoxraIl. In cultivated ground and waste places from Me. to Wash., Fla. and Calif.-Alt. 4000-6000 ft.-Near Boulder; Idaho Springs; Ft. Collins; Granada.

3. Chaetochloa italica (L.) Scribn. (Setaria italica Kunth.) Italian Mirlet, Hungarian Grass. Cultivated and escaped in fields and waste places from Que. to Minn., Fla. and Colo.-Grass station, Ft. Collins.

4. Chaetochloa composita (H. B. K.) Scribn. In dry soil from Tex. to Colo. and Ariz.; also in Mex.-Alt. 4000-6000 ft.-Cañon City.

i2. Cenchrus L. Sand-Bur, Sand-Spur, Cock-Spur, Bur-Grass.

1. Cenchrus tribuloides $\mathrm{L}$. In sandy soil from Me. to Minn., Fla. and Tex. -Alt. 4000-6500 ft.-Near Boulder; Ft. Collins; Cañon City; Colorado Springs.

Tribe 4. ORYZEAE.

I3. homalocenchrus Mieg. Rice Cut-Grass, Catch-fly Grass.

1. Homalocenchrus oryzoides (L.) Poll. In wet places and swamps from N. Sc. to Wash., Fla. and Calif.-Alt. $4000-5500 \mathrm{ft} .-\mathrm{New}$ Windsor, Weld Co.; Cañon City; river-flats east of Ft. Collins.

\section{Tribe 5. PHALARIEAE.}

14. PHALARIS L. Canary-grass.

Outer glumes not winged; inflorescence a narrow panicle. I. $P$, arundinacea. Outer glumes winged; inflorescence a spike or spike-like panicle.

Spikelets narrow; third and fourth glumes much reduced; blade subulate, hairy. 2. $P$. caroliniana.

Spikelets broad, third and fourth glumes thin, membranous; blade lanceolate, glabrous or sparingly hairy. 3. P. canariensis.

i. Phalaris arundinacea L. In swamp and wet meadows from N. Sc. to B. C., N. J. and Nev. Also in Europe and Asia.-Alt. 4000-9000 ft.-Georgetown; Gunnison; New Windsor, Weld Co.; Fort Collins; Hamor's Lake; Table Rock.

2. Phalaris caroliniana Walt. In wet soil from S. C. to Calif., Fla. and Mex.-Brantly Cañon, Las Animas Co. 
3. Phalaris canariensis L. Introduced from Europe and Africa; in waste places from N. S. to S. D., Va. and Colo.-Alt. up to $8500 \mathrm{ft}$.-Gunnison; Colorado Springs.

5. Savastana. Holy Grass, Vanilla Grass.

r. Savastana odorata (L.) Scribn. (Hierochloe borealis R. \& S.) Among bushes and on banks from Lab. to Alaska, N. J. and Ariz.-Alt. 6500-8500 ft.-Stove Prairie, Larimer Co.; West Cliff; South Park; along the Conejos River, north of Antonito.

\section{Tribe 6. AGROSTIDEAE.}

\section{i6. ARISTIDA L. Poverty Grass, Wire Grass.}

Spikelets crowded, 4-6 on the short panicle-branches, which are spikelet-bearing to the base or nearly so. 1. A. fasciculata.

Spikelets not crowded, usually I-3, or if more the branches of the panicle or their divisions with a long, naked base

Second glume of the spikelet $1.5 \mathrm{~cm}$. long or less, usually equalling or slightly exceeding the flowering glume. $\quad$ 2. A. Fendleriana.

Second glume of the spikelet $2 \mathrm{~cm}$. long, from more than $1 / 2$ longer than to nearly twice as long as the flowering glume. 3 . Aongiseta.

I. Aristida fasciculata Torr. In dry soil from Kans. to Calif. and Tex.; also in Mex.-Alt. up to $5500 \mathrm{ft}$-Cañon City.

z. Aristida Fendleriana Steud. ( $A$. purpurea Coult.; not Nutt.) In dry sandy soil from S. D. to Mont., Tex. and Calif.-Alt. 4000-8500 ft.-Ios Pinos; Buena Vista; South Park; Salida, Chaffee Co.

3. Aristida longiseta Steud. In dry soil from Ill. to S. D., Wash., Tex. and Mex.-Alt. 4000-8500 ft.-Near Boulder; Trail Glen; New Windsor, Weld Co.; mountains between Sunshine and Ward; Arboles; Durango; Ft. Collins; Colorado Springs; Cucharas Valley; Denver; Pueblo; foot-hills, Larimer Co.; Palisades; Cañon City.

\section{I7. Stipa L. Porcupine-grass, OAt-grass, Wild OAts.}

Outer glumes of the spikelet $2 \mathrm{~cm}$. long or more.

Awn plumose.

Awn not plumose.

I. S. neo-mexicana.

Base of panicle usually included in upper sheaths; flowering scale 8-12 mm. long; awn slender and curled above. 2. S. comata.

Base of panicle exserted; flowering scale over Iz mm. long; awn straight above or nearly so.

Flowering scales $\mathrm{I} 2-\mathrm{I} 5 \mathrm{~mm}$. long.

Flowering scales $20-25 \mathrm{~mm}$. long.

Outer glumes of the spikelets $1.5 \mathrm{~cm}$. long or less.

3. S. Treedyi.

4. S. spartea.

Panicle loose and open.

Awn plumose; panicle-branches ascending.

5. S. Porteri.

Awn not plumose; panicle-branches diverging or reflexed at maturity.

Panicle dense and spike-like.

6. S. Richardsonii.

Empty glumes scarious or hyaline, the nerves hence prominent.

Flowering glumes about $5 \mathrm{~mm}$. long, long-hairy towards the apex.

12. S. Lettermannii. 
Flowering glumes over $5 \mathrm{~mm}$. long, equally hairy throughout.

Flowering glumes 5-6 mm. long, spindle-shaped when mature; callus short.

7. S. viridula.

Flowering glumes $6-7 \mathrm{~mm}$. long, almost cylindric; callus long and pointed. $\quad$ 8. S. Nelsonii.

Empty glumes firm, thickish, membranous or herbaceous; nerves not prominent.

Flowering glumes 4-5 mm. long; leaf-blades very narrow, involute.

Flowering glumes 8-Io $\mathrm{mm}$. long; leaf-blades broad.

Panicle slender; stem low and slender.

Panicle stout and dense; stem tall and stout.

9. S. minor.

Io. S. Scribneri.

II. S. Vaseyi.

r. Stipa neo-mexicana (Thurb.) Scribn. Dry hills from Colo. to N. Mex. and Calif.-Alt. up to $6000 \mathrm{ft}$-Colorado Springs.

2. Stipa comata Trin. \& Rupr. On dry plains and hills, especially in sandy soil, from Alb. to Alaska, N. Mex. and Calif.-Alt. 4000-8500 ft.-Along the Platte River, Denver; New Windsor, Weld Co.; Mancos; Almeha; Ft. Collins; mesas opposite Grand Junction; Rist Cañon; near Narrows along Poudre River.

3. Stipa Tweedyi Scribn. Plains and valleys from Alb. to Wash., Colo. and Ariz.-Alt. 5000-I0,000 ft.-Ft. Collins; near Badito, between La Veta and Gardner; Walsenburg; Arboles; Grayback mining camps; Black Cañon of the Gunnison; Chester, Saguache Co.; Durango; Mancos; North Park; Gypsum; Rist Cañon.

4. Stipa spartea Trin. On prairies from Man. to B. C., Ills, and Colo. -Reported from Colorado Springs (Porter); South Park (Canby, Mehan); but doubtful.

5. Stipa Porteri Rydb. (S. Mongolica Porter \& Coult.; not Turcz.) Mountains of Colo.-Twin Lakes.

6. Stipa Richardsonii Link. In meadow lands and hillsides from Alb. to Mont., S. D. and Colo.-Mountains west of Laramie River, Larimer Co.

7. Stipa viriđula Trin. (S. parviflora Americana Schultes) Dry prairies and hills from Sask. to Mont., Kans. and Utah.-Alt. $4000-8500 \mathrm{ft}$.-Gato; Columbine; plains, Larimer Co.; Rist Cañon.

8. Stipa Nelsonii Scribner. Dry plains and hills from Ass. to Ida. and Colo.-Alt. 7500-ro,000 ft.-Near Boulder; hills about Box Cañon, west of Ouray; Cerro Summit; Idaho Springs; Poncha Pass; Georgetown; Durango; West Mancos Cañon; Rist Cañon; Poudre Cañon.

9. Stipa minor (Vasey) Scribn. (S. viridula minor Vasey) Dry hillsides and mountain valleys from Mont. to Utah and N. M.-Alt. 8000-12,500 ft.-North Park; Twin Lakes; Marshall Pass; Roger's; Cumbres; Colorado Springs; Robinson, Summit Co.; Long Gulch; near Chamber's Lake; Ute Pass road; along the Michigan, North Park; Anita Peak, Routt Co.

10. Stipa Scribneri Vasey. On foot-hills and mountain-sides of Colo. and N. M.-Alt. 5000-9500 ft.-Plains and foot-hills near Boulder; Trail Glen; Clear Creek Cañon, Golden; near Empire; Royal Gorge; Georgetown.

1x. Stipa Vaseyi Scribn. (S. viridula robusta Vasey.) On foot-hills and mountain-sides from Colo. to Ida., Tex. and N. M.; also in Mex.-Alt. 5000$9000 \mathrm{ft}$-Colorado Springs; New Windsor, Weld Co.; Idaho Springs; foot- 
hills, Larimer Co.; Pagosa Springs; Manitou; Twin Lakes; Hardin's ranch; Soldier Cañon; gulch west of Soldier Cañon; hills west of Dixon Cañon. r2. Stipa Lettermannii Vasey. Hills and plains from Wyo. and Ida. to Colo. and Utah.--Manitou.

\section{I8. ORYZOPSIS Michx. Mountain Rice.}

Spikelets, exclusive of awn, 2.5-4 $\mathrm{mm}$. long; leaves very slender and involute.

Outer glumes 3-5 mm. long; inflorescence very narrow with short, erect branches.

I. O. exigua.

Outer glumes $2.5 \mathrm{~mm}$. long; inflorescence at length open with long, often spreading or reflexed branches.

2. O. micrantha.

Spikelets, exclusive of the awn, 6-8 mm. long; leaves broad and often flat.

3. O. asperifolia.

1. Oryzopsis exigua Thurber. On hillsides from Mont. to Wash., Colo. and Ore.-Alt. about 8500 ft.-Pearl.

2. Oryzopsis micrantha (Trin. \& Rup.) Thurber. On hillsides and among bushes, from Ass. to Mont., Neb., N. M. and Ariz.-Alt. 4000-8500 ft.-Estes Park; near Badito, between La Veta and Gardner; Georgetown; Arboles; Idaho Springs; Durango; Glen Eyrie; Walsenburg; Roaring Fork, Larimer Co.

3. Oryzopsis asperifolia Michx. In woods from N. Sc. to B. C., Pa. and N. M.-Alt, up to $9000 \mathrm{ft}$.-Veta Pass.

\section{I9. ERIOCOMA Nutt.}

Panicle open, dichotomously branched with divergent branches. I. O. cuspidata. Panicle narrow, with few spikelets on short, erect branches.

z. O. Webberi.

I. Eriocoma cuspidata Nutt. (Oryzopsis cuspidata Benth.) On dry barren plains, cañons and sand-hills from Sask. to Wash., Tex. and Calif.; also Mex.-Alt. 4000-9500 ft.-Grand Junction; Black Cañon; Buena Vista; New Windsor, Weld Co.; Arboles; Pueblo; Fort Collins; Mancos; along Platte River, Denver; Sangre de Cristo Creek; river bluffs north of La Veta; Walsenburg; Howe's Gulch; Cherokee Hill; hills about Trinidad; Dixon Cañon; near Fork's Hotel, Manitou; Middle Park.

2. Eriocoma Webberi Thurber. On desert lands from western Colo, to Nev. and Calif.-Alt. up to $5500 \mathrm{ft}$.--Grand Junction.

\section{MUHLENBERGIA Schreb.}

Panicle contracted, narrow, spike-like, the short branches rarely spreading.

Empty glumes awl-shaped; leafy and branched plants, with long root-stocks covered by imbricated scales.

Flowering glumes not awned, basal hairs not equalling the flowering glume. Empty glumes about equalling the flowering glume in length, sharp-pointed, about $3 \mathrm{~mm}$. long.

I. M. mexicana.

Empty glumes exceeding the flowering glume, generally twice as long, awned, about $5 \mathrm{~mm}$. long.

2. $M$. racemosa.

Flowering glumes distinctly awned; basal hairs equalling the flowering glume. 3. $M$. comata.

Empty glumes lanceolate to ovate; plants mostly tufted and leafy at the base, only in $M$. Richardsonis with an elongated, scaly root-stock. 
Second glume not toothed or slightly so; flowering glume awnless or rarely very short-awned.

Empty glumes more than half as long as the flowering glume, acuminate. Flowering glumes scabrous, green or dark.
Panicle dense, obtuse, 5-10 $\mathrm{mm}$. wide.
4. M. Wrightii.

Panicle slender and lax, attenuate at the apex, less than $5 \mathrm{~mm}$. wide.

Flowering glumes more or less purplish, sparingly long-hairy.

5. M. cuspidata.

6. M. Thurberi.

Empty glumes less than half as long as the flowering glume, obtuse or abruptly acute.

Spikelets (excluding the awn if present) $1.5 \mathrm{~mm}$. or more long.

Plant with a strong perennial, scaly root-stock. 7. M. Richardsonis.

Plant annual; root-stock, if any, very slender.

Flowering glumes merely awn-pointed, decidedly purplish; plant $1-2$ dm. high.

Spikelets $2 \mathrm{~mm}$. long or more; inflorescence short and rather dense; stem $0.5-1 \mathrm{~mm}$. thick. 8 . M. simplex.

Spikelets about I.5 mm. long; inflorescence slender and lax; stem very slender, filiform. $9 . M$. filiformis.

Flowering glumes with a distinct awn $I / 2-I ~ m m$. long, greenish; plant $4-6 \mathrm{~cm}$. high. $\quad$ Io: $M$. aristata.

Spikelets about I $\mathrm{mm}$. Iong; plant less than $4 \mathrm{~cm}$. high, annual.

II. $M$. Wolfii.

Second glume sharply 3-5-toothed; flowering glume long-awned; awn at least $\pi / 2$ as long as the glume.

Stem 3-6 dm. high, leafy; panicle $7-12 \mathrm{~cm}$. long; awn 8-15 mm. long. 12. $M$. gracilis.

Stem I-3 high, almost naked above; panicle $5-7 \mathrm{~cm}$. long; awn I-4 mm. long.

Spikelets 3-4 mm. long; awn $2-4 \mathrm{~mm}$; leaves usually stiff.

I3. $M$. subalpina.

Spikelets about $2 \mathrm{~mm}$. long; awn I-2 $\mathrm{mm}$.; leaves filiform.

Panicle open, its branches long and spreading.

I4. M. filiculmis.

Plants densely cespitose, branched only at the base.

Secondary branches of the panicle single; basal leaves short, strongly recurved. I5. $M$. gracillima.

Secondary branches of the panicle fascicled; basal leaves not recurved.

Plants diffusely branched, prostrate.

16. $M$. pungens.

I7. $M$. Porteri.

1. Muhlenbergia mexicana (L.) Trin. In wet meadows and swamps from N. B. to N. D., N. C. and Colo.-Alt. $4000-6500 \mathrm{ft}$.-New Windsor, Weld Co.; Rocky Ford; Fort Collins; gulch west of Soldier Cañon; Tobe Miller's ranch, near La Porte.

2. Muhlenbergia racemosa (Michx.) B. S. P. (M. glomerata Trin.) In wet meadows from Newf. to B. C., N. J., N. M. and Ore.-Alt. 4000-10,000 ft.-Colorado Springs; Cheyenne Mountain; Engelmann Cañon; vicinity of Ouray; New Windsor, Weld Co.; Estes Park, Larimer Co.; Fort Collins; Black Cañon; Deer Run; Manitou; Middle Park.

3. Muhlenbergia comata (Thurb.) Benth. In wet soil, especially in sand from Mont. to Wash., Kans. and Calif.-Alt. 6500-10,000 ft.-Mountains near Pagosa Peak; Gunnison; Carlton Lake, Grand Co.; Georgetown; Gypsum Creek Cañon, Eagle Co.; Twin Lakes; Hinsdale Co.; Empire.

4. Muhlenbergia Wrightii Vasey. In wet places in the mountains of Colo., 
N. M., Ariz. and Mex.-Ait. about $7500 \mathrm{ft}$--Mountains, Larimer Co.; LaVeta.

5. Muhlenbergia cuspidata (Torr.) Rydb. (Vilfa cuspidata Torr.; Sporobolus cuspidatus Woods) On dry plains from Man. to Alb., Mo. and Colo. -Exact locality not given.

6. Muhlenbergia Thurberi Rydb. (Vilfa filiculmis Thurber; Sporobolus filiculmis Vasey; not Dewey) Cañons and dry plains from Colo. to W. Tex. and N. M.-Alt. up to $9500 \mathrm{ft}$.-Cañons west of Ouray.

7. Muhlenbergia Richardsonis (Trin.) Rydb. (Vilfa Richardsonis Trin.; Sporobolus depauperatus Coulter in part) On prairies and in meadows from Anticosti to B. C., N. M. and Calif.-Alt. 4000-900o ft.-Arboles; Georgetown; Durango; Mancos; Gunnison; Elk River, Routt Co.; Grizzly Creek; West Mancos Cañon; North Park; Mountain View, Pike's Peak; Twin Lakes; Colorado Springs; South Park; Alamosa; Como.

8. Muhlenbergia simplex (Scribn.) Rydb. (Sporobolus simplex Scribn.) In meadows and along brooks from Nebr. to Wyo. and N. Mex.-Alt. 800oIo,00o ft.-Georgetown; mountains between Sunshine and Ward; Twin Lakes; southeast of Jefferson, South Park; Crystal Park.

9. Muhlenbergia filiformis (Thurber) Rydb. (Vilfa depauperate filiformis Thurber) In wet places from Wyo. and Ore. to Colo. and Calif.-Steamboat Springs, Routt Co.

Io. Muhlenbergia aristata Rydb. (Sporobolus aristatus Rydb.) Perhaps only a variety of the preceding. In wet places from Wyo. to Utah and Colo. -Alt. about $8500 \mathrm{ft}$-CColumbine.

Ir. Muhlenbergia Wolfii (Vasey) Rydb. (Sporobolus Wolfii Vasey) On wet shores in the mountains of Colo--Alt. 9000-I0,000 ft.-South Park; Twin Lakes; Halfway House.

I2. Muhlenbergia gracilis Trin. On gravelly or sandy soil in the mountains from Tex. to Colo. and Calif.; also Mexico.-Alt. 5000-Io,000 ft.Monument Park; Georgetown; Twin Lakes; Ruxton Dell; cañon northeast side of Cheyenne Mountain; vicinity of Boulder; Como; Home; Buena Vista; Jefferson, South Park; Manitou; Colorado Springs; Cheyenne Cañon; Clear Creek; Georgetown; Bosworth's ranch, Stove Prairie; gulch west of Soldier Cañon; southeast of Jefferson, South Park; Middle Park; Ute Pass; Empire.

13. Muhlenbergia subalpina Vasey. (M. gracilis breviaristata Vasey) On dry hills from Wyo. to N. M.-Alt. about Io,00o ft.-Estes Park, Larimer Co.; Beaver Park; Twin Lakes; Ute Pass; Como.

14. Muhlenbergia filiculmis Vasey. Perhaps only a depauperate alpine form of the preceding. Mountains of Colo.-Alt. $8500 \mathrm{ft}$-G Green Mountain Falls; Como.

15. Muhlenbergia gracillima Torr. On plains and foot-hills and in cañons from Kans. to Colo., Tex. and N. M.-Alt. 4000-ro,000 ft.-Huerfano; Manitou; Fort Collins; along the Platte River, near Denver; Colorado Springs; Twin Lakes; Timnath; near Owl Cañon.

16. Muhlenbergia pungens Thurb. Blow-out Grass. On sand-hills and "bad-lands" from Neb. to Utah.-Alt. 4000-10,000 ft.-Twin Lakes; Sterling, Logan Co. 
17. Muhlenbergia Porteri Scribn. (M. Texana Thurb.; not Buck1.) On hills and plains from Tex. to Colo. and Calif.; also Mex.-Alt. about 6500 ft.-Cañon City.

21. LYCURUS $H$. B. K.

1. Lycurus pheoides H. B. K. On dry hillsides from Tex. to Colo. and Ariz.; also Mex.-Alt. 60oo-7500 ft--Garden of the Gods; Meadow Park; gulch west of Soldier Cañon.

22. PHLEUM L. Timothy.

Spikes usually elongated-cylindric; awns less than $1 / 2$ the length of the outer glumes. $\quad$ I. P. pratense. Spikes short, ovoid or oblong; awn about $1 / 2$ the length of the outer glume.

2. P. alpinum.

I. Phleum pratense L. In meadows and waste places, escaped from cultivation from N. Sc. to B. C., Fla. and Calif.-Alt. up to II,000 ft.-Pagosa Springs; Alpine Tunnel; Ruxton Park; Mancos.

2. Phleum alpinum $L$. In mountain meadows from Lab. to Alaska, N. H. and Calif.; also in northern Europe and Asia.-Alt. 8500-12,000 ft--Near Pagosa Peak; Dead Lake; Ruxton Park; mountains west of Cameron Pass; Chamber's Lake; LaPlata; Georgetown; Seven Lakes; West Indian Creek; Lake City; Robinson, Summit Co.; Gray's Peak; Beaver Creek; Boreas; Hematite; Pike's Peak.

\section{ALOPECURUS L. FoxtaIL.}

Spike elongated-cylindric, 3-7 cm. long; 4-6 mm. in diameter.

Spike oblong, 2-4 cm. lơng; 9-12 mm. in diameter.

1. A. aristulatus.

2. A. occidentalis.

r. Alopecurus aristulatus Michx. In wet meadows from Me. to Alaska, Pa. and Calif.-Alt. 4000-II,500 ft.-Wahatoya Creek; Colorado Springs; Arboles; Laramie River, Larimer Co.; Grizzly Creek; Mancos; Dead Lake; vicinity of Boulder; Manitou; Twin Lakes; South Park; Tobe Miller's ranch, near La Porte; Quimby; Barne's Camp; Spring Cañon; Soda Creek; Poudre Cañon; Hotchkiss; Table Rock; Fossil Creek; along Purgatory River, near Trinidad.

2. Alopecurus occidentalis Scribn. (A. alpinus of Coult. Man.; not L.) In wet meadows from Alb. to B. C., Colo. and Utah.-Alt. 8500-I I,000 ft.Cameron Pass; Marshall Pass.

24. PHIPPSIA R. Br.

I. Phippsia algida R. Br. In arctic-alpine localities from Greenl. to Alaska; also in Colo., arctic Europe and Asia.-Chicago Lake, near Georgetown.

\section{BLEPHARINEURON Nash.}

1. Blepharineuron tricholepis (Torr.) Nash. (Sporobolus tricholepis Torr.) Mountain valleys from Colo. to Utah, Tex. and Ariz.; also Mex.- 
Alt. 6000-12,000 ft.-Near Pagosa Peak; Ruxton Park; Mount Ouray; Montezuma; Ruxton Dell; Ribbon Lake; South Park; Colorado Springs; Minnehaha; Hinsdale Co.; Middle Park; southeast of Jefferson, South Park; Pagosa Peak.

26. SpOROBOlUS R. Br. Dropseed, Poverty-grass, Wire-Grass.

\section{Perennials.}

First glume one-half as long as the second or less; plant not with long, scaly root-stocks.

Branches of the panicle verticillate.

Branches of the panicle scattered.

Spikelets about $2 \mathrm{~mm}$. long; first glume lanceolate.

Sheath naked or sparingly ciliate at the throat; empty glumes glabrous.

I. S. argutus.

2. S. airoides.

Sheath with a conspicuous tuft of hairs at the throat; empty glumes scabrous on the keel.

Leaf-blades $6 \mathrm{~cm}$. Iong or less, widely spreading, involute; sheath pubescent with long hairs, at least towards the base.

3. S. Nealeyi.

Leaf-blades not widely spreading; sheaths glabrous, except the apex, and slightly on the margins.

Panicle usually more or less included in the sheaths; its lower branches much exceeding the upper ones. 4. S. cryptandrus.

Panicle always exserted, oblong, comparatively narrow; its lower branches but little, if any, exceeding the upper ones.

5. S. Alexuosus.

Spikelets $4.5-5 \mathrm{~mm}$. long; first glume subulate, usuaily awned.

6. S. heterolepis.

First glume almost equalling the second; plants with long, scaly root-stocks.

Annuals; empty glumes almost equal, ovate.

7. S. asperifolius.

8. S. confusus.

1. Sporobolus argutus (Nees) Kunth. On the plains from $\mathrm{Kan}$. to Colo., Tex. and Mex.; also West Indies.-Exact locality not given (Vasey).

2. Sporobolus airoides Torr. Dry prairies and river-valleys from Neb. to Tex. and Calif.-Alt. 4000-II,000 ft.-Cañon City; Marshall Pass; South Park; Mancos; Fort Collins ; Doyles; Arboles; Colorado Springs; La Porte; Palisade, Mesa Co.; Grand Junction; Alamosa; Cottonwood Creek; Gunnison.

3. Sporobolus Nealleyi Vasey. In dry places from Tex. to Colo. and $\mathrm{N}$. M.-Alt. about $7500 \mathrm{ft}$.- Vicinity of Alamosa.

4. Sporobolus cryptandrus (Torr.) Gray. In sandy soil from Mass. to Wash., Pa., Tex., Ariz. and Ore.-Alt. 4000-8000 ft.-Cañon City; Empire; Manitou; Denver; Deer Run; plains and foot-hills, near Boulder; Colorado Springs; Fort Collins; Salida, Chaffee Co.; La Veta; Georgetown; Spring Cañon; Poudre Cañon; gulch, west of Soldier Cañon.

5. Sporobolus flexuosus (Thurber) Rydb. (S. cryptandrus flexuosus Thurber.) In sandy places from 'Tex. to Nev. and Mex.-Reported from Colorado, but doubtful.

6. Sporobolus heterolepis A. Gray. On dry prairies from Que. to Sask., $\mathrm{Pa}$. and Colo.-Exact locality not given.

7. Sporobolus asperifolius (Nees \& Mey.) Thurber. On dry prairies from Ass. to B. C., Mo., Tex. and Calif.-Alt. 4000-7500 ft.-Cottonwood Creek; 
Saguache Creek; Fort Collins; Denver; Durango; vicinity of Boulder; Gunnison; Cottonwood Creek; Manitou; Grand Junction.

8. Sporobolus confusus Vasey. (S. ramulosus of Coult. Man.; not Kunth.) In wet, sandy places from Neb. to Mont., Tex. and Ariz.; also in Mex.-Alt. 4000-8500 ft.-Colorado Springs; Saguache Creek; Cimarron; Minnehaha; Ouray; Gunnison; Piedra; Buena Vista; mountains of Larimer Co.; Twin Lakes; Alamosa; vicinity of Fort Collins; Table Rock.

\section{POLYPOGON Desf. BeARD-GRASS.}

1. Polypogon monspeliensis (L.) Desf. In waste places from N. H. to B. C., S. C. and Calif.-Alt. about $5000 \mathrm{ft}$--Fort Collins; Poudre River.

28. CINNA L. WOOD REED-GRASS.

1. Cinna latifolia (Trev.) Griseb. (C. pendula Trin.) In damp woods from Newf. to B. C., N. C. and Utah.-Alt. 4000-7500 ft.-Empire; Buffalo Pass road, Routt Co.; Idaho Springs; Salida.

29. AGrostis L. Red-top, Herd-grass, Tiorin, Bent-grass, Hair-grass, TICKLE-GRASS.

Palet conspicuous, at least one-third as long as the flowering glume.

Panicle large; branches verticillate; spikelets about $3 \mathrm{~mm}$. long; stem 3-10 dm. high. I. A. alba.

Panicle small and narrow; branches scattered or in pairs; spikelets about 2 $\mathrm{mm}$. long; stem $0.6-3 \mathrm{dm}$. high.

Palet minute or wanting.

Branches of the contracted panicle short, at least some of them spikelet-bearing to the base.

3. A. asperifolia.

Branches of the panicle more slender, naked below.

Flowering glume awnless or short-awned; the awn not exceeding the spikelet.

Branches of the panicle filiform, branched far above the middle, at last divaricate or reflexed; plant usually over $3 \mathrm{dm}$. high.

Branches short, $I-3 \mathrm{~cm}$. long, ascending; plant $\mathrm{I}-3 \mathrm{dm}$. high.

5. A. tenuiculmis.

Flowering glume with a long, bent awn, which exceeds the spikelet by onehalf.

6. A. canina $L$.

r. Agrostis alba L. In wet meadows from Newf. to B. C., Fla. and Calif.; native also of Europe and cultivated.-Alt. 4000-8500 ft.-Gunnison; Golden; Fort Collins; Engelmann Cañon; Georgetown; Ouray; Twin Lakes; Manitou; gulch west of Soldier Cañon; Baxter's ranch.

z. Agrostis depressa Vasey. In wet mountain meadows and along brooks from Wyo. to Utah and Colo.-Alt. 9000-II,000 ft.-Georgetown; Beaver Creek.

3. Agrostis asperifolia Trin. (A. exarata Coulter, in part) In wet meadows from Man. to N. M. and Calif.-Alt. 4000-I0,500 ft.-Beaver Creek; near Pagosa Peak; Arboles; along the Lower Cucharas River; Twin Lakes; Fort Collins; gulch west of Soldier Cañon. 
4. Agrostis hiemalis (Walt.) B. S. P. (A. scabra Willd.) On prairies and hills, both in dry and wet soil, from Lab. to Alaska, Fla. and Calif.; also in Mex.-Alt. 4000-II,000 ft.-Vicinity of Fort Collins; Baxter's ranch; Poudre Cañon; Twin Lakes; Taylor River; about Ouray; Gunnison; North Cheyenne Cañon; Ruxton Dell; Pagosa Springs; near Pagosa Peak; near Boulder; mountains between Sunshine and Ward; Cameron Pass; Estes Park; Grand Lake; Hamor's Lake; Grizzly Creek; Georgetown; mountains, Larimer Co.; Marshall Pass; Valley and Empire; Veta Pass; Salida; Twin Lakes; South Park; Como; gulch west of Soldier Cañon; Little Beaver Creek; between Graymont and Silver Plume; Steamboat Springs; RabbitEar Range.

5. Agrostis tenuiculmis Nash. (A. tennis Vasey) In mountain meadows from Mont. to Wash., Colo. and Calif.-Alt. Io,000-II,500 ft.-South Park; Mt. Elbert; Dead Lake; near Pagosa Peak; summit of North Park Range. Routt Co.

6. Agrostis canina L. Along mountain brooks from Newf. and Alaska to Pa., Colo. and Nev.-Alt. about gooo ft.-Silver Plume.

30. Calamagrostis Adans. Reed-Grass, Blue-joint.

Awn strongly geniculate, exserted, longer than the empty glumes; callus-hairs much shorter than the flowering glume; panicle dense and spike-like.

r. C. purpurascens.

Awn straight or nearly so, included; callus-hairs not much shorter than the flowering glume (except in C. scopulorum).

Panicle open, the lower branches wide-spreading and often drooping; leafblades flat; callus-hairs copious, almost equalling the glume.

Spikelets 4-6 mm. long; empty glumes narrow, sharply acuminate; awn stout, attached below the middle, considerably exceeding the glume.

2. C. Langsdorffi.

Spikelets 3-4 mm. long, awn attached near the middle, equalling or slightly exceeding the glume.

3. C. canadensis.

Panicle more or less contracted, branches ascending.

Leaf-blades flat or nearly so.

Callus-hairs copious, $2 / 3$ as long as the flowering glume or longer.

Plant cespitose; empty glumes acute. $\quad 9 . C$. hyperborea elongata.

Plant not cespitose; empty glumes long-acuminate.

Callus-hairs sparse, $I / 2$ as long as the glume. 5. C. scopulorim.

Leaf-blades involute.

Culm and the narrow leaf-blades soft, not rigid; plant not cespitose.

Spikelets $2.5-4 \mathrm{~mm}$. long; empty glumes thin, sharp-acuminate.

6. C. neglecta.

Spikelets $2 \mathrm{~mm}$. long; empty glumes thickish, barely acutish.

7. C. micrantha.

Culm and the usually broader leaf-blades hard, more or less rigid.

Plant not cespitose, tall; panicle very long. 8. C. inexpansa.

Plant strongly cespitose; panicle short and dense.

9. C. hyperborea.

I. Calamagrostis purpurascens $\mathrm{R}$. Br. (Deyeuxia sylvatica Vasey; not DC.) On dry, stony hills and alpine table-lands from Greenl. to Alaska, Colo. and Calif.-Alt. 6500-I2,500 ft.-Silver Plume; mountains above Idaho Springs; mountains between Sunshine and Ward; South Park; Mt. Ouray; Mt. Garfield; Georgetown; Front Range, Larimer Co.; Webster; Pike's Peak; 
Stove Prairie Hill, Larimer Co.; mountains of Estes Park; Buena Vista; Clear Creek; near Chambers' Lake; Como; above Beaver Creek; Happy Hollow; Devil's Causeway; Graymont.

2. Calamagrostis Langsdorfii (Link.) Trin. (D. Langsdorffi Trin.) In wet meadows and open woods from Greenl. to Alaska, N. C. and Calif.East of Laramie River, Larimer Co.

3. Calamagrostis canadensis (Michx.) Beauv. (D. Canadensis Munro.) In wet thickets and open woods; also in meadows from Lab. to B. C., N. C. and Calif.-Alt. 4000-Ir,000 ft.-Fremont Co.; Middle Park; near Pagosa Peak; Engelmann Cañon; Red Mountain, south of Ouray; Alpine Tunnel; Georgetown; Rabbit-Ear Pass; mountains and cañons, west of Palmer Lake; Estes Park; vicinity of Pike's Peak; Gunnison; Buena Vista; Veta Pass; vicinity of Ft. Collins; Table Rock; Barnes' Camp; Elk Cañon.

C. canadensis acuminata Vasey is a variety approaching the preceding species, in having larger flowers and more acuminate glumes. It has the same range as the species.-Alt. 9000-10,000 ft.-Near Pagosa Peak; Anita Peak.

4. Calamagrostis Scribneri Beal. In open marshes and wet meadows from Alb. to B. C., Colo. and Wash.-Alt. about $9000 \mathrm{ft}$.-Near Pagosa Peak.

5. Calamagrostis scopulorum M. E. Jones. Among rocks in Utah and Colo. -Alt. about 9000 ft.-Near Pagosa Peak.

6. Calamagrostis neglecta (Ehrh.) Gaertn. In open meadows from Lab. to Alaska, Me. and Colo.-Alt. 8000-900o ft.-Georgetown; Ironton Park; Twin Lakes.

7. Calamagrostis micrantha Kearney. In wet meadows from Ass. to Colo. -Alt. about $8500 \mathrm{ft}$.-Steamboat Springs.

8. Calamagrostis inexpansa A. Gray. In wet meadows and swamps from N. Y. to Ida., N. J. and Colo.-Alt. about 8000 ft.-Penn's Gulch.

9. Calamagrostis hyperborea Lange. (D. stricta Am. auth. in part.) On sandy shores and among rocks, from Greenl. to Alaska, Vt. and Calif.-Alt. 4000-8500 ft.-Clear Creek; Hamor's Lake; Georgetown; Twin Lakes.

The following varieties are recognized by Kearney:

C. hyperborea stenodes Kearney, with narrow, strongly involute leaves, narrow panicle and smaller (3-3.5 $\mathrm{mm}$. long), less scabrous empty glumes. In swamps from Ass. to Mont. and Colo.-Alamosa; South Park.

C. hyperborea elongata Kearney, with broader, often flattened, leaves and large, often interrupted, panicle. In wet meadows and swamps, especially in the plain regions, from Ont. to B. C., Colo. and Calif.-Veta Pass; Penn's Gulch; Gunnison; Fort Garland.

C. hyperborea americana (Vasey) Kearney, with shorter, merely acute, empty glumes and short dense inflorescence. In meadows and on prairies from Vt. to B. C., Colo. and Ore.-Breckenridge; Durango.

\section{Calamovilfa Hack. Reed-Grass, Sand-Grass.}

1. Calamovilfa longifolia (Hook) Hack. (Calamagrostis longifolia Hook.) On sandy shores and sand-hills, from Ont. and Man. to Ind. and Colo.-Alt. 4000-5000 ft.-Tobe Miller's ranch, near La Porte; vicinity of Fort Collins. 


\section{Tribe 7. AVENEAE.}

32. DESCHAMPSIA Beauv. HaIRGRASS.

Empty glumes not extending beyond the apex of the upper flowering glume; leaves narrow.

Empty glumes 4-5 mm. long; awn from half longer than to twice as long as the flowering glume.

Empty glumes 3-4 $\mathrm{mm}$. long.

I. D. alpicola.

Awn about half longer than the flowering glume; leaves short, almost filiform; plant 2-3 dm. high.

2. D. curtifolia.

Awn slightly if at all exceeding the flowering glume; leaves long and firm; plant usually $3-8 \mathrm{dm}$. high.

3. D. caespitosa.

Empty glumes much exceeding the upper flowering glume; leaves broad.

4. D. atropurpurea.

1. Deschampsia alpicola Rydb. (D. caespitosa alpina Vasey; not D. alpina R. \& S.) In alpine meadows and on slopes, from Colo. to southern Wyo. and Utah; a similar, if not identical, form in Alaska.-Alt. 9000-14,000 ft.-Berthoud's Pass; Twin Lakes; Pike's Peak; Silver Plume; South Park; near Pagosa Peak; East River; Seven Lakes; Mt. Ouray; Georgetown; Cache la Poudre, Larimer Co.; Tennessee Pass; Dead Lake; vicinity of Gray's Peak; Clear Creek; Cameron Pass; Gray's Peak; Ethel Peak, Larimer Co.

2. Deschampsia curtifolia Scribn. (D. brachyphylla Nash, in part.) On wet alpine slopes from Mont. to Colo.-Alt. Ir,000-I2,000 ft.-Little Kate Mine, La Plata Mountains; crater of Mt. Richtofen.

3. Deschampsia caespitosa (L.) Beauv. In wet meadows and swamps from Newf. to Alaska, N. J. and Calif.-Alt. 7500-I I,000 ft.-Twin Lakes; Georgetown; Pagosa Springs; Cache la Poudre, Larimer Co.; Hamor's Lake; North Park; Gunnison; Marshall Pass; Ruxton Park; Grizzly Creek; Steamboat Springs; Silver Plume; Pike's Peak; Como; North Park; Deadman Cañon; near Chambers' Lake; Fort Collins; Barnes' Camp; Ragged Mountains, Gunnison Co.; Hahn's Peak, Routt Co.; summit of North Park Range.

4. Deschampsia atropurpurea (Wah1.) Scheele. In alpine and subarctic meadows from Lab. to Alaska, northern N. Y. and Calif.-Alt. about I0,000 ft.-Buffalo Pass, near Divide, Routt Co.

\section{TRISETUM Pers. False OAts.}

Leaf-sheaths and blades long-hairy; upper part at the stem densely pubescent.

I. T. subspicatum.

Leaf-sheaths and blades glaborous or the lowest sheath short-pubescent, with reflexed hairs; stem glabrous or slightly scabrous in the inforescence.

Inflorescence long, dense, cylindric; lower empty glume only slightly narrower than the upper; leaf-blades not much broader than the sheaths and without conspicuous auricles.

2. T. majus.

Inflorescence lanceolate, open; lower empty glume scarcely more than half as broad as the upper; leaf-blades much broader than the sheaths and therefore with conspicuous auricles at the base.

3. T. montanum.

I. Trisetum subspicatum (L.) Beauv. (T. subspicatum molle Coult.) On mountains and hillsides from Greenl. to Alaska, N. H., Colo. and Calif.; also in northern Europe.-Alt. 10,00o-13,00o ft.-Twin Lakes; Valley Spur; Seven Lakes; Georgetown; Gray's Peak; Cameron Pass; Pike's Peak; Dead 
Lake; Windy Point; Ironton, San Juan Co.; Mt. Bartlett; Devil's Causeway; mountains above Graymont; along the Michigan, North Park; Ethel Peak, Larimer Co.

2. Trisetum majus (Vasey) Rydb. (T. subspicatum major Vasey; T. subspicatum Coult., mainly; not Beauv.) In meadows and on hillsides from Mont. to B. C., Colo. and Utah.-Alt. 8000-12,000 ft.-Below Berthoud's Pass; Middle Park; near Pagosa Peak; Mt. Baldy; Pike's Peak; Marshall Pass; Cumberland Mine; Ironton, San Juan Co; Cameron Pass; Idaho Springs; Georgetown; Cache la Poudre, Larimer Co, Upper La Plata; Seven Lakes; North Park; Trapper's Lake; near Chambers' Lake; along Michigan, North Park; Ute Pass.

3. Trisetum montanum Vasey. In moist places, especially among bushes from southern Wyo. to N. M.-Alt. 7500-I0,00o ft.-Twin Lakes; near Pagosa Peaks; vicinity of Ouray; Minnehaha; Idaho Springs; Ruxton Creek; Villa Grove, Saguache Co.; Beaver Creek; Cameron Pass.

\section{GRAPHEPHORUM Desv.}

Empty glumes equal or nearly so, $6-7 \mathrm{~mm}$. long.

Empty glumes unequal; the lower $3-4 \mathrm{~mm}$. long, the upper $4-5 \mathrm{~mm}$.

Inflorescence open; culm minutely pubescent at the nodes; rachilla short-hairy.

Inflorescence narrow; culm perfectly glabrous; rachilla long-hairy.

2. G. Shearii.

3. S. Wolfii.

I. Graphephorum muticum (Boland.) Scribn. (G. melicoides Coult, ; not Beautv.) In wet meadows from Alb. to Wash., Colo. to Calif--Alt. 9000I0,500 ft.-Near Ironton, San Juan Co.; Marshall Pass; headwaters of Pass Creek; Cumbres; Barnes' Camp; along Walton Creek; Ute Pass road; Cameron Pass.

2. Graphephorum Shearii (Scribn.) Rydb. (Trisetum argenteum Scribn.; not R. \& S.; T. Shearii Scribn.) Among rocks at an altitude of $9000 \mathrm{ft.}$ Las Animas Cañon, below Silverton.

3. Graphephorum Wolfii Vasey. ( $T$. Wolfi Vasey.) In wet places in willow thickets.-Alt. about I0,500 ft.-Twin Lakes; Cameron Pass.

\section{AVENa L. OAts, OAt-grass.}

Empty glumes shorter than the flowering glumes; panicle lax, narrow and somewhat nodding; flowering glume hairy at the base.

Empty glumes longer than the flowering glumes.

Panicle narrow and spike-like, strict; empty glumes 8-14 mm. long; flowering glumes hairy only at the base.

Plant I-I.5 dm. high; leaves strongly involute; callus of the flowering glume and prolongation of the rachilla long-hairy.

2. A. Mortoniana.

Plant 2-4 dm. high; leaves mostly flat; callus and prolongation of the rachilla short-hairy.

3. A. americana.

Panicle open; empty glume over $2 \mathrm{~cm}$. long; flowering glumes often hairy up to the base of the awn.

4. A. fatua.

1. Avena striata Michx. In woods from N. B. to B. C., Pa. and Colo.Alt. 7000-II,000 ft.-Crystal Park; mountains, Larimer Co.; Little Kate Mine, La Plata Mountains; Pennock's mountain ranch. 
2. Avena Mortoniana Scribn. On mountain tops of Colo.-Alt. 13,000I4,000 ft.-Mountains near Silver Plume; Gray's Peak; Robinson, Summit Co.; Cameron Pass; Beaver Creek; Mt. Garfield.

3. Avena americana Scribn. On ridges and hillsides from Sask. to Alb., S. D. and Colo.-Alt. about ro,00o ft.-Ruxton Dell.

4. Avena fatua L. WILD OATS. Naturalized from Europe and Asia, in grain fields from Minn. to B. C., Colo. and Calif.-Alt. about $5000 \mathrm{ft}$.-Fort Collins.

\section{DANTHONIA DC. WILD OAT-GRAss.}

Flowering glume pubescent only on the margin and at the base.

Spikelets on slender, spreading and somewhat drooping pedicels; stem leafy throughout.

1. D. californica.

Spikelet on short erect pedicels in a dense, spike-like inflorescence; stem naked above.

2. D. intermedia.

Flowering glumes hairy on the back as well as on the margins and base; inflorescence spike-like, with short, erect branches.

Empty glumes $15-20 \mathrm{~mm}$. long.

Empty glumes ro mm. or less long.

3. D. Parryi.

4. D. spicata.

I. Danthonia californica Bolander. In wet meadows from Mont. to B. C., Colo. and Calif.-Alt. 5000-I0,000 ft.--Steamboat Springs; along the Michigan, North Park; pasture, Walton Creek flats; Arapahoe Pass.

๘. Danthonia intermedia Scribn. In meadows and on mountain slopes from Alb. to B. C., Colo, and Calif.-Alt. 9000-II,500 ft.-Silverton; Red Dirt Divide, Routt Co.; Middle Park; Dead Lake; near Pagosa Peak; Ruxton Dell; Rabbit-Ear Pass; Marshall Pass.

3. Danthonia Parryi Scribn. In mountain valleys from Alb. to N. M.Alt. 8500-10,000 ft.-Twin Lakes; Empire City; South Park; Chicken Creek, west of Mt. Hesperus; Bear Creek Cañon; Georgetown; Ute Pass; Ruxton Dell; Dillon.

4. Danthonia spicata (L.) Beauv. In dry soil from Newf. to B. C., N. C., La. and Colo.-Alt. about $6500 \mathrm{ft}$-North Cheyenne Cañon.

Tribe 8. CHLORIDEAE.

37. SPARTINA Schreb. Marsh-grass, Cord-Grass.

First glume awn-pointed, equalling the third; second glume long-awned.

I. S. cynosuraides. First glume acute, shorter than the third; second glume acute.

z. S. gracilis.

I. Spartina cynosuroides (L.) Willd. In swamps and streams from N. S. to Mackenzie River, N. J., Tex. and Colo.-Alt. 4000-600o ft.-Near Boulder; Fort Collins; Tobe Miller's ranch; Poudre Cañon.

2. Spartina gracilis Trin. In saline or alkaline meadows from Sask. to B. C., Colo, and Ariz.-Alt. 4000-5500 ft.-Grand Junction; Sagauche Creek; Cañon City.

38. BECKMANNIA Host. Slough-grass.

I. Beckmannia erucaeformis (L.) Host. In swamps and wet meadows from Ont. to Alaska, Iowa, Colo. and Calif.-Alt. 4000-9000 ft-Gunnison; 
Wahatoya Creek; Middle Park; near Denver; Trimble Springs; North Park; Sangre de Cristo Creek; Saguache Creek; Fort Collins; Chambers' Lake; Larimer Co.; Fort Collins.

39. SCHedonardus Steud. Wild CRAB-Grass.

I. Schedonardus paniculatus (Nutt.) Trelease. (S. Texanus Steud.) In sandy soil, especially on river-banks from Ill. and Man. to Ass., Tex. and N. M.-Alt. 4000-6000 ft.-Vicinity of Boulder; New Windsor, Weld Co.; Fort Collins; Colorado Springs; vicinity of Pike's Peak; Arboles; Denver.

40. Bouteloua lag. Grama, Mesquit-grass.

Spikelets usually more than one; cespitose perennials.

Awns manifestly arising from between the lobes of the flowering glumes.

Awns terminating the lobes of the flowering glumes.

Stem densely villous below.

1. B. polystachya.

Stem glabrous.

Rachilla bearing the rudimentary glumes and awns glabrous; second glume strongly papillose-hispid on the keel.

3. B. hirsuta.

Rachilla bearing the rudimentary glumes and awns with a tuft of long hairs at the apex; second glume scabrous and sparingly long-ciliate on the keel.

Spikelet solitary; tufted annual.

4. B. oligostachya.

5. B. prostrata.

x. Bouteloua polystachya (Benth.) Torr. In river-valleys from Tex. to Calif.--San Juan and Mancos Valleys (Brandegee).

2. Bouteloua eriopoda Torr. In dry soil from Tex. to Calif.-San Juan Valley (Brandegee).

3. Bouteloua hirsuta Lag. On plains and prairies, especially in sandy soil, from Ill. and Minn. to S. D., Tex. and Ariz.-Alt. 4000-7000 ft.-Vicinity of Boulder; Twin Lakes; Manitou; Colorado Springs; Meadow Park.

4. Bouteloua oligostachya (Nutt.) Torr. On plains and prairies from Wis. and Man. to Ass., Miss. and Ariz.; also in Mex.-Alt. 4000-8000 ft.-Vicinity of Boulder; New Windsor, Weld Co.; Buena Vista; Fort Collins; Denver; Mancos; Durango; Fort Morgan; Georgetown; Walsenburg; Gunnison; Colorado Springs; Twin Lakes; Fort Garland; between Ft. Collins and La Porte; Alamosa; Poudre Cañon; Baxter's ranch; prairie near Long Lake; Rocky Ford.

5. Bouteloua prostrata Lag. Plains and hills from Tex. to Colo. and Ariz.; also in Mex.-Alt. 7500-8500 ft.-Colorado Springs; vicinity of Ouray; Manitou.

\section{I. ANTHEROPOGON Muhl.}

r. Antheropogon curtipendulus (Michx.) Fourn. (Bouteloua racemosa Lag.) On hillsides, in cañons and dry valleys from Ont. to N. D., N. J., Tex. and Ariz.; also in Mex.-Alt. 4000-7000 ft.-Vicinity of Boulder; Manitou; foot-hills, Larimer Co.; Meadow Park; Durango; Walsenburg; Fort Collins; Colorado Springs; gulch west of Soldier Cañon; Poudre Cañon. 
42. LEPTOCHLOA Beativ.

r. Leptochloa mucronata (Michx.) Kunth. In fields from Va. to Colo., Fla. and Calif.-Locality not given (Letterman).

\section{BULBILIS Raf. BUFFalo-Grass.}

x. Bulbilis dactyloides (Nutt.) Raf. (Buchloe dactyloides (Nutt.) Engelm.) On prairies and plains from Minn, to N. D., Wyo., Ark. and N. Mex.; also Mex.-Alt. 4000-6000 ft.-Vicinity of Boulder; New Windsor, Weld Co.; plains near Denver; Fossil Creek, Larimer Co.; Fort Collins; Quimby; Spring Cañon.

\section{Tribe 9. FESTUCEAE.}

44. SCHLEROPOGON Phillippi.

I. Schleropogon brevifolius Phillippi. On rocky ridges from Tex to Colo. and Ariz.-Alt. about $5000 \mathrm{ft}$-Pueblo.

\section{PHRAGMITES Trin. REED.}

1. Phragmites Phragmites (L.) Karst. ( $P$. communtis Trin.) In lakes and swamps from Newf. to B. C., Fla. and Calif.; also in Mex., W. Ind., Europe and Asia.-Alt. 4000-6000 ft.-Hotchkiss, Delta Co.; LaSalle; Deer Run; Loveland, Larimer Co.; along lower Cucharas River.

\section{MUNROA Torr. False Buffalo-grass.}

s. Munroa squarrosa (Nutt.) Torr. On dry plains from N. D. to Ass., Tex. and Ariz.-Alt. 4000-8500 ft.-Boulder City; Fort Collins; plains near Denver; Manitou; Black Cañon; New Windsor, Weld Co.; near Golden; Idaho Springs; Colorado Springs; Salida; valley north of Georgetown; gulch west of Soldier Cañon; Florence; Boulder; Lafayette.

47. TRIPLASIS Beauv. SAND-GRASS.

1. Triplasis purpurea (Walt.) Chapm. On sandy beaches from Ont. to Neb., Fla. and Tex.-Locality not given (Hall and Harbour).

\section{DASYOCHLOA Willd.}

1. Dasyochloa pulchella (H. B. K.) Willd. (Triodia pulchella Willd.) On hills and plains from Wyo. to Tex. and Calif.; also in Mex.-San Juan Valley (Brandegee).

\section{ERIONEURON Nash.}

1. Erioneuron pilosum (Buckley) Nash. (Triodia acuminata Benth.) In dry, gravelly soil from Kans. to Colo., Tex. and Ariz.-Alt. 4000-5500 ft.Brantly Cañon, Las Animas Co.; Delta; Grand Junction; Cañon City; Pueblo; Royal Gorge; dry mesas, 9 miles above Delta. 


\section{TRIDENS R. \& S.}

Second empty glume $\mathrm{x}$-nerved.

Second empty glume 3-5-nerved.

1. T. muticus.

2. T. elongatus.

1. Tridens muticus (Torr.) Nash. (Triodia mutica Benth.) On dry hills from Tex. to Colo. and Ariz.; also northern Mex.-Cañon City (Porter).

2. Tridens elongatus (Buckley) Nash. On plains and prairies from Tex. to Colo. and Ariz.-Alt. about $5500 \mathrm{ft}$-Pueblo; Cañon City.

\section{I. DIPLACHNE Beauv.}

1. Diplachne acuminata Nash. In wet places from Ark. to Neb. and Colo. -Alt. 4000-5500 ft.-New Windsor, Weld Co.; Cañon City.

\section{REDFIELDIA Vasey.}

I. Redfieldia flexuosa (Thurb.) Vasey. (Graphephorum flexuosum Thurb.) In sand-hills from S. D. to Ind. Terr. and Tex.-Alt. $4000-5500 \mathrm{ft}$ - - Sterling, Logan Co.; Fort Garland.

\section{KOEleria Pers. Prairie-grass, June-grass.}

1. Koeleria cristata (L.) Pers. On prairies and plains from Ont. to B. C., $\mathrm{Pa}$, and Calif. A very variable species and perhaps a composite one. The form common in the Rocky Mountain region has narrow, involute, glabrous or puberulent leaves and narrow panicle, and has been described under the name $K$. nitida Nutt.-Alt. 4000-10,000 ft.-Middle Park; Pagosa Springs; vicinity of Boulder; foot-hills, Larimer Co.; Arboles; Gunnison; Sangre de Cristo Creek; Golden; Twin Lakes; Mancos; Crystal Park; Minnehaha; Cimarron; vicinity of Ouray; near Pike's Peak; Stove Prairie Hill, Larimer Co.; La Veta; Manitou; North Park; Happy Hollow; Hotchkiss; Horsetooth Gulch; Table Rock; Manitou Junction; Dixon Cañon; hills about Dolores; dry hills along Trail Creek; Como; Grizzly Creek; Fort Collins; Hardin's ranch; Willow Creek, Routt Co.

54. ERAGROSTIS Beauv. Siunk-GRASS, Stink-Grass.

Culm often decumbent at the base, much branched, I-5 $\mathrm{dm}$. high; annuals; panicle green.

Spikelets $1.5 \mathrm{~mm}$. or less wide; palet remaining attached to the continuous rachis, after the flowering glume has fallen.

Spikelets $2.5-5 \mathrm{~mm}$. wide; palet falling with the flowering glume and the internodes of the rachis.

Culm erect, rigid, simple; perennial; panicle purple. $\quad 3$. E. pectinacea.

1. Eragrostis Purshii Schrad. In dry or sandy places from Ont. to Wash., Fla. and Calif.-Alt. 4000-7500 ft.-Alamosa, Conejos Co.; Cañon City, Fremont Co.; along the river, Ft. Collins.

2. Eragrostis major Host. (E. poaeoides megastachya A. Gray.) Naturalized from Europe, in waste places and fields from Ont. to Wash, Fla. and Calif.-Alt. 4000-6000 ft.-Vicinity of Boulder; Longmont; New Windsor, Weld Co.; Cañon City, Fremont Co.; Cheyenne Mountain; Tobe Miller's ranch; near Ft. Collins. 
3. Eragrostis pectinacea (Michx.) Steud. In sandy soil from Mass. and S. D. to Fla., Tex. and Colo.-Alt. 4000-5000 ft.-Meadow Park.

55. CATABROSA Bealv. WATER WhORL-Grass.

I. Catabrosa aquatica (L.) Beatuv. In water, where it is often floating, from Lab. to Alaska, Nebr., Colo. and Utah.-Alt. 5000-9500 ft.-Sangre de Cristo Creek; Rabbit-Ear Pass; Fort Collins; Breckenridge; near Gray's Peak; gulch west of Pennock's.

\section{EATONIA Raf.}

Second empty glume much wider than the flowering glumes, rounded or truncate and somewhat cucullate at the apex.

Intermediate nerves of the second glume almost as prominent as the lateral ones; leaf-blades firm, much broader than the sheaths and therefore with prominent auricles.

1. E. robusta.

Intermediate nerves of the second glume faint, the lateral strong; leaf-blades soft, not much wider than the sheaths; auricles not prominent.

\section{E. obtusata.}

Second empty glume not much wider if at all than the flowering glumes, obtuse or acute.

Second empty glumes rather firm, as well as the flowering glumes obtusish. 3. E. intermedia.

Second empty glume thin and with a broad, scarious margin, acutish; flowering glumes acute.

4. E. pennsylvanica.

I. Eatonia robusta (Vasey) Rydb. (E. obtusata robusta Vasey.) On river-banks from Neb. to Wash., N. M. and Ariz.-Alt. 4000-5000 ft.-Vicinity of Boulder; Rocky Ford.

2. Eatonia obtusata (Michx.) A. Gray. In meadows from Mass. to Mont., Fla. and Ariz,-Alt. 4000-600o ft.-About Boulder; Manitou; gulch west of Soldier Cañon; near Timnath; Fort Collins; Hotchkiss, Delta Co.

3. Eatonia intermedia Rydb. In meadows from Alb. to Colo.-Alt. 5000$8000 \mathrm{ft} .-$ Pagosa Springs; Durango; Gunnison.

4. Eatonia pennsylvanica (DC.) A. Gray. In open woods and among bushes from N. B. to B. C., Ga. and Colo.-Alt. $4000-7500 \mathrm{ft}$.-Vicinity of Pike's Peak; Arboles; Pagosa Springs; Alamosa.

\section{Melica L. Melic-Grass.}

Stem not bulblike-thickened at the base.

1. M. parviflora.

Stem bulblike-thickened at the base.

Second empty glume much shorter than the flowering glume of the lowest flower; spikelets flattened.

2. M. spectabilis.

Second empty glume about equalling the flowering glume of the lowest flower; spikelets terete or nearly so.

3. M. bulbosa.

I. Melica Porteri Scribn. (M. parviflora (Porter) Scribn.) On hillsides and in cañons, especially among bushes, from Neb. to Colo., Tex. and Ariz. -Alt. 6000-9000 ft.-Cheyenne Cañon; mountains near Pagosa Peak; Engelmann Cañon; vicinity of Ouray; Idaho Springs; Glen Eyrie; Upper La Plata; vicinity of Pike's Peak; Black Cañon; Manitou; vicinity of Pine Grove. 
2. Melica spectabilis Scribn. In meadows from Mont. to Wash., Colo. and Oregon.-Alt. 8000-9000 ft.-Honnold; North Park; foot of Mt. Richtofen, on the Michigan; mountain west of Cameron Pass.

3. Melica bulbosa Geyer. In meadows and on hillsides from Mont. to Wash., Colo., Utah and Ore.-Rabbit-Ears, Larimer Co.; Glenwood Springs, Garfield Co. Osterhout's specimens (somewhat undeveloped) have unusually broad leaves and may belong to the closely related $M$. californica Scribn.

\section{DACTYLIS L. ORCHARD-GRASS.}

x. Dactylis glomerata L. Cultivated and naturalized from Europe; in fields and waste places from N. B. to Wash., Fla. and Calif.-Alt. 4000-9000 ft.Cucharas River, below La Veta; Chicken Creek; Veta Pass, Costilla Co.; Fort Collins.

\section{BRIZA L. QUAKING-Grass.}

r. Briza maxima L. Introduced ornamental grass, and escaped along irrigation ditches.-Alt. about $7500 \mathrm{ft}$.-Gunnison.

\section{6o. Distichlis Raf. Salt-grass, Marsh Spike-grass.}

1. Distichlis stricta (Torr.) Rydb. (D. maritima stricta Thurber.) In salt marshes from Sask. to Wash., Mo., Tex. and Calif.-Alt. 4000-7500 ft.Grand Junction; Deer Run; New Windsor, Weld Co.; near Denver; Fort Collins; Saguache Creek; Alamosa; Rueblo; Rocky Ford.

\section{6r. POA L. Blue-grass, Meadow-Grass, Bunch-Grass.}

Annuals.

Perennials.

I. Annuae.

Cobweb at the base of the flowers present, although in some species scant; flowering glume acute (except in $P$. compressa), and usually strongly keeled; plants with horizontal rootstocks, never true bunch-grasses.

Intermediate nerves of the flowering glumes strong.

Inflorescence with numerous many-flowered spikelets; its branches in fruit ascending; the lower in 3 's or 4's; flowering glumes acutish; cobweb copious.

II. Pratenses.

Inflorescence with usually few-flowered spikelets; its branches reflexed or spreading in fruit; flowering glumes very acute.

Spikelets few and usually purplish; branches of the inflorescence few, solitary or in pairs, only in $P$. callichroa in 3 's. III. REFLEXAE.

Spikelets many, green; branches of the inflorescence many; the lower often in 3 's or 4's.

IV. Platyphyliak.

Intermediate veins of the flowering glumes faint or obsolete.

Stem compressed; panicles narrow, open. V. CoMpressae.

Stem not compressed.

Branches of the panicles reflexed.

Branches of the large panicle not reflexed.

VI. Apertae.

Flowers green; nerves of the empty glumes strong; meadow species with flaccid leaves.

VII. Serotinae.

Flowers more or less purplish; nerves of the empty glumes usually faint; hill species with rather stiff leaves. VIII. RupICOLAE.

Cobweb at the base of the flowers none. 
Spikelets rounded at the base; empty glumes very broad and their backs strongly arched; low, somewhat tufted plants, with short but open panicle and broad leaves.

IX. Alpinae.

Spikelets acute at the base; empty glumes narrower and not strongly arched on the back.

Flowering glumes 3-4 mm. long; low alpine plants with few, more or less purplish spikelets.

Branches of the inflorescence ascending.

VIII. Rupicolae.

Branches of the inflorescence spreading or reflexed. ( $P$. alpicola in)

III. REFLEXAE.

Flowering glumes $5 \mathrm{~mm}$. or more; plants comparatively tall or robust.

Spikelets decidedly flattened; flowering glumes acute.

Nerves and inter-nerves more or less hairy, at least below; flowers perfect.

Inflorescence open; plants with horizontal rootstocks; innovations (i. $\iota .$, new shoots) extra-vaginal (except in $P$. pseudopratensis).

Intermediate nerves of the flowering glumes faint; spikelets purplish. $X$. Phoeniceae.

Intermediate nerves of the flowering glumes strong; spikelets green or slightly purple-tinged. XI. WheElrianaE.

Inflorescence narrow; plants more or less tufted, without creeping rootstock.

Leaves not filiform; innovations mostly extra-vaginal. XII. EPILES,

Leaves filiform; plant true bunch-grasses with intra-vaginal innovations.

XIII. Filifoliae.

Nerves of the flowering glumes villous, but the inter-nerves glabrous; plants dioecious; bunch-grasses with intra-vaginal innovations.

XIV. Fendlerianae.

Spikelets only slightly flattened; flowering glumes narrow, nearly straight on the back, rounded at the apex; bunch-grasses with narrow panicles and intra-vaginal innovations.

XV. BuckleyanaE.

\section{Annuae.}

Low, I-2 dm. high; branches of the panicle spreading.

Taller, erect, 2-5 dm. high; branches of the panicle erect.

I. P. annua.

L. P. Bigelovii.

\section{Pratenses.}

One very variable species.

3. P. pratensis.

III. REFLEXAE.

Cobweb present but scant.

Internerves of the flowering glumes more or less pubescent, at least below.

Spikelets 3-4-flowered; stem-leaves usually folded or involute; plant usually less than $3 \mathrm{dm}$. high.

Internerves of the flowering glumes short-pubescent below; leaves filiform, involute; those of the sterile shoots usually arcuate. 4. P. cenisia.

Internerves of the flowering glumes long-hairy; leaves $\mathrm{I}-2 \mathrm{~mm}$. wide, usually conduplicate, rather firm.

5. $P$. arctica.

Spikelets 5-7-flowered; leaves all flat, 3-4 mm. wide; stem fully $3 \mathrm{dm}$. high.

Internerves of the flowering glumes glabrous.

6. $P$. callichroa.

Intermediate nerves of the flowering glumes pubescent; plant $3 \mathrm{dm}$. or less

high; leaves mostly basal, firm; stemleaves I-2, usually conduplicate.

Intermediate nerves of the flowering glumes glabrous; plant usually over $3 \mathrm{dm}$. high; stemleaves several, flat and flaccid.

Hairs of the mid-nerves and lateral nerves copious and spreading.

8. P. reflexa. 
Hairs of the mid-nerves and lateral nerves few and appressed or none.

9. P. leptocoma.

Cobweb lacking; internerves and the intermediate nerves glabrous; mid-nerves and lateral nerves hairy; habit like $P$. arctica. ro. P. alpicola.

\section{Platyphyllae.}

One species.

II. P. platyphylla.

\section{Compressae.}

One species.

I2. P. compressa.

\section{Vi. Apertae.}

Branches of the inforescence short, usually in pairs.

Branches of the inforescence very long, in 3 's to 5 's.

I3. P. aperta.

I4. $P$. macroclada.

\section{ViI. Serotinae.}

Stem stout; leaves $2-5 \mathrm{~mm}$. wide; ligule $3-4 \mathrm{~mm}$. long, triangular; branches of the panicle at last spreading; second glume narrower than the flowering glumes, $3 / 4$ as long or more.

I5. $P$. serotina.

Stem slender; leaves seldom over $2 \mathrm{~mm}$. wide; ligule about $\mathrm{I} \mathrm{mm}$. long, truncate; branches of the panicle ascending; second glume as wide as the flowering glumes and $2 / 3$ as long.

Flowers green; empty glumes, especially the second, with broad, scarious margins and strong lateral nerves. 16. $P$. interior.

Flowers usually purple-tinged; scarious margin of the empty glumes scarcely evident and lateral nerves faint. I7. P. crocata.

\section{RupicolaE.}

Mid-nerve and lateral nerves of the flowering glumes pubescent; plant strict, I-5 $\mathrm{dm}$. high.

Empty glumes shorter than the flowering glumes; their lateral nerves indistinct.

Cobweb at the base of the flowers scant; stem slender and leafy, usually 3-5 dm. high.

17. $P$. crocata.

Cobweb none; stem I-2 (seldom 3) dm. high, leafy mostly at the base.

Flowering glumes $3 \mathrm{~mm}$. long or less, firm, obtuse. I8. $P$. rupicola. Flowering glumes about $4 \mathrm{~mm}$. long, acute, thin. I9. P. Pattersonii.

Empty glumes equalling or longer than the flowering glumes, $i$. e., their tips almost as high as the tip of the subtended flowers; their lateral nerves more prominent. 20. P. Grayana.

Nerves of the flowering glumes glabrous; plant seldom over $5 \mathrm{~cm}$. high.

iX. Alfinae.

21. P. Lettermanii.

One species.

22. $P$. alpina.

\section{Phoeniceae.}

One species.

XI. WheElertanae.

23. P. phoenicea.

Leaf-sheaths retrorsely stigose.

Internerves of the very acute flowering glumes merely strigulose or scabrous. Nerves scabrous.

Nerves silky or villous on the lower portion.

24. $P$. Wheeleri.

Internerves as well as nerves of the obtusish flowering glumes villous at least below.

26. $P$. tricholepis.

Leaf-sheaths glabrous.

Internerves of the lanceolate flowering glumes scabrous or strigulose; innovations very few and consisting of wholly extravaginal runners.

27. $P$. occidentalis. 
Internerves of the ovate flowering glumes pubescent; innovation several, both extra- and intra-vaginal.

28. $P$. pseudopratensis.

\section{EPILes.}

Flowering glumes about $5 \mathrm{~mm}$. long, strongly purple-tinged, but slightly scabrous; stem-leaves broad.

29. P. subpurpurea.

Flowering glumes about $4 \mathrm{~mm}$. long or less, usually greenish or slightly purple; stem-leaves narrow.

One species.

\section{Filifoliae.}

30. P. epilis.

31. P. nematophylla.

\section{Xiv. Fendlertanae.}

Ligules 5-7 mm. long, acute or acuminate.

32. P. longiligula.

Ligules short, rounded or truncate at the apex; those of the innovations obsolete.

Panicle very narrow and long-peduncled, contracted. 33. P. longipedunculata.

Panicle more open at least in anthesis.

Flowering glumes narrowly oblong; leaves very slender and rough.

Flowering glumes ovate.

34. P. scabriuscula.

Panicle very short; plant low; leaves smooth below, scabrous above.

35. P. brevipaniculata.

Panicle longer; plant $3^{-6} \mathrm{dm}$. high; leaves scabrous below, hispid-puberulent above.

\section{Buckleyanae.}

36. P. Fendleriana.

Internerves of the flowering glumes glabrous; nerves silky.

Plant low; leaves stiff, involute and often arcuate.

Plant tall; leaves broad and flat.

Internerves of flowering glumes more or less scabrous or strigose.

Flowering glumes merely scabrous throughout.

Empty glumes strongly nerved, elongated lanceolate, almost equalling the oblong, very scabrous flowering glumes; leaves usually broad $(2-3 \mathrm{~mm}$.) and flat; ligules lanceolate, acute.

38. $P$. nevadensis.

Empty glumes not strongly nerved, ovate-lanceolate, usually much shorter than the flowering glumes, which are broader and less scabrous.

Ligules narrowly lanceolate, $3-4 \mathrm{~mm}$. long, acuminate; stem-leaves very narrow and involute.

39. P. laevigata.

Ligules short, I-2 mm. long, triangular or broadly ovate and acutish or truncate.

Plant 2-4 dm. high; leaves mostly basal and stiff, short, seldom $8 \mathrm{~cm}$. long; ligules rounded.

Plant 4-Io dm. high, leafy throughout; leaves longer.

Ligules ovate or rounded, acute or obtuse; leaves soft.

Ligules very short, truncate; leaves rather firm.

4I. $P$. confusa.

42. $P$. truncata.

Flowering glumes more or less strigose on the lower portion, scabrous above. Flowering glumes not longer than the empty glumes, ovate; pubescence much longer on the nerves.

43. P. pratericola.

Flowering glumes oblong, longer than the empty glumes; pubescence on the nerves scarcely stronger than that on the internerves.

Ligules ovate or rounded, obtuse or acutish.

Ligules lanceolate, acuminate.

Plant yellowish green; leaves all filiform, soft and usually involute.

$$
\text { 44. P. lucida. }
$$

Plant dark green, leaves broader, flat or conduplicate; at least those of the stem firm.

Creeping rootstock none; panicle dense; flowering glumes greenish at the base and purple above; leaves usually narrow and conduplicate. 
Creeping rootstock often present; panicle narrow and usually lax; flowering glumes if at all purplish only slightly so at the very tip; leaves flat. 46. P. Sheldonii.

1. Poa annua L. In waste and cultivated places, from Lab. and B. C. to Ga. and Calif.; also in Mex. Naturalized from Europe-Alt. up to $9000 \mathrm{ft}$. - Hamor's Lake, north of Durango.

2. Poa Bigelovii V. \& S. From Tex. to Colo. and Calif.-Alt. up to 6000 ft.-."Colorado," locality not given; Colorado Springs; along Purgatoire River, near Trinidad.

3. Poa pratensis L. In meadows from Lab. and Alaska to Fla. and Calif.; also native of Europe and Asia.-Alt. 4000-II,500 ft.-Mountains northeast of Dolores; Fort Collins; Marshall Pass; Manitou; Villa Grove; Beaver Creek; Dead Lake; Crystal Park; mountains near Pagosa Peak; vicinity of Ouray; Cameron Cañon; Pagosa Springs; Happy Hollow; Cucharas Valley, near La Veta; Sangre de Cristo Creek; La Plata Cañon; Parrott City; Pass Creek; Cascade Cañon; Quimby; along Conejos River, north of Antonito.

4. Poa cenisia A11. (Poa flexuosa Wahl.) In wet places in arctic or alpine regions from Greenl. to Alaska; also in Colo.-Alt. about 10,500 ft.-Mountains near Pagosa Peak.

5. Poa arctica $\mathrm{R}$. Br. In wet places in arctic or alpine regions along the arctic coast and Alaska, the Canadian Rockies and Colo--Alt. II,000-I4,000 ft.-Gray's Peak; Mt. Bartlett; Saddle, Pike's Peak; mountains near Pagosa Peak; Chambers' Lake.

6. Poa callichroa Rydb. On alpine peaks of Colo.-Alt. about II,500 ft.Dead Lake; Campton's Ranch.

7. Poa pudica Rydab. ( $P$. arctica Scribn.; in part.) In wet places in alpine or subalpine Colo.-Alt. II,000-I3,000 ft.-High mountains about Empire; near Pagosa Peak; Stephen's Mine.

8. Poa reflexa V. \& S. In wet meadows from Mont. and Ore. to N. M.Alt. 8000-13,000 ft.-Twin Lakes; Seven Lakes; Silver Plume; high mountains about Empire; Cameron Pass; Marshall Pass; near Teller, North Park; Upper La Plata River; near Pagosa Peak; Democrat Mountain; headwaters of Sangre de Cristo Creek; Pass Creek; near Ironton, San Juan Co.; Chambers' Lake; Ute Pass road; Four-Mile Hill.

9. Poa leptocoma Bong. In wet meadows from Mont. and Alaska to Colo. and Calif.-Alt. 8500-I2,500 ft.-Villa Grove; Pike's Peak Valley; chaparrelcovered hills southeast of Ouray; near Pagosa Peak; Columbine; Chicken Creek; Upper La Plata River; Ruby; Beaver Creek; Cameron Pass; Little Kate Mine, La Plata Mountains.

Io. Poa alpicola Nash. (Poa laxa Thurb.) In wet places on the alpine peaks of Colo. and Utah; perhaps also Calif.--Alt. II,500-I3,000 ft.-Long's Peak; headwaters of Clear Creek and alpine ridges east of Middle Park; Bottomless Pit, near Pike's Peak; top of Mt. Hayden; Estes Park; Gray's Peak.

II. Poa platyphylla Nash \& Rydb. (Poa occidentalis Vasey.) Along mountain streams of Colo. and N. M.-Alt. 7000-10,500 ft.-Near Pagosa Peak; Veta Pass; Cucharas River, near La Veta; Ojo; Wahatoya Cañon; headwaters of Sangre de Cristo Creek; Bob Creek, west of Mt. Hesperus; 
Beaver Creek; Horsetooth Gulch; Howe's Gulch; Happy Hollow; Brantly Cañon; Rabbit-ears, Larimer Co.

I2. Poa compressa $\mathrm{L}$. In woodlands, among bushes and in cultivated places from N. H. and B. C. to N. C. and Calif.-Alt. up to $9500 \mathrm{ft}$-Veta Pass, Costilla Co.

13. Poa aperta Scribn. In the mountains of Colo--Telluride; about Ouray; Breckenridge.

I4. Poa macroclada Rydb. Mountains of Colo.-Alt. about $9000 \mathrm{ft}$ Rogers.

I5. Poa serotina Ehr. In wet meadows and swamps from Newf. and B. C. to N. J. and Calif.; also in Europe-CAlt. 4000-9500 ft.-New Windsor, Weld Co.; plains and foot-hills, near Boulder; Mountain View; Fort Collins; gulch west of Soldier Cañon; along Poudre River.

16. Poa interior Rydb. (Poa nemoralis Am. auth.; in part.) In wet meadows from the Canadian Rockies and Wash. to N. Mex.-Alt. 5000-Io,000 ft.Fort Collins; Ute Pass; Twin Lakes; Estes Park; South Park; Marshall Pass; Beaver Creek; Stove Prairie Hill; hills about Box Cañon, west of Ouray; Cerro Summit; Andrew's Shetland ranch; La Plata Cañon; cañon west of Pennock's ranch, near Ft. Collins; Table Rock; foot of Mt. Richtofen, on Michigan River; Hotchkiss; mountains northeast of Dolores.

17. Poa crocata Mich. ( $P$. caesia strictior A. Gray, and $P$. nemoralis Am. auth.; in part.) On hills and dryer meadows from Lab. and Alaska to Vt., Minn. and Ariz.-Alt. 5000-13,000 ft.-Fort Collins; Happy Hollow; near Narrows; Mount Baldy; Barnes' Camp; foot of Mt. Richtofen, North Park; South Park; Ruxton Creek; Robinson, Summit Co.; headwaters of Clear Creek and alpine ridges east of Middle Park; near Georgetown; in valley near Empire; mountains near Pagosa Peak; Gentian Ridge; West Spanish Peak; mountains between Sunshine and Ward; Graymont; Gunnison; Cameron's Cone; Crystal Park; Marshall Pass; Anita Peak; Willow Creek, Routt Co.

18. Poa rupicola Nash. (Poa rupestris Vasey.) On the mountains from Mont. and Ore. to Colo. and Utah.-Alt. II,500-I3,000 ft.-South Park; Gray's Peak; Silver Plume; Pike's Peak; Seven Lakes; near Pagosa Peak.

A form with more hairy glumes has been collected at the following localities: near Manitou; Little Kate Mine, La Plata Mountains; mountain near Veta Pass; mountain meadows, Pike's Peak; Cameron Pass, above timber line.

I9. Poa Pattersonii Vasey. On the mountain peaks of Colo. and Ariz.Alt. 10,000-13,000 ft.-South Park; headwaters of Clear Creek and alpine ridges east of Middle Park; summit of Mt. Garfield; West Spanish Peak; east of Cameron Pass, above timber line; mountains above Beaver Creek; Como Pass, above timber line.

20. Poa Grayana Vaseyy. On the mountains of Colo. and Wyo.-Alt. about I3,000 ft.-Pike's Peak: Peak Slope; Saddle; Devil's Causeway; Cameron Pass.

2r. Poa Lettermannii Vasey. (Poa Brandegei Beal.) On the alpine peaks of Colo. and Wyo.-Alt. about I4,000 ft.-Gray's Peak.

22. Poa alpina $L$. In wet places on the mountain tops, along streams and 
in the arctics, from Greenl. and Alaska to Qute, Colo. and Utah.-Alt. 9000I3,000 ft.-Cameron Pass; near Pagosa Peak; Tennessee Pass; La Plata Cañon; Little Kate Mine, La Plata Mountains; mountains of Estes Park; South Park; Mt. Hesperus; Gray's Peak; Georgetown; Mt. Harvard; South Park; Mt. Richtofen; bank of Michigan, North Park.

23. Poa phoenicea Rydb. Mountains of Colo--Alt. about I2,500 ft.Vicinity of Pike's Peak: Peak Valley; Windy Point.

24. Poa Wheeleri Vasey. (Poa cuspidata Vasey.) In meadows from Mont. and Ida, to Colo. and Ore.-Alt. 6000-II,000 ft.-Berthoud's Pass; Marshall Pass; Ute Pass Road; North Park; Cameron Pass; Rist Cañon; Anita Peak; summit of North Park Range; Rabbit-Ear Range.

25. Poa Vaseyana Scribn. In mountain meadows of Colo.-Alt. 90ooIo,000 ft.-Silver Plume; Mt. Princeton; near Chambers' Lake.

26. Poa tricholepis Rydb. Mountain meadows of Colo.-Alt. 7500-II,500 ft.-Near Pagosa Peak; cañons and meadows, west of Ouray.

27. Poa occidentalis (Vasey) Rydb. (Poa flexuosa occcidentalis Vasey.) In the mountains of Colo. and Utah.-Alt. I0,000-II,500 ft.-Twin Lakes; Beaver Creek.

28. Poa pseudopratensis Scribn. \& Rydb. In wet places from Neb. to S. D. and Colo.-Alt. 4500-6000 ft.-Colorado Springs; New Windsor, Weld Co.; along river below Fort Collins.

29. Poa subpurpurea Rydb. ( $P$. purpurascens Vasey; not Sprengel.) In the mountains from Mont. and Wash. to Colo.-Cameron Pass.

30. Poa epilis Scribn. In the mountains from Mont. to Colo. and Utah.Alt. 10,000-13,000 ft.-Buffalo Pass; Silver Plume; Camp Creek; high mountains, vicinity of Gray's Peak; Buena Vista; near Pagosa Peak; Cameron Pass; Little Kate Mine, La Plata Mountains; Poudre Cañon; Beaver Creek; summit of North Park Range.

3r. Poa nematophylla Rydb. Dry hills of Colo--Meeker, Rio Blanco Co.

32. Poa longiligula Scribn. \& Williams. Hillsides and plains from S. D. and Ore. to N. M. and Calif.-Alt. 7000-Io,ooo ft--Navajo Cañon; "Colorado Terr."; Glenwood Springs; Buena Vista; South Park; Sierra Sangre de Cristo; Black Cañon; Table Rock; Palisades; Horsetooth Gulch; bank of Grizzly Creek; North Park.

33. Poa longipedunculata Scribn. Hills and mountain-sides from Wyo. to N. Mex.-Alt. 5000-I2,500 ft.-Mountains northeast of Dolores; hills about Trinidad; Rist Cañon; Silver Plume; Gray's Peak; Graymont; Stove Prairie; Lake Ranch; Bear Creek Divide; Beaver Creek; Marshall Pass; Manitou; Dolores; Veta Mountain; Poverty Ridge; near Pagosa Peak; Ojo; Crystal Park; Los Pinos; Grayback mining camps and Placer Gulch; Turkey Creek and tributaries; West Spanish Peak; West Mancos Cañon; West Indian Creek; plains near Denver; Black Cañon.

Poa longipedunculata virescens Williams. Chambers' Lake; hills about Trinidad.

34. Poa scabriuscula Williams. Dry mountains of Utah and Colo-Alt. about $8500 \mathrm{ft}$.-South Park.

35. Poa brevipaniculata Scribn. \& Williams. Dry meadows and mountainsides in Colo.-Alt. 5500-10,000 ft.-Horsetooth Gulch; gulch west of Sol- 
dier Cañon; Mt. Hesperus; Bob Creek; Cripple Creek; river-bluffs north of La Veta; Estes Park; Ojo; Veta Mountain; hills southeast of La Veta; Table Rock; Trinidad; headwaters of Pass Creek; Piney and Beaver Creeks; West Mancos River; Los Pinos; Van Boxle's ranch, above Cimarron; Seven Lakes; mountains near Veta Pass; Mt. Hesperus; West Indian Creek.

Poa brevipaniculata subpallida Williams is a low variety with pale-green color--Rocky Mountains (Hall \& Harbour); Bear Creek; headwaters of Clear Creek and alpine ridges, east of Middle Park; Stove Prairie Hill.

36. Poa Fendleriana (Steud.) Vasey. Dry hills and table lands from Colo. to N. Mex. and Calif.-Alt. 600o-I I,50o ft.-Trinidad; Upper LaPlata; Manitou; Los Pinos; near Pagosa Peak; near Badito; Colorado Springs.

37. Poa glaucifolia S. \& W. Moist banks from S. D. and Mont. to Colo. -Fort Collins and Calloway Hill.

38. Poa Nevadensis Scribn. In dry meadows and on hillsides from Mont. and B. C. to Colo., Nev. and Ore.-Ait. 5000-6500 ft.-Gulch west of Soldier Cañon; near Fort Collins; dry hills near Wood's ranch.

39. Poa laevigata Scribn. On dry meadows and hillsides from Mont. and Wash. to Colo.-Alt. 6500-9000 ft.-Gunnison; Chester; Iola; Mancos; along the Michigan, North Park; Rabbit-Ears, Larimer Co.

40. Poa juncifolia Scribn. Dry hills and plains of Wyo., Utah and Colo. -Middle Park; South Park; Georgetown; Hardin's ranch.

4r. Poa confusa Rydb. Dry meadows and open "parks" in the mountains from Mont. and Nebr. to Colo.-Alt. 5000-10,000 ft.-Twin Lakes; dry plains, North Park; Colorado and Wyoming State line; near Ft. Collins.

A form with the glumes slightly strigose below.-Clear Lake; Georgetown.

42. Poa truncata Rydb. Meadows of Colo-_Alt. about 5000 ft.-Dillon, Summit Co.; Holdredge Ranch, North Park.

43. Poa pratericola Rydb. \& Nash. ( $P$. andina Nutt.) Dry plains and prairies of Nebr., Wyo. and Colo.-Alt. 4000-I2,000 ft.-South Park; Green River; Twin Lakes; La Porte; mountains near Pagosa Peak.

44. Poa lucida Vasey. On dry hills from S. D. and Wyo, to Colo.-Alt. 5000-9000 ft.-Twin Lakes; Graymont; South Park; North Park; Columbine; vicinity of Ft. Collins; Crystal Creek; La Plata Cañon; Mancos; Holdredge Meadow, North Park; Beaver Creek Camp.

45. Poa Buckleyana Nash. On dry plains and hills from Nebr., Mont. and Wash. to Colo. and Utah.-Alt. 5000-I2,000 ft.-Silver Plume; Buena Vista ; Leroux Creek, Delta Co.; Cimarron; Encampment Meadows; meadow near Pinkhampton; Holdredge Meadow, North Park; Cameron Pass, above timber line; Marshall Pass; mountains above Beaver Creek.

46. Poa Sheldonii Vasey. On dry hills and mountain-sides in Colo--Alt. 8000-I2,000 ft.-Headwaters of Clear Creek and alpine ridges east of Middle Park; along Cottonwood Creek, near Buena Vista; Silver Plume; Mt. Ouray; Chicken Creek, west of Mt. Hesperus; West Mancos Cañon; Bob Creek; Como. 
62. Panicularia Fabr. Manna-grass, Reed Meadow-grass.

Spikelets ovate or oblong, $6 \mathrm{~mm}$. or less long.

Flowering glumes slightly if at all scarious and entire at the apex.

Spikelets $3 \mathrm{~mm}$. long or less; branches of the panicle drooping.

I. $P$. nervata.

Spikelets 4-6 $\mathrm{mm}$. long; branches of the panicle ascending or spreading.

Flowering glumes with broad, dentate, scarious margins.

Spikelets 4-6-flowered.

Spikelets $2-3$-flowered.

Spikelets linear, I $2 \mathrm{~mm}$. or more long.

z. P. ámericana.

I. Panicularia nervata (Willd.) Kuntze. (Glyceria nervata Trin.) In wet meadows and swamps from Lab. to B. C., Fla. and Calif.; also in Mex. -Alt. 4000-9000 ft.-Manitou; Crystal Park; mountains of Larimer Co.; Democrat Mountain; near Pagosa Peak; Pagosa Springs; Dome Rock Valley; Placer, Costilla Co.; Bosworth's ranch; Happy Hollow; Pagosa Springs.

z. Panicularia americana (Torr.) MacM. (G. aquatica Coult.; not Smith) In swamps and along streams from N. B. to Alaska, Tenn. and Nev.-Alt. 4000-8500 ft.-Mancos; mountains, Larimer Co.; Denver; Fort Collins; Pleasant Grove; New Windsor, Weld Co.; Saguache Creek; LaVeta; Baxter's ranch; cañon west of Palmers Lake; Table Rock; Bosworth's ranch, Stove Prairie; Pagosa Peak.

3. Panicularia pauciflora (Presl) Kuntze. (G. pauciflora Presl.) In wet meadows from Mont. to B. C., Colo, and Calif.-Alt. 9000-I0,500 ft.-Bob Creek, west of Mt. Hesperus; near Pagosa Peak; Chester; near Chambers' Lake; east slope of Rabbit-Ear Range; mountains northeast of Dolores; Pagosa Peak.

4. Panicularia Holmii Beal. Dense thickets in Colo.-Alt. about $8500 \mathrm{ft}$. Lamb's ranch, Long's Peak (Beal).

5. Panicularia borealis Nash. In shallow water from Me. to Alaska, $\mathbf{N}$. Y., Colo. and Calif.-Alt. 5000-8500 ft.-Cerro Summit; Buffalo Pass Road, Routt Co.; Boulder.

\section{PUCCINELlia Parl. Meadow-GRass.}

1. Puccinellia airoides (Nutt.) Wats. \& Coult. (Glyceria distans Coult.; in part.) In wet meadows, especially in alkaline soil, from Man. to Mackenzie River, B. C., Kans. and Nev.-Alt. 4000-II,000 ft.-Buena Vista; Iola; Gunnison; Fort Collins; South Park; Durango; Alpine Tunnel; Saguache Creek; Doyle's; Georgetown; Colorado Springs; Walsenburg; Boulder; Longmont.

\section{FestuCA L. Fescue-grass.}

Empty glumes firm, the second 3-5-nerved.

Annuals or biennials; stamens I-2.

Spikelets 7-I2-flowered; awn not much exceeding the flowering glume in length, often much shorter.

I. F. octoflora.

Spikelets I-7-flowered; awn much longer than the body of the flowering glume.

2. F. microstacliys.

Perennials; stamens 3 . 
Leaves $4 \mathrm{~mm}$. or more wide, flat; culm from a rootstock or with stolons.

Awns long, usually longer than the body of the flowering glumes; empty glumes narrowly lanceolate; branches of panicle reflexed or spreading.

Awns, if any, very short; branches of the panicle ascending.

Glumes narrowly lanceolate, acuminate and awn-pointed; spikelets 3-4flowered. 4. F. fratercula.

Glumes broadly lanceolate, abruptly acute; spikelets 5-9-flowered. 5. F. elatior.

Leaves (at least those of the sterile shoots) $2 \mathrm{~mm}$. or less wide, strongly involute.

Culm from a rootstock or with stolons; sterile shoots mostly extra-vaginal. Body of the flowering glume 5-6 mm. long; stem-leaves firm and often flat; spikelets 4-I0-flowered. 6. F. rubra.

Body of the flowering glume $4 \mathrm{~mm}$. long; leaves very narrow and soft; spikelets 2-3-flowered. 7. F. Earlei.

Culm densely tufted, no rootstock; sterile shoots mostly intra-vaginal.

Flowering glumes (without the awns) 3-4 $\mathrm{mm}$. long, not twice as long as the first glume; plants I-2 (rarely 3 ) dm. high; inflorescence spikelike.

Flowering glumes lanceolate, long-acuminate and long-awned; panicle dense; leaves short and firm. 8 . F. brachyphylla.

Flowering glumes oblong-lanceolate, abruptly contracted into a short awn; panicle lax; leaves filiform and soft. 9. F. minutifora.

Flowering glumes (without the awns) 5-8 $\mathrm{mm}$. long, more than twice as long as the first glume.

Basal sheaths short; blades of stem-leaves rarely $8 \mathrm{~cm}$. long. Awns short, less than half as long as the glumes; inflorescence usually dense and its branches very short.

Iо. F. pseudovina.

Awns long, nearly equalling to much exceeding the body of the glumes in length; inflorescence open and branches more slender.

II. F. ingrata.

Basal sheath long and loose; blades of stem-leaves usually over I $\mathrm{dm}$. long; inflorescence narrow and awn short. 12. F. arizonica.

Empty glumes thin, ovate-lanceolate, more or less scarious; second glume I-nerved or 3-nerved only at the base; culms densely tufted with numerous basal sheaths.

Ligules long and acuminate; infloreșcence open. $x_{3}$. F. Thurberi.

Ligules short and rounded; inflorescence narrow and spikelike.

I4. F. confinis.

I. Festuca octoflora Walt. (F. tenella Willd.) In dry, sandy soil from Que. to B. C., Fla. and Calif.-Alt. 4000-9000 ft.-Denver; New Windsor, Weld Co.; Veta Pass; Walsenburg; Denver; Wray; Quimby; Horsetooth Gulch; Palisades.

2. Festuca microstachys Nutt. In sandy soil from Ida. to B. C., Colo., Ariz. and Calif.- "Western Colorado."

3. Festuca Jonesii Vasey. In woods from Mont. to B. C., Colo., Utah and Wash.—"Western Colorado."

4. Festuca fratercula Rupr. On open hillsides, in cañons and meadows from Colo. to Arizona and Mex.-Alt. 7500-9500 ft.-Near Pagosa Peak; cañons and adjoining meadows, west of Ouray.

5. Festuca elatior L. In field, among bushes and in waste places from N. Sc. to Wash., N. C. and Calif. Cultivated and naturalized from Europe. -Alt. up to $5000 \mathrm{ft}$.-Fort Collins; Durango. 
6. Festuca rubra L. In meadows from Lab. to Alaska, N. C. and Calif.; also in Europe and Asia.-Alt. up to $5000 \mathrm{ft} .-\mathrm{Ft}$. Collins.

7. Festuca Earlei Rydb. In cañons of Colo.-Alt. about $9500 \mathrm{ft}$.-LaPlata Cañon.

8. Festuca brachyphylla Schultes. ( $F$, orina. brevifolia S. Wats.) In arctic-alpine localities, in rather barren soil, from Greenl. to Alaska, Vt. and Calif.-Alt. 9500-I4,500 ft.-Gray's Peak; Mt. Lincoln; Little Kate Mine, La Plata Mountains; Cumberland Mine; Cameron Pass; Pike's Peak; West Spanish Peak; near Pagosa Peak; Mt. Lincoln; Mt. McClellan; high mountains near Clear Creek; Beaver Creek; mountains northeast of Boreas; mountain above Barnes' Camp.

9. Festuca minutiflora Rydb. On alpine peaks in Colo. and Calif.-Alt. I0,000-I2,000 ft.-Headwaters of Clear Creek; Manitou; Mt. Ouray; near Pagosa Peak; Como; Tennessee Pass; Mt. Lincoln; Cameron Pass; Mountains northeast of Boreas.

10. Festuca pseudovina Hackel. On dry hillsides and mountains from Sask. to B. C., Mich. and Colo.; also in Europe.-Alt. 9000-I2,500 ft.-Berthoud's Pass; Cameron Pass; Dead Lake; Mount Garfield; Beaver Creek; Poverty Flats; Palsgrove Cañon; Happy Hollow; near Teller, North Park; Chambers' Lake; Twin Lakes; mountains above Clear Creek; Veta Pass; Ute Pass road; Boreas; mountains northwest of Boreas.

II. Festuca ingrata (Hack.) Rydb. ( $F$. ovina of western reports and $F$. ovina ingrata Hack.) On hillsides and in dryer meadows from Mont. to B. C., Colo. and Utah.-Alt. 3000-12,000 ft.-Grizzly Creek; Chicken Creek; Mount Garfield; Rabbit-Ear Pass; North Park; Wolcott, Eagle Co.; Barnes' Camp; along the Michigan, North Park; Beaver Creek; Como; near Monument; flats along Elk River; Campton's ranch; grass plot, Ft. Collins; Pinkham Creek, Larimer Co.; Willow Creek, Routt Co.

Festuca ingrata nudata (Vasey) Rydb. (F. ovina nudata Vasey) is a variety with narrower panicle, longer basal leaves, nearly naked stem and glabrous glumes.-Middle Park; North Park.

I2. Festuca arizonica Vasey. (Including F. Vaseyana Hack.) On rocky slopes from Colo. to Utah, N. M. and Ariz.-Alt. 7000-I0,000 ft.-Georgetown Pass; Twin Lakes; Pagosa Springs; West Mancos Cañon; foot-hills east of Mancos; Cottonwood Lake; Democrat Mountain; Idaho Springs; Veta Pass.

13. Festuca Thurberi Vasey. (S. scabrella Vaseyana Hack.) On hillsides in Colo. and southern Wyo.-Alt. 8000-I2,000 ft.-Twin Lakes; Mt. Lincoln; Veta Pass; vicinity of Pike's Peak; Cimarron; Grizzly Creek; near Pagosa Peak; Front Range, Larimer Co.; foot-hills east of Mancos; West Mancos Cañon; Dark Cañon; Chicken Creek; Beaver Creek; North Park; Sangrẻ de Cristo Creek; South Park; Argentine Pass; Happy Hollow; Hahn's Peak.

I4. Festuca confinis Vasey. (Poa Kingii S. Wats.) In cañons and on hillsides from Mont. to Colo. and Calif.-Alt. 6500-I0,000 ft.-Stove Prairie Hill and Stove Prairie, Larimer Co.; Boulder Cañon; Rist Cañon; Happy Hollow; Colorado and Wyoming State line; Beaver Creek. 


\section{BROMUS L. Broom-grass, Chiess.}

Flowering glumes compressed-keeled.

Palet less than $3 / 4$ as long as the flowering glume.

Leaves glabrous; glumes glabrous or merely scabrous.

Leaves pubescent; glumes hairy at least when young.

Palet more than $3 / 4$ as long as the glume.

Flowering glumes rounded on the back, at least at the base.

Flowering glumes oval or broadly elliptic; second empty glume 5-7-nerved; first 3-nerved; introduced annuals.

Flowering glumes nearly as broad as long, awnless or with a short, dorsal awn.

4. B. brizaeformis.

Flowering glumes much longer than broad, always conspictuously awned.

Flowering glumes glabrous.

Sheaths glabrous; awn much shorter than the flowering glume, nearly erect.

5. B. secalinus.

Sheaths pubescent; awn fully as long as the glume, at maturity strongly divergent.

Flowering glumes more or less hairy.

6. B. patulus.

7. B. hordeaceus.

Flowering glumes lanceolate or oblong-lanceolate; second empty glume 3nerved; first one I-nerved except in $B$. Porteri.

Awns shorter than the glumes; perennials and all except $B$. inermis native. Inflorescence more or less drooping.
First empty glume 3 -nerved.
8. B. Porteri.

First empty glume I-nerved.

Flowering glumes evenly pubescent on the back; sheaths densely lanate.

9. B. lanatipes.

Flowering glumes ciliate on the margins, glabrous or sparingly hairy on the back; sheaths glabrous or the lower sparingly hirsute.

Inflorescence not dropping.

Io. B. Richardsoni.

Inflorescence narrow, its branches erect; flowering glumes usually awned.

Ir. B. Pumpellianus.

Inflorescence broad, its branches spreading; flowering glumes usually awnless.

Awn longer than the glumes; introduced annuals.

12. $B$. inermis.

Spikelets numerous on slender, recurved, secund pedicels; flowering glumes 8-I2 mm. long.

I3. B, tectorum.

Spikelets few; pedicels not secund; flowering glumes I $2-16 \mathrm{~mm}$. long.

I4. B. sterilis.

1. Bromus polyanthus Scribin. In meadows from Mont. to Ore., N. M. and Calif.-Alt. 6000-II,500 ft.-Trimble Springs; hills above Dix P. O.; Cerro Summit; West Mancos Cañon; Rabbit-Ear Pass; Keblar Pass; Robinson, Summit Co.; Walsenburg; Veta Pass; foot of Mt. Richtofen, on the Michigan; near Chambers' Lake; Cameron Pass.

2. Bromus marginatus H. \& A. In meadows from Alb. to B. C., Colo. and Calif.-Alt. 5000-6000 ft.-Steamboat Springs, Routt Co.; Ft. Collins; Fish Creek Falls, Routt Co.

Bromus marginatus latior Shear is a large variety with large open panicle and longer awns.-Vicinity of Boulder.

3. Bromus unioloides (Willd.) H. B. K. Meadows from Ala. and Calif. to La. and Tex.-Fort Collins; Cherokee Hill.

4. Bromus brizaeformis F. \& M. Locally introduced from Mass. to Wash., Del. and Calif. Native of Europe and Asia.-Alt. 5000-6000 ft.-Vicinity of Boulder. 
5. Bromus secalinus L. In waste places and fields from Me. to Wash., Fla. and Calif. Introduced from Europe and Asia.-Alt. about $5000 \mathrm{ft}$.-Boulder; Fort Collins.

6. Bromus patulus M. \& K. In waste places from Mass, to Wyo., Mo. and Colo. Introduced from Europe.-Alt. about $5000 \mathrm{ft}$.-Fort Collins.

7. Bromus hordeaceus L. ( $B$. mollis L.) In waste places from $\mathrm{Me}$. to Wash., Del., Colo. and Ariz. Introduced from Europe--Denver.

8. Bromus Porteri (Coult.) Nash. (B. Kalmii Porteri Coult.) On hillsides and in meadows from Man. to Sask., Alb., Colo. and Ariz.-Alt. 7000I I,000 ft.-About Ouray; West Mancos Cañon; Georgetown; Mancos; Cerro Summit; Arboles; Durango; North Park; Cameron Pass; Stove Prairie Hill; Twin Lakes; Buffalo Peaks; Gunnison; Marshall Pass; Robinson; Clear Creek; Middle Park; Wagon Wheel Gap; Chambers' Lake; Ft. Collins; Four-Mile Hill; Michigan Hill, Cameron Pass; Dolores.

9. Bromus lanatipes (Shear) Rydb. (B. Porteri lanatipes Shear.) On hillsides in Colo.-Alt. 5000-9000 ft.-Lower Boulder Cañon, Boulder Co.; Idaho Springs; Mountain View; Hiawatha; vicinity of Boulder; Lafayette; Empire Pass; Dome Rock Valley; Fort Collins; Poudre Cañon; Rist Cañon; quaking asp grove, west Gunnison Co.; gulch west of Soldier Cañon; Hahn's Peak, Routt Co.

10. Bromus Richardsonii Link. (B. ciliatus Coult.; not L.) In meadows and on hillsides from Sask, to B. C., Colo., Ariz. and Ore.-Alt. 6000-I1,000 ft.-Cheyenne Mountain; vicinity of Pike's Peak; near Pagosa Peak; Pandora; Gunnison; mountains of Larimer Co.; Upper La Plata River; Beaver Creek; about Ouray; Mount Baldy; Ruxton Dell; Estes Park; Colorado Springs; Silver Plume; Marshall Pass; Tobe Miller's ranch; Moon's ranch; Happy Hollow; Four-Mile Hill; gulch west of Soldier Cañon; bank of Poudre; Andrew s ranch; western Gunnison Co.

Ir. Bromus Pumpellianus Scribn. In meadows and on hillsides from Sask. to Alaska and Colo--Alt. 6000-10,000 ft.-On Grizzly Creek; Veta Pass; Gray's Peak; Walsenburg; Como; Beaver Creek Camp.

Bromus Pumpellianus melicoides Shear is an awnless variety.-Beaver Creek.

I2. Bromus inermis Leyss. Escaped occasionally from cultivation from Ohio to Mont. and Colo.-Alt. about $5000 \mathrm{ft}$.-Fort Collins.

I3. Bromus tectorum L. In waste places from Mass. to Wash., Va. and Utah. Introduced from Europe--Alt. 5000-6000 ft.-Longmont, Boulder Co.; vicinity of Boulder; Fort Collins.

14. Bromus sterilis L. In waste places from Mass. and Ohio to Pa. and Colo. Introduced from Europe and Asia._Alt. about $5000 \mathrm{ft}$.-Fort Collins; estray in garden plot.

Tribe IO. HORDEAE.

66. AGROPYRON. WHEAT-GRASS, QUACK-GRASS.

Rachis of the spike breaking up at maturity, the joints falling with the spikelet. Rachis of the spike continuous. I. A. Scribneri.

Cespitose, the innovations intra-vaginal; no horizontal stolons (except in $A$. arizonicum). 
Spikelets compressed, remote on the axis; awns divergent.

Spikelets erect.

Spikelets spreading.

Empty glumes acute or obtuse; stem-leaves $3-4$, not glaucous..

Empty glumes acuminate or awn-pointed; stem-leaves $6-7$, glaucous.
Elum.

4. A. arizonicum.

Spikelets subterete, approximate on the rachis or somewhat distant in $A$. tenerum.

Awn strongly divergent.

Awn erect or none.

I6. A. Bakeri.

Awn long, usually longer than the body of the flowering glume.

Plant tall, over $3 \mathrm{dm}$. high, erect or ascending; empty glumes broadest below the middle; spike elongated.

Stem stout; spike 7-Io $\mathrm{mm}$. wide, erect but usually unilateral; spikelets (excluding the awns) I $2-15 \mathrm{~mm}$. long.

5. A. Richardsoni.

Stem slender; spike about $5 \mathrm{~mm}$. wide, usually nodding, seldom unilateral; spikelets (excluding the awns) about I cm. long.

6. A. caninum.

Plant 2-3 dm. high, densely tufted, decumbent at the base, geniculate; empty glumes broadest above the middle; spike short.

Awn short or none.

7. A. andinum.

Spike stout and dense, $3-8 \mathrm{~cm}$. long, usually tinged with purple; empty glumes broadest above the middle.

8. A. violaceum.

Spike slender and lax, 7-20 cm. long, green; empty glumes broadest below the middle.

9. A. tenerum.

Stoloniferous, sometimes slightly tufted; innovations extra-vaginal; flowering glumes acute or merely awn-pointed.

Sheath not pubescent.

Flowering glumes glabrous or merely scabrous.

Spikelets erect, nearly cylindrical or slightly compressed.

Leafblades hairy above; empty glumes shorter than the spikelets, which are usually distant.

I o. A. lanceolatum.

Leafblades scabrous but not hairy, spikelets usually not very lax. Empty glumes nearly equalling the spikelets; spike elongated.

I I. A. pseudorepens.

Empty glumes half as long as the spikelet; spike short.

Spikelets spreading, much flattened.

Flowering glumes densely pubescent.

12. $A$. riparium.

I3. A. occidentale.

14. A. molle.

Sheaths pubescent; flowering glumes very scabrous or short-pubescent.

I5. A. Palmeri.

1. Agropyron Scribneri Vasey. On high mountain-tops from Mont. to Colo. and Ariz.-Alt. I0,000-13,000 ft.-Silver Plume; Gray's Peak; near Pagosa Peak; Cumberland Mine, La Plata Mountains; Mt. Garfield; Bald Mountain; West Spanish Peak; Buena Vista; headwaters of Clear Creek; Cameron Pass; mountains above Beaver Creek.

2. Agropyron Vaseyi S. \& S. On dry hills and mountain-sides from Mont. to Ore., Colo. and Utah.-Alt. 5000-6000 ft.-Vicinity of Boulder; Ute Pass; Golden; Horsetooth Gulch; gulch west of Soldier Cañon; foot-hills of Larimer Co.

3. Agropyron spicatum (Pursh) Rydb. (A. divergens Nees; A. strigosum Coult.) On dry hills and mountains from Mont. to Wash., Ariz. and Calif. -Alt. 5000-6500 ft.-Hot Sulphur Springs, Middle Park; along Platte River; 
Bosworth ranch, Larimer Co.; Glenwood Springs, Garfield Co.; foot-hills, Larimer Co.; Poudre Cañon; Rist Cañon; Pinkham Creek, Larimer Co.

4. Agropyron arizonicum S. \& S. In the mountains from Colo. to Ariz. and Mex.-Alt. 8000-II,000 ft.-Mountains between Sunshine and Ward, Boulder Co.; near Pagosa Peak; Robinson, Summit Co.

5. Agropyron Richardsoni (Trin.) Schrad. (A. unilaterale Cassidy.) In meadows and among bushes from Minn. and Sask. to B. C., Iowa and Colo. -Alt. 7000-Io,ooo ft.-Veta Pass; Manitou; Graymont; LaPlata Cañon; Crystal Park; mountains of Larimer Co.; Dillon; Salida, Chaffee Co.; Twin Lakes; Empire; along the Michigan, North Park; Como; Bosworth's ranch, Stove Prairie.

6. Agropyron caninum (L.) Beatv. In meadows from N. Sc. to Ida., N. C. and Colo.-Alt. about $7000 \mathrm{ft}$-Mancos; North Park; Red Stone.

7. Agropyron andinum (S. \& S.) Rydb. (A. violaceum andinum S. \& S.) On high mountain-tops from Mont. to Colo.-Alt. about $9000 \mathrm{ft}$-Silver Plume; summit of North Park Range.

8. Agropyron violaceum (Hornem.) Vasey. In the mountains from Greenl. to Alaska, N. H. and Utah.-Alt. 6500-I2,000 ft.-Near Pagosa Peak; West Mancos Cañon; Cerro Summit; Crystal Park; Trinidad; near Badito; Green Mountain Falls; Gunnison; Buena Vista; Empire; Ft. Collins; gulch west of Soldier Cañon; La Porte; mountain west of Cameron Pass; Four-Mile Hill; North Park; near Chambers' Lake; Cameron Pass; Willow Creek and Fish Creek Falls, Routt Co.

9. Agropyron tenerum Vasey. On hillsides from Lab. to Alaska, N. H., Mo, and Colo.-Alt. 4000-7500 ft.-Fort Garland; New Windsor, Weld Co.; Colorado Springs; Arboles; Mancos; Fort Collins; Trimble Springs, north of Durango; Deer Run; Gunnison; Twin Lakes; Mancos; Soldier's Cañon.

10. Agropyron lanceolatum S. \& S. On the plains from Wyo. to Wash. and Colo.-Alt. abot1t $5000 \mathrm{ft}$.-Fort Collins; Calloway Hill; Horsetooth Gulch.

II. Agropyron pseudorepens S. \& S. In meadows from Iowa to Alb., N. M. and Utah.-Alt. 4000-ro,000 ft.-Clear Creek, near Empire; Kebler Pass; mountains near Pagosa Peak; vicinity of Boulder; Colorado Springs; La Porte; Beaver Creek; Durango; Grizzly Creek; New Windsor, Weld Co.; Pike's Peak; Fontaine qui Bouille Valley; Veta Pass; Ft. Collins; Graymont.

22. Agropyron riparium S. \& S. On river banks from Mont. to Colo.Alt. about $7000 \mathrm{ft}$-Colorado Springs.

13. Agropyron occidentale Scribn. (A. repens glaucum Am. auth.) On prairies and plains from Man. and Sask. to Ore., Mo., N. M. and Ariz.Alt. 4000-9500 ft.-Veta Pass; Weston's Pass; Trimble Springs, north of Durango; Longmont, Boulder Co.; Wahatoya Creek; Ft. Morgan; South Park; Hotchkiss; Table Rock; Ft. Collins; La Porte.

14. Agropyron molle (S. \& S.) Rydb. In dryer valleys on the plains, especially in alkaline soil, from Sask. to Wash. and N. M.-Alt. 5000-9000 ft.-Weston's Pass; Arboles; New Windsor, Weld Co.; Mancos; Cerro Summit; Sangre de Cristo Creek; Wahatoya Creek; Golden; Cañon City, Fremont Co.; North Park; Hardin's ranch; Ft. Collins. 
I5. Agropyron Palmeri (S. \& S.). (A. spicatum Palmeri S. \& S.) In the mountains of Colo., N. M. and Ariz.-Alt. up to 7000 ft-Mancos; Arboles; Quimby.

I6. Agropyron Bakeri E. Nelson. Mountains of southern Colo.-Alt. 9000 ft.-Near Pagosa Peak.

\section{HORDEUM L. BARLey, SQUiRREL-TAIL.}

Empty glumes all alike, subulate-filiform.

Empty glumes $3-6 \mathrm{~cm}$. long; flowering glume of lateral spikelets long-awned.

I. H. jubatum.

Empty glumes $\mathrm{I}-2 \mathrm{~cm}$. long; flowering glume of lateral spikelets short-awned or awn-pointed.

Lateral spikelets flower-bearing.

Lateral spikelets neutral.

Empty glumes of the middle spikelet lanceolate.

2. H. boreale.

3. $H$. nodosum.

4. H. pusillum.

1. Hordeum jubatum L. On prairies and in meadows from Lab. to Alaska, N. J., Tex. and Calif.-Alt. 4000-II,00o ft.-Mancos; Cerro Summit; Arboles; vicinity of Boulder; Fort Collins; Fort Morgan; Golden; New Windsor; Alpine Tunnel; Ute Pass; Twin Lakes.

z. Hordeum boreale S. \& S. In meadows from Mont. to Alaska, Colo. and Wash.-Alt. up to Io,ooo ft.-Marshall Pass; South Park; Como; North Park.

3. Hordeum nodosum L. In meadows from Mont. to Alaska, Tex. and Calif.-Alt. 5000-9500 ft.-Georgetown; North Park; South Park; Durango; Golden; Twin Lakes; Ft. Collins; Chamber's Lake.

4. Hordeum pusillum Nutt. In arid valleys from I1l. to Ida., Ga. and Ariz. -Alt. 4000-6000 ft.-Foot-hills, Larimer Co.; New Windsor, Weld Co.; near the river, east of Ft. Collins; Buckhorn Creek, Larimer Co.

\section{SITANION Raf.}

Some of the empty glumes 2-cleft; lowest flower of one or both spikelets sterile and like the empty glumes, but inserted on a rachilla and falling away with it.

Sterile shoots numerous; stem slender; flowering glume 3-awned.

I, S. Hystrix.

Sterile shoots few; stem stout; flowering glume I-awned. 2. S. molle.

Empty glumes all entire; lowest flower of both spikelets perfect.

Flowering glumes glabrous.

Stem-leaves very long, erect, flexuose, strongly involute. 3. S. longifolium. Stem-leaves short, rigid, spreading or divaricate.

Flowering glumes soft-pubescent.

4. S. brevifolium. 5. S. pubiflorum.

1. Sitanion Hystrix (Nutt.) Smith. (Ageliops Hystrix Nutt.) On dry shale hills and among sage brush on the plains from Wyo. to Wash. and Colo.-Walsenburg; North Park.

2. Sitanion molle J. G. Smith. On moist mountain-sides in Colo.-Alt. Io,500 ft.-East side Buffalo Pass, Larimer Co.

3. Sitanion longifolium J. G. Smith. On hillsides and among rocks from Nebr. to Nev., Tex. and Ariz.-Alt. 6500-9000 ft.-Villa Grove, Saguache Co.; Denver; Mancos; North Park; mountains of Larimer Co.; Hardin's ranch; Oak Mesa, Delta Co.; Anita Peak, Routt Co. 
4. Sitanion brevifolium J. G. Smith. On hills and mountain-sides from Wyo. to Utalh, Colo. and Ariz.-Alt. 5000-10,00o ft.-Mancos; Ouray; Marshall Pass; vicinity of Boulder; mountains between Sunshine and Ward, Boulder Co.; Twin Lakes; Georgetown; Walsenburg; Colorado Springs; La Veta; vicinity of Ft. Collins; Willow Creek, Routt Co.

5. Sitanion pubiflorum J. G. Smith. On dry hills from Colo. to Ariz. and N. M.-Alt. about $6000 \mathrm{ft}$.--Trinidad.

\section{ELYMUS L. WILd RyE, LyME-GRAsS.}

Flowering glumes long-awned; empty glumes lanceolate or linear-lanceolate, narrowed at the base.

Spike broad; spikelets spreading.

Flowering glumes hirsute or villose.

1. E. canadensis.

Flowering glumes scabrous or strigose-hispidulous or nearly glabrous.

Robust; spike usually included at the base; leaves $8-15 \mathrm{~mm}$. wide.

Slender; spike exserted; leaves seldom over $5 \mathrm{~mm}$. wide.

2. E, robustus.

3. E. brachystachys.

Spike narrow; spikelets erect.

Leaves 7-15 mm. wide, spreading; empty glumes lanceolate, acuminate to short-awned.

4. E. glaucus.

Leaves less than $5 \mathrm{~mm}$. wide, usually nearly erect; empty glumes very narrowly linear-lanceolate, long-awned.

Spike 7-8 mm. thick; awns $30-40 \mathrm{~mm}$. long. 5 5. E. Saundersii.

Spike $5 \mathrm{~mm}$. thick or less; awns 5-Io mm. long. 6. E. Macounii.

Flowering glumes awnless or short-awned; empty glumes linear-aristiform or subulate, or if broader not narrowed at the base.

Empty glumes aristiform or narrowly subulate.

Plant stout, I-2 m. high; spikelets $2-6$ at each joint; flowering glumes acute or very short-awned; in our form scabrous-stigulose.

Plant slender, $3-10$ dm. high; spikelets $\mathrm{x}-2$ at each joint.

7. E. condensatus.

Flowering glumes broadly lanceolate, acute or minutely awn-pointed, glabrous; rachis scabrous on the sharp angle; spikelets erect.

8. E. triticoides.

Flowering glumes narrowly lanceolate, awned; rachis nearly terete, strigose; spikelets somewhat spreading.

Flowering glumes glabrous.

Flowering glumes strigose.

Flowering glumes villous.

9. E. ambiguns.

Iо. E. strigosus.

I2. E. villiflorus.

Empty glumes lanceolate-subulate, tapering from a rather broad base; spikelets usually singly; flowering glumes glabrous.

I I. E. simplex.

I. Elymus canadensis L. On river-banks and among bushes from $\mathbf{N}$. S. and Wash. to Ga. and N. M.-Alt. 4000-7000 ft.-Durango; Fort Collins; along Platte River, near Denver; La Porte, Larimer Co.; Salida, Chaffee Co.; gulch west of Soldier Cañon; Black's Lake.

2. Elymus robustus S. \& S. On river-banks from S. D. to Ida., Mo. and Colo.-Alt. 5000-6000 ft.-Idaho Springs; Black Cañon; vicinity of Boulder; Fontaine qui Bouille.

3. Elymus brachystachys Scribn. \& Ball. On dry plains and hills from Mich. and S. D. to Tex., N. M. and Utah; also in Mex.-Alt. $4000-6500 \mathrm{ft}$. -Rist Cañon, Larimer Co. ; eastern Colorado; along river, east of Ft. Collins.

4. Elymus glaucus Buckley. (Elymus Sibiricus Thurb.; not L.) In mead- 
ows and among bushes from Mich, to Alb., B. C., Colo. and Calif.-Alt. 7000-II,000 ft.-Mountains near Pagosa Peak; Hamor's Lake, north of Durango; about Ouray; Keblar Pass; Villa Grove; Horsetooth Gulch; Ute Pass road; mountains above Cameron Pass; edge of aspen grove, western Gunnison Co.

5. Elymus Saundersii Vasey. On mountains in Colorado.-Exact locality not given.

6. Elymus Macounii Vasey. In meadows from Man. and Sask. to Alb., N. Mex. and Utah.-Alt. 4000-7000 ft.-Denver; Durango; Fort Collins; Gunnison; Manitou.

7. Elymus condensatus Presl. On hills and in dryer valleys from Alb. and B. C. to N. M. and Calif.-Alt. 5000-I0,000 ft.-Grand River at Hot Sulphur Springs; Doyle's; vicinity of Boulder; Chester, Saguache Co.; Grant Creek; Deadman Cañon; Campton's ranch; Miller's ranch, near La Porte.

8. Elymus triticoides Nutt. In meadows and on hillsides from Mont. to Wash., Colo. and Calif.-Alt. 6000-900o ft.-Grant Creek; foot-hills, Larimer Co.; Georgetown; Barnes' ranch, Larimer Co.; Rist Cañon.

9. Elymus ambiguus Vasey \& Scribn. In cañons and on hillsides in Colo. -Alt. 6000-9000 ft.-Penn Gulch; Empire; Fort Garland; Minnehaha; near Manitou; Engelmann Cañon; Rist Cañon, Larimer Co.; near Badito; Artists' Glen; North Cheyenne Cañon; Veta Pass; Campton's ranch.

гo. Elymus strigosus Rydb. In the foot-hills and on shale slopes in Colo. and Wyo.-Alt. about $7700 \mathrm{ft} .-$ Near Boulder.

Ix. Elymus simplex S. \& W. Dry plains and hills from Wyo. and Colo. to Ore.-Alt. up to II,00o ft.-Robinson, Summit Co.

I2. Elymus villiflorus Rydb. On plains and foot-hills of Colo. Apparently the same also in the Black Hills and the Canadian Rockies-Alt. 5000-6000 ft.-Vicinity of Boulder.

\section{LOLIUM L. RYE-GRASS.}

I. Lolium perenne L. In waste places and cultivated ground from N. S. to Va., Calif. and Wash.-Ft. Collins.

\section{Family I9. CYPERACEAE. Sedge Family.}

Flowers of the spikelets perfect or at least one perfect.

Glumes of the spikelets 2-ranked.

Perianth present, the members bristle-like; inflorescence axillary.

I. Dulichium.

Perianth wanting; inflorescence in terminal, solitary or umbelled heads.

Glumes of the spikelets spirally imbricated.

2. Cyperus.

Base of the style not at all or only slightly thickened, deciduous.

Perianth-bristles conspicuously elongated.

Perianth-bristles not conspicuously elongated.

3. ERIOPHORUM.

4. Scirpus.

Base of the styles manifestly swollen, persistent as a tubercle on the achenes.

Perianth present; spike solitary.

Perianth wanting; spikelets umbellate.

5. ELEOCHARIS.

6. Fimbristylis.

Flowers monoecious or dioecious.

Achenes not enclosed in a perigynium; glumes 2-flowered.

Achenes enclosed in a perigynium; glumes 1 -flowered.

7. Elyna.

8. CarEX. 


\section{DULICHIUM L. C. Richard.}

I. Dulichium arundinaceum (L.) Britt. In wet and muddy places from N. S. to B. C., Fla. and Tex.-Locality not given.

\section{2. cyperus L. Cyperus, Galingale, Nut-grass, Papyrus.}

Rachis persistent.

Annuals.

Glumes awned or mucronate.

Glumes acute, neither awned nor mucronate.

Perennials.

Glumes, tipped with a curved or bent awn.

Glumes blunt or merely mucronate.

Rachis deciduous above the two empty glumes.
1. C. inflexus.

2. C. acuminatus.

3. C. Fendlerianus.

4. C. Bushii.

5. C. filiculmis.

1. Cyperus inflezus Muhl. In wet, sandy soil from Vt. to B. C., Fla. and Calif.; also in Mex.-Alt. 5000-6500 ft.-Plains and foot-hills near Boulder; Ft. Collins; along Platte River, near Denver; Cañon City; New Windsor, Weld Co.; Arkansas River; along Poudre River.

2. Cyperus acuminatus Torr. \& Hook. In wet soil from Ill. to Ore., La. and Calif.-Exact locality not given.

3. Cyperus Fendlerianus Boeckl. In wet soil from Tex. to Colo., Ariz. and Mex.-Alt. $4000-6000$ ft.-Colorado Springs; Arkansas Cañon.

4. Cyperus Bushii Britt. (C. Schweinitzii Coult.; not Torr.) In sandy soil from Wisc. to Ore., Kans. and Colo.-Alt. 4000-5000 ft.-Denver; Meadow Park.

5. Cyperus filiculmis Vahl. In dry fields and on hills from N. H. to Minn., Fla. and Tex.-Alt. about $5500 \mathrm{ft}$-Colorado Springs.

\section{ERIOPHORUM L. COTTON-GRASS.}

Achenes obovoid, obtuse.

Glumes ovate-lanceolate; achenes light brown.

Glumes oval or ovate, obtuse; achenes dark brown, almost black.

Achenes linear-oblong, acute.

2. E. ocreatum.

3. E. gracile.

1. Eriophorum polystachyon L. In bogs from Greenl. to Alaska, Ga. and Colo.-Ait. 4000-II,500 ft.--Hamor's Lake, north of Durango; Seven Lakes; West Cliff; Estes Park, Larimer Co.

2. Eriophorum ocreatum A. Nels. In bogs of Wyo. and Colo.-Twin Lakes.

3. Eriophorum gracile Koch. In bogs from Newf. to Alaska, Pa. and Calif.-Estes Park, Larimer Co.

\section{SCIRPUS L. Bull-RUSh, Club-RUSh.}

Involucre of a single bract or wanting.

Spikelets solitary, rarely 2 together; plants dwarfed.

Annuals; bristles none.

Perennials; bristles present.

Involucre none.

Involucre of one erect bract.

1. S. coloradensis.

2. S. pauciflorus. 
Bristles present, longer than the achenes.

Bristles wanting.

3. S. caespitosus.

4. S. pumilis.

Spikelets normally more than one, usually several or many; taller plants.

Spikelets few, I-12, appearing lateral.

Annual with fibrous roots.

Perennial with rootstocks.

Spikelets numerous, umbellate.

Involucre of 2 or more leaves with flat blades.

Spikelets few, umbelled or capitate, relatively large. 8. S. campestris.

Spikelets numerous, in compound umbels or in umbelled heads, relatively small.

Style-branches 2 ; achenes plano-convex; bristles mostly 4.

Style-branches 3 ; achenes 3 -angular; bristles 6 .

5. S. Hallii.

6. S. americanus.

7. S. lacustre.

9. S. rubrotinctus.

10. S. atrovirens.

I. Scirpus coloradensis Britt. On muddy shores of lakes in northern Colo. -Alt. about $5000 \mathrm{ft}$--Larimer Co.

2. Scirpus pauciflorus Lightf. In wet soil from Anticosti to B. C., N. Y. and Calif.-Alt. 9500-II,500 ft--Antonito; Seven Lakes; Ruxton Dell; Georgetown.

3. Scirpus caespitosus L. In bogs and among wet rocks from Greenl. to Alaska, N. C. and Colo.; also Europe and Asia.-Lat. $39^{\circ}-41^{\circ} . *$

4. Scirpus pumilus Vahl. In wet places in alpine regions in Alb. and Colo. - "Rocky Mountains."

5. Scirpus Hallii A. Gray. In wet soil from Mass. to Colo., Fla. and Tex.; also Mex.-Locality not given.

6. Scirpus americanus Pers. (S. pungens Vahl.) In fresh and alkaline swamps from Me. to B. C., Fla. and Calif.-Alt. $4000-6500 \mathrm{ft}$.-Plains and foot-hills near Boulder; Julesburg; mesas near Pueblo; Colorado Springs; Lake City; Spring Cañon; Platte River, Denver; Fort Collins.

7. Scirpus lacustris L. In lakes and swamps from Newf. to B. C., Fla. and Calif.-Alt. 4000-8500 ft.-Gypsum, Eagle Co.; Walsenburg; Ft. Collins; Grand Junction; Buffalo Pass, Park Range; New Windsor, Weld Co.; near Ft. Collins.

8. Scirpus campestris Britton. (S. maritimus of Coult. Man.) In wet places, especially with alkaline soil, from Man. to Wash., Tex. and Ariz.; also Mex.-Alt. 4000-6500 ft.-Ft. Collins; New Windsor, Weld Co.; Montrose; Walsenburg; Grand Junction; lowland along Poudre River; Ft. Collins.

9. Scirpus rubrotictus Fernald. In swamps from Newf. to Ida., N. Y. and Colo.-Alt. 4000-8000 ft.-McCoy; La Veta; Steamboat Springs, Routt Co.

Io. Scirpus atrovirens Muhl. In swamps from N. Sc. to Sask., Ga. and La. and Colo. West of Man. and Nebr. it is only represented by v, pallidus Britt.-Alt. 4000-6000 ft.-Plains and foot-hills near Boulder; Ft. Collins; New Windsor, Weld Co.; along Poudre River, Ft. Collins.

\section{ELEOCHARIS R. Br. SPIKE-RUSH.}

Style-branches 2.

Annuals with fibrous roots.

Perennials with horizontal rootstock.

Culm stout; tubercle conic-triangular.

Culm slender; tubercle narrower.

1. E. atropurpurea.

2. E. palustris.

3. E. glaucescens.

* Hall \& Harbour, who collected in Colorado, did not give any definite localities. On the labels is only given: Rocky Mts., lat. $39^{\circ}-41^{\circ}$. 
Style-branches 3 .

Achenes cancellate and longitudinally ribbed; spikelet flat.

Achenes smooth, papillose or reticulate; spikelet terete.

Achenes papillose.

Achenes finely reticulate.

Spikelets ovoid, blunt.

Spikelets narrowly oblong, acute.

4. E. acicularis.

5. E. acuminata.

6. E. arenicola.

7. E. montana.

^. Eleocharis atropurpurea (Retz.) Kunth. In wet soil from Iowa to Colo, Fla. and N. Mex.; also Mex. and Trop. Am.-Reported from Colorado, but doubtful.

2. Eleocharis palustris (L.) R. \& S. In swamps from Lab. and Alaska to Va. and Calif,; also in Europe and Asia.-Alt. 4000-10,000 ft.-Trimble Springs, near Durango; Gunnison; Ruxton Dell; Sterling, Logan Co.; New Windsor, Weld Co.; Ft. Collins; along Platte River, near Denver.

3. Eleocharis glaucescens (Willd.) Schultes. In swamps and wet meadows from Me. to Mont., Fla. and Ariz.-Alt. 4000-7000 ft.-Cucharas River, below La Veta; Julesburg; mesas near Pueblo; Quimby.

4. Eleocharis acicularis (L.) R. \& S. In wet soil and mud from Newf. to Sask., Wash., Fla. and Calif.; also Mex., Cent. Am., Europe and Asia.-Alt. 4000-I0,000 ft.-Divide between Colorado Springs and Denver; New Windsor, Weld Co.; Georgetown; river bank, Ft. Collins.

5. Eleocharis acuminata (Muhl.) Nees. In wet soil from N. Sc. to Alb., Ga., La. and Colo.-Mt. Lincoln.

6. Eleocharis arenicola Torr. On sandy shores and in swamps from S. C. to Colo., Fla. and Tex.-Salida.

7. Eleocharis montana (H. B. K.) R. \& S. In wet places from Colo. to Calif. and Mex.-Alt. about $7000 \mathrm{ft}$.-Dolores.

\section{FIMBRISTYLIS Vah1.}

Leaves strongly involute.

Leaves flat.

I. F. castanea.

z. F. thermalis.

I. Fimbristylis castanea (Michx.) Vahl. In saline soil from N. Y. to Neb., Fla. and Tex.-Lat. $39^{\circ}-4 I^{\circ}$.

2. Fimbristylis thermalis S. Wats. Usually near warm springs from Colo. to Calif.-Sterling, Logan Co.

\section{ELYNA Schrad.}

I. Elyna Bellardi (All.) Koch. (Kobresia scirpina Willd.) In wet places in alpine or arctic regions from Greenl. to Alaska and Alb.; also in Colo. -Alt. 8500-13,000 ft.-South Park; Twin Lakes; Georgetown; Clear Creek, near Georgetown; summit of Mt. Garfield; Ruxton Dell; Sierra Blanca.

\section{CAREX L. SEDGe.}

Stigmata 2 ; spikes all or nearly all bisexual, or dioecious, sessile.

VIGneaE.

Stigmata 3 ; or if 2 , the spikes mostly unisexual, the lateral ones pistillate (species of Microrhynchae, $C$. pulla and $C$. misandra).

Carices genuinae. 


\section{VIGNEAE.}

1. Spike single, androgynous* or unisexual.

Perigynia erect, with the hyaline beak split on the convex face.

2. NeurochlaEnaE.

Perigynia spreading at maturity, spongious at the base with a serrate bidentate beak.

II. Spikes several.

A. Beak of the perigynium entire, truncate or oblique.

Spikes remote; perigynia erect, several-nerved; scales hyaline.

Spikes green; perigynia not winged.

Spikes brown; perigynia winged.

Spikes sessile in a rounded or ovoid head.

Perigynia erect, prominently many-nerved.

Perigynia spreading, nerveless or nearly so.
5. C. gynocrates.

B. Beak of perigynitum bidentate or in the last split on one side.

I. Spikes androgynous or dioecious.

Perigynia elliptic and acuminate to orbicular, faintly nerved or nerveless, slightly spreading, spongious at the base, from green to brownish.

Perigynia ovate or lanceolate, nerved.

I. BrachystachyaE.

21. C. siccata.

io. Cephalostachyae.

i i. Sphaerostachyae.

Spikes in a dense-flowered spicate inflorescence; bracts often conspicuous; perigynia not spongious at the base, winged.

6. Xerochlaenae.

Spikes in an interrupted spicate inflorescence; bracts inconspicuous; perigynia spongious at the base. 7. Phannocarpat

2. Spikes gynaecandrous. $\uparrow$

Perigynia wingless.

Spikes silvery to light green, remote; perigynia membranous, light green, erect.

3. ARgyranthaE.

Spikes brownish.

Perigynia spreading, spongious at the base; spikes in a spicate inflorescence.

4. Astrostachyae.

Perigynia erect; spikes in an oval or rounded head.

Perigynia winged.

23. C. Bonplandii.

Perigynia lanceolate to ovate, narrowly winged; scales brownish.

Perigynia ovate to nearly orbicular, broadly winged; scales green to light brown.

9. Pterocarpae.

\section{CARICES GENUINAE.}

I. Perigynia neither inflated nor tapering into a long beak.

A. Spike solitary.

Perigynia glabrous; beak not ciliate.

Perigynia erect or in C. obtusata horizontally bent.

Perigynia greenish.

i6. Leiochlaenae.

Perigynia brown.

Achenes terete.

Achenes triquetrous.

Perigynia reflexed.

Perigynia pubescent or at least the beak ciliate.

Perigynia membranous; scales very broad and scarious-margined; bracts not foliaceous.

19. LAM PROChLAENAE.

34. C. Parryana.

17. Athrochlaenae.

20. Ely yanthae.

Perigynia not membranous; scales narrow, acuminate; bracts more or less foliaceous.

B. Spikes several.

58. C. scirpoidea and 59. C. oreocharis.

* Staminate above, pistillate below.

$\dagger$ Pistillate above, staminate below. 
I. Perigynia compressed; scales very dark.

Spikes all gynaecandrous or the lateral pistillate; stigmata 3 (except sometimes in C. misandra).

Spikes all gynaecandrous.

Lateral spikes pistillate.

Spikes sessile or nearly so. I2. Melananthae.

Spikes long-peduncled.

i2. Melananthae.

I2. MELANANTHAE.
I8. Stenocarpae.

Terminal spike staminate, the lateral pistillate or the uppermost of these staminate or androgynous.

Stigmata 3 ; spikes oblong.

Stigmata 2 ; spikes cylindrical.

35. C. Raynoldsii.

I3. MicrorhynCHAE.

z. Perigynia turgid.

Spikes 2-4, all gynaecandrous, dark brown; perigynia gibbous, papillose.

i 4. Aeorastachyae.

Spikes several; the terminal and sometimes the uppermost of the lateral ones staminate; the rest pistillate or in C. Backii all androgynous.

Perigynia glabrous; spikes peduncled.

Beak short or none; spikes erect, loosely flowered; perigynia nerved.

Beak prominent, bifid or bidentate.

I5. CENCHROCARPAE.

Spikes not very densely flowered, drooping; perigynia faintly nerved, erect or slightly spreading.

23. HymenochlaEnaE.

Spikes densely flowered, erect; perigynia nerved, squarose at maturity.

Perigynia pubescent.

24. Spirostachyae.

Pistillate spikes few-flowered, roundish; perigynia obovate to globose, obscurely nerved; bracts foliaceous but sheathless.

2I. SPHAERIDIOPHORAE.

Pistillate spikes cylindric, dense-flowered; perigynia ovate or ovatelanceolate, nerved; bracts sheathing.

22. TRICHOCARFAE.

II. Perigynia inflated and tapering into a long beak.

Perigynia abruptly contracted into a very long, slender beak.

Perigynia gradually tapering into the beak.

66. C. longirostris.

Perigynia, at least the lower, reflexed at maturity, sessile; bracts sheathing.

Perigynia not reflexed.

Bracts sheathless; perigynia sessile.

Bracts sheathing; perigynia stipitate.

25. ECHINOSTACHYAE.

26. Physocarpae.

27. RHYNCHOPHORAE.

1. VIGNEAE. Stigmata 2. Spikes all or nearly all bisexual or dioccious, sessile.

\section{BRACHYSTACHYAE.}

Spikes several, short and few-flowered, sessile, remote, light-green; scáles hyaline; perigynium erect, several-nerved, spongious at the base.

Spikes gynaecandrous ( $i$.e., pistillate above, staminate below); bracts inconspicuous; perigynium light-green, ovate, tapering into a short, almost entire beak.

Spikes androgynous (i, staminate above, pistillate below) I. C. canescens. conspicuous; perigynium shining reddish-brown, abruptly-beaked.

\section{Neurochlaenae.}

2. C. tenella.

Spike single, androgynous, shining reddish-brown; perigynium erect, oblong, faintly nerved, scabrous along the short hyaline beak, with the orifice slit on the convex face.

One species.

3. C. nardina. 


\section{Argyranthae.}

Spikes several, short and loose-flowered, sessile, remote, silvery to lightgreen, gynaecandrous; bracts short; scales hyaline; perigynium erect, membranaceous, light-green, stipitate, lanceolate, nerved, serrate along the margins, tapering into a long bidentate beak.

One species.

4. C. Derveyana.

\section{Astrostachyae.}

Spike single or several, short and few-flowered, sessile, remote; bracts short and narrow; scales brownish; perigynium sessile, spreading at maturity, cordate to ovate, several-nerved, spongious at base, tapering into a serrate, bidentate beak.

Spike single, unisexual or androgynous. Spike several, gynaecandrous.

Perigynium narrowly ovate, faintly nerved.

Perigynium broadly ovate, prominently nerved.

5. C. gynocrates.

6. C. stellulata.

7. C. sterilis.

\section{ACANTHOPHORAE.}

Spikes several, short, but dense-flowered, sessile, androgynous; bracts often long; scales greenish to brown; perigynium slightly spreading, elliptical and acuminate to suborbicular, faintly nerved or nerveless, spongious at base, narrowly winged, the beak serrulate, bidentate.

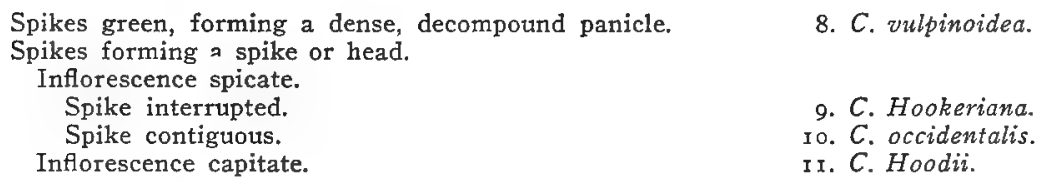

10. C. occidentalis.

Spike contiguous.
Inflorescence capitate.

\section{Xerochlaenae.}

Spikes many, small, in a dense-flowered spicate inflorescence, sessile, contiguous, androgynous or dioecious; bracts often conspicuous; scales brownish; perigynium stipitate, erect, ovate to lanceolate, nerved, brown, winged, serrulate along the margins, tapering into a distinct, bidentate beak.

Scales acuminate.

Perigynium ovate, acuminate; spikes often unisexual. $\quad$ I2. C. marcida.

Perigynium lanceolate; spikes bisexual.

Scales awned, perigynium ovate-lanceolate; spikes mostly unisexual.

I 3. C. Sartwellit.

I4. C. Douglasii.

\section{Phaenocarpae.}

Spikes small, many in an interrupted spicate inflorescence, sometimes paniculately branched, sessile, contiguous or nearly so, androgynous; bracts inconspict1ous; scales brownish; perigynium somewhat spreading, ovate, nerved, shining brown, spongious at base, the beak serrulate, bidentate.

One species.

I 5. C. teretiuscula.

\section{Athrostachyae.}

Spikes several, but not many, in a dense-flowered spike or head, sessile, gynaecandrous; bracts seldom conspictous; scales brownish; perigynium 
erect, lanceolate to ovate, more or less winged, very seldom wingless, tapering into a long serrtulate or ciliate beak, with the orifice oblique or bidentate.

Perigynium winged.

Spikes ih an oval or roundish head; perigynium ovate to lanceolate; beak slit on the convex side.

Bracts longer than the inflorescence.

Bracts inconspicuous.

17. C. athrostachya.

Perigynium broadly ovate to suborbicular, rather light brown or greenish.

Perigynium lanceolate, very dark brown and shining. I8a. C. ebenea.

Spikes in a more or less distinct spike.

Perigynium lanceolate, narrowly winged, ciliate; inflorescence short.

Perigynium ovate.

I6. C. scoparia.

Beak bidentate.

Perigynium thin, green; spikes nodding when young, tapering at the base.

Perigynium firm, brown; spikes erect, strict.

20. C. pratensis.

Beak not bidentate.

'Beak slit on the convex side.

Beak oblique at the orifice.

Perigynium not winged.

22. C. Liddonii.

19. C. petasata.

21. C. siccata.

23. C. Bonplandii.

\section{Pterocarpae.}

Spikes several, large and heavy, dense-flowered, contiguous or the lower ones remote, sessile, gynaecandrous; bracts inconspicuous; scales light-brown to green; perigynium erect, ovate to almost orbicular, much compressed, nerved, broadly winged, prominently serrulate, the beak bidentate.

Spikes ovate in a roundish head.

Spikes in a spicate inflorescence.

Perigynium about 5 -nerved.

Perigynium 7-I5-nerved.
25. C. straminiformis.

24. C. straminea.

26. C. festucacea.

io. Cephalostachyae.

Spikes several, reddish brown, androgynous, dense-flowered, sessile in a roundish or ovoid head; bracts inconspicuous; scales ovate, acute; perigynium stipitate, erect, ovate, turgid, spongious, prominently many-nerved, shining reddish-brown, the beak scabrous, obliquely cut, with hyaline orifice.

One species.

27. C. stenophylla.

II. Sphaerostachyae.

Spikes several, androgynous, dense-flowered, sessile in a roundish head; bracts inconspicuous; scales broadly ovate with hyaline margins; perigynium spreading at maturity, stipitate, ovate, turgid, nerveless or nearly so, yellowish, becoming fuscous at maturity, scabrous along the prominent, obliquely cut beak.

One species.

28. C. incurva. 
II. CARICES GENUINAE. Stigmata 2 or 3. Spikes mostly unisexual.

\section{Melananthae.}

Spikes several, dense-flowered, mostly peduncled and drooping, contiguous, gynaecandrous or the terminal staminate, the lateral pistillate; bracts conspicuous, but narrow, sheathless; scales dark-colored; perigynium sessile, erect, very seldom spreading, sessile, more or less compressed, elliptical, fewnerved, granulated and often scabrous along the upper margins, purplishspotted to almost black, the beak short, entire to emarginate; stigmata 3 .

Spikes several.

Terminal spike gynaecandrous or in C. Parryana sometimes pistillate.

All spikes gynaecandrous peduncled and often somewhat drooping.

Spikes ovate.

Scales and perigynia blackish.

Scales and perigynia copper-colored.

Spikes cylindric; scales blackish; perigynia light-green.

3I. C. atrata.

32. C. chalciolepis.

33. C. bella.

Lateral spikes pistillate, sessile, erect.

Spikes contiguous in a dense head.

Perigynia erect.

Perigynia spreading.

Spikes somewhat remote, spicate.

Perigynia subtriquetrous; lateral spikes usually small or none; scales purplish, with hyaline margins.

Perigynia compressed; lateral spikes not reduced; scales purplish.

36. C. Bu.tbaumii.

Terminal spike staminate, the lateral pistillate and peduncied, but erect and contiguous.

Spike single.

35. C. Raynoldsii.

34. C. Parryana.

\section{MICRORHYNCHAE.}

Spikes several, cylindrical, often dense-flowered, sessile or short peduncled, erect, remote, the terminal staminate, the lateral pistillate or the uppermost staminate or androgynous; bracts foliaceous, sheathless; scales dark, obtuse; perigynia often stipitate, erect, compressed, roundish-ovate to elliptical, more or less prominently nerved, granulated, often scabrous along the upper margins, pale green, the beak mostly minute, entire to emarginate; stigmata 2.

Perigynia compressed; beak not bent horizontally.

Spikes sessile.

Perigynia several-nerved; spikes remote.

Perigynia stipitate, deciduous; beak entire.

Perigynia persistent; beak bidentate.

Perigynia 2-nerved, not deciduous; spikes contiguous.

Spikes peduncled.

Spikes short; scales spreading, acuminate, longer than the scabrous roundish perigynia.

Spikes long and cylindric, remote.

Perigynia rhombic, entirely beakless.

Perigynia beaked.

Perigynia stipitate, oval.

Perigynia sessile, obovate to broadly elliptic. .

38. C. vulgaris.

44. C. nebraskensis.

39. C. rigida.

Perigynium turgid, with a beak bent horizontally; spikes sessile or nearly so.

45. C. scopulorum. 


\section{Agorastachyae.}

Spikes several, short, but dense-flowered, long-peduncled and drooping, somewhat remote, the terminal staminate, the lateral gynaecandrous; bracts narrow, sheathless; scales dark-colored, lanceolate-acuminate, longer than the perigynium, which is stipitate, erect, orbicular to obovate gibbous, papillose, nerved, with a short, entire beak; stigmata 3 .

One species.

46. C. magellanica.

\section{Cenchrocarpae.}

Spikes several, loose-flowered, peduncled, but erect, contiguous, the terminal staminate or gynaecandrous, the lateral pistillate; bracts foliaceous, sheathing; scales dark or greenish; perigynium erect, turgid, glabrous, distinctly several-nerved, the beak short or none; stigmata 3 .

Terminal spike staminate or gynaecandrous; perigynium globose, orange-colored, beakless or nearly so.

47. C. aurea.

Terminal spike staminate; perigynium obovate, greenish, abruptly beaked, with the orifice byaline. 48. C. Torreyi.

i6. Leiochlaenae.

Spike one, lax and few-flowered, androgynous; scales hyaline, mutcronate; perigynium erect, pale-green, stipitate with a short beak or beakless.

Perigynium many-nerved, elliptical, emarginate, beakless.

Perigynium oval, two-nerved, shortly beaked.

49. C. polytrichoides. 50. C. Geyeri.

\section{I7. Athrochlaenae.}

Spike one, dense and many-flowered, androgynous, the pistillate portion squarrose at maturity; scales lanceolate to oblong, deciduous; perigynium shining, brown, reflexed at maturity, ovate to linear-oblong, prominently stipitate, nerveless, tapering into a long beak; stigmata mostly 3 .

Rootstock creeping, stoloniferous; leaves flat; perigynium ovate, the beak twolobed. 5I. C. nigricans.

Rootstock caespitose, matted; leaves very narrow, involute; perigynium linearoblong, the beak obliquely cut.

52. C. pyrenaica.

\section{I8. Stenocarpae.}

Spikes several, very dark, dense-flowered, borne on long, capillary peduncles, more or less drooping, the terminal gynaecandrous, the lateral pistillate; scales very dark, acuminate; perigynium purplish, erect, attenuated at both ends, compressed, nerveless, the beak long, serrulate, with the orifice oliquely cut to bifid, hyaline; stigmata 2 or 3 .

One species.

53. C. misandra.

19. LAMPROCHLAENAE.

Spike one, short and few-flowered, androgynous; scales broad, brownish; perigynium obovate to elliptical, obscurely nerved or nerveless, the beak short, with the orifice entire or obliquely cut; stigmata 3 . 
Spike dull-brown; perigynium erect or slightly spreading at maturity, obovate, shortly beaked or beakless, the orifice entire.

54. C. rupestris. Spike shining, reddish-brown; perigynium horizontally bent at maturity, turgid, coriaceous, obscurely nerved, the short beak with hyaline orifice.

55. C. obtusata.

\section{Elynanthae.}

Spike single, androgynous, the pistillate portion few-flowered; scales very broad; perigynium membranaceous, whitish to brown, erect, sessile, oval to obovoid, pubescent or ciliate above, the beak short, with the orifice entire or obliquely cut; stigmata 3 .

Spike silvery-shining, light-brown; perigynium oval, pubescent, the beak entire. 56. C. filifolia.

Spike reddish-brown; perigynium obovoid, attenuated at both ends, the beak ciliate, obliquely cut.

57. C. elynoides.

\section{I. SphaERIDiophorae.}

Spike one, the plant dioecious or monoecious, or several, the terminal staminate, the lateral pistillate; the latter few-flowered, roundish, mostly sessile or the basal long-peduncled; bracts foliaceous, sheathless; scales acuminate, often mucronate, green to blackish; perigynium dark-green, stipitate or sessile, obovate to globose, pubescent, obscurely nerved, the beak mostly short, obliquely cut or bidentate, with the teeth erect; stigmata 3 .

Spikes solitary; beak short, obliquely cut.

Dioecious; spike very dark, many-flowered; perigynium strigosely hairy, obovate to oval.

58. C. scirpoidea.

Monoecious ; spike androgynous, silvery-shining; perigynium minutely pubescent, broadly elliptic.

59. C. oreocharis.

Spikes several.

Rhizome stoloniferous; spikes dark-colored, sessile or nearly so; perigynium globose, abruptly beaked; beak short, entire or 2-lobed. 6o. C. pennsylvanica.

Rhizome caespitose; spikes peduncled, light-green to brown.

Perigynium oval, stipitate; beak bifid. 6 6. C. Rossii.

Perigynium globose; beak long, obliquely cut. $\quad 62$. C. umbellata.

\section{Trichocarpae.}

Spikes several, cylindrical, dense-flowered, sessile or the lowest one peduncled, but erect, remote, the terminal and uppermost lateral staminate, the others pistillate; bracts foliaceous, long and sheathing; scales purplish or brown, mucronate to aristate; perigynia erect, sessile, ovate to ovate-lanceolate, turgid, more or less pubescent, nerved, the beak prominent, bidentate; stigmata 3 .

Perigynium ovate, densely pubescent.

63. C. lanuginosa. Perigynium ovate-lanceolate, sparingly pubescent, the beak with very long, diverging teeth.

64. C. aristata.

\section{HymenochlaenaE.}

Spikes several, androgynous or the terminal staminate, the lateral pistillate, not very dense-flowered, long-peduncled and drooping; bracts foliaceous, sheathing; scales hyaline, mucronate; perigynia erect to slightly 
spreading, oval to elliptical, glabrous below, faintly nerved, the beak prominent, scabrous, bifid or bidentate; stigmata 3 .

Spikes androgynous, light-green.

65. C. Backii.

Spikes staminate or pistillate on the same culm.

Spikes green; perigynium inflated, orbicular, the beak very long, linear, with the orifice obliquely cut. 66. C. longirostris.

Spikes shining, reddish-brown; perigynium elliptical, the beak entire.

67. C. capillaris.

\section{Spirostachyae.}

Spikes several, rather short, dense-flowered, peduncled, but erect, remote, squarrose at maturity, the terminal staminate, the lateral pistillate; bracts foliaceous, sheathing; scales light-brown, acuminate; perigynia greenish, spreading, oval to elliptical, turgid, sessile, nerved, glabrous, the beak long, scabrous, bifid; stigmata 3 .

One species.

68. C. viridula.

\section{ECHINOSTACHYAE.}

Spike one, androgynous, or several, the terminal staminate, the lateral pistillate, cylindrical, dense-flowered, peduncled, but erect, squarrose at maturity; bracts foliaceous, very long, sheathing; scales lanceolate, light-brown; perigynium greenish, more or less inflated, nerved, glabrous, the beak long, bidentate; stigmata 3 .

Spike one, androgynous; perigynium reflexed at maturity, narrowly lanceolate, orifice of beak oblique; rhacheola extended through orifice of the beak.

69. C. microglochin.

Spikes several, the terminal staminate, the lateral pistillate; perigynium ovate, much inflated, spreading at maturity, the beak bifurcate; rhacheola not extended. 70. C. retrorsa.

\section{Physocarpae.}

Spike one, androgynous, or several, the terminal and, sometimes, the uppermost lateral staminate, the others pistillate, cylindrical, sessile or the lowermost pedtuncled, dark-colored; bracts foliaceous, sheathless; scales lanceolate, acuminate, brownish or purple; perigynia shining, spreading, but not reflexed, membranaceous, globular to oblong-elliptical, inflated, sessile; nerved, the beak short, bidentate or merely emarginate; stigmata 2 or 3 .

Spike single, androgynous; perigynium elliptical, tapering into a bidentate beak. Spikes several.

7 I. C. Engelmannii.

Pistillate spikes cylindrical, often very long; perigynium inflated, many-nerved, oblong-elliptical, tapering into a cylindrical, bifurcate beak; stigmata 3 . 72. C. utriculata.

Pistillate spikes short, blackish; perigynium slightly inflated, broadly ovate, nerveless, the beak short, emarginate; stigmata 2.73. C. pulla.

\section{RHYNCHOPHORAE.}

Spikes several, cylindrical, very robust and dense-flowered, sessile or nearly so, mostly erect, contiguous, the terminal and, sometimes, the uppermost lateral staminate, the others pistillate; bracts foliaceous and very long, sheath- 
ing; scales light-green, lanceolate, mucronate to aristate; perigynia greenish, erect, stipitate, membranaceous, ovate, much inflated, prominently nerved, glabrous or scabrous along the long beak, which is sharply bifurcate; stigmata 3 .

Perigynium subglobose, glabrous, the beak bifurcate.

74. C. monile.

Perigynium very large, ovate, scabrous, prominently stipitate, the beak very long, bifurcate.

75. C. lupulina.

1. Carex canescens L. In bogs from Newf. to B. C., Va., Colo. and Ore.; also in Europe and Asia.-Alt. 8500-II,500 ft.-Marshall Pass; Lake Moraine; Trapper's Lake; Bob Creek, west of Mt. Hesperus; lat. $39^{\circ}-4 \mathrm{I}^{\circ} . *$

2. Carex tenella Schkur. In bogs, especially in the woods, from Newf. to B. C., N. J., Colo. and Calif.-Alt. 6000-II,500 ft.-North Park; Castle Cañon; Graymont; Colorado Springs; near Gray's Peak; near Pagosa Peak; Bob Creek, west of Mt. Hesperus; Twin Lakes; Little Beaver Creek; Mt. Elbert; along Quail Creek, near Stevens' Mine.

3. Carex nardina Fries. From Greenl. to Alaska, Colo. and Ore.; also Europe.-Alt. I0,000-12,000 ft.-Silver Plume; Mt. Elbert.

4. Carex Deweyana Schwein. In woods from N. S. to Ore., Pa. and N. Mex.-Alt. 4000-500o ft.-Foot-hills, Larimer Co.

5. Carex gynocrates Wormskj. In bogs from Labr. and Alaska to Pa. and Colo.-Mosquito; South Park.

6. Carex stellulata Good. In bogs, Labr. and Alaska to Colo.; also Europe and Asia.-Wet Mountain Valley; Beaver Creek, Larimer Co.

7. Carez sterilis Willd. In moist soil from Newf. to B. C., Fla. and Calif. -Twin Lakes; South Park.

8. Carex vulpinoidea Michx. In swamps and wet meadows from N. B. to Man., Fla., Tex. and Colo.-Alt. 4000-5000 ft.-Brantly Cañon, Las Animas Co.

9. Carex Hookeriana Dew. Dry meadows from Sask. and B. C. to Colo. and Calif.-Alt. about $5000 \mathrm{ft} .-\mathrm{Ft}$. Collins; Los Pinos; hills about Trinidad; dry meadows at Dix; gulch south of Rist Cañon.

ro. Carex occidentalis Bailey. (C. muricata Americana Bailey.) In meadows from Colo. to N. M. and Ariz.-Alt. 6500-II,000 ft.-Near Pagosa Peak; Sierra Blanca; Montrose; Estes Park; Cedar Edge; Green Mountain Falls, near Pike's Peak; La Plata Cañon; Mt. Hesperus; gulch west of Soldier Cañon; lat. $39^{\circ}-41^{\circ}$.

II. Carex Hoodii Boott. (C. muricata confixa Bailey.) In meadows from Mont. and B. C. to Colo. and Calif.-Alt. up to ro,ooo ft.-Continental Divide, Routt Co.; foot of Mt. Richtofen, on the Michigan; Four-Mile Hill, Routt Co.; Hahn's Peak, Routt Co.; Rabbit-Ears, Larimer Co.

12. Carex marcida Dewey. In meadows from Man. to B. C., Neb., N. M. and Nev.-Alt. 4000-8500 ft.-Gunnison; Colorado Springs; mesas near Pueblo; Cucharas River, below La Veta; North Park; Pagosa Springs; Durango; Ft. Collins; Buena Vista; Twin Lakes; South Park; moist meadow, Fort Collins.

13. Carex Sartwellii Dewey. In swamps from Ont. to B. C., N. Y. and Utah.-South Park; lat. $39^{\circ}-41^{\circ}$.

* See footnote on page 59 . 
I4. Carez Douglasii Boott. In dry or alkaline soil from Man. to B. C., Neb., N. M. and Calif.-Alt. 5000-II,000 ft.-Antonito; Ruxton Dell; Gunnison; Ironton; plains near Denver; Cucharas Valley, near La Veta; Ft. Collins; La Plata Cañon; Grizzly Creek; pasture, Walton Creek flats; near Long's Peak; in the Spruce Zone, headwaters of Clear Creek.

I5. Carex teretiuscula Good. In swamps and meadows from N. Sc. to B. C., Pa. and Colo.-Alt. up to $9000 \mathrm{ft}$.-Hamor's Lake.

I6. Carex scoparia Schkur. In moist soil from N. S. to Man., Fla. and Colo.-Ait. up to $7000 \mathrm{ft}$.-Cheyenne Cañon.

17. Carex athrostachya Olney. In meadows and copses from Ass, and B. C. to Colo, and Calif.-Alt. 8000-II,000 ft.-North Park; Mt. Massive.

18. Carex festiva Dewey. Grassy mountain sides and meadows from Ass. and B. C. to Mex.-Alt. 6500-13,000 ft.-Marshall Pass; Sierra Blanca; Seven Lakes; Gunnison; Honnold; Cascade Cañon; Chrystal Park; West Indian Creek; headwaters of Sangre de Cristo Creek; Pass Creek; Dolores; La Plata Cañon; Bob Creek; Silver Plume; Andrew's Shetland ranch; Mosquito; foot of Mt. Richtofen, on the Michigan; Cameron Pass; Como; Chambers' Lake; Mt. Massive; White House Mountain; Mt. Lincoln; Pike's Peak; Gunnison; Georgetown; not uncommon in the Aspen and Spruce Zones from Silver Plume to Stevens' Mine; Gray's Peak.

C. festiva var. pachystachya Bailey.-Bob Creek; banks of streams, near Pagosa Peak.

C. festiva var. stricta Bailey.-Walton Creek flats, Routt Co.; Georgetown; Silver Plume.

C. festiva var. decumbens Holm.-Empire; mountains near Pagosa Peak; Mt. Kelso, near Stevens' Mine.

I8a. Carex ebenea Rydb. (Carex festiva Haydeniana Bailey; not C. Haydeniana Oln.) In mountain meadows from Alb. and B. C. to Colo. and Utah. -Alt. 6000-12,000 ft.-Ironton; Alpine Tunnel; Pike's Peak; Bottomless Pit; Mt. Harvard; between Cheyenne Mountain and Seven Lakes; near Pagosa Peak; Silver Plume; Cameron Pass; Chambers' Lake; Clear Creek Cañon; Marshall Pass, Gunnison watershed; Mt. Kelso; Thompson's Cañon, on Long's Peak; Mt. Massive; Mt. Elbert.

19. Carex petasata Dewey. (C. leporina Bailey in Coulter's Man.) In mountain meadows from Alb. and Alaska to Colo. and Ore.-Alt. IO,00oI3,000 ft.-Bottomless Pit; Chambers' Lake; Windy Point on Pike's Peak; Cameron Pass, at timber line; La Plata River; James' Peak; Mt. Massive; Mt. Kelso.

20. Carex pratensis Drej. In meadows from Ont. to Alaska, Mich. and Colo.-Alt. 5000-8500 ft.-Middle Park; Stone Basin, Larimer Co.; Howe's Gulch; Long's Peak.

2I. Carex siccata Dewey. In dry fields and hills from Ont. to B. C., N. Y. and Calif.-Alt. 5000-Io,000 ft.-Calvin Cañon; Mosquito; La Veta River; Silver Plume; Fort Collins; near Pike's Peak; between Bald Mountain and Seven Lakes; Chambers' Lake; Mt. Massive; Mt. Kelso; Lamb's ranch, near Long's Peak; Colorado Springs; Georgetown; South Park; Middle Park, along Grand River.

22. Carex Liddonii Boott. In meadows from Mont. and B. C. to Colo. and Calif.-Alt. about $7500 \mathrm{ft}$.-Mountains in Larimer Co.; Campton's ranch. 
23. Carex Bonplandii minor Olney. (C. illota Bailey.) Mountains of Wyo., Colo. and Utah.-Alt. about II,500 ft.-Headwaters of Clear Creek; Ethel Peak, Larimer Co.

24. Carex straminea Willd. In dry fields and on foot-hills from N. B. to Man., Pa. and Colo.-Alt. 4000-6500 ft.-Foot-hills, Larimer Co.; Clear Creek Cañon.

25. Carex straminiformis Bailey. In dry meadows and on hillsides from Wash. to Colo. and Calif.-Alt. about 9500 ft.-West Mancos Cañon.

26. Carex festucacea Schkur. In rich soil from N. B. to Minn., Fla. and Colo.-Alt. 4000-5000 ft.-Windsor; Brantly Cañon, Las Animas Co.

27. Carex stenophylla Wahl. On dry plains from Man. to B. C., Iowa and Colo.-Alt. 4000-10,500 ft.-South Park; Turkey Creek and tributaries; mesas near Colorado Springs; Como; vicinity of Horsetooth; Georgetown.

28. Carex incurva Lightf. In alpine-arctic regions from Greenl. to Alaska and Colo.; also in Europe and Asia.-Alpine ridge, near Middle Park; Gray's Peak; Silver Plume.

29. Carex alpina $S w$. In rocky places, in arctic or alpine regions from Lab. and Alaska to Ont. and Colo.-Alt. 8500-12,000 ft.-Seven Lakes; South Park; Ruxton Dell; Pike's Peak; La Plata River; Beaver Creek; Idaho Springs; Georgetown.

C. alpina var. Stevenii Holm.-Georgetown; Colorado Springs; Silver Plume; Middle Park; Lamb's ranch, near Long's Peak; between Graymont and Stevens' Mine; Gray's Peak.

3o. Carex melanocephala Turcz. (C. nova Bailey.) In the mountains from Mont. to Colo.-Alt. 8500-I2,000 ft.-Sierra Blanca; Middle Park; Alpine Tunnel; west side of Bald Mountain; Pike's Peak; Ouray; Upper La Plata River; Silver Plume; Oro City; Wet Mountain Valley; Chambers' Lake; Mt. Elbert; Mt. Kelso; headwaters of Clear Creek.

31. Carex atrata L. In arctic-alpine localities from Lab. and Alaska to Que., Colo. and Calif.-Alt. II,500-I3,000 ft.-Sierra Blanca; South Park; Long's Peak; Gray's Peak; lat. $39^{\circ}-41^{\circ}$.

32. Carex chalciolepis Holm. Mountains of Colorado.-Alt. 8500-13,000 ft. -Marshall Pass; Ouray; Mt. Hesperus; Devil's Causeway; Cameron Pass; Silver Plume; Bottomless Pit; near Pagosa Peak; Little Kate Mine; West Spanish Peak; Bald Mountain; Pike's Peak; Estes Park; Empire; James' Peak; Mt. Massive; Mt. Elbert; Mt. Kelso; Long's Peak; Gray's Peak.

33. Carex bella Bailey. Mountains of Colo., Utah and Ariz.-Alt. 900oI I,500 ft.-Sierra Blanca; Upper La Plata River; Mt. Hesperus; Stage Coach Mountain; West Spanish Peak; South Park.

34. Carex Parryana Dewey. In alpine and arctic regions from Hudson Bay to B. C. and Colo.-Alt. 6500-10,000 ft.-South Park; Table Rock; Mosquito; South Pass; Twin Lakes; lat. $39^{\circ}-41^{\circ}$.

35. Carex Raynoldsii Dewey. In motntain meadows from Mont. and Wash. to Colo. and Calif.-Foot of Mt. Richtofen, on the Michigan; RabbitEar Range, Routt Co.

36. Carex Buxbaumii Wahl. In bogs from Newf. to Alaska, Ga. and Calif. -Twin Lakes; lat. $39^{\circ}-41^{\circ}$.

37. Carex rhomboidea Holm. In alpine swamps of Colo.-Alt. 8500-9500 ft.-In swamps near Long's Peak; Twin Lakes. 
38. Carex vulgaris Fries. (C. Goodenovii J. Gay.) In wet grounds from Newf. to Alaska, Pa. and Colo.-Alt. 6000-10,000 ft.-Silver Plume. Co.

C. vulgaris var. lipocarpa Holm.-Columbine; Steamboat Springs, Routt

39. Carex rigida Good. (C. vulgaris alpina Booth.) In the mountains from Alaska to Colo,-Alt. about I $x, 500 \mathrm{ft}$.-Headwaters of Clear Creek.

40. Carex chimaphila Holm. Alpine regions of Colorado.-Alt. I1,000I2,00o ft.-Alpine Tunnel; Long's Peak.

4I. Carex acutina Bailey. Mountains from Mackenzie and Alaska to Colo. and Ore.-Alt. 8500-10,000 ft.-Foot of Mt. Richtofen, on the Michigan; Silver Plume; Georgetown; Graymont; Lamb's ranch, near Long's Peak; James' Peak.

42. C. acutina var. petrophila Holm.-Dry rocks near Graymont.

43. Carex variabilis Bailey. (C. stricta Bailey in Coulter's Man.) Wet meadows from Mont. to Colo.-Alt. 8500-II,500 ft.-Seven Lakes; Sierra Blanca; Ruxton Dell; Grizzly Creek; Twin Lakes; Leadville; Ute Pass; Empire; Cameron Pass; Georgetown; Mt. Massive; Mt. Kelso.

C. variabilis var. sciaphila Holm.-Mt. Massive, i I,000 ft.

44. Carex nebraskensis Dewey. In meadows from Nebr. to Ore. and $\mathrm{N}$. M.-Alt. 4000-7000 ft.-Wahatoya Creek; Palmer Lake; near Pike's Peak; Colorado Springs; Ft. Collins; Oak Creek; Weston Pass; Twin Lakes; Monument Park.

45. Carex scopulorum Holm. (C. Tolmici subsessilis Bailey, in part.) Mountains of Colo.-Alt. Io,000-I2,000 ft.-Sierra Blanca; Marshall Pass; Pike's Peak; Clark's Peak; Bottomless Pit; Mt. Harvard; Estes Park; Silver Plume; Mt. Massive; headwaters of Clear Creek; Stevens' Mine; Mt. Kelso; Gray's Peak.

46. Carex magellanica Lam. In bogs from Newf. to B. C., Pa. and Utah; also in Europe and South America.-Alt. about 8500 ft.-Estes Park.

47. Carex aurea Nutt. In wet meadows from Newf. to B. C., Pa., Utah and Wash.-Alt. 4000-II,000 ft.-Gunnison; Palsgrove Cañon; Seven Lakes; Green Mountain Falls; North Cheyenne Cañon; Wahatoya Creek; Piedra; Los Pinos; Georgetown; Elk River, Routt Co.; Mancos; West Mancos Cañon; North Park; Twin Lakes; Mt. La Plata; Clear Creek Cañon, near Graymont.

48. Carex Torreyi Tuck. In dry soil from N. Y. to N. W. T. and Colo.Near Golden City.

49. Carex polytrichoides Willd. In bogs and swamps from Newf. to B. C., Fla., Tex. and Ore.-Alt. up to Io,000 ft.Twin Lakes; lat. $39^{\circ}-4 \mathrm{I}^{\circ}$.

50. Carex Geyeri Boott. Dry mountain sides from Mont. and B. C. to Colo. and Ore--Alt. 8500-II,000 ft.-Bob Creek, west of Mt. Hesperus; North Park, near Teller; foot of Mt. Richtofen, on the Michigan; Chambers' Lake; lat. $39^{\circ}-41^{\circ}$.

51. Carex nigricans C. A. Mey. On the higher mountains from Alb. and Alaska to Colo. and northern Calif.-Alt. I0,000-I3,000 ft.-Telluride; Thompson's Cañon, on Long's Peak; headwaters of Clear Creek; lat. $39^{\circ}-$ $4 \mathrm{r}^{\circ}$.

52. Carex pyrenaica Wahl. On the higher mountains from Alb. and Alaska to Colo. and Ore.; also in Europe.-Alt. II,500-I4,000 ft.-Sierra 
Blanca; Mt. Harvard; Gray's Peak; Cameron Pass; Telluride; Pagosa Peak; Long's Peak; lat. $39^{\circ}-41^{\circ}$.

53. Carex misandra $\mathrm{R}$. Br. In arctic and alpine regions from ${ }^{\circ} \mathrm{Lab}$. to Alaska and Colo.; also in Europe and Asia.-Alt. about 12,000 ft.-Gray's Peak.

54. Carex rupestris All. In alpine and arctic regions from Greenl. to Alaska and Colo.-Alt. II,500-I3,000 ft.-Pike's Peak; Cumberland Mines; Gray's Peak; James' Peak; Mt. Elbert; Long's Peak; Floral Mountain; lat. $39^{\circ}-41^{\circ}$

55. Carex obtusata Lilj. On dry hills and prairies from Newf. and B. C. to Colo.-Alt. 8000-Io,00o ft.-Ruxton Dell; Georgetown; Chicken Creek, west of Mt. Hesperus; South Park; Long's Peak; lat. $39^{\circ}-41^{\circ}$.

56. Carex filifolia Nutt. On dry plains from Man. to B. C., Neb., Colo. and Calif.-Alt. 4000-I0,000 ft.-Lat. $39^{\circ}-4 \mathrm{I}^{\circ}$; Ute Pass; Table Rock; Silver Plume.

57. Carex elynoides Holm. Mountains of Colo.-Alt. II,500-13,000 ft.Alpine Tunnel; near Pagosa Peak; Mt. Princeton, Chaffee Co.; Mt. Massive and Mt. Kelso.

58. Carex scirpoidea Michx. In rocky soil from Greenl. to Alaska, Mass. and Calif.-San Juan Co.; South Park; lat. $39^{\circ}-41^{\circ}$.

59. Carex oreocharis Holm. Mountains of Colo.-Alt. about $8500 \mathrm{ft}$.Lamb's ranch, near Long's Peak.

6o. Carex pennsylvanica Lam. In dry soil from N. B. to Alb., N. C. and Colo. In the state only represented by var. vespertina Bailey.-Alt. 5000$8500 \mathrm{ft}$.-New Windsor; Colorado Springs; foot-hills, Larimer Co.; Ft. Collins; headwaters of Pass Creek; Como; vicinity of Horsetooth; Trail Creek and Rist Cañon; Ute Pass; mountains near Central City; Dixon Cañon; Horsetooth Gulch.

6r. Carex Rossii Boott. Mountains from Alb. and B. C. to Colo.-Alt. 6000-II,500 ft.-Middle Park; Chambers' Lake; Cameron Pass; Little Kate Mine, La Plata Mountains; Silver Plume; near Pagosa Peak; Colorado Springs; Twin Lakes; headwaters of Beaver Creek; Mt. Massive; headwaters of Clear Creek.

62. Carex umbellata Schkur. In dry soil from N. Sc. to Ore., N. J. and Colo. In the state represented by var. brevirostris Boott.-Alt. about 6000 ft.-Near Golden City.

63. Carex lanuginosa Michx. In swamps and wet meadows from $\mathrm{N}$. Sc. to B. C., N. J., N. M. and Calif.-Alt. 4000-8500 ft.-Gunnison; Twin Lakes; Windsor; Turkey Creek and tributaries; mountains in Larimer Co.; Durango; swales, Ute Pass; Cañon City; Campton's ranch; Pagosa Spring; Estes Park.

64. Carex aristata R. Br. In bogs from Ont. to Ore., N. Y. and Utah.Alt. 4000-600o ft.-Saguache Creek; river bank, near Fort Collins.

65. Carex Backii Boott. In woods and thickets from Ont. to Man., N. Y. and Colo.-Alt. up to $5500 \mathrm{ft}$.-Ft. Collins; lat. $39^{\circ}-41^{\circ}$.

66. Carex longirostris Torr. On banks and in moist thickets from N. B. to $\mathrm{N}$. W. Terr., Pa. and Colo. In the state represented by var. minor Boott. -Gulch west of Pennocks and south of Rist Cañon; lat. $39^{\circ}-41^{\circ}$. 
67. Carex capillaris L. In alpine-arctic regions from Greenl. to Alaska, N. H. and Colo.-Alt. I0,000-I2,00o ft.-South Park; West Spanish Peak; Pike's Peak; Georgetown; Devil's Causeway; West Mancos Cañon; Twin Lakes; Middle Park; Thompson's Cañon, on Long's Peak; Silver Plume; lat. $39^{\circ}-41^{\circ}$.

68. Carex viridula Michx. In bogs and among wet rocks from Newf. to Wash., Pa., Colo. and Utah.-Hamor's Lake.

69. Carex microglochin Wahl. In arctic-alpine regions from Green1. to B. C. and Mont.; also in Colo., Europe and Asia.-Lat. $39^{\circ}-4 \mathrm{I}^{\circ}$

70. Carex retrorsa Schkur. In swamps and wet meadows from N. S. to Ore, $\mathrm{Pa}$. and Colo.-Durango.

7I. Carex Engelmannii Bailey. Alpine slopes of Colo.-Alt. about I2,000 ft.-Silver Plume; Upper Clear Creek region.

72. Carex utriculata Boott. In marshes from Lab. to B. C., Del. and Calif. -Alt. 5000-10,000 ft.-Gunnison; Veta Pass; South Park; Bijou Basin; Steamboat Springs; Bob Creek, west of Mt. Hesperus; Hamor's Lake, north of Durango; Cascades near Pike's Peak; Twin Lakes; Upper Laramie River; near Chambers' Lake; Little Beaver Creek.

C. utriculata var. minor.-Not uncommon with the type.

73. Carex pulla Good. (C. saxatilis L.) In arctic-alpine regions from Greenl. to Alaska and Colo.; also in Europe and Asia-Alt. 7000-10,000 ft. -Seven Lakes; Deep Creek Lake; White River Plateau.

74. Carex monile Tuck. In marshes and wet meadows, N. Sc. to B. C., N. J. and Calif.-Alt. up to I0,00o ft.-Twin Lakes; Upper Laramie River; Chambers' Lake; Hamor's Lake.

75. Carex lupulina Muhl. In swamps from Ont. to Mont., Fla. and Tex. -Alt. up to $6500 \mathrm{ft}$.-Durango.

\section{Order I4. ARALES.}

Plants normal, with flowers on a spadix.

Plants reduced to small floating thalloid structures, with only $I-3$ flowers.

Fam. 2I. LEMNACEAE.

Family 2o. ARACEAE. Arum Family.

i. acorus L. Sweet frag, Calamus.

1. Acorus Calamus L. In marshes and streams from N. S. to Minn., Fla., Colo. and Texas.-Alt. 3500-4500 ft.-Fort Collins.

Family 2I. LEMNACEAE Dumort. Duck-weed Family.

1. LEMNA L. Duck-WeEd.

Fronds long-stalked, mostly submerged, forming large masses. Fronds short-stalked or sessile, floating on the surface.

Fronds pale and usually strongly gibbous beneath.

Fronds green or purplish beneath, not gibbous.

I. L. trisulca.

2. L. gibba.

3. L. minor.

I. Lemna trisulca $L$. In springs and running water from N. S. to Sask., B. C., N. J., Tex. and Cal.; also in the Old World.-Alt. $3500-8000 \mathrm{ft.}-$ 
Parlin, Gunnison Co.; Van Boxle's ranch, above Cimarron; near Grand Lake; Spicer, Larimer Co.

2. Lemna gibba L. In ponds from Nebr. to Cal., Tex. and Mex.; also in the Old World and Australia_-Alt. 3500-I2,500 ft.-Pike's Peak; near Boulder.

3. Lemna minor L. In still water and slow streams from Lab. to Alaska, Fla. and Mex.; also in the Old World and Australia.-Alt. 4000-900o ft.Trinidad; along Uncompahgre River, near Ouray; Ironton Park, 9 miles south of Ouray; Hayden, Routt Co.

\section{Order I5. XYRIDALES.}

Calyx and corolla free, of very different members; stamens free.

Fam. 22. Commelinaceae.

Calyx and corolla of quite similar members and partly united; stamens partly adnate to the perianth.

Fam. 23. Pontideriaceae.

\section{Family 22, COMMELINACEAE. SPIDERWORT FAMILY.}

Perfect stamens 3 , rarely 2 ; petals unequal; bracts spathe-like.

Perfect stamens 6 , rarely 5 ; petals all alike; bracts leaf-like. $\begin{aligned} & \text { 2. Commedina. } \\ & \text { Tradescantra. }\end{aligned}$

\section{COMMElina, Day-Flower, Dew-Flower.}

I. Commelina crispa Wooton. In sandy soil from Mo. to Neb., Colo., Tex. and N. M.-Alt. 4000-6500 ft.-Cañon City.

\section{TRADESCANTIA L. SPIDERWORT.}

Flowers $1-1.5 \mathrm{~cm}$. in diameter; plant glabrous or calyx and pedicels sparingly glandular; leaves 4-6 $\mathrm{mm}$. wide.

I. T. scopulorum.

Flowers $2-3 \mathrm{~cm}$. in diameter; calyx and pedicels usually densely glandular-pube$\begin{array}{ll}\text { scent; leaves } 6-8 \mathrm{~mm} \text {. wide. } & \text { 2. T. occidentalis. }\end{array}$

I. Tradescantia scopulorum Rose. In moist ground from Black Hills of S. D. to Colo., N. M. and Ariz.-Alt. 4000-5000 ft.-Boulder; Denver; Colorado City.

2. Tradescantia occidentalis Britton. On sand-hills and in rocky ground from Neb. to Mont., Tex. and N. M.-Alt. 4000-6000 ft--Denver; Eads; New Windsor; Fort Collins; Walsenburg; near Boulder; Pennock's mountain range; Spring Cañon; Horsetooth Gulch; Wray.

Family 23. PONTEDERIACEAE Dumort. Pickerell-weed Family.

\section{HETERANTHERA Willd.}

I. Heteranthera limosa (Sw.) Willd. In shallow water or mud from Va. to Neb., Fla. and La. and Colo.; also W. Ind., Mex. and Cent. Am.-Alt. 4000-5500 ft.-Between Longmont and Loveland; eastern Larimer County; west side of Cache La Poudre; Limnath Co. 


\section{Order I6. LILIALES.}

Styles present, distinct or united; stigmas terminal.

Styles distinct; capsule septicidal.

24. Melanthaceae.

Styles united, often very short or obsolete during anthesis.

Capsules septicidal; petals and sepals very unlike. 30. Calochortacear.

Capsules loculicidal; petals and sepals nearly alike.

Sepals and petals chaffy.

Sepals and petals not chaffy.

Herbs with bulbs, corms or rootstocks.

Plants with bulbs or corms, or short, erect rootstocks.

Flowers in umbels, at first included in and later subtended by a scarious involucre.

26. Alliaceas.

Flowers solitary or racemose, or in Leucocrinum by shortening of the stem umbel-like, without involucre. 27. LILIACEAE.

Plants with elongated, horizontal rootstocks. 28. Convallariaceae.

Shrubby plants with woody caudices or trees. 29. Dracaenaceae.

Styles wanting.

Flowers perfect; plants not climbing.

Leaves and bracts alternate; plants with bulbs; fruit a capsule.

30. Calochortaceae.

Leaves or leaf-like bracts whorled; plants with rootstock; fruit a berry.

3I. TRILIIACEAE.

Flowers dioecious; plants climbing or trailing.

32. Smilacaceae.

Family 24. MElanthaceaE R. Br. Bunch-Flower Family.

Plants with rootstock and large oval clasping leaves; petals and sepals gland-

less. 1. Veratrum.

Plants with bulbs and linear leaves; petals and sepals with more or less distinct glands.

Ovary partly inferior; glands obcordate.

Ovary wholly superior; glands obovate or semiorbicular.

z. Anticiea.

3. TOXicoscordion.

\section{“x. Veratrum L. White Hellebore.}

Petals oblong-lanceolate.

Petals oval.

1. V. tenuipetalum.

2. V. speciosum.

I. Veratrum tenuipetaium Heller. Along stream in Colorado.-Alt. about 9000 ft.-."Colorado"; Rabbit-Ear Pass; Fish Creek Falls.

2. Veratrum speciosum Rydb. ( $V$. californicum Wats., and Coulter; not Durand.) In Colorado also erroneously called Skunk Cabbage. In mountain meadows, along streams, from Mont. to Wash., Colo. and Calif.-Alt. 6500-10,000 ft.-Breckenridge; Marshall Pass; Indian Creek Pass; Wahatoya Creek, near La Veta; Pagosa Peak; Columbine; Oak Mesa.

\section{ANTICLEA Kunth.}

Petals and sepals 7-8 $\mathrm{mm}$. long, 7-13-nerved. Petals and sepals 5-6 mm. long, 3-7-nerved.

I. A. elegans.

2. A. coloradensis.

1. Anticlea elegans (Pursh) Rydb. (Zygadenus elegans Pursh; Z. dilatatus Greene) In meadows from Sask. to Alaska, Colo. and Nev.-Alt. 6500-12,500 ft.-La Veta; Indian Creek Pass; La Plata Mountains; Chambers' Lake; North Cheyenne Cañon; Larimer County; Marshall Pass; Al- 
pine; Ruxton Park; Minnehaha; Mount Garfield; mountains above Graymont; Medicine Bow Mountain; Silverton.

z. Anticlea coloradensis Rydb. In the mountains from Colo. to Utah and N. M.-Alt. 8500-12,000 ft.-Idaho Springs; Leroux Creek; Mt. La Prata; Marshall Pass; Steamboat Springs; Estes Park; Middle Park; Pike's Peak; high mountains about Empire; divide between Arkansas River and Bayou Salade; foot-hills, Larimer Co.; above Beaver Creek; Rist Cañon; bank of the Michigan; Gore Pass; Stove Prairie Hill; Redstone; Baxter's ranch; Buffalo Pass; Medicine Bow Mountains.

\section{3. toxicoscordion Rydb. Poison Camass, Death Camass, Hogs' Potato.}

Jetals and sepals rounded or obtuse at the apex; leaves $3^{-5} \mathrm{~mm}$. wide.

Petals and sepals acute at the apex ; leaves over $5 \mathrm{~mm}$. wide.
I. T. T. Galcatum.

I. Toxicoscordion gramineum Rydb. (Zygadenus venenosus Wats., in part.) Gravelly hillsides from Sask. to Ida. and Colo.-Alt. 5000-7000 ft.-Howe's Gulch.

2. Toxicoscordion falcatum Rydb. (Zygadenus Nuttallii Coulter, in part; not A. Gray.) Hills and mesas of Colorado.-Alt. 5000-7500 ft.-Fort Collins; La Veta; Walsenburg; Los Pinos; Denver; Spring Cañon near Calloway Ranch; Palmer Lake; Boulder.

Family 25. JUNCACEAE Vent. Rush Family.

Leaf-sheaths open; capsules I- or 3-celled, with axial or parietal placentae; seeds many.

Leaf-sheaths closed; capsule I-celled, with basal placentae; seeds 3 .

r. JUNCUS L. Rushes.

I. Junicus.

2. JUNCOIDES

I. Lower bracts of the inflorescence terete, erect, appearing like a continuation of the stem; inflorescence therefore apparently lateral.

A. Flowers several in a more or less compound panicle; seeds apiculate (EFFUSI).

Stem light-green, striate when dry, on account of the free hypodermal fibrovascular bundles; sepals and petals green; stamens 3 .

$$
\text { 1. J. filiformis. }
$$

Stem dark-green or at the base purplish, not striate; sepals and petals dark purplish-brown; stamens 6 .

Inflorescence congested; branches $I-3 \mathrm{~cm}$. long; petals and sepals acute or short-acuminate, almost equal in length. $\quad$ 2. J. balticus montanus.

Inflorescence open; branches $4-8 \mathrm{~cm}$. long; sepals long-acuminate and much exceeding the acute petals.

3. J. balticus vallicola.

B. Flowers I-5, of which one is subsessile and the others pediceled (SUBTRIFLORI).

Upper sheath merely bristle-pointed; petals and sepals with green backs and dark-brown margins.

4. J. Drummondii.

Upper sheaths leaf-bearing; green backs of the petals and sepals less prominent. Sepals and petals linear-lanceolate, light-brown; capsule acute.

5. J. Parryi.

Sepals and petals broadly lanceolate, very dark-brown; capsule retuse.

6. J. Hallii.

II. Lower bracts not appearing as a continuation of the stem, or if so channeled on the upper side; inflorescence terminal. 
A. Leaves neither septate nor equitant.

¿. Leaves not fistulose; flowers many.

a. Flowers bracteolate, inserted singly on the branches of the inflores. cence; leaves narrowly linear, either flat or subterete and channeled. u. Perennials; stem simple (Tenues).

Seeds long, caudate; leaves subterete, with a shallow groove above. 7. J. Vaseyi.

Seeds not caudate; leaves flat, but often involute; lunate in crosssection.

Auricles at the summit of the sheaths membranous, whitish; petals and sepals scarcely spreading.

Auricles scarcely produced beyond the insertion, scarcely scarious; inflorescence open.

Perianth 3-4 $\mathrm{mm}$. long, equalling the capsule.

8. J. interior.

Perianth $4.5-5 \mathrm{~mm}$. long, exceeding the capsule.

9. J. arizonicus.

Auricles conspicuously produced beyond the point of insertion; flowers few, congested.

Io. $J$. confusus.

Auricles cartilaginous, yellowish-brown; petals and sepals spreading.

$\beta$. Annuals; stem branching (Bufonir).

I I. J. Dudleyi.

I2. J. bufonius.

b. Flowers not bracteolate, in true heads on the branches of the inflorescence; leaves broad and grasslike (GRAMINIFOLII).

13. J. longistylis.

2. Leaves fistulose ( $i$. e., hollow); flowers few, in small heads (CASTANeI).

Stem leafy only at the base, but the uppermost leaf often with a long sheath; petals and sepals about $4 \mathrm{~mm}$. long; leaves about I $\mathrm{mm}$. in diameter; lower bract of inflorescence membranous.

14. J. triglumis.

Stem more or less leafy; leaves about $2 \mathrm{~mm}$. in diameter; perianth 5-6 $\mathrm{mm}$. long; lower bracts foliaceous.

B. Leaves septate.

I5. J. castaneus.

1. Leaves terete, not equitant.

a. Septa poorly developed; heads I-3 (see J. triglumis and $J$. castaneus).

b. Septa well developed; heads usually several (in J. Mertensianus usually only I) (Nodosi).

Inflorescence with short branches; flowers echinate-spreading or the lowest of the head reflexed; capsule narrowly lanceolate.

Heads $7-8 \mathrm{~mm}$. in diameter; leaf-blades erect; petals usually longer than the sepals.

I6. J. nodosus.

Heads over I o mm. in diameter; leaf-blades usually spreading; sepals longer than the petals. $\quad$ I $7 . T$. Torreyi.

Inflorescence with elongated branches or in J. Mertensianus with a single head; flowers erect-ascending; capsule oblong.

Heads several; leaves terete; seeds not caudate.

I8. J. truncatus.

Heads solitary or rarely $2-3$; leaves somewhat flattened; seed usually caudate. 19. J. Mertensianus.

z. Leaves equitant, laterally flattened, so that one edge is towards the stem (ENSIFOLII).

Flower-clusters numerous, small, 5-I2-flowered, light-colored.

Flower-clusters few, I5-25-flowered.

20. J. brunnescens.

Flowers greenish or light-brown; ligules of the sheath usually without auricles.

21. J. parous.

Flowers fuscous or very dark-brown; ligules of the sheath produced into small auricles. 22. J. saximontanus.

I. Juncus filiformis L. In wet places from Lab. to Alaska, Pa., Utah and Wash.-Reported from Colorado (Coulter), but doubtful. 
2. Juncus balticus montanus Engelm. In meadows and marshes from Lab. to Wash., Colo. and Utah.-Alt. 5000-II,000 ft.-North Park; Clear Creek bottoms, above Georgetown; east of Ft. Collins; Hardin's ranch; Penn's Gulch; Lake City ; Cottonwood Creek; Buena Vista; Sangre de Cristo; Palmer Lake; Green Mountain; Georgetown; Andrew's Shetland ranch; Garland; Gunnison; Alpine Tunnel; Julesburg; Ruxton Dell, Pike's Peak; Cucharas River; Cambres; Moon's ranch; along the Conejos River, north of Antonito; Leroux Creek; Table Rock; Chambers' Lake; Gore Pass.

3 Juncus balticus vallicola Rydb. In wet meadows from Mont. to Alaska, Colo., Utah and Wash.-Alt. 4000-7500 ft.-Denver; Andrews' Shetland ranch; Mancos; Dolores.

4. Juncus Drummondii Mey. On wet alpine slopes from Mont. to Alaska, Colo. and Calif.-Alt. 8500-13,000 ft.-Red Mountain, south of Ouray; Georgetown; Windy Point and Bottomless Pit, Pike's Peak; Sierra Blanca; Alpine Tunnel; Cameron Pass; Pagosa Peak; Ironton; Berthoud Pass; Buffalo Pass; Park Range; mountains west of Cameron Pass; Buffalo Pass; Anita Peak, Routt Co.; summit of North Park Range.

5. Juncus Parryi Engelm. On alpine slopes from Mont. to Wash., Colo. and Calif.-Alt. 10,000-13,000 ft.-Headwaters of Clear Creek; Gray's Peak.

6. Juncus Hallii Engelm. On alpine slopes of Colo. and Wyo.-Alt. about I0,000 ft.-Marshall Pass.

7. Juncus Vaseyi Engelm. In meadows from Me. to Minn. and Colo.Grand Lake.

8. Juncus interior Wiegand. ( $J$. tenuis Coulter, in part; not Willd.) In meadows from Ills. to Wyo., Mo. and Colo.-Alt. 4000-6000 ft.-Grand Lake; Fort Collins; plains and foot-hills near Boulder; foot-hills, Larimer Co.; Poudre Cañon; bank of Poudre, La Porte.

9. Juncus arizonicus Wiegand. In meadows from Texas to Col. and Ariz.-Alt. up to about $5000 \mathrm{ft}$ - -New Windsor.

Io. Juncus confusus Coville. ( $J$. tenuis congestus Engelm.; in part.) In wet meadows from Mont. to Wash. and Colo.-Alt. 6500-10,000 ft.-Chicken Creek; North Park; mountain north of Steamboat Springs; Fort Collins; Chambers' Lake; Grizzly Creek.

II. Juncus Dudleyi Wiegand. ( $J$. tenuis Coulter, in part; not Willd.) In meadows from Me. to Wash., N. Y. and Mexico.-Alt. 4000-8500 ft.-Platte River, Denver; Gunnison; Mancos; Cheyenne Mountain; Ft. Collins.

12. Juncus bufonius $L$. In wet and sandy soil from Lab. to Alaska, Fla., Calif. and Mex.; also in the Old World.-Alt. 4000-9000 ft.-Georgetown; Gunnison; Fort Collins; Wahatoya Creek; Villa Grove; Hebron; plains and foot-hills, near Bouider.

13. Juncus longistylis Torr. In meadows from Alb. to Ida., Nebr., N. M., Calif. and Mex.-Alt. 4000-I0,000 ft.-Dolores; Chambers' Lake; Moon's ranch; Trimble Springs, Durango; Upper Larimie River; Pike's Peak; headwaters of Pass Creek; Ruxton Dell; La Veta; Gunnison; Blind Cañon; Placer; Sangre de Cristo Creek; Denver; South Cheyenne Cañon; headwaters of Clear Creek; Gunnison; Como; Leroux Creek; Graymont.

I4 Juncus triglumis $L$. In arctic and alpine regions from Lab. to Alaska, N. Y. and Colo.-Alt. about II,500 ft.-Seven Lakes; headwaters of Clear Creek. 
15. Juncus castaneus Smith. In arctic and alpine regions from Greenl. to Alaska and Colo.-Alt. 9500-12,500 ft.-Seven Lakes; headwaters of Clear Creek; Ruxton Park.

16. Juncus nodosus L. In wet meadows, along rivers and in marshes, from N. Sc. to Mackenzie River, B. C., Va. and Nev.-Alt. $4000-6500$ ft.-Trimble Springs; Durango; Colorado Springs; Ft. Collins; Poudre Cañon.

17. Juncus Torreyi Coville. In wet places, especially in sandy soil, from N. Y. to Mont., Tex. and Ariz.-Alt. $4000-6500 \mathrm{ft}$--Plains and foot-hills, near Boulder; Huerfano Valley; Walsenburg; Julesburg; Fort Collins; Cañon City; Denver; Larimer County; Colorado Springs.

18. Juncus truncatus Rydb. (J. alpinus insignis of Coulter's Man.; in part.) In wet places in Colo. and Wyo.-Alt. 6000-9000 ft.-Meadow Height; Elk River, Routt Co.; Grizzly Creek.

19. Juncus Mertensianus Bong. In wet mountain meadows from Mont. to Alaska, Colo. and Calif,-Alt. 8500-II,000 ft.-Pagosa Peak; North Park; Marshall Pass; Breckenridge; Georgetown; Ironton; Red Mountain, Ouray; Buffalo Pass; Park Range.

A form with 2 or 3 heads was collected on the Upper La Plata River. This has been taken for the var. paniculatus Engelm., to which it scarcely belongs.

20. Juncus brunnescens Rydb. ( $J$. xiphioides montanus Engelm., in part.) In wet meadows from Colo. to Nev., N. M. and Ariz.-Pagosa Spring.

2I. Juncus parous Rydb. In wet mountain meadows from Colo. to N. M. -Garland; North Cheyenne Cañon; Steamboat Springs; Pike's Peak.

22. Juncus saximontanus A. Nelson. ( $J$. xiphioides montanus Engelm., mainly.) In wet meadows from Alb. to B. C., Colo. and Calif.-Alt. 8500I0,000 ft.-La Plata River; Garland; Pagosa Springs; Sangre de Cristo Creek; Carlton Lake, near Grand Lake; Ouray; Redcliffe; Rogers; Mount Harvard; Steamboat Springs; Ironton Park, Ouray; foot of Mount Richtofen, on the Michigan; Steamboat Springs; Graymont; Gypsum Creek Cañon; Hebron, North Park.

\section{JUNCOIDES Adans. WoOD-RUSH.}

Flowers on slender pedicels in a corymbiform inflorescence.

Flowers subsessile in headlike or spikelike clusters.

Spikelets peduncled, forming a corymb.

Flowers light-yeliow.

Flowers brown or feruginous.

Spikelets subsessile, forming a compound spike.

I. J. parviflorum.

Plant tall, 4-5 dm. high; inflorescence subcapitate; stem-leaves broad and flat; bractlets not ciliate.

4. J. subcapitatum.

Plant I-2, rarely 3-4 dm. high; spike usually elongated and nodding; stemleaves narrow, attenuate; bractlets ciliate.

5. J. spicatum.

1. Juncoides parviflorum (Ehrh.) Coville. (Luzula spadicea parviflora and v. melanocarpa Meyer.) In wet meadows from Greenl. to Alaska, Colo. and Calif.-Alt. 8500-II,500 ft.-Beaver Creek; White River Plateau; Silver Plume; Crystal Park; Villa Grove; Cameron Pass; Mt. Robinson; Seven Lakes, Pike's Peak; Pagosa Peak; Caribou; Bald Mountain; Salida; headwaters of Sangre de Cristo Creek; Little Kate Mine, La Plata Mountains. 
2. Juncoides comosum (Meyer) Sheld, (Luzula comosa Meyer.) In wet meadows from Mont. to Alaska, Colo. and Cal.-Alt. about $8500 \mathrm{ft}$.-Crystal Park.

3. Juncoides intermedium (Thuill.) Rydb. (Luzula campestris Am. auth.) In woodlands and meadows from Newf. to B. C., Colo. and Calif-Alt. 8500-10,000 ft.-North Park; Chambers' Lake; Middle Park.

4. Juncoides subcapitatum Rydb. Along mountain streams, near the timber line. Found only at the type locality.-Silver Plume.

5. Juncoides spicatum (L.) Kuntze. (Luzula spicata Desv.) On hillsides and in mountain meadows from Greenl. to B. C., N. H. and Calif.-Alt. I0,000-I3,000 ft.-Cameron Pass; Pagosa Peak; La Plata Mountains; Pike's Peak; West Spanish Peak; Seven Lakes; Mt. Harvard; Mt. Garfield; Gray's Peak.

\section{Family 26. AlliaceAE Batch. Onion Family.}

\section{x. Allium L. Onion, Garlic, Leek, Chives.}

I. Bulb crowning a persistent rootstock.

Leaves terete and hollow.

Leaves flat or channeled, not hollow.

I. A. sibiricum.

Umbels not nodding; petals and sepals long-acuminate.

Umbels nodding; petals and sepals obtuse or acute.

Leaves rounded-convex on the back, not keeled.

Leaves almost flat and keeled.

Umbels few-flowered; leaves I-2 mm. wide.

Umbels many-flowered; leaves $3-5 \mathrm{~mm}$. wide.

II. Bulbs without rootstock.

Outer bulb coat fibrous.

Umbels bulblet-bearing.

Umbels not bulblet-bearing.

Capsule not crested; involucre usually 3 -leaved.

Capsule more or less crested.

Bracts broadly ovate in anthesis, not reflexed ; flowers white or light-rose; several layers of the bulb-coat fibrous.

Petals and sepals over I cm. long; peduncles often 2 or 3 from the loose sheaths; bracts 3 .

2. A. brevistylum.

3. A. recurvatum.

4. A. neo-mexicanum.

5. A. cernuum.

Petals and sepals less than I $\mathrm{cm}$. long; peduncles single from the close sheaths; bracts usually 2 .

Plant 3-6 dm. high; pedicels I2-I $5 \mathrm{~mm}$. long; petals and sepals $6-8$ mm. long.

9. A. Geyeri.

Plant $\mathrm{I}-3 \mathrm{dm}$. high; pedicels $8-\mathrm{I} 2 \mathrm{~mm}$. long; petals and sepals about $5 \mathrm{~mm}$. long.

Io. $A$. reticulatum.

Bracts lanceolate, usually 3 , soon reflexed; only the outer bulb-coat fibrous; flowers red-purple.

I I. A. Pikeanum.

Outer bulb-coat not fibrous, but often more or less reticulated.

Petals long-acuminate, serrulate.

Petals acute, not serrulate.

I2. A. acuminatum.

I3. A. Brandegei.

I. Allium sibiricum L. (A. Schoenoprasum Am, auth., mostly; not L.) In dry places from Me. to Alaska, N. Y., Colo. and Oreg.-Alt. 5000-8500 ft.-Upper Laramie River; Northern State line.

z. Allium brevistylum S. Wats. In wet woodlands from Mont. to Colo. and Utah.-Alt. 6500-9000 ft.-Cañon of the Cache la Poudre; North Park, near Teller; North Platte, near Hebron; Cerro Summit, near Chambers Lake; forks of Poudre and Big South. 
3. Allium recurvatum Rydb. (A. cernuum of Coulter's Man., mainly.) On banks and hillsides from the Black Hills of S. D. to B. C. and N. M.-Alt. 5000-8500 ft.-Colorado Springs; Cheyenne Mountain; Pike's Peak; Gunnison; Garden of the Gods; North Cheyenne Cañon; Engelmann Cañon; Parlin, Gunnison County; Minnehaha; Yampa; Villa Grove; Cerro Summit; Larimer County; mountains between Sunshine and Ward; Howe's Gulch; Redstone; Poudre Cañon; Clear Creek bottoms, below Georgetown; Empire.

4. Allium neo-mexicanum Rydb. In rocky places of Colo., N. M. and Ariz. - Headwaters of Clear Creek.

5. Allium cernuum Roth. In rich, rocky soil from N. Y. to Sask., Mont., W. Va. and Colo., but very rare in the Rocky Mountain region.-Pagosa Springs.

6. Allium rubrum Osterhout. In rich ground from Colorado and Wyoming.-North Park, Continental Divide; in pastures along Walton Creek.

7. Allium Nuttallii S. Wats. In dry, rocky or sandy plains from S. D. to Wyo, Kans. and Colo.-Alt. 4000-600o ft.-Colorado Springs; Denver; southwest of Ward, Boulder County.

8. Allium macropetalum Rydb. In the mountains of Colo.-Palisades.

9. Allium Geyeri S. Wats. (A. dictyotum Greene; $A$. reticulatum deserticola Jones.) In dry soil and hillsides from N. D. to Wash. and N. M.Alt. 5000-II,500 ft.-Upper La Plata Cañon; Indian Creek Pass; Pagosa Springs; near Ironton; Mt. Abram; Red Mountain road, near Ouray; Cimarron; Swallows, between Pueblo and Cañon City; Dixon Cañon; Ft. Collins; mountains above Manitou; Como and vicinity; gulch west of Pennock's; Spring Cañon; Moon's ranch; Dillon Cañon; Medicine Bow Mountains.

10. Allium reticulatum Fraser. In dry, gravelly soil from Sask. to Idaho, Colo, and Utah.-Alt. 5000-8500 ft.-Mesas near Pueblo; La Veta; Aztec; Arboles; South Park; Soldier Cañon; Horsetooth Mountain; Quimby; Horsetooth Gulch.

II. Allium Pikeanum Rydb. In rocky places in Colo.-Alt. II,000-I3,000 ft.--Pike's Peak: near Halfway House; Bald Mountain; Peak Valley.

I2. Allium acuminatum Hook. In dry soil from Mont. to B. C., Col., Ariz. and Ore.-Alt. 6500-8500 ft.-Mancos; Cerro Summit; Honnold; Durango; Dolores.

I3. Allium Brandegei S. Wats. From Ida. to Wash., Colo. and Ore-Elk Mountains; Steamboat Springs; Rabbit-Ear Range, Routt Co.

\section{Family 27. LiliaceaE Adans. Lily Family.}

Plant with a short rootstock; flowers subumbellate on subterranian pedicels from the crown of the rootstock; petals and sepals united into a long tube.

I. LEUCOCRINUM.

Plant with bulbs or corms, either leafy-stemmed or scapiferous; petals and sepals distinct or nearly so.

Bulb scaly; plant tall, leafy.

Anthers versatile; petals and sepals oblanceolate, clawed with a linear nectariferous groove. z. LILIUM. 
Anthers fixed near the base, slightly if at all versatile; petals and sepals obovate-oblanceolate, not clawed, in ours mottled; nectary a shallow pit.

Bulb tunicated, anthers strictly basifixed.

3. Fritillaria.

Leaves 2, basal or nearly so; flowers nodding.

Leaves several, alternate; flowers not nodding.

4. ERythronium.

5. Lloydia.

\section{LEUCOCRINUM Nutt.}

I. Leucocrinum montanum Nutt. In sandy soil from S. D. to Mont. and Colo.-Alt. 4000-6500 ft.-Denver; headwaters of Clear Creek; Boulder; Pike's Peak; Colorado Springs; Larimer County; New Windsor; Table Rock; Howe's Gulch; gulch west of Dixon Cañon; Spring Cañon; bank of Cache la Poudre River; Rist Cañon; bluffs north of La Porte; hills west of Soldier Cañon; vicinity of Horsetooth Gulch; Boulder; Colorado City.

Leaves linear.

«. IILIUM L. LILy.

Leaves lanceolate.

1. L. umbellatum.

2. L. montanum.

x. Lilium umbellatum Pursh. Hills, among bushes, from Hudson Bay to B. C., Ky. and Colo.-Baxter's ranch; Empire.

2. Lilium montanum A. Nelson. On hills, among bushes, from Mont. to Colo.-Alt. 6500-I0,000 ft.-Crystal Park; West Spanish Peak; Hamor's Lake, north of Durango; Larimer County; Long Gulch; Stove Prairie Hill; Rist Cañon; Laramie River, at Sherwood's.

\section{Fritillaria L. Fritillary, Tiger Lily.}

1. Fritillaria atropurpurea Nutt. On hillsides from N. Dak. to Ida., Colo. and Calif.-Alt. 4000-9500 ft.-Poverty Ridge, near Cimarron; Lamb's ranch.

\section{ERYTHRONIUM. AdDer's-tongue, Dog-tooth Violet.}

1. Erythronium parviflorum (S. Wats.) Gooding. (E. grandiflorum parviflorum S. Wats.) On rich hillsides from Wyo. to Colo. and Utah.-Alt. 8500-II,500 ft.-Cameron Pass; Bear Creek Divide; West La Plata Mountains; North Park; Grand Mesa; mountain west of North Park; source of Leroux; Rabbit-Ears, Larimer Co.

\section{LLOYDIA Salisb.}

1. Lloydia serotina (L.) Sweet. In exposed alpine or arctic regions from Mont. to Alaska and Colo.; also in the Old World.-Alt. I0,000-I4,000 ft.Crystal Lake; Arapahoe Peak; headwaters of Clear Creek; Red Mountain; Saddle Cliff, Pike's Peak; Alpine Tunnel; Carson; West Spanish Peak; Mt. Hesperus; mountains above Graymont; Franklin; mountains northeast of Boreas.

Family 28. CONVALLARIACEAE Link. Lily-of-THe-VALley Family.

Sepals and petals distinct.

Flowers white, in terminal racemes or panicles; anthers introrse, stem simple. I. VAGNERA.

Flowers axillary or terminal, solitary or in small umbelliform clusters; anthers extrorse or opening laterally; stem branched. 
Flowers axillary, greenish-white; filaments slender; anthers acute.

Flowers terminal, yellow; filaments dilated; anthers obtuse, 3. Disporum. Sepals and petals partially united into a tube; flowers axillary. 4. SALOMONIA.

1. Vagnera Adans. False Solomon's Seal, Wild Spikenard.

Inflorescence paniculate.

Leaf-blades acuminate; the lower contracted at the base into distinct petioles.

Leaf-blades acute; all sessile and more or less clasping.

1. V. racemosa.

Inflorescence racemose.

Petals and sepals linear or linear-lanceolate.

2. V. amplexicaulis.

Petals and sepals oblong-lanceolate.

3. V. leptopetala.

Pedicels short, slightly if at all longer than the flowers or the fruit; leaves lanceolate, acute.

4. V. stellata.

Pedicels long; the lower often $2-3$ times as long as the flowers or the fruit; leaves narrowly lanceolate, long-attenuate.

5. V. liliacea.

I. Vagnera racemosa (L.) Morong. (Smilacina racemosa Desf.) In moist woods from N. S. to Wash., Ga. and Calif.-Alt. 6500-8500 ft.-Ojo; Ouray; Boulder Cañon.

2. Vagnera amplexicaulis (Nutt.) Morong. (Smilacina amplexicaulis Nutt.) In rich woods from Mont. to B. C., Colo. and Calif.-Alt. 6000-9000 ft.-La Plata River Cañon; Big Creek Gulch, Routt Co.; Black Cañon; Poverty Ridge, Cimarron; Redcliffe; Ouray; Veta Mountain; headwaters of Pass Creek; near Pagosa Peak; Gore Pass; banks of Fish Creek; gulch south of Boulder; Hematite.

3. Vagnera leptopetala Rydb. In dark, wooded cañons of Colo.-Alt. 9000-Io,000 ft.-Headwaters of Sangre de Cristo Creek; Dark Cañon; Chicken Creek, West La Plata Mountains; near Pagosa Peak; Los Pinos.

4. Vagnera stellata (L.) Morong. (Smilacina stellata Desf.) In open woodlands from Newf. to Sask., Mont., Va. and Colo.-Alt. 4000-12,000 ft.Ojo; Halfway House, Pike's Peak; Colorado Springs; Ft. Collins; banks of Poudre River, north of La Porte; Horsetooth Gulch; mountain north of Steamboat Springs; Franklin; Campton's ranch.

5. Vagnera liliacea (Greene.) Rydb. (Smilacina sessilifolia of Coulter's Man. in part, not Nutt.) In moist woodlands from S. D. to B. C., N. M. and Calif.-Alt. 7500-9000 ft.-Chaparral-covered hills southeast of Ouray; Van Boxle's Ranch, above Cimarron; headwaters of Sangre de Cristo Creek; Pike's Peak.

\section{STREPTOPUS Michx. Twisted-STALK.}

I. Streptopus amplexifolius (L.) DC. In moist wood from Greenl, to Alaska, N. C., Colo. and Ore.-Alt. 6500-I0,000 ft.-Cameron Pass; RabbitEar Range; Upper La Plata River; near Pagosa Peak; Sangre de Cristo Creek; Keblar Pass; Columbine; Grant Lake; Jack Brook; mountains above Beaver Creek; Bosworth's ranch; Stove Prairie; Big Creek Gulch; Steamboat Springs.

\section{DISPORUM Salisb.}

I. Disporum trachycarpum (S. Wats.) B. \& H. (Prosartes trachycarpa S. Wats.) On mountain sides and in cañons from Man. to B. C., Colo. and 
Ariz.-Alt. 7500-II,000 ft.-Chaparral-covered hills southeast of Ouray; mountains about Ouray; near Pagosa Peak; Tunnel Mountain; gulch south of Boulder; foot-hills near Ft. Collins; Big Creek Gulch, Routt Co.; Eldora; Baltimore.

\section{SALOMONIA.}

1. Salomonia commutata (R. \& S.) Britton. (Polygonatum giganteum Dietr.) River banks and moist woods from R. I. to Utah, Ga. and Ariz.Locality not given.

\section{Family 29. DRACAENACEAE Iink. YuCCA FAMILY.}

Flowers perfect, large; ovary many-ovuled and capsule many-seeded. 1 . Yucca. Flowers polygamo-dioecious; ovules 2 in each cell; capsule often 1 -seeded.

2. Nolina.

1. YUCCA. YUCCA, SPANish Bayonet.

Fruit a dry capsule.

Leaves narrowly linear, very long; style swollen, green.

Leaves linear-lanceolate, short; style not swollen, white. Fruit fleshy.

1. Y. glauca.

2. Y. Harrimaniae.

3. Y. baccata.

I. Yucca glauca Nutt. ( $Y$. angustifolia Pursh.) On dry plains and hills from Nebr. to Mont., Tex. and Ariz.-Alt. 4000-600o ft.-Colorado Springs; Walsenburg; near Boulder; Poudre flats, west of Ft. Collins.

2. Yucca Harrimaniae Trelease. On arid plains and hills of Utah and Western Colorado.-Alt. about $6500 \mathrm{ft}$-Cimarron; Durango.

3. Yucca baccata Torr. On arid plains from Colo. to Nev., Tex. to Calif.; also in Mex.-Alt. 4000-5500 ft.-Trinidad; hills south of Dolores; Durango.

2. NOLINA Michx.

1. Nolina Greenei S. Wats. Dry mesas, Colo.-Alt. about $5000 \mathrm{ft}$.Trinidad.

Family 3o. Calochortaceat Rydb. Mariposa Lily Family.

I. Calochortus Pursh. Mariposa Lily, Sego Lily.

Petals abruptly acuminate; glands oblong.

Petals rounded or merely acute at the apex.

Anthers obtuse; glands not broader than long.

Anthers acute; glands broader than long.
I. C. acuminatus.

z. C. Nuttallii.

3. C. Gunnisonii.

x. Calochortus acuminatus Rydb. On dry hills from Mont. to Colo. and Utah.-Alt. about $6500 \mathrm{ft}$.-Mancos.

2. Calochortus Nuttallii T. \& G. On hillsides from Mont. to Colo. and Calif.-Alt. 6000-7000 ft.-Cimarron.

3. Calochortus Gunnisonii S. Wats. In meadows from Mont. to Colo. and Ariz.-Alt. 5000-I0,000 ft.-North Park, near Teller; Boulder; headwaters of Clear Creek; Middle Park; Mancos; Como; Piedra; Veta Pass; Jack's Cabin, Gunnison watershed; Yampa; Ruxton Dell, near Pike's Peak; La Veta; Villa Grove; Table Rock; Four Mile Hill; Spring Cañon; Horsetooth Gulch; Brant's Soda Spring, near North Platte; Trinidad; Dixon Cañon. 
Family 3I. TRILLIACEAE Lindl. Trilium Family.

I. TRILLIUM L. TRILlium, Wake-RoBiN.

I. Trillium ovatum Pursh. In rich woods from Mont. to Wash., Colo. and Calif.-Alt. about $9000 \mathrm{ft}$--Columbine.

\section{Family 32. SMILACACEAE Vent. Smilax Family.}

1. NEMEXIA Raf. Smilax, Carrion-Flower.

1. Nemexia lasioneuron (Hook.) Rydb. (Smilax lasioneuron Hook.; $S$. herbacea Am. authors, in part; Nemcria herbacea melica A. Nelson) Among bushes from Sask. to western Nebr. and Colo-Horsetooth Gulch; along Buckhorn Creek, Larimer Co.; Colorado Springs; South Cheyenne Cañon.

\section{Order I7. AMARYLLIDALES.}

\section{Family 33. IXIACEAE Ecklon. IRIS FAMILY.}

Styles alternate with the stamens; petals and sepals nearly equal.

1. Sisyrinchivis. Styles opposite and arching over the stamens, sepals much larger than the petals, reflexed.

\section{SISYRINCHIUM L. BLUE-EYEd GRASS.}

Outer bracts of the spathe little or not at all longer than the inner.

Small and slender; flowers $10 \mathrm{~mm}$. or less long; capsule less than $3 \mathrm{~mm}$. high. 1. S. halophilum.

Stouter; flowers $12 \mathrm{~mm}$. or more long; capsule $4 \mathrm{~mm}$. or more high.

\section{S. occidentale.}

Outer bracts of the spathe conspicuously prolonged, sometimes $2-3$ times as long as the inner one.

Petals and sepals not emarginate, narrowed to the aristulate tip. 3. S. alpestre.

Petals and sepals more or less retuse or abruptly contracted to the aristulate apex.

4. S. angustifolium.

1. Sisyrinchium halophilum Greene. In alkaline meadows from Idaho to Colo. and Calif.-Colorado (Bicknell).

2. Sisyrinchium occidentale Bickn. In wet meadows from Mont. to Idaho and Colorado.-North Park; Doyles; Sapinero.

3. Sisyrinchium alpestre Bickn. In motn1tain meadows of Colorado.Alt. about 8000 ft.-Parlin, Gunnison Co.

4. Sisyrinchium angustifolium Miller. In meadows and around streams from Newf. to the Mackenzie River and B. C., south to Va. and Colo._Alt. 4000-900o ft.-Gunnison; Arboles; near Seven Lakes, Pike's Peak; Crystal Park; Dolores; Mancos; Chicken Creek; Grayback mining camps; Cucharas River, below La Veta; Sangre de Cristo Creek; Ft. Collins; North Boulder Peak.

2. IRIS L. IrIS, Blue FlaG, Fleur-de-Lis.

r. Iris missouriensis Nutt. In meadows, marshes and along streams from N. Dak, to Ida., Colo. and Calif,-Alt. 8000-10,000 ft.-Mancos; Marshall 
Pass; Crystal Park; Veta Mountain; Stove Prairie; river-flats near Ft. Collins; Ruxton ranch; Hematite; Cherry Creek; Andrew's ranch.

\section{Order I8. ORCHIDALES.}

\section{Family 34. ORCHIDACEAE Lindl. ORChID Family.}

I. Fertile stamens 2 ; lip a large inflated sack.

II. Fertile stamen 1.

1. CyPRipedium.

A. Pollinia caudate at the base, attached to a viscid disk or gland.

Gland surrounded by a thin membrane; lip toothed at the apex.

Gland naked; lip entire.

2. Coeloglossum.

Sepals 3-5 nerved; plants with rootstocks or fibrous-fleshy roots.

Stem scapiform, I-leaved at the base; anther sacks divergent.

Stem leafy; anther-cells parallel or nearly so.

3. Lysiella.

Sepals I-nerved; plants with rounded or oblong, undivided corms.

B. Pollinia not produced into caudicles.

5. Piperia.

I. Pollinia granulose or powdery.

Anthers operculate.

6. EpIPACtis.

Anthers not operculate.

Leaves green throughout, borne on the stem.

Leaves alternate; spike mostly twisted.

Leaves 2, opposite; spike not twisted.

Leaves white-reticulate, basal.

2. Pollinia waxy or smooth.

Plants with corms (solid bulbs); rarely if ever with corralloid roots; leaves solitary, not scale-like.

Leaf cauline; lip not sackate; flowers small, racemose.

Leaf basal; lip saccate; flowers large, solitary.

io. Achronithes.

i. Cytherea.

Plants with coralloid roots; leaves numerous, reduced to scales.

I 2. CORALlORRHizA.

\section{CYPRIPEDIUM L. Ladies' SlipPer.}

Leaves alternate; flowers solitary, terminal, or also in the axils of the upper leaves.

Lip $2-2.5 \mathrm{~cm}$.; rarely $3 \mathrm{~cm}$. long.

Lip $3.5-4 \mathrm{~cm}$. long.

7. IвIDiUm.

8. OPHRYS.

9. Peramium.

Leaves 2 , opposite or nearly so; flowers usually several, in a

เ. C. parviflorum.

2. C. pubescens.

raceme.

contracted bracted

1. Cypripedium parviflorum Salisb. In woods from Newf. to B. C., Ga. and Colo.-La Veta; Piedra.

2. Cypripedium pubescens Willd. In rich wood from N. S. to Minn., Ga. and Nebr.-Stove Prairie Hill.

3. Cypripedium fasciculatum Kell. In rich soil from Wash. to Calif. and Colo.-Estes Park.

2. COELOGLOSSUM Hartm. LONG-BRACTED ORCHIS.

I. Coeloglossum bracteatum (Willd.) Parl. In boggy woods from N. B. to Alaska, N. C. and Colo.-Exact locality not given. 
3. LYSIELLA Rydb.

I. Iysiella obtusata (Pursh) Rydb. In boggy places in the woods from Newf. to Alaska, N. Y. and Colo.-Alt. 8500-r1,500 ft.-Chicken Creek, West La Plata Mountains; North Park; Clear Creek; camp on Little Beaver Creek; bank of Michigan, North Park.

\section{LIMNORCHIS Rydb. BOg ORCHID.}

Connective of the anther narrow; anther cells therefore close together; spur not longer than the tip.

Flowers greenish or purplish.

Spur $1 / 2-2 / 3$ as long as the lip, very saccate.

Lip linear or nearly so, 5-7 mm. long; ovary slightly curved; spike elongated. $\quad$ I. L. stricta.

Lip lanceolate, fleshy $4-5 \mathrm{~mm}$. long; ovary strongly curved; spike usually short. $\quad$ z. L. purpurascens.

Spur almost equalling the lip, scarcely saccate. 3. L. viridiflora.

Flowers whitish. 4 4. Lorealis.

Connective of the anther broad; anther cells therefore distant; spur much exceeding the tip.

5. L. laxiflora.

I. Limnorchis stricta (Lind1.) Rydb. In bogs from Mont. to Alaska, Colo. and Wash.-Alt. 8500-ro,000 ft.-Upper La Plata; Jack Brook; Twin Lakes; Manitou.

2. Limnorchis purpurascens Rydb. On rich brook-banks in the mountain woods of Colo.-Alt. 7500-II,000 ft-Gunnison; Parlin; Iron Mountain; Georgetown; Como; mouth of Cheyenne Cañon; Barnes' Camp; camp on Little Beaver Creek; swamp above Beaver Creek; Franklin; mountains north of Steamboat Springs.

3. Limnorchis viridiflora (Cham.) Rydb. (Habenaria hyperborea S. Wats. and of Coult. Man.; not R. Br.) In bogs from Alb. to Alaska and Colo.Alt. 6500-10,000 ft.-McCoy; Ouray; Gunnison; La Veta; Cascade; Piedra ; Wahatoya Creek; Georgetown; West La Plata Mountains; Clear Creek; Barnes' Camp; mountains above Ouray; mountain north of Steamboat Springs.

4. Limnorchis borealis (Cham.) Rydb. (Habenaria dilatata of Coult. Man.) In bogs from Mont. to Alaska, Colo. and Wash.-Alt. 8500-Io,000 ft.-Chambers' Lake; Columbine; Veta Pass; Graymont; Gore Pass; summit of North Park Range.

5. Limnorchis laxiflora Rydb. In bogs from Ore. to Colo. and Utah.Uncompahgre Mountains; Los Pinos; Franklin.

\section{PIPERIA Rydb.}

I. Piperia unalaschensis (Spreng.) Rydb. (Habenaria Unalaschensis S. Wats.) In damp rich woods from Mont. to Alaska, Colo: and Calif.-Alt. about $8500 \mathrm{ft}$.-South Boulder Peak.

\section{EPIPACTIS R. Br. Helleborine.}

I. Epipactis gigantea Dougl. In rich woodlands from Mont. to B. C., Western Tex. and Calif.-Alt. about $8500 \mathrm{ft}$.-Glenwood Springs. 


\section{IBIDIUM Salisb. LAdIES' TREsSES.}

Callosities at the base of the lip obsolete; lower sepals coherent with the petals and upper sepal. Callosities nipple-shaped, directed downward; lower sepals free.

I. Ibidium strictum (Rydb.) House. (Spiranthes Romanzoffiana of Coulter's Man.; not Cham.; Gyrostachys stricta Rydb.) In springy places, rich hillsides and open woods from Newf. to Alaska, Pa. and Colo.-Alt. 5000Io,ooo ft.-Gunnison; West Cliff ; Cabin Cañon; Jack's Cabin ; Parlin ; Wahatoya Creek; Marshall Pass; Twin Lakes; Empire.

2. Ibidium porrifolium (Lind.) Rydb. In marshes from Ida. to Wash., Colo. and Cal.-Camp Harding, near Pike's Peak.

\section{OPHRYS (Tourn.) L. TWAyblade.}

Lip broad at the base, with distinct auricles, slightly cleft at the apex; leaves oblong to oval.

i. L. borealis.

Lip narrow and narrowed at the base, 2-cleft for about half its length into linearlanceolate lobes, without auricles, but with a pair of divergent teeth; leaves reniform.

2. L. nephrophylla.

1. Ophrys borealis (Morong) Rydb. (Listera borealis Morong) In woods from Hudson Bay to the Mackenzie and Mont.; also in Colo.-Saguache Range.

2. Ophrys nephrophylla Rydb. (Listera cordata Am. auth., partly; not R. Br.; Listera nephrophylla Rydb.) In woods from Mont. to Alaska, Colo. and Ore.-Alt. Io,000-II,500 ft.-Larimer Co.; Slide Rock Cañon, West La Plata Mountains; Beaver Creek; Franklin.

\section{Peramium Salisb. Rattle-snake Plantain.}

Lip evidently sackate, with recurved margins.

Lip scarcely sackate, with incurved margins.

I. P. ophiodes.

2. P. Menziesii.

1. Peramium ophioides (Fernald) Rydb. In woods from Prince Edwards Island to the Black Hills of S. D., N. C. and Colo.-Alt. about $8500 \mathrm{ft}$ Minnehaha; Pike's Peak.

2. Peramium Menziesii (Lindl.) Morong. (Goodyeara Menziesii Lindl.) In mountain woods from Que. to B. C., N. Y. and Calif.-Alt. 7500-9000 ft.Mt. Abram, Ouary; Pagosa Peak.

\section{Io. ACROANTHES Raf. Adders' Mouth.}

x. Acroanthes monophylla (L.) Greene. In woods from Que. to Minn., Pa. and Colo.-Alt. about 7500 ft.-Glen Mountain Falls.

11. Cytherea Salisb. Calypso.

1. Cytherea bulbosa (L.) House. (Calypso borealis Salisb.) In cold woods from Lab. to Alaska, Me. and Calif.-Alt. 8000-10,000 ft.-Telluride; East Indian Creek. 
I2. CORALLORRHIZA R. Br. CoRAL-ROot.

The small spur or callosity adnate to the ovary.

Lip entire; whole plant yellow.

I. C. ochrolenca.

Lip with 2 lobes or teeth below the middle; plant brownish.

Lobes or teeth small; lip unspotted; spur very small.

2. C. Corallorrhiza.

Lobes prominent; lip spotted; spur manifest.

Spur or callosity lacking.

3. C. multiflora.

4. C. Vreelandii.

1. Corallorrhiza ochroleuca Rydb. In woods of western Nebr. and Colo.Alt. about $8500 \mathrm{ft}$ - - Near La Veta.

2. Corallorrhiza Corallorrhiza (L.) Karst. (C. innata R. Br.) In woods from N. Sc. to Alaska, Ga. and Colo.-Alt. about ro,ooo ft.-Caribou.

3. Corallorrhiza multiflora Nutt. In woods from N. S. to Alaska, Fla. and Calif.-Alt. 4000-9500 ft.-Crystal Forest; Damfino Creek; Ouray; Cascade Cañon; West Indian Creek; Sangre de Cristo Creek; near Pagosa Peak; North Boulder Peak; Elizabethtown.

4. Corallorrhiza Vreelandii Rydb. In wet woods of Colo. and N. M.-Alt. about 8500 ft.-Veta Mountain; Pennock's mountain ranch. 


\section{Sub-class 2. DICOTYLEDONES.}

\section{Order I9. SALICALES.}

\section{Family 35. SALICACEAE Lind1. Wrllow Family.}

Bracts incised; disk cup-shaped; stamens usually Io or more; stigmata elongated and expanded; winter buds with several scales.

I. Populus.

Bracts entire; disk reduced to I or more small glands; stamens less than Io, usually 2 ; stigmas short, not expanded; winter-buds with one scale each.

2. SALiX.

\section{POPUlus L. Poplar, Cottonwood, Aspen.}

Petioles strongly flattened laterally.

Leaf-blades suborbicular, acute or very short acuminate. I. P. trenuloides.

Leaf-blades broadly deltoid or cordate, abruptly long acuminate.

Teeth of the leaves few, less than io on each side; cup of the pistillate flowers $6-8 \mathrm{~mm}$. broad; pedicels equalling or exceeding the capsule.

z. P. Wislizeni.

- Teeth of the leaves many, more than Io on each side; cup of the pistillate flowers less than $6 \mathrm{~mm}$. broad; pedicels shorter than the capsule.

Petioles terete or nearly so.

3. P. occidentalis.

Petioles half as long as the blade or longer; blades ovate or rhombic, abruptly long-acuminate.

4. P. acuminata.

Petioles about one-third as long as the blades or less; blades lanceolate, not abruptly acuminate.

5. $P$. angustifolia.

^. Populus tremuloides Michx. In open woods and on mountain sides from Newf. to Alaska, Tenn. and Nev.-Alt. 600o-10,000 ft.--Near Georgetown; Cheyenne Cañon; dry rocks, Cheyenne Mountain; Minnehaha; chaparrelcovered hills southeast of Ouray; South Park; near Pagosa Peak; South Cheyenne Cañon; Colorado Springs; Ojo; foot-hills, Larimer Co.; Chicken Creek, West La Plata Mountains; Rist Cañon; Fort Collins; Redstone; Howe's Gulch.

2. Populus Wislizeni (S. Wats.) Sarg. In cañons and on river banks from Tex. to Colo. and Ariz.-Alt. 4000-9000 ft.-River bottoms, Arboles; Grand Junction; plains, Colorado Springs.

3. Populus occidentalis (Rydb.) Britton. ( $P$. deltoides occidentalis Rydb.; $P$. angulata Port. \& Coult.; not Ait.) In river valleys and hillsides from Sask. to Mont., Kans. and Ariz.-Alt. 4000-7000 ft.-Plains near Denver; Walsenburg; Palisade; near Boulder; Lyons; Fort Collins; along the Arkansas River, Lamar; Eldora to Baltimore.

4. Populus acuminata Rydb. On river bottoms and in cañons from the Black Hills of S. D. to Ida., N. M. and Nev.-Alt. $4000-6000$ ft.-Fort Collins; Walsenburg; Denver; Hardin's ranch; Redstone.

5. Populus angustifolia James. In cañons and along streams from N. D. to Wash., N. M. and Calif.-Alt. 6000-Ir,000 ft.-Pike's Peak; Upper Platte; plains near Denver; South Cheyenne Cañon, Colorado Springs; Gunnison; 
Cimarron; chaparrel-covered hills southeast of Ouray; Turkey Creek and tributaries; Fort Collins; Mancos; Garden of the Gods; near Boulder; Rist Cañon; banks of the Poudre River; Redstone; Hardin's ranch; Trinidad.

Capsule glabrous.

\section{SALIX L. WILLOW.}

Filaments hairy, at least below; bracts caducous, light yellow.

Stamens $3-7$; stipe slender, $2-5$ times as long as the nectaries.

Petioles without glands; leaves serrulate, thin.

I. AMygdalinaE.

Petioles with glands; leaves densely glandular-serrate.

Stamens 2; stipe very short or none.

II. Pentandrae.

Filaments glabrous; bracts persistant, seldom light yellow.

III. LONGIFOLIAE.

Capsule hairy.

IV. CORDatae.

Filaments hairy.

Leaf-blades linear to lanceolate not very veiny; bracts caducous; tall shrubs.

III. LONGIFOLIAE.

Leaf-blades oval or suborbicular, very veiny; bracts persistent; depressed shrubs.

Filaments glabrous; bracts more or less persistent.

Capsule rostrate, distinctly stipitate; style none or short, always shorter than the stipe.

Stipe equalling or exceeding the bracts; styles $1 / 2 \mathrm{~mm}$. or less long.

V. Rostratae.

Stipe shorter than the bracts; styles tisually about I mm. long.

VI. BRACHYSTACHYAE.

Capsule scarcely rostrate, subsessile or if stipitate, stipe shorter than the style.

Style evident, at least $\mathrm{I} / 2 \mathrm{~mm}$. long.

Leaves permanently white-silky or tomentose, at least beneath.

VII. Pellitae.

Leaves either green or grayish beneath. VIII. ARCTICAE.

Style none; depressed shrubs with entire strongly veined leaves.

IX. Reticulatae.

I. Amygdalinae.

Leaf-blades narrowly lanceolate; petioles short.

Leaf-blades broadly lanceolate; petioles slender.

1. S. Wrightii.

ఒ. S. amygdaloides.

Represented only by

II. Pentandrae.

Capsule glabrous.

Capsule sessile.

Capsule stipitate.

Leaves permanently silky.

Leaves $3-5 \mathrm{~mm}$. wide; ovary without hairy swelling at the apex.

5. S. luteosericea.

Leaves $z-3 \mathrm{~mm}$. wide; ovary with a hairy swelling at the apex.

Leaves glabrous when mature.

3. S. Fendleriana.

III. LoNGIFOLIAE.

4. S. exigua.

6. S. stenophylla.

Capsule more or less pubescent.

7. S. linearifolia.

Capsule sparingly silky, often becoming glabrous in age.

Leaves permanently silky; bracts not densely silky.

5. S. luteosericea.

Leaves glabrous or nearly so when mature; bracts densely silky; aments dense.

Capsule densely white-villous; stigma sessile.

8. S. sessilifiora.

9. S. argophylla. 


\section{Cordatae.}

Capsule long-stipitate; stipe in fruit $1.5-6 \mathrm{~mm}$. long, equalling or longer than the bracts; style $0.5 \mathrm{~mm}$. or less long; aments leafy-peduncled.

Leaves dark green above, strongly serrate; young branches not light fellow.

Leaves yellowish green, entire or $S$. cordata.

II. $S$. Watsoni.
Capsule subsessile or very short-stipitate; stipe in fruit less than $1.5 \mathrm{~mm}$. long and much shorter than the bracts; style $0.5-1.5 \mathrm{~mm}$. long; aments subsessile and naked or subtended by a few small leaves.

Branches without a bloom.

Leaves lanceolate to ovate or obovate, more or less distinctly serrate.

Leaves thin, ovate or obovate, light green and dull above.

Leaves firm, dark-green and shining above, lanceolate.

I2. S. padophylla.

Style I.5 mm. long; aments $2.5-6 \mathrm{~cm}$. long. I $3 . S$. pseudocordata.

Style less than I mm. long; aments $1-2.5 \mathrm{~cm}$. long.

Leaves linear-lanceolate to oblong, entire.

Branches with a bloom.

I4. S. monticola.

I5. S. Wolfii.

I6. S. irrorata.

\section{Rostratae.}

Leaves linear to lanceolate or oblanceolate.

Leaves more or less silky; branches usually with a bloom.

Leaves not silky; branches without a bloom. 17. S. Geyeriana.

Leaves ovate to obovate.

Mature leaves thin, glabrous, faintly nerved.

I8. S. macrocarpa.

i9. S. perrostrata.

Mature leaves firm, pubescent or tomentose beneath, more strongly nerved.

20. S. Bebbiana.

\section{Brachystachyae.}

Only represented by

$$
\text { 21. S. Nuttallii. }
$$

ViI. Peiljtae.

Only represented by

22. S. pachnophora.

VIII. Arcticae.

Leaves grayish-villous on both sides, although less so above.

Twigs white-villous; branches yellow or grayish. 23. S. brachycarpa.

Twigs puberulent, rarely villous; branches usually purplish.

Leaf-blades oblong or linear-oblong; bracts obovate; shrub depressed.

24. S. pseudolapponum.

Leaf-blades oblanceolate or obovate-oblanceolate; bracts oblong; shrub not depressed.

25. S. glaucops.

Leaves glabrate or when young covered with white hairs parallel to the midrib.

Shrubs not creeping; leaf-blades oval to oblong or lanceolate.

Aments leafy-peduncled.

Aments subsessile, naked from lateral buds.

25. S. glaucops glabrata.

Shrubs creeping; leaf-blades obovate to oblanceolate.

27. S. petrophila.

IX. Reticulatae.

Only represented by

28. S. saximontana.

1. Salix Wrightii Anders. Along streams from Tex. to Colo. and Calif. -Alt. 4000-5500 ft.-Arkansas River; Denver.

2. Salix amygdaloides Anders. Along streams from Que. to Wash., N. Y., Mo. and Ariz.-Alt. 4000-7000 ft.-Plains, Colorado Springs; Denver; Wal- 
senburg; Cucharas river, below La Veta; mesas near Pueblo; Fort Collins; near Boulder; gulch west of Pennock's mountain ranch; Trinidad; La Porte.

3. Salix Fendleriana Anders. ( $S$. pentandra caudata Nutt.; $S$. lasiandra Fendlerwana Bebb.) Wet mountain valleys and along streams from Alb. to B. C., N. M. and Calif.-Alt. 7000-ro,00o ft.-New Windsor; Gunnison; on Turkey Creek and tributaries; Los Pinos; along the Uncompahgre River, near Ouray; Ojo; Mancos; Cimarron; Fort Collins; along the Conejos River, north of Antonito; Trail Creek; Steamboat Springs.

4. Salix exigua Nutt. On river-banks from Mackenzie River to Wash., Colo. and Calif.-Alt. 5000-10,000 ft.--Plains, Colorado Springs; Twin Lakes; North Park; Los Pinos; Trinidad.

5. Salix luteosericea Rydb. On sandy river-bals from Neb. to Mont., Ida. and Colo.-Alt. 4000-6000 ft.-Fort Collins; plains, Larimer Co.; Walsenburg; Sterling, Logan Co.; near Boulder; Elizabethtown; Denver; Walton Creek; along the Conejos River, north of Antonito; Rist Cañon; Dolores.

6. Salix stenophylla Rydb. Along streams from Tex. to Colo. and N. M. -Alt. 4000-8000 ft.-Mancos; Cucharas River, below La Veta; Walsenburg; Gunnison; Cerro Summit.

7. Salix linearifolia Rydb. ( $S$. longifolia tenerrima Henders.) Along streams from Minn. and Sask. to Wash., Ark. and Colo.-Exact locality not given.

8. Salix sessiliflora Nutt. Along streams from Alb. to Mont., Colo. and Nev.-Alt. 4000-8000 ft.-Grand Cañon; along Uncompahgre River, near Ouray; Grand Junction; Cerro Summit.

9. Salix argophylla Nutt. Along streams from Mont. to Wash., Tex. and Calif.-Alt. about 5000 ft.-Fort Collins; Rist Cañon.

Io. Salix cordata angustata (Pursh) Anders. In river-valleys from N. B. to Wash., Va. and N. M.-Alt. 4000-Io,00o ft.-Los Pinos; Walsenburg; Cucharas River, below La Veta; on Turkey Creek and tributaries.

II. Salix Watsoni (Bebb.) Rydb. (S. cordata Watsoni Bebb.; S. Aava Rydb.; not Schoepf.) In river-valleys from Mont. to Calif. and Colo--Alt. 6000-7000 ft.-Manitou; South Park; Middle Park; Walsenburg; Cucharas Valley, near La Veta.

12. Salix padophylla Rydb. In valleys from Mont. to N. M.-Alt. 80ooI , 00o ft.-Los Pinos; Pass Creek; Ojo; Bob Creek, West La Plata Mountains; North Park; on Turkey Creek and tributaries; Gunnison; Carson; Silverton; near Chambers' Lake; Dolores.

I3. Salix pseudocordata Anders. (S. Novae-Angliae pseudocordato Anders.) Along streams from Sask. to Alb. and Colo.-Alt. 6000-7000 ft. -Manitou; North Park; South Cheyenne Cañon.

I4. Salix monticola Bebb. In mountain valleys from Alb. to Ore., Colo. and Nev.-Alt. 2200-3000 ft.-Pike's Peak; Lake City; Georgetown; headwaters of Sangre de Cristo Creek; North Cheyenne Cañon; Chamber's Lake; Sheep Creek, above Campton's.

15. Salix Wolfii Bebb. In mountain valleys of Wyoming and Colo.-Alt. 8000-10,500 ft.-South Park; Tennessee Pass; on Grizzly Creek; Ironton Park, nine miles south of Ouray; North Park; Rico; Eldora to Baltimore; Camp Creek, Larimer Co. 
I6. Salix irrorata Anders. In cañons and along streams from Colo, to $\mathrm{N}$. M.-Alt. 6000-900o ft.--Dry rocks, Cheyenne Mountain; Manitou; Cucharas Valley, near La Veta; South Cheyenne Cañon; foot-hills, Larimer Co.; Los Pinos; Ironton Park, nine miles sotth of Ouray; Gunnison; Crest Butte, Gunnison watershed; Grizzly Creek; Sheep Creek, above Campton's; Horsetooth Gulch; Rist Cañon; Howe's Gulch.

I7. Salix Geyeriana Anders. In mountain valleys along streams from Wyo. to Wash., Colo, and Ore-Alt. 8000-Io,000 ft.-Mountains of Estes Park; Minturn; Columbine; Sargent's; Pinkham Creek, Larimer Co.

I8. Salix macrocarpa Nutt. Along streams in the mountains from Wyo. to Wash. and Colo.-Alt. up to I0,000 ft.-Seven Lakes; Stove Prairie, Larimer Co.

I9. Salix perrostrata Rydb. In valleys and in wet places in the foot-hills from Hudson Bay to Alaska and Colo.-Alt. I500-2700 ft.-Foot-hills, Colorado Springs; foot-hills west of Fort Collins; Los Pinos; South Cheyenne Cañon; Ruxton; Green Mountain Falls; Ojo; Cimarron; Chicken Creek, West La Plata Mountains; Pike's Peak Trail; Rist Cañon; mountains northeast of Dolores; Boulder.

20. Salix Bebbiana Sarg. (S. rostrata Richardson) In valleys and on hillsides from Anticosti to Alaska, N. J. and Calif.-Alt. 5000-Io,000 ft.Manitou; Ruxton Dell; Pike's Peak; North Park, Larimer Co.; mountains of Estes Park, Larimer Co.; Horsetooth Gulch; Boulder; Beaver Creek.

2I. Salix Nuttallii Sarg. (S. flavescens Nutt.) Along streams and in wet valleys from Ass. and B. C. to N. M. and Calif.-Alt. 7000-II,000 ft.-Hills about Box Cañon, west of Ouray; Wahatoya Cañon; Little Kate Basin, La Plata Mountains; mountains, Larimer Co.; Artists' Glen; North Cheyenne Cañon; chaparral-covered hills southeast of Ouray; Stove Prairie, Larimer Co.; Mount Baldy; Barnes' Camp on Little South; Redstone; Eldora to Baltimore; Empire.

22. Salix pachnophora Rydb. In the mountains along streams, Colo. and N. M.-Alt. 7000-8000 ft.-Rico, Dolores Co.; along Uncompahgre River; near Ouray; Chambers' Lake; Hahn's Peak, Routt Co.; Rabbit-Ears.

23. Salix brachycarpa Nutt. (Salix desertorum stricta Anderson; S. stricta Rydb.) In springy places in the mountains from Que. to Alb. and Colo.Alt. 7000-I I,000 ft.-Twin Lakes; Pike's Peak; Sheep Creek, above Campton's; near Higho; Veta Pass, Sangre de Cristo Range; Walden, Larimer Co.

24. Salix pseudolapponum Seem. On mountain tops of Colorado.-Alt. 9000-13,000 ft.-Gray's Peak; Georgetown; Cimarron Pass; Alpine Tunnel; Mt. Abram, Ouray; Sierra Blanca; Little Kate Basin, La Plata Mountains; Mt. Hesperus, above timber line; West Spanish Peak; headwaters of Sangre de Cristo Creek; Twin Lakes; Bottomless Pit; east slope Pike's Peak; Dead Lake; Tennessee Pass; bank of Michigan, North Park; mountains above Graymont; Eldora to Baltimore; Berthoud Pass.

25. Salix glaucops Anders. In alpine bogs and springy places from Alb. to Yukon Terr., Colo. and Calif.--Alt. 7000-13,000 ft.-In var. glabrata Anders., the leaves are nearly glabrous above--Mountains between Sunshine and Ward; Brush Creek, Custer Co.; mountains south of Ward, Boulder Co.; Bear Creek Divide, West La Plata Mountains; Alpine Tunnel; Mt. Abram, 
Ouray; Sheep Creek, above Campton's; Sierra Blanca; near Pagosa Peak; Silver Plume; timber line, Pike's Peak; Ironton Park, nine miles south of Ouray; Mt. Harvard; Red Mountain, south of Ouray; Marshall's Pass; Carson; Lake Moraine; mountains above Boreas; head of Red River, Frankin; Hematite; Cameron Pass; southeast of Jefferson; Empire.

26. Salix chlorophylla Anders. In mountain bogs from Lab. to Alaska, N. H. and Colo.-Alt. 8000-12,000 ft.-Georgetown; Clear Creek, Middle Park; Alpine Tunnel; mountains above Boreas; Pike's Peak; Little Kate Basin; Wahatoya Cañon; Buffalo Pass, Park Range; Red Mountain, south of Ouray; Columbine; mountains of Estes Park, Larimer Co.; Carson; Marshall Pass; mountains above Boreas; Cameron Pass; Rabbit-Ears, Larimer Co.; Beaver Creek; North Park Range, Routt Co.

27. Salix petrophila Rydb. ( $S$. arctica petraea Anderson) On exposed mountain tops from N. H. to B. C., Colo. and Utah.-Alt. I2,000-I4,000 ft. -Gray's Peak; near Pagosa Peak; mountains above Boreas; Mt. Howard; Marshall Pass.

28. Salix saximontana Rydb. (S. reticulata Port. \& Coult., in part) On exposed mountain tops from Wyo. to Colo. and Nev.-Alt. 9000-14,000 ft.Clear Creek, Middle Park; Arapahoe Peak; Argentine Pass; Floral Mountain; Georgetown; Mt. Hesperus; mountains above Cameron Pass; Gray's Peak; Bald Mountain; West Spanish Peak; Mount Garfield; Sierra Blanca; Alpine Tunnel; Franklin; Ragged Mountain, Gunnison Co.; Ethel Peak, Larimer Co.

\section{Order 20. FAGALES.}

Staminate and pistillate flowers both in aments; fruit not with a bur or cup.

Staminate flowers 2 or 3 together in the axils of the bracts, each with a calyx; pistillate flowers without a calyx. 36. Betulaceae. Staminate flowers solitary in the axils of each bract without a calyx; pistillate flowers with a calyx. 37. CORYLACEAE.

Staminate flowers in aments; pistillate often solitary, the involucre becoming a cup or bur. 38. FAGACEAE.

\section{Family 36 . BETUlaCEAE Agardh. Birch Family.}

Stamens 2; bracts of the mature pistillate aments membranous, usually 3-lobed, deciduous with the nut.

I. Betula.

Stamens ustrally $4(3-6)$; bracts of the mature pistillate aments thickened and woody, erose or toothed, persistent.

2. Alnus.

\section{BETULA L, BiRCH.}

Wings of the fruit much wider than the body; trees or tall shrubs.

Wing of the fontinalis.

Wing of the fruit usually narrower than the body; low shrubs. z. B. glandulosa.

1. Betula fontinalis Sarg. (B. occidentalis S. Wats.; not Hook.) Along streams from S. D. and Alb. to Yukon Terr., N. M. and Ore.-Alt. 5000$9000 \mathrm{ft}$.-Walsenburg; Garland; Engelmann Cañon; foot-hills, Fort Collins; Livermore, Larimer Co.; South Cheyenne Cañon; North Cheyenne Cañon; Ojo; Pass Creek; foot-hills near Fort Collins; Elizabethtown; Howe's Gulch; west of Rist Cañon; Rist Cañon; Eldora to Baltimore; Elk River, Routt Co. 
2. Betula glandulosa Michx. In bogs from Greenl. to Alaska, N. H., Colo. and Ore.-Alt. 9000-II,000 ft.-Middle Park; Argentine Pass; Cameron Pass; mountains above Como; Twin Lakes; Seven Lakes; Blue River; Ironton Park, nine miles south of Ouray; Ruxton Park; head of Muddy River, Middle Park; Pike's Peak; Tennessee Pass; Silverton; Breckenridge; between Como and Boreas; bank of the Big Muddy; western Gunnison Co.; Eldora to Baltimore.

\section{ALNUS Gaertn. ALDER.}

I. Alnus tenuifolia Nutt. (A. incanavirescens $\mathrm{S}$. Wats.) Along streams from Mont. to Alaska, N. M. and Calif.-Alt. 6000-10,000 ft.-Mountains between Sunshine and Ward; Ojo; Turkey Creek and tributaries; cañon, Idaho Springs; Cucharas Valley, near La Veta; Hermosa; near Pagosa Peak; headwaters of Pass Creek; Larimer Co.; Bob Creek, West La Plata Mountains; Red Mountain, south of Ouray; Lower Boulder Cañon, Boulder Co.; Parlin; Colorado Springs; Black Cañon of the Gunnison; Rist Cañon; foothills near Fort Collins; Steamboat Springs; Dolores.

\section{Family 37. CORYLACEAE Mirbel. Hazel-Nut Family.}

\section{CORYLUS L. HAZEL-NUT.}

I. Corylus rostrata Ait. In thickets and open woods and on hillsides from N. S. to N. D., Ga, and Colo.-Alt. I200-8000 ft.-Lower Boulder Cañon, Boulder Co.; North Cheyenne Cañon; foot-hills, Larimer Co.; Rist Cañon; gulch west of Soldier Cañon; vicinity of Arthur's Rock.

\section{Family 38 . FAGACEAE Drude. Beech Family.}

\section{QUERCUS L. OAK.}

Leaves lobed or divided, not evergreen; lobes rounded, obtuse or acute, but not spinulose-tipped.

Leaves bright green, early deciduous.

Mature leaves softly pubescent, almost velvety beneath, deeply divided.

r. $Q$. utahensis.

Mature leaves glabrate, puberulent or somewhat pubescent, but not velvety beneath.

Cup flat, covering less than $1 / 4$ of the acorn.

z. Q. Vreelandii.

Cup hemispheric, covering $1 / 3$ to $1 / 2$ of the acorn.

Acorns barrel-shaped, obtuse.

Mature leaves very thin, glabrate beneath or puberulent only on the veins; cup covering about $1 / 2$ of the acorn; scales of cup thin.

3. Q. leptophylla.

Mature leaves firm, puberulent beneath, cup covering about $1 / 3$ of the acorn; scales of cup thick, corky.

Leaves mostly oblong in outline, lobed halfway to the midrib or less, rather dull. 4. Q. Gunnisonii.

Leaves obovate in outline, divided deeper than halfway to the midrib, very shining above.

Lobes of the leaves broadly oblong, rounded at the apex.

Lobes of the leaves ovate or triangular, acute.

5. Q. nitescens.

6. Q. novomexicana. 
Acorns ovoid, acute; cup covering about $I / 2$ of the acorn.

7. Q. Gambellii.

Leaves pale green, more persistent.

Lobes oblong-ovate, obtuse or acutish, not mucronate.

Lobes triangular-ovate, mucronate.

8. Q. venustula.

9. Q. Fendleri.

Leaves persistent, evergreen, sinuate; lobes or teeth spinulose-tipped or mucronate.

Leaves decidedly crisped, sinuately lobed; lobes distinctly spinulose-tipped.

I0. $Q$. pungens.

Leaves flat, sinuately toothed; teeth mucronate or slightly spinulose-tipped. II. Q. undulata.

1. Quercus utahensis (A. DC.) Rydb. (Q. stellata Utahensis A. DC.) A small tree, often to feet or more high, growing in the mountain regions of Utah, Colo., Ariz. and N. M.-Alt. 4000-9000 ft.-Chaparral-covered hills southeast of Ouray; Hotchkiss, Delta Co.; Trinidad; Glenwood Springs; Mancos; North Cheyenne Cañon; Wahatoya Cañon; hills about Box Cañon, west of Ouray; Manitou; Mancos Cañon; west of Palmer Lake; Glen Eyrie.

2. Quercus Vreelandii Rydb. A chaparral-forming shrub, I-I.5 m. high, growing on hillsides in Colo, and N. M.-Alt. 4000-9000 ft.-Chaparral-covered hills southeast of Ouray; Cerro; Glenwood Springs; butte five miles southwest of La Veta; South Cheyenne Cañon; Colorado Springs.

3. Quercus leptophylla Rydb. A tree, IO-I $5 \mathrm{~m}$. high, growing along streams in the mountains of Colorado.-Alt. 5500-8500 ft.-Turkey Creek and tributaries; Cucharas River, above La Veta; North Cheyenne Cañon; Routt Co.; Chicken Creek, West La Plata Mountains.

4. Quercus Gunnisonii (Torr.) Rydb. A chaparral-forming shrub, I-3 m. high, growing on hillsides and mesas from Colo. to Utah, N. M. and Ariz.Alt. 6000-8000 ft.-North Cheyenne Cañon; butte five miles southwest of La Veta; Colorado Springs; Cochetopa Pass; Cañon of Arkansas; Cañon City; Durango; hills back of Manitou; Steamboat Springs; Denver.

5. Quercus nitescens Rydb. A chaparral-forming shrub, 3-5 m. high, growing on mesas and hillsides, but along streams sometimes forming a small tree; in Colo. and eastern Utah.-Alt. 6000-II,000 ft.-Butte five miles southwest of La Veta; Glenwood Springs; chaparral-covered hills southeast of Ouray; Red Mountain, south of Ouray; hills about Box Cañon, west of Ouray; West Mancos Cañon; Four-Mile Hill, Routt Co.; Los Pinos; Ute Pass, near Pike's Peak; Cheyenne Cañon, near Pike's Peak.

6. Quercus novomexicana (A. DC.) Rydb. (Q. Douglasii Novomexicana A. DC.) A chaparral-forming shrub, 3-5 m. high, or along streams a small tree, from Colo. to Utah and N. M.-Alt. 4000-900o ft.-Glenwood Springs; Engelmann Cañon; between Pallas and Sydney; Cucharas River, above La Veta; Mancos; Manitou; chaparral-covered hills southeast of Ouray; Cheyenne Mountain; Cañon City.

7. Quercus Gambellii Nutt. A chaparral-forming shrub, 3-5 m. high, growing on hillsides from Colo. to Utah and N. M.-Alt. 6500-9000 ft.-Chaparralcovered hills southeast of Ouray; Cucharas River, above La Veta; Gunnison; Twelve-Mile Creek; north of Cheyenne Cañon; Manitou; Cañon of the Arkansas; South Park; Ute Pass; Garden of the Gods.

8. Quercus venustula Greene. A small shrub, I-2 m. high, known only from the type locality.-Raton Mountains, near Trinidad. 
9. Quercus Fendleri Liebm. A shrub, I-3 m. high, growing on dry hillsides from Colo. to Tex. and Ariz.-Alt. 5000-7000 ft.-Mesas near Colorado Springs; McElmo Cañon; Raton Mountains, near Trinidad; Cañon of Arkansas; Green Horn Mountains; Poncho Pass; Purgatory River, near Trinidad.

Io. Quercus pungens Liebm. (Q. undulata Wrightii Engelm.) A low shrub, I-3 m. high, on dry hills from Colo. to Utah, Tex. and Ariz.; also Mex.-Cañon City; Arkansas Cañon.

I 1. Quercus undulata Torr. (Q. undulata Jamesii Engelm.) A shrub, I-3 m. high, growing on dry hills from Colo. to Tex. and Ariz.-" Rocky Mountains"; Cañon of the Arkansas; Steamboat Springs.

\section{Order 2I. URTICALES.}

Style and stigma I; ovules erect or ascending; herbs with small greenish flowers; - fruit an achene.

Styles and stigmas 2 ; ovules pendulous.

Herbs or herbacious vines with opposite leaves; fruit an achene.

Trees or shrubs with alternate leaves; fruit a samara or drupe.

40. Cannabin aceae.

4I. UlmaceaE.

\section{Family 39. URTICACEAE Reichenb. Nettle Family.}

Herbs with stinging hairs; leaves opposite; flowers not involucrate.

Herbs without stinging hairs; leaves alternate; flowers involucrate by leafy bracts.

z. Parietaria.

I. URTICA L. NetTle.

Teeth of the leaves ovate, strongly directed forward; stem sparingly strigose and bristly.

Teeth of the leaves broadly triangular, not strongly directed forward; stem glabrous or nearly so.

2. U. gracilenta.

I. Urtica gracilis Ait. In alluvial soil along streams from N. S. to Alaska, N. C. and N. M.-Alt. 4000-900o ft.-Mountains between Sunshine and Ward; Steamboat Springs; Mancos; Bob Creek, West La Plata Mountains; Fort Collins; along the Uncompahgre River, near Ouray; chaparral-covered hills southeast of Ouray; Gunnison; Spring Cañon; Campton's ranch.

¿. Urtica gracilenta Greene. (U. Breweri Coulter; not S. Wats.) Along streams from Wyo. to Tex. and N. M.-Alt. up to gooo ft.-Near Pagosa Peak.

\section{¿. PARIETARIA L. Pellitory.}

Leaf-blades lanceolate, $2-7 \mathrm{~cm}$. long, twice as long as the petioles or longer. I. $P$. pennsylvanica. Leaf-blades oblong or ovate-oblong, $0.5^{-2} \mathrm{~cm}$. long, not twice as long as the petioles.

2. P. obtusa.

r. Parietaria pennsylvanica Muhl. On shaded banks and hillsides from Jnt. to B. C., Fla. and Mex.-Alt. 4000-7000 ft.-Steamboat Springs; Lower Boulder Cañon, Boulder Co.; Black Cañon; foot-hills, Larimer Co.; gulch west of Pennock's mountain ranch; along Poudre River, near Fort Collins; Horsetooth Gulch. 
2. Parietaria obtusa Rydb. In shaded places from Colo. to Utah, Tex. and Calif.-Alt. up to 6000 ft.-El Paso; Sunset Cañon.

Family 40. CANNABINACEAE Lindl. Hemp Family.

I. HUMULUS L. HOPS.

1. Humulus lupulus neo-mexicanus Cockerell. The native hops of the Rocky Mountain region has deeper divided leaves and more sharply acuminate bracts than the cultivated variety. It grows along streams from Wyo. to Utah, N. M. and Ariz.-Alt. 5000-8000 ft.-Fort Collins; Colorado Springs; along the Uncompahgre River, near Ouray; Parlin, Gunnison Co.; Walsenburg; Manitou; cañon west of Palmer Lake; along Cache la Poudre River; Poudre Cañon.

Family 4I. ULMACEAE Mirbel. Elir Family.

I. CELTIS L. HACKBERRY.

I. Celtis reticulata Torr. (C. occidentalis Port. \& Coult.; not L.) On hillsides, in rocky places, from Tex. to Colo. and Ariz.-Alt. 4000-6000 ft."Colorado," locality not given; plains and foot-hills near Boulder; near Osborne City; Golden; gulch west of Pennock's mountain ranch; foot-hills $6-8$ miles west of Fort Collins.

\section{Order 22. SANTALALES.}

Leaves opposite: fruit a berry; tree-parasites.

Leaves alternate: fruit a drupe or nut; root-parasites or saprophytes.

42. LoRanthaceae. 43. Santalaceae.

\section{Family 42. LORANThaceaE D. Don. Mistletoe Family.}

Anthers 2-celled; pollen-grains smooth; berry globose, pulpy and semi-translucent. 1. Phoradendron. Anthers I-celled; pollen spinulose; berry compressed, fleshy, opaque.

\section{PHORADENDRON Nutt.}

2. Razoumofskya.

I. Phoradendron juniperinum Engelm. Parasitic on species of Sabina from Colo. and Ore. to Tex. and Calif.; also in Mex.-Mancos; Hotchkiss; Paxton ranch.

\section{RAZOUMOFSKYA Hoffm.}

Staminate flowers all or nearly all terminal on distinct peduncles, dichotomously paniculate (on Pinus Murrayana, contorta and divaricata). I. $R$. americana.

Staminate flowers nearly all axillary, forming simple or compound spikes.

Branches $\mathrm{I}-2 \mathrm{~mm}$. in diameter.

Plant yellowish-green; accessory branches of fruiting specimens flowerbearing.

Spikes short, 3-5-flowered; stems bluntly angled (on Pseudotsuga mucronata).

Spikes many-flowered; stems sharply angled (on Pinus flexilis).

2. R. Douglasii.

3. R. cyanocarpa. 
Plant greenish-brown; accessory branches merely leaf-bearing (on Caryopitys edulis and monophylla).

4. R. divaricata.

Branches 3-4 mm. in diameter (on Pinus scopulorum, and ponderosa).

5. R. cryptopoda.

I. Razoumofskya americana (Nutt.) Kuntze. (Arceuthobium Americanum Nutt.) Parasitic on Pinus Murrayana, contorta and divaricata, from Sask. and B. C. to Colo. and Ore.-Dillon; Grand Lake; Sunset.

2. Razoumofskya Douglasii (Engelm.) Kuntze. (A. Douglasii Engelm.) Parasitic on Pseudotsuga, from Ida. to N. M.-South Cheyenne Cañon; El Paso Co.; West Mancos Cañon.

3. Razoumofskya cyanocarpa A. Nels. Parasitic on Pinus flexilis, from Wyo. to Colo.-Cheyenne Mountain.

4. Razoumofskya divaricata (Engelm.) Kuntze. (A. divaricatum Engelm.) Parasitic on Caryopitys edulis and monophylla.-Mancos; Dillon.

5. Razoumofskya cryptopoda (Engelm.) Coville. (Arceuthobium cryptopodum Engelm.; A. robustum Engelm.) Parasitic on Pinus scopulorum and ponderosa.-Between Sunshine and Ward, Boulder Co.; West Indian Creek; Custer Co.; Stove Prairie Hill; Rist Cañon.

Family 43. SANTALACEAE R. Br. SANdal-wood Family.

I. COMANDRA Nutt. Bastard ToAd-Flax.

I. Comandra pallida A. DC. On plains and hills from Man., Alb. and B. C. to N. M. and Utah.-Alt. 4000-8000 ft.-Van Boxle's ranch, above Cimarron; Cucharas River, below La Veta; Wahatoya Creek; Los Pinos; Steamboat Springs; Mancos; Fort Collins; Boulder; Dolores; along Poudre River; Horsetooth Gulch; Colorado City; Pinkham Creek, Larimer Co.

\section{Order 23. POL'YGONALES.}

\section{Family 44. POLYGONACEAE Lindl. Buckwheat Family.}

Flowers subtended by involucres; stamens 9 .

I. Eriogonum.

Flowers not involucrate; stamens 4-8.

Stigmas tufted.

Perianth 6-parted; styles 3-parted; achenes 3-angled. 2. Rumex.

Perianth 4-parted; style 2-parted; achenes lenticular. 3. OXYria.

Stigmas capitate.

Leaf-blades jointed at the base; ochreae 2-lobed, becoming lacerate; filaments at least the inner dilated.

4. Polygonum.

Leaf-blades not jointed at the base; ochreae not 2-lobed; filaments slender.

Ochreae cylindric, truncate.

5. Persicaria.

Ochrea oblique, more or less open on the side facing the leaf.

Simple strict herbs with terminal spikes; perianth-lobes not keeled.

6. Bistorta.

Twining vines with flowers in axillary clusters; outer perianth-lobes winged or keeled.

7. TINIARIa.

\section{ERIOGONUM L.}

Achenes 3-winged; perianth not accrescent.

I. Alata.

Achenes merely 3 -angled; perianth accrescent in iruit.

Perianth with a stipe-like base.

Involucres in branching cymes.

II. Eriantha. 
Involucres in simple or compound umbel-like or head-like clusters. Perianths hairy. III. FLAVA. Perianth glabrous.

IV. UMBELLATA.

Perianth without a stipe-like base.

Ovaries and fruit pubescent; involucres few, capitate or subcymose.

Ovaries and fruit glabrous or nearly so.

V. LACHNOGYNA.

Involucres in head-like or umbel-like clusters.

Perianth-lobes very unequal.

Perianth-lobes equal or nearly so.

VI. Heterosepala.

Involucres in open cymes.

Cymes I-sided and spike-like.

VII. Capitata.

Cymes dichotomous or trichotomous.

X. Virgata.

Bracts scale-like.

Involucres, except those in the forks of the inflorescence, sessile in the bractlets; the uppermost conglomerate.

Perennial with a suffruticose caudex or shrubby.

VIII. CORYMBosa.

Annuals, erect and strict.

IX. AnNuA.

Involucres all peduncled, never conglomerate.

XI. Pedunculata.

Bracts leaf-like.

Primary cauline leaves scale-like, with a pair or a fascicle of welldeveloped secondary leaves in their axils. XII. Divaricata.

Primary cauline leaves well developed, often also with secondary leaves in their axils.

XIII. Foliosa.

\section{Alata.}

Involucres hairy, when mature $3-3.5 \mathrm{~mm}$. long and $1.5-2 \mathrm{~mm}$. wide; stem and leaves manifestly hairy.

I. E. alatum.

Involucres glabrous, when mature $2-2.5 \mathrm{~mm}$. long and of the same width; stem and leaves nearly glabrous.

2. E. triste.

\section{ERIANTha.}

Perianth whitish; styles hairy at least to the middle.

Perianth yellow; styles hairy only at the base.

Involucres $6-8 \mathrm{~mm}$. long; leaf-blades oblong to oblanceolate.

Involucres 9-1o $\mathrm{mm}$. long; leaf-blades suborbicular to oval.

3. E. Jamesii.

\section{Flava.}

5. E. arcuatum.

Stipe-like base of the perianth very short; old leaf-bases permanently tomentose.

Leaf-bases thickened; perianth copiously white-pubescent; leaf-blades silky above; involucres usually several.

6. E. flavum.

Leaf-bases not thickened; perianth sparingly pubescent; leaf-blades slightly floccose above; involucres $\mathrm{I}-3$. 7 . E. aureum.

Stipe-like base of the perianth slender; old leaf-bases glabrous.

8. E. ranthum.

Perianth deep yellow.

IV. Umbellata.

Umbels simple.

Leaves densely tomentose beneath.

Leaves almost glabrous at maturity.

Umbels compound; leaves tomentose beneath.

9. E. umbellatum.

Io. E. umbelliferum.

Perianth cream-color.

Perianth about $6 \mathrm{~mm}$. long at maturity; leaf-blades spatulate-oblong or elliptic, glabrous above at maturity. 12. E. subalpinum.

Perianth about $8 \mathrm{~mm}$. long at maturity; leaf-blades oval or ovate, permanently tomentose above.

13. E. latum. 


\section{Lachnogyna.}

Leaves and scape silky; the latter elongated, I dm. or more high; the former 2-4 cm. long, long-petioled; blades oblanceolate to oblong, acute.

Inflorescence irregularly branched.

Inforescence subcapitate.

Leaves lanate, strongly revolute; scape usually none.

I 4. E. lachnogynum.

I5. E. Tetraneuris.

I6. E. acaule.

\section{Heterosepala.}

Involucres about $7 \mathrm{~mm}$. long; leaf-blades oval.

Involucres $4-5 \mathrm{~mm}$. long.

Perianth bright yellow, or purplish; leaf-blades about as broad as long. I8. E. ovalifolium.

Perianth cream-colored to isabel-colored; leaf-blades elliptic to oval or spatulate, decidedly longer than broad. I9. E. ochroleucum.

Perianth yellow.

\section{Vil. Capitata.}

Perianth white or brownish or pinkish.

Perianth pubescent.

20. E. chrysocephalum

Perianth glabrous.

2I. E. multiceps.

Lobes of the involucres much shorter than the tube.

Lobes of the involucres about as long as the tube.

22. E. coloradense.

23. E. pauciflorum.

Perianth yellow.

VIII. Corymbosa.

Leaves crowded on the short branches of the caudex; blades oblong to linearoblong, flat. 24. E. campanulatum.

Leaves more scattered on the elongated branches of the caudex; blades narrowly linear, strongly revolute.

25. E. brevicaule.

Perianth white or pinkish.

Shrubs or herbaceous plants with a woody caudex, mostly over $2 \mathrm{dm}$. high; leaves not heath-like.

Flowering branches leafy only at the base.

Involucres in the forks of the inflorescence sessile.

Leaves mostly flat; involucres narrowly turbinate; perianth $2-2.5 \mathrm{~mm}$. long. 26. E. lonchophyllum.

Leaves mostly revolute; involucres campanulate; perianth $3-3.5 \mathrm{~mm}$. long. $\quad 27$. E. nudicaule.

Involucres in the forks of the inflorescence distinctly peduncled, at least the lower.

Involucres broadly campanulate, about as wide as long.

Involucres turbinate, decidedly longer than broad.

Leaves narrowly linear-oblanceolate or linear, usually revolute.

Leaves spatulate to oblanceolate, flat.

29. E. tristichum.

30. E. salicinum.

Flowering branches leafy halfway or more.

Leaf-blades relatively broad, broadly oblong to oval, obtuse.

Involucres $4-5 \mathrm{~mm}$. long.

Involucres $2-2.5 \mathrm{~mm}$. long.

Branches of inflorescence divaricate.

31. E. Fendlerianum.

Branches of inflorescence ascending.

32. E. divergens.

33. E. coryinbosum.

Leaf-blades narrow, from spatulate to linear, acute.

Leaf-blades spatulate or oblanceolate, mostly flat.

Inflorescence many times compound, copiously branched; internodes long.

Inflorescence tomentulose, broom-like, with strongly ascending branches; involucres about $1.5 \mathrm{~mm}$. long. 34. E. effusum. 
Inflorescence glabrous, lax with spreading branches; involucre 2-2.5 $\mathrm{mm}$. long.

30. E. salicinum.

Inflorescence less compound; branches and internodes short, mostly spreading.

Leaf-blades linear, revolute.

35. E. microthecum.

36. E. Simpsonii.

Dwarf depressed undershrubs, less than I dm. high, with heath-like leaves. 37. E. contortum.

\section{Annua.}

One species.

38. E. annuนm.

\section{Virgata.}

Leaves crowded on the ends of the short caudex; blades abruptly narrowed at the base or subcordate.

39. E. racemosum.

Leaves scattered on the fruticose branches; blades tapering at the base.

40. E. Wrightii.

\section{Pedunculata.}

Perianth glabrous.

Scapes and branches glabrous.

Peduncles erect or ascending.

Perianth-lobes nearly equal and similar; leaves glabrous.

4I. E. Gordonii.

Perianth-lobes very unequal and dissimilar; leaves floccose beneath. Outer perianth-lobes dilated above; involucres about $1.5 \mathrm{~mm}$. long. 42. E. rotundifolium.

Outer perianth-lobes not dilated above; involucres about $3 \mathrm{~mm}$. long.

Peduncles reflexed or deflexed.

43. E. tenellum.

44. E. cernuum.

Scapes and branches villous or glandular, especially near the nodes.

Perianth glandular or pubescent. 45. E. trinervatun.

Scapes and branches glandular, especially near the nodes, not inflated.

48. E. glandulosum. scape inflated.

Accessory branches at the lower forks of the inflorescence many and nearly as strong as the three main branches; branches divaricate. 46. E. fusiforme.

Accessory branches at the lower forks of the inflorescence none or few and small; branches ascending. 47. E. inflatum.

One species.

XII. Divaricata.

One species.

XIII. Foliosa.

49. E. divaricatum.

5o. E. salsuginosum.

r. Eriogonum alatum Torr. In sandy soil from Neb. and Wyo. to Tex. and Ariz.-Alt. 4000-10,000 ft.-Headwaters of Clear Creek and alpine ridges east of Middle Park; plains and foot-hills near Boulder; Green Mountain Falls; Sand Creek Pass; South Park; Williams' Cañon, near Pike's Peak; Sangre de Cristo Creek; Table Rock; Pagosa Springs; Thompson's Park, La Plata Mountains; Spring Cañon; Dillon Cañon, near Trinidad; plains, near foot-hills, Larimer Co.

2. Eriogonum triste S. Wats. (E. alatum glabriusculum Torr.). In sandy soil from Colo. to Tex. and N. M.-North Park; headwaters of Clear Creek and alpine ridges east of Middle Park.

3. Eriogonum Jamesii Benth. On plains and hills from Kans. and Colo. to Tex. and Ariz.-Alt. 4000-9000 ft.-Headwaters of Platte River; Colorado 
Springs; Durango; Middle Park; La Veta; Grand Junction; Morrison; Gunnison; Salida; Sangre de Cristo Creek; Red Rock Cañon, near Pike's Peak; Rosita; Buena Vista.

4. Eriogonum Bakeri Greene. (E. Alavum vegetius T. \& G.; E. Jamesii flavescens S. Wats.; E. vegetius (T. \& G.) Nels.) On plains and hills from Wyo. and Utah to N. M. and Ariz.-Alt. 9000-10,000 ft.-Meadow Park; mountains between Sunshine and Ward; Bald Mountain, west of Loveland; Black Cañon; Horsetooth Gulch, Fort Collins; Poudre Cañon; Moon's ranch.

5. Eriogonum arcuatum Greene. Mountains in Colo-Alt, about $7000 \mathrm{ft}$.; known only from the type locality.-Pagosa Springs.

6. Eriogonum flavum Nutt. (E. crassifolium Dougl.) On dry hills and mountains and in cañons from Sask. and Alb. to Neb. and Colo--Alt. 400oI2,000 ft.-Headwaters of Clear Creek and alpine ridges east of Middle Park; plains and foot-hills near Boulder; Sand Creek Pass; Twin Lakes; Medicine Bow Mountains; Minnehaha; Ruxton; Georgetown; Fossil Creek; Artists' Glen and Cheyenne Cañon, near Pike's Peak.

7. Eriogonum aureum Nutt. (E. chloranthum Greene.) Mountains of Colo.-Alt. II,000-13,000 ft.-Mount Ouray; Marshall Pass.

8. Eriogonum xanthum Small, On exposed mountain tops in Colorado.Alt. $x 2,000-14,000$ ft.-Gray's Peak; spur of Mt. Harvard.

9. Eriogonum umbellatum Torr. On mountains and dry valleys in Wyo., Ida., Colo. and Utah.-Alt. 6000-12,000 ft.-Headwaters of Clear Creek and alpine ridges east of Middle Park; North Park; Arkansas Junction, near Leadville; plains and foot-hills near Boulder; mountains between Sunshine and Ward; Gunnison; Fort Collins; Clear Creek Cañon; near Denver; Mancos; South Table Mountain, Golden; cañons and meadows, Ouray; Kelso Mountain; Horsetooth Gulch; Colorado and Wyoming State line; near Narrows; hills west of Soldier Cañon; camp on Grizzly Creek, foot of RabbitEar Range; Empire.

Io. Eriogonum umbelliferum Small. Mountains from Wyo. and Nev. to Colo. and Utah.-Alt. 7000-II,00o ft.-Veta Pass; Grayback mining camps; vicinity of Ouray; Redcliffe, Eagle Co.; Van Boxle's ranch, above Cimarron; Black Cañon; headwaters of Sangre de Cristo Creek; Glenwood Springs; Leroux Creek, Delta Co.; Lake Creek; Middle Park; Spicer, Larimer Co.

II. Eriogonum croceum Small. Mountains from Ida. and Wash. to Colo.Alt. up to $9000 \mathrm{ft}$-F - esperus; Telluride; Piedra.

I2. Eriogonum subalpinum Greene. In dry mountain valleys from Alb. and B. C. to Colo. and Nev.-Alt. 5000-I0,000 ft.-Headwaters of Arkansas River; Larimer Co.; near Pinkhampton, North Park; Arkansas Junction, near Leadville; edge of Wyoming, North Park; Crested Butte; Dillon; Idaho Springs; South Park; Middle Park; foot of Mt. Richtofen, on the Michigan; north bank of Poudre River; forks of Poudre and Big South; Rustic; Empire; Pinkham Creek.

13. Eriogonum latum Small. In dry valleys and on plains from Mont. and Wash. to Colo. and Utah.-Alt. about $5000 \mathrm{ft}$.-Denver.

14. Eriogonum lachnogymum Torr. Dry plains and cañons from Kans. and Colo. to Tex. and N. M.-A1t. about 5000 ft.-Brantly Cañon, Las Animas Co. 
I5. Eriogonum Tetraneuris Small. Dry mesas of Colorado.-Alt. about 5000 ft.-Bank of the Cimarron River; mesas near Pueblo.

16. Eriogonum acaule Nutt. On dry hills from Wyo. and Ida. to Colo."Southwest Colorado."

I7. Eriogonum orthocaulum Small. Dry plains and hills from Alb. and Ida. to Colo, and Nev.-Rifle, Garfield Co.

I8. Eriogonum ovalifolium Nutt. Dry plains and hills from Mont. and Wash. to N. M. and Calif.-Alt. 6000-7000 ft.-Mancos; Grand Junction.

I9. Eriogonum ochroleucum Small. Dry rocky hills from Mont. and Ida. to Colo. and Nev.-Grand Junction.

20. Eriogonum chrysocephalum A. Gray. (E. Kingii laxifoliun T. \& G.; E. laxifolium A. Nels.) Dry hills and plains of Neb., Wyo., Colo. and Utah. - "Southern Colorado" (Brandegee).

2r. Eriogonum multiceps Nees. Dry plains and "bad-lands" from N. D. and Mont. to Neb. and Colo.-Exact locality not given.

22. Eriogonum coloradense Small. Mountain in Colo.-Mt. Harvard.

23. Eriogonum pauciflorum Pursh. In sandy soil in Wyo. and Colo-_Alt. up to 9000 ft.-Middle Park; in low sandy valleys, North Park; North Fork, Larimer Co.

24. Eriogonum campanulatum Nutt. Dry hills and plains from Neb. and Wyo. to Colo. and Utah._- Colorado" (Parry); Middle Pärk.

25. Eriogonum brevicaule Nutt. On dry plains from Mont. to Colo, and Utah.-Egeria Park; Elk River, Routt Co.

26. Eriogonum lonchophyllum T. \& G. On plains of N. M. and Colo.Durango.

27. Eriogonum nudicaule (Torr.) Small. (E. effusum nudicaule Torr.) Plains from Kans. and Utah to Tex.-Alt. about $7500 \mathrm{ft}$-Cimarron.

28. Eriogonum scoparium. Small. Plains of Colo. and N. M.-Alt. 50008000 ft.-Vicinity of Gunnison; Denver; Durango; between Porter and Durango.

29. Eriogonum tristichum Small. Plains of Colo.-Alt. 5000-9000 ft.Parlin, Gunnison Co.; Mesa Verde; Arboles; Black Cañon, Gunnison; Durango.

30. Eriogonum salicinum Greene. Cañon in Colo.-Alt. about $7000 \mathrm{ft}$; known only from type locality.-Black Cañons, near Gunnison.

31. Eriogonum Fendlerianum (Benth.) Small. (E. microthecum Fendlerianum Benth.) Dry plains of Colo. and N. M,-Alt. about $5000 \mathrm{ft}$-Cañon City ; Pueblo.

32. Eriogonum divergens Small. (E. corymbosum divaricatum Torr.; not E. divaricatum Hook.) Dry plains from Colo. to Utah and Ariz.--Green River.

33. Eriogonum corymbosum Benth. Dry plains of Colo.-Alt. 5000-7000 ft. -Along San Juan River; Grand River; Mancos.

34. Eriogonum effusum Nutt. Dry plains from Mont. to Neb. and Colo.Alt. 4000-8000 ft.-Wahatoya Creek; Denver; Cañon City; vicinity of Boulder; Morrison; Golden; Buena Vista; Manitou; New Windsor, Weld Co.; mesas, Cucharas Valley, near La Veta; Fort Collins; headwaters of Clear Creek and alpine ridges east of Middle Park; Salida; Fort Collins; Table Rock; La Veta. 
35. Eriogonum microthecum Nutt. Dry plains from Mont. and Wash. to Colo. and Calif.-Colorado City; Beaver Creek.

36. Eriogonum Simpsonii Benth. Dry plains from Colo. to Tex. and Ariz. -San Luis Valley; Rio Florido.

37. Eriogonum contortum Small. Arid plains of western Colo,-Grand Junction.

38. Eriogonum annuum Nutt. In sandy soil from S. D. and Mont. to Tex. and Mex.-Alt. 4000-7500 ft.-Piney Creek of Grand River; Denver; Manitou; Ute Pass; Colorado Springs; Golden; Table Rock.

39. Eriogonum racemosum Nutt. Dry plains and hills from Colo. and Utah to Tex. and Ariz.-Alt. 6000-800o ft.-Between Parrott and Hesperus; Jack's Cabin; Gunnison; hills about Box Cañon, west of Ouray; Dolores; Piedra; between Porter and Durango; Mancos; Durango.

40. Eriogonum Wrightii Torr. Dry plains from Colo. and Utah to Tex. and Calif.; also northern Mex.-“Colorado" (Thurber).

4I. Eriogonum Gordonij Benth. Dry plains and "bad-lands" of Wyo. and Colo.-Cañon City; Gunnison Valley; mesa, Montrose; Grand Junction.

42. Eriogonum rotundifolium Benth. Dry plains from Colo. to Tex. and N. M. ; also in northern Mex.- "Near the Rocky Mountains."

43. Eriogonum tenellum Torr. In arid places from Colo. to Tex. and Mex. - "Southwest Colorado."

44. Eriogonum cernuum Nutt. "Bad-lands," hills and in cañons from Mont. and Ida. to Colo. and Ariz.-Alt. 4000-Io,00o ft.-Cañon City; South Park; along the McElmo River; Grand Junction; along Platte River, near Denver; Parlin, Gunnison Co.; Valley Spur; Granite; Buena Vista; Gunnison; Minnehaha; Black Cañon of the Gunnison; Troublesome; Upper Arkansas River; Bahia Salada, South Park; Sierra Blanca; Sargent's.

45. Eriogonum trinervatum Small. Arid places of Colo. and Utah.-Alt. 4000-7000 ft.-Cimarron; Grand Junction.

46. Eriogonum fusiforme Small. In sandy places and dry hills from Colo. to Utah and Ariz.-Alt. 4000-500o ft.-Grand Junction; Palisade, Mesa Co.; dry adobe hills, between Delta and Hotchkiss.

47. Eriogonum inflatum Torr. In arid places from Colo. to Ariz. and Cal. -Alt. 4000-5000 ft.-On the Upper Colorado; Grand Junction.

48. Eriogonum glandulosum Nutt. (E. Alexum Jones.) Arid places of Colo. -Alt. about $6000 \mathrm{ft} .-\mathrm{McE}$ lmo Cañon; Grand Junction.

49. Eriogonum divaricatum Hook. Dry hills from Wyo. to Colo. and Ariz. -San Juan and Mancos Valleys (Brandegee).

50. Eriogonum salsuginosus Hook. In dry alkaline soil from Wyo. to Utah and N. M.-Alt. 4000-6000 ft.-Near the Mancos River; Grand Junction; McElmo Cañon; San Juan Valley.

\section{RUMEX L. SORRel, DOCK.}

Flowers dioecious; foliage acid.

Leaves with auricled or hastate bases.

Leaves narrowed at the base, neither auricled nor hastate.

Flowers perfect, or andro-polygamous; foliage not acid. 1. R. Acetosella. 2. R. pauciflorus. Inner perianth-lobes entire, undulate or denticulate. Inner perianth-lobes without tubercles. 
Inner perianth-lobes in fruit over $2 \mathrm{~cm}$. broad, plants with deep-seated woody rootstock.

Inner perianth-lobes in fruit less than $1.5 \mathrm{~cm}$. in diameter.

Plants with clusters of tuberous roots; inner perianth-lobes in fruit I-I.5 cm. broad.

Achene about $7 \mathrm{~mm}$. long; inner perianth-lobes in fruit broader than long; plant low.

4. $R$. salinus.

Achenes about $5 \mathrm{~mm}$. long; inner perianth-lobes in fruit longer than broad.

5. $R$. hymenosepalus.

Plants with taproots or thickened rootstocks; inner perianth-lobes in fruit 5-10 mm. wide.

Plants low, less than $3 \mathrm{dm}$. high, with short tuber-like rootstock; fruit maturing before the inner perianth-lobes become enlarged.

6. $R$. praecox.

Plant tall, not with a tuber-like rootstock; inner perianth-lobes well enlarged in fruit.

Inner perianth-lobes in fruit with rounded apex, not conspicuously punctate.

7. R. occidentalis.

Inner perianth-lobes abruptly pointed, conspicuously punctate.

Fruiting inner perianth-lobes broader than long, sinuate on the margin.

8. R. densiflorus.

Fruiting inner perianth-lobes longer than broad, sharply dentate.

9. R. subalpinus.

Inner perianth-lobes or at least one of them bearing a tubercle in fruit.

Only one tubercled.

Leaves dark green, more or less crisp; fruiting inner perianth-lobes 8-9 $\mathrm{mm}$. broad, reniform.

Iо. R. Patientia.

Leaves pale green, not crisp; fruiting inner perianth-lobes. 5-6 mm. broad, deltoid ovate. II. R. altissimus.

All three petals bearing tubercles.

Leaves wavy-margined, dark green, not glaucescent.

Leaves flat, light green and glaucescent.

I2. $R$. crispus.

I3. $R$. salicifolius.

Inner perianth-lobes in fruit spinulose on the margin.

Tall plants; lower leaf-blades cordate at the base; one tubercle.

14. $R$. obtusifolius.

Low plants; lower leaf-blades narrowed at the base; 3 tubercles.

I5. $R$. persicarioides.

x. Rumex Asetosella L. In waste places, old fields, roadsides, etc., from Lab, and Alaska to Fla. and Calif.; introduced from Europe.-Alt. about 5000 ft.-Boulder.

2. Rumex pauciflorus Nutt. ( $R$. Geyeri (Meisn.) Trelease.) In meadows from Mont. and Wash. to Colo, and Calif.-Continental Divide, Larimer Co.; Steamboat Springs; Rabbit-Ears.

3. Rumex venosus Pursh. In sandy soil from Ass. and Wash. to Kans. and Nev.-Alt. 4000-8000 ft.-Cucharas River, below La Veta; Fort Collins; Pleasant Valley; upper part of Platte; Miller's ranch; Bingham Hill; Pueblo; Wray; Colorado Springs.

4. Rumex salinus A. Nels. In sandy soil in Wyo. and Colo--Palisades.

5. Rumex hymenosepalus Torr. In sandy soil from Ind. Terr. and Utah to Tex. and Calif.-Alt. 4000-9000 ft.-Grayback mining camps; Grand Junction.

6. Rumex praecox Rydb. Along brooks in the higher mountains of Wyo. and Colo.-Alt. 8000-Io,000 ft.-Grayback mining camps; Bob Creek, west La Plata Mountains. 
7. Rumex occidentalis S. Wats. In wet ground from Alb. and B. C. to N. M. and Calif.-Alt. 5000-8000 ft.-West Cliff; Hot Sulphur Springs; Steamboat Springs; Veta Pass; Mountain View, Pike's Peak; Gunnison; Idaho Springs; Pine Creek; Twin Lakes; Parlin, Gunnison Co.; forks of White River.

8. Rumex densiflorus Osterh. (R. Bakeri Greene.) In wet ground in Wyo. and Colo.-Alt. up to ro,0oo ft.-Idaho Springs; North Park; Gunnison; Fort Collins; summit of North Park Range, Routt Co.

9. Rumex subalpinus M. E. Jones. In swampy ground in the mountains of Colo. and Utah.-Alt. about Io,0oo ft.-Keblar Pass; Pagosa Peak; Cameron Pass; North Park; Deadman Cañon.

ro. Rumex Patientia L. Cultivated and occasionally escaped from Mass. and N. J. to Utah; native of Europe--Pass Creek; Little Kate Basin (?).

II. Rumex altissimus Wood. In valleys and wet places from Mass. and Wash. to Va. and Colo.-Mouth of Deer Creek.

I2. Rumex crispus L. In waste places from Newf. and Mont. to Fla. and Calif.; introduced from Europe.-Alt. about $5000 \mathrm{ft}$.-Fort Collins.

13. Rumex salicifolius Weim. Along rivers and lakes from Ont. and Alaska to Tex. and Calif.; also in Mex.-Alt. 4000-10,00o ft.-Zola; Sangre de Cristo Creek; Calhan; Fort Collins; Cucharas Valley, near La Veta; La Plata; Boulder; New Windsor; Robinson; Alamosa; Pitkin; Empire; Pueblo; Steamboat Springs.

I4. Rumex obtusifolius L. In waste places from Vt. and Neb. to Ga. and Colo.; introduced from Europe.-Alt. about $5000 \mathrm{ft}$,-Fort Collins.

15. Rumex persicarioides L. ( $R$. maritimus L.) In or near water from Que. and B. C. to N. C. and Calif.-Parlin; Gunnison; Cañon City; Higho; New Windsor; Steamboat Springs; above Bents' Fort.

\section{OXYRIA Hill. Mountain Sorrel.}

I. Oxyria digyna (L.) Compt. In the mountains among rocks from Greenl. and Alaska to N. H., Colo., Ariz. and Calif.; also in Europe and Asia.-Alt. 9000-I4,00o ft.-Cameron Pass; headwaters of Clear Creek; Ouray; Bottomless Pit, Pike's Peak; Mt. Harvard; Red Mountain, south of Ouray; Redcliffe; Ironton; Clear Lake; Pagosa Peak; Mt. Hesperus; Chambers' Lake; Berthoud Pass; Beaver Creek; Graymont; Hahn's Peak.

Fruit erect.

\section{POLYGONUM L. KNOT-WEED.}

Inflorescence of small axillary clusters, scattered more or less throughout the plant; all with elongated stems or branches; perianth-lobes never keeled near the apex.

Plants copiously leafy throughout; upper leaves scarcely reduced, more crowded.

Perianth-lobes with yellowish green margins; plant erect with spreading branches in age, leaves broad, yellowish green.

ఎ. P. erectum.

Perianth-lobes with white, pink or purplish margins; plants prostrate or diffusely spreading; leaves from bright to pale bluish green.

Leaves thick, prominently veined, usually pale; ocrea very conspicuous; faces of the achenes granular.

2. P. buxiforme.

Leaves thin, not prominently veined, bright green; ocrea not conspicuous; faces of the achenes finely striate.

3. $P$. aviculare. 
Plants with the upper leaves more scattered and reduced, mostly erect perennials.

Upper bracts not subulate; achenes dull.

Lobes of the perianth with yellowish margins; perianth $3-4 \mathrm{~mm}$. Iong; achenes about $3 \mathrm{~mm}$., nearly smooth.

4. $P$. ramosissimum.

Lobes of the perianth with whitish or pinkish margins; perianth $2-3 \mathrm{~mm}$. long; achenes $2-2.5 \mathrm{~mm}$. long, distinctly granulate or striate.

Upper bracts subulate; achenes smooth and shiny.

5. P. rubescens.

6. $P$. sawatchense.

Inflorescence aggregated at the ends of the branches; bracts leaf-like and usually broades than the narrowly linear leaves; plants dwarf annuals.

None of the perianth-lobes keeled.

Leaves several, gradually merging into the bracts; achenes blunt-angled and strongly striate.

7. P. Watsonii.

Leaf usually solitary and much longer than the bracts; achenes sharp-angled and obscurely striate.

Some of the perianth-lobes keeled near the apex. $\quad 9 . P$. Kelloggii.

Fruit reflexed.

Upper bracts much reduced and subulate.

Perianth I.5-2 mm. long; leaves narrowly linear; achenes exerted. Io. P. Engelmannii.

Perianth 4-5 mm. long; lower leaves oblanceolate to linear-oblanceolate; achenes included.

Upper-bracts foliaceous, relatively broad, lanceolate or oblong.

Achenes included.

Achenes exserted. II. P. Douglasii.

I. Polygonum erectum L. In waste places from $\mathrm{Me}$. and $\mathrm{Alb}$. to Ga. and Ark. and Kans. Also reported from Colorado, but no exact locality given.

2. Polygonum buxiforme Small. ( $P$. litorale Small, in part) In sandy and alkaline soil from Ont. and Wash. to Va., Tex. and Nev.-Alt. 4000-I0,000 ft.-Georgetown; Silver Plume; along Platte River, Denver; Montrose; Fort Collins; Colorado Springs.

3. Polygonum aviculare $L$. In waste grounds from Newf. and Sask. to Va. and Calif.; introduced from Europe.-Alt. 4000-8000 ft.-Fort Collins; Gunnison.

4. Polygonum ramosissimum Michx. In river valleys and low ground from Minn, and Wash. to Ills., N. M. and Nev.-Alt. 4000-Io,000 ft.-Cheyenne Mountain; Fort Collins; Upper La Plata Cañon.

5. Polygonum rubescens Small. In sandy soil from Ida. to Colo. and Utah. -Alt. 4500-8000 ft.-Parlin, Gunnison Co.; Larimer Co.

6. Polygonum sawatchense Small. On hillsides from S. D. and Wash. to Colo., Ariz. and Calif.-Alt. 4000-9000 ft.-Saguache Range; Box Cañon, west of Ouray; Calhan; Veta Pass; Estes Park.

7. Polygonum Watsonii Small. (Polygonum imbricatum S. Wats.) In wet places from Mont. and Wash. to Colo, and Calif.-Alt, 6000-Io,00o ft.South Park; Leroux Park; Upper West Mancos Cañon; Chambers' Lake.

8. Polygonum unifolium Small. In wet places from Mont. to Colo.--Tennessee Pass.

9. Polygonum Kelloggii Greene. In wet soil from Wash. and Mont. to Calif.-Alt. 6000-10,000 ft.-Steamboat Springs; Bard Creek Valley, near Empire.

10. Polygonum Engelmannii Greene. ( $P$. tenue microspermum Engelm.) On hillsides and mountains from Mont. and B. C. to Colo.-Alt. 5000-10,000 
ft.-Georgetown; Golden; Bergen Park; Idaho Springs; Boulder; Manitou; Dale Creek; Lower Boulder Cañon.

Ir. Polygonum Douglasii Greene. ( $P$ tenue Coulter; not Michx.) On hillsides and in sandy soil from Vt. and B. C. to N. Y., N. M. and Calif.Alt. 4000-10,000 ft.-Larimer Co.; Brantly Cañon, Las Animas Co.; Pagosa Springs; Wahatoya Creek; cañons west of Ouray (broad-leaved form); Sheepshorn Divide, Middle Park; Pagosa Peak (broad-leaved) ; Eagle River; Boulder; Soldier Cañon; Big Creek Gulch; Walton Creek; Arthur's Rock; Bosworth ranch; Horsetooth Gulch; Chambers' Lake; Boulder; Golden; Idaho Springs.

A form more branched at the base is Polygonum Douglasii consimile (Greene) Small. ( $P$. consimile Greene)-Lower Bouder Cañon.

12. Polygonum montanum (Small) Greene. (P. tenue latifolium Engelm.) In the mountains from Alb. to Colo. and Calif.-Alt. 8000-I2,000 ft.-Marshall Pass; Red Mountain; Ironton Park; North Park; Mt. Harvard; Silver Plume; White River Plateau.

x3. Polygonum commixtum Greene. In the mountains from Colo. to Mont. -Alt. 8000-I2,000 ft.-Silver Plume; Grizzly Creek; Cameron Pass; Mt. Robinson; summit of mountains west of North Park.

\section{PERsicaria Adans. Smart-weed, Lady's Thumb.}

Racemes terminal only and usually solitary; plants aquatic.

Ocrea without a spreading foliaceous top.

Plant usually floating; leaf-blades of an oblong type, glabrous, acute or obtuse.

I. $P$. coccinea.

Plant ustally diffuse and emersed; leaf-blades of a lanceolate type, pubescent, acuminate.

2. P. Muhlenbergii.

Ocrea with a spreading foliaceous top; leaf-blades narrowly oblong or lanceolate

(broader in floating forms), pubescent.

Racemes axillary as well as terminal, numerous.

Ocrea without marginal bristles.

Racemes erect; glands on the branches and inflorescence numerous, stalked. 4. P. omissa.

Racemes drooping; glands on the branches and inflorescence sessile. Styles united only at the base.

5. P. incarnata.

Styles united to about the middle.

Leaves deep green on both sides. $\quad 6$. P. lapathifolia.

Leaves pale beneath. 7 7. P. incana.

Ocrea bristle-fringed.

Racemes oblong or cylindric, densely flowered, about $1 \mathrm{~cm}$. thick in fruit; perianth not punctate, usually pink to red-purple. 8. P. Persicaria.

Racemes slender, loosely flowered, about $5 \mathrm{~mm}$. thick in fruit; perianth white or pale-green, copiously punctate.

Racemes erect; achenes smooth and shining. 9. P. punctata. Racemes nodding, at least in fruit; achenes granular and dull.

то. P. Hydropiper.

I. Persicaria coccinea (Muhl.) Greene. (Polygonum amphibium Hook.; not L.; $P$. coccineum Muhl.) In water or rarely in mud from $\mathrm{Me}$. and Alaska to N. J. and Calif.-Alt. up to $9000 \mathrm{ft.-West} \mathrm{Cliff,} \mathrm{Pike's} \mathrm{Peak;}$ McCoy; Ouray; Veta Mountain; Hamor's Lake; Gunnison.

2. Persicaria Muhlenbergii (S. Wats.) Small. (Polygonum Muhlenbergii S. Wats.) In swamps, mud and shallow water from $\mathrm{Me}$. and B. C. to Va. 
and Calif; ; also in Mex.-Alt. up to $6000 \mathrm{ft}$---Uncompahgre Mountains, near Los Pinos; Fort Collins; Alamosa.

3. Persicaria Hartwrightii (A. Gray) Small. (Polygonum Hartwrightii A. Gray.) In wet places and shallow water from $\mathrm{Me}$. and Wash. to $\mathrm{Pa}$. and Calif.-Alt. 4000-60oo ft.-Cañon City; Denver.

4. Persicaria omissa (Greene) Small. (Polygonum Pennsylvanicum Coult.; not L.; P. omissum Greene.) In wet ground and dried up ponds in Kans. and Colo.-Alt. up to $5000 \mathrm{ft}$-Loveland, Larimer Co.

5. Persicaria incarnata (E11.) Small. (Polygonum incarnatum Ell.) In wet soil from Vt. and Ida. to Fla. and Calif.-Alt. up to $5000 \mathrm{ft}$.-Fort Collins; New Windsor.

6. Persicaria lapathifolia (L.) S. F. Gray. (Polygonum lapathifolium L.) * In wet soil from Que. and B. C. to Fla. and Calif; also in Mex., W. Ind., Europe and Asia.-Alt. up to $5000 \mathrm{ft}$.-Fort Collins.

7. Persicaria incana (Koch) S. F. Gray. (Polygonum lapathifolium incanum Koch.) In swamps from Newf. and B. C. to N. Y. and Colo.-Alt. up to $6000 \mathrm{ft}$--Alamosa.

8. Persicaria Persicaria (L.) Small. (Polygonum Persicaria L.) In waste places and rich ground from Newf. and B. C. to Fla. and Calif.; also in Mex. and Europe.-Alt. 4000-6000 ft.-Boulder; Livermore; Fort Collins.

9. Persicaria punctata (E11.) Small. (Polygonum punctatum Ell.) In swamps and wet places from Me. and Wash. to Fla. and Calif.; also in Mex., Cent. Am., W. Ind. and S. Am.-Alt. up to $5000 \mathrm{ft}$-Fort Collins; plains near Boulder.

10. Persicaria Hydropiper (L.) Opiz. (Polygonum Hydropiper L.) In wet places from Newf. and B. C. to Ga. and Calif.; also in Mex., Cent. Am. and Europe.-Alt. 4000-5000 ft.-Fort Collins; Denver.

\section{BISTORTA Tourn. Bistort.}

Racemes not viviparous (not bulblet bearing), oblong, I-2 $\mathrm{cm}$. thick.

Perianth 5-6 mm. long; leaf-blades lanceolate, oblong or oblanceolate.

Perianth 3-4 mm. long; basal leaf-blades linear.

Racemes viviparous (bulblet bearing below), linear, 5-8 mm. thick.

I. $B$. bistortoides.

2. B. linearifolia.

3. B. vivipara.

1. Bistorta bistortoides (Pursh) Small. (Polygonum Bistorta oblongifolium Meisn.) In wet meadows and swamps in the mountains from Mont. and Wash. to N. M. and Calif.-Alt. 7000-I3,000 ft.--"Rocky Mountains"; Lake City; Halfway House, Pike's Peak; Cabin Cañon; Mt. Harvard; Columbine; South Park; Mt. Garfield; Pagosa Peak; Grayback mining camps and Placer Gulch; Garden of the Gods; Ruxton; Cameron Pass; Graymont; Chicken Creek, West La Plata Mountains; Marshall Pass; Oak Mesa; Beaver Creek, Larimer Co.; Boreas; Gore Pass.

2. Bistorta linearifolia (S. Wats.) Greene. (Polygonum Bistorta linearifolium S. Wats.) In alpine swamps and along streams from Mont. to Colo. and Nev.-Alt. 7000-ro,000 ft.-Alpine ridges east of Middle Park; "Rocky Mountains"; Pike's Peak.

3. Bistorta vivipara (L.) S. F. Gray. ( $P$. viviparum L.) In alpine or sub- 
arctic swamps from Greenl. and Alaska to N. H. and Colo.; also Europe and Asia.-Alt. 8000-I2,000 ft.-Alpine Tunnel; Grand Lake; Robinson; Seven Lakes; Little Kate Basin, La Plata Mountains; West Spanish Peak; Cameron Pass; Indian Creek Pass; White River Plateau; Gray's Peak; North Park; Eldora to Baltimore; Beaver Creek; Cameron Pass; Gore Pass; Graymont.

\section{TINIARIA Reichenb. False Buckwheat.}

Outer sepals merely keeled at maturity.

Outer sepals developing conspicuous wings.

T. Convolvulus. $T$. scandens.

I. Tiniaria Convolvulus (L.) Webb. \& Moq. (Polygonum Convolvulus L.) Among bushes from N. S. and B. C. to Fla. and Calif.-Alt. 4000-9000 ft.-Box Cañon, west of Ouray; Engelmann Cañon; Fort Collins; Colorado Springs.

2. Tiniaria scandens (L.) Small. (Polygonum scandens L.) In thickets from N. S. to Mont., Fla., La. and Colo.-Exact locality not given.

\section{Order 24. CHENOPODIALES.}

Fruit a utricle, achene or anthocarp, indehiscent, circumscissile or bursting irregularly.

Fruit a utricle.

Stipules wanting.

Bracts not scarious. 45. Chenopodiaceae.

Bracts scarious.

Stipules present, scarious. 47. Corrigrolaciae.

46. Amaranthaceae.

Fruit an anthocarp, the achene surrounded by the tube of the corolla-like calyx.

Fruit a capsule, dehiscent by apical or longitudinal valves.

48. Allioniaceae.

Ovary several-celled; corolla wanting.

Ovary I-celled; corolla mostly present.

49. Tetragoniaceae.

Sepals, 2 ; or, if more (in Lewisia), plant scapose, with fleshy basal leaves and the flowers solitary on a jointed scape. 50. Portulacaceae.

Sepals, 4-5; plants leafy-stemmed.

Sepals distinct; petals not clawed; ovary sessile. $5 \mathrm{x}$. Alsinaceae.

Sepals united; petals clawed; ovary more or less distinctly stipitate.

52. Caryophyllaceae.

\section{Family 45. CHENOPODIACEAE Dumort. Goosefoot Family.}

Embryo annular.

Stems and branches not jointed; leaves not scale-like.

Flowers perfect, all with perianth, not inclosed in a pair of bracts.

Fruit inclosed in the calyx.

Calyx in fruit not transversely winged.

Sepals $3-5$, stamens $I-5$.

Fruiting calyx herbaceous.

Fruiting calyx fleshy, red.

Sepals I; stamens 1 .

Calyx in fruit transversely winged.

Flowers paniculate; leaves ample, sinuate, flat.

Flowers spicate; leaves linear, terete.

Fruit laterally flattened, exserted from the marcescent calyx.

I. Chenopodium.

2. BLITUM.

4. Monolepis.

3. Cycloloma.

9. KoснiA.

io. Coriospermum. 
Flowers monoecious or dioecious; the pistillate inclosed in two accrescent bractlets.

Pericarp not hairy.

Bracts compressed, $i$. $t$., with one side towards the axis; leaves more or less farinose; testa mostly coriaceous. 5. Atriplex.

Bracts ob-compressed, $i$. e., with one edge towards the axis; testa membranous.

Pericarp hastate with crested margins, 2-toothed apex; more or less farinaceous herbs with toothed leaves. 6. SuckLEYA.

Pericarp obovate or orbicular, entire; undershrubs with entire leaves.

Pericarp densely hairy, conical; low and tomentose shrubs.

7. Grayia.

Stems and branches fleshy, jointed; leaves scale-like.

8. Eurotia.

it. Salicornia.

Embryo spirally coiled.

Shrubs with monoecious bractless flowers; staminate flowers in spikes, without perianth; pistillate ones solitary, axillary; fruiting calyx transversely winged.

Herbs with perfect bracteolate flowers.

Fruiting calyx transversely winged; leaves spiny.

Fruiting calyx not winged; leaves fleshy, not spiny.

12. Sarcobatus.

14. Salsola.

I3. Dondia.

\section{Chenopodidm L. Goosefoot, Lamb's Quarters, Pig-Weed.}

Leaves more or less mealy or glabrate, never glandular or sweet-scented, sinuately lobed, dentate or entire; embryo forming a complete ring.

Stamens 5 ; calyx not at all fleshy in fruit.

Leaves entire or sinuately toothed, but not with large, divaricate teeth; seeds $\mathrm{I}-\mathrm{I.5} \mathrm{mm}$. in diameter.

Calyx lobes carinate; at least the upper panicles exceeding the leaves.

Pericarp easily separating from the seeds.

Leaves linear or oblong, entire or slightly sinuately toothed.

Leaves thin, linear; inflorescence not very dense; spikes somewhat interrupted below. $\quad$.. C. leptophyllum.

Leaves thick, oblong; inflorescence dense and crowded. Plant densely mealy, yellowish.

Plant tall with nearly erect branches. 2. C. oblongifolium. Plant low with spreading-ascending branches.

Plant only slightly mealy, dark green.

3. C. desiccatum.

eaves broadly ovate or triangular, more or

4. C. Wolfi.

Plant densely mealy; leaves rather thick.

Plant low and spreading.

Plant tall and erect.

Plant sparingly mealy; leaves very thin.

Pericarp firmly attached to the seed.

Leaves subentire or merely hastately toothed.

Leaves thick, more or less mealy; none of them cuspidate.

$8 . C$. $W$
Leaves thin, glabrate, all or the upper usually cuspidate.

5. C. incanum.

6. C. albescens.

7. C. Fremontii.

9. C. Berlandieri.

Leaves more or less sinuately dentate; inflorescence dense.

Io. C. album.

Calyx lobes not carinate; panicles mostly axillary, shorter than the leaves.

II. C. glaucum.

Leaves with large divergent acute lobes; seeds about $2 \mathrm{~mm}$. in diameter.

Stamens 1-2; calyx reddish and slightly fleshy in fruit.

12. C. hybridum.

Plant usually over I dm. high, erect; leaves usually more or less toothed.

13. C. rubrum. 
Plant less than I dm. high, prostrate; leaves entire or merely hastately toothed. 14. C. humile.

Leaves glandular, sweet-scented, pinnately lobed; embryo horseshoe-shaped.

Lobes of the leaves rounded or broadly oblong, more or less toothed.

Lobes of the leaves lanceolate, entire.

I5. C. Botrys.

I6. C. cornutum.

I. Chenopodium leptophyllum Nutt. On prairies, in waste places and fields from Neb. to Mont., Mo. and Ariz.-Alt. 4000-8000 ft.-Gunnison; Buena Vista; Deer Run, Gunnison watershed; entrance to Grand Cañon, I5 miles from Grand Junction.

2. Chenopodium oblongifolium (S. Wats.) Rydb. (C. leptophyllum oblongifolium S. Wats.) On dry prairies and plains from N. D. to Wyo., Mo., Tex. and Ariz.-Atl. 4000-7000 ft.-Crow Creek; foot-hills, Larimer Co.; Fort Collins; Wray.

3. Chenopodium desiccatum Aven Nelson. Dry waste places in Colo-_Fort Collins.

4. Chenopodium Wolfii Rydb. In dry places in the mountains of Wyo. and Colo.-Alt. 7000-10,000 ft.-Twin Lakes; Cheyenne Mountain; Crow Creek; Grizzly Creek; Parlin, Gunnison Co.; Steamboat Springs.

5. Chenopodium incanum (S. Wats.) Heller. (C. Fremontii incanum S. Wats.) In dry grounds, especially in prairie dog towns.--Alt. 4000-5000 ft. -Crow Creek; Fort Collins.

6. Chenopodium albescens Small. In dry soil from Tex to Colo.Durango.

7. Chenopodium Fremontii S. Wats. Among bushes and in cañons from S. D. to Mont., N. M. and Ariz.; also in Mex.-Alt. 4000-9000 ft.-Vicinity of Fort Collins; Sangre de Cristo Creek; Minnehaha; southeast of Ouray; Poudre Cañon.

8. Chenopodium Watsonii A. Nelson. (C. olidum S. Wats.) In dry places from Colo. to Ariz.-Alt. up to ro,ooo ft.-Valley Spur.

9. Chenopodium Berlandieri Moq. In dry soil from Mo. to Wyo., Fla. and Tex.-Alt. 4000-900o ft.-Sheepshorn Divide, North Park; near Pagosa Peak; Huerfano Valley.

Io. Chenopodium album L. In fields and waste places; introduced and naturalized from Europe; from Newf. to Alb., Fla. and Calif.-Gunnison; about Fort Collins.

I1. Chenopodium glaucum L. In alkaline soil from Alb. to Colo. and Utah; also in Europe.-Alt. 4000-8000 ft.-Walsenburg; Steamboat Springs; New Windsor; Gunnison; La Veta; above Palisade.

12. Chenopodium hybridum $L$. In waste places and around dwellings from Que. to B. C., N. Y. and Utah.-Alt. 4000-8000 ft.--Park Range; Steamboat Springs; Mancos; Hotchkiss, Larimer Co.; Johnston Cañon; Gunnison; Horsetooth Gulch; gulch west of Soldier Cañon; Big Creek Gulch.

13. Chenopodium rubrum (L.) Reichenb. In alkaline flats and meadows from N. Y. to Alb., Mo. and Colo.-Alt. 4000-8000 ft.-Hot Springs in San Luis Valley; Mt. Harvard; Gunnison; West Cliff; Delta; north of Trapper's Lake; falls of the Poudre.

14. Chenopodium humile Hook. In alkaline meadows from Mont. to B. C., Neb. and Colo.-Alt. up to $8000 \mathrm{ft}$.-Gunnison. 
15. Chenopodium Botrys L. In waste places from N. S. to B. C., Ga. and Calif.; also Mex.-Alt. $4000-8000$ ft.-Plains and foot-hills near Boulder; Ouray; Idaho Springs; Box Cañon, west of Ouray; Clear Creek Cañon, above Golden.

I6. Chenopodium cornutum B. \& H. In dry places from Colo. to N. M. and Ariz.; also in Mex.-Alt. 4000-8000 ft.-Huerfano Co.; Buena Vista; Little Veta Mountain.

\section{Blitum L. StrawberRy Blite.}

Leaves more or less dentate, truncate or broadly cuneate at the base; inflorescence dense and leafy.

1. B. capitatum.

Leaves entire, except the hastate teeth at the cuneate base; inflorescence slender and naked above.

2. B. hastatum.

I. Blitum capitatum L. In rocky soil from N. S. to Alaska, N. J. and Calif.-Alt. 6000-10,000 ft.-Mountains between Sunshine and Ward, Boulder Co.; Hamor's Lake, above Durango; Georgetown; Sangre de Cristo Creek; North Park; Gunnison; Veta Pass; La Veta; Minnehaha; Ouray; Breckenridge; Anchor; Poudre Cañon; Elizabethtown; Chambers' Lake; Buena Vista; forks of Poudre and Big-tooth.

2. Blitum hastatum Rydb. In stony ground from Wyo. to Utah and Colo. -Alt. 6000-9500 ft.-Big Creek Gulch, Routt Co.; Trapper's Lake.

\section{CYCLOLOMA Moq.}

I. Cycloloma atriplicifolium (Spreng.) Coult. (C. platyphyllum Moq.) In sandy soils from Ont. to Mont., Ark. and Ariz.-Alt. 4000-6000 ft.-La Salle; Denver; New Windsor, Weld Co.; near Boulder; Elk Cañon.

\section{MONOLEPIS Schrad.}

Leaves lanceolate, hastately lobed, flower clusters several flowered; pericarp somewhat fleshy.

Leaves spatulate, entire; flower-clusters I-3-flowered; pericarp thin.

I. M: Nuttalliana. 2. M. pusilla.

I. Monolepis Nuttalliana (R. \& S.) Engelm. ( $M$. chenopodioides Moq.) In alkaline soil from Minn. to Wash., Tex. and Calif.-Alt. 4000-9000 ft.Near Bents' Fort; valley near Empire; Sangre de Cristo Creek; headwaters of Pass Creek; Arboles; Durango; vicinity of Fort Collins; Gunnison; New Windsor, Weld Co.; Buena Vista; Montrose; Platte River Valley; Grand Junction; Fort Collins.

2. Monolepis pusilla Torr. In alkaline soil from Wyo. and Colo. to Calif.Grand Junction.

\section{ATRIPLEX L. Orache.}

Annuals.

Bracts united only at the base; radicle inferior.

Bracts thin, broadly ovate, mucronate.

Bracts thick, deltoid or lanceolate, acute.

I7. $A$, hortensis.

Stem tall, erect; leaves broadly ovate or triangular-hastate.

Stem low, 2-4 dm. high, spreading or ascending; leaf-blades lanceolate, hastately lobed.

2. A. subspicata. 
Bracts united to above the middle; radicle superior.

Bracts usually broadly cuneate, truncate at the apex, seldom with tubercles; leaves linear.

3. A. Wolfii.

Bracts rhombic-orbicular, conspicuously toothed and appendaged, or tubercled on the back; leaf-blades rhombic, cordate or ovate.

Leaf-blades large, more or less hastate, truncate or cuneate at the base. Leaf-blades rhombic-deltoid, minutely scurfy, acute.

Leaves subsessile or the lower short petioled with winged petioles, very thin; plant a thumble-weed, $\mathrm{I}-3 \mathrm{~m}$. in diameter. 4. A. expansa.

Leaves petioled, firmer; plant scarcely a thumble-weed.

5. A. argentea.

Leaf-blades subcordate, coarsely scurfy, obtuse. 6. A. cornuta.

Leaf-blades small, I cm. or less, ovate-lanceolate, rounded at the base, subPerennials.

sessile, firm. $\quad 7$. A. philonitra.

Bracts not winged on the back.

Bracts with entire margins or merely wavy, without appendages on the back; leaf-blades entire, broadly oval. 8. A. confertifolia.

Bracts either with a distinctly toothed margin or appendaged on the back, or both.

Bracts broadest above the middle.

Bracts 3 -toothed, only rarely tubercled on the back.

Bracts entire, strongly tubercled or appendaged on the back.

9. A. eremicola.

Io. A. corrugata.

Bracts broadest below the middle, strongly tubercled or appendaged; leaf-blades oblanceolate to spatulate.

Leaf-blades oblanceolate or narrowly spatulate, subsessile or shortpetioled.

Low; leaves usually short-petioled; staminate flowers brown-puberulent, in panicles. Ir. A. oblanceolata.

Usually tall; leaves subsessile; staminate flower yellow in interrupted spikes. $\quad$ I2. A. Nuttallii.

Leaf-blades broadly spatulate, distinctly petioled; staminate spikes brown, interrupted.

I3. A. cuneata.

Bracts broadly 4-winged on the back.

Wings thick, laciniate-toothed.

Wings thin, sinuately dentate or subentire.

Wings when fully developed 4-6 mm. wide, distinctly dentate; leaves broad, linear-oblong to spatulate. 15. A. canescens.

Wings very broad and thin, fully $8 \mathrm{~mm}$. wide, merely sinuate; leaves linear.

16. A. occidentalis.

r. Atriplex carnosa A. Nels. (A. patula hastata of Coulter's Man.) In alkaline or saline meadows from Nebr. to Mont. and Kan.-Fort Collins.

z. Atriplex subspicata (S. Wats.) Rydb. (A. patula subspicata S. Wats.) In alkaline soil from N. D. to Mont., Colo. and Utah.-Alt. up to $9500 \mathrm{ft}$.Pitkin; Delta.

3. Atriplex Wolfii S. Wats. In alkaline soil, in Wyo. and Colo.-San Luis Valley; Saguache.

4. Atriplex expansa S. Wats. (A. pabularis A. Nels.) In alkaline soil from Ind. Terr. to Mont., Tex. and Calif.-About Fort Collins; Delta.

5. Atriplex argentea Nutt. In alkaline flats and dry lakes from N. D. to B. C., Kans. and Colo.-Alt. 4000-5000 ft.-Grand Junction; Mancos; Pueblo; vicinity of Fort Collins.

6. Atriplex cornuta M. E. Jones. In alkaline soil from Colo. to Utah.Alt. 4000-6000 ft.-Colorado Springs. 
7. Atriplex philonitra A. Nels. In alkaline soil, in the plain regions of Wyo, and Colo.-Alt. 4000-5000 ft.-Mancos; Grand Junction; plains of the San Juan; Hotchkiss; between Hotchkiss and Smith's Fork; Delta Co.

8. Atriplex confertifolia S. Wats. On mesas and alkaline flats from Wyo. to Nev., Colo., Ariz. and Calif.-Alt. 4000-600o ft.-Pueblo; Mancos; Rifle, Garfield Co.; Denver; Grand Junction; Deer Run; Delta; Hotchkiss; Palisades.

9. Atriplex eremicola Osterh. On saline bottom-lands and dry plains in southern Wyo. and northern Colo.-North Park; Grand Junction.

Io. Atriplex corrugata Watson. On arid plains of Colo.-Hotchkiss, Delta Co.

Ix. Atriplex oblanceolata Rydb. On arid plains of Wyo. and Colo.-Delta; Hotchkiss; Grand Junction; Fort Collins.

I2. Atriplex Nuttallii S. Wats. In bad-lands and arid valleys from Sask. to Mont., Colo. and Nev.-Alt. 4000-6000 ft.-Arboles; Cañon City; Grand Junction; about Fort Collins; Hotchkiss; Gypsum ; Fossil Creek.

13. Atriplex cuneata A. Nelson. In arid places of Utah and Colo._-"Southwestern Colorado"; Grand Junction (Nelson). The Mancos specimens cited by Nelson belong to $A$. confertifolia.

14. Atriplex odontoptera Rydb. On dry plain of Wyo. and N. Colo.-Alt. about $5000 \mathrm{ft}-\mathrm{New}$ Windsor.

15. Atriplex canescens James. On dry mesas and alkaline valleys from $\mathrm{S}$. D. to Wyo., Kans., N. M. and Calif.-Alt. 400o-700o ft.-Wolcott; Walsenburg; Fort Collins; Cañon City; Huerfano Valley; Grand Junction; Pueblo; between Bents' Fort and Upper Pueblo; Olathie; Gypsum; Hotchkiss, Delta Co.

16. Atriplex occidentalis Torr. On dry mesas from Colo. to Utah, Texas and Ariz.-Alt. 4000-7000 ft.-Boulder; Huerfano Valley; Mancos; Pueblo.

17. Atriplex hortensis L. Escaped from cultivation in waste places,-Alt. up to $7000 \mathrm{ft}$.-Boulder; Glenwood Springs; La Veta; vicinity of Fort Collins.

6. SUCKLEYA A. Gray.

I. Suckleya Suckleyana (Torr.) Rydb. (S. petiolata A. Gray.) River valleys from Mont. to Colo--Alt. 5000-6000 ft.-Six miles southeast of Golden; Cheyenne Wells; Denver.

\section{GRAYIA H. \& A.}

I. Grayia Brandegei A. Gray. In desert regions of Colo.-Hill's ranch, Elmo Creek.

\section{EURotia Adans. White Sage, Winter Sage.}

1. Eurotia lanata (Pursh) Moq. On hillsides and sage plains from S. D. to Wash., Kans. and Calif.-Alt. 4000-8000 ft.-Fort Collins; Salida; New Windsor; Gunnison; La Veta; Trail Glen; Grand River, above Kremmling; Boulder; bluffs north of La Porte; Barlow ranch, three miles from Forks' Hotel; banks of Cache la Poudre; Gypsum; Fort Collins. 


\section{IXOCHIA Rath.}

Perennials; leaves narrowly linear, fleshy.

Branches tomentulose, soon glabrate; leaves somewhat hairy when young; fruit nearly smooth.

1. K. americana.

Branches and leaves densely and permanently hairy; fruit very pubescent.

Annual ; leaves linear-lanceolate, not fleshy.

2. K. vestita.

3. K. scoparia.

1. Kochia americana $S$. Wats. In alkaline meadows and marshes from Wyo, to Cal., Colo. and Ariz.-Alt. about $4600 \mathrm{ft}$--Grand Junction.

z. Kochia vestita S. Wats. In alkaline meadows and marshes from Wyo. to Cal, and Colo.-Alt. 4000-600o ft.-Grand Junction; McElmo Cañon.

3. Kochia scoparia Schrad. Introduced from Europe and sparingly growing in waste places from N. Y. and Mich. to Pa. and Colo--Alt. about 5000 ft.--Fort Collins; New Windsor.

\section{IO. CORIOSPERMUM L. BUG-SEED.}

Fruit with a distinct wing at least $\mathrm{s} / 2 \mathrm{~mm}$. wide.

Spike lax; lower bracts much narrower than the fruit.

Spike dense; lower bracts rarely narrower than the fruit.

1. C. nitidum.

Fruit merely acute, margined, scarcely winged.

Plant glabrous.

Plant more or less villous.

2. C. marginale.

3. C. emarginatum.

4. C. villosum.

1. Coriospermum nitidum Kit. (C. hyssoppifolium microcarpum S. Wats.) On sand-hills and in cañons from Ills. to N. D., Tex. and Colo.; also in Europe and Asia.--Alt. 4000-7000 ft.-Huerfano Valley; Colorado Springs; Cañon City.

2. Coriospermum marginale Rydb. In valleys of Wyo. and Colo.-Alt. 4000-7000 ft.-Denver; Huerfano Valley; Rocky Ford; near Boulder.

3. Coriospermum emarginatum Rydb. In valleys of Wyo. and Colo.-Colorado (exact locality not given).

4. Coriospermum villosum Rydb. In sandy valleys from Alb. to Ore., Colo. and Nev.-Alt. 7000-8000 ft.-Salida; Gunnison; Buena Vista.

\section{SALICORNIA I. GLASS-WORT.}

I. Salicornia herbacea L. (S. rubra A. Nelson.) In salt marshes from Que. to B. C., Ga. and Calif.-North Park; Larimer Co.

I2. SARCOBATUS Nees. Grease-wood.

I. Sarcobatus vermiculatus (Hook) Torr. In dry alkaline or saline soil from Neb. to Wash., Tex. and Calif.-Alt. 4000-9000 ft.-Salida; Mancos; Grand Junction; Mancos Cañon; Lake John, North Park; near Montrose; Walsenburg; Olathie; Black Cañon of the Gunnison; Gypsum; Middle Park.

13. DONDIA Adans. SeA Blite.

Sepals more or less fleshy, but none of them carinate; leaves narrowed at the base. Plant perennial, stout.

Plant annual, slender. 1. D. Moquini. 2. D. diffusa. 
Sepals very fleshy, one or two decidedly carinate; leaves broadest near the base. Plant depressed, spreading.

Plant erect.

3. D. depressa.

4. D. erecta.

1. Dondia Moquini (Torr.) A. Nels. (Chenopodium Moquini Torr.; Swaeda Torreyana S. Wats.) In salt marshes from Wyo. to Nev., Colo. and Lower Calif.-Cañon City; Hotchkiss.

ఒ. Dondia diffusa (S. Wats.) Heller. (Swaeda diffusa S. Wats.) In salt marshes from Nebr. to Nev. and Colo.-Alt. 4000-6000 ft.-Salida; Grand Junction; Mancos; Cañon City; Delta ; Pueblo.

3. Dondia depressa (Pursh) Britton. (Salsola depressa Pursh; Swaeda depressa S. Wats.) In salt marshes from Sask. to Mont., Colo. and Nev.Alt. up to $8000 \mathrm{ft}$.-Buena Vista; river bottom land, Fort Collins; Delta.

4. Dondia erecta (S. Wats.) A. Nels. (Swaeda depressa erecta S. Wats.) In salt marshes from N. D. to Mont., Colo. and Nev.-Alt. 4000-9000 ft.Grand Junction; Lake John, North Park; Fort Collins; Pueblo; along Poudre River.

-I4. Salsola L. Russian Thistle, Salt-wort.

I. Salsola Tragus L. In waste places and old fields; introduced from Europe and naturalized from Ont. to Wash., Mo. and Colo.-Alt. 4000-7000 ft.Near Boulder; Pueblo; Denver; Huerfano Valley; Cañon City; Walsenburg; La Salle.

\section{Family 46. AMARANTHACEAE J. St. Hil. Amaranth Family.}

Anthers 2-celled; green plants with alternate leaves.

Perianth present in all flowers.

Perianth wanting in the pistillate flowers.

I. Amaranthus.

Anthers I-celled; stellate or woolly plants with mainly opposite leaves.

Filaments united into a short cup at the base; calyx neither crested nor spiny; plants stellate, diffuse.

3. Cladotrix.

Filaments united into a long tube; calyx crested and tubercled or spiny at maturity; plants woolly, erect.

4. Froelichia.

\section{I. amaranthos L. Amaranth, Pigweed.}

Sepals clawed; flowers in terminal and axillary spikes.

Bracts lanceolate, shorter than the flowers.

Bracts subulate, longer than the flowers.

1. A. Torreyi.

Sepals not clawed.

Plants tall, simple; flowers in terminal and axillary spikes.

Stamens 3 ; sepals $\mathrm{I}-2 \mathrm{~mm}$. long.

Stamens 5 ; sepals $2-3 \mathrm{~mm}$. long.

2. A. Palmeri.

Spikes stout, 8-I $4 \mathrm{~mm}$. thick, strict; stem usually more or less pubescent.

4. $A$. retroflexus.

Spikes slender, 4-6 mm. thick, usually drooping; stem glabrous.

5. A. hybridus.

Plant low, much branched; flowers in small axillary spikes, shorter than the leaves.

Sepals 4-5; bracts lanceolate-subulate, a little longer than the sepals; plant prostrate.

6. A. blitoides.

Sepals 3 ; bracts much longer than the sepals, pungent; plant erect, glabrous. 7. A. graecizens. 
I. Amaranthus Torreyi (A. Gray) Benth. (Amblogyne Torreyi A. Gray.) In sandy soil from Iowa and Wyo. to Mex. and L. Cal.-Alt. 4000-5000 ft.Fort Collins; north fork of Gunnison, Delta Co.

z. Amaranthus Palmeri S. Wats. In sandy soil from Kans. and Colo. to Tex. and Ariz.; also in Mex.-Alt. about $6000 \mathrm{ft} .-$ Clear Creek Cañon, above Golden.

3. Amaranthus Powellii S. Wats. In sandy valleys from Colo. to Texas and Calif.-Alt. up to $9000 \mathrm{ft}$.-Southeast of Ouray; Boulder; Alamosa.

4. Amaranthus retroflexus L. In waste places from Vt. to Ida., Fla. and Mex.; naturalized from Europe.-Alt. up to $6000 \mathrm{ft}$.-Denver; Cheyenne Mountain; Fort Collins; Durango.

5. Amaranthus hybridus L. In waste places from R. I. to Colo., Fla. and Calif.; also in Mex.; naturalized from Europe--Upper Rio Grande; exact locality not given.

6. Amaranthus blitoides S. Wats. In dry grounds, roadsides and waste places from N. Y. to Mont., La. and Calif.-Alt. 4000-I0,000 ft.-Pike's Peak trail; Manitou; Colorado Springs; Ouray; Buena Vista; Durango; vicinity of Fort Collins.

7. Amaranthus graecizens L. ( $A$. albus L.) In cultivated grounds and waste places from R. I. to Wash., Fla. and Ariz.; introduced from tropical America,-Alt. 4000-6000 ft.-Colorado Springs; Fort Collins.

\section{ACNIDA L. WATER Hemp.}

I. Acnida tamariscina (Nutt.) Wood. In alluvial soil from Ill. to S. D., La. and N. M.-Alt. up to $5000 \mathrm{ft}$.--Fort Collins.

\section{CLADOTRIX Nutt.}

I. Clađotrix lanuginosa Nutt. In dry soil from Kans. to Colo., Tex., Ariz. and Mex.-Rocky Ford.

\section{FROELICHIA Moench.}

Stout, 6-I $2 \mathrm{dm}$. tall; crest of fruiting calyx continuous, dentate. 1. F. campestris: Slender, 2-5 dm. high; crest of fruiting calyx interrupted.

z. F. gracilis.

I. Froelichia campestris Small. (F. Floridana Coult.; in part.) In sandy soil from Mo. to Colo. and Tex.-Alt. about $5000 \mathrm{ft}$.-New Windsor, Weld. Co.

2. Froelichia gracilis Moq. In sandy valleys from Neb. to Colo., Ark. and Texas.-Alt. 4000-6000 ft.-Boulder; Colorado Springs; Denver; along Poudre; Fort Collins; Manitou; Ute Pass.

Family 47 CORRIGIOLACEAE Reichenb. WhItLOW-WORT FAMILY.

I. PARONYCHIA Adans. WhITLOW-WORTH.

Flowers solitary; leaves scarcely exceeding the bracts; plants densely pulvinate.

Leaves elliptic, thick, not spinulose-tipped.

Leaves linear, chartaceous, spinulose-tipped.

Leaves arcuate, spreading; spinules of sepals over I $\mathrm{mm}$. long.

2. $P$. sessilifiora. 
Leaves straight, ascending; spinules of sepals less than I $\mathrm{mm}$.

Flowers more or less clustered; leaves much longer than the bracts.

3. P. brevispina.

Plant low and diffuse, less than I dm. high; calyx fully $3 \mathrm{~mm}$. long.

4. P. diffusa.

Plant taller, I dm. or more high; stem erect or ascending; calyx $2-2.5 \mathrm{~mm}$. long.

Branches of the cymes ascending; calyx about $2.5 \mathrm{~mm}$. long; sepals lanceolate, gradually acuminate. 5. P. Janesii.

Branches of the cymes divarcate; calyx about $2 \mathrm{~mm}$. long; sepals oblong, abruptly acuminate.

6. P. Wardii.

I. Paronychia pulvinata A. Gray. On exposed mountain tops from Wyo. to Colo. and Utah.-Alt. II,000-r4,00o ft.-Cameron Pass; Mt. Garfield; Gray's Peak; Pike's Peak trail; Massif de l'Arapahoe; Berthoud Pass.

2. Paronychia sessiliflora Nutt. On dry ridges from Sask. to Alb., Tex. and Utah.-Alt. 5000-8000 ft.-Upper Larimer River.

3. Paronychia brevispina (A. Nels.) Rydb. ( $P$. sessiliflora brevispina A. Nels.) On dry hills in Wyo. and Colo.-Waldon, North Park.

4. Paronychia diffusa A. Nels. On dry plains and mountains from S. D. to Wyo., Kans, and Colo.-Alt. 5000-I3,000 ft.-Castle Rock, near Golden; Gray's Peak; Pike's Peak trail; Table Rock.

5. Paronychia Jamesii T. \& G. On dry plains and mountains from Neb. to Wyo., Tex. and N. M.; also in Mex.-Alt. 4000-Io,00o ft.-Ruxton Ridge; Pike's Peak; river flats east of Ft. Collins; Horsetooth Mountain; mountains between Sunshine and Ward; Boulder; Larimer Co.; Morrison; Meadow Park, Lyons; Colorado City; Spring Cañon; Ft. Collins; Horsetooth Mountain.

6. Paronychia Wardii Rydb. On dry plains from Neb. to Colo., Kans. and Tex.-Alt, up to $7000 \mathrm{ft}-$-Colorado City; Cheyenne Mountain.

Family 48. ALLIONIACEAE Reichenb. Four-o'ClOCK FAMILY.

Bracts distinct.

Bracts united.

1. ABRONIA.

Fruit neither strongly tubercled nor winged.

Fruit not ribbed; involucre herbaceous, little if at all enlarging in fruit, not becoming membranous.

Stamens usually 5 ; involucres campanulate, not enlarged in fruit.

2. QUAMOCLIDION.

Stamens 3 ; involucre totate, somewhat enlarged in fruit in the manner of the next genus, but not membranous.

3. Allioniella.

Fruit ribbed; involucre rotate, in fruit becoming much enlarged and membranous.

4. Allionia.

Fruit with two rows of strong tubercles on the back and surrounded by two toothed inflexed wings.

5. WEDELIA.

r. ABRONIA Juss.

Fruit narrowly winged or crested; wings or crests not completely encircling the fruit.

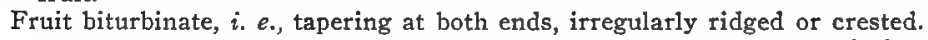

Fr. A. fragrans.

Fruit turbinate or obpyramidal, i. e., almost truncate above, distinctly winged; the wings very broad above.

Bracts broadly ovate or obovate, acute or obtusish. 
Stem puberulent.

Stem glabrous.

Bracts oblong-lanceolate or lanceolate, attenuate or cuspidate.

2. A. elliptica.

3. A. glabra.

4. A. Carletoni.

Fruit completely surrounded by the broad netted-veined membranous wings.

Flowers $3 \mathrm{~cm}$. or more long; limb about I cm. wide; peduncles longer than the leaves.

Flowers $1.5-2 \mathrm{~cm}$. long; limb about $5 \mathrm{~mm}$. wide.

5. A. cycloptera.

6. A. micrantha.

1. Abronia fragrans Nutt. In dry sandy soil from S. D. to Ida., Kans, and N. M.-Alt. 4000-7000 ft.-New Windsor, Weld Co.; Crow Creek; Ft. Collins; Salida; Cucharas River, below La Veta; Walsenburg; near Pueblo; Table Rock; Fossil Creek; Colorado Springs.

z. Abronia elliptica A. Nels. (A. Bakeri Greene.) In sandy soil in Wyo. and Colo.-Alt. 4000-5000 ft.-Deer Run; Grand Junction; Rifle, Garfield Co.

3. Abronia glabra Rydb. In dry arid soil in Colo. and Utah.-Grand Junction; near Ft. Collins; Hotchkiss.

4. Abronia Carletoni Coult. \& Fisch. Dry plains of Colo.-Alt. about 5000 ft.-Ft. Collins.

5. Abronia cycloptera A. Gray. Plains from Wyo. to Tex. and Calif.Exact locality not given.

6. Abronia micrantha A. Gray. On dry mesas and in sandy soil from S. D. to Mont. and N. M.-Alt. 4000-9000 ft.-Near Pike's Peak; Crow Creek; Cañon City; Grand Junction; Trinidad; valley of upper Arkansas River; Swallows, between Cañon City and Pueblo; near Badito; near Pueblo; headwaters of Sangre de Cristo Creek; Walsenburg; Salida; New Windsor; Conejos River, north of Antonito.

\section{QUAMOCLIDION DC. FOUR-o'ClOCK.}

I. Quamoclidion multiflorum Torr. (Mirabilis multiflora A. Gray.) In valleys from Colo. to Utah, Texas and Ariz.-Alt. 4000-7000 ft.-Florence; Pueblo; Deer Run; Cucharas Junction; Cañon City; Cucharas Valley, near La Veta; Grand Junction; Cimarron; Pueblo; Florence.

\section{ALLIONIELla Rydb.}

I. Allioniella oxybaphoides (A. Gray) Rydb. (Mirabilis oxybaphoides A. Gray) In valleys from Colo. to Utah and Tex.- Alt. 7000-8000 ft.-Salida; Buena Vista; Trail Glen.

\section{ALLIONIA Loeffi. UMBRELLA-WORT.}

Leaves from cordate to broadly ovate-lanceolate; all distinctly petioled.

1. A. nyctaginea.

Leaves ovate-lanceolate, oblong or linear, sessile or only the lower short-petioled.

Involucres in open terminal cymes.

Stem more or less hirsute as well as viscid.

Leaves ovate or broadly oblong, as well as the stem conspicuously hirsute. 2. A. hirsuta.

Leaves linear-lanceolate, almost glabrous; stem sparingly hirsute or glabrous except under the nodes.

Stem glabrous below, not hirsute, viscid-puberulent above.

Lower leaves ovate, rounded at the base.

3. A. pilosa.

Lower leaves lanceolate to linear, tapering at the base.

4. A. sessilifolia. 
Leaves erect or ascending; lobes of the involucre rounded or broadly triangular-ovate.

Plant prostrate or diffuse; involucres and branches of the inflorescence densely viscid hairy.

Plants more simple, erect or ascending; branches of the inflorescence usually merely viscid-puberulent.

Leaves from ovate or obovate to linear-lanceolate, usually over 5 mm. wide.

6. A. lanceolata.

Leaves narrowly linear, less than $5 \mathrm{~mm}$. wide. 7. A. linearis.

Leaves divergent; lobes of the involucre elliptic or oval.

8. A. divaricata.

Involucres on solitary axillary peduncles, rarely also in small dense terminal clusters.

9. A. Bodinii.

I. Allionia myctaginia Michx. (Oxybaphus myctaginius Sweet) In alluvial soil from Ill. to Sask., Mo. and Colo.-Alt. 4000-5000 ft.-Denver; Ft. Collins; buttes along Poudre River, near Ft. Collins.

2. Allionia hirsuta Pursh. On plains and sandy valleys from Minn. to S. D., Nebr. and Colo.-Alt. 400o-700o ft.-Cheyenne Mountain; Manitou; Colorado Springs; Cucharas Valley, near La Veta; North Cheyenne Cañon; Colorado Springs; Englemann Cañon; vicinity of Ft. Collins.

3. Allionia pilosa (Nutt.) Rydb. In dry and sandy soil from Wis. to Sask., La. and Tex.-Alt. 4000-7000 ft.-New Windsor, Weld Co.; La Veta.

4. Allionia sessilifolia Osterhout. Plains of Colo-Livermore.

5. Allionia diffusa Heller. In sandy soil and on plains from N. D. to Wyo., Kans, and Ariz.-Alt. 4000-900o ft.-Minnehaha; Piedra; Ft. Collins; Pueblo; Horsetooth Gulch; Table Rock; Hotchkiss; above Rustic; Grand Junction.

6. Allionia lanceolata Rydb. On plains and prairies and in dry sandy soil from Minn. to Wyo., Tenn., Tex. and Colo.-Alt. 5000-7000 ft.-Estes Park, Larimer Co.; Cañon City; New Windsor, Weld Co.; vicinity of Ft. Collins.

7. Allionia linearis Pursh. (Oxybaphus angustifolius Sweet.) On dry plains from Minn. to Mont., La. and Ariz.; also in Mex.-Alt. $4000-9000 \mathrm{ft}$ Grand Cañon of Arkansas; Platte River, Denver; Grand Junction; southeast of Ouray; Parlin, Gunnison, Co.

8. Allionia divaricata Rydb. In sandy valleys from Colo. to N. M. and Ariz.-Durango.

9. Allionia Bodinii (Holz.) Morong. (Oxybaphus Bodinii Holz.) On dry mesas from Colo. to Utah and Tex.-Alt. 4000-6000 ft.-Pueblo; Ft. Collins.

5. WEDELIA Loeff.

I. Wedelia incarnata L. In valleys from Colo. to Tex. and Ariz.; also Mexico and Tropical America--Cañon City (Greene).

Family 49. TETRAGONIACEAE Reichenb. Carpet-weed Family.

r. SESSUVIUM L. SEA-PURSLANE.

1. Sessuvium sessile Pers. On saline plains from Kans. to Nev., Tex. and Calif.; also Mex.-Alt. about 8000 ft.-Alamosa. 
Family 5o. PORTUlaCaCEAE Reichenb. Purslane Family.

Ovary superior.

Sepals 2.

Sepals deciduous; capsule 3-valved.

Sepals persistent.

Capsule 3 -valved from the apex.

Plants with corms or fleshy roots; stem-leaves opposite. z. Claytonia.

Plants with slender rootstocles or annual roots.

Stem with a single sessile pair of leaves, with an erect or ascending rootstock or in ours annual roots.

3. Limia.

Stem decumbent or floating, with several pairs of stem-leaves, rooting at the nodes and producing filiform runners, forming bulblets at the apex.

4. Crunocallis.

Capsule circumscissile near the base.

Plants with fleshy roots and short caudices and numerous basal leaves.

$\begin{array}{ll} & \\ \text { Plants with globose corms and } 2-3 \text { cauline leaves. } & \text { 6. EREOBRoMA. } \\ 4-8 . & \text { 7. LEWISIA. }\end{array}$

Sepals $4-8$.

Ovary partly inferior; upper portion circumscissile, falling off with the sepals.

8. Portulaca.

\section{TALINUM Adans. FAME-FLOWER.}

Flowers about I cm. wide; stamens 5 .

Flowers $2-3 \mathrm{~cm}$; stamens many.

1. T. parviflorum.

2. T. calycinum.

I. Talinum parviflorum Nutt. ( $T$. teretifolium Porter \& Coult, n not L.) In rocky soil from Minn. to S. D., Tex. and Ariz.; also in Mex.-Alt. 40007000 ft.-Garden of the Gods; Denver, along the Platte River; Ft. Collins; Mason's river-front farm; Spring Cañon.

z. Talinum calycinum Engelm. In sandy soil from Ark. to Colo., Tex, to N. M.-Exact locality not given.

\section{2. claytonia L. Spring Beauty.}

Plant with rounded corms; basal leaves few.

Stem leaves linear or narrowly lanceolate, I-ribbed or indistinctly 3 -ribbed.

Leaves petioled; corolla white.

Leaves sessile; corolla pink.

Stem leaves broadly lanceolate, distinctly 3-ribbed.

I. C. virginiana.

2. C. rosea.

3. C. lanceolata.

Plants with a short caudex and a fleshy tap root; basal leaves numerous.

4. C. megarrhiza.

1. Claytonia virginiana L. Around springs from N. S. and Mont. to Va., Tex. and Colo.-Alt. 5000-7000 ft.-Foot-hills, Ft. Collins; Soldier,Cañon; Larimer Co.

2. Claytonia.rosea Rydb. In rich damp soil in Wyo. and Colo.-Alt. 7000$8000 \mathrm{ft}$-Graham's Peak; hills southeast of La Veta.

3. Claytonia lanceolata Pursh. (C. Caraliniana sessilifolia Torr.) In wet rich soil from Sask. and B. C. to Colo. and Calif.-Alt. up to $9000 \mathrm{ft}$.-Howe's Gulch; gulch west of Dixon Cañon; Horsetooth Gulch; Grand Mesa.

4. Claytonia megarrhiza Parry. Among rock-slides, on the higher mountains, from Mont. to Colo. and Utah.-Alt. 8000-I4,000 ft.-West Spanish Peak; Cameron Pass; Gray's Peak; Central City; James' Peak; Pike's Peak; near Pagosa Peak; Little Kate Basin, La Plata Mountains; Como; Boreas; 
Carson; Mt. Bartlett; Robinson; mountains near Empire; Massif de l'Arapahoe; Lake City; headwaters of Clear Creek; mountains northwest of Como; Boreas; Devil's Causeway; Berthoud Pass; Ethel Peak.

3. liminia L. Spanish Lettuce.

I. Limnia depressa (A. Gray) Rydb. (Claytonia parvifora depressa A. Gray) On river banks and near springs from S. D. to Wash., Colo., Ariz. and Calif.-Reported from Colorado, but doubtful.

\section{CRUNOCallis Rydb. Water Spring Beauty.}

I. Crunocallis Chamissonis (Esch.) Rydb. (Claytonia Chamissonis Esch.) In streams from Minn. to B. C., N. M. and Calif.-Alt. 5000-10,000 ft.-RabbitEar Pass; Beaver Creek; Long Gulch; Ward, Boulder Co.; Middle Park; Green Mountain Falls; North Park; Empire; Moon's ranch, Larimer Co.; Empire; Walton Creek, North Park; Baxter's ranch; Table Rock; Middle Park; Arapahoe Pass; Beaver Creek; Long Gulch.

\section{OREOBROMA Howell.}

Sepals not erose-denticulate.

Sepals erose-denticulate.

1. O. nevadensis.

2. O. Grayi.

1. Oreobroma nevadensis (S. Wats.) Howell. (Calandrinia Nevadensis S. Wats.) On dry mountains from Wash. to Colo. and Calif.--Steamboat Springs.

2. Oreobroma pygmaea (A. Gray) Howell. (Calandrinia pygmaec A. Gray) Dry mountain sides from Mont, to Colo. and Calif.-Alt. up to I2,000 ft.Mountain northeast of Boreas; Ragged Mountain, Gunnison Co.; Leroux Parks; Cameron Pass; Bob Creek; Boreas; Leadville; Grayback mining camp; Arapahoe Peak.

\section{EROCALLIS Rydb:}

I. Erocallis triphylla (S. Wats.) Rydb. (Claytonia triphylla S. Wats.; Oreobroma triphylla Howell) In the mountains from Wyo. and Wash. to Colo. and Calif.-Cameron Pass.

\section{LEWISIA Pursh. BitTer Root.}

I. Lewisia ređeviva Pursh. On stony ridges from Mont. to Colo., Ariz. and Calif.-Pinkham Creek, Larimer Co.

\section{Portulaca l. Purslane, Pussley.}

Stem prostrate; sepals pointed in the bud; seeds obscurely granulate.

Stem ascending; sepals obtuse in the bud; seeds echinate-tuberculate.

$\therefore$ oleracea.

2. $P$. retusa.

x. Portulaca oleracea L. In waste places and cultivated soil from Maine to Mont., Fla. and Mex.-Alt. 4000-5000 ft.-Ft. Collins.

2. Portulaca retusa Engelm. In sandy soil from Ark. to Nev., Tex. and N. M.-Alt. up to $6000 \mathrm{ft}$.-Colorado Springs. 
Family 5 I. ALSINACEAE Wahl. Chickweed Failly.

Stipules wanting.

Petals 2-cleft or 2-parted.

Capsule short ovate or oblong; styles usually 3 .

1. Alsine.

Capsule long, cylindric and often curved; styles usually $5 . \quad 2$. Cerastium.

Petals entire or merely notched.

Styles as many as the sepals and alternate with them.

3. Sagina.

Styles fewer than the sepals or if occasionally of the same number opposite them.

Seeds with a basal membranous appendage (strophiole) at the hylum.

Seeds not strophiolate.

4. Moehringia.

Capsules opening by twice as many valves as the styles.

Capsules opening by as many valves as the styles.

Stipules present.

5. Arenaria.

6. Alsinopsis.

7. TISSA.

\section{I. alsine L. Starwort. Chick-weed, Stitchwort.}

Lower leaves ovate, abruptly contracted into a distinct petiole.

Leaves all sessile or subsessile.

I. A. media.

Plant not at all viscid.

Upper bracts at least scarious.

Petals minute or none; branches of the inflorescence at last reflexed.

2. A. baicalensis.

Petals equalling or exceeding the sepals; branches of the inflorescence ascending.

Leaves broadest about the middle, narrowed at the base.

Leaves broadest near the base.

3. A. longifolia.

Leaves narrowly linear-lanceolate, light green; flowers usually many.

Leaves lanceolate, bluish green; flowers few, often solitary.

4. A. longipes.

5. A. laeta.

None of the bracts scarious.

Leaves linear to lanceolate, more than four times as long as broad.

Petals equalling or exceeding the sepals.

Plant low, less than I dm. high, bluish green. 5. A. laeta.

Plant tall, light green; stem over I dm. long. $\quad 6$. A. borealis.

Petals much shorter than the sepals or none.

7. A. crassifolia.

Leaves ovate-lanceolate, ovate or oval, less than four times as long as broad.

Leaves thin.

Stem glabrous or nearly so; sepals obtuse.

Stem distinctly pubescent; sepals acutish.

Leaves very thick and fleshy.

Plant more or less viscid, especially the upper portion.

8. A. obtusa.

9. A. calycantha.

10. A. polygonoides.

II. A. Jame iana.

I. Alsine media L. (Stellaria media Cyr.) Introduced around dwellings. Native of Europe and Asia.-Ft. Collins.

2. Alsine baicalensis Coville. (Stellaria umbellata Turcz.) Along mountain streams from Mont. to Ore., Colo. and Calif.-Alt. 8000-I4,000 ft.Cameron Pass; Red Mountain; Seven Lakes; Buffalo Pass; Beaver Creek; Ouray; Ruby; West Spanish Peak; Grayback mining camps; Silver Plume; near Pagosa Peak; Middle Park; Mt. Hesperus; Trapper's Lake; Pike's Peak; Gray's Peak; Ironton; Argentine Pass; northeast of Boreas; Eldora to Baltimore; summit of North Park Range, Larimer Co. 
3. Alsine longifolia (Muh1.) Britt. (Stellaria longifolia Muh1.) In wet meadows from Newf. to Alaska, Md. and Colo.-Alt. 4000-II,00o ft.-Pike's Peak; Sangre de Cristo Creek; Tennessee Pass; Mancos; Larimer Co.; Andrew's Shetland ranch; Idaho Springs; Higho; Parlin; Sheephorn Divide; Gunnison; Iola; headwaters of Clear Creek; Graymont; Conejos River, north of Antonito; Baxter's ranch; Table Rock; Steamboat Springs.

4. Alsine longipes (Goldie) Coville. (Stellaria longipes Goldie) In wet meadows from Lab. to B. C. and Colo.-Alt. 8000-10,000 ft.-Leroux Parks; Caribou.

In the Rocky Mountain region it is mostly represented by var. stricta (Richardson) Rydb. (Stellaria stricta Richardson.) It differs from the type in having acute sepals. Its range extends farther southwest to Calif.-Alt. 8000-11,000 ft.-West Indian Creek; Moon's ranch, Larimer Co.; Marshall Pass; Dark Cañon; Tennessee Pass; Eldora to Baltimore.

5. Alsine laeta (Richards.) Rydb. In wet places in the mountain sides from Lab. to B. C., Que. and Nev.-Ait. 9000-I2,000 ft.-Little Veta Mountain; West Spanish Peak; Bob and Chicken Creeks; Beaver Creek; Devil's Causeway.

6. Alsine borealis (Bigel.) Britt. In wet meadows from Lab. to Alaska, N. J. and Calif.-Idaho Springs; Trapper's Lake.

7. Alsine crassifolia (Ehrh.) Britton. (Stellaria crassifolia Ehrh.) Marshes and wet places from Lab. to Alaska, Que. and Colo.-Alt. about Io,000 ft.-Como.

8. Alsine obtusa (Engelm.) Rose. (Stellaria obtusa Engelm.) In wet places from Mont. to B. C., Colo., Utah and Wash.-Alt. up to Io,00o ft.Ruby; Anthracite Creek.

9. Alsine calycantha (Bong.) Rydb. (Stellaria calycantha Bong.) In bogs and wet meadows from Mont. to Alaska, Colo. and Calif.-Alt. 9000-I0,500 ft.-Bogs, Columbine; Bob Creek.

ıo. Alsine polygonoides Greene. In wet places in Colo.-Alt. about II,500 ft.-Little Kate Basin, La Plata Mountains.

Ir. Alsine Jamesiana (Torr.) Heller. (Stellaria Jamesiana Torr.) In wet woodlands from Wyo. to N. M. and Calif.-Alt. 5000-9000 ft.-Howe's Gulch; Rist Cañon; Poverty Ridge; near Cimarron; mountains west of Steamboat Springs; Four-Mile Hill, Routt Co.; Mesa Verde; Cucharas River, below La Veta; Apex; hills south of Rifle, Garfield Co.; Mancos; Platte Cañon; Rabbit-Ears, Larimer Co.

\section{Cerastium L. Mouse-ear Chickweed, Powder-horn.}

Annual; pods $2-3$ times as long as the calyx.

Pedicels in fruit $\mathrm{I}-3$ times as long as the calyx, straight or nearly so.

I. C. brachypodum.

Pedicels in fruit 5 times as long as the calyx or longer, strongly curved above.

Perennials; pods I-2 times as long as the calyx.

2. C. longipedunculatum.

Leaves oblong, ovate or oval, mostly obtuse or acutish.

Petals I $\mathrm{cm}$. long or more, fully twice as long as the calyx.

Sepals, at least the outer, oval, obtuse, scarious-margined at the tip as well as on the sides.

3. C. prulchellum.

Sepals lanceolate, acute, scarious-margined mostly only on the sides.

4. C. Earlei. 
Petals less than I cm. long.

Sepals tinged with purple; stem depressed.

Sepals light green; plant not depressed.

Leaves, except the uppermost, linear or linear-lanceolate, acute.

Leaves of the inflorescence short, broadly ovate.

Leaves all linear or linear-lanceolate or linear-oblong.

Stem villous with reflexed hairs.

Stem finely glandular puberulent.

Leaves thin and soft, all linear or narrowly linear-lanceolate; midrib not prominent.

Leaves thick and firm; midrib prominent.

5. C. beeringianum.

6. C. pilosum.

7. C. oreophilnm.

8. C. campestre.

9. C. scopulorum.

ı. C. occidentale.

1. Cerastium brachypodium (Engelm.) Robbinson. In dry sandy soil from S. D. to Mont., Mo., Tex. and Ariz.; also Mex.-Alt. 4000-7500 ft.-Mountains, Larimer Co.; Pennock's mountain ranch; gulch west of Pennock's; Ft. Collins; gulch west of Soldier Cañon; Horsetooth Gulch; Howe's Gulch; Bijou Basin.

2. Cerastium longipeđunculatum Muhl. (C. nutans Ra.) In wet places from N. S. to B. C., N. C., Ariz. and Ore--Alt. $4000-9000$ ft.-Veta Pass; Iola; Veta Mountain.

3. Cerastium pulchellum Rydb. On alpine peaks of Colo.-Alt. I3,000 ft.Hayden Peak.

4. Cerastium Earlei Rydb. In wet places among rocks in the mountains of Colorado.-Alt. 9000-I2,000 ft.-Near La Plata Post Office; Little Kate Basin; Mt. Robinson; Cumberland Basin; Horsetooth Gulch.

5. Cerastium beeringianum C. \& S. In alpine-arctic regions among rocks from Alb. to Alaska, Colo. and Ariz.-Alt. 9000-I2,00o ft.-Gray's Peak; Seven Lakes; Upper West Mancos Cañon; Mt. Hesperus, at timber line; mountains of Estes Park; Bottomless Pit, near Pike's Peak; West Spanish Peak; headwaters of Clear Creek; southeast of Cameron Pass.

6. Cerastium pilosum Greene. In alpine places among rocks in Colo--Alt. 5000-I2,000 ft.-Mountains above Ouray; Horsetooth Gulch.

7. Cerastium oreophilum Greene. In wet places among the mountains from Colo. to Calif.-Alt. 5000-I2,000 ft.-Seven Lakes; foot-hills, Larimer Co.; foot-hills west of Ft. Collins; Pass Creek; mountain near Veta Pass.

8. Cerastium campestre Greene. On hills and mountain-sides from Alb. to Yukon, Wash. and Colo.-Alt. 5000-7000 ft.-Mt. Abram, Ouray ; Pike's Peak; foot-hills north of Ft. Collins; Berthoud Pass; Continental Divide; Muddy Pass; North Park; Soldier Cañon; Horsetooth Gulch; Trapper's Lake; Pennock's; Como; Dixon Cañon; Spring Cañon, Howe's Gulch; Coup Divide.

9. Cerastium scopulorum Greene. In mountains from Colo. to Wyo. and N. M.-Alt. 9000-II,000 ft.-Near La Plata Post Office; Little Kate Basin, La Plata Mountains; vicinity of Como; Robinson; Veta Pass; Cameron Pass; Dixon Cañon.

I0. Cerastium occidentale Greene. On dry hills from Mont. to Colo. and Utah.-Alt. 8000-I2,000 ft.-Cripple Creek road; Seven Lakes; Cameron Pass; Veta Mountain; Clear Creek Station; Empire; Horsetooth Mountain; Horsetooth Gulch; Bear Creek Cañon; Spicer, Larimer Co.; Rabbit-Ear Range, Routt Co. 


\section{SAGINA L. PEAL-WORT.}

Basal leaves linear-filiform; petals shorter than the green sepals. 1 . S. saginoides. Basal leaves subulate; petals longer than the purple-tinged sepals.

$$
\text { 2. S. nivalis. }
$$

1. Sagina saginoides (L.) Britton. (S. Linnaei Presl) In wet places, among rocks and on brook-banks from Greenl, to Alaska, Que., Colo. and Utah.-Alt. 8000-Io,000 ft.-Twin Lakes; Grayback mining camps; La Plata Post Office; headwaters of Clear Creek; Cameron Pass; Buffalo Pass; Empire; Chambers' Lake.

2. Sagina nivalis Fries. In arctic-alpine localities from Lab. to Alaska and Colo.-Alt. about I4,000 ft.- Gray's Peak.

\section{MOEHRINGIA L}

Leaves elliptic-oblong or oval, usually obtuse; sepals obtuse or acutish; stem terete. Leaves lanceolate, acute; sepals very acute or acuminate; stem angled.

$$
\text { I. } M \text {. lateriflora. }
$$

2. M. macrophylla.

I. Moehringia lateriflora (L.) Fenz. (Arenaria lateriflora L.) In wet places, especially among bushes, from Lab, to Alaska, N. J. and Utah.-Alt. 5000Io,000 ft.-Happy Hollow, Larimer Co.; headwaters of Pass Creek; Leroux Creek, Delta Co.; Rifle, Garfield Co.; Stove Prairie; Walton Creek.

z. Moehringia macrophylla (Hook.) Torr. (A. macrophylla Hook.) In wet places, among bushes, from Lab. to B. C., Vt. and Calif.-Alt. ro,o0o-I2,000 ft.-Red Mountain; Slide Rock Cañon.

\section{ARENARIA L. SANDWORT.}

Leaves neither narrowly linear nor pungent.

Plant low and spreading; stem less than I dm. long; leaves ovate or ovatelanceolate, less than $\mathrm{I} \mathrm{cm}$. long. $\quad$ I. A. polycaulos.

Plant taller; stem 2-3 dm. long; leaves oblong or linear-oblong, over c $\mathrm{cm}$. long.

Leaves narrowly linear, more or 'less rigid and pungent.

2. A. confusa.

Sepals ovate to ovate-lanceolate.

Inflorescence contracted and headlike.

Inflorescence more open.

3. A. congesta.

Flowers mostly subsessile in small glomerules at the ends of the brañches of the very irregular cymes.

4. A. Burkei.

Flowers all pedicelled in open regular cymes; inflorescence more or less glandular.

Leaves distinctly pungent; plant sparingly glandular-puberulent.

5. A. uintahensis.

- Leaves more fleshy, hardly pungent; inflorescence and calyx densely glandular-pubescent.

6. A. Tweedyi.

Sepals narrowly lanceolate, acuminate.

Cymes open, not densely congested.

Plant more or less glandular.

Plant perfectly glabrous.

Cymes densely congested.

7. A. Fendleri.

Sepals 8-ro $\mathrm{mm}$. long; stem leaves $2-3 \mathrm{~cm}$. long.

8. A. Eastwoodiae.

Sepals 5-7 mm. long; stem-leaves $0.5-1.5 \mathrm{~cm}$. long.

9. A. pinetorum.

I0. A. Hookeri.

I. Arenaria polycaulos Rydb. (A. saxosa Coulter; not A. Gray) On dry hills from Colo. to Ariz.-Alt. 9000-10,000 ft.-La Plata Post Office; Dark Cañon; Breckenridge; Grayback mining camps; Mt. Harvard; Silverton. 
2. Arenaria confusa Rydb. (A. saxosa Robinson, in part) In sandy soil from Colo. to N. M. and Ariz,-Alt. 7500-12,000 ft.-Ouray; Wahatoya Creek; near Pagosa Peak; La Plata Mountains; Mancos.

3. Arenaria congesta Nutt. On dry plains from Mont. to Wash., Colo. and Calif.-Alt. 7000-10,000 ft.-Oak mesa, Delta Co.; Little Muddy Creek, Gunnison Co.; Twin Lakes; North Park; along the Michigan; Middle Park; Ouray; Cimarron.

4. Arenaria Burkei Howell. (A. subcongesta (Wats.) Rydb.). On plains and hills from Mont. to Colo. and Nev.-Alt. about $8000 \mathrm{ft}$ - - Hills about Box Cañon, west of Ouray; Willow Creek, Routt Co.

5. Arenaria uintahensis A. Nels. Dry plains from Mont. and Ida. to Colo. and Calif.-Alt. about $8000 \mathrm{ft}$.-Mesa on the Gunnison River; Grand Junction.

6. Arenaria Tweedyi Rydb. On dry mountains of Colo.-Alt. about 12,000 ft.-La Plata Mountains.

7. Arenaria Fendleri A. Gray. On dry hills and mountains from Wyo. to N. M. and Ariz.-Alt. 7000-13,500 ft.-Mountains between Sunshine and Ward; Crystal Park; Stage Coach Mountain; butte 5 miles southwest of La Veta; Callian; Cascades, near Pike's Peak; Sangre de Cristo Creek; Cameron Pass; Crystal Lake; Colorado Springs; Caribou; headwaters of Clear Creek; Gray's Peak; Dillon Cañon; vicinity of Como; Leroux Creek; Cameron Pass; Moon's ranch; Wood's ranch; mountains between Steele's and Little Beaver; Graymont; West Cameron Pass; South Park, southeast of Jefferson; Monument; Campton's Pass; Ethel Peak.

Arenaria Fendleri Porteri Rydb. On dry mountain ridges of Colo.Alt. 7000-13,500 ft.-Mount Ouray; Pike's Peak; Alpine Tunnel; mountains west of Como; South Park, southeast of Jefferson; Silver Plume; Georgetown; Stephan's Mine; divide between Colorado Springs and Denver; Estes Park, Larimer Co.; Pike's Peak; Little Kate Basin, La Plata Mountains; West Spanish Peak; La Plata Post Office; north of Cheyenne Cañon; Empire; Berthoud Pass.

Arenaria Fendleri diffusa Porter \& Coulter. On dry mountains of Colo.Alt. 5000-Io,000 ft.-Mountains between Steele's and Little Beaver; Como; Mt. Harvard; Green Mountain Falls; Georgetown; Cheyenne Mountain; Middle Park; Boulder.

8. Arenaria Eastwoodiae Rydb. (A. Fendleri glabrescens Wats.?) On dry hills in western Colo.-Grand Junction.

9. Arenaria pinetorum A. Nels. On dry hills from S. D. to Ida., Neb. and Colo.-Livermore, Larimer Co.; Cedar Hills; Owl Cañon.

ro. Arenaria Hookeri Nutt. On dry hills from Mont. to Nebr. and Colo.Alt. 4000-7000 ft.-Larimer Co.; Cedar Hills.

6. ALSINOPSIS Small. SANDWORT.

Sepals acute or acuminate.

Petals 6-7 $\mathrm{mm}$. long, much exceeding the sepals.

Petals sma11, scarcely exceeding the sepals.

Plant densely glandular.

Plant glabrous or nearly so.

Leaves linear-subulate, usually over I cm. long, I-nerved, obtuse, more or

$\begin{array}{ll}\text { less triangular, fleshy. } & \text { 3. A. Rossii. }\end{array}$

I. A. macrantha.

2. A. propinqua. 
Leaves linear-lanceolate, 3 -nerved, acutish, flat, less than I cm. long. 4. A. quadrivalvis. Sepals obtuse.

5. A. obtusiloba.

1. Alsinopsis macrantha Rydb. In sandy soil in the mountains of Colo. - Little Kate Basin, La Plata Mountains.

2. Alsinopsis propinqua (Richards.) Rydb. (Arenaria propinqua Richardson; $A$. verna hirta Am. auth.; $A$ verna aequicaulis $\mathrm{A}$. Nels.) In sandy soil from Hudson Bay and Mackenzie River, to B. C., Colo. to Utah.-Alt. 800013,000 ft.-Pike's Peak; Silverton; Saddle Cliffs; Georgetown; Little Kate Basin, La Plata Mountains; near Pagosa Peak; South Park; Boreas; Beaver Creek; Chambers' Lake; Eldora to Baltimore.

3. Alsinopsis Rossii (Richards.) Rydb. (Arenaria Rossii Richards.) In arctic-alpine regions from the arctic coast to Colo. and Wash.-Alt. Ir,00013,500 ft.-Sierra Blanca; Bald Mountain.

4. Alsinopsis quadrivalvis (R. Br.) Rydb. (Arenaria quadrivalvis R. Br.) In alpine-arctic situations, along the arctic coast of North America and on alpine peaks in Colo.-." Colorado."

5. Alsinopsis obtusiloba Rydb. (Arenaria obtusa Torr.; not All.; A. biflora S. Wats., in part; A. Sajanensis Robinson; scarcely Willd.) On exposed mountain tops from Alb. to B. C., N. M. and Utah.Alt. Io,000-13,500 ft.-Mt. Garfield; Pike's Peak; Beaver Creek; Ward, Boulder Co.; Mount Ouray; Alpine Tunnel; Mt. Harvard; Cameron Pass; Iron Mountain; West Spanish Peak; near Pagosa Peak; Gray's Peak; Mt. Princeton; Seven Lakes; Caribou; Empire; headwaters of Clear Creek; Massif de l'Arapahoe; mountains near Como; Cameron Pass; Graymont; Beaver Creek; Berthoud Pass; northwest of Como; Gray's Peak; Cameron Pass; Graymont; Ethel Peak.

\section{TISSA Adans. SANd SpURRY.}

I. Tissa sparsiflora Greene. Sandy and alkaline soil from Wyo. to B. C., Colo. and Ore.-New Windsor.

Family 52. CARYOPHYLlaCEAE Reichenb. Pink Family.

Calyx-ribs, usually Io, at least twice as many as the teeth, running both into the teeth and the sinuses.

Styles mostly 3 ; capsule usually septate at the base.

Styles 5 ; capsule I-celled to the base.

Calyx strongly 5 -angled and 5 -ribbed.

^. Silene.

2. Lychis.

3. Vaccaria.

\section{r. Silene L. Catchfly, Campion.}

Annuals.

Glabrous or nearly so or the upper nodes glutinous.

Stem-leaves linear or linear-lanceolate; bracts narrowly linear-lanceolate. Petals exceeding the sepals by $2-5 \mathrm{~mm}$; blade obovate-cuneate, 2 -cleft. I. S. antirrhina.

Petals none or small, not exceeding the sepals; blade cuneate, truncate or emarginate at the apex.

2. S. antirrhina depauperata.

Stem-leaves oblanceolate or lanceolate; bracts lanceolate, more or less scariousmargined below.

Viscid-pubescent or hirsute throughout.

3. S. antirrhina vaccariifolia.

4. S. noctifiora. 
Perennials.

Calyx not much inflated.

Plant caulescent, rather tall, not densely matted.

Inflorescence thyroid-paniculate, racemiform or spicate, not leafy; flowers over I cm. long.

Claws and auricles of the petals narrow; the latter laciniate; leaves linear or linear-lanceolate.

5. S. Scouleri.

Claws and auricles of the petals broad; the latter ciliate; leaves oblanceolate.

6. S. Hallii.

Inflorescence leafy; the flowers borne in the axils of the branches, less than I cm. long.

Leaves broadly oblanceolate, spreading; branches of the inflorescence divaricate.

7. S. Menziesii.

Leaves narrowly oblanceolate, ascending; branches of the inflorescence usually ascending or erect.

8. S. stellarioides.

Plant subacaulescent, densely cespitose, dwarf. 9. S. acaulis.

Calyx much inflated and bladdery.

Io. S. vulgaris.

I. Silene antirrhina L. In waste places from Newf. to B. C., Fla. and Calif.-Alt. 5000-6500 ft.-Palmer Lake; northwest of Soldier Cañon.

z. Silene antirrhina depauperata Rydb. In sandy soil from Sask. to B. C., Colo. and Ariz.--Exact locality not given.

3. Silene antirrhina vaccariifolia Rydb. On hillsides from Mont. and Ida. to Colo.-Alt. 5000-7000 ft.-Larimer Co.; Rist Cañon; near Golden.

4. Silene noctiflora L. In waste places and fields from N. S. to Man., Fla. and Utah. Naturalized from Europe--Alt. about $5000 \mathrm{ft}$.Ft. Collins.

5. Silene Scouleri Hook. In the mountain valleys and hillsides from Ida. to B. C., Colo. and Ore.-Alt. up to $9000 \mathrm{ft}$-Near Pagosa Peak.

6. Silene Hallii S. Wats. In the mountains of Colo. and N. M.-Alt. 600oI2,000 ft.-Jack's Cabin, Gunnison watershed; foot-hills, Larimer Co. ; Ruxton Dell; Villa Grove; Cheyenne Cañon; Mancos; Upper La Plata Cañon; headwaters of Clear Creek; Gray's Peak; Bosworth's ranch; Stove Prairie; Mt. Harvard.

7. Silene Menziesii Hook. In wet soil, especially among bushes, from Mont. to B. C., Neb., Colo. and Calif.-Alt. 7000-I0,500 ft.-Ouray; Bob Creek; headwaters of Clear Creek; Graymont; Gore Pass; North Park; Hotchkiss; Dolores.

8. Silene stellarioides Nutt. Among bushes from Mont. to Wash. and Colo.-Alt. 7000-9000 ft.-Gunnison; Leroux Creek, Delta Co.; Middle Park; Mancos; Los Pinos; Sangre de Cristo Creek.

9. Silene acaulis L. On exposed mountain tops, often near the snow, from Greenl. to Alaska, N. H. and Ariz.-Alt. 9000-I3,000 ft.-Saddle, Pike's Peak; West Spanish Peak; Mt. Hesperus and Little Kate Basin; near Pagosa Peak; Mt. Harvard; Boreas; Gray's Peak; Cameron Pass; Marshall Pass; Massif de l'Arapahoe; Crystal Lake; Beaver Creek; Leroux Creek; Ethel Peak.

ro. Silene vulgaris (Moench) Garcke. ( $S$. inflata J. E. Smith.) Introduced from Europe, in meadows and waste places, from N. B. and Ills. to N. J. and Colo.-Manitou.

\section{IXCHNIS L.}

Tall, $3 \mathrm{dm}$. high or more, several to many-flowered.

Petals included.

Petals exserted.

Low, about I dm. high; flowers I- 3 .

I. L. Drummondii.

2. L. striata.

3. L. montana. 
I. Lychnis Drummondii (Hook.) S. Wats. On dry hills and plains from Man. to B. C., N. M. and Ariz.-Alt. 4000-I0,000 ft.-Sangre de Cristo Creek; Middle Park; Ironton Park, 9 miles south of Ouray; hills about Box Cañon, west of Ouray; Marshall Pass; Georgetown; Yampa; mountains between Sunshine and Ward; Trapper's Lake; South Park; Empire; vicinity of Como; Leroux Creek, Delta Co.

z. Lychnis striata Rydb. On hillsides from Wyo. to Utah and Colo.-Alt. 8000-10,000 ft.-Cameron Pass; Silver Plume.

3. Lychnis montana S. Wats. Mountains of Colo. and Wyo.-- Colorado"; exact locality not given.

\section{VACCARIA Medic. Cow-Herb.}

1. Vaccaria Vaccaria (L.) Britton. (Saponaria Vaccaria L.) In waste places from Ont. to Alaska, Fla. and Calif.-Naturalized from Europe.-Alt. 5000-8000 ft.-Cucharas Valley; Wahatoya Creek; Pagosa Springs; Boulder; Ft. Collins; Pueblo.

\section{Order 25. RANALES.}

Stamens numerous; anther-sacs opening by slits.

Gynoecium of single or several free carpels.

Submerged water plants with minute axillary sessile monoecious flowers; anthers with horn-like appendages.

53. Ceratophillaceae.

Land plants or rarely water plants with perfect or rarely dioecious flowers; anthers not with horn-like appendages.

54. Ranun Culaceae.

Gynoecium of several united carpels; water plants with floating, reniform or orbicular-cordate leaf-blades.

55. NyMPhaEACEAE.

Stamens definite (in ours 6); anther-sacs opening by hinged valves.

56. Berberidaceae.

\section{Family 53. CERATOPHYLLACEAE. A Gray.}

\section{CERATOPHYLLUM L.}

1. Ceratophyllum demersum L. In water from Newf. and Ore. to Fla. and Calif.-Platte River.

Family 54. RANUNCULACEAE Juss. Crowfoot Family.

Carpels with several ovules; fruit a follicle or a berry.

Flowers regular.

Petals inconspicuous or none, not spurred.

Fruit follicles; leaves simple; flowers solitary.

Petals wanting; leaf-blades entire or toothed.

1. Caltha.

Petals present, small, linear, clawed; leaf-blades palmately parted and toothed.

2. Trollius.

Fruit a berry; leaves twice or thrice ternately compound; flowers racemose. 3. Actaea.

Petals conspicuous, produced into a spur or at least saccate at the base;

leaves ternately compound. 4. Aquilegia.

Flowers irregular.

Posterior sepal spurred.

Posterior sepal hooded, helmet-shaped or boat-shaped.

5. Delphinium.

6. Aconitum. 
Carpels $x$-ovuled; fruit an achene.

Petals wanting; sepals often petal-like.

Sepals imbricated in the bud; leaves all alternate, or only those subtending the inflorescence opposite.

Flowers subtended by opposite or verticillate leaf-like bracts.

Styles short, not elongated in fruit.

Styles much elongated in fruit, plumose.

7. ANEMONE.

8. Pulsatilla.

Flowers not subtended by opposite or verticillate bracts; leaves all alternate, ternately compound.

Sepals valvate in the bud; leaves all opposite.

Flowers cymose-paniculate, dioecious or polygamo-dioecious; stamens and sepals spreading.

Flowers solitary, perfect.

Stamens érect; sepals thickish, more or less converging; staminodia wanting.

IO. VIORNA.

Stamens spreading; sepals thin, spreading from the base; staminodia often present.

Petals usually present.

Sepals spurred; small annuals with basal linear leaves; receptacle in fruit elongated-cylindrical.

it. Atragene.

Sepals not spurred; plant usually bearing cauline as well as basal leaves; receptacle in fruit spherical, conical or short-cylindric.

Achenes transversely wrinkled; petals white. I3. Batrachium.

Achenes not transversely wrinkled; petals yellowish at least without.

Achenes not ribbed.

Achenes longitudinally ribbed.

Achenes compressed; leaves simple, crenate or lobed.

Achenes terete; leaves compound.

I5. HaLerpestes.•

I6. Cyrtorhyncha.

I. Caltha L. Marsh-marigold, MEadow-Gowan.

I. Caltha leptosepala Hook. (C. rotundifolia (Huth) Greene; C. chionophila Greene.) Along brooks and below the snow from the Canadian Rockies to Colo.-Alt. 8000-I2,000 ft.-Cameron Pass; Graymont; Beaver Creek; Alpine Tunnel; Bear Creek Divide; Marshall Pass; Pike's Peak; Red Mountain, south of Ouray; Columbine; Grand Mesa; Carson; Gore Pass; Seven Lakes; near Ironton; Chambers' Lake; Gray's Peak; Front Range, Larimer Co.; South Cottonwood Gulch, Chaffee Co.; Mt. Harvard; Lake City; Empire; Rabbit-Ear Range, Routt Co.

\section{z. TROLLIUS L. GLOBE-FLOWER.}

I. Trollius albiflorus (A. Gray) Rydb. (T. laxus albiflorus Gray) In swamps and along streams from Mont. to Wash., Colo. and Utah.-Alt. 900012,000 ft.-Above Beaver Creek; Leroux Park; Cameron Pass; Slide Rock Cañon; Mt. Hesperus, above timber line; Pagosa Peak; Grand Mesa; Graymont; Red Mountain; Marshall Pass; Crystal Lake; headwaters of Clear Creek; Massif de l'Arapahoe.

\section{ACTAEA L. BANE-BERRy.}

Filaments whitish; raceme short; pedicels in fruit $1-3 \mathrm{~cm}$. long.

Fruit white, ellipsoid, 9-I $2 \mathrm{~mm}$. long.

Fruit red, spherical or nearly so, 5-7 $\mathrm{mm}$. long.

1. A. eburnea.

2. A. arguta.

Filaments greenish; raceme elongated; pedicels very short, even in fruit less than I $\mathrm{cm}$. long; fruit red.

3. A. viridiflora. 
I. Actaea eburnea Rydb. In rich woods and cañons from Newf. to Alb., Vt. and Utah.-Alt. 8000-10,000 ft.-Mancos; Ouray; Ragged Mountain, Gunnison Co.

2. Actaea arguta Nutt. In rich woods and cañons from Mont. to Alaska, Colo. and Calif.-Alt. 8000-Io,000 ft.-Mountains above Ouray; Wahatoya Cañon; Black Cañon; Veta Pass; Artists' Glen; near Pike's Peak.

3. Actaea viridiflora Greene. In cañons from Colo. to Ariz.-Alt. about 8000 ft.-Four-Mile Hill, Routt Co.; hills west of Ouray; Trapper's Lake.

\section{AQuilegia L. Columbine.}

Petals merely saccate, not spurred; terminal leaflet rhombic, acute.

Petals spurred; all leaflets obtuse.

I. A. Eastwoodiae.

Lamina of the petals longer than the strongly curved spur; flowers blue; stem low.

Lamina of the petals shorter than the slightly curved or straight spur.

2. A. saximontana.

Spur not over $2 \mathrm{~cm}$. long; flowers nodding.

Sepals and spur red.

Whole flower light yellow.

Spur $3-7 \mathrm{~cm}$. long; flowers in anthesis usually erect.

Basal leaves usually twice ternate; spur $3-4 \mathrm{~cm}$. long; sepals blue or white. 5. A. coerulea.

Basal leaves usually thrice ternate; spurs $4-7 \mathrm{~cm}$. long; sepals yellow. Spur 4-5 cm. long; sepals less than $2 \mathrm{~cm}$. long, ovate-lanceolate, acute; follicles strongly curved outward.

3. A. elegantula.

4. A. micrantha.

Spur 5-7 cm. long; sepals $2-3 \mathrm{~cm}$. long, lanceolate to ovate-lanceolate, acuminate; follicles almost straight.

7. A. chrysantha.

I. Aquilegia Eastwoodiae Rydb. (A. ecalcarata Eastw.; A. micrantha Mancosana Eastwood; $A$. Mancosana Cockerell) In dark cañons, Colo.Johnston Cañon, Mesa Verde.

2. Aquilegia saximontana Rydb. (A. brevistyla A. Gray; not Hook.) Among rocks, Colo.-Alt. I0,000-I2,000 ft.-Cameron Pass; Gray's Peak; headwaters of Clear Creek; Bottomless Pit; Argentine Pass.

3. Aquilegia elegantula Greene. (A. Canadensis A. Gray, in part) On wooded hillsides in Colo. and N. M.-Alt. 7500-II,000 ft.-Rico; Silverton; Marshall Pass; Slide Rock Cañon; Mancos; about Ouray; Van Boxle's ranch, above Cimarron; Minturn, Eagle Co.; Glenwood Springs; headwaters of Sangre de Cristo Creek; mountain near Veta Pass; West Indian Creek; Lake City.

4. Aquilegia micrantha Eastw. In cañons of Colo. and Utah.--Johnston Cañon.

5. Aquilegia coerulea James. In woods and on mountain-sides from Mont. to Utah and Colo.--Alt. 6500-I2,000 ft.-Vicinity of Como and Como Pass, above timber line; west of Rist Cañon; Beaver Creek; Pennock's mountain ranch; Table Rock; timber line above Graymont; Baxter's ranch; Cameron Pass; Trapper's Lake; Horsetooth Gulch; Horsetooth Mountain; Poudre River; Rist Cañon; Bosworth's; above Beaver Creek; forks of Poudre and Big South; Empire; Mt. Hesperus, above timber line; West Spanish Peak; Bob Creek; below Gray's Peak; Middle Park; mountains near Veta Pass; Sangre de Cristo Creek; North Cheyenne Cañon; Marshall Pass; Mt. Ouray; near Teller, North Park; Pike's Peak; Columbine; Dark Cañon; 
North Boulder Peak; headwaters of Clear Creek; Rabbit-Ears, Larimer Co.; Hahn's Peak. [State Flower of Colorado.]

6. Aquilegia thalictrifolia Rydb. (A. chrysantha Coulter, in part.) In the mountains of Colo. and western Tex.-Alt. 6000-9000 ft.--Alpine Tunnel; Colorado Springs; Bear Creek Cañon; Cañon City; Grand Cañon of the Arkansas.

7. Aquilegia chrysantha A. Gray. In the mountains of N. M. and Ariz. It has also been reported from Colo., but no locality given.

\section{Delphinium L. Larkspur.}

Pedicels erect or nearly so.

Sepals white, only tinged with blue; pods over I $\mathrm{cm}$. long, about four times as long as broad; seeds squamellate.

Spur almost three times as long as the upper petals, more or less curved; seeds $3 \mathrm{~mm}$. long, black, slightly squamellate.

I. D. Penardii.

Spur scarcely twice as long as the upper petals, almost straight; seeds $1.5^{-2}$ $\mathrm{mm}$. long, brown, strongly squamellate.

Lobes of the lateral petals divergent; lower pedicels elongated; spur mostly erect.

2. D. camporum.

Lobes of the lateral petals not divergent; lower pedicels not elongated; spur mostly horizontal.

3. D. albescens.

Sepals dark blue; pod less than I cm. long, only 2-3 times as long as broad; seed not squamellate, but wing-margined; stem and leaves glabrous and glaucous.

Pedicels ascending or spreading.

Inflorescence few-flowered, the lower pedicels elongated; sepals broad, spreading; leaf-segments narrow.

Roots fascicled, thick, but not tuberiform; stem usually viscid, at least above; blades of the lateral petals about I cm. long.

4. D. bicolor.

Roots tuberiform; stem not viscid; blades of the lateral petals about $5 \mathrm{~mm}$. long.

Flowers dark blue.

Flowers light blue.

Lower pedicels not elongated.

Segments of the basal leaves obtuse, mucronate; flowers light blue.

Segments of all the leaves acute or acuminate.

Plant not at all viscid; follicles pubescent.

Stem grayish strigose throughout.

Leaves divided into cuneate, merely cleft segments.

Leaves repeatedly divided into linear division.

8. D. geraniifolium.

Stem 3-5 dm. high; bractlets oblong, close under the calyx.

9. D. Geyeri.

Stem 5-20 dm. high; bractlets subulate, $2-3 \mathrm{~mm}$. below the calyx.

Stem glabrous and glaucous at least below.

I. D. robustum.

Inflorescence dense; follicles scarcely at all arcuate.

Leaves puberulent; inflorescence stigose.

Leaf-divisions broad, cuneate, merely cleft into lanceolate lobes.

Leaves repeatedly dissected into linear lobes. Io. D. cuculatum.

II. D. robustum.

Leaves glabrous and glaucous; inflorescence almost glabrous.

Inforescence lax; follicles strongly arcuate.

I2. D. elongatum.

Plants more or less viscid, at least the pedicels.

I 3. D. ramosum. 
Plant tall, 4-20 dm. high, not cespitose.

Follicles viscid pubescent.

Flowers light blue or yellowish, tinged with blue or purple.

Flowers dark blue.

14. D. multiflorum.

Follicles glabrous.

Sepals obtuse.

Sepals acute or acuminate.

I5. D. occidentale.

I6. D. reticulatum.

1 7. D. Barbeyi.

Plants about I $\mathrm{dm}$. high, cespitose, viscid pubescent.

I8. D. alpestre.

I. Delphinium Penardii Huth. On dry plains of Colo.-Alt. 5000-8000 ft.Horsetooth Gulch; bank of Arkansas River; Poudre flats, north of Ft. Collins; Ft. Collins; Dixon Cañon; near Badito; Wahatoya Creek; Brantly Cañon, Las Animas Co.

2. Delphinium camporum Greene. On dry plains from Colo. to Tex. and Ariz.-Alt. $4000-8000$ ft.-Plains and foot-hills near Boulder; New Windsor; near Badito; Walsenburg.

3. Delphinium albescens Rydb. In meadows from Ills. to Man., Ind. Terr. and Colo.-Alt. 4000-5000 ft.-Ft. Collins.

4. Delphinium bicolor Nutt. Hills and plains from Ass. and Wash. to S. D., Utah and Ore.-Also reported from Colorado; but doubtful.

5. Delphinium Nelsonii Greene. On hillsides from Alb. to Wash., Neb. and Utah.-Alt. 4000-10,000 ft.-Four-Mile Hill, Routt Co.; hills west of Soldier Cañon; Horsetooth Gulch; Dolores; Ouray; Howe's Gulch; Rist Cañon; Spring Cañon; Table Rock; Grand Junction; Wyoming State line; Minturn, Eagle Co.; Ft. Collins; foot-hills, Larimer Co.; Chicken Creek; Los Pinos; Van Boxle's ranch, above Cimarron; foot-hills west of Ft. Collins; Mesa Verde; Cerro Summit; Ironton; Apex; near Boulder; Steamboat Springs; Beaver Creek, Larimer Co.

6. Delphinium dumetorum Greene. In the mountains of Colo--Alt. about $7000 \mathrm{ft}$. -Cimarron.

7. Delphinium scaposum Greene. On dry plains from Colo. to N. M. and Ariz.-Alt. about $7000 \mathrm{ft} .-$ Mancos.

8. Delphinium geraniifolium Rydb. On hills from Colo. and Ariz.-Colorado Springs.

9. Delphinium Geyeri Greene. On the plains from Wyo. to Colo.-Alt. 5000-7000 ft.-Foot-hills, Larimer Co.; Rist Cañon; Horsetooth Gulch; hills south of Horsetooth Mountain; plains near Ft. Collins; Livermore, Larimer Co.; New Windsor.

10. Delphinium cuculatum A. Nels. On mountain sides from Mont. and Ida. to Colo.-Alt. about $9000 \mathrm{ft}$-Four-Mile Hill, Routt Co.

II. Delphinium robustum Rydb. In mountain meadows from Mont. to N. M.-Alt. 6000-9000 ft.-Wahatoya Creek; La Veta; Colorado Springs; Indian Creek Pass; foot-hills, Larimer Co.

12. Delphinium elongatum Rydb. On hills and mountains of Colo--Alt. 7000-I0,000 ft.-Elk Cañon; Baxter's ranch; foot-hills, Larimer Co.; Villa Grove; alpine ridge east of Middle Park; headwaters of Clear Creek.

13. Delphinium ramosum Rydb. In cañons and on mountain sides in Wyo. and Colo.-Alt. 6000-9000 ft.-Crystal Park; Williams' Cañon; Artists' Glen; North Cheyenne Cañon; Idaho Springs. 
I4. Delphinium multiflorum Rydb. On mountain sides from Mont. to Wash. and Colo.-Alt. about $8000 \mathrm{ft}$ - - North Park; Columbine; divide road to Steamboat Springs; Wilson, San Miguel Co.

15. Delphinium occidentale S. Wats. (D. quercetorum Greene.) On the mountains from Wyo. to Utah and Colo.-Alt. 8000-10,000 ft.-Cerro Summit; Berthoud Pass.

16. Delphinium reticulatum (A. Nels.) Rydb. (Delphinium occidentale reticulatum A. Nels.) On mountain-sides in Wyo. and Colo.-Mouth of Basin Creek; Upper La Plata Cañon.

17. Delphinium Barbeyi Huth. (D. scopulorum subalpinum A. Gray; D. subalpinum A. Nels.) In shady places in the mountains of Wyo, and Colo.-Alt. 8000-r3,000 ft.-Cameron Pass; Boreas; Gray's Peak; Mt. Abram, Ouray; Buffalo Pass; Columbine; near Ironton; Silver Plume; Indian Creek Pass; near Pagosa Peak; Upper La Plata Cañon; Sangre de Cristo Creek; Hinsdale Co.; Empire; Rabbit-Ears, Larimer Co.

18. Delphinium alpestre Rydb. On alpine peaks, among rocks, in Colo.-Alt. I0,000-13,000 ft.--Mountain northwest of Como; West Spanish Peak.

\section{ACONITUM L. MONKHOOD.}

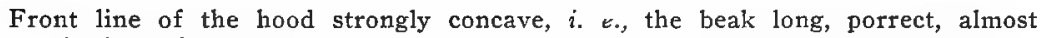
horizontal.

Lower sepals at least $3 / 4$ as long as the lateral ones; leaf segments rather broad. 1. A. Bakeri.

Lower sepals $1 / 2-2 / 3$ as long as the lateral ones; leaf segments narrow. 2. A. porrectum.

Front line of the hood almost straight, $i$. e., the beak directed downward.

Lateral sepals very oblique; upper margin semi-reniform. 3. A. columbianum.

Lateral sepals moderately oblique; upper margin slightly, if at all, concave. Flowers blue. Flowers ochroleucous. 4. A. insigne. 5. A. ochroleucum.

I. Aconitum Bakeri Greene. (A. atrocyaneum Rydb.) In the mountains of Colo., Wyo. and Utah.-Alt. I0,000-I2,000 ft.-Boreas; Steamboat Springs; gulch west of Bear River; Marshall Pass; Cameron Pass; near Ironton, San Juan Co.

z. Aconitum porrectum Rydb. In the mountains of Colo. and Wyo.-Alt. 6000-10,000 ft.-Graymont; Arapahoe Pass; foot-hills, Larimer Co.; Coffee Pot Springs; Columbine; Pike's Peak; North Park; Villa Grove; La Plata Mountains; Lake City; Rabbit-Ears, Larimer Co.

3. Aconitum columbianum Nutt. In meadows and open woods from Mont. to B. C., N. M. and Calif.-Alt. 9000-12,000 ft.-Ruxton Park; Ruxton Creek; Pike's Peak; Ouray; Hinsdale Co.

4. Aconitum insigne Greene. In the mountains of Colo-Alt. 7000-II,000 ft.-Bosworth's ranch; Stove Prairie; Beaver Creek; Alpine Tunnel; Parlin, Gunnison Co.; Middle Park; foot-hills, Larimer Co.; Veta Pass; Sangre de Cristo Creek; Central City; La Plata Mountains; near Pagosa Peak; Eldora to Baltimore; Empire.

5. Aconitum ochroleucum A. Nels. In the mountains of Colo. and Wyo.Alt. about gooo ft.-Indian Creek Pass; Ruxton Park, Pike's Peak; Eldora to Baltimore. 


\section{ANEMONE L. ANemone, Wind-Flower.}

Achenes densely villous.

Style filiform, usually deciduous; heads of fruit spherical or nearly so; involucral leaves short-petioled.

Leaves ternate; divisions broadly cuneate or flabelliform, crenate or slightly cleft.

1. A. parviflora.

Leaves 2-4 times ternate; segments linear to lanceolate. 2. A. globosa.

Styles subulate, persistent; heads of fruit cylindrical; involucral leaves longpetioled.

Achenes not villous.

Flowers cymose; achenes sparingly hirsute when young, sessile; style long, straight.

Flowers subumbellate; achenes glabrous, stipitate; style short, curved.

5. A. narcissiflora.

I. Anemone parviflora Michx. On exposed mountain tops from Lab. to Alaska, Ont, and Colo.-Alt. about I0.500 ft.-South Cottonwood Gulch, Chaffee Co.

2. Anemone globosa Nutt. (A. multifida Hook., in part; not Poir.) In meadows and on hillsides from S. D. to Mackenzie River and Alaska, Colo. and Calif.-Alt. 7000-12,000 ft.-Rist Cañon; gulch east of Stove Prairie; Barnes' Camp; forks of Poudre and Big South Rivers; near foot of RabbitEar Range; near Georgetown; Campton's ranch; Carson; Mt. Abram, Ouray; Placer; Ironton Park, 9 miles south of Ouray; Veta Pass; Crystal Park; Ruxton Park; Pagosa Springs; Central City; Tennessee Pass; Grizzly Creek; Mt. Harvard; Grayback mining camps; Little Veta Mountains; Caribou; Lake City; Empire; Eldora to Baltimore.

3. Anemone cylindrica A. Gray. Among bushes and on hillsides from N. B. to B. C., N. J. and Ariz.-Alt. 400o-800o ft.-Pennock's; Horsetooth Mountain; foot-hills, Larimer Co.; Dillon Cañon, Trinidad; hills west of Soldier Cañon; Trinidad; La Veta; Wahatoya Creek; Mancos; Pagosa Springs; Piedra.

4. Anemone canadensis L. ( $A$. dichotoma $\mathrm{L}$.) In river valleys and among bushes from Lab. to Alb., Md. and N. M.-Alt. 4000-900o ft.-Rist Cañon; Ft. Collins; Table Rock; Poudre Flats; Garland; Sangre de Cristo Creek; New Windsor.

5. Anemone narcissiflora $L$. In the mountains from Alb. to Alaska and Colo.-Alt. 8000-13,000 ft.-Cameron Pass; Beaver Creek; near Teller, North Park; Tennessee Pass; mountains northeast of Boreas; Mt. Harvard; Buffalo Pass; Alpine Tunnel; South Park; summit of North Park Range, Larimer Co.

\section{PULSATIlla Adans. Pasque Flower.}

1. Pulsatilla hirsutissima (Pursh.) Britton. (Ancmone patens Nuttalliana A. Gray.) On plains and hills from Ills. to Mackenzie, Alb., Tex. and Wash.-Alt. 4000-10,000 ft.-Cameron Pass; foot-hills, Larimer Co.; Clear Creek; Hermosa; Manitou; Crystal Park; about Ouray; mountains near Veta Pass; South Cheyenne Cañon; foot-hills west of Ft. Collins; Horsetooth Gulch; Howe's Gulch; Stove Prairie Hill; Poudre Cañon; Dixon's Cañon; Ojo; Lake City; Pike's Peak; North Boulder Peak; Eldora to Baltimore; Bear Creek Cañon. 


\section{Clematis L. Virgin's Bower.}

1. Clematis ligusticifolia Nutt. Among bushes and in cañons from N. D. to B. C., Mo. and Calif.-Alt. 4000-8000 ft.-Log Cañon; Poudre River, near Ft. Collins; Rist Cañon; Redstone; Narrows; Deer Run; Ft. Collins; near Ouray; Manitou; Cucharas Valley, near La Veta; Piedra; Arkansas Valley; Salida; Durango; plains, Colorado Springs.

\section{IO. VIORNA Reichenb. LEATHER-FLOWER, VASE-VINE.}

Sepals not at all or very slightly dilated above.

Divisions of the leaves ovate or ovate-lanceolate, $2-5 \mathrm{~cm}$. long. $1 . V$. Scottii.

Divisions of the leaves linear to lanceolate, $I-2 \mathrm{~cm}$. long. 2. V. Bakeri.

Sepals conspicuously dilated at the apex.

Sepals acute or short-acuminate; plant in age glabrate; divisions of the leaves lanceolate. 3. V. Jonesii.

Sepals obtuse or merely acutish; plant permanently villous; divisions of the leaves linear.

4. V. eriophora.

I. Viorna Scottii (Porter) Rydb. (Clemaitis Scottii Porter; C. Douglasii Scottii Coulter) In open woods and on hillsides from S. D. to Wyo. and N. M.-Alt. 4000-900o it.-Vicinity of Dillon Cañon; Trinidad; La Veta; Veta Pass; Poverty Ridge, near Cimarron; Grizzly Creek; La Plata River Valley, near Hesperus Post Office; Cañon City.

z. Viorna Bakeri (Greene) Rydb. (Clematis Bakeri Greene) In mountains of Colo.-Alt. about $7000 \mathrm{ft}$-LLos Pinos; Camp Creek, Larimer Co.

3. Viorna Jonesii (Kuntze) Rydb. (Clematis Douglasii Jonesii Kuntze) On hillsides and in cañons from Colo. to Nev.-Alt. 5000-9000 ft.-Howe's Gulch, near Ft. Collins; vicinity of Ouray; Dolores; Cimarron; Dixon Cañon; foot-hills near Boulder.

4. Viorna eriophora Rydb. (Clematis eriophora Rydb.) In the foot-hills of Colo., Utah and Wyo.-Alt. 4000-7000 ft.-Foot-hills, Larimer Co.; gulch west of Dixon Cañon; Howe's Gulch; Rist Cañon; Horsetooth Gulch; Ft. Collins; Clear Creek; mesas near Colorado Springs; mountains near Golden City; Pagosa.

\section{iI. Atragene L. Bell-Rue, Purple Virgin's Bower.}

Leaves merely ternate.

Staminodia usually decidedly spatulate; leaflets toothed or cleft; teeth and apex rounded.

3. A. diversiloba.

Staminodia linear or none; leaflets entire or crenate above the middle, longacuminate.

Leaves twice or thrice ternate; staminodia linear or lacking.

Secondary leaflets merely toothed or cleft.

Secondary leaflets divided to near the base.

1. A. occidentalis.

2. A. pseudalpina.

4. A. tenuiloba.

1. Atragene occidentalis Hornem. (A. Columbiana Nutt.; Clematis verticillaris Coult., in part) In mountain woods from Mont. to B. C., Colo. and Utah.-Alt. 5000-700o ft.-Foot-hills, Larimer Co. ; Howe's Gulch; gulch east of Stove Prairie; Rist Cañon; Baxter's ranch; Ft. Collins; Four-Mile Hill, Routt Co.; Empire; Camp Creek, Larimer Co.

2. Atragene pseudalpina (Kuntze) Rydb. (Clematis alpina occidentalis A. Gray; not $A$. occidentalis Hornem.) On hillsides, among bushes and in 
open woods, in Colo. and N. M.-Alt. 7000-10,000 ft.-Van Boxle's ranch, above Cimarron; Minnehaha; Ojo; hills southeast of La Veta; Veta Pass; Idaho Springs; Mt. Abram, Ouray; chaparral-covered hills southeast of Ouray; Lake City; Cheyenne Cañon.

3. Atragene diversiloba Rydb. In mountains of Colo.-Mountains near Denver.

4. Atragene tenuiloba (A. Gray) Britton. (Clematis alpina tenuiloba A. Gray.) In mountain woods from S. D. to Mont., Colo. and Ariz.-Ait. 7000-10,000 ft.-Placer; Sheep Cañon; North Cheyenne Cañon; Williams' Cañon, above Manitou; Colorado Springs; Pike's Peak.

\section{MYOSURUS L. MOUSE-TAIL.}

Achenes with a flat back, only slightly carinate and tipped with a very short appressed beak.

1. M. minimus. Achenes strongly carinate on the back, tipped with a Iong subulate ascending beak. 2. $M$. aristatus.

I. Myosurus minimus L. In muddy places and shallow water from Ont. to Wash., Fla. and Calif.; also in Europe and northern Africa._Alt. up to $5000 \mathrm{ft}$-Denver (Eastwood).

z. Myosurus aristatus Benth. In muddy places from Mont. to Wash., Colo. and Calif.-Alt. up to $9000 \mathrm{ft}$-_Long's Peak.

13. BatrachiUm S. F. Gray. White Water-Crowfoot.

Petals 5-7 mm. long, broadly obovate; stamens many.

Segments of the leaves ro-15 $\mathrm{mm}$. long, rather rigid, scarcely collapsing when withdrawn from the water.

I. B. trichophyllum.

Segments of the leaves $15-30 \mathrm{~mm}$. long, flaccid, collapsing when withdrawn from the water.

Petals less than $5 \mathrm{~mm}$. long, oblong-obovate; stamens 5-I 2.

Stem slender; leaves not very flaccid.

Stem filiform; leaves very flaccid.

2. B. flaccidum.

I. Batrachium trichophyllum (Chaix.) Bosh. (Ranunculus aquatilis trichophyllus Chaix.) In water from N. S. to B. C., N. C. and Calif.; also in Mex., Europe and Asia.-Alt. 4000-9000 ft.-Near Ouray; Grizzly Creek; Ft. Collins; Sangre de Cristo Creek; New Windsor; Denver.

2. Batrachium flaccidum (Pers.) Rupr. (Ranunculus aquatilis trichophyllus A. Gray, in part) In water from Lab. to Wash., N. C. and Low. Calif. -Alt. 4000-10,000 ft.-Ft. Collins; Trail Creek, near junction with North Poudre; Trapper's Lake; below Carson; Upper Laramie River; Boulder.

3. Batrachium Drouetii (F. Schultz) Nym. In water from Vt. to Alaska, R. I. and Low. Calif.-Alt. 7000-8000 ft.-Along Uncompahgre River, near Ouray; Parlin, Gunnison Co.; Piedra.

4. Batrachium confervoides Fries. In water from Man. to Alaska, south to Colo.-In Grand Lake.

\section{I4. RANUNCULUS L. CROWfoot, Butter-cup.}

Leaves linear to oval, entire or merely denticulate or crenate; none divided or cleft.

Some of the leaves at least cleft.

Sepals black-hairy.

Flam a ulaE.

Sepals not black-hairy.

Nivales. 
Some of the basal leaves entire.

None of the leaves entire.

Glaberrimi.

Plants neither immersed in the water nor creeping in the mud, if rooting at the nodes, not with palmately lobed or dissected leaves.

Achenes turgid, marginless.

Petals much exceeding the sepals.

Basal leaf-blades not divided to the base. AFrines.

Basal leaf-blades divided to the base, $2-3$ times ternate. Triternati.

Petals scarcely exceeding the sepals.

Achenes compressed with a distinct margin.

Beak of the achenes distinctly hooked.

Beak of the achenes straight or nearly so.

Abortivi.

Plants immersed in the water or creeping in the

lobed, divided or dissected.

Recurvati.

REPENTES.

Multifidi.

\section{Flammulate.}

Stem filiform, prostrate, rooting at the nodes.

Stem not filiform, erect or ascending, not rooting.

Petals distinctly clawed; beak of the achenes stout.

Petals not clawed; beak of the achenes filiform.

1. R. reptans.

2. R. unguiculatus.

3. R. alismaefolins.

Nivales.

Leaf-blades spatulate or elliptic, 2-4-toothed at the apex. 4. R. Macauleyi.

GLABERRIMI.

Basal leaf-blades elliptic to oval, usually all entire. $\quad$ 5. R. ellipticus.

\section{Affines.}

Achenes pubescent; heads oblong to cylindric.

Basal leaf-blades or some of them merely crenate; the rest 3 -cleft at the apex with a narrow middle lobe.

Petals broadly obovate, about $I^{\circ} \mathrm{cm}$. long; sepals densely villous.

Petals oblong-obovate, $3^{-6} \mathrm{~mm}$. long; sepals not densely villous.
Petals 5-6 mm. long; head of achenes oblong.
7. R. inamoenus.

Petals 3-5 mm. long; head of achenes cylindric.

8. R. micropetalus.

Basal leaf-blades all digitately or pedately cleft with acute lobes.

Achenes glabrous.

9. R. affinis.

Plant glabrous, except the sepals.

Lobes of the stem-leaves elliptic, oval or obovate. Io. R. Eschscholtzii.

Lobes of the upper stem-leaves linear to oblong.

Basal leaf-blades orbicular, seldom reniform, seldom cleft more than halfway down; heads of fruit decidedly oblong; stipules semi-circular, about $2 \mathrm{~mm}$. long.

II. $R$. alpeophilus.

Basal leaf-blades decidedly reniform, cleft deeper than half-way down; heads of achenes spherical or nearly so; stipules of the stem-leaves oval, 3-4 $\mathrm{mm}$. long.

Plant more or less pubescent.

I2. $R$, ochreatus.

I3. $R$. ovalis.

\section{Triternati.}

One species.

I4. R. adonens.

Abortivi.

Basal leaf-blades, at least some of them, merely crenate.

Achenes pubescent; heads of achenes cylindric.

Achenes glabrous; heads spherical.

8. R. micropetalus. 
Basal leaf-blades cordate at the base; plant glabrous. I5. $R$. abortivus.

Basal leaf-blades rarely cordate at the base; plant hairy. 16. $R$. micranthus.

All the leaf-blades divided or lobed.

Lower leaf-blades less deeply lobed, often not more than half down to the base.

Leaf-blades all divided to near the base. 17. $R$. sceleratus. I8. $R$. eremogenes.

\section{RECURVATI.}

Flowers small; petals only $2-5 \mathrm{~mm}$. long.

Stem glabrous.

Stem hairy; with spreading hairs.

Petals $2-3 \mathrm{~mm}$. long.

Petals $4-5 \mathrm{~mm}$. long.

Flowers larger; petals $5-10 \mathrm{~mm}$. long; stem appressed-pubescent.

19. R. Douglasii.

20. $R$. Bongardii. 21. R. Earlei.

REPENTES.

Heads of achenes oblong, about $5 \mathrm{~mm}$. thick.

Heads of achenes globose, about $8 \mathrm{~mm}$. thick.

23. $R$. pennsylvanicus. 24. R. Macounii.

\section{Multifidi.}

Leaf-blades deeply cordate at the base; primary divisions lobed or dissected. 25. R. Purshii.

Leaf-blades truncate or slightly cordate at the base; primary lobes merely crenate or entire. 26. $R$. intertextus.

I. Ranunculus reptans L. (R. Flammula reptans E. Meyer) On sandy shores from Lab. to Alaska, N. J., Utah and Ore.-Alt. 5000-10,000 ft.Vicinity of Como; bank of Michigan, North Park; Trapper's Lake; plains and foot-hills near Boulder; Ward; Gunnison; Parlin; Twin Lakes; Steamboat Springs.

2. Ranunculus unguiculatus Greene. In wet places in the mountains of Colo.-Alt. 9000-I2,000 ft.-Grand Mesa; Buffalo Pass; near Pagosa Peak; Deep Creek Lake, Garfield Co.; Rabbit-Ear Range, Routt Co.; Beaver Creek.

3. Ranunculus alismaefolius Geyer. ( $R$. calthaefolius Greene) In wet places from Wyo. to Nev,, Colo., Utah and Ore.-Alt. I0,000-I2,000 ft.Deep Creek Lake; Bear Creek Divide; Cameron Pass; Tennessee Pass; Golden; Berthoud Pass; headwaters of Clear Creek; alpine ridges east of Middle Park.

4. Ranunculus Macauleyi A. Gray. In wet places, among rocks, on alpine peaks of Colo.-Alt. I0,000-I2,000 ft.-Red Mountain; Carson; Pagosa Peak; West Spanish Peak; Bear Creek Divide; Hinsdale Co.

5. Ranunculus ellipticus Greene. ( $R$. glaberrimus Coulter, in part.) In wet places from Mont. to B. C., Colo. and Calif.-Alt. 5000-I2,000 ft.-Rist. Cañon; foot-hills, Larimer Co.; gulch west of Bellone; Dixon Cañon; foot of Horsetooth Mountain; Ft. Collins; Berthoud Pass.

6. Ranunculus cardiophyllus Hook. ( $R$. affnis cardiophyllus A. Gray) In wet meadows and bogs from Sask. to Colo.-Alt. 5000-10,000 ft.-Table Rock; gulch east of Stove Prairie; Campton's ranch, I2 miles below Grand Lake; Veta Pass; Twin Lakes; Tennessee Pass; Graham's Peak; divide between Colorado Springs and Denver; Eldora to Baltimore. 
7. Ranunculus inamoenus Greene. In meadows and along streams from Mont. to N. M. and Utah.-Alt. 7000-Io,000 ft.-Silverton; Boreas; Mancos; Breckenridge; Bob Creek; Veta Mountain; Cucharas River, above La Veta; Manitot: headwaters of Sangre de Cristo Creek; Los Pinos; West Indian Creek; Palsgrove Cañon; Grand Mesa; Caribou; Berthoud Pass; Eldora to Baltimore; Rabbit-Ear Range, Routt Co.

8. Ranunculus micropetalus (Greene) Rydb. ( $R$. affinis micropetalus Greene) In wet meadows and along streams from Colo. to Utah and Ariz.Alt. 7000-1I,000 ft.-Rico; Silverton; gulch east of Stove Prairie; Rabbit-Ear Pass; Chambers' Lake; Ironton Park, 9 miles south of Ouray; headwaters of Sangre de Cristo Creek; Iron Mountain; Cucharas Valley, near La Veta; West Spanish Peak.

9. Ranunculus affinis $\mathrm{R}$. Br. In alpine bogs and meadows from Sask. to Alaska and Colo.-Alt. 7000-12,00o ft.-Stove Prairie Hill; Boreas; West Indian Creek; Eldora to Baltimore.

Io. Ranunculus Eschscholtzii Schlecht. In wet alpine or subarctic localities from Wyo. to Alaska, Colo., Nev. and Wash.-Mt. Heseprus, at timber line; Mt. Barrett.

II. Ranunculus alpeophilus A. Nels. In wet places neat the snow from Mont. to Colo.-Alt. 9000-I2,000 ft.-Boreas; Trapper's Lake; Beaver Creek; Mt. Abram, Ouray; Alpine Tunnel; Tennessee Pass; Caribou; Berthoud Pass.

2. Ranunculus ocreatus Greene. In wet places on alpine peaks in Colo.Head of Leroux Creek, Delta Co.; Mt. Hesperus, at timber line; Mt. Abram, Ouray.

13. Ranunculus ovalis Raf. ( $R$. rhomboideus Goldie.) In meadows from Lab. to Athabaska, Que, and Colo--Alt. 4000-7500 ft.-Stove Prairie Hill; Table Rock; Cherry Creek, El Paso Co.

14. Ranunculus adoneus A. Gray. On alpine peaks from Wyo. to Colo. and Utah.-Alt. Io,000-I2,000 ft.--Mountains about Graymont; above Beaver Creek; above timber line, West Como Pass; Berthoud Pass; Georgetown; south fork of Cache la Poudre River; Cameron Pass; Ward, Boulder Co.; Spicer, Larimer Co.

I5. Ranunculus abortivus L. In woods and wet grounds from Lab. to Sask., Fla. and Colo.-Alt. 4000-8000 ft.-Rist Cañon; Pennock's mountain ranch; Walton Creek; Victoria; Clear Creek; Cucharas Valley, near La Veta; Cascade; Ft. Collins; Cameron Pass; Steamboat Springs.

16. Ranunculus micranthus Nutt. In rich woods from Mass. to Sask, Pa. and Colo.-Twin Lakes.

I7. Ranunculus sceleratus L. In swamps and ditches from N. B. to Wyo., Fla. and Colo.-Villa Grove.

18. Ranunculus eremogenes Greene. In swamps and on lake shores from Sask. to Alb., N. M. and Calif.-Alt. 4000-8000 ft.-Poudre, near La Porte; Ft. Collins; Montrose; Placer; near Boulder; Gunnison; Black Cañon; New Windsor; Arboles; Cucharas Valley, near La Veta.

I9. Ranunculus Douglasii Howell. ( $R$. tenellus Nutt.; not Viv.) On river banks and wet meadows from Mont. to Alaska, Colo. and Calif.-Alt. about 8500 ft.-Leroux Creek, Delta Co. 
20. Ranunculus Bongardii Greene. ( $R$. tenellus Lyallii A. Gray) Along streams from Mont. to Alaska, Colo. and Ore.-Near Wyoming line, North Park.

21. Ranunculus Earlei Greene. Along mountain streams in Colo.-Alt. up to Io,00o ft.-Gore Pass; Leroux Creek; Hotchkiss, Delta Co.; Mancos; Bob Creek.

22. Ranunculus acriformis A. Gray. Along streams in Wyo. and northern Colo.-Alt. up to $9000 \mathrm{ft}$.-Laramie River.

23. Ranunculus pennsylvanicus L. f. On river banks from N. S. to Ida., Ga. and Colo.-Alamosa.

24. Ranunculus Macounii Britton. Along streams and in wet places from Ont. to Alb., Iowa and Colo.-Alt. 4000-8000 ft.-Ft. Collins; Bear River; Steamboat Springs; Durango; bank of Michigan, Walden; New Windsor; Gunnison; Mancos; Middle Park; La Veta; Kremmling; Cucharas Valley, near La Veta; Routt Co.

25. Ranunculus Purshii Richardson. ( $R$. multifidus Coult., in part) In water and on muddy fiats from N. S. to Alaska, Ont., Colo. and Ore.-Alt. 400oIo,000 ft.-Laramie River; above Beaver Creek; Ft. Collins; bank of Michigan, at Walden; Front Range, Larimer Co.; Wahatoya Creek; Parlin, Gunnison Co.; stream I2 miles below Grand Lake; Gunnison.

26. Ranunculus intertextus Greene. ( $R$. hyperboreus natans Coult.; not Regel; $R$. natans A. Gray; not Meyer) In water in Wyo. and Colo.-Alt. 8000-Io,000 ft.-Vicinity of Como; Graymont; Georgetown; Breckenridge; Cassell's; South Park; Empire City.

\section{HALERPESTES Greene.}

I. Halerpestes Cymbalaria (Pursh) Greene. (Ranunculus Cymbalaria Pursh; Oxygraphis Cymbalaria Prantl) In wet and especially alkaline soil from Lab. to Alaska, N. J. and Calif.-Alt. 4000-I0,000 ft.-Ft. Collins; . Pueblo; Gypsum; Trail Creek; Graymont; Colorado Springs; Montrose; Grizzly Creek; Durango; Arboles; Sangre de Cristo Creek; Walsenburg; Parlin; Ouray; Palsgrove Cañon.

\section{I6. CYRTORRHYNCHA Nutt.}

Sepals broadly rounded-ovate, not clawed; petals usually wanting.

Sepals spatulate or obovate, clawed; petals usually present.

Leaf segments thick, mostly acute; panicle corymbiform.

Leaf segments thin, broad; inflorescence not corymbiform.

I. C. neglecta.

2. C. ranunculina.

3. C. rupestris.

1. Cyrtorrhyncha neglecta Greene. In the mountains of Colo.-Horsetooth Mountain; Golden City.

z. Cyrtorrhyncha ranunculina Nutt. In the mountains of Wyo. and Colo. -Alt. 6000-8000 ft.-Hills west of Soldier Cañon; Rist Cañon; foot-hills, Ft. Collins; Howe's Gulch, Larimer Co.; Spring Cañon; Horsetooth Mountain; Dixon Cañon; Green Mountain Falls; Ohio Creek.

3. Cyrtorrhyncha rupestris Greene. In the mountains of Colorado.-Black Cañon. 


\section{I7. THALICTRUM L. Meadow-Rue.}

Flowers perfect.

Plant $2 \mathrm{dm}$. or less high; achenes turgid; filaments filiform. I. T. alpinum.

Plant 3-Io dm. high; achenes flat and very oblique; filaments clavate.

Flowers dioecious or polygamous.

2. T. sparsiflorum.

Achenes turgid, thick-walled; ribs thick and almost corky, separated by acute grooves.

Plants polygamous; stem-leaves subsessile.

Achenes, petioles and lower surface of the leaves decidedly viscid-pubescent.

3. T. dasycarpum.

Achenes, petioles and the lower surface of the leaves glabrous or slightly viscid-puberulent.

Plants dioecious; stem-leaves petioled.

4. T. purpurascens.

5. T. venulosum.

Achenes more or less flattened, thin-wailed; ribs not thick, separated by wide shallow rounded grooves; achenes not twice as long as broad, decidedly oblique.

6. T. Fendleri.

I. Thalictrum alpinum L. In alpine and arctic bogs from Greenl. to Alaska, Colo. and Calif.-Alt. 9000-I2,000 ft.-Como; Alpine Tunnel; Seven Lakes; Tennessee Pass; near Wyoming line, North Park; Hamor's Lake, above Durango; West Indian Creek; Pike's Peak; headwaters of Clear Creek; alpine ridges east of Middle Park.

2. Thalictrum sparsiflorum Turcz. In wet ground from Mont. to Alaska, Colo. and Calif.-Alt. 6000-8500 ft.-Happy Hollow; near Georgetown; Carleton Lake; Parlin; Long Gulch, Larimer Co.; Minnehaha; headwaters of Clear Creek; Empire.

3. Thalictrum dasycarpum Fisch. \& Lall. In wet meadows from Ont. to Sask. and Colo.-Alt. 400o-8000 ft.-Ft. Collins; La Veta; New Windsor; bank of river, Larimer Co.; Wahatoya Creek; Pagosa Springs; Walsenburg.

4. Thalictrum purpurascens L. ( $T$. Cormeti Torr., in part; not L.) In wet meadows from N. S. to Sask., Fla. and Colo.-Alt, 4000-6000 ft.-Along the Poudre; Ft. Collins and La Porte; plains and foot-hills near Boulder.

5. Thalictrum venulosum Trelease. On hills and in open woods from Man. to B. C. and Colo.-Alt. 5000-I2,000 ft.-Dillon Cañon; Cache la Poudre; Gunnison; Estes Park; Cumberland Mine, La Plata Mountains.

6. Thalictrum Fendleri Engelm. In the mountains from Wyo. to N. M. and Ariz--Alt. 6000-10,000 ft.-Foot-hills, Larimer Co.; Dillon Cañon, Trinidad; gulch west of Pennock's; Livermore; Steamboat Springs; FourMile Hill, Routt Co. ; vicinity of Ouray; Villa Grove; Ute Pass; Dillon; foot of Pike's Peak; Veta Pass; West Indian Creek; North Cheyenne Cañon; Mancos; Silver Plume; Idaho Springs; Arboles; Pagosa Peak; Chicken Creek; Bob Creek; Colorado Springs; Turkey Creek; Sangre de Cristo Creek; Eldora to Baltimore.

\section{Family 55. NYMPHAEACEAE DC. Water-Lily Family.}

\section{NYMPHAEA L. YELLOW WATER-LILY.}

I. Nymphaea polysepala (Engelm.) Greene. In lakes and slow streams from Mont. to Alaska, Colo. to Calif.-Alt. up to I , ooo ft.-Chambers' Lake; Bierstadt Lake. 


\section{Family 56. BERBERIDACEAE. Barberry Family.}

Primary leaves of the shoots reduced to spines; in their axils short branches with secondary, unifoliate leaves.

Primary leaves of the shoots pinnate; no spines.

1. BERBERIS.

z. Odostemon.

\section{BERBERIS L. BARBERRY.}

I. Berberis Fendleri A. Gray. In the mountains of Colo. and N. M.-Alt. 6000-7000 ft.-Durango; Mancos; Arboles; Mancos Cañon.

\section{z. OdOSTEMON Raf. Oregon Grapes.}

Fruit becoming dry and inflated at maturity; leaflets less than $3 \mathrm{~cm}$. long; shrub r $5-36 \mathrm{dm}$. high. 1. O. Fremontii.

Fruit fleshy, not inflated at maturity; leaflets $3^{-6} \mathrm{~cm}$. long; shrub prostrate, I-3 dm. high.

2. O. Aquifolium.

1. Odostemon Fremontii (Torr.) Rydb. (Berberis Fremontii Torr.) In the mountains of Colo., Utah, N. M. and Ariz.-Smith Fork Cañon, Delta Co.

2. Odostemon Aquifolium (Pursh) Rydb. (Berberis Aquifolium Pursh; $B$. repens Lindl.) On hills from Mont. and Ida. to N. M. and Calif.-Alt. 4000Io,000 ft.-Vicinity of Horsetooth; Horsetooth Gulch; Rist Cañon; Clear Creek Cañon, above Golden; Platte Cañon; Ouray; Snake River; hills southeast of La Veta; East Indian Creek; Veta Mountain; cañon of La Plata River; foot-hills, Larimer Co.; about Ouray; Lake City; near Boulder.

\section{Order 26. PAPAVERALES.}

Sepals 2 or 3 ; endosperm present.

Flowers regular; stamens in ours numerous.

Flowers irregular; stamens 6 , diadelphous.

Sepals 4, rarely more; endosperm wanting.

Capsule 2-celled; stamens 6 , tetradynamous, rarely 2 or 4 .

Capsule I-celled; stamens not tetradynamous, 6 or more.

57. Papaveraceae. 58. FumariaceaE.

59. BRASSICACEAE.

6o. Capparidaceae.

\section{Family 57. PAPAVERACEAE Juss. Poppy Family.}

Capsule opening by many dentiform lids under the stigma; placentae ceptiform.

r. Papaver.

Capsule opening by $4^{-6}$ valves at the summit; placentae nerviform. 2. Argemone.

\section{PAPAVER L. POPPY.}

I. Papaver radicatum Rottb. ( $P$. alpinum and $P$. nudicaule A. Gray; not L.) In arctic regions and on alpine mountain tops from Greenl. and Lab. to Alaska and in Colo.; also in Europe.-Alt. I3,000-I4,000 ft.-Gray's Peak.

Corolla yellow.

2. ARgemone L. Prickly Poppy.

Corolla white.

I. A. mexicana.

Stem unarmed or prickly, but not hispid pubescent.

2. A. intermedia.

Stem hispid pubescent as well as spiny; leaf-blades deeply and usually doubly lobed.

3. A. hispida. 
I. Argemone mexicana L. Introduced from Mexico and sparingly established from N. J. to Fla. and N. M. It has been reported from Colorado, but doubtful.

2. Argemone intermedia Sweet. (A. platyceras Coult., in part) In sandy soil, on the plains and in the foot-hills, in cañons and draws from S. D. to Wyo., Tex. and Mex.-Alt. 4000-7500 ft.-Dixon Cañon; Spring Cañon; Trinidad; Manitou; Black Cañon; plains and foot-hills near Boulder; New Windsor; Ft. Collins.

3. Argemone hispida A. Gray. (A. bipinnatifida Greene) On sandy soil, on the plains and in the foot-hills, from Wyo. to Utah and N. M.-Alt. 4500$9000 \mathrm{ft} .-\mathrm{Ft}$. Collins; along Platte River, Denver; Huerfano Valley, near Gardner; Veta Pass; west of New Windsor; foot-hills, Colorado Springs; plains and foot-hills near Boulder; Redcliffe.

\section{Family 58. FUMARIACEAE. Fumi'lory Family.}

Capsule 2-valved, several-seeded.

Fruit globose, indehiscent, I-seeded.

1. Capnoides.

2. FUMARIA.

\section{CAPNOIDES Adans. CORYdalis.}

Annual or biennial; corolla yellow.

Bracts narrowly lanceolate; pod torulose, pedulous. 1. C. aureum.

Bracts ovate-lanceolate, ovate or obovate; pod erect on curved pedicels, not torulose.

2. C. montanum.

Perennials with thickened roots; corolla white or tinged with purple.

3. C. Brandegei.

I. Capnoides aureum (Willd.) Kuntze. (Corydalis aurea Willd.) Among bushes, in open woods and on hillsides, from N. S. to Alaska, Pa. and Calif. -Alt. 4000-10,000 ft.-Dillon Cañon, Trinidad; above Beaver Creek; Platte River Valley; Stove Prairie Hill; Trail Creek; near Boulder; mountains between Sunshine and Ward; Engelmann Cañon; Ouray; Villa Grove; Georgetown; river bank near Ft. Collins; West Indian Creek; Green Mountain Falls; Cucharas Valley, near La Veta; South Park; Manitou; West Mancos Cañon; Ward, Boulder Co.; Sapinero; Minnehaha; Marshall Pass; Pike's Peak; mountain sides near Empire; Ute Pass; Walden, Larimer Co.

2. Capnoides montanum (Engelm.) Britton. (Corydalis aurea occidentalis A. Gray; Capnoides pachylobum Greene) On river banks and in cañons from S. D. to Utah, Tex, and Ariz.-Alt. $4000-8000$ ft.-Trinidad; gulch west of Soldier Cañon; Horşetooth Gulch; foot-hills of Larimer Co.; Howe's Gulch; Los Pinos; hills southeast of La Veta; Arboles; near Boulder; Rist Cañon; Spring Cañon; Poudre flats; Trinidad; Manitou; mountains between Sunshine and Ward; New Windsor; Upper West Mancos Cañon.

3. Capnoides Brandegei (S. Wats.) Heller. (Corydalis Brandegei S. Wats.) In the mountains of Colo. and Utah.-Alt. 9000-Io,000 ft.-Leroux Creek; Crystal Creek; Ruby; near Pagosa Peak; Piedra Mountains.

\section{FUMARIA L. FUMITORY.}

1. Fumaria officinalis L. Introduced from Europe and established locally from N. S. to Fla., Colo, and Tex.-Ft. Collins. 


\section{Family 59. BRASSIACEAE Lind. Mustard Family.}

I. Pods sessile or short-stipitate (in two species of Thelypodium); sepals erect or conivent in anthesis; anthers not twisted (except in Thelypodium).

$A$. Pods compressed or flattened contrary to the narrow partition.

Pods not didymous; plants not densely stellate, except in Smeloziskya.

Pods orbicular, oval or cuneate, strongly flattened; plant not stellate.

Cells of the pod I-seeded.

Pods ovate-cordate, acute at the apex, neither winged nor retuse.

I. Cardaria.

Pods orbicular, elliptic or rarely ovate, retuse or notched at the apex, usually winged.

Cells of the pods 2 -seeded.

Pods more or less winged; cotyledons acumbent; hairs of the plant simple or none.

3. Thlaspi.

Pods cuneate, wingless; cotyledons incumbent; plants with branched hairs.

4. BURSA.

Pods ovate or lanceolate, not strongly flattened; plant stellate.

Pods more or less didymous; plants stellate.

5. Smelowskya.

Seeds solitary in each cell; pods strongly flattened. 6. DithyreA.

Seeds several in each cell; pods more or less inflated. 7. PhySARIA.

$B$. Pods neither compressed nor flattened contrary to the partition.

1. Anthers not sagittate at the base.

$a$. Pods terete or tetragonal.

Pods short, scarcely more than twice as long as broad, or less.

Cotyledons accumbent; valves of the pods nerveless.

Pubescence stellate; seeds flat.

Pubescence not stellate; seeds terete.

8. LESQUERELLA.

Cotyledons incumbent or folded transversely ; valves of the pod I-nerved; pubescence not densely stellate.

Pods long, several times as long as broad.

Pods scarcely beaked, merely tipped by a short style or a sessile stigma.

Pods terete or nearly so.

Seeds in two rows in each cell of the pod.

Valves of the pod nerveless; seeds globose or oblong, turgid; cotyledons accumbent.

Io. RORIPA.

Valves of the pods $I$-nerved; cotyledons at least partly incumbent.

Seeds flattened; leaves entire or toothed II. TLRritis.

Seeds turgid; leaves pinnatifid. I3. SopHIA.

Seeds in one row in each cell of the pod.

Glabrous perennials with creeping rootstocks.

More or less hairy annuals or perennials with tap-roots.

Pubescence of simple hairs; leaves runcinate or entire.

Pubescence of forked hairs; leaves pinnately dissected.

iza. Sisymbrium.

Pods 4-angled.

I3. Sophia.

Stem leaves clasping by a cordate base.

Stem leaves not clasping.

Corolla white.

Lorolla yellow.

Seeds plump; leaf-blades entire or toothed.

Seeds flat; leaf-blades pinnatifid.

23. Conringis.

I4. Stenophragma.

15. ERYSIMUM.

Pod with a long distinct beak.

I6. BARBAREA.

Beak flat and sword-like.

Beak elongated, conic or 4-angled.

I7. Sinapis.

I8. BRAsSicA.

$b$. Pod flattened parallel to the broad partition. 
Pod orbicular; valves convex, with flattened margins; filaments dilated and toothed near the base.

I9. Allyssum.

Pod oblong, ovate or linear, rarely nearly orbicular; valves flat, or if convex not with flattened margins; filaments unappendaged.

Valves nerveless.

Valves not elastically dehiscent; seeds in two rows; pod usually short. 20. Draba.

Valves elastically dehiscent; seeds in one row; pod long.

Valves nerved and reticulate, not elastically dehiscent.

2i. Cardamine.

Pod short, from orbicular to linear-oblong. 20. Draba.

Pods elongated-linear.

Cotyledons accumbent.

Cotyledons incumbent.

22. ARABIS.

23. Conringia.

2. Anthers sagittate at the base.

Calyx campanulate, open; petals ample.

Pod flat.

Pod terete or tetragonal.

24. Streptanthus.

Calyx urn-shaped, closed; blades of the petals narrow, undulate-crisp.

25. EukLisia.

II. Pod terete long-stipitate; sepals spreading in anthesis; anthers curved and spirally twisted. 27. Stanleya.

\section{CARDARIA Desv.}

1. Cardaria Draba (L.) Desv. (Lepidium Draba L.) Introduced from Europe; in waste places from Wyo. to Colo. and Calif.-Alt. $4000-5000 \mathrm{ft}$ Palisades; Grand Junction; near Boulder.

\section{LEPIDIUM L. PEPPER-GRASS.}

Style evident, at least equalling the wing-margins of the fruit.

None of the leaves pinnatifid.

Blades of the basal leaves truncate and 3 -toothed at the apex.

Blades of the basal leaves acute, serrate or crenate.

I. L. spatulatum.

2. L. crenatum.

Basal leaves at least pinnatifid.

Segments of the basal leaves short obovate or broadly oblanceolate in outline.

3. L. montanum.

Segments of the basal leaves elongated, linear, oblong or lanceolate.

Only the lowest leaves pinnatifid; pod broadly oval; style scarcely longer than the width of the wing-margin.

4. L. alyssoides.

Lower stem-leaves also pinnatifid; pod narrower, acutish at both ends; style about twice as long as the wing-margin.

Plant low, $3 \mathrm{dm}$. high or less; leaves or their lobes narrowly linear.

5. L. Jonesii.

Plant tall, $4^{-8} \mathrm{dm}$. high; upper leaves broadly linear or oblong.

6. L. Eastroodiae.

Style obsolete, at least much shorter than the wing-margin of the fruit, or stigma subsessile.

Petals conspicuous, at least equalling the sepals, spatulate or obovate.

Blades of the petals broadly obovate, much exceeding the sepals; style short.

Blades of the petals spatulate; style none.

7. L. idahoense.

Cotyledons accumbent; petals broadly spatulate.

Cotyledons incumbent; petals narrowly spatulate.

8. L. virginicum.

Stem glabrous or nearly so; petals well exceeding the sepal.

9. L. medium.

Stem glandular puberulent; petals about equalling the sepal.

ro. L. ramosum. 
Petals none or minute, scarcely more than half as long as the sepals, linear or linear-spatulate.

Plant branched at the base; petals often present.

Axillary racemes very short and dense, usually shorter than the leaves; petals more than half as long as the sepals. . II. L. ramosissimum. Axillary racemes at last elongated; petals very minute or none.

12. L. divergens.

Plant simple below, branched above; petals none; racemes elongated.

13. L. densiflorum.

I. Lepidium spathulatum (Robinson) Vasey. (L. scopulorum spathulatum Robinson) In the mountains of Colo.-Between Meeker and Craig; headwaters of Bear Creek.

2. Lepidium crenatum (Greene) Rydb. (Thelypodium crenatum Greene) In river valleys of Colo. and Utah.-Paonia; Mancos.

3. Lepidium montanum Nutt. In mountain valleys and on plains from Wyo' to Wash., Colo, and Ariz.; also in Mex.-Alt. 7000-Io,00o ft.-Pitkin; Lake City.

4. Lepidium alyssoides. A. Gray. In river valleys from Colo. to Tex. and Ariz.; also in Mex.-Alt. 5000-8000 ft.-Grand Junction; Conejos River, north of Antonito; Alamosa.

5. Lepidium Jonesii Rydb. In mountain valleys of Colo. and Utah.-Alt. 4000-7000 ft.-Palisades; Grand Junction; Spring Cañon; Montrose.

6. Lepidium Eastwoodiae Wooton. In river valleys of Colo. and N. M.Alt. 5000-9000 ft.-Glenwood Springs; Sangre de Cristo Creek; Pueblo Co.

7. Lepidium idahoense Heller. In sandy river valley in Ida. and Colo.Alt. up to $7000 \mathrm{ft}$.-South of Horsetooth Mountain; Spring Cañon; foot-hills, Larimer Co.

8. Lepidium virginicum L. In waste places from Que. to Minn., Fla. and Tex.-Alt. 7000-10,000 ft--Along the Conejos River, north of Antonito; Horsetooth Gulch; near Pagosa Peak.

9. Lepidium medium Greene. In waste places and on sandy soil from Mo. to Tex. and Calif.-Alt. 5000-7000 ft.-Grand Junction; gulch west of Pennock's; Reno; Larimer Co.; plains and foot-hills near Boulder; Lower Boulder Cañon.

I0. Lepidium ramosum A. Nels. In arid soil from S. D. to Wyo., Colo. and Utah.-Alt. up to Io,00o ft.-Vicinity of Como; Wolcott, Eagle Co.

II. Lepidium ramosissimum A. Nels. In arid soil from Neb. to Wyo. and Colo.-Alt. 4000-9000 ft.-Pitkin; plains, Colorado Springs. Pass.

12. Lepidium divergens Osterh. In the mountains of Colo.-Tennessee

I3. Lepidium densiflorum Schrad. (L. apetalum Aschers.; not Willd.; $L$. intermedium A. Gray) In waste places and sandy soil from Me. to Alb., DC. and Calif.-Alt. 4000-9000 ft.-Quimby; Ft. Collins; New Windsor, Weld Co.; plains, Larimer Co.; Arboles; chaparral-covered hills southeast of Ouray; Dix.

\section{THLASPI L. PENNY-GRASS.}

Pod orbicular in outline, broadly wing-margined and deeply notched at the apex.

I. T. arvense.

Pods obovate or cuneate in outline, with narrow margins, truncate or slightly notched at the apex. 
Pods emarginate; sinus narrow.

Rootstock rather slender; stem I-z dm. high; petals spatulate, about $5 \mathrm{~mm}$. long. $\quad$ 2. T. Nuttallii.

Rootstock stout, densely caespitose; stems less than $1 \mathrm{dm}$. high; petals broadly obovate, $6-7 \mathrm{~mm}$. long.

Pods truncate or nearly so at the apex; sinus broad and open.

Stem $2-3 \mathrm{dm}$. high; stem-leaves ample, broader than the basal ones; sepals green.

4. T. glaucun.

Stems I dm. high or less; stem-leaves reduced; sepals and often also petals purplish.

5. T. purpurascens.

I. Thlaspi arvense L. In waste places from Lab. to B. C., N. Y. and Colo. Introduced from Europe.-Alt. 5000-I0,000 ft.-Quimby; Silverton; plains and foot-hills near Boulder; Pass Creek.

2. Thlaspi Nuttallii Rydb. ( $T$. cochleariforme Nutt.; not DC.) Among rocks in the mountains from Mont. to Wash. and Colo.-Ait. 8000-I2,000 ft.Dead Lake; Minturn, Eagle Co.; Bob Creek; banks of Michigan Creek, near Teller; North Park.

3. Thlaspi coloradense Rydb. In wet places, among rocks, on the peaks, in Colo.-Alt. 6000-14,400 ft.-Foot-hills, Larimer Co.; Gray's Peak; along Beaver Creek; above timber line, west of Cameron Pass; Sierra Blanca; summit of Pike's Peak; Grand Mesa; west slope of Bald Mountain; Clear Creek; Red Mountain, south of Ouray; Seven Lakes; Los Pinos; Tennessee Pass; Cheyenne Mountain; West Spanish Peak; South Cheyenne Cañon; Massif de l'Arapahoe; Spicer, Larimer Co.

4. Thlaspi glaucum A. Nels. In mountain valleys and cañons from Ida. to Colo. and Utah.-Alt. 8000-13.000 ft.-Spring Cañon; Red Mountain; Pike's Peak Valley; Silver Plume; Gray's Peak; Bob Creek; Cameron Pass; Pass Creek; near Ironton, San Juan Co.; Rabbit-Ears, Larimer Co.

5. Thlaspi purpurascens Rydb. Among rocks, on the peaks of Colo. and Ariz.-Alt. 7000-I4,300 ft.-Gray's Peak; Cimarron; Spring Cañon; Horsetooth Gulch; gulch west of Dixon Cañon; Rist Cañon; Table Rock; Front Range, Larimer Co.; Dixon Cañon; headwaters of Sangre de Cristo Creek; Iron Mountain; Eldora to Baltimore.

\section{BURSA Weber. Shepherd's Purse.}

1. Bursa Bursa-pastoris (L.) Britton. In waste places and fields from Lab. to Wash. and Calif.-Alt. 4000-9000 ft.-Quimby; Table Rock; Ft. Collins; hills about Box Cañon, west of Ouray; Sangre de Cristo Creek; Mancos.

\section{SMELOWSIIA.}

Segments of basal leaves spatulate.

Segments of the basal leaves linear or linear-oblong.

1. S. americana.

2. S. lineariloba.

I. Smelowskia americana Rydb. (S. calycina B. \& H.; not C. A. Mey.) On the higher mountain tops from Mont. to Colo. and Nev.-Alt. I0,000I2,000 ft.-Cumberland Basin, La Plata Mountains; Devil's Causeway; mountain northwest of Como; Ragged Mountain, Gunnison Co.; Mt. Abram, Ouray.

2. Smelowskia lineariloba Rydb. On alpine peaks of Colo--Alt. I2,000I4,000 ft.-Douglass Mountain; Georgetown; Silver Plume; northwest of Como; near Ironton, San Juan Co.; Mt. Bartlett, Robinson. 


\section{DITHYREA Harv.}

1. Dithyrea Wislizeni Engelm. In dry regions from Tex and Colo. to Utah and Ariz.-Alt. 4500-6000 ft.-Valley of the San Juan (Brandegee).

\section{PHYSaRia A. Gray. Double Bladder-Pod.}

Pods deeply cordate at the base; lower sinus almost as deep as the upper.

1. P. didymocarpa.

Pods not cordate at the base or slightly so; lower sinus none or very shallow.

Basal leaves or at least some of them more or less fiddle-shaped.

Leaves of the decumbent flowering stems reduced; terminal lobe of the basal leaves rounded or reniform, very obtuse, entire. $\quad 2$. P. vitulifera.

Leaves of the ascending flowering stems ample; terminal lobe of the basal leaves rhombic or ovate, obtuse or acute, sinuate. 3. P. floribunda.

Basal leaves oblanceolate or spatulate, acute, not fiddle-shaped, $2-4 \mathrm{~cm}$. long. 4. P. acutifolia.

I. Physaria didymocarpa (Hook.) A. Gray. On dry hills from Sask. and Alb. to Colo. and Utah.-Alt. 5000-7000 ft.-Bluffs north of La Porte; Ft. Collins; Ruxton; Durango; Mancos.

z. Physaria vitulifera Rydb. In mountain valleys and cañons of Colo.Alt. 8000-10,000 ft.-Palisades; Idaho Springs; Grand Junction; headwaters of Clear Creek; alpine ridges east of Middle Park; Bear Creek Cañon.

3. Physaria floribunda Rydb. In mountain valleys of Colo.-Alt. 5000$9000 \mathrm{ft}$-Plains and foot-hills near Boulder; Wolcott; Veta Pass; Golden, Jefferson Co.; Cimarron; Sangre de Cristo Creek; Clear Creek Cañon; Hotchkiss; Eldora to Baltimore.

4. Physaria acutifolia Rydb. On dry hills in Wyo. and Colo.-Alt. 500oI0,500 ft.-Grand Junction; Ruxton Ridge; North Cheyenne Cañon; Steamboat Springs.

\section{LESQUerella S. Wats. Bladder-PoD.}

Ovary and pod stellate-pubescent.

Pods ovoid or ellipsoid.

Pods distinctly compressed and acute at the apex.

Pods 6-8 mm. Iong; plant usually over I dm. high.

Basal leaf-blades broadly oval; septum elliptic in outline; style equalling the pod in length.

I. L. Shearis.

Basal leaf-blades oblanceolate to obovate; septum ovate in outline; style much shorter than the pod.

Pods 3-5 mm. long; plant I dm. or less high.

2. L. curvipes.

Leaves narrowly linear-oblanceolate; plant pulvinate. 3. L. alpina.

Leaves narrowly linear; plant multicipital with a subterranean woody caudex.

4. L. parvula.

Pods not compressed above.

Basal leaf-blades rounded or broadly spatulate.

Stem-leaves small, generally less than I cm. long, linear-oblanceolate.

Stem-leaves oblanceolate to obovate, I-2 $\mathrm{cm}$. long.

5. L. prostrata.

Basal leaf-blades linear-oblanceolate.

6. L. montana.

7. L. arenosa.

Pods globose.

Stem very slender; stem-leaves oblanceolate, $\mathrm{I}-3 \mathrm{~cm}$. long.

Stem stouter, strict; stem-leaves linear, $2-6 \mathrm{~cm}$. long.

7. L. arenosa.

8. L. argentea.

Ovary and pod glabrous, globose. 
Basal leaf-blades oblanceolate.

Plant usually over $3 \mathrm{dm}$. high; flowers and fruit corymbose.

Plant usually less than $3 \mathrm{dm}$ high. inflorescence at least 9. L. Engelmanni. racemose. $\quad$ ro. L. stenophylla.

Basal leaves broadly oval.

I I. L. ovalifolia.

1. Lesquerella Shearis Rydb. On plains and foot-hills of Colo.-Alt. 500o$8000 \mathrm{ft}$-Botilder; Palmer Lake; Idaho Springs.

z. Lesquerella curvipes A. Nels. On dry hills from Mont. to Colo.-Alt. up to ro,ooo $\mathrm{ft}$.-C Como.

3. Lesquerella alpina ( $\mathrm{Nutt}$ ) S. Wats. (Vesicaria alpina Nutt.) Dry Hills from N. D. and Mont. to Colo.-Florence; North Park.

4. Lesquerella parvula Greene. On dry hills in Colo.-Mt. Bross, Middle Park.

5. Lesquerella prostrata A. Nels. In dry places, in the mountains, from Ass. to Colo-Alt. 5000-8000 ft.-Northern State line; mountain near Veta Pass; between La Veta and Gardner.

6. Lesquerella montana (A. Gray) S. Wats. (Vesicaria montana A. Gray) On hillsides and in the mountains from Wyo, to N. M.-Alt. 5000-II,000 ft. -Larimer Co.; Horsetooth Gulch; Palmer Lake; Fossil Creek; Ft. Collins; Rist Cañon, Larimer Co.; Salida; Mancos; Trinidad; mesas near Colorado Springs; river bluffs north of La Veta; Los Pinos; plains near Denver; hills southeast of La Veta; Manitou; Veta Pass; South Park.

7. Lesquerella arenosa (Richardson) Rydb. On dry hills from Sask. to S. D. and Colo.-Dolores.

8. Lesquerella argentea (Pursh) MacM. (Vesicaria Ludoviciana DC.) On plains and dry hills from Minn. to N. D., Kans, and Colo.-Wray; north of Craig, Routt Co.; Clear Creek; 25 miles below Manitou.

9. Lesquerella Engelmanni (A. Gray) S. Wats. On dry mesas from Kans. and Colo. to Tex. and N. M.--Pueblo.

10. Lesquerella stenophylla (A. Gray) Rydb. (Vesicaria stenophylla A. Gray and $V$. Fendleri, in part.) On dry mesas from Colo. to Tex. and N. M.; also in Mex.-Alt. 4000-5000 ft.-Florence; Swallow's, between Pueblo and Cañon City; mesas near Pueblo; Brantly Cañon, Las Animas Co.; Pueblo.

I1. Lesquerella ovalifolia Rydb. (L. ovata Greene.) On dry mesas and hillsides from Neb. to Colo. and Kans.-Alt. about I5oo m.-Mesas near Pueblo.

\section{IO. RORIPA ScOP. WATER-CRESS.}

Aquatics, usually immersed and rooting, with pinnate leaves and white petals. 1. R. Nasturtium.

Terrestrial or marsh plants with pinnatifid leaves and yellow petals (except in $R$. trachycarpa.

Perennials with rootstocks; petals much exceeding the sepals. Pods pappillose. Leaves thin; petals white; fruit recurved. Leaves thick; petals yellow; fruit erect. Pods not papillose.

Annuals or biennials.

Pods spherical to oblong-ellipsoid; in the latter case shorter than the pedicels. Pedicels 4-Io mm. long; pods $3-5 \mathrm{~mm}$. long (rarely $6-7 \mathrm{~mm}$. in $R$. palustris), I.5-2 $\mathrm{mm}$. thick. 
Stem more or less hirsute.

Stem glabrous.

Stem tall, 3-8 dm. high; stigma prominent, 2-lobed.

6. R. palustris.

Stem low, divaricately branched, I-3 dm. high; stigma scarcely thicker than the style.

Pedicels $2-5 \mathrm{~mm}$. long; pods globose.

5. R. hispida.

ods oblong to linear-cylindric, equalling or longer than the short pedicels.

Style about I mm. long.

Leaves nearly all pinnatifid with obtuse divisions. 9. $R$. obtusa.

Leaves mostly sinuate, or, if pinnatifid, with acute divisions.

Pods short, ellipsoid, straight on straight pedicels.

8. R. sphaerocarpa.

Pods elongated ovoid, curved on curved pedicels. xo. $R$. curvipes.

Style minute, $5 \mathrm{~mm}$. or less long.

Low, slender, less than $2 \mathrm{dm}$. high; leaves not auricled at the base.

II. R. lyrata.

Stouter, over $2 \mathrm{dm}$. high; petioles of the stem-leaves auricled at the base. I2. $R$. Underwoodii.

I. Roripa Nasturtium (L.) Rusby. (Nasturtium officinale R. Br.) In slow brooks and streams from N. S. to Wash., Va. and Calif.-Alt. I200$2800 \mathrm{~m}$--Along Poudre, Ft. Collins; Durango; plains and foot-hills near Boulder; about Ouray; swamp near Ft. Collins.

2. Roripa trachycarpa (A. Gray) Greene. (Nasturtium trachycarpum A. Gray) On river banks in Colo.-Alt. about $6000 \mathrm{ft} .-\mathrm{Walsenburg;} \mathrm{"South-}$ western Colorado."

3. Roripa calycina (Engelm.) Rydb. ( $N$. calycinum Engelm.) On sandy river bottoms from Mont. to Wash. and N. M.-Alt, about $5000 \mathrm{ft}$. Ft. Collins.

4. Roripa sinuata (Nutt.) A. S. Hitchc. (Nasturtium sinuatum Nutt.) On river banks and in wet ground from Minn. to Wash., Mo. and Ariz.Alt. 4000-8000 ft.-Ft. Collins; Horsetooth Gulch; Gunnison; New Windsor; mesas near Pueblo; Pike's Peak; near Boulder.

5. Roripa hispida (Desv.) Britton. ( $N$. hispidum Desv.) In swamps from N. B. to the Mackenzie and B. C., south to Fla. and N. M.-Alt. 4000-9000 ft.-Ft. Collins; Cache la Poudre banks; Quimby; plains and foot-hills near Boulder; Gunnison; Pass Creek.

6. Roripa palustris (L.) Bess. ( $N$. palustre DC.) In swamps from Lab. to B. C., Ga., N. M. and Nev.-Alt. up to Io,0oo ft.-Trapper's Lake; Durango; Twin Lakes.

7. Roripa alpina (S. Wats.) Rydb. (N. obtusum alpinum S. Wats.) In wet places in the mountains from Mont. and Ida. to Colo, and Utah.Ft. Collins; Poudre Cañon; Steamboat Springs; Fish Creek; Hotchkiss.

8. Roripa sphaerocarpa (A. Gray) Britton. ( $N$. sphaerocarpum A. Gray; $N$. obtusum sphaerocarpum S. Wats.) In wet places from Ills. to Wyo., Calif. and Ariz.-North Park, near Wyoming line; near Ironton, San Juan Co.

9. Roripa obtusa (Nutt.) Britton. On sandy beaches and river banks from Mich. to Wash., Tex, and Utah.-Alt. 4000-I0,000 ft.-New Windsor; Mt. Harvard; Massif de l'Arapahoe; Hotchkiss, Delta Co.

10. Roripa curvipes Greene. In wet places in mountain valleys of Colo. and Wyo.-Alt. 7000-8000 ft.-Squaw Hill, above Cimarron; Dale Creek, Larimer Co.; Gunnison. 
I Roripa lyrata (Nutt.) Greene. (N. lyratum Nutt.) In sandy wet soil from Mont. to Wash., Colo. and Calif.-New Windsor.

I2. Roripa Underwoodii Rydb. In wet places in the mountains of Colo.Alt. about II,ooo ft.-Red Mountain, south of Ouray.

\section{TURRITIS L.}

I. Turritis glabra L. (Arabis perfoliata Lam.) In waste places and on sandy soil from Que, and Alb. to Pa., Colo, and Calif.-Alt. 4000-900o ft.Middle Park; Mancos; near Pagosa Peak; Almelia; Hotchkiss; Platte Cañon; Steamboat Springs.

\section{I2. SCHOENOCRAMBE Greene.}

Leaves all linear, entire.

Plant decumbent, slender; pods ascending, more or less arcuate; style about I $\mathrm{mm}$. long.

I. S. decumbens.

Plant erect, stouter; pods erect or nearly so, straight; style obsolete, $0.5 \mathrm{~mm}$. or less long.

Some of the lower leaves pinnatifid.

2. S. linifolia.

3. S. pinnata.

I. Schoenocrambe decumbens Rydb. In dry places from Mont. to Colo. and Utah.-Alt. up to $7000 \mathrm{ft}$.-Gypsum.

2. Schoenocrambe linifolia (Nutt.) Greene. (Sisymbrium linifolium Nutt.) In dry places from Mont. to B. C., Colo. and Utah.-Alt. 5000-7000 ft.Cimarron; Arboles; Grand Junction.

3. Schoenocrambe pinnata Greene. On dry hills from Wyo. to Colo. and Nev.-Alt. about $7000 \mathrm{ft}$--Cimarron.

\section{I3. SisymbriUM L. Hedge Mustard.}

1. Sisymbrium officinale (L.) Scop. In waste places from Newf. to B. C., Fla. and Calif.; naturalized from Europe,-Platte near Denver (Eastwood).

\section{SOPHIA Adans. Herb-Sophia, Tansey-mustard.}

Pedicels ascending or spreading.

Pods linear, I mm. wide, somewhat curved; seeds in one row.

Pods 8-r $5 \mathrm{~mm}$. long; stem simple or with ascending branches.

Pods divergent; segments of the uppermost leaves often entire.

Pods ascending; segments of the leaves all sharply cut-lobed.

$$
\text { I. S. leptophylla. }
$$

\section{S. incisa.}

Pods 5-8 $\mathrm{mm}$. long; stem diffusely branched.

3. S. purpurascens.

Pods more or less clavate, 5-1 $2 \mathrm{~mm}$. long, $\mathrm{I}-2 \mathrm{~mm}$. wide; seeds usually in two more or less distinct rows.

Pods 8-I $2 \mathrm{~mm}$. long, mostly erect on spreading pedicels.

Leaves and stem green, only sparingly stellate.

Stem divaricately branched; branches making with the stem an angle of $45^{\circ}$ or more; pedicels 8-1o mm. long, usually shorter than the pods. 4. S. ramosa.

Stem simple or with erect or strongly ascending branches.

Petals much exceeding the sepals; terminal segments of the upper leaves usually elongated, linear, entire. 5. S. filipes.

Petals not much exceeding the sepals; terminal segment of the upper leaves not elongated.

Leaves and stem cinereous-stellate. 
Petals longer than the sepals, about $2 \mathrm{~mm}$. long; upper leaves mostly once pinnate, with elongated broad terminal segments.

7. S. andrenarum.

Petals not longer than the sepals, about $1.5 \mathrm{~mm}$. long; upper leaves usually more dissected; terminal segment narrow, not elongated.

Pods 5-8 mm. long.

Pods acute above, acuminate below; style obsolete.

Pods acuminate at both ends; style evident.

Pedicels erect.

Pods over T mm. thick.

Plant green and almost glabrous.

Plant cinereous-pubescent.

8. S. halictorum.

9. S. pinnata.

Io. S. procera.

Pods about .75 mm. thick; plant glandular puberulent, especially the inflorescence, or glabrous.

ro. S. procera.

II. S. brevipes.

1. Sophia leptophylla Rydb. In dry places from Wyo. and Ida. to Colo.Alt. about $6500 \mathrm{ft} .-F o o t-h i l l s$, Larimer Co.; Bosworth's ranch; Stove Prairie.

2. Sophia incisa (Engelm.) Greene. On hillsides from Wyo. to N. M.Alt. 600o-900o ft.-Walcott; Chicken Creek; Idaho Springs; southeast of La Veta; Mancos; west of Steamboat Springs; Horsetooth Gulch; Cimarron; Glenwood Springs, Garfield Co.

3. Sophia purpurascens Rydb. On mountain sides in Colo.-Alt. about II,ooo ft.-Known only from the type locality: Red Mountain, south of Otray.

4. Sophia ramosa Rydb. On mountain sides in Colo.-Alt. about $9000 \mathrm{ft.}$ Known only from Pitkin.

5. Sophia filipes (A. Gray) Heller. On hillsides from N. D. and Wash. to Colo.-Mancos.

6. Sophia intermedia Rydb. On hillsides and prairies and in sandy soil from Mich, and B. C. to Tenn. and Calif-Alt. 4000-900o ft.-Sangre de Cristo Creek; near Ironton, San Juan Co.; Buena Vista; Parlin; Mancos; plains near Denver; southeast and north of La Veta.

7. Sophia andrenarum Cockerell. On hillsides and in sandy valleys from Mont. and Wash. to N. M.-Alt. 4000-7000 ft.-Cañon City; Walsenburg; river bluffs north of La Veta; Cucharas Valley, near La Veta; Ft. Collins; New Windsor, Weld Co.; Los Pinos; near Poudre River; Antonito.

8. Sophia halictorum Cockerell. In sandy valleys from Colo. and Utah to Tex. and N. M.-Alt. up to $6000 \mathrm{ft}$.-Walsenburg.

9. Sophia pinnata (Walt.) Howell. In sandy soil from Va. and Colo. to Fla. and Ariz.-Alt. 4000-5500 ft.-Plains near Denver; mesas near Pueblo; Ft. Collins; Cache la Poudre; Lamar; Gypsum; New Windsor, Weld Co.

10. Sophia procera Greene. In sandy valleys from Wyo. to N. M. and Utah.-Alt. 7500-9000 ft.-Ironton Park, 9 miles south of Ouray; Box Cañon, west of Ouray; near Pagosa Peak; Tennessee Pass.

II. Sophia brevipes (Nutt.) Rydb. (Sisymbrium canescens brevipes Nutt.; S. incisum Hartwcgianum S. Wats.; (?) S. Hartwegianum Fourn.) In sandy valleys, among bushes, from Mackenzie to Minn. and Utah.-Mancos; east side Poudre River, above Ft. Collins; Middle Park.

12. Sophia glandulifera Rydb. In sandy places from Wyo. to N. M.La Veta. 


\section{STENOPHRAGMA Celac.}

I. Stenophragma virgata (Nutt.) Greene. (Sisymbrium virgatum Nutt.) In dry places in Wyo. and Colo.-Exact locality not given (Hall \& Harbour); McCoy's, Eagle Co.

\section{I6. ERYSIMUM L.}

Petals less than I cm. long.

Petals 3-5 mm. long.

Petals 8-Io mm. long.

1. E. cheiranthoides.

Petals over I $\mathrm{cm}$. long.

2. E. parvitlorum.

Petals light yellow.

Plants biennial or short-lived perennials; not cespitose.

Basal leaves, as well as the whole plant, grayish.

Pods widely spreading, $5-8 \mathrm{~cm}$. long, stout; stem-leaves usually sinuatedentate.

3. E. asperum.

Pods strongly ascending or almost erect, 8-12 cm. long.

Claws of the petals one-half longer than the sepals; stem-leaves broadly oblanceolate, usually sinuate-dentate.

4. E. elatum.

Claws of the petals scarcely exceeding the sepals; stem-leaves entire or nearly so.

Stem-leaves linear or nearly so; pods usually twisted.

Stem-leaves oblanceolate; pods straight.

5. E. asperrimum.

6. E. oblanceolatum.

Basal leaves, at least, silvery white; stem leaves narrowly linear.

Plants 2-3 dm. high; stem-leaves sinuate-dentate. 7. E. Bakeri.

Plants I-2 dm. high; stem-leaves entire.

8. E. argillosum.

Plants low cespitose perennials.

Leaves entire-margined or nearly so.

Leaves sinuate-dentate.

9. E. nivale.

Iо. E. radicatum.

Petals varying from orange to dark brown or purple.

Plant simple, 3-5 dm. high; basal leaves 5-10 $\mathrm{cm}$. Iong, oblanceolate.

Plant cespitose, I-2 dm. high; basal leaves $2-4 \mathrm{~cm}$. long, spatulate.

I I. E. Wheeleri.

I2. E. amoenum.

I. Erysimum cheiranthoides L. In waste places, on river banks and among bushes, from Newf. and Alaska to Tenn. and Utah.-Alt. 4000-9000 ft.Headwaters of Sangre de Cristo Creek; Middle Park; along the Poudre; Ft. Collins; Grizzly Creek; North Park; New Windsor, Weld Co.

2. Erysimum parviflorum Nutt. (E. inconspicuum (S. Wats.) MacM.) On hillsides from Minn. and Alb. to Colo. and Nev.-Alt. 5000-8000 ft.-Dix Post Office; Mancos; Durango; Ruxton.

3. Erysimum asperım DC. Dry plains and hills, Sask. to Ark. and Colo. -Alt. 4000-9500 ft.-Butte, 5 miles southwest of La Veta; mountains between Sunshine and Ward.

4. Erysimum elatum Nutt. On hills from N. D., Mont. and Wash. to Colo. and Calif.-Alt. up to $6000 \mathrm{ft}$--Foot-hills, Larimer Co.; Rist Cañon; Horsetooth Gulch; Quimby; Cucharas River, below La Veta; Horsetooth Gulch; Pike's Peak; Crystal Park; Camp Creek, Larimer Co.

5. Erysimum asperrimum (Greene) Rydb. (Cheiranthus asperrimus Greene) On hills from S. D. and Mont. to N. M. and Ariz.-Alt. 50009000 ft.-Sangre de Cristo Creek; Minnehaha; near Pueblo; Manitou; Williams' Cañon, above Manitou; Spring Cañon; Table Rock; Trinidad; Dixon Cañon; Howe's Gulch; Horsetooth Gulch; Rist Cañon. 
6. Erysimum oblanceolatum Rydb. In the mountains of Wyo. and Colo.Alt. 5000-II,000 ft.-Golden; near La Plata Post Office; Hamor's Lake, above Durango; Williams' Cañon; near Pueblo; Georgetown; Stove Prairie Hill; Cameron Pass; Dixon Cañon; plains and foot-hills near Boulder; Alpine Tunnel; Cimarron.

7. Erysimum Bakeri (Greene) Rydb. (Chieranthus aridus Greene; $C$. Bakeri Greene) On dry hills in Colo. and N. M.-Golden City.

8. Erysimum argillosum (Greene) Rydb. (C. argillosus Greene) On dry mesas and bluffs of Colo.-Alt. about $5000 \mathrm{ft}$-Pueblo; plains near Denver; bluffs north of La Porte.

9. Erysimum nivale (Greene) Rydb. (C. nivalis Greene) In the higher mountains of Wyo. and Colo.-Alt. II,000-13,000 ft.-Mountains northeast of Boreas; mountains above Graymont; mountain northwest of Como; above Ouray; Carson; Argentine Pass; Mt. Hesperus, above timber line; Slide Rock Cañon; West La Plata Mountains.

10. Erysimum radicum Rydb. On the higher peaks of Colo.-Alt. Io,oooI3,000 ft.-Pike's Peak; Bottomless Pit.

II. Erysimum Wheeleri S. Wats. (E. asperum alpestre Cockerell) On dry hills and plains in the mountains from Colo. and Utah to Tex. and Ariz. -Alt. 5000-I2,000 ft.-Mountains between Sunshine and Ward; plains and foot-hills near Boulder; East Indian Creek; Turkey Creek and tributaries; Veta Mountain; Ojo; west slope Bald Mountain; Slide Rock Cañon, West La Plata Mountains; foot-hills near Ft. Collins; mountains near Veta Pass; headwaters of Pass Creek; Horsetooth Gulch; Howe's Gulch; Montrose; Dillon Cañon; Chicago Lakes; near Boulder.

12. Erysimum amoenum (Greene) Rydb. (Cheiranthus nivalis amoenus Greene.) On the higher peaks of Colo.-Alt. I0,000-13,000 ft.-La Plata Mountains; Silverton; near Ironton, San Juan Co.; Mt. Abram; mountains near Ouray; Berthoud Pass.

\section{I7. BARBAREA L. WINTER-CRESS, Scurvy-GRASS.}

Pods sharply 4-angled, stout-pediceled; leaf-segments 4-8 pairs. 1. B. praecox. Pods obtusely 4-angled; leaf-segments $\mathrm{I}-4$ pairs.

¿. B. americana.

I. Barbarea praecox (J. E. Smith) R. Br. In waste places from N. Y. to Wash., Fla. and Calif.; sparingly introduced from Europe--Hotchkiss.

2. Barbarea americana Rydb. (B. vulgaris gracilis $\mathrm{S}$. Wats.; not $\mathrm{DC}$.) In rich soil from Sask, and Mont. to Colo. and Nev $\rightarrow$ Between Eldora and Baltimore.

\section{SiNAPIS L. White Mustard.}

I. Sinapis alba L. Introduced in grain fields and waste places from Me. to B. C. and Calif.-Ft. Collins.

19. Brassica L. Wild Mustard, Turnips, Cabbage.

Pedicels I-2 cm. long; plant glabrous.

Pedicels about $5 \mathrm{~mm}$. long; plant sparingly hispid.

1. B. juncea.

2. B. arvensis.

I. Brassica juncea (L.) Coss. Sparingly introduced from Europe; in waste places from N. H. to Colo., Va. and N. M.-Alt. about $8000 \mathrm{ft}$-Hills about Box Cañon, west of Ouray. 
z. Brassica arvensis (L.) B. S. P. (B. Sinapistrum Boiss.) Introduced from Europe and sometimes a troublesome weed in grain fields from Newf. to Alb. and Colo--Ft. Collins.

\section{ALYSSUM L.}

1. Alyssum alyssoides (L.) Gouan. ( $A$. calycinum L.) In fields and waste places and on hillsides from N. H. and Iowa to N. J. and Colo.; introduced from Europe.-Alt. about $5000 \mathrm{ft}$.-Boulder.

\section{DRABA L. WhITLOW-GRASS.}

Winter annuals or No. 7 sometimes perennial; style obsolete.

Pods hairy.

Flowers white; leaves all crowded on the lower part of the stem; racemes short on long naked peduncles.

Infiorescence even in fruit corymbiform; petals minute or none.

Inflorescence in fruit elongated; petals conspicuous. 2 2. D. coloradensis.

Flowers yellow or in age sometimes whitish; stem more or less leafy throughout.

Basal leaves obovate, ovate or oblong; stem-leaves ample; pedicels longer than the pods.

3. D. nemorosa.

Basal leaves oblanceolate or oblong; stem-leaves smaller, oblong-lanceolate; pedicels shorter than the pods. 4 4. D. montana.

Pods glabrous.

Stem more or less leafy.

Basal leaves obovate; stem-leaves several, broad. 5. D. lutea.

Basal leaves oblanceolate; stem-leaves very few and small.

6. D. nitida.

Stem scapiform or with d single leaf; leaves in basal rosettes.

Basal leaves oblanceolate or narrowly spatulate, hirsute.

7. D. crassifolia.

Basal leaves narrowly linear-oblanceolate, glabrous, except the very sparingly ciliate margins.

8. D. Parryi.

Perennials; style usually evident.

Plant scapose or nearly so; leaves ciliate on the margins.

Petals white.

Petals yellow.

9. D. Aladnizensis.

Stem leafy.

Petals white; leaves stellate; plant usually over $\mathrm{r} d \mathrm{dm}$. high.

Petals yellow.

$$
\text { Io. D. cana. }
$$

Plants glabrous, except the margins of the leaves, which are occasionally ciliate.

Leaves linear or narrowly linear-oblanceolate, thin.

Leaves much shorter than the flowering stems; pods lance-linear.

Leaves almost equalling the flowering stems; pods ovate.
I 2 . D. graminea.

I. D. chrysantha.

Leaves spatulate or broadly oblanceolate, thick. I3. D. crassa.

Plants decidedly hairy, at least on the stem.

Pubescence long-hirsute, with simple or slightly branched hairs.

Pubescence dense, mostly of branched or stellate hairs.

I 4. D. streptocarpa.

Styles I.5-2 mm. long; pods glabrous or slightly puberulent.

Pubescence rather sparse and minute; stem-leaves usually sharply toothed.

I5. D. spectabilis. 
Pubescence dense and grayish; stem-leaves entire-margined or minutely denticulate.

Style I mm. long; pod decidedly pubescent.

16. D. Helleriana.

Stem erect or nearly so.

Leaves thin; basal ones usually over $2 \mathrm{~cm}$. long; cauline ovate to lanceolate.

Petals $5 \mathrm{~mm}$. or more long; stem-leaves often dentate.

I7. D. luteola.

Petals 3-4 $\mathrm{mm}$. long; stem-leaves entire-margined.

I8. D. aureformis.

Leaves thick; basal ones I-2 cm. long; cauline lanceolate or oblong. I9. $D$. aurea.

Flowering stem decumbent; leaves finely stellate; pods twisted. 20. D. decumbens.

I. Draba micrantha Nutt. (D. caroliniana micrantha A. Gray) In arid soil from Ill. to Wash., Tex. and N. M.-Alt. 4000-6000 ft.-Mancos; Denver; foot-hills west of Ft. Collins.

2. Draba coloradensis Rydb. (D. cuneifolia Coult., in part; not Nutt.) On plains and hillsides of Colo.-Alt. 4000-5500 ft.-Hills west of Soldier Cañon; Ft. Collins; Mancos; foot-hills west of Ft. Collins; plains near Denver; near Boulder; New Windsor.

3. Draba nemorosa L. In dry places, often among grass, from Mich. to Mont., B. C., Colo. and Ore.-Alt. 4000-Io,000 ft.-Georgetown; mountain near Veta Pass; foot-hills west of Ft. Collins; headwaters of Sangre de Cristo Creek; Rist Cañon; Horsetooth Gulch; Poudre River; west of Soldier Cañon; Howe's Gulch; near Chambers' Lake; Parlin, Gunnison Co.; Middle Park; Georgetown.

4. Draba montana S. Wats. In the mountains of Colo--Alt. up to $2700 \mathrm{~m}$. -Ironton Park, 9 miles south of Ouray.

5. Draba lutea Gilib. ( $D$. nemorosa leiocarpa, in part) On hillsides from Hudson Bay to Alaska, Mich., Colo. and Ore.-Idaho Springs; Georgetown; Rabbit-Ear Range, Routt Co.

6. Draba nitida Greene. (D. stenoloba Wats. \& Brew.; not Ledeb.) On hillsides from Wyo. to Ore., Colo. and southern Calif.-Alt. 8000-II,000 ft.Near Teller, North Park; Tennessee Pass; Cameron Pass; mountains east of Cameron Pass; Grayback mining camps; Flat Top Mountains; Marshall Pass; Sargent's; South Park; near Chambers' Lake.

7. Draba crassifolia Graham. On exposed mountain-tops from Greenl. to B. C., Colo, and Utah.-Alt. I0,000-I4,000 ft.-Mountains northeast of Boreas; near Ironton, San Juan Co.; vicinity of Como; Leroux Creek, Delta Co.; Sierra Blanca; Massif de l'Arapahoe; summit of North Park Range, Larimer Co.

8. Draba Parryi Rydb. On alpine peaks of Colo. and Wyo.-Alt. 10,000I3,000 ft.-Foot of Gray's Peak; Cameron Pass; Cumberland Basin, La Plata Mountains; Red Mountain; Alpine Tunnel.

9. Draba fladnizensis Wulf. In arctic regions and on alpine peaks, on wet rocks, from Lab. and B. C. to Colo. and Utah.-Alt. about 13,000 ft.Gray's Peak trail; Gray's Peak; West Spanish Peaks; Parlin.

10. Draba cana Rydb. (D. incana confusa of Coult. Man.; not Poir.) In the mountains, among rocks, from Lab. and Yukon to Colo.-Alt. I1,000-I2,000 ft.-Massif de l'Arapahoe; northeast of Boreas; Red Mountain; Pike's Peak. 
II. Draba chrysantha S. Wats. On alpine peaks of Colo. and N. M.-Alt. 12,000-13,000 ft.-Gray's Peak.

12. Draba graminea Greene. On alpine peaks of Colo-_Alt. about 12,500 ft.-Telluride; Carson.

13. Draba crassa Rydb. On alpine peaks of Wyo. and Colo-Ait. 8000I2,500 ft.-Cumberland Mine, La Plata Mountains.

14. Draba streptocarpa A. Gray. On alpine peaks and rocky places in the higher mountains of Colo.-Alt. 6000-13,000 ft.-Pike's Peak; headwaters of Clear Creek; South Park; Gray's Peak; West Indian Creek; West Spanish Peak; near Colorado Springs; headwaters of Sangre de Cristo Creek; mountains near Veta Pass; North Cheyenne Cañon; Robinson; northwest of Como; east of Cameron Pass; Pennock's mountain ranch; Beaver Creek; Chambers' Lake; Crystal Park; Gentian Ridge; headwaters of Clear Creek and alpine ridges east of Middle Park; Gray's Peak; South Park; Empire; Eldora to Baltimore.

Draba streptocarpa Grayana Rydb. Alpine peaks of Colo.-Alt. I2,00013,000 ft.-Mountains northwest of Como; Gray's Peak trail.

I5. Draba spectabilis Greene. In the mountains of Wyo. and Colo.-Alt. 9000-12,000 ft.-Near Ironton, San Juan Co.; Cumberland Basin and Bob Creek, La Plata Mountains; Upper La Plata Cañon; Mt. Hesperus; mountains about Ouray; Red Mountain.

r6. Draba Helleriana Greene. (D. oxyloba Greene.) In the mountains of Colo. and N. M.-Alt. 8000-I0,000 ft.-Sargent's; Van Boxle's ranch, above Cimarron; Grayback Mining Camps; headwaters of Sangre de Cristo Creek; Ojo; Silverton.

I7. Draba luteola Greene. In the mountains of Colo.-Alt. 9000-I2,000 ft. -Cumberland Basin, La Plata Mountains; Idaho Springs; Upper Cañon of the La Plata; near Pagosa Peak; Eldora to Baltimore.

I8. Draba aureiformis Rydb. ( $D$. Bakeri Greene.) In the mountains of Colo. and the Black Hills of S. D.-Alt. 900o-II,000 ft.-Near Graymont; headwaters of Pass Creek; Carson; Palsgrove Cañon.

I9. Draba aurea Wahl. Among rocks in the higher mountains and in subarctic regions from Greenl. to B. C. to Colo, and Ariz.; also in northern Europe.-Alt. 9000-r3,000 ft.-Headwaters of Clear Creek; Massif de l'Arapahoe; Battlement Crag, Pike's Peak; Como; West Spanish Peak; near Ironton, San Juan Co.; between Bald Mountain and Seven Lakes; Dark Cañon; Cripple Creek road; vicinity of Como; Boreas; Silverton; Leroux Creek; Chambers' Lake; Graymont; Alpine Tunnel; Grand Lake; Mt. Abram, Ouray; Mt. Baldy; Mt. Garfield; Middle Park; Eldora to Baltimore.

20. Draba decumbens Rydb. Alpine peaks of Colo-Alt. I2,000-I3,000 ft. -Gray's Peak.

22. CARDAMINE L. BitTER-CRESS.

Leaves all entire; blades more or less cordate, dentate.

Plant glabrous or nearly so.

1. C. cordifolia.

Plant, at least the stem, densely pilose; leaves also hairy. 2. C. infausta.

Leaves, at least some of them, pinnate.

Petals about $5 \mathrm{~mm}$. long; leaflets $\mathrm{I}-7$; the terminal much larger, cordate, ovate or reniform, sinuately toothed.

Petals 2-4 mm. long; leaflets 5-I5, from linear to obovate.

3. C. vallicola. 
Plant perfectly glabrous; beak of the pod less than I mm. long.

4. C. pennsylvanica.

Plant more or less hairy, at least on the lower part of the stem or the base of the petioles; beak of the pod over r $\mathrm{mm}$. long.

5. C. acuminata.

I. Cardamine cordifolia A. Gray. In brooks and on shady banks from Wyo. to N. M. and Ariz.-Alt. 7500-II,000 ft.-Rico; Gore Pass; Graymont; Chambers' Lake; Villa Grove; mountains between Sunshine and Ward; Marshall Pass; cañons and adjoining meadows west of Ouray; Idaho Springs; Clear Creek; Ironton; Tennessee Pass; near Pagosa Peak; on Bob Creek, West La Plata Mountains; Como; Silver Plume; Gray's Peak; Ojo; Pass Creek; Caribou; Eldora to Baltimore; summit of North Park Range, Larimer Co.; Spicer.

2. Cardamine infausta Greene. (C. cardiophylla Rydb.) In brooks in Colo.-Alt. up to ro,000 ft.-Above Beaver Creek; Tennessee Pass.

3. Cardamine vallicola Greene. In shady wet woods and on river banks in Wyo. and Colo.-Alt. 5000-8000 ft.-Bank of Poudre River, Ft. Collins; Columbine; Dale Creek.

4. Cardamine pennsylvanica Muhl. On shaded banks from Newf. to Wash., Fla., Kans. and Ore.-Walton Creek; North Park.

5. Cardamine acuminata Nutt. On shaded banks from Mont. to Alaska, Colo. and Ore.-Alt. about $5000 \mathrm{ft}$.-Ft. Collins.

\section{ARABIS L. ROCK-CRESS.}

Pods erect or nearly so.

Leaves coarsely hirsute; the cauline ones cordate or auricled at the base.

Leaves not coarsely hirsute.

Pubescence if any sparse and consisting of 2 -forked hairs. Plant perfectly glabrous.

Lower leaves more or less hairy.

Lower leaves narrowly oblanceolate; cauline narrow and acuminate; pods about $1.5 \mathrm{~mm}$. wide. 3. A. oxyphylla.

Lower leaves spatulate; cauline not long-acuminate; pods about $2 \mathrm{~mm}$. wide.

Pubescence of the lower leaves distinctly stellate.

4. A. commixa.

Stem over $3 \mathrm{dm}$. high; basal leaves $3^{-10} \mathrm{~cm}$. long; petals purple. 5. A. oblanceolata.

Stem usually less than $3 \mathrm{dm}$. high; basal leaves $\mathrm{I}-2 \mathrm{~cm}$. long; petals white or pinkish.

6. A. Cyandalii.

Pods spreading or reflexed.

Leaves more or less stellate.

Leaves finely stellate without coarser simple hairs.

Stem 3-5 dm. high, branched; basal leaves oblanceolate, 5-10 cm. long, denticulate.

Stems I-4 dm. high, simple; basal leaves $\mathrm{I}-5 \mathrm{~cm}$. long.

Plant green, minutely stellate or sometimes glabrate; basal leaves usually entire.

Plant densely stellate; basal leaves dentate.

12. A. lignifera.

Petals about $8 \mathrm{~mm}$. long; sepals and upper leaves usually glabrous.

I3. A. rhodantha.

Petals about $6 \mathrm{~mm}$. long; sepals stellate; leaves usually all stellate.

Leaves hispid on the margins as well as stellate.
Leaves not stellate, perfectly glabrous or with ciliate margins.

8. $A$. consanguinea. 
Plants not densely cespitose; stem-leaves lanceolate-sagittate; basal leaves oblanceolate or spatulate. 10. A. divaricarpa.

Plants densely cespitose; stem-leaves oblong or lance-oblong, indistinctly auricled; basal leaves narrowly linear-oblanceolate. II. A. oxylobula.

I. Arabis ovata (Pursh) Poir. (A. hirsuta Hook., in part; not L.) In waste places and sandy or rocky soil from N. B. and Alb. to Ga. and Calif.Alt. 4000-10,000 ft.--Boulder Cañon; Mancos; Ojo; Cucharas River, below La Veta; Pagosa Springs; West Indian Creek; South Park; Chicken Creek, La Plata Mountains; North Cheyenne Cañon; Williams' Cañon; butte, 5 miles southwest of La Veta; foot-hills, Larimer Co.; Horsetooth Gulch; gulch south of Boulder; Spring Cañon; Moon's ranch; Dixon Cañon; gulch west of Soldier Cañon; Rustic; Cache la Poudre; South Park; Colorado Springs; Castle Cañon; Cimarron; Lake City; Eldora to Baltimore.

2. Arabis philonipha A. Nelson. On hillsides from Mont. and Wash. to Colo. and Utah.-Alt. up to $9500 \mathrm{ft}$.-Breckenridge; Villa Grove; mountains between Sunshine and Ward.

3. Arabis oxyphylla Greene. On hillsides and in cañons from Wyo. to Colo. and Utah.-Alt. 7000-II,500 ft.-Cucharas River, below La Veta; Chicken Creek, West La Plata Mountains; Hounold; Cripple Creek road; near Pagosa Peak; near Chambers' Lake; Carson; Cerro Summit; Van Boxle's ranch, above Cimarron; Dark Cañon; Alpine Tunnel; Empire; Camp Creek, and Beaver Creek, Larimer Co.

4. Arabis connexa Greene. In the mountains from Mont. to Colo. and Utah.-Alt. 9000-II,000 ft.-Lake City; near Pagosa Peak; headwaters of Sangre de Cristo Creek; Eldora to Baltimore.

5. Arabis oblanceolata Rydb. On mountains in Colo,-Alt. about Io,000 ft.-Valley Spur.

6. Arabis Crandalii Robinson. (A. stenoloba Greene) In the mountains of Colo.-Alt. about $7000 \mathrm{ft}$-Cimarron.

7. Arabis Selbyi Rydb. (A. recondita Greene, in part) On mountains of Colo.-Alt. 7000-9500 ft.-West of Ouray; Glenwood Springs (the last specimen included by Dr. Greene in $A$. recondita Greene, but does not agree with the description).

8. Arabis consanguinea Greene. In the mountains of Colo.-Alt. 7000-9000 ft.-Los Pinos; headwaters of Pass Creek; Van Boxle's ranch, above Cimarron.

9. Arabis Fendleri (S. Wats.) Greene. (A. Hoelboellii Fendleri S. Wats.) In the mountains of Colo. and N. M.-Alt. 7000-Io,000 ft.-Georgetown; Como; butte, 5 miles southwest of La Veta; Wahatoya Cañon; river bluffs north of La Veta; hilis southeast of La Veta; Mancos.

10. Arabis divaricarpa A. Nels. On dry hills from Ass. to Colo. and Utah. -Alt. 8000-9500 ft.-Mountains between Sunshine and Ward.

II. Arabis oxylobula Greene. In the mountains of Colo.-Leadville; Trapper's Lake; Glenwood Springs.

12. Arabis lignifera A. Nels. In the mountains of Wyo. and Colo.-Alt. about 8000 ft.-Columbine.

13. Arabis rhodantha Greene. In the mountains of Colo. and Utah.-Alt. up to 8000 ft.-Mancos; Ojo. 
24. CONRINGIA Heist.

1. Conringia orientalis (L.) Dum. Introduced from Europe; from Me. and Alb. to Del. and Colo.-Minnehaha.

\section{STREPTANTHUS Nutt.}

I. Streptanthus wyomingensis A. Nels. On dry hills of Wyo. and Colo.Alt. about 7000 ft.-Palisades, Mesa Co.; Cimarron; Glenwood Springs, Garfield Co.

26. EUKLISIA (Nutt.) Rydb.

Stem leaves oblong or ovate, with cordate base.

Leaves thick; sepals with bristles near the apex.

Leaves thin; sepals without bristles.

Stem leaves linear.

I. E. crassifolia.

2. E. cordata.

3. E. longirostris.

1. Euklisia crassifolia (Greene) Rydb. (Streptanthus crassifolius Greene) On dry hills from Colo. to Utah, N. M. and Ariz.-Alt. about $7000 \mathrm{ft}$ Grand Junction; Cimarron.

2. Euklisia cordata (Nutt.) Rydb. (Streptanthus cordatus Nutt.) On dry hilis from Wyo. to Colo. and Utah.-McCoy's, Eagle Co.; Mesa Verde.

3. Euklisia longirostris (S. Wats.) Rydb. (Arabis and Streptanthus longirostris S. Wats.) In valleys from Wyo. to Utah, N. M. and Ariz.-Palisades.

\section{THELYPODIUM Endl.}

Plant glabrous or with simple hairs.

Upper leaf-blades auricled at the base.

Petals rose-color, purplish or white.

Pods 7-10 cm. long.

I. T. elegans.

Pods $3-5 \mathrm{~cm}$. long.

Stem-leaves lanceolate-sagittate; petals rose or purplish.

Stem-leaves ovate-sagittate; petals white or straw color.

2. T. paniculatum.

Petals bright yellow.

3. T. Bakeri.

Upper leaf-blades attenuate at the base.

4. T. aureum.

Some of the leaves sinuately toothed or laciniate.

Pedicels slender, 6-15 mm. long; upper leaves entire or slightly toothed; pods divergent. 5 5. T. Wrightii.

Pedicels short and stout, $2-5 \mathrm{~mm}$. long; most of the leaves laciniate; pods reflexed. 6 . T. utahensis.

Leaves all entire or the lower sometimes repand.

Inflorescence dense; stigma truncate; lower leaf-blades obovate or oblanceolate.

Inflorescence very short; stipes I $\mathrm{mm}$. long; pod rather stout.

7. T. integrifolium.

Inflorescence more elongated; stipes $2-3 \mathrm{~mm}$. long; pod very slender.

8. $T$, gracilipes.

Inflorescence very slender and lax; stigmas conical; leaves all linear.

Plant pubescent with branched hairs.

9. T. linearifolium. I0. T. micranthum.

I. Thelypodium elegans M. E. Jones. On adobe plains in Utah and Colo. -Southwestern Colorado. 
2. Thelypodium paniculatum A. Nels. (T. sagittatum Endl.; T. torulosum Heller) On dry hills from Mont. to Colo, and Utah.-Alt. 7000-9500 ft.On Grizzly Creek; Pearl North Park; Canadian River.

3. Thely podium Bakeri Greene. On dry hills in Colo.-Alt. about $7000 \mathrm{ft}$. -Cimarron.

4. Thelypodium aureum Eastw. On dry hills in Colo.-Alt. about $5000 \mathrm{ft}$. Durango.

5. Thelypodium Wrightii A. Gray. In the mountains of Colo, Utah, N. M. and Ariz.-Durango; Glenwood Springs, Garfield Co.

6. Thelypodium utahense Rydb. In river valleys of Colo, and Utah.Minturn, Eagle Co.

7. Thelypodium integrifolium (Nutt.) Endl. ( $T$. lilacinum Green.) On plains and in river-valleys from Mont. to Wash., Neb. and Calif.-Alt. 40008000 ft.-Miller's ranch; Ft. Collins; Poudre Cañon; Villa Grove; meadows, Lake John, Middle Park; New Windsor, Weld Co.; Doyle's; Hayden, Routt Co.

8. Thelypodium gracilipes (Robinson) Rydb. In valleys of Colo.-Alt. about $7000 \mathrm{ft}$.-Durango.

9. Thelypodium linearifolium (A. Gray) S. Wats. In river valleys and on hillsides from Colo. to Tex. and Ariz.; also in Mex.-Alt. 8000-9000 ft.Sangre de Cristo Creek.

ro. Thelypodium micranthum S. Wats. Rocky hills from western Tex. and Colo. to Ariz. and Mex.-Alt. about $7000 \mathrm{ft}$.-Manitou.

\section{STANLEYA Nutt.}

Blades of the petals linear-oblong to elliptic; flowers bright yellow.

Blades of the petals one-third to one-half as long as the claws.

Pod decidedly tortuose.

Pod arcuate, not tortuose.

I. S. bipinnata.

2. S. glauca.

Blades of the petals about as long as the claws.

Leaf-blades broadly lanceolate, the lower with short, broad lobes; blades of the petals oblong; pod ascending.

3. S. integrifolia.

Leaf-blades linear-lanceolate, all often entire; blades of the petals broadly elliptic; pod recurved.

Blades of the petals rounded oval; flowers ochroleucous.

4. S. arcuata.

5. S. albescens.

I. Stanleya bipinnata Greene. In dry places of Wyo. and Colo.-North Fork, Larimer Co.

2. Stanleya glauca Rydb. In dry soil from N. D. to Wyo., Colo. and Utah. -Alt. 4000-8000 ft.-Entrance of Soldier Cañon to Sulphur Springs; north of Ft. Collins; Arkansas River; Cedar Hills; Ft. Collins; Florence; Dixon Cañon; Spring Cañon; near Badito, between La Veta and Gardner; Mancos; McElmo Cañon; Garden of the Gods; Pueblo; Pike's Peak.

3. Stanleya integrifolia James. (S. pinnatifida integrifolia Robinson) In dry soil from S. D. to Wyo., Kans, and Colo.-Alt. $4000-7000$ ft.-Hochkiss, Delta Co. ; Cimarron.

4. Stanleya arcuata Rydb. In dry soil from Wyo, to Nev., Colo. and Calif. -Grand Junction.

5. Stanleya albescens Jones. On river banks in western Colo, and N. M. -Along Gunnison River, above Delta; Grand Junction. 
Family 60. CAPPARIDACEAE Lindl. Caper Family.

Pods elongated; receptacle with an appendage or gland.

Appendage tubular; petals cuneate-flabelliform, laciniate, very unequal.

i. Cristatella.

Appendage solid; petals entire, emarginate or 3 -toothed, but not laciniate.

Stamens I 2-24; capsule sessile or short stipitate.

2. Polanisia.

Stamens 6 ; capsule long-stipitate.

3. Peritoma.

Pods short, broader than long, more or less flattened contrary to the partition; receptacle without appendage.

4. Cleomelia.

\section{CRISTATELLA Nutt.}

r. Cristatella Jamesii T. \& G. In sandy soil from Neb. and Colo. to Tex. -Sterling, Logan Co.

\section{POLANISIA Raf.}

I. Polanisia trachysperma T. \&. G. In sandy soil from Ass. to Tex. and Nev.-Alt. $4000-7000$ ft.-Cañon City; plains and foot-hills near Boulder; New Windsor, Weld Co.; Ft. Collins; Salida; Howe's Gulch; Mason's riverfront farm; Rocky Ford; Soldier Cañon; Poudre Cañon.

Petals yellow.

3. PERITOMA DC.

Petals purple, pink or white.

Petals 8-I $2 \mathrm{~mm}$. long, tusually 3 -toothed.

Stamens exserted; petals usually rose color or purplish. $\quad$ 2. $P$. serrulatum.

Stamens included; petals white,

Petals about $4 \mathrm{~mm}$. long, entire.

3. $P$. inornatum.

4. P. Sonorae.

I. Peritoma luteum (Hook.) Greene. (Cleome lutea Nutt.) In sandy soil from Wyo, and Wash. to Colo., Ariz. and Ore.-Alt. 4000-8000 ft.-Grand Junction; Cimarron and Squaw Hill; Gunnison Valley, above Delta.

«. Peritoma serrulatum (Pursh) DC. (Cleome serrulata Pursh.) In valleys, especially in light or sandy soil, from Sask, and Ida. to Mo. and Ariz. -Alt. 4000-9000 ft.-Boulder; Colorado Springs; Gunnison; Sapinero; Durango; Manitou; along Uncompahgre River, near Ouray; Crow Creek; along Platte River, Denver; Ft. Collins; Poudre flats, north of Ft. Collins; Trinidad; near Badito, between La Veta and Gardner; Sangre de Cristo Creek; Redstone; Pueblo; Dixon Cañon; Ft. Collins; Cache la Poudre; Walsenburg; Manitou.

3. Peritoma inornatum Greene. In dry soil in western Colo.-Grand Junction.

4. Peritoma Sonorae (A. Gray) Rydb. (Cleome Sonorae A. Gray.) In saline soil from Colo. to N. M. and Sonora.-Alt. $4000-5000 \mathrm{ft}$.-Saguache; San Luis; Alamosa.

\section{CLEOMELIA DC.}

Capsule rhomboidal with more or less distinct conical or horn-like projections; stipe shorter than the pedicels; style obsolete; seeds rugulose.

I. C. angustifolia.

Capsule obscurely rhomboidal, merely gibbous on the back; stipe equalling the pedicels; style conspicuous; seeds smooth and shining.

2. C. oocarpa. 
1. Cleomella angustifolia Torr. In valley, especially in sandy or alkaline soil, from Neb. and Utah to Tex.-Headwaters of Clear Creek; Julesburg. z. Cleomella oocarpa A. Gray. In alkaline plains and desert regions from Colo. to Calif.--Mesa Verde, about Rio Mancos (Brandegee).

\section{Order 27. ROSALES.}

Flowers regular or nearly so (actinomorphic).

Endosperm present usually copious and fleshy; stipules mostly wanting.

Herbs.

Carpels as many as the sepals; succulent plants.

Carpels fewer than the sepals; plant scarcely succulent.

Staminodia wanting; carpels 2 or rarely 3 , distinct or only partly united.

Fam. 62. Saxifragaceae.

Staminodia present; carpels 3 or 4 , wholly united into a I-celled gynoecium.

Shrubs or trees.

Fam. 63. Parnassiaceae.

Leaves opposite; fruit a leathery capsule, more or less adnate to the hypanthium; stipules wanting.

Fam. 64. Hydrangiaceae.

Leaves alternate.

Fruit thin-walled follicles, free from the hypanthium; stipules present (Opulaster in)

Fam. 66. Rosaceae.

Fruit a berry; hypanthium adnate to and prolonged beyond the ovary.

Endosperm wanting or scant; stipules mostly present.

Carpels several or numerous, or, if solitary, becoming an achene.

Carpels distinct, free from the hypanthium; fruit achenes, follicles or drupelets.

Fam. 66. Rosacear.

Carpels united, enclosed by and adnate to the hypanthium; fruit a pome.

Carpel solitary, not becoming an achene.

Fam. 67. MaLACEAE.

Ovary 2-ovuled; fruit a drupe; leaves simple. Fam. 68. Amygdalaceae.

Ovary several-ovuled; fruit a legume; leaves pinnately compound.

Fam. 69. Mimosaceae.

Flowers irregular (mostly zygomorphic).

Upper petal enclosed by the lateral ones in the bud; corolla not papilionaceous.

Fam. 70. CASSIACEAE.

Upper petal enclosing the lateral ones in bud; corolla papilionaceous.

Fam. 7 I. Fabaceae.

\section{Family 6r. CRASSUlaceae DC. Orpine Family.}

Stamens as many as the sepals; minute herbs.

1. Tillaeastrum.

Stamens twice as many as the sepals; succulent herbs.

Flowers axillary in dense congested racemes; petals rose-colored.

Flowers terminal, arranged in one-sided raceme-like branches.

2. Clementsia.

Carpels erect; flowers polygamous or dioecious; petals in ours purplish.

3. RHODIOLA.

Carpels spreading; flowers perfect; petals in ours yellow. 4. SEDUM.

i. TILlaEAstrum Britton. Pigmy-Weed.

I. Tillaeastrum aquaticum (L.) Britt. (Tillaea aquatica L.; T. augustifolia Nutt.) On muddy shores from N. S. and Wash. to Md., La. and Lower Calif.-Alt. up to Io,000 ft.-Twin Lakes. 


\section{Clementsia Rose. Red Orpine.}

I. Clementsia rhodantha (A. Gray) Rose. (Sedum rhodanthum A. Gray) In meadows and along streams from Mont. to Colo. and Ariz.--Alt. Io,000I3,000 ft.-Gray's Peak; headwaters of Clear Creek; Caribou; Pike's Peak; Gore Pass; Cameron Pass; Pagosa Peak; Villa Grove; Dark Cañon; Marshall Pass; near Georgetown; Twin Lakes; Chambers' Lake; Berthoud Pass.

\section{RHODIOLA L. ROSE-ROOT, ROSE-WORT.}

Flowers dioecious; carpels $3-5 \mathrm{~mm}$. Iong, abruptly contracted into a short divergent or reflexed beak.

Flowers polygamous; carpels $6-8 \mathrm{~mm}$. long, gradually tapering into a long ascending beak.

4. R. polygama.

1. Rhodiola integrifolia Raf. (Sedum rhodiola Coult., in part; not DC.; Sedum frigidum Rydb.) On high alpine peaks from Alb. and Alaska to Colo, and Calif.-Alt. 9000-I4,000 ft.-Pike's Peak; Mount Garfield; Grayback mining camps; West Spanish Peak.

๘. Rhodiola polygama (Rydb.) Britt. \& Rose. (Sedum polygamum Rydb.) On alpine peaks of Colo. and N. M.-Alt. 9000-13,000 ft.--Engineer Mountain; headwaters of Clear Creek; Carson; Basin Creek, La Plata Mountains; Mount Hesperus; near Ironton; Pike's Peak; Chambers' Lake; Mt. Lincoln; West Spanish Peak; South Park; Leroux Park; Estes Park; Bethoud Pass.

\section{SEDUM L. StOne-Crop, OrPine.}

1. Sedum stenopetalum Pursh. On dry rocky or gravelly hills from Alb. and B. C. to N. M. and Calif.-Alt. 4000-12,000 ft.-Gray's Peak; Pike's Peak; Clear Creek Cañon; Colorado Springs; headwaters of Clear Creek; Cameron Pass; Larimer Co.; Hamor's Lake; Bald Mountain; Mt. Garfield; Grayback mining camp; Silver Plume; Morrison; Telluride; Minnehaha; Cimarron; Denver; West Spanish Peak; Ft. Collins; Ironton; Green Mountain Falls; Howe's Gulch; mountains southeast of Cameron Pass; forks of Poudre and Big South; gulch west of Pennock's; Horsetooth Gulch; near Narrows; Dixon Cañon; Table Rock; mountains between Sunshine and Ward.

\section{Family 62. SAXIFRAGACEAE Dumort. Saxifrage Family.}

Placentae parietal, sometimes nearly basal.

Flowers solitary and axillary to leaf-like bracts, or $2-$ in small corymbs, each subtended by a leaf-like bract.

1. Chrysosplenium.

Flowers in more or less elongated racemes or panicles.

Flower-stalk axial from a slender bulbiferous rootstock; gynoecium 3-carpellary. $\quad 2$. Lithophragma.

Flower stalks a lateral shoot from a stout scaly rootstock; gynoecium 2-carpellary.

Inflorescence racemose.

Petals pinnately cleft or pinnatifid.

Petals entire, toothed or 3 -cleft above.

3. Pectiantia.

Placentae axial.

5. Heuchera. 
Hypanthium well developed and accrescent, at maturity longer than the sepals. Stamens 5; sepals imbricated; petals marcescent. 6. Sullivantia.

Stamens Io; petals not marcescent.

Petals clawed; styles partially united; plants with thick rootstocks.

Petals clawless; styles distinct; plants with slender rootstocks or with
Pecks ofisets.

Plants without caudices, only producing annual flowering stems.

8. SAXIFRAGA.

Plants with perennial, very leafy caudices, often with offsets; the flowering stems very different.

g. Muscaria.

Hypanthium only slightly developed, unchanged at maturity, or if slightly accrescent flat and plants acaulescent.

Plants acaulescent.

Corolla essentially regular, the petals about equal in shape and length. io. Micranthes.

Corolla irregular, 3 petals with blades of an ovate or lanceolate type and 2 narrower and longer.

Plants caulescent. i i. Spatularia. I2. Leptasea.

\section{ChRysosplenium L. Golden Saxifrage.}

1. Chrysosplenium tetrandrum Fries. In wet places from Greenl. and Alaska to Alb. and B. C.; also in Colo, and northern Europe-CUper Platte (Hall \& Harbour).

\section{¿. LITHOPHRAGMA Nutt.}

Hypanthium campanulate, with a rounded base, adnate only to the base of the ovary.

Stem-leaves rarely bulbiferous in the axils; stipules long and narrow ; free portion triangular or lanceolate, not fimbriate.

1. L. australis.

-Stem-leaves usually bulbiferous in the axils; stipules short and broad; free portion round and fimbriate.

c. L. bulbifera.

Hypanthium turbinate or obconic, adnate to the lower half of the ovary.

3. L. parviflora.

I. Lithophragma australis Rydb. In sandy mountain valleys and hillsides from Wyo. and Utah to N. M. and Ariz.-Alt. 7000-9000 ft.-Platte Cañon; headwaters of Sangre de Cristo Creek; Van Boxle's ranch, above Cimarron.

2. Lithophragma bulbifera Rydb. (Tellima tenella S. Wats.) On hillsides from the Black Hills of S. D., Mont. and B. C. to Colo. and Calif.-Alt. up to II,ooo ft.-Tennessee Pass.

3. Lithophragma parviflora (Hook.) Nutt. (Tellima parviflora Hook.) In rocky and gravelly places from Alb. to B. C., Colo. and Calif.-Locality not given.

\section{Pectianthia Raf. Mitre-wort.}

I. Pectianthia pentandra (Hook) Rydb. (Mitella pentandra Hook.) In springy places in the woods and along streams, from Alb. and Alaska to Colo. and Calif.-Alt. 8000-12,000 ft.-Beaver Creek; Marshall Pass; Red Mountain; Slide Rock Cañon; Empire; Estes Park; Berthoud Pass; Cameron Pass; Ruby; Damfino Creek; headwaters of Clear Creek and alpine ridges east of Middle Park; Empire; Caribou; Golden. 


\section{OZOMELIS Raf. Mitre-WORT.}

Petals 3 -fid to the middle; hypanthium with the sepals $3-5 \mathrm{~mm}$. long.

I. O. stauropetala.

Petals entire or 3 -fid only at the apex; hypanthium with the sepals $1.5-3 \mathrm{~mm}$. long. Hypanthium with the sepals $z-3 \mathrm{~mm}$. long; leaf-blades indistinctly lobed and with shallow crenulations; petals often entire. 2. O. stenopetala.

Hypanthium with the sepals I.5-2 mm. long; leaf-blades distinctly lobed and deeply crenate; petals 3 -cleft.

3. O. Parryi.

I. Ozomelis stauropetala (Piper) Rydb. (Mitella stauropetala Piper; $M$. trifida Coulter, in part.) In springy places in the woods from Mont. and Wash. to Colo. and Ore.-Alt. about ro,00o ft.-Mt. Hesperus.

2. Ozomelis stenopetala (Piper) Rydb. (Mitella stenopetala Piper) In springy places in Utah and Colo.-Alt. 8000-10,000 ft.-Mt. Hesperus; Eldora to Baltimore.

3. Ozomelis Parryi (Piper) Rydb. (Mitella stenopetala Parryi Piper) Mountains of Wyo. and Colo.-Alt. about $9500 \mathrm{ft}$-Trapper's Lake.

\section{HEUChERA L. ALUM-Root.}

Stamens equalling or exceeding the sepals.

Panicle open, not spike-like; plant tall; hypanthium very oblique.

I. H. hispida.

Panicle contracted, dense, spike-like; plant low; hypanthium not very oblique.

Stamens much shorter than the sepals.

2. $H$. bracteata.

Hypanthium campanulate, yellowish or pinkish; sepals almost erect.

Hypanthium saucer-shaped, greenish; sepals spreading.

3. H. Hallii.

4. $H$. parvifolia.

I. Heuchera hispida Pursh. In woods and on hillsides, Ont. to Ass., Va. and Colo.-Edgerton.

2. Heuchera bracteata (Torr.) Ser. On rocky ridges in Colo. and northern Wyo--Ait. 6000-I0,000 ft.-Rist Cañon; Grand Lake; Georgetown; Andrew's Shetland ranch; foot-hills, Larimer Co.; Gray's Peak; North Cheyenne Cañon; Boulder Cañon; road between Denver and Idaho City; Horsetooth Mountain; mountains between Sunshine and Ward; Eldora to Baltimore; Berthoud Pass; between Denver and Idaho City; Golden; Empire.

3. Heuchera Hallii A. Gray. On rocky ridges in Colo.-Alt. 7000-12,000 ft. -Mt. Garfield; Cameron's Cone; Pike's Peak; Rock Mountain Pass; Georgetown; Ruxton; Pike's Peak; Cheyenne Mountain; Bald Mountain; Grand Cañon of the Arkansas; Graymont.

4. Heuchera parvifolia Nutt. On hills from Alb. and Ore, to N. M. and Ariz.-Alt. 6000-13,000 ft.-Mt. Abram, Ouray; foot-hills, Larimer Co.; Cameron Pass; Howe's Gulch; Minnehaha; Marshall Pass; Colorado Springs; Douglass Mountain, Georgetown; Van Boxle's ranch, above Cimarron; Halfway House; Chicken Creek, West La Plata Mountains; Grizzly Creek; near La Veta; Ojo; Cumberland Basin; Upper La Plata Cañon; North Cheyenne Cañon; near Pagosa Peak; Ironton; Wahatoya Cañon; Veta Pass; Mt. Princeton; West Spanish Peak; Ward, Boulder Co.; Red Mountain; Manitou; Lake City; Caribou; Dillon Cañon, Trinidad; Estes Park; Empire; northeast of Boreas; Spring Cañon; Dixon Cañon; Horse- 
tooth Gulch; Mancos; Ute Pass; Golden; Sangre de Cristo; Hahn's Peak; Fish Creek Falls, Routt Co.

\section{SULLIVANTIA T. \& G.}

I. Sullivantia Hapemanii (Coult. \& Fish.) Coulter. (Boykinia Purpusi Brandegee.) In rocky places from Wis. and Wyo. to Colo.-Black Cañon of the Gunnison.

\section{TELESONIX Raf.}

I. Telesonix Jamesii (Torr.) Raf. (Saxifraga Jamesii Torr.) On exposed mountain-tops in Colo.-Alt. 8000-I3,000 ft.-Mt. Garfield; Pike's Peak; Minnehaha.

\section{SAXIFRAGA L. SAXIFRAgE.}

Flowers normal, none of them represented by clusters of bulblets. I. S. debilis. Flowers below the terminal one replaced by clusters of bulblets.

Lobes of the stem-leaves linear to triangular lanceolate; petals cuneate. 2. S. cernua.

Lobes of the stem-leaves broad and rounded, as broad as long or broader; petals fiddle-shaped.

3. S. simulata.

I. Saxifraga debilis Engelm. Among wet rocks, on alpine peaks, from Mont, to Colo. and Utah.-Alt. 9000-13,000 ft.-Mt. Hesperus; Sierra Blanca; Mt. Abram, Ouray; Front Range, Larimer Co.; Redcliffe, Eagle Co.; West Spanish Peak; Gray's Peak; Cameron Pass; Bottomless Pit, near Pike's Peak; Ruby; Massif de l'Arapahoe; mountains above Beaver Creek.

2. Saxifraga cernua L. Among wet rocks, on alpine peaks, from Greenl. and Alaska to Lab. and Colo; also in Europe-Alt. about 13,000 ft.-Mt. Abram, Otiray.

3. Saxifraga simulata Small. Among rocks, on the higher peaks, in the Black Hills of S. D. and Colo.-Alt. Io,000-r3,000 ft.-West Spanish Peak.

\section{MUSCARIA Haw.}

Leaves of the caudex with entire or slightly 3-toothed blades. I. $M$. adscendens. Leaves of the caudex with 3 -cleft or prominently 3 -lobed blades.

2. M. delicatula.

r. Muscaria adscendens (L.) Small. (Saxifraga adscendens L.) Among rocks, on alpine peaks, from Alb. and B. C. to Colo. and Utah.-Alt. Io,oooI3,000 ft.-Gray's Peak; Deep Creek Lake; West Spanish Peak; Pike's Peak.

2. Muscaria delicatula Small. On alpine peaks from Alb. to Colo. and Utah.-Gray's Peak.

\section{Io. MICRANTHES Haw.}

Filaments subuiate or filiform-subulate, or rarely narrowly linear.

Cymules wholly or mainly aggregated into a head, or one or two lower ones remote or peduncled; leaves petioled; blades rhombic ovate.

I. M. rhomboidea.

Cymules in narrow pyramidal or corymb-like panicles; leaves subsessile, oblanceolate-oblong.

Panicle wide, peduncles of the lower cymules elongated.

Panicle narrow; peduncles permanently very short.

Filaments clavate or spatulate; petals spotted.

2. M. arnoglossa.

3. M. brachypus.

4. M. arguta. 
I. Micranthes rhomboidea (Greene) Small. (Saxifraga rhomboidea Greene.) Among rocks in the mountains from Mont. and Ida. to Colo.Alt. 5000-12,000 ft.-Gray's Peak; West Spanish Peak; near Ironton; Grand Mesa; Marshall Pass; Seven Lakes; Black Rock Creek; Pike's Peak; Ft. Collins; Georgetown; foot-hills, Larimer Co.; Tennessee Pass; Bear Creek Divide, West La Plata Mountains; Iron Mountain; headwaters of Beaver Creek; gulch west of Dixon Cañon; Massif de 1'Arapahoe; near Pagosa Peak; Rist Cañon; mountains west of Cameron Pass; Soldier Cañon; Boreas; Beaver Creek; Eldora to Baltimore; Berthoud Pass; Rabbit-Ear Range, Routt Co.

2. Micranthes arnoglossa (Greene) Small. (Saxifraga arnoglossa Greene.) On hills and mountains from Mont. and Wash. to Colo. and Calif.-Alt. 900012,000 ft.-Mountains of Delta Co.; Marshall Pass; Silver Plume.

3. Micranthes brachypus Small. In the mountains from Colo. to Nev.Alt. II,000-12,000 ft.--Half-Moon Creek; Berthoud Pass.

4. Micranthes arguta (D. Don.) Small. (Saxifraga arguta D. Don.; S. denudata Nutt.; S. punctata Hook., in part; not L.) In springy places and along streams from Mont. and B. C. to N. M. and Calif.-Alt. 8000-12,000 ft.-Mountains between Sunshine and Ward; Villa Grove; Mt. Abram, Ouray; Dark Cañon; Wyoming line in North Park; Georgetown; Middle Park; Grayback mining camps; near Pagosa Peak; Pike's Peak; RabbitEar Range; headwaters of Clear Creek; Silver Plume; Clear Lake; Berthoud Pass; Upper La Plata Cañon; Cameron Pass; Ruby; headwaters of Pass Creek; Massif de l'Arapahoe; Beaver Creek; Leroux Park, Graymont; Gore Pass; Anita Peak.

\section{SPATULARIA Haw.}

r. Spatularia Vreelandii Small. On the higher peaks of Mont. and Colo. -Mt. Evans.

\section{LEPTASEA Haw.}

Leaf-blades not spine-tipped at the apex, more or less ciliate.

Petals suborbicular or oval, $5.5-6.5 \mathrm{~mm}$. long, abruptly narrowed into short claws.

Petals elliptic to oblong, 9-13 mm. long, clawless.

Leaf-blades spine-tipped at the apex.

1. L. chrysantha.

Petals white, usually spotted, oblong or oblong-lanceolate or elliptic; plant cespitose, not stoloniferous.

Petals yellow, broadly obovate; plant with flagelliform stolons.

3. L. anstromontana.

4. L. fagellaris.

1. Leptasea chrysantha (A. Gray) Small. (Sarifraga chrysantha A. Gray) On alpine peaks, among rocks, of Colo.-Alt. II,000-I4,000 ft.-Pike's Peak; Mt. Bartlett; Central City; Gray's Peak; mountains of Estes Park; Massif de l'Arapahoe; Berthoud Pass.

«. Leptasea Hirculus (L.) Small. (Saxifraga Hirculus L.) On the higher mountains, in wet places, from Greenl. and Alaska to Colo. and B. C.; also in Europe and Asia.-Alt. 9000-II,000 ft.-Beaver Park; Twin Lakes; Caribou. 
3. Leptasea austromontana (Wieg.) Small. (Saxifraga bronchiales Torr.; not L.; S. austromontana Wieg.) On rocks and stony hills from Alb. and B. C. to N. M. and Wash.-Alt. 6000-13,000 ft.-Red Mountain; Ouray; Minnehaha; Mt. Garfield; Halfway House, Pike's Peak; Central City; West Spanish Peak; Little Veta Mountain; Black Cañon; Upper La Plata Cañon; Como; Silver Plume; near Colorado Springs; Pagosa Peak; El Paso Co.; Georgetown; near Denver; Andrew's Shetland ranch; Caribou; South Boulder Peak; Massif de l'Arapahoe; Palmer Lake; headwaters of Clear Creek; Lake City; near Empire; west of Cameron Pass; Graymont; Ragged Mountain, Gunnison Co.; Estes Park; Cameron Pass; mountains above Ouray; Buffalo Pass; Pennock's mountain ranch; Devil's Causeway; Twin Lakes; mountains between Sunshine and Ward; Anita Peak.

4. Leptasea flagellaris (Willd.) Small. (Saxifraga fagellaris Willd.) On alpine peaks, among rocks, from Greenl. and Alaska to Colo. and Ariz.Alt. Io,000-14,000 ft.-Red Mountain; summit of Pike's Peak; Mt. Abram, Ouray; Cumberland Basin, La Plata Mountains; Mt. Harvard; Pike's Peak; West Spanish Peak; Gray's Peak; headwaters of Clear Creek; Massif de l'Arapahoe.

Family 63. Parnassiaceae Dumort. Grass-of-Parnassus Family.

\section{Parmassia L. Grass of Parnassus.}

Petals fimbriate on the sides; basal leaf-blades reniform.

Petals obovate, 5-nerved; staminodial scales with 5-9 lobes; sepals elliptic. 1. P. fimbriata.

Petals oblong, 3-nerved; staminodial scales 3-5-lobed; sepals narrowly lanceolate.

Petals not fimbricate; basal leaf-blades tapering at the base.

2. P. rivularis.

3. P. parvitlora.

x. Parnassia fimbriata Banks. On banks of streams and in springy places from Alb. and Alaska to Colo. and Calif.--Alt. 9000-II,00o ft.-Twin Lakes; North Park; Ruby; Ragged Mountain, Gunnison Co.; near Pagosa Peak; Cameron Pass; Marshall Pass; Caribou.

2. Parnassia rivularis Osterhout. Along mountain brooks in Colo.-North Park, near Wyoming line.

3. Parnassia parviflora DC. In wet places from Que. and Alaska to Colo. and Utah.-Alt. 7000-8000 ft.-North Park; Gypsum Creek; cañon, Eagle Co.; Pagosa Springs; Wahatoya Creek; Marshall Pass; Iola; Parlin; La Veta; Lake John, North Park; Buena Vista; Big Muddy, Gunnison Co.

Family 64. HYDRANGEACEAE Dumort. Hydrangea Family.

Stamens 15 or more; ovary inferior.

I. Philadelphus.

Stamens 8-10; ovary mostly superior.

Hypanthium adnate to the base of the I-celled ovary or incompletely 3-7-celled capsule; petals 5 .

2. EDWINIA.

Hypanthium adnate for half its length to the 4-celled ovary and capsule; petals 4 . 


\section{Philadelphus L. Syringa, Mock Orangeg.}

Hypanthium 4-5 mm. long; sepals acuminate; leaves much paler beneath; styles united.

I. P. microphyllus.

Hypanthium about $2 \mathrm{~mm}$. long or in fruit $3-4 \mathrm{~mm}$. long; sepals acute.

Styles wholly or nearly wholly united; stigmas usually oblong.

Styles with the upper half distinct; stigmas decidedly clavate.

2. P. occidentalis.

3. P. minutus.

I. Philadelphus microphyllus A. Gray. Mountains of N. M. and Colo.Brantly Cañon; Cañon City (Brandegee), "Colorado."

2. Philadelphus occidentalis A. Nels. Mountains from Wyo. to Colo. and Utah.-Alt. 5000-7000 ft.-Cañon City; Glenwood Springs ( $A$. Nelson).

3. Philadelphus minutus Rydb. Cañons of Colo.-Ait. 7000 ft.-Black Cañon of the Gunnison.

\section{EDWINIA Heller.}

I. Edwinia americana (T. \& G.) Heller. (Jamesia americana T. \& G.) On cliffs, mountain sides and in cañons, from Wyo. and Utah to N. M.Alt. 5000-10,000 ft.-Rist Cañon; Minnehaha; Pike's Peak; Rock Mountain Pass; Ward; West Spanish Peak; Central City; Engelmann's Cañon; North Cheyenne Cañon; Green Mountain Falls; foot-hills, Larimer Co.; Georgetown; Cañon City; headwaters of Clear Creek and alpine ridges east of Middle Park; Manitou; Graymont; Narrows, Moon's ranch; Horsetooth Gulch; Soldier Cañon; Howè's Gulch; Pennock's mountain ranch; mountains between Sunshine and Ward; Eldora to Baltimore.

\section{FENDLERA Engelm. \& Gray.}

1. Fendlera rupicola Engelm. \& Gray. On hills from Colo. to N. M. and Ariz.; also in Mex.-Alt. 5000-8000 ft.-Durango; Mancos; Cerro Summit; Los Pinos; Hotchkiss, Delta Co.; Dolores.

\section{Family 65. GROSSULARIACEAE. GoOseberRy Family.}

\section{RIBes L. Goose-berry, Currant.}

Leaves plicate in vernation.

Stems usually with subaxillary spines.

Racemes I-4-flowered; hypanthium campanulate to tubular.

Calyx and tube of hypanthium externally glabrous or the former with a few scattered hairs.

Peduncles and bracts more or less glandular or pubescent; leaves finely puberulent.

1. R. Purpusi.

Peduncles and bracts glabrous or the latter ciliate; leaf-blades cordate at the base, in age glabrose and shining. $\quad$ 2. $R$. vallicola.

Calyx and hypanthium pubescent.

Racemes several-flowered; hypanthium saucer-shaped.

Leaves densely pubescent; fruit red.

Leaves glabrate; fruit black.

3. R. leptanthum.

Stem unarmed; raceme many-flowered.

4. $R$. lentum.

5. R. parvulum. 
Hypanthium campanulate.

Berry glandular-bristly.

Leaves glabrous; fruit spherical.

Tube of the hypanthium saucer-shaped; bracts minute, lanceolate to linear; fruit without a bloom.

6. $R$. coloradense.

Tube of the hypanthium campanulate; fruit black with a bloom; bracts conspicuous oblong, spatulate or obovate. $7 . R$. Wolfii.

Leaves pubescent and often very glandular; fruit ovoid; tube of hypanthium deeply campanulate.

8. $R$. viscosissimum.

Berry glabrous; tube of the hypanthium deeply campanulate; fruit black;

bracts persistent.

Hypanthium tubular.

Petioles and veins of the leaves with stalked glands.

Petioles and veins with sessile glands or glandless. I I $R$. pumilum.

Leaves convolute in bud, stem unarmed; hypanthium tubular.

I 2. R. longifolitm.

I. Ribes Purpusi Koehne. In the mountains from Wyo. to N. M.-Alt. 5000-I0,000 ft.-Cucharas Valley, near La Veta; Ojo; foot-hills west of Ft. Collins; Sierra Blanca; near Steamboat Springs; West Indian Creek; Villa Grove; Grand Lake; Dillon; mountains between Sunshine and Ward; Soldier Cañon; Horsetooth Gulch; Rist Cañon; Dixon Cañon; Cheyenne Cañon.

2. Ribes valicola Greene. (R. saxosum Coville; not Hook; $R$. oxycanthoides of Coulter's Man.) In the mountains from Mont. and Wash. to Colo. and Calif.-Alt. 8000-900o ft.-Upper Cañon of the West Mancos; Los Pinos; Cerro Summit; Steamboat Springs.

3. Ribes leptanthum A. Gray. In the mountains from Mont, to Colo. and Ariz.-Alt. 6000-Io,ooo ft.-Bob Creek, West La Plata Mountains; Ute Pass; foot-hills, Sierra Blanca; Buena Vista; North Cheyenne Cañon; Crystal Lake; Manitou; South Cheyenne Cañon; Cañon City; Poncha Pass; Garden of the Gods; Mancos.

4. Ribes lentum (Jones) Coville \& Rose. ( $R$. lacustre molle A. Gray.) In the mountains from Wyo. to Colo, and Calif.-Alt. 8000-I2,000 ft.-Mount Ouray; Windy Point; Lake City; Veta; Georgetown; Cameron Pass; Cañon of the Cache la Poudre; near La Plata Post Office; Bob Creek; Pagosa Peak; West Indian Creek; Wahatoya Cañon; near Empire; Seven Lakes; four miles west of Cameron Pass; Telluride; Grand Mesa; Cottonwood Lake; Jack Brook; mountains near Seven Lakes; Pike's Peak; Hahn's Peak; Red Mountain, south of Ouray; headwaters of Clear Creek and alpine ridges east of Middle Park; Empire; near Buffalo Pass, Park Range; Eldora to Baltimore; Berthoud Pass; Graymont.

5. Ribes parvulum (A. Gray) Rydb. ( $R$. lacustre parvulum A. Gray.) In the mountains from Alb. and Yukon to Colo. and Utah.-Alt. 7000-I2,000 ft. -Black Cañon; Ouray; Red Mountain, south of Ouray; Berthoud Pass; Silverton; Big Creek; Anita Peak; Pinkham Creek.

6. Ribes coloradense Coville. In the mountains from Colo. to N. M.Alt. 9000-II,000 ft.-Silverton; Marshall Pass; Slide Rock Cañon; near Pagosa Peak; Sangre de Cristo Creek; Silver Plume; Telluride; Twin Lakes; Berthoud Pass; Cameron Pass; Rabbit-Ear Range, Routt Co. 
7. Ribes Wolfii Rothrock. ( $R$, mogollonicum Greene) In woods from Colo. and Utah to N. M. and Ariz.-Alt. 7500-I2,000 ft.-Van Boxle's ranch, above Cimarron; Redcliffe, Eagle Co.; cañons near Ouray; Mt. Abram, Ouray; Box Cañon; Bear Creek Divide; Wahatoya Cañon; Hinsdale Co.; Buffalo Pass, Park Range; Leroux.

8. Ribes viscosissimum Pursh. On wooded hillsides from Mont. and Wash. to Colo. and Calif.-Steamboat Springs, Routt Co.

9. Ribes floridum L'Her. In wet woods from N. S. and Mont. to Va. and Colo.-Notch Mountain.

10. Ribes pumilum Nutt. ( $R$. cereum Coulter, in part.) On dry hills from Mont. to N. M. and Ariz.-Alt. 5000-10,0000 ft.-Foot-hills west of Ft. Collins; Larimer Co.; Ute Pass, Walsenburg; Colorado Springs; Turkey Creek and tributaries; Cucharas Valley, near La Veta; near Boulder; Horsetooth Gulch; La Porte; Rist Cañon; Howe's Gulch; Soldier Cañon; Stove Prairie; Trinidad; Ute Pass; Beaver Creek.

II. Ribes inebrians Lindl. ( $R$. cereum Coulter, in part.) On hills from Mont. to N. M. and Utah.-Alt. 5000-II,000 ft.-Ouray; Buena Vista; Cerro Summit; hills about Box Cañon, west of Ouray; Bob Creek, West La Plata Mountains; West Mancos Cañon; mesas near Colorado Springs; Minturn; Lake City; Pike's Peak trail.

12. Ribes longifolium Nutt. (R. aureum T. \& G., mainly; not Pursh.) On the plains and in the foot-hills from S. D. and Wyo. to Kans. and Ariz.Alt. 4000-7000 ft.-Ft. Collins; near Denver; Steamboat Springs; West Soldier Cañon; Horsetooth Gulch; Manitou; Boulder; Villa Grove; Rocky Mountains.

\section{Family 66. ROSACEAE Juss. Rose FAmily.}

Hypanthium neither fleshy nor prickly nor strongly constricted at the throat, if at all inclosing the fruit merely loosely investing it.

Carpels few, becoming 2-4-seeded follicles, more or less united at the base and opening along both sutures; shrubs with palmately veined leaves.

i. Opulaster.

Carpels usually many, rarely few, becoming 1 -seeded (rarely 2 -seeded) achenes or drupelets.

Carpels becoming more or less fleshy drupelets.

Styles club-shaped; stigmas 2-lobed; receptacle flat; unarmed shrubs with shreddy bark and digitately veined, maple-like leaves.

Drupelets capped by hard hairy cushions; style glabrous; erect shrubs.

2. Rubacer.

Drupelets without cushions; styles hairy; prostrate or reclining shrubs.

3. Oreobatus.

Styles filiform, glabrous; stigmas capitate: receptacle hemispherical, conical or nipple-shaped; drupelets without cushions; leaves in our species pinnate and stem prickly.

Carpels dry achenes.

Style articulated to the ovary and deciduous.

Style terminal or nearly so; ovules pendulous and anatropous.

Stamens inserted very near the base of the receptacle on a more or less evident annular thickening.

5. Potentilla.

Stamens separated from the receptacle by a wide open space; no indication of an annular thickening.

6. HORKELIA.

Style lateral or basal; ovules not pendulous. 
Style lateral; ovules ascending and amphitropous.

Achenes glabrous; herbs.

Achenes numerous; stamens about 20.

Receptacle neither enlarged in fruit nor becoming pulpy; leaves interruptedly pinnate; petals yellow.

7. Argentina.

Receptacle much enlarged in fruit and becoming red and pulpy; leaves trifoliate; petals white or pinkish. 8. Fragaria.

Achenes 10-I 5 ; stamens 5 ; leaves trifoliate; petals yellowish.

Achenes hairy; shrubs with pinnate leaves.

9. Sibbaldia.

io. DASIPHORA.

Styles nearly basal; ovules ascending or erect, orthotropous.

Stamens 5; pistils 5-10; bractlets wanting; leaves twice ternate.

in. Chamalerhodos.

Stamens and pistils numerous; bractlets present; leaves pinnate. I 2. DRymocallis.

Style not articulated to the ovary, persistent, at least the lower portion.

Style geniculated above, the upper hairy portion deciduous; herbs.

Style not geniculated above, wholly persistent.

I 3. GeUm.

Petals normally 5 or none.

Herbs with woody rootstocks and pinnate leaves; bractlets present; carpels numerous. I 4. Sieversia.

Shrubs or trees.

Bractlets present; carpels numerous with plumose styles. $\cdot$

Bractlets wanting; carpels solitary or few.

I5. Fallugia.

Hypanthium saucer-shaped or hemispherical ; carpels 5 ; flowers panicled. I6. HoLodiscus.

Hypanthium funnel-form or tubular; carpels solitary; flowers solitary.

Petals 5 ; style not elongated in fruit; calyx persistent; leaves 3-cleft. 17. Kunzia.

Petals wanting; style elongated and plumose in fruit; calyx deciduous from the hypanthium; leaves toothed.

i8. Cercocarpus.

Petals 8-9; dwarf matted undershrubs with solitary flowers and simple, in ours crenate leaves. I 9. Dryas.

Hypanthium constricted at the throat, wholly enclosing the achenes.

Hypanthium dry, turbinate; upper portions armed with hooked prickles; herbs; carpels few; flowers racemose.

20. Agrimonia.

Hypanthium in fruit becoming fleshy; carpels numerous; shrubs with large flowers solitary or in small corymbs. 2I. Rosa.

\section{OPULASTER Medic. Nine-Bark.}

Carpels $3-5$, united only at the base.

1. O. intermedius.

Carpels 2, united at least half their length.

Bracts obovate or spatulate, often foliaceous and more persistent.

Bracts linear or linear-oblanceolate, membranous and caducous.

2. O. Ramaleyi.

Pedicels and hypanthium almost glabrous.

Pedicels, hypanthium and sepals decidedly stellate.

3. O. glabratus.

4. O. monogynus.

1. Opulaster intermedius Rydb. (Physocarpus opulifolius Coulter, in part.) On river banks and hillsides from Ill. and S. D. to Mo. and Colo.-Alt. 4000-7000 ft.-Pike's Peak; North Cheyenne Cañon; Colorado Springs; Lower Boulder Cañon.

2. Opulaster Ramaleyi Aven Nelson. (O. bracteatus Rydb.) In the foothills of Colo.-Alt. 5000-6000 ft.-New Windsor; Buckthorn Creek, Larimer Co.; Cheyenne Cañon; foot-hills west of Ft. Collins. 
3. Opulaster glabratus Rydb. Along streams in the mountains of Colo.Alt. 5000-II,000 ft.-West Spanish Peak; Turkey Creek and tributaries; Rist Cañon; North Poudre; Boulder.

3. Opulaster monogynus (Torr.) Kuntze. (Physocarpus Torreyi Max.) On the mountain tops from S. D. and Wyo. to N. M. and Nev.-Alt. 6000$9000 \mathrm{ft}$-Denver; Cheyenne Cañon; Colorado Springs; Flouissant; Upper Bear Creek; Pike's Peak; foot-hills, Larimer Co.; Glen Eyrie; Livermore, Larimer Co.; Idaho Springs; Cascade Cañon; Engelmann Cañon; near Georgetown; Minnehaha; Black Cañon; headwaters of Pass Creek; Stove Prairie Hill; North Poudre; Table Rock; Pennock's mountain ranch; Howe's Gulch; Rist Cañon; Baxter's ranch.

2. RUBACER Rydb. FLOWERING RASPBerRy, SALMON-BERRY.

1. Rubacer parviflorus (Nutt.) Rydb. (Rubus Nutkanus Moç.) On wooded hillsides from Ont. and Alaska to N. M. and Calif.; also in Mex.Alt. 6000-9000 ft.-Four-Mile Hill; La Plata Cañon; Steamboat Springs; Redcliffe; Eagle Cliff; Box Cañon, west of Ouray; Ouray; near Pagosa Peak; Fish Creek; Rico; Rabbit-Ear Range, Routt Co.

\section{OREOBATUS Rydb.}

r. Oreobatus deliciosus (James) Rydb. (Rubus deliciosus James) On the mountains of Colo-Alt. 5000-I0,000 ft.-Pike's Peak; Manitou; headwaters of Clear Creek; Apex; foot-hills west of Ft. Collins; Colorado Springs; Cheyenne Cañon; near Maniton; Cheyenne Mountain; Turkey Creek and tributaries; Georgetown; Bear Cañon; Ute Pass; Rist Cañon; Howe's Gulch; Palmer Lake; Spring Cañon; Dixon Cañon; Stove Prairie Hill; Horsetooth Gulch; gulch south of Bouider; Engelmann Cañon.

\section{RUBUS L. RASPBerRy, BLACKBerRy, BRAmble.}

Stems, pedicels and petioles glandular bristly, not prickly; fruit red.

Stems, pedicels and petioles more or less prickly, not bristly; fruit black.

$$
\text { I. R. strigosus. }
$$

ᄂ. $R$. occidentalis.

I. Rubus strigosus Michx. On hills and in rocky woods from Lab. and Mackenzie to N. J. and Neb.-Alt. 6000-Io,000 ft.-Minnehaha; Box Cañon, west of Ouray; Ouray; Manitou; Grayback mining camps and Placer Gulch; Cheyenne Cañon; Chambers' Lake; foot-hills, Larimer Co.; Upper West Mancos Cañon; Campton's ranch; Cache la Poudre; Fish Creek Falls, Routt Co.

z. Rubus occidentalis L. In open woods and among bushes from Que. and Minn. to Ga. and Colo.-Locality not given, perhaps doubtful.

\section{Potentilla L. Five-finger, Cinguefoil,}

Flowers many in very leafy cymes; annuals or biennials or short-lived perennials; style fusiform.

I. Supinae.

Flowers cymose, but cymes not very leafy, generally rather few-flowered; perennials with a strongly developed rootstock. 
Leaves mainly digitate, rarely pinnate with approximate leaflets or with a pair of small leaflets on the petioles.

Leaves or at least the basal ones 5-9-foliolate.

Additional smaller leaflets on the petioles not present.

Plants less than $2 \mathrm{dm}$. high.

Leaves tomentose at least beneath.

II. ConCINNAE.

Leaves not tomentose.

Plants more than $2 \mathrm{dm}$. high.

Additional smaller leaflets on the petioles present.

III. AUREAE.

IV. Graciles.

V. Subjugae.

Leaves 3 -foliolate, tomentose beneath.

VI. NIVEAE.

Leaves manifestly pinnate.

Style not longer than the mature achenes, thickened or glandular below; leaves nore or less tomentose, but not necessarily white beneath.

Style much longer than the mature achenes, filiform.

ViI. Multifidae.

Leaflets approximate, $3-7$.

Leaves tomentose beneath.

Leaves not at all tomentose.

VIII. RUBRICAUILES.

III. Aureat.

Leaflets rather distant 7-2I.

Leaves green on both sides and only slightly hairy.

Leaves grayish or whitish, silky or tomentose.

iX. Multijugae.

X. LEUCOPHYLLAE.

\section{Supinae.}

Achenes with a corky gibbosity on the upper suture; leaves pinnate with $3-5$ pairs of leaflets.

Achenes not gibbous.

Leaves pinnate, with 2 approximate pairs of leaflets; the upper ternate.

Leaves all ternate (or the lower rarely digitately 5 -foliate).

2. $P$. rivalis.

Petals shorter than the sepals; achenes whitish.

Stem diffusely branched, spreading; leaflets cuneate; inflorescence cymose.

3. P. lencocarpa.

Stem erect, strict; leaflets broadly obovate; inflorescerice falsely racemose. 4. P. laterifiora.

Petals about equalling the sepals; stem stout, strict; achenes brownish.

5. P. monspeliensis.

Middle leaflet sessile.

II. Concinnae.

Leaflets obovate or cuneate, deeply toothed or incised.

Leaflets oblong, with entire margins, only 3 -toothed (rarely 5 -toothed) at the very apex.

Middle leaflet petioled.

7. P. bicrenata.

8. $P$. quinquefolia.

Only one species. $\quad$ 9. P. dissecta.

III. Aurgat.

IV. Graciles.

Leaves green on both sides, not at all tomentose beneath.

Leaflets cuneate at the base, usually toothed only above the middle; plants low, usually less than $3 \mathrm{dm}$. high.

9. $P$. dissecta.

Leaflets oblanceolate, toothed to near the base; plants 3-6 dm. high.

Stem glabrous or appressed-pubescent; leaflets coarsely toothed or cleft halfway to the mid-rib or less.

Slender; leaves thin, not strongly ribbed; inflorescence open; bracts small.

ro. $P$. jucunda.

Stout; leaves thick and strongly ribbed; inflorescence dense; bracts conspicuous.

I I. P. Nuttallii. 
Stem with spreading hairs; leaflets cleft to near the mid-rib.

Leaves more or less tomentose beneath.

12. P. brinnescens.

Leaves sparingly tomentose and grayish beneath; leaflets dissected about threefourths to the mid-rib. 13. P. Bakeri.

Leaves densely white-tomentose beneath; leaflets merely crenate or toothed.

Lower stem-leaves 5 -foliolate; plant $3 \mathrm{dm}$. or more high.

Hypanthium and calyx not tomentose, as well as the pedicels more or less viscid; pubescence of stem and petioles usually loose.

14. P. filipes.

Hypanthium and calyx more or less tomentose, not viscid; pubescence of the stem and petioles usually appressed.

Stem-leaves all ternate; plant $\mathrm{I}-2$ (seldom 3) dm. high. I 5. P. pulcherrima.

8. P. quinquefolia.

\section{Subjugae.}

One species.

VI. Niveae.

16. P. subjuga.

Stem I-2 dm. high, more or less leafy, several-flowered. 17. P. nivea.
Stem less than I dm. high, subscapose, usually $1-2$ flowered. I8. P. uniflora.

ViI. Multifidae.

Pubescence not silvery white.

Plant dark green; branches of inflorescence rather long, erect.

I9. $P$. atrovirens.

Plant usually yellowish green; branches of inflorescence short and ascending.

Pubescence silvery white, at least beneath.

2o. P. pennsylvanica.

Leaves white-silky on both sides; lobes of the leaflets linear.

21. P. bipinnatifia.

Leaves greenish above; lobes of the leaflets oblong or lanceolate.

22. P. platyloba.

VIII. RuBricaUles.

Sepals lanceolate to linear, acuminate.

Leaves densely silky or tomentose on both sides.

Leaves greenish above.

Segments of the leaflets oblong to orbicular in outline.

Stems decumbent or prostrate; segments of the leaves oblong.

24. P. rubripes.

Stems ascending; segments of the leaves orbicular or nearly so.

25. $P$. ninutifolia.

Segments of the leaflets linear; stems erect.

26. $P$. tenerrina.

Sepals broadly ovate or ovate-triangular, obtusish or abruptly mucronate.

Plant densely cespitose; leaves silky and finely tomentose beneath.

Plants with a few spreading branches; leaves floccose beneath.

27. P. sarimontana.

6. $P$. concinna.

iX. Multijugae.

Leaflets dissected to near the mid-rib.

Stem erect, with $\mathrm{I}-3$ small leaves.

Stem decumbent or ascending, leafy.

Leaflets merely coarsely toothed; stem erect.

28. P. pinnatisecta.

29. P. plattensis.

3o. R. rupincola.

\section{LEUCOPHYLLAE.}

Leaves white-tomentose, floccose or silky, at least beneath.

Bractlets nearly equalling the acute sepals; leaves silky as well as tomentulose; hence shining. 
Leaves nearly equally white on both sides; upper leaflets not decurrent. 31. P. Hippiana.

Leaves greener above; upper 3 leaflets more or less decurrent on the rachis. 32. P. propinqua.

Bractlets much shorter than the acuminate sepals; leaves merely floccose; hence dull.

Leaves thick, densely floccose; pistils numerous.

33. P. effusa.

Leaves thin; tomentum sparse and more or less deciduous; pistils few.

Leaves grayish silky.

34. P. coloradensis.

Stem stout, erect, 6-7 dm. high; leaflets obovate or oblong, coarsely serrate, the upper decurrent on the rachis. 35. P. ambigens.

Stem I-4 dm. high; leaflets cuneate, toothed at the apex only, conduplicate, none decurrent.

36. P. crinita.

I. Potentilla paradoxa Nutt. ( $P$. supina Am. auth.; not L.) In wet places from Ont. and Wash. to N. M. ; also Mex. and western Asia.-Steamboat Lake.

2. Potentilla rivalis Nutt. In wet places from Sask, and Ore. to Mex.Alt. up to 8000 ft.-Lee's Lake; along the Conejos River, north of Antonito; Ft. Collins; Quimby; along the Platte River, Denver; Georgetown; New Windsor.

3. Potentilla leucocarpa Rydb. ( $P$. milligrana Engelm.; not Dougl.) In wet meadows from Ill, and Wash. to N. M. and Calif.-Poudre Cañon; Middle Park; Steamboat Springs.

4. Potentilla lateriflora Rydb. ( $P$. bicnnis Rydb., in part; not Greene) In loose soil from Ass. and B. C. to Colo. and Ariz.-Alt. about $8000 \mathrm{ft} .-$ Gunnison.

5. Potentilla monspeliensis L. ( $P$. norvegica hirsuta T. \& G.) In fields and waste places from Lab. and Alaska to D. C. and Mex.-Alt. up to 8000 ft.-Along Conejos River, north of Antonito; Rist Cañon; Soldier Cañon; Gypsum; La Porte; Ft. Collins; Rocky Ford; near Botlder; Gunnison; Ironton Park; Ruxton Park; New Windsor; Pagosa Springs; Green Mountain Falls; Pike's Peak; Placer Gulch; Beaver Creek.

6. Potentilla concinna Richardson. ( $P$. humifusa Nutt.) Dry hills and mountains from Sask. and Alb. to Colo. and Utah.-Alt. 5000-Io,000 ft.Devil's Causeway; North Park; Empire; Lake City; Georgetown; Cameron Pass; Mt. Abram; Cumberland Mine, La Plata Mountains; Little Kate Mine; West Spanish Peak; Little Veta Mountain; headwaters of Sangre de Cristo Creek; Spicer, Larimer Co.

7. Potentilla bicrenata Rydb. Dry mountains of N. M. and Colo."Colorado."

8. Potentilla quinquefolia Rydb. ( $P$. nivca subquinata Lange; $P$. nivea pentaphylla Lehm.) On dry mountains from Greenl. and B. C. to Colo.Alt. Io,000-I4,000 ft.-Cumberland Mine, La Plata Mountains; West Spanish Peak; Mt. Hesperus; Hahn's Peak.

9. Potentilla dissecta Pursh. ( $P$ diversifolia Lehm.) On hills and mountain sides from Sask, and B. C. to Colo. and Calif.-Alt. up to I3,000 ft.Lake City; headwaters of Clear Creek; Cameron Pass; Lake City; Caribou; Willis Gulch; Pagosa Springs; Carson; Alpine Tunnel; Buffalo Pass Park; Mt. Princeton; Little Kate Mine; Ouray; Estes Park; Spicer. 
Potentilla dissecta glaucophylla (Lehm.) S. Wats. A taller and more glabrous variety.-Boreas; Beaver Creek Cañon; above Beaver Creek; Beaver Creek; camp on Little Beaver; Graymont; Cameron Pass; Lake City; Caribou; Red Mountain; Alpine Tunnel; Silver Plume; Camp Creek.

10. Potentilla juncunda A. Nels. In the mountains of Wyo. and Colo.Alt. up to I0,000 ft.-Chambers' Lake; Beaver Creek; Cameron Pass; Little Kate Mine.

II. Potentilla Nuttallii Lehm. ( $P$. gracilis rigida S. Wats.) In mountain valleys from Sask, and B. C. to Colo. and Calif.-Sheephorn Divide, Middle Park; Grizzly Creek; northwest of North Park.

12. Potentilla brunnescens Rydb. In dry mountain meadows from Mont. to Colo.-Alt. about 8000 ft.-Columbine; Grizzly Creek; Steamboat Springs; Walden.

13. Potentilla Bakeri Rydb. In the mountains of Colo.-Alt. 800o-9000 ft.-Grizzly Creek; southwest North Park; Doyle's; Gunnison watershed.

14. Potentilla filipes Rydb. In the mountains of Colo--Alt. 5000-I0,000 ft.-Forks of Poudre and Big South; above Ouray; along Bear River; Como; Chambers' Lake; Dolores.

I5. Potentilla pulcherrima Lehm. In mountain meadows from Sask. and Alb. to N. M. and Nev.-Alt. 8000-Io,000 ft.-Lake City; mountains above Denver; Larimer Co.; near Empire; Como; Silverton; Beaver Creek; along the Conejos River, north of Antonito; Rico; Stove Prairie Hill, Larimer Co.; Campton's ranch; Dolores; headwaters of Clear Creek.

16. Potentilla subjuga Rydb. Mountains of Colo.-Alt. $8000-9000$ ft.Near Empire.

7. Potentilla nivea $L$. In alpine-arctic situations from Lab. and Alaska to Colo.; also in Europe and Asia.-Alt. ro,000-r3,000 ft.-Devil's Causeway; Empire; Ouray; West Spanish Peak; Cumberland Mine, La Plata Mountain; mountains of Estes Park.

18. Potentilla uniflora Ledeb. In alpine-arctic situations from Green1, and Alaska to Colo. and Ore.-Alt. I0,000-13,000 ft.-High mountains about Empire; Hinsdale Co.; Cameron Pass; Estes Park; Boreas.

19. Potentilla atrovirens Rydb. On plains and hills from Minn. and Wyo. to Colo.-Williams' Cañon, Pike's Peak.

20. Potentilla pennsylvanica strigosa Pursh. On plains from Hudson Bay and Alb. to Kans. and N. M. (the true P. Pensylvanica L. is not found in Colo.).-Alt. up to $8000 \mathrm{ft}$--Antonito; West Mancos Cañon; Central City; Empire.

Potentilla pennsylvanica arachnoidea Lehm. On high plains from Mont. and Utah to N. M. and Ariz.-Alt. 5000-8000 ft.-Lake City; Sangre de Cristo Creek; Chicken Creek; Otray; near Boulder; mountains of Estes Park.

21. Potentilla bipinnatifida Dougl. On plains from Sask. and Alb. to Neb. and Colo.-Alt. 400o-ro,000 ft.-Larimer Co.; Como; Antonito; Higho; Ute Pass; Indian Creek Pass; Gunnison.

22. Potentilla platyloba Rydb. ( $P$. bipinnatifida platyloba Rydb.) On plains from Hudson Bay and Alb. to Neb. and Colo.-Mountain View; Gunnison; Pitkin; Empire. 
23. Potentilla filicaulis (Nutt.) Rydb. (P. effusa filicaulis Nutt.) In the mountains from Colo. to Ida.-Beaver Creek.

24. Potentilla rubripes Rydb. ( $P$. rubricaulis Rydb., mainly; not Lehm.) In the higher mountains from Alb. to Colo.-Alt. I0,000-I3,000 ft.-Estes Park; Mt. Abram, Ouray; Pike's Peak; Little Kate Mine, La Plata Mountains; Cameron Pass; Berthoud Pass; Rabbit-Ears, Larimer Co.

25. Potentilla minutifolia Rydb. On the higher peaks of Colo.-Alt. 900oI3,000 ft.-Graymont; Georgetown; Saddle, Pike's Peak; mountains of Estes Park; Cumberland Mine; Eldora to Baltimore.

26. Potentilla tenerrima Rydb. On the higher mountains of Colo,-Alt. I0,000-I3,000 ft.-Pike's Peak; West Spanish Peak.

27. Potentilla saximontana Rydb. On the higher peaks of Colo.-Alt. I0,000-I3,000 ft.-Pike's Peak; West Spanish Peak.

28. Potentilla pinnatisecta ( $\mathrm{S}$. Wats.) Rydb. In the mountains from Alb. to Colo. and Utah.-Alt. 8000-I2,000 ft.-Little Kate Mine, La Plata Mountains; mountains of Estes Park.

29. Potentilla plattensis Nutt. In mountain meadows from Sask. to Colo. and Utah.-Alt. 8000-I0,000 ft.-Platte River, South Park; Tobe Miller's ranch; Walden; Gunnison; Ojo; Placer Gulch; headwaters of Sangre de Cristo Creek; Buena Vista.

3o. Potentilla rupincola Osterh. Mountains in Colo.-Dale Creek, Larimer Co.

3r. Potentilla Hippiana Lehm. On plains and in meadows from Minn., Sask. and Alb. to N. M. and Ariz.-Alt. 4000-10,000 ft-Wear Empire; Trapper's Lake; Estes Park; Willow Creek; Georgetown; Gunnison; Colorado Springs; South Park; Chambers' Lake; Upper Laramie River; Forrester's ranch, Larimer Co.; North Park; Indian Creek Pass.

32. Potentilla propinqua Rydb. ( $P$. Hippiana diffusa Lehm.) In meadows from Colo. to N. M. and Ariz.-Alt. 600o-10,000 ft.-Rico; Como; near Narrows; Durango; Chambers' Lake; near Pagosa Peak; Mancos; Pagosa Springs; Ruxton Dell; Chicken Creek; Pitkin; Mt. Hesperus; North Park; Grizzly Creek, southwest of North Park.

33. Potentilla effusa Dougl. On plains and hills from Ass. and Mont. to N. M.-Alt. 5000-I0,000 ft.-Crow Creek; near Empire; Bosworth's ranch; Poudre flats, above Ft. Collins; Estes Park, Larimer Co.; Table Rock; Moore's ranch; Manitou; Cameron Pass; Cascade; Indian Creek Pass; Sangre de Cristo Creek; near Boulder.

34. Potentilla coloradensis Rydb. In the mountains of Colo.-Alt. 800oIo,ooo ft.-Georgetown; South Park; Estes Park, Larimer Co.; Empire; Chambers' Lake; Minnehaha; Silver Plume; Como.

35. Potentilla ambigens Greene. In the mountains of Colo. and N. M.36. Potentilla crinita A. Gray. On dry hills of Colo., Utah, N. M. and Ariz.-Piedra.

\section{HORIKELIA C. \& S.}

r. Horkelia Gordonii Hook. On dry mountains from Mont. and Wash. to Colo. and Calif.-Alt. about II,00o ft.-Buffalo Pass; summit of North Park Range, Routt Co.; Ethel Peak. 


\section{ARgentina Lam. Silver-leaf, Goose-tansy.}

Leaves green and glabrate above.

Leaves silvery-white on both sides.

1. A. anserina.

ᄂ. A. argentea.

I. Argentina anserina (L.) Rydb: (Potentilla anserina L.) Wet soil from Greenl. and Alaska to N. J., Colo, and Calif.-Alt. 4000-10,000 ft.-Bear River; Steamboat Springs; Ft. Collins; Como; Platte Cañon.

2. Argentina argentea Rydb. (A. anserima concolor Rydb.; not Potentilla anserina concolor Ser.) In wet mountain meadows from Ass. and Wash. to N. M. and Ariz.-Black's Lake; Upper Sangre de Cristo Creek.

\section{FRAGARIA L. STRAWBERRY.}

Pubescence of the scape and petioles spreading or reflexed; achenes superficial. Calyx in fruit spreading; scape usually with a leafy bract. I. F. bracteata. Calyx in fruit reflexed; scape generally without a leafy bract.

2. F. americana.

Pubescence of the scape and petioles appressed or ascending; achenes set in pits. Plant not glaucous; scape densely strigose.

Leaflets over $3 \mathrm{~cm}$. long, very veiny beneath; runners numerous.

$\begin{array}{ll} & 3 . F \text {. prolifica. } \\ \text { Leaflets } \mathrm{I}-3 \mathrm{~cm} \text {. long, not very veiny; runners few. } & 4 . F \text {. pumila. }\end{array}$

Plant more or less glaucous.

Leaves thin.

Leaflets obovate; scape several-flowered.

Leaflets oblong-cuneate; scape I-4-flowered.

Leaves rather thick, firm; leaflets oblong-cuneate.

I. Fragaria bracteata Heller. In meadows and open copses from Mont. and B. C. to N. M. and Calif.-Alt. 8000-II,000 ft.-Minnehaha; Little Veta Mountain; Pike's Peak; Georgetown.

2. Fragaria americana (Porter) Britton. (F. vcsca Pursh, in part; not L.) In meadows and woods and on hillsides from Newf. and Man. to Va. and N. M.-Dillon Cañon; Pennock's mountain ranch; Rist Cañon; Boulder; Ute Pass.

3. Fragaria prolifica Baker \& Rydb. In the mountains of Colo.-Alt. 7000Io,ooo ft.-Cameron Pass; Grayback mining camps and Placer Gulch; Pike's Peak; Seven Lakes; bank of Poudre; near Silverton; Como; Chambers' Lake; Columbine; Red Monntain; Breckenridge; Wahatoya Cañon; Pike's Peak; Cheyenne Cañon.

4. Fragaria pumila Rydb. On hillsides from S. D. and Wyo. to Colo.Pike's Peak; Gunnison; Seven Lakes.

5. Fragaria glauca (S. Wats.) Rydb. In meadows and open woods from Mackenzie and Mont. to S. D., Colo. and Nev.-Alt. 8000-Ir,000 ft.-Pike's Peak; Veta Mountain; Cucharas Valley, near La Veta; Pass Creek; East Indian Creek; Andrew's ranch, Larimer Co.; Little Kate Basin, La Plata Mountains; bank of Poudre; Howe's Gulch; Como.

6. Fragaria pauciflora Rydb. On hills from Hudson Bay and Alb. to Colo. and Utah.-Alt. 7000-900o ft.-North Boulder Peak; below Halfway House, Pike's Peak; Andrew's Shetland ranch; North Park, near Teller; Pennock's mountain ranch; along the Conejos River, north of Antonito; Minnehaha.

7. Fragaria ovalis (Lehm.) Rydb. (Potentilla ovalis Lehm.; Fragaria frma Rydb.) On dry hills from Colo. and Utah to Cent. Mex.-Bear Creek Divide, La Plata Mountains. 


\section{SIBBALDIA L.}

I. Sibbaldia procumbens L. On alpine peaks and in arctic regions from Greenl. and Alaska to N. H., Colo. and Calif.; also in Europe and Asia.Alt. ro,000-14,00o ft.-Massif de l'Arapahoe; Red Mountain, south of Ouray; Silver Plume; Mt. Harvard; West Spanish Peak; Tennessee Pass, seven miles west of Leadville; near Pagosa Peak; Boreas; Cameron Pass; Little Kate Basin, La Plata Mountains; Beaver Creek; Leroux Creek; Rabbit-Ear Range; Berthoud Pass.

\section{IO. DASIPHORA Raf. ShrubBy Cinquefoll.}

I. Dasiphora fruticosa (L.) Rydb. (Potentilla fruticosa L.) In meadows and on rocks from Lab, and Alaska to N. J., N. M. and Calif.-Alt. about Io,ooo ft.-Vicinity of Como; North Park; Berthoud Pass.

\section{CHAMAERHODOS Bunge.}

1. Chamaerhodos erecta (L.) Bunge. On dry plains from Sask. and Alaska to Colo.-Alt. up to $9000 \mathrm{ft}$--South Park, southeast of Jefferson.

\section{I2. DRYMOCALLIS Tourr.}

Petals white; leaves densely and coarsely hairy.

Petals yellow; leaves sparingly and finely pubescent.

I. D. arguta.

Corolla ${ }^{5} 5^{-20} \mathrm{~mm}$. in diameter; petals much exceeding the sepals.

2. D. fissa.

Corolla $r 0-15 \mathrm{~mm}$. in diameter; petals slightly if at all exceeding the sepals.

3. D. glandulosa.

I. Drymocallis arguta (Pursh) Rydb. On prairies, plains, meadows and hillsides from N. B. and Mackenzie to D. C. and Colo.-Table Rock; Steamboat Springs.

2. Drymocallis fissa (Nutt.) Rydb. (Potentilla fissa Nutt.) In the mountains from Mont. to Colo.-Alt. 6000-r2,000 ft.-Near Narrows, Rist Cañon; Horsetooth Gulch; Dixon Cañon; Beaver Creek; Table Rock; Empire; Bear Creek Cañon; Wyoming State line; Pennock's mountain ranch; Beaver Creek; summit of North Park Range, Larimer Co.

3. Drymocallis glandulosa (Nutt.) Rydb. (Potentilla glandulosa Nutt.) In the mountains from Alb. and B. C. to S. D., N. M. and Calif,--Leroux Creeks, Delta Co.; Rist Cañon.

Petals yellow, clawless.

I3. GEUM L. AVENS.

Upper internode of the style long-hairy; lower not glandular; petals $5-7 \mathrm{~mm}$. long.

1. G. strictum.

Upper internode of the style sparingly short-hairy; lower more or less glandularpuberulent; petals $4-5 \mathrm{~mm}$. long.

Petals pink or purplish, more or less clawed.

2. G. oregonense.

3. G. rivale.

1. Geum strictum Ait. In low meadows and among bushes from Newf. and B. C. to Pa., Mo. and Mex.-Alt. 4000-10,000 ft.-Headwaters of Sangre de Cristo Creek; Mancos; Stove Prairie, Larimer Co.; Moon's ranch; Buena Vista; Victoria; Piedra; Gunnison; Parlin, Gunnison Co.; Silver Plume; 
Soldier Cañon; Graymont; Ft. Collins; Happy Hollow; Elk Cañon; Bosworth's ranch; Boulder.

2. Geum oregonense (Scheutz) Rydb. (G. urbanum oregonense Scheutz; G. macrophyllum Cot1ter, in part; not Willd.) In mountain meadows from Mackenzie and B. C. to N. M. and Calif.-Alt. 6000-10,000 ft.-La Plata Cañon; Veta Pass; Marshall Pass; Cascade Cañon; Chicken Creek, west of Mt. Hesperus; Grizzly Creek; Chambers' Lake; White River Plateau; Hounold; Yampa; Victoria; Ironton Park, nine miles south of Ouray; Mancos; Castle Cañon; Arapahoe Pass; Elk Cañon; Beaver Creek; Rico; foothills, Larimer Co.; Medicine Bow Mountains; Arapahoe Pass; Empire; Eldora to Baltimore; Steamboat Springs.

3. Geum rivale L. In swamps and wet meadows from Newf. and B. C. to N. J. and Colo.-Alt. 8000-900o ft.-Estes Park; Twin Lakes; headwaters of Sangre de Cristo Creek; Indian Creek Pass; Victoria; Parlin, Gunnison Co.; Ironton Park, nine miles south of Ouray; Crystal Park; Empire; Walden.

\section{Sieversia R. Br. Mountain Avens.}

Petals light purple; styles in fruit much elongated, plumose. 1. S. ciliata.

Petals yellow; styles scarcely elongating in fruit, appressed hairy.

2. S. turbinata.

I. Sieversia ciliata (Pursh) Don. (Geum ciliatum Pursh; G. triflorum Pursh) On hills from Lab. and B. C. to N. Y. and Calif.; also in Mex.Alt. 8000-12,000 ft.-Como, South Park; Mt. Harvard; Chicken Creek, West La Plata Mountains; North Park; Twin Lakes; Pike's Peak; Pagosa; near Graymont; Marshall Pass; Van Boxle's ranch, above Cimarron; west of Ouray; Red Mountain road, south of Ouray; Dead Lake; Palsgrove Cañon; Arapahoe Pass; on the Michigan; Big South; near Silverton; Beaver Creek.

z. Sieversia turbinata (Rydb.) Greene. (Geum turbinatum Rydb.; $G$. Rossii T. \& G.; not Ser.) On the higher peaks from Wyo. to N. M. and Ariz.-Alt. I0,000-I4,000 ft.-Gray's Peak; Uncompahgre Peak; Cameron Pass; Pike's Peak; West Spanish Peak; near Pagosa Peak; Cumberland Basin, La Plata Mountains; Bear Creek Divide, West La Plata Mountains; Flat Top Mountains; Alpine Tunnel; Carson; Beaver Creek; Boreas; Devil's Causeway; Graymont; Berthoud Pass; Ethel Peak.

\section{FALLUGIA Endl.}

I. Fallugia acuminata (Woot.) Rydb. (F. paradoxa Coult., in part; and v. acuminata Woot.) On dry hills from Colo. and Utah to Tex and Ariz.-Alt. 8000-9000 ft.-Sangre de Cristo Creek; Cimarron.

\section{r6. HOLODISCUS Max.}

Leaf-blades broadly rounded ovate-spatulate, more or less double-toothed, with rounded teeth.

Leaf-blades oval or obovate, with simple ovate teeth.

Leaf-blades $1.5-4 \mathrm{~cm}$. long; panicle open, with spreading or reflexed, long branches.

Leaf-blades $\mathrm{I}-\mathrm{I} .5 \mathrm{~cm}$. long; panicle contracted, with

2. $H$. australis. branches. 
I. Holodiscus dumosus (Nutt.) Heller. (Spiraea dumosa Nutt.) On hills and mountains from Wyo. and Utah to Colo. and Ariz.-Alt. 5000-9000 ft.-Cheyenne Mountain; near Georgetown; Grand Junction; Glenwood Springs; Idaho Springs; Black Cañon; southeast of Ouray; Ragged Mountain, Gunnison Co.; Ute Pass; North Cheyenne Cañon; vicinity of Pine Grove; Empire.

2. Holodiscus australis Heller. On hills from Colo. to N. M. and Ariz.Alt. 6000-9000 ft.-Colorado Springs; Sangre de Cristo Creek; Cheyenne Cañon; Georgetown; Minnehaha.

3. Holodiscus microphyllus Rydb. On dry hills from Ida. and Ore. to Colo. and Calif.-Alt. about $9000 \mathrm{ft}$.-.Chicken Creek; Mt. Harvard.

I7. KUNZIA Spreng.

I. Kunzia tridentata (Pursh) Spreng. (Purshia tridentata DC.) On dry hills from Mont. and Wash. to N. M. and Calif.-Alt. 7000-8000 ft.-Livermore, Larimer Co.; Dolores; Walcott; divide road to Steamboat Springs; Pearl; between Pallas and Sydney; Rist Cañon; Stove Prairie Hill; Horsetooth Gulch; north of Poudre; Pinkham Creek.

\section{I8. COLEOGYNE Torr.}

I. Coleogyne ramosissima Torr. From southwestern Colo. and Nev, to Ariz. and Calif.-Alt. 5250 ft.-Near Hovenweep Castle (Brandegee).

19. Cercocarpus H. B. K. Mountain Holly.

1. Cercocarpus parvifolius Nutt. On hills from S. D. and Mont. to N. M. and Utah.-Alt. 5000-Io,000 ft.-Golden; Colorado Springs; Boulder; Cerro Summit; Manitou; Cucharas River, above La Veta; Livermore, Larimer Co.; Mancos; Trail Glen, Pike's Peak; North Cheyenne Cañon; foot-hills, Larimer Co.; Horsetooth Gulch; gulch west of Pennock's; Rist Cañon; Pennock's mountain ranch; Poudre Cañon; Trinidad; Ft. Collins; Eldora to Baltimore.

20. DRYAS L.

I. Dryas octopetala L. On alpine peaks and in arctic regions from Greenl. and Alaska to N. H., Colo, and Utah.-Alt. II,000-r4,00o ft.-Mt. Bartlett, Robinson; Bottomless Pit; Silver Plume; Mt. Harvard; mountains south of Ward; Front Range, Larimer Co.; above Beaver Creek; Cameron Pass.

\section{2x. AGRIMONIA L. AgRIMony.}

I. Agrimonia Brittoniana occidentalis Bickn. Among bushes from S. D. and Wyo. to N. M. and Ariz. The type-species extends east to Que. and W. Va.-Alt. about $5000 \mathrm{ft} .-\mathrm{Ft}$. Collins; North Cheyenne Cañon; Poudre flats; Table Rock; Redstone. 
22. ROSA L. Rose, Brier.

Infrastipular spines not present.

Stems bristly or prickly.

Flowers corymbose at the end of the stems or of almost erect branches.

Leaf-blades glabrous; stipules, leaf-stalks and sepals more or less glandular.

Leaf-blades densely pubescent, at least beneath.

1. $R$. arkansana.

Flowers solitary at the ends of spreading branches.

2. R. pratincola.

Leaflets finely but distinctly pubescent beneath.

Leaflets rather firm, coarsely serrate; fruit spherical or nearly so.

Leaves thin, sharply serrate; fruit elongated-ellipsoid.

3. R. Sayi.

4. R. Engelmannii.

Leaflets glabrous; fruit rounded-obovate or spherical. 5. R. melina. Stem unarmed.

Infrastipular spines present.

Hypanthium and fruit bristly.

II. R. Bakeri.

Hypanthium and fruit glabrous.

Leaflets glabrous or nearly so.

Spines curved.

Leaflets $\mathrm{I}-2 \mathrm{~cm}$. long; spines stout; fruit I $\mathrm{cm}$. or less in diameter.

Leaflets $2-3.5 \mathrm{~cm}$. long; fruit $\mathrm{I}-\mathbf{1 . 5} \mathrm{cm}$. in diameter.

Spines slender; leaves not bluish green, thin.

Spines stout; leaves bluish green, thick.

Spines straight or nearly so.

6. R. Underwoodii.

Leaflets decidedly pubescent beneath.

Fruit over I $\mathrm{cm}$. broad; leaflets large; flowers solitary; spines stout.

I I. R. Bakeri.

Fruit less than $\mathrm{I} \mathrm{cm}$. broad; spines weak, slightly curved or straight; flowers often corymbose.

Petioles and stipules densely glandular. I2. $R$. Fendleri.

Petioles not glandular; stipules merely glandular-toothed or entire.

Spines very slender and straight.

Spines stouter and somewhat curved.

13. $R$. aciculata.

14. R. Maximilliani.

1. Rosa arkansana Porter. In the Arkansas Cañon of Colo.

2. Rosa pratincola Greene. ( $R$. Arkansana S. Wats.; also Coult. Man.; not Pbrter.) On prairies and plains from Minn. and Alb. to Kans, and Colo. -Alt. 4000-6000 ft.-Veta Pass; Colorado Springs.

3. Rosa Sayi Schweinitz. On hills and mountains, in open woods, from Que. and Alb. to Mich. and Colo.-Alt. 5000-10,000 ft.-North Cheyenne Cañon; Cottonwood Lake; Ruxton Park, Pike's Peak; Front Range, Larimer Co.; Blue River, above Kremmling; Minnehaha; Hounold; Boulder; Columbine; Marshall Pass; falls of Poudre; west of Steamboat Springs; Campton's ranch; Beaver Creek; Horsetooth Mountain; gulch west of Pennock's; Boulder; Eldora to Baltimore.

4. Rosa Engelmannii S. Wats. In open woods from Upper Mich. and N. D. to Tex. and Colo.-Alt. up to $9000 \mathrm{ft}$.-Manitou; headwaters of Pass Creek; Minnehaha Falls.

5. Rosa Underwoodii Rydb. In cañons of Colo.-Alt. 8000-9000 ft.-Box Cañon, west of Ouray; La Plata Cañon.

6. Rosa manca Greene. In the mountains of Colo.-Alt. 7500-9000 ft.Mancos; southeast of Ouray.

7. Rosa melina Greene. In the mountains of Colo. and Wyo.-Alt. 6000Io,00o ft.-Chambers' Lake; West Spanish Peak; southeast of Ouray; Cerro Summit; B!ack Cañon. 
8. Rosa pandorana Greene. In the mountains of Colo.-Pandora.

9. Rosa Macounii Greene. In valleys and along streams from S. D. and Alb. to Kans, and Colo.-Colorado Springs; Pike's Peak; Mancos; New Windsor; North Cheyenne Cañon; Horsetooth Mountain.

10. Rosa Bakeri Rydb. In cañons and on hillsides from Mont. and Ida. to Colo.-Alt. 7500-9000 ft.--Box Cañon, west of Ouray; Dix Post Office; Four-Mile Hill, Routt Co.; Parlin.

I I. Rosa Fendleri Crepin. In valleys and along streams from S. D. and Mont. to N. M. and Ariz.-Alt. 500o-900o ft.-Blue River, above Kremmling; Golden; Twin Lakes; mountains between Sunshine and Ward; Boulder.

12. Rosa aciculata (Cockerell) Rydb. (R. blanda aciculata Cockerell) In rich valleys of Colo and N. M.-Alt. 6000-10,000 ft.-Walsenburg; mountains between Sunshine and Ward.

13. Rosa Maximiliani Nees. (?Rosa Woodsii Lindl.) In valleys and on foot-hills from Sask. and Wash. to Colo. and Utah.-Alt. 6000-9000 ft.Gunnison; Blue River, above Kremmling; foot-hills, Larimer Co.; Sangre de Cristo Creek; Pagosa Springs; southeast of Ouray; New Windsor; Horsetooth Mountain; Steamboat Springs.

\section{Family 67. MALACEAE Small. Apple Family.}

Cavities of the ovary becoming twice as many as the styles by a false, complete or incomplete partition; leaves simple, toothed.

Styles 5 ; flowers racemose.

1. Amelanchier.

Styles 2 ; flowers solitary or in sessile 2-3-flowered corymbs. 2. PERAPHYLLUM.

Cavities of the ovary as many as the styles; flowers in corymbiform, compound cymes.

Leaves simple, but more or less lobed; ovules solitary in each carpel.

Leaves pinnate; ovules 2 in each carpel.

3. Cratalgus.

4. Sorbus.

\section{AMELANCHIER L. June-Berry.}

Leaf-blades obtuse to truncate at the apex.

Leaf-blades orbicular or nearly so, truncate at the apex.

Mature leaves glabrous or sparingly and loosely villous.

Whole plant perfectly glabrous; bud-scales glabrous. 1. A. polycarpa.

Inflorescence and lower surface of the leaves white-villous when young; bud-scales hairy.

Petals 12-15 mm. long; mature leaves perfectly glabrous.
Leaf-blades elliptic.
2. A. elliptica.

Leaf-blades suborbicular or broadly oval.

3. A. alnifolia.

Petals about $8 \mathrm{~mm}$. long; mature leaves often somewhat villous beneath.

Mature leaves finely pubescent on both sides, or rarely glabrate above.

4. A. oreophila.

5. A. Bakeri.

Leaf-blades oval or obovate, obtuse or rounded at the apex, more or less glaucous beneath, entire or slightly toothed. 6 . A prunifolia.

Leaves more or less ovate, acute.

7. A. rubescens.

I. Amelanchier polycarpa Greene. Hills of Colo. and Wyo.-Alt. 7000I I,ooo ft.-Piedra; Mt. Abram, Ouray; Hounold; Twin Lakes; Bob Creek, west of La Plata Mountains; Cerro Summit; Ojo. 
2. Amelanchier elliptica A. Nels. Hills from S. D. to Colo.-Alt. 6000$8000 \mathrm{ft}$-Cerro Summit; Crystal Creek; Beaver Creek.

3. Amelanchier alnifolia Nutt. Dry hills and rolling plains from N. D. and Mont. to Colo. and Utah.-Alt 4000-8000 ft.-Poverty Ridge, near Cimarron; Cerro Summit; Hounold; Glenwood Springs; Horsetooth Gulch; Hounold; Central City; Four-Mile Hill; Parlin; Pallas; Pandora.

4. Amelanchier oreophila A. Nelson. Hills of Wyo. and Colo.-Alt. 500o$8000 \mathrm{ft}$.-Willow Creek; Camp Creek; Ojo; hills southeast of La Veta; Van Boxle's ranch, above Cimarron; Los Pinos (Bayfield) ; Cottonwood Lake; City Creek Cañon; Minturn.

5. Amelanchier Bakeri Greene. Dry hills of Colo.-Alt. 6000-8000 ft. Cedar Creek; Mancos; Los Pinos (Bayfield); Wolcott; Twin Lakes.

6. Amelanchier prunifolia Greene. Dry hills and mountains of Colo. and Utah.-Alt. 4000-8000 ft.-Mancos; Cerro Summit.

7. Amelanchier rubescens Greene. Dry hills of Colo. and N. M.-Between Rifle and Meeker; Cedar Creek.

\section{PERAPHYLLUM Nutt.}

I. Peraphyllum ramosissimum Nutt. Dry hills and mountains from Ore. to Colo. and Calif.-Alt. 6500-8000 ft.-Mancos; Los Pinos (Bayfield) ; Cerro Summit; Cimarron; Durango; Dolores.

\section{CRataegus L. HAWthORN.}

Inflorescence pubescent; leaves hairy beneath, at least on the veins.

Leaf-blades orbicular or broadly obovate, abruptly contracted at the base, 5-7 $\mathrm{cm}$. wide, less distinctly lobed, toothed to near the base.

1. C. coloradensis.

Leaf-blades obovate or rhombic, with a cuneate base, 5-9 lobed, with triangular acute lobes, 3-5 $\mathrm{cm}$. wide.

Inflorescence glabrous; leaves glabrous beneath.

Leaf-blades serrate or incised; fruit 8-10 mm. broad.

Leaf-blades rhombic, incisedly lobed with acte serrate lobes.

3. C. cerronis.

Leaf-blades oblanceolate or rhombic-oblanceolate, merely irregularly serrate.

Leaf-blades crenate; fruit $6-7 \mathrm{~mm}$. long.

4. C. Wheeleri.

5. C. saligna.

I. Crataegus coloradensis Aven Nelson. Cañons of Colo.-Alt. 5000-6000 ft.-Colorado Springs; Boulder.

2. Crataegus occidentalis Britton. River-banks from N. D. and Mont. to Neb. and Colo.-Alt. 4000-6000 ft.-Golden; foot-hills, Larimer Co.; Boulder; Lower Boulder Cañon; Horsetooth Gulch.

3. Crataegus cerronis A. Nels. Along streams in Colo.-Alt. 5000-8000 ft. -Colorado Springs; Larin; Golden; Livermore; Boulder; Cerro Summit.

4. Crataegus Wheeleri A. Nels. Along streams from Wyo. to Colo. and Utah.-Alt. about $6000 \mathrm{ft}$.-Wolcott; Steamboat Springs; between Pallas and Sydney; Steele Cañon; Villa Grove; Dix; between Meeker and Craig; between Rifle and Meeker; Spring Creek, above Uncompahgre River.

5. Crataegus saligna Greene. Hillsides of Colo.-Alt. up to $7000 \mathrm{ft}$. Cimarron; Gypsum Creek Cañon; Meeker; Wolcott; Gunnison; Parlin. 


\section{SORBUS L. Mountain Ash.}

I. Sorbus scopulina Greene. (Pyrus sambucifolia T. \& G.; not C. \& S.) In moist ground and hillsides from Alb. and Wash. to Colo. and Utah.Alt. 5000-10,000 ft.-Near Ouray; Upper La Plata Cañon; Four-Mile Hill, Routt Co.; Pagosa Peak; Box Cañon, west of Ouray; Victoria; North Cheyenne Cañon; west of Palmer Lake; Buffalo Pass; Empire; Rabbit-Ear Range, Routt Co.

Family 68. AMYGDALACEAE Reichenb. Plum Family.

1. Prdnus l. Plums, Cherries.

Flowers in lateral scaly umbels or corymbs, expanding with or before the leaves.

Pits of the fruit flattened; leaves convolute in vernation. I. P. americana.

Pits globose, not flattened; leaves conduplicate in vernation.

Low, decumbent shrubs; inflorescence strictly sessile and umbel-like.

z. P. Besseyi.

Erect shrubs or trees; inflorescence corymbiform, more or less peduncled.

Flowers in long racemes, ending leafy branches of the season.

3. P. pennsylvanica.

4. P. melanocarpa.

I. Prunus americana Marsh. Along streams from N. Y. and Mont. to Fla. and Colo.-Alt. 4000-7000 ft.-Boulder; foot-hills of Larimer Co.; Walsenburg; plains near Denver; gulch west of Dixon Cañon; vicinity of Horsetooth; Rist Cañon; Horsetooth Gulch; Trinidad; Cache la Poudre; Manitou.

2. Prunus Besseyi Bailey. On sand-hills from N. D. to Kans. and Colo. -Alt. 4000-5500 ft.-Ft. Collins; foot-hills west of Ft. Collins; north of La Porte; Horsetooth Mountain; Black's Lake.

3. Prunus pennsylvanica L. f. In rocky woods and on hillsides and along streams from Newf. and N. D. to Ga. and Colo.-Alt. 4000-9500 ft.-Estes Park, Larimer Co.; Ft. Collins; Minnehaha; gulch west of Pennock's; Pike's Peak; Rist Cañon; Stove Prairie Hill; Redstone; mountains between Sunshine and Ward; Eldora to Baltimore; Manitou.

4. Prunus melanocarpa (A. Nels.) Rydb. ( $P$. demissa Torr., in part; not Walp. ; Cerasus demissa melanocarpa A. Nels.) On hillsides from N. D., Alb., and B. C. to N. M. and Calif.-Alt. 4000-8000 ft.-Lake City; foot-hills, Larimer Co.; Estes Park; Mancos; Cheyenne Cañon; butte, five miles southwest of La Veta; Cucharas River, below La Veta; Dillon Cañon; Trinidad; Ft. Collins; Cache la Poudre; Bosworth's ranch; gulch west of Pennock's; Horsetooth Gulch; Dixon Cañon; Purgatory River, Trinidad; Pinkham Creek.

Family 69. MIMOSACEAE Reichenb. Mimosa Family.

Valves of the pod not separating from the continuous margin, not prickly; stems erect, unarmed.

I. Acuan.

Valves of the pod separating from the continuous margin; pod 4-angled, prickly; stems prostrate, prickly.

2. Morongia. 


\section{1. acuan Medic, Prairie Mimosa.}

I. Acuan illinoensis (Michx.) Kuntze. (Desmanthus brachylobus Benth.) In rich bottom lands from Ind. and S. D. to Fla., Tex. and Colo.-Sterling.

\section{MORONGIA Britton. Sensitive-Brier.}

ז. Morongia uncinata (Willd.) Britton. (Schrankia uncinata Willd.) On prairies from Ill. and S. D. to Fla. and Tex.-Exact locality not given.

\section{Family 70. Cassiaceae link. Senna Family.}

Leaves simply pinnate; corolla very irregular; one of the lateral petals (standard) and the lowest petal larger than the rest. I. CHAMAECRISTA.

Leaves twice pinnate; corolla regularly zygomorph, the upper petal only differing materially from the rest.

z. HoFfMANSEggia.

\section{CHAMAECRISTA Moench.}

I. Chamaecrista fasciculata (Michx.) Greene. (Cassia fasciculata Michx.; C. Chamaecrista Walt.; not L.) In prairies from Me. and S. D. to Fla., Tex. and Colo.-Denver.

\section{HOFFMANSEGGIA Cav.}

Leaves, flowers and pods with black glandular dots; pods short, $2-2.5 \mathrm{~cm}$. long, straight on the back or nearly so.

Dark glandular dots none; pods $3-4 \mathrm{~cm}$. long, strongly arcuate. 1. H. Jamesii.

2. H. drepanocarpa.

1. Hoffmanseggia Jamesii Torr. In dry soil from Colo. to Tex. and Ariz. -Alt. 4000-7000 ft.-Rocky Ford; Colorado City; Arkansas River; Wray.

2. Hoffmanseggia drepanocarpa A. Gray. In dry soil from Colo to Tex. and Ariz,--Cañon City.

\section{Family 7r. FABACEAE Reichenb. Pea Family.}

Filaments distinct.

Leaves pinnate. Tribe I. SophoreaE.

Leaves digitately 3 -foliate. Tribe II. PodalyrieaE.

Filaments monadelphous or diadelphous.

Rachis of the leaves not produced into a tendril or bristle-like appendage, representing the terminal leaflet.

Fruit 2-valved or indehiscent, not a loment.

Foliage not glandular-dotted.

Anthers of 2 kinds; filaments monadelphous; leaves digitate; calyx 2lipped. Tribe III. Genis IEAe.

Anthers all alike; filaments diadelphous; calyx 5-toothed.

Leaflets toothed.

Leaflets not toothed.

Tribe IV. TrifolieaE.

Leaves irregularly pinnate; leaflets even in number, 4 or 6; stipules gland-like; flowers umbellate. Tribe V. LOTEAE.

Leaves odd-pinnate; stipules not gland-like; flowers racemose or capitate.

Foliage glandular-dotted.

Pod prickly.

Pod not prickly, indehiscent.

Tribe VI. GalegeaE.

Tribe VII. GlycyrrhizeaE.

Tribe VIII. Psoraleae. 
Pod a loment, $i$. e., brèaking up transversely into $\mathrm{I}$-seeded indehiscent reticulate internodes.

Tribe IX. HedysareaE.

Rachis of the leaves produced into a tendril or bristle-like appendage.

Tribe X. Vicieae.

One genus.

One genus

One genus
TRIBE I. SOPHOREAE.

1. Sophora.

Tribe II. PODALYRIEAE.

z. Thermopsis.

Tribe III. GENISTEAE.

3. Lupinus.

Tribe IV. TRIFOLIAE.

Leaves digitate; in ours 3 -foliolate.

Leaves pinnately 3 -foliolate.

Pod curved or coiled.

Pod straight.

One genus.

TRIBE V. LOTEAE.
4. Trifolium.

5. Medicago.

6. Melilotus.
7. Anisolotus.

Tribe. VI. GALEGEAE.

I. Leaves pinnate or unifoliolate.

A. Blade of the standard as broad as long, spreading; trees.

Leaflets with stipels; pod broad, margined on one edge.

Leaflets without stipels; pod narrow.

8. ROBINIA.

9. Peteria,

B. Blade of the standard relatively narrow, mostly erect; herbs.

I. Keel (lower petals) not produced into a beak.

u. Pods 2-celled, with a perfect partition.

Pods fleshy, indehiscent or very tardily dehiscent.

Pods membranous, leathery or woody, dehiscent.

io. Geoprumnon.

Pods not inflated.

Pods ovoid or oblong, rarely almost didymous, terete or vertically flattened, leathery or woody.

i i. Astragalus.

Pods linear, somewhat laterally flattened, membranous.

Pods strongly inflated, papery.

I2. Hamosa.

I3. Cystium.

$b$. Pods I-celled, the partition, if any, rudimentary.

Lower suture strongly intruded, making the pod sagittate or obcordate in cross-section; pod membranous, rarely leathery.

I4. TIUM.

Lower suture not intruded or merely slightly so; pods in the latter case woody.

Pods strongly inflated, papery.

25. PHACA.

Pods not inflated, or slightly so, membranous to woody.

Pods with a partial partition, formed by the inflexion of the lower suture.

Pods membranous.

I 5. ATELOPHRAGMA.

Pods woody.

Pods stipitate; leaves unifoliolate.

Pods sessile; leaves pinnate.

Calyx-tube short, campanulate, equalling or shorter than the lobes; tall glabrous plants.

i 7. Phacopsis.

Calyx cylindrical, longer than the lobes; low cespitose, cinerous or villous plants.

18. XYLOPHACOS.

Pods without a vestige of a partition. 
Pods not with two grooves on the upper side (or if slightly grooved, sessile).

Pods with a fleshy epicarp, in fruit cross-ribbed; leaflets obscurely articulated to the rachis, fleshy, narrow.

ig. Ctenophylum.

Pods without fleshy epicarp; leaflets distinctly articulated to the rachis.

Pods woody or at least leathery, flattened or slightly intruded on the lower side.

Calyx cylindrical; flowers large; plant mostly low and cespitose.

I8. XYLOPHACOS.

Calyx campanulate; flowers small.

Corolla yellow; calyx-lobes linear-lanceolate, equalling the tube; stipules united; stem low.

20. CNEMIDOPHACOS.

Corolla purple; calyx-lobes triangular; much shorter than the tube; stipules free or nearly so; stem tall and slender. 2 I. Microphacos.

Pods membranous, ustually more or less flattened laterally, with both sutures prominent.

Leaflets spinulose-tipped; pod I-2-seeded.

23. Kentrophyta.

Leaflets not spinulose-tipped; pods several-seeded.

Pods with two grooves on the upper side, stipitate.

24. Homalobus.

2. Keel (lower petals) produced into a beak.

22. Dimolcos.

II. Leaves digitately 3 -foliolate.

Flowers racemose.

27. Aragallus.

Flowers capitate (some species of).

26. Orophaca.

4. TRIFOLIUM.

One genus.

\section{TrIbe VII. GLYCYRRHIZEAE.}

Tribe VIII. PSORALEAE.

Petal I (standard); leaves odd-pinnate.

Petals 5.

Wings and keel free from the filament-tube; leaves in our digitate.

30. Psoralea.

Wings and keel adnate to the filament-tube; leaves odd-pinnate.

Stamens 9 or 10.

3i. Parosela.

Stamens 5 .

32. Petalostemon.

TRIBE IX. HEDYSAREAE.

Pod 4-several-seeded, neither spiny nor toothed.

Pod I-z-seeded, more or less spiny or toothed.

33. Hedysarum.

34. ONOBRYCHIS.

TRIBE X. VICIEAE.

Style filiform, hairy all around and below the apex; stamen-tube usually oblique at the summit. 35. Vicia.

Style flattened towards the apex, hairy on the inner side; stamen-tube usually truncate or nearly so. 36. LATHYRUS.

\section{SOPHORA L.}

I. Sophora sericea Nutt. Dry prairies from S. D. and Wyo. to Tex. and Ariz.-Alt. 4000-7000 ft.-New Windsor, Weld Co.; Colorado Springs; Ft. Collins; mesas near Pueblo; Walsenburg; Poudre Flats; Trinidad; Boulder; Colorado City. 
Pods erect or ascending.

\section{THERMOPSIS R. Br.}

Pods straight.

Pods strictly erect and appressed, densely pubescent; stipules narrow.

Pods ascending-erect, sparingly pubescent; stipules broad.

Pods arcuate, with spreading tips.

Pods strongly divaricate or reflexed, curved.

Pods mostly horizontal, arcuate.

Pods reflexed, curved in a half-circle or more.

1. T. montana.

I. Thermopsis montana Nutt. ( $T$. stricta Greene) In meadows from Mont. and Wash. to Colo., Utah and Ore-Alt. 5000-9000 ft.-Hounold; Larimer Co.; Grayback mining camps and Placer Gulch; along Conejos River, north of Antonito; Sapinero; Gunnison.

2. Thermopsis pinetorum Greene. In open woodlands and on hillsides in Colo, and N. M.-Alt. 5000-9000 ft.-Chicken Creek, West La Plata Mountains; East Indian Creek; Los Pinos (Bayfield); Grayback mining camps and Placer Gulch; Table Rock; foot of Horsetooth Mountain; Rist Cañon; Boulder; Colorado Springs; Marshall Pass.

3. Thermopsis divaricarpa A. Nels. In valleys and on foot-hills in Wyo. and Colo.-Alt. 5000-II,000 ft.-Denver; Cucharas Valley, near La Veta; Veta Mountain; Ute Pass; Sangre de Cristo Creek; mountain near Veta Pass; Ft. Collins; Howe's Gulch; Beaver Creek; Horsetooth Mountain; Cache la Poudre; foot-hills near Boulder; Eldora to Baltimore; Rist Cañon; Anita Peak.

4. Thermopsis arenosa A. Nels. In sandy soil from Sask, and Mont. to Colo.-Alt. 8000-Io,000 ft.-Empire; Eldora to Baltimore.

5. Thermopsis rhombifolia (Nutt.) Richardson. In sandy soil from Sask. and Mont. to Colo.-Alt. $4000-8000 \mathrm{ft}$-Manitou; butte five miles southwest of La Veta; mesas near Colorado Springs; Black's Lake; west of Soldier Cañon; north of La Porte; north of Ft. Collins; Trinidad.

\section{LUPINUS L. LUPINE.}

A. Perennials ; cotyledons petioled after germination.

I. Stems tall, $3 \mathrm{dm}$. or more, scarcely cespitose.

I. Leaves glabrous above, at least in age.

Stem pubescent with long and spreading hairs or glabrous.

Banner not with a dark spot; leaflets of the basal leaves oblanceolate, acute.

Banner with a dark spot; leaffets of the basal leaves spatulate, obtuse, mucronate.

Stem appressed-pubescent, at least above.

2. L. ammophilus.

Flowers large, over I $2 \mathrm{~mm}$. long; banner with a dark spot.

3. L. plattensis.

Flowers small or middle-sized, I $2 \mathrm{~mm}$. or less long; banner not with a dark spot.

Plant green; stem and lower surface of the leaves sparingly appressedpubescent.

Flowers middle-sized, 8-12 mm. long.

Plant purplish; calyx strongly gibbous at the base.

Plant green; calyx not strongly gibbous.

4. L. rubricaulis.

lowers very small, $6-8 \mathrm{~mm}$. long.

5. L. alpestris. 
Flowers about $8 \mathrm{~mm}$. long.

6. L. parvifiorus.

Flowers about $6 \mathrm{~mm}$. long.

Plant vivid green, not at all canescent. 7. L. floribundus.

Plant dark green; inflorescence and young leaves canescent.

8. L. myrianthus.

Plant light green; stem more strigose; leaves more or less silvery; flowers light blue or white.

Flowers about $8 \mathrm{~mm}$. long; leaflets linear. Ir. L. tenellus.

Flowers 10-12 mm. long; leaflets oblanceolate.

12. L. decumbens.

z. Leaves permanently pubescent above.

Plant green; leaves appressed-pubescent or slightly silky; pubescence of the stem long, spreading.

9. L. comatus.

Plants more or less canescent or silvery; at least the upper part of the stem, inflorescence and the lower surface of the leaves densely silky or villous.

Stem appressed-pubescent.

Calyx distinctly spurred at the base. Io. L. argophyllus.

Calyx not spurred, but sometimes rather strongly gibbous at the base.

Flowers less than I2 mm. long; banner not conspicuously lightspotted.

Pubescence of the leaves finely silky, short, not dense, and perfectly appressed.

Pubescence of the inflorescence finely appressed-silky; leaflets oblanceolate.

I3. $L$, argenteus.

Pubescence of the inforescence looser and spreading.

I2. L. decumbens var.

Pubescence of the leaves dense, longer and often looser.

I 4. L. oreophilus.

Flowers $12 \mathrm{~mm}$. or more long; banner with a large conspicuous light spot.

Stem few-leaved, only slightly exceeding the long basal leaves. I5. L. hunicola.

Stem very leafy, many times exceeding the basal leaves.

I6. L. sericeus.

Stem with dense pubescence of spreading usually short hairs.

Corolla blue; banner with a light spot.

I7. L. Bakeri.

Corolla at first white; the banner changing into purple; no light spot.

I8. L. dichrous.

II. Stem low, less than $3 \mathrm{dm}$. high, densely cespitose.

Inflorescence much exceeding the leaves.

I9. L. psoralioides.

Inflorescence not exceeding the leaves.

Racemes very dense and short, sessile; bracts lanceolate, about equalling the flowers; pubescence rather appressed.

20. L. caespitosus.

Racemes elongated; bracts subulate, exceeding the flowers; pubescence loose.

21. L. Watsoni.

B. Annuals; cotyledons after germination sessile, clasping the stem; pod 2 -seeded. Raceme dense, subcapitate; lower lip of the calyx 2-3-toothed.

Plant almost stemless; lower lip of the calyx oval or ovate.

22. L. brevicaulis.

Plant with a distinct leafy stem; lower lip of the calyx oblong-lanceolate.

23. L. Kingii.

Racemes more elongated and less dense; lower lip of the calyx entire. 24. L. pusillus.

1. Lupinus amplus Greene. In the mountains of Colo.-Alt. about 8000 ft.-Cerro Summit; below Steamboat Springs.

2. Lupinus ammophilus Greene. (L. Sitgreavesii Coult. Man., in part.) In the mountains of Colo. and N. M.-Alt. 6000-7000 ft.-Los Pinos (Bayfield); Mancos; Durango. 
3. Lupinus plattensis S. Wats. On hillsides in western Neb., Wyo. and Colo.-Alt. 5000-8000 ft.-Walsenburg; Denver; La Veta; butte five miles southwest of La Veta.

4. Lupinus rubricaulis Greene. Hills in Colo.-Alt. about $9000 \mathrm{ft}$-Custer Butte.

5. Lupinus alpestris A. Nels. (L. alsophilus Greene.) In mountain valleys from Mont. to Colo. and Utah.-Alt. 8000-II,000 ft.-North fork of Cache la Poudre; divide above Steamboat Springs; Grizzly Creek; Little Veta Mountain; Four-Mile Hill; North Park; Buffalo Pass; mountains above Ouray; summit of North Park Range, Routt Co.

6. Lupinus parviflorus Nutt. In open woods, on hillsides, among bushes, S. D. and Mont. to Colo. and Utah.-Alt. 8000-12,000 ft.-Near Empire; Red Mountain road, south of Ouray; Pearl; North Park, near Teller; Berthoud Pass; Breckenridge.

7. Lupinus floribundus Greene. In the mountains of Colo.-Upper Bear Creek.

8. Lupinus myrianthus Greene. In the mountains of Colo-Alt. 80009000 ft.-Pitkin; Parlin, Gunnison Co.; Jack's Cabin.

9. Lupinus comatus Rydb. In the mountains of Colo.-Alt. about 8000 ft.-Lake City; Chicken Creek, La Plata Mountains; Gunnison Co.

Io. Lupinus argophyllus (A. Gray) Cockerell. (L. decumbens argophyllus A. Gray; L. Helleri Greene; L. aduncus Greene) Valleys and river banks from Neb. and Colo. to N. M.-Alt. 4000-9000 ft.-Durango; Sangre de Cristo Creek; Grayback mining camps and Placer Gulch; Mancos; Mesa Verde; Colorado Springs; Antonito; bank of Conejos River.

II. Lupinus tenellus Nutt. In the mountains from Mont. to Colo. and Calif.-Estes Park; Mt. Harvard; Middle Park; Twin Lakes; Kremmling.

12. Lupinus decumbens Torr. ( $L$. argenteus decumbens A. Gray; L. leptostachys Greene) On prairies and hillsides from Neb., Mont. and Ore. to Colo. and Calif.-Alt. 4000-9000 ft.-Boulder; Douglass Co.; foot-hills, Larimer Co.; Colorado Springs; Wahatoya Creek; La Veta; Mosquito Pass; Moon's ranch; Victoria; Veta Mountain; North Park; Trail Creek; Rist Cañon; Sapinero; New Windsor; Bosworth's ranch; Pennock's mountain ranch; Horsetooth Mountain; Callaway; Redcliffe.

Lupinus decumbens argentatus Rydb. Leaflets broader than in the type and not conduplicate. On prairies and hillsides in Wyo. and Colo.-Alt. 5000-9000 ft.-High mountains, Larimer Co.; between Sunshine and Ward; foot-hills near Boulder.

13. Lupinus argenteus Pursh. On prairies from Mont. to Colo.-Glenwood Springs.

14. Lupinus oreophilus Greene. In the mountains from Wyo. to Utah and Colo.-West Cliff; Cimarron; Steamboat Springs; Meeker; Rio Blanco Co.

15. Lupinus humicola A. Nels. In rich soil in Colo. and Wyo--Near Ironton, San Juan Co.

16. Lupinus sericeus Pursh. On prairies from Ass. and Wash. to Wyo. and Nev. A doubtful specimen has been collected in Colo.-Minturn.

17. Lupinus Bakeri Greene. In the mountains of Colo.-Alt. 7000-8500 ft.-Hesperus; Los Pinos (Bayfield); Cedar Edge. 
18. Lupinus dichrous Greene. In the mountains of Colo.-Alt. about 7000 ft.-Cedar Edge.

19. Lupinus psoralioides Pollard. Open gravelly soil in Colo.-Gunnison.

20. Lupinus caespitosus Nutt. On hillsides from Mont. to Colo. and Utah.-Alt. about 8000 ft.-Hinsdale Co.; North Park, near Teller; twelve miles below Grand Lake; Gunnison; Kremmling.

2x. Lupinus Watsoni Heller. (Lupinus aridus Utahensis S. Wats.) In sandy soil from Ida. to Colo. and Utah.-North Park; Gunnison.

22. Lupinus brevicaulis $\mathrm{S}$. Wats. On hills from Colo. and Utah to N. M. and Ariz.-Alt. 5000-6000 ft.-Arboles; Hotchkiss, Delta Co.

23. Lupinus Kingii S. Wats. (L. Sileri S. Wats.) In dry soil from Utah and Colo. to Ariz.-Alt. 4000-8000 ft.-Mancos; Garland; Piedra; Thompson's Park, La Plata Mountains; Gunnison.

24. Lupinus pusillus Pursh. On dry plains from Mont. and Ore. to Kans., N. M. and Utah.-Alt. I500-1600 m--Mesas near Pueblo; New Windsor; Crow Creek; La Porte, Larimer Co.; Wray; Hotchkiss; Lamar; Rocky Ford; Ft. Collins; Walsenburg.

\section{TRIFOLIUM L. Clover.}

Heads not involucrate.

Plants mostly tall ; stem leafy.

Calyx hairy.

Heads sessile; corolla red-purple; free portion of the stipules ovate.

I. T. pratense.

Heads long-peduncled; corolla white or pink; free portion of the stipules elongated-lanceolate.

Plants cespitose from a woody root; stems ascending; corolla salmoncolor.

Plant erect from a creeping rootstock; corolla white.

Calyx glabrous; peduncles axillary; corolla white or rose-color.

2. T. Rusbyi.

3. T. Rydbergii.

4. T. repens.

Plants low, cespitose; stems scapiform.

Calyx glabrous.

Heads I-3-flowered; flowers not reflexed; calyx-teeth lanceolate; caudex thick, densely cespitose with short branches.

5. T. nanum.

Heads several-flowered; flowers reflexed; calyx-teeth subulate; branches of the caudex more slender and elongated. $\quad$ 6. T. Brandegei.

Calyx pubescent.

Leaflets oval or obovate, strongly veined and sharply dentate. Flowers $\mathrm{I} 0-\mathrm{I} 2 \mathrm{~mm}$. long. Flowers about $8 \mathrm{~mm}$. long.

7. T. subacaulescens.

8. $T$. gymnocarpon.

Leaflets lanceolate or linear-lanceolate, entire and not strongly veined.

Flowers reflexed in fruit; bracts minute, truncate and toothed.

Calyx $2 / 3-3 / 4$ as long as the corolla; its teeth fully twice as long as the tube.

9. T. stenolobum.

Calyx about half as long as the corolla; its teeth only slightly longer than the tube.

Banner acuminate; leaflets linear-lanceolate. Io. $T$. attenuatum.

Banner obtuse, minutely mucronate; leaflets oblong-lanceolate to elliptic.

II. T. bracteolatum.

Flowers not reflexed in fruit; bracts more conspicuous, lanceolate to subulate, long-attenuate.

Bracts narrowly linear-lanceolate or subulate, much exceeding the calyx-tube and often almost equalling the calyx-teeth; plant bright green.

เ2. T. lividum. 
Bracts slightly, if at all, exceeding the calyx-tube, distinctly scariousmargined and abruptly contracted into a long acumination; plant grayish.

Heads more or less involucrate by more or less united bracts.

I3. T. dasyphyllum.

Plants low, cespitose; stem scapiform; bracts united only at the base.

Bracts lanceolate to linear-subulate; leaflets entire (see No. 9-13).

Bracts oblong, oval, ovate or obovate; leaflets dentate.

Banner long-acute, much exceedings the wings. I4. T. salictorum.

Banner blunt, slightly exceeding the wings.

I5. T. Parryi.

Plants with elongated leafy stem; bracts united to a monophyllous involucre.

Corolla i $2-15 \mathrm{~mm}$. long.

Corolla about Io $\mathrm{mm}$. long.

I6. T. Fendleri.

I7. $T$, oxydon.

s. Trifolium pratensis L. Cultivated and escaped along roads, around dwellings and in waste places from Newf, and B. C. to Colo. and Calif.Ft. Collins.

2. Trifolium Rusbyi Greene. In meadows from Colo. to Ariz. and Calif. - Mancos.

3. Trifolium Rydbergii Greene. ( $T$. longipes A. Gray and Coult., in part; not Nutt.) In meadows from Mont. and Ida. to Colo. and Utah.-Alt. 6000-10,000 ft.-Chicken Creek, West La Plata Mountains; mountain near Veta Pass; Pearl; Elk River, Routt Co.; West Indian Creek; Gore Pass; Dolores; Holdredge's ranch, North Park; Camp Creek.

4. Trifolium repens L. Cultivated and escaped in waste places and meadows from Newf. to B. C. to Fla, and Calif.-Alt. up to $7000 \mathrm{ft}$-Cucharas Valley, near La Veta.

5. Trifolium nanum Torr. In the mountains from Mont, to Colo--Alt. 9000-I4,00o ft.-Mt. Evans; Lake City; Pike's Peak; near Empire; Carson; Gray's Peak; mountains above Como; West Spanish Peak; Hayden Peak; near Pagosa Peak; Cameron Pass; Berthoud Pass.

6. Trifolium Brandegei $S$. Wats. In the mountains of Colo--Alt. up to I2,500 ft.-Near Pagosa Peak; Cumberland Basin, La Plata Mountains.

7. Trifolium subcaulescens A. Gray. ( $T$. nemorale Greene) In dry soil in Colo. and N. M.-Los Pinos; Glenwood Springs; Mancos.

8. Trifolium gymnocarpon Nutt. In arid places from Wyo. to Colo. and Utah.-Alt. up to $8000 \mathrm{ft}$.-North Park; Cerro Summit.

9. Trifolium stenolobum Rydb. On alpine peaks of Colo--Alt. 9000I2,000 ft.-Little Kate Basin, La Plata Mountains; Upper La Plata Cañon; near Ironton, San Juan Co.

10. Trifolium attenuatum Greene. On alpine peaks of Colo.-Alt. about ri,500 ft.-Near Pagosa Peak.

11. Trifolium bacteolatum Rydb. ( $T$. lilacinum Rydb.; not Greene; $S$. petraeum Greene) On mountain peaks of southern Colo.-Alt. 9000-ro,000 ft.-West Spanish Peak.

I2. Trifolium lividum Rydb. On alpine peaks of Wyo. and Colo.-Alt. ro,000-I2,000 ft.-Massif de l'Arapahoe; Graymont; Alpine Tunnel.

13. Trifolium dasyphyllum Torr. On alpine peaks from Mont. to Colo. -Alt. 7000-13,000 ft.-Berthoud Pass; Eldora to Baltimore; Lake City; Pike's Peak; Hinsdale Co.; headwaters of Clear Creek; Cameron Pass; Bald Mountain; Mt. Harvard; Silver Plume; mountains above Boreas; Twin Lakes; mountains of Larimer Co.; Flat Top Mountains, Routt Co.; 
mountains south of Ward, Boulder Co.; Devil's Causeway; above Beaver Creek; Leroux Creek; Twin Lakes; Spicer.

14. Trifolium salictorum Greene. Mountains of Colo-Alt. about 12,000 ft.-Carson.

I5. Trifolium Parryi A. Gray. In the mountains of Wyo., Utah and Colo. -Alt. I0,000-13,000 ft.-Twin Lakes; headwaters of Clear Creek; Tennessee Pass, seven miles west of Leadville; Cameron Pass; Buena Vista, Chaffee Co.; Marshall Pass; mountains above Boreas; Estes Park; Silver Plume; Gray's Peak; Robinson; Chambers' Lake; Graymont; Leroux Creek; above Beaver Creek; Berthoud Pass.

16. Trifolium Fendleri Greene. In meadows from Colo. to N. M. and Ariz.; also in Mex.-Alt. up to $8000 \mathrm{ft}$-Wahatoya Creek; Gunnison; La Veta; Parlin, Gunnison Co.; Buena Vista; along the Conejos River, north of Antonito; Monte Vista.

17. Trifolium oxyodon Greene. In meadows from Colo. to Ariz.-Alt. up to $7700 \mathrm{ft}$.-Gunnison.

\section{5. medicago L. Alfalfa, Lucerne, Medic.}

1. Medicago sativa L. Cultivated from Europe and escaped from Me. and Ida. to Va. and Utah.-Alt. 5000-6000 ft.-Colorado Springs; Ft. Collins; Boulder.

6. Melilotus Juss. Sweet Clover.

Corolla white; banner a little longer than the wings.

Corolla yellow; banner about equalling the wings.

1. M. alba.

2. $M$. officinalis.

I. Melilotus alba Desv. In waste places from N. S. and D. C. to Ida. and Nev. Naturalized from Europe; also cultivated.-Alt. 4000-7000 ft.Cucharas Valley, near La Veta.

z. Melilotus officinalis (L.) Lam. In waste places from N. S. and La. to Ida. and Colo. Naturalized from Europe; occasionally cultivated for bees.-Alt. 4000-6000 ft.-Ft. Collins; Boulder.

\section{ANISOLOTUS Bernh. BIRD'S-FOot TREEFoIL.}

I. Anisolotus Wrightii (A. Gray) Rydb. (Hosackia Wrightii A. Gray) In dry soil from Colo. to N. M. and Ariz.-Alt. $7000-8000 \mathrm{ft}$.-Dolores; Mancos.

\section{ROBINIA L. LOCUST-TREE.}

I. Robinia neo-mexicana A. Gray. Along streams from Colo. to N. M. and Ariz.-Alt. 4000-7000 ft.-Trinidad; Walsenburg; La Veta; Denver.

\section{PETERIA A. Gray.}

I. Peteria scoparia A. Gray. Dry regions from Colo. and Utah to N. M: and Ariz.-La Plata Valley (Brandegee).

\section{io. Geoprumnon Rydb. Buffalo Beans, Ground Plums.}

Corolla yellowish white, with purple-keel; leaflets oval or obovate.

Corolla purple; leaflets oblong to linear.

I. G. succulentum.

«. G. crassicarpum. 
I. Geoprumnon succulentum (Richardson) Rydb. (Astragalus succulentus Richardson; A. prunifer Rydb.) On plains and hills from Sask. and Mont. to S. D. and Colo.-Alt. 4000-7000 ft.-Ft. Collins; foot-hills, Larimer Co.; Colorado Springs; Cucharas River, below La Veta; Walsenburg; bank of Cache la Poudre; Horsetooth Gulch; Velmont.

2. Geoprumnon crassicarpum (Nutt.) Rydb. (Astragalus crassicarpus Nutt.; $A$. caryocarpus Ker) On prairies and plains from Man. and Mont. to Mo. and Tex.-Alt. 4000-5000 ft.-Plains near Denver; South Park; Lamar; Ft. Collins; Howe's Gulch.

\section{AStragalus L. Loco Weed, Milk Vetch.}

Plants cespitose, subscapose, villous-pubescent; pods sulcate on both sutures.

Pod glabrous, deeply sulcate.

I. A. mollissimus.

Pod villous, slightly sulcate.

Calyx densely villous; leaflets 6-12 pairs.

Calyx sparingly nigrescent; leaflets $3^{-6}$ pairs.

2. A. Bigelovii.

3. A. anisus.

Plants with elongated leafy stems.

Pods not sulcate or slightly so on the lower suture, round or nearly so in cross-section.

Bracts linear-lanceolate, long-attenuate; the lower almost as long as the calyces; calyx-teeth all narrow, subulate, fully half as long as the tube; pod glabrous.

4. A. canadensis.

Bracts ovate to lanceolate, scarcely half as long as the calyces; calyx-teeth short, less than half as long as the tube; the upper broader; pod more or less hairy.

5. A. oreophilus.

Pod deeply sulcate on the lower suture, cordate or triangular in cross-section.

Pod with appressed gray or black pubescence.

Corolla purple or pink, seldom white ; calyx-teeth much shorter than the tube.

Corolla sulphur-yellow; calyx-teeth almost equalling the tube.

6. A. nitidus.

Pod villous with long spreading hairs.

7. A. sulphurescens.

Corolla ochroleucous; bracts broadly spatulate, very obtuse.

8. A. virgultatus.

Corolla purple; bracts ovate-lanceolate or oblong, often acutish.

9. A. goniatus.

I. Astragalus mollissimus Torr. On prairies from Neb. and Wyo. to Tex. and N. M.-At. 4000-5000 ft.-Ft. Collins; Lamar.

2. Astragalus Bigelovii A. Gray. In dry soil from Colo. to Tex. and Ariz.; also in Mex.-Alt. 4000-5000 ft.-Grand Junction.

3. Astragalus anisus Jones. On dry mesas of Colo.-Pueblo.

4. Astragalus canadensis L. Among bushes and in meadows from Que. and B. C. to Fla. and Calif.-Alt. 4000-500o ft.-La Veta; Roswell; Lower Boulder Cañon, Boulder Co.; Ft. Collins; Poudre flats; between Ft. Collins and La Porte; gulch west of Soldier Cañon; along Conejos River.

5. Astragalus oreophilus Rydb. (A. Mortonii Coulter, in part; not Nutt.) Among bushes in Colo.-Alt. 5000-8000 ft.-Pagosa Springs; mountains, Larimer Co.; Wahatoya Creek; Trimble Springs, above Durango; Stove Prairie, Larimer Co.; plains and foot-hills near Boulder; Walsenburg.

6. Astragalus nitidus Dougl. ( $A$. adsurgens Hook, and Am. auth.; not Pall.) On hills and plains from Minn., Sask. and Alb. to Colo. and Oregon. -Alt. 4000-II,000 ft.-South Park; Manitou Springs; Platte River; Chey- 
enne Cañon; Walsenburg; Little Veta Mountain; Colorado Springs; Mit. Harvard; west of Soldier Cañon; La Porte; Como; Redcliffe.

7. Astragalus sulphurescens Rydb. On hills and mountains of Colo-Alt. 5000-I0,000 ft.-Boulder Cañon; Georgetown; Platte River, Denver; Estes Park; vicinity of Como; Long Gulch; near Boulder; Empire.

8. Astragalus virgultatus Sheld. (A. hypoglottis bracteosus Osterh.) In mountain meadows of Colo. and Wyo.-Alt. 5000-8000 ft.-Boulder; Gunnison.

9. Astragalus goniatus Nutt. (A. hypoglottis polyspermus T. \& G.; $A$. hypoglottis Richardson; not L.) In meadows and river valleys from Sask. and Wash. to Colo. and Calif.-Alt. 4000-9000 ft.-Boulder; Valmont; Alamosa; Parlin, Gunnison Co.; Cimarron; Salida; butte five miles southwest of La Veta; Ft. Collins; Dillon; Buena Vista; Arboles; Cucharas River, below La Veta; Pagosa Springs; Stove Prairie, Larimer Co.; near La Plata Post Office; Sangre de Cristo Creek; Table Rock; Horsetooth Gulch; Dolores; Como; Colorado City.

I2. HAMOSA Medic.

Plant acaulescent, silvery-white.

Plant caulescent, not silvery.

Pods curved.

Pods straight.

1. A. scaposa.

4. H. Nuttalliana.

3. H. leptocarpa.

1. Hamosa scaposa (A. Gray) Rydb. (Astragalus scaposus A. Gray.) On dry hills from Wyo. to N. M. and Ariz.-McElmo Cañon.

2. Hamosa Nuttalliana (DC.) Rydb. (A. Nuttallianus DC.) In dry soil from Colo. and Ark. to Tex. and N. M.-Alt. 4000-5000 ft.-Palisades.

3. Hamosa leptocarpa (T. \& G.) Rydb. (A. leptocarpus T. \& G.) In dry soil from Tex. to Colo.-Lake City.

\section{I3. CYSTIUM Stev.}

1. Cystium diphysum (A. Gray) Rydb. (Astragalus diphysus A. Gray) On hills from Colo, and Utah to N. M. and Ariz.-"Southwestern Colorado" (Brandegee); exact locality not given.

\section{TIUM Medic.}

Stipe equalling or exceeding the calyx; pod not incurved.

Pods not black-hairy; corolla white or ochroleucous.

Plant villous; pod cordate in cross-section.

I. T. Drummondii.

Plant appressed-pubescent or glabrous ; pod more or less triangular or inverted $V$-shaped in cross-section.

Calyx not black-hairy; pod straight. $\quad$ 2. T. racemosum.

$\begin{array}{ll}\text { Calyx black-hairy; pod arcuate. } & \text { 3. T. scopulorum. }\end{array}$

Pod black-hairy; corolla purple.

Stipe shorter than the calyx or almost none; pod incurved.

Pod mottled; plant green.

4. T. alpinum.

Pod not mottled; plant cinereous.

Pod appressed-pubescent.

Pod hirsute-villous with spreading hairs.

5. T. sparsiflorum.

6. T. huministratum.

7. $T$. desperatum. 
r. Tium Drummondii (Dougl.) Rydb. (Astragalus Drummondii Dougl.) On hills, plains and valleys from Sask, and Alb. to Neb. and Colo-CAlt. 4000-8000 ft.-Southeast of La Veta; Cimarron; La Veta; Cheyenne Cañon; Ft. Collins; Colorado Springs; Horsetooth Gulch; east of Soldier Cañon; Boulder.

2. Tium racemosum (Pursh) Rydb. (Astragalus racemosus Pursh.) On plains and hills, N. D. to Kans. and N. M.-Oak Creek; Apishipa Creek, Otero Co.; east of Soldier Cañon.

3. Tium scopulorum (Porter) Rydb. (Astragalus scopulorum Porter; $A$. rasus Sheldon) On hills and open woods in the mountains of Colo.-Alt. 5000-9000 ft.-Grand Junction; Mancos; Grayback mining camps and Placer Gulch; Los Pinos; Cerro Summit; Cimarron; Dolores.

4. Tium alpinum (L.) Rydb. (Astragalus alpinus L.) In the mountains and in open woodlands from Lab. and Alaska to Vt. and Colo.-Alt. 6000-II,000 ft.-Lake City; Boulder Cañon; near Empire; Carson; Twin Lakes; Veta Pass; North Park; Twin Lake Creek; near La Plata Post Office; Mt. Harvard; headwaters of Sangre de Cristo Creek; Como, South Park; Piedra; North Park, near Teller; Leroux Park; Michigan River; Chambers' Lake; Graymont.

5. Tium sparsiflorum (A. Gray) Rydb. (Astragahs sparsiflorus A. Gray) In the mountains of Colo.-Alt. about $8000 \mathrm{ft}$-Cascade Cañon.

6. Tium huministratum (A. Gray) Rydb. (Astragalus huministratus A. Gray) In the mountains from Colo. and Utah to N. M. and Ariz,-Alt. about $7000 \mathrm{ft}$.-Los Pinos.

7. Tium desperatum (Jones) Rydb. (Astragalus desperatus Jones) In the mountains of Colo. and Utah.-Grand Cañon.

\section{I5. ATELOPHRAGMA Rydb.}

Pods stipitate, flat.

Pod long-stipitate, glabrous, at least in age.

Pod short-stipitate, hairy.

I. A. aboriginum.

Pod sessile, more turgid.

Racemes many-flowered; leaflets oblong; septum narrow.

Racemes elongated; pod short obovate.

Racemes short; pod oblong.

Racemes few-flowered; leaflets linear; septum broad.

2. A. Macounii.

I. Atelophragma aboriginum (Richardson) Rydb. (Phaca aboriginorum Richardson) On mountain sides and in open woods from Alb. and Yukon to Colo. and Nev.-Alt, up to I0,000 ft--Mountain near Veta Pass.

2. Atelophragma Macounii Rydb. (Astragalus Macouni Rydb.) In the mountains from Alb. and B. C. to Colo.-Exact locality not given.

3. Atelophragma elegans (Hook.) Rydb. (Phaca elegans Hook.; Astragalus oroboides americanus A. Gray) In the mountains from Que., Sask. and Idaho to Colo.-Alt. 7000-13,000 ft.-Georgetown; Mt. Lincoln; Lake City; headwaters of Clear Creek; near Empire; South Park; Mancos; North Park; Empire.

4. Atelophragma Shearis Rydb. In the mountains of Colo.-Twin Lakes.

5. Atelophragma Brandegei (Porter) Rydb. (Astragalus Brandegei Porter) In the mountains from Colo. and Utah to Ariz.-Alt. about $6500 \mathrm{ft}$.Arkansas River bluffs; Pleasant Valley. 


\section{I6. JONESIELLA Rydb.}

I. Jonesiella asclepiadoides (Jones) Rydb. (Astragalus asclepiadoides Jones) In arid soil of Colo. and Utah.--Southeast of Hotchkiss; Grand Junction.

I7. PHACOPSIS Rydb.

Plant perfectly glabrous; leaflets oval, retuse or obtuse. I. P. praelongus. Plant hispidulous-strigose on the upper part of the stem and the lower surface of the leaves.

2. P. Pattersonii.

I. Phacopsis praelongus (Sheldon) Rydb. (A. procerus A. Gray) From Colo. to N. M, and Ariz.-Alt. 2500-6500 ft.-Arboles; Cimarron.

2. Phacopsis Pattersonii (A. Gray) Rydb. (A. Pattersonii A. Gray) On plains and open ground in Colo. and Utah.-Alt. up to $7000 \mathrm{ft}$.-Mancos; Wolcott, Eagle Co.; Grand River Cañon; Hotchkiss; Grand Junction; Ridgeway.

\section{XYLOPHACOS Rydb.}

Pod short-hairy or glabrous.

Plant villous; both of the sutures inflexed. 1. X. Parryi.

Plant cinereous; none of the sutures or only the dorsal one inflexed. Pod at first somewhat fleshy, in age spongy; plant acaulescent.

Pod coriaceous.

2. X. pygmaeus.

Pods straight or nearly so.

Pods when mature somewhat compressed laterally.

Pods when mature compressed vertically.

3. X. missouriensis.

Pods more or less curved.

Pods obtuse at the base; dorsal suture strongly inflexed; leaves whitesilky on both sides.

Pods tapering at both ends. 5. X. Shortianus.

Pod over $3 \mathrm{~cm}$. long; upper suture strongly arched; calyx-teeth short, triangular.

6. $X$. amphioxus.

Pod less than $3 \mathrm{~cm}$. long; upper suture straight or slightly curved; calyx-teeth linear-subulate.

Pod long-hairy, densely villous; corolla yellow or keel purple.

Leaflets broadly obovate, appressed-silky.

Leaflets elliptic or oblanceolate, long-villous.
7. $X$. uintensis.

8. X. Nezberryi.

9. X. Purshii.

I. Xylophacos Parryi (A. Gray) Rydb. (Astragalus Parryi A. Gray) On mountain ridges of Wyo. and Colo.-Alt. 5000-10,000 ft. - Near Empire; Turkey Creek and tributaries; Ft. Collins; Wahatoya Cañon; headwaters of Sangre de Cristo Creek; headwaters of Pass Creek; Estes Park; Bijou Basin; Platte Cañon; Rist Cañon; Chambers' Lake; vicinity of Como; near Boulder.

2. Xylophacos pygmaeus (Nutt.) Rydb. (Phaca pygmaea Nutt.; $A$. chamaeluce A. Gray; $A$. Cicadae Jones) Dry hills and arid plains of Colo., Wyo. and Utah.-Grand Junction.

3. Xylophacos missouriensis (Nutt.) Rydb. (A. Missouriensis Nutt.) On plains from Sask, and Mont. to Kans, and N. M.-Alt. 4000-10,000 ft. -Ft. Collins; New Windsor, Weld Co.; Arboles; Walsenburg; river bluffs north of La Veta; mesas near Pueblo; Turkey Creek and tributaries; Grand Junction. 
4. Xylophacos vespertinus (Sheld.) Rydb. (A. vespertinus Sheld.) In arid places of W. Colo, and N. Mex.-Grand Junction.

5. Xylophacos Shortianus (Nutt.) Rydb. (A. Shortianus Nutt.) On plains and dry hills from western Neb. and Wyo. to Colo. and Ariz.-Alt. 4000-9000 ft.-Ute Pass; plains near Denver; Clear Creek Cañon; Ft. Collins; Rist Cañon; Spring Cañon; west of Dixon Cañon; Hotchkiss; Table Rock; Soldier Cañon; vicinity of Horsetooth; Grand Junction; north of La Porte; near Boulder; Sapinero; Arboles.

6. Xylophacos amphioxus (A. Gray) Rydb. (A. amphioxus A. Gray) On dry plains and hills from southwestern Colo. to Utah and Ariz.-Exact locality not given.

7. Xylophacos uintensis (Jones) Rydb. (Astragalus Uintensis Jones) On dry mesas from Colo. to Utah and Ariz.-Alt. 4000-7000 ft.-Mancos; mesas near Pueblo; Cimarron; Grand Junction.

8. Xylophacos Newberryi A. Gray. Dry hills from southwestern Colo. and Utah to N. M. and Ariz.-Exact locality not given.

9. Xylophacos Purshii Dougl. On plains and hills from Mont. and B. C. to northern Colo. and Calif.-Along North Platte.

\section{CTENOPHYLLUM Rydb.}

I. Ctenophyllum pectinatum (Hook.) Rydb. (Phaca pectinata Hook.; Astragalus pectinatus Dougl.) On dry plains from Alb. and Sask. to Kans. and Colo.-Ft. Collins.

\section{CNEMIDOPHACOS Rydb.}

I. Cnemidophacos flavus (Nutt.) Rydb. (Astragalus flavus Nutt.) On dry mesas from Wyo. to N. M.-Alt. about $6000 \mathrm{ft}$.-Grand Junction; Mancos; Arboles.

\section{I. MICROPHACOS Rydb.}

I. Microphacos microlobus (A. Gray) Rydb. (Astragalus microlobus A. Gray) On plains and hills from S. D. and Mont. to Kans. and Colo.-Alt. 4000-7000 ft.-Ft. Collins; Walsenburg; New Windsor; mesas near Pueblo; Cucharas Valley, near La Veta; Denver; Colorado City.

22. DIHOLCOS Rydb.

Corolla over I cm. long; calyx-teeth nearly as long as the tube.
Corolla purplish or pinkish; pod strigose.
Corolla whitish; pod glabrous.
1. D. bisulcatus.
2. D. decalvans.

Corolla whitish or straw color, less than I $\mathrm{cm}$. long; calyx-teeth much shorter than the tube.

3. D. Haydenianus.

I. Diholcos bisulcatus (Hook.) Rydb. (Phaca bisulcata Hook.; Astragalus bisulcatus A. Gray) On plains and in river valleys from Sask. and Mont. to Neb. and Colo.-Alt. 4000-8000 ft.-Pueblo; between La Veta and Gardner; Ft. Collins; mesas near Pueblo; Lamar; Spring Cañon; Platte River; Colorado Springs. 
z. Diholcos decalvans (Gandoger) Rydb. (A. bisulcatus decalvans Gandoger) River valleys of Colo.-Alt. about $5000 \mathrm{ft}$.-New Windsor, Weld Co.; Ft. Collins; Dixon Cañon; Quimby.

3. Diholcos Haydenianus (A. Gray) Rydb. (A. Haydenianus A. Gray) In the mountains of Wyo. and Colo.-Alt. about $7000 \mathrm{ft}$.-Rio Blanco, south of Pagosa; Mancos; Pagosa Springs; Montrose; La Veta; Gunnison; Ridgeway.

\section{KENTROPHYTA Nutt.}

Stipules united only at the base, more or less herbaceous.

Plants 3-4 dm. high, usually erect; stipules with long spinulose tips.

Plant low; stipules not spinulose-tipped.

Stipules united for about half their length, scarious.

z. K. impensa.

Corolla ochroleucous, about $4 \mathrm{~mm}$. long; leaflets less than $5 \mathrm{~mm}$. long.

4. K. Wolfi.

Corolla purple, about $6 \mathrm{~mm}$. long; leaflets over $5 \mathrm{~mm}$. long. $5 . K$. aculeata.

r. Kentrophyta impensa (Sheldon) Rydb. (Astragalus viridis impensus Sheldon; $A$. Kentrophyta elatus S. Wats.) In cañons and bad-lands from Colo. to Nev, and Ariz.-Grand River Cañon.

2. Kentrophyta viridis Nutt. (Astragalus Kentrophyta A. Gray, in part.) In cañons and bad-lands of Wyo. and Colo.-Palisades.

3. Kentrophyta Wolfii Rydb. (Homalobus Wolfii Rydb.) On dry hills of Colo.-South Park.

4. Kentrophyta aculeata (A. Nels.) Rydb. (A. tegetarius implexus Canby; A. aculeatus A. Nels.) On dry hills and mountains from Mont. to Colo. and Utah.-Alt. 8000-I0,000 ft.-Chambers' Lake; Georgetown.

\section{HOMALOBUS Nutt.}

Leaves simple or some rarely pinnately 3 -foliolate; plants pulvinate-cespitose.

Leaves pinnately 5 -many-foliolate.

SIMPLICIFOLII.

Pods sessile or short-stipitate; stipe seldom exceeding the calyx.

Pods more or less compressed.

Pods oval, ovate, broadly oblong or elliptical

Pods linear, $1.5 \mathrm{~cm}$. or more long.

Pods terete or nearly so.

TENELLI.

Pods long-stipitate; stipe many times as long as the calyx. Macrocarpi.

One species.

Simplicifolit.

Pods strictly sessile.

Tenelli.

I. H. caespitosus.

Pods erect on long pedicels.

Pods spreading or reflexed on short pedicels.

Pods glabrous ; plant canescent.

Pods hairy ; plant green.

Pods short-stipitate.

Leaflets broadly linear or oblong; corolla ochroleucous.

Leaflets narrowly linear; corolla whitish, tinged with purple.

2. A. grallator.

3. H. Wingatanus.

4. H. Clementis.

5. H. tenellus.

6. H. acerbus.

CAmpestres.

Calyx-teeth lanceolate to subulate, half as long as the tube or longer.

Pods arcuate.

Pods straight.

7. H. decumbens. 
Leaflets linear or linear-oblong, acute, ascending.

Leaflets narrowly linear, silvery-canescent.

Low and very cespitose, $1-2 \mathrm{dm}$. high; pods about $1.5 \mathrm{~cm}$. long; keel with a very narrow end.

8. H. camporum.

Tall, 3-4 dm. high, more simple; pods $2-2.5 \mathrm{~cm}$. long; keel with a broader end. $\quad$ 9. H. campestris.

Leaflets oblong or lanceolate, strigose but not canescent; terminal leaflet longer, tapering into the rachis without a distinct articulation; racemes long and lax.

Leaflets, at least of the lower leaves, oval or elliptical, spreading. Io. $H$. decurrens.

Calyx-teeth triangular, $x / 4-I / 3$ as long as the tube; leaflets linear. II. H. hylophilus.

Low, depressed; pods $12-15 \mathrm{~mm}$. long, sessile.

12. H. tenuifolins.

Taller, $2 \mathrm{dm}$. or more high; pods over I $5 \mathrm{~mm}$. long, often slightly stipitate.

Frexuosi.

I3. H. junciformis.

Pod oblong, over $5 \mathrm{~mm}$. in diameter.

Inflorescence short; flowers about I5 mm. long; pod glabrous.

14. H. Hallii.

Inflorescence elongated and lax; flowers about Io $\mathrm{mm}$. long; pod pubescent.

Pod linear, 2-3 mm. thick. 15. H. Fendleri.

Pod abruptly contracted into a short or obsolete stipe.

Stem decumbent; stipe minute or obsolete.

Stem erect; stipe almost equalling the calyx.

Pod gradually tapering into the short stipe.

I6. H. Aexuosus.

17. H. proximus.

18. H. Salidae.

One species.

Macrocarpi.

1. Homalobus caespitosus Nutt. (Astragalus caespitosus A. Gray.) On dry hills from Ass. and Mont. to Colo. and Utah.-Alt. 4000-6000 ft.Livermore, Larimer Co.; north of La Porte.

z. Homalobus grallator (S. Wats.) Rydb. (A. grallator S. Wats.) On river banks from Colo. to Nev.-Steamboat Springs.

3. Homalobus wingatanus (S. Wats.) Rydb. (A. Wingatanus S. Wats.) On dry hills in S. Colo. and N. Mex.-Mancos.

4. Homalobus Clementis Rydb. In the mountains of Colo.-Alt. up to ro,ooo ft.-Marshall Pass; Sangre de Cristo; Big Creek Gulch.

5. Homalobus tenellus (Pursh) Britton. (Astragalus tenellus Pursh; Astragalus multiflorus (Pursh) A. Gray) On plains and hilis from Minn., Sask. and Yukon to Neb., Colo. and Nev.-Alt. 4000-Io,00o ft.-Near Empire; Ward, Boulder Co.; Swallows, between Cañon City and Pueblo; Estes Park; near mouth of Leroux Creek; Middle Park; Ft. Collins; near Boulder; mountains between Sunshine and Ward; Marshall Pass.

6. Homalobus acerbus (Sheld.) Rydb. (A. acerbus Sheld.) In the mountains of Colo.-Alt. about $8000 \mathrm{ft}$.-Glenwood Springs.

7. Homalobus decumbens Nutt. (A. decumbons A. Gray) In the mountains of Colo. and Wyo.-Steamboat Springs.

8. Homalobus camporum Rydb. On plains and hills from Alb. to Colo. and Utah.-Alt. 8000-10,000 ft.-Grayback mining camps and Placer Gulch; North Park.

9. Homalobus campestris Nutt. (A. campestris A. Gray; A. convallarius Greene) On plains from Mont. and B. C. to Colo. and Utah.-Alt. up to 
I0,000 ft.-Lake City; Cañon City; Como, South Park; Big South; Stove Prairie Hill; Gore Pass; Rabbit-Ear Range; North Park; Estes Park; forks of Poudre and Big South; mountains of Larimer Co.; Pinkham Creek.

10. Homalobus decurrens Rydb. On wooded hills in Colo.-Alt. 8000I0,000 ft.-Estes Park; Grayback mining camps and Placer Gulch; Como; Stove Prairie Hill.

Ir. Homalobus hylophilus Rydb. On wooded hillsides from Mont. and Ida. to Colo. and Utah.-Alt, about $8000 \mathrm{ft}$--Cerro Summit; North Park, near Teller; Leadville; Empire.

12. Homalobus tenuifolius Nutt. From the Canadian Rockies to the mountains of Colo.--Lake City.

13. Homalobus junciformis (A. Nels.) Rydb. (Astragalus junciformis A. Nels.) On dry plains and hills from Mont. to Colo. and Utah.-Alt. about 7000 ft.-Glenwood Springs; Cedar Edge.

14. Homalobus Hallii (A. Gray) Rydb. (Astragalus Hallii A. Gray) In the mountains of Colo.-Alt. 7000-Io,000 ft.-South Park; Garland; Como, South Park; Leadville; Alamosa; Dolores; Horsetooth Gulch; Como, South Park; Black Cañon.

15. Homalobus Fendleri (A. Gray) Rydb. (A. Fendleri A. Gray) On dry hills of Colo. and N. M.-Alt. 4000-7000 ft.-Mancos; Los Pinos.

16. Homalobus flexuosus (Dougl.) Rydb. (Phaca Alexuosa Hook; A. Alexuosus Dougl.) On dry plains and hills from Minn., Sask. and Alb. to Kans. and Colo.-Alt. 4000-9000 ft.-Upper Arkansas; South Park; Los Pinos; Salida; Gunnison; New Windsor; Buena Vista; Veta Pass; Idaho Springs; Sangre de Cristo Creek; Cucharas River, below La Veta; foot-hills, Larimer Co.; Grayback mining camps and Placer Gulch; Ft. Collins; northwest of Soldier Cañon; Horsetooth Gulch; Almelia; Estes Park; near Boulder; Empire.

17. Homalobus proximus Rydb. On dry hills of Colo--Arboles.

18. Homalobus Salidae Rydb. On hills in Colo.-Salida.

19. Homalobus macrocarpus (A Gray) Rydb. (Phaca macrocarpa A. Gray; $A$. lonchocarpus Torr.) In open woods from Colo. and Utah to $\mathrm{N}$. M.-Alt. 600o-10,000 ft.-Pagosa Springs; Thompson Park, La Plata Mountains; Turkey Creek and tributaries; Arboles; Durango.

\section{PHACA L.}

Upper suture not acute; pod circular or oval in cross-section.

Pod short-stipitate.

Pod not mottled, erect or ascending.

Pod ashy, with minute white hairs.

Pod glabrous.

Pod mottled, spreading or reflexed.

Leaflets linear or none; plant grayish-pubescent.

Terminal leaflet none, represented by the much produced rachis; lateral leaflets also often absent.

Leaflets present; rachis not produced.

Leaflets broadly oval or obcordate; plant glabrous. Pod sessile.

I I. $P$. Wetherillii.

I. P. Eastwoodiae.
2. P. longifolia.

3. P. picta.

4. $P$. artipes. 
Pod over $1.2 \mathrm{~cm}$. long.

Pod 2-2.5 cm. long; corolla ochroleucous.

Pod I2-I5 mm. long; corolla purple.

5. P. Candolleana.

Pod 3-I $2 \mathrm{~mm}$. long.

Pod ovoid; plant 3-6 dm. high; raceme many-flowered.

7. P. Bodinii.

Pods ellipsoid; plant usually less than $3 \mathrm{dm}$. high; raceme few-flowered.

Plant cespitose; stem slender, $\mathrm{r}-2 \mathrm{dm}$. high, slender; leaflets $0.5^{-1} \mathrm{~cm}$. long.

8. P. paucifiora.

Plant pulvinate-cespitose, almost stemless; leaflets minute.

9. P. humillima.

Upper suture of the pod straight or curved upwards, acute; pod in cross-section obovate.

Io. $P$. elatiocarpa.

1. Phaca Eastwoodiae (Jones) Rydb. (Astragalus Preussii sulcatus Jones; A. Eastwoodiae Jones) In Utah and Colo.-Westwater.

z. Phaca longifolia (Pursh) Nutt. (A. pictus filifolius A. Gray) On sandy soil from S. D. and Wyo. to Colo. and N. M.-Salida; Manitous; Manitou Junction.

3. Phaca picta A. Gray. (A. pictus foliosus A. Gray) In sandy soil from Colo. and Utah to N. M.-Denver; Colorado Springs.

4. Phaca artipes (A. Gray) Rydb. (Astragalus artipes A. Gray) In the mountains of Colo.-Alt. 7000-8000 ft.-Cerro Summit; Cedar Edge; Leroux Creek.

5. Phaca Candolleana H. B. K. (Astragalus triflorus A. Gray) In dry places from Colo. to N. M. and Calif.; also Mex.-Cañon City.

6. Phaca cerussata (Sheld.) Rydb. (Astragalus cerusatus Sheld.) Mountain sides in Colo.-Cañon City, Fremont Co.

7. Phaca Bodinii (Sheld.) Rydb. (Astragalus Bodinii Sheld.) In valleys from Mont. to Neb. and Colo.-Alt. 4000-5000 ft.-North Park, Larimer Co.

8. Phaca pauciflora Nutt. (A. leptaleus A. Gray) In the mountains of Colo.-Alt. 7000-Io,000 ft.-Mt. Harvard; North Park, Larimer Co.; Como, South Park; Gunnison; Laramie River.

9. Phaca humillima (A. Gray) Rydb. (A. humillimus A. Gray) On arid table-lands of Colo.-Mesa Verde, near Mancos River.

ro. Phaca elatiocarpa (Sheld.) Rydb. (Astragalus lotiflorus brachypus A. Gray; A. elatiocarpus Sheld.) On plains from Minn. to Ass. to Mo., Tex. and Calif.-Cañon City; Colorado Springs.

II. Phaca Wetherillii (Jones) Rydb. (Astragalus Wetherillii Jones) Dry hills and mesas of Colo.-Grand Junction.

\section{OROPHACA Britton.}

Densely cespitose; flowers 8-10 mm. long; inflorescence not exceeding the leaves. Flowers about 1o $\mathrm{mm}$. long; pods puberulent. 1. O. tridactylica. $\begin{array}{ll}\text { Flowers about } 8 \mathrm{~mm} \text {. long; pods hoary. } & \text { 2. O. aretioides. }\end{array}$

Broadly cespitose with prostrate branches; flowers about $6 \mathrm{~mm}$. long; peduncles usually exceeding the leaves; pods hoary.

3. O. sericea.

r. Orophaca tridactylica (A. Gray) Rydb. (Astragalus tridactylicus A. Gray) On plains and hills of Colorado.-Alt. 5000-6000 ft.-Livermore; St. Vrain's Cañon; Ft. Collins; plains near Denver; foot-hills west of Ft. Collins; east of Black's Lake; near New Windsor. 
2. Orophaca aretioides (Jones) Rydb. (Astragalus sericoleucus aretioides Jones) On dry hills and plains of Wyo, and Colo.-Alt. about $5000 \mathrm{ft}$. - Ft. Collins; vicinity of Horsetooth; plains near Denver.

3. Orophaca sericea (Nutt.) Britton. (Phaca sericeus Nutt.; A. sericoleucus A. Gray) On plains and hills from Neb. to Wyo. and Colo.-Julesburg.

27. ARAGALlUS Necker. OxYTROPE, Loco-WeEd.

Stipules adnate to the petioles only slightly at the base; pods pendant, I-celled, many times exceeding the calyx.

1. A. deflexus.

Stipules decidedly adnate to the petioles; pods not pendant.

Leaves strictly pinnate; leaflets opposite.

Fruiting calyx inflated, enclosing the fruit; plants densely cespitose, less than $1.5 \mathrm{dm}$. high.

Fruiting calyx not inflated, much exceeded by the pod.

Inflorescence $I-3$-flowered; plants dwarf, pulvinate.

Pods inflated, I-celled, ovoid.

Pods not inflated, oblong, almost 2-celled.

¿. A. multiceps.

Inflorescence many-flowered; plants mostly over $1.5 \mathrm{dm}$. high and pod oblong, not inflated.

Corolla purple, rarely white.

Leaflets linear or linear-lanceolate, not silvery-canescent.

5. A. Lambertii.

Leaflets oblong-lanceolate to oval, silvery-canescent. 6. A. sericeus.

Corolla yeliow or white with a purple spot on the keel. Flowers I2-I $5 \mathrm{~mm}$. long; pods semi-membranaceous.

Flowers I $8-25 \mathrm{~mm}$. long; pods coriaceous.

7. A. monticola.

8. A. albiflorus.

Leaflets verticillate.

9. A. Richardsonii.

1. Aragallus deflexus (Pall.) Heller. (Oxytropis deflexa (Pall.) DC.) In the mountains from Sask. and Alaska to N. M.-Alt. 6000-Ir,000 ft.-Near Empire; Lake City; Como, South Park; North Park, near Teller; Georgetown; Sangre de Cristo Creek; Sargent; Twin Lakes; Alamosa; Kremmling; Carson; North Park; Arboles; Dolores; along the Conejos River, north of Antonito; Buena Vista; Empire; Hahn's Peak.

2. Aragallus multiceps (Nutt.) Heller. (Oxytropis multiceps Nutt.) On dry hills and mountains from western Neb. to Wyo. and Colo.-Alt. 4000Io,000 ft.-Table Rock; Calhan; Manitou golf links; Colorado Springs.

Aragallus multiceps minor (A. Gray) Rydb. (Oxytropis multiceps minor A. Gray) In the mountains of Colo.-Alt. 8000-ro,000 ft.-Mountains between Sunshine and Ward; Empire; mountains of Estes Park; headwaters of Clear Creek; Caribou.

3. Aragallus Hallii (Bunge) Rydb. (Oxytropis Hallii Bunge) On high mountains of Colo.-Alt. Io,000-Ir,000 ft.-Little Veta Mountain.

4. Aragallus Parryi (A. Gray) Greene. (Oxytropis Parryi A. Gray) In high mountain valleys of Colo.-Georgetown.

5. Aragallus Lambertii (Pursh) Greene. (O. Lambertii Pursh) On plains, prairies, hills and table-lands from Minn. and Mont. to Mo. and Colo.-Alt. 4000-9000 ft.-Boulder; Colorado Springs; Cheyenne Cañon; headwaters of Pass Creek; Cucharas River, below La Veta; mesas near Colorado Springs; between Colorado Springs and Cripple Creek; Horsetooth Gulch; Palmer Lake; Howe's Gulch; Poudre Flats; mountains between Sunshine and Ward; near Boulder; Eldora to Baltimore; Hardin's ranch; Table Rock. 
6. Aragallus sericeus (Nutt.) Greene. (Oxytropis sericea Nutt.) On hills and table-lands from N. D. and Wyo. to N. M. and Ariz.-Alt. 400o9000 ft.-Estes Park; Sargents; La Veta; Cimarron; Grayback mining camps and Placer Gulch; Platte Cañon; Horsetooth Gulch; Campton's ranch; west of Rist Cañon; Wray; Pinkham Creek.

7. Aragallus monticola (A. Gray) Greene. (O. monticola A. Gray) On mountain ridges from Sask. and Wash. to Colo.-.- Colorado" ; exact locality not given.

8. Aragallus albiflorus A. Nels. In mountain valleys of Wyo. and Colo. -Alt. 5000-II,000 ft.-Cucharas Valley, near La Veta; butte five miles southwest of La Veta; Iron Mountain; Placer; Ft. Collins; Buena Vista; Chambers' Lake; west of Rist Cañon; Palmer Lake; Pennock's mountain ranch; Campton's ranch, North Poudre.

9. Aragallus Richardsonii (Hook.) Greene. (Oxytropis splendens Richardsonii Hook.) In mountain valleys from Sask. and Yukon to Colo. -Alt. 8000-I0,000 ft.-North Park; Georgetown; Middle Park; Como, South Park; mountain near Veta Pass; Twin Lakes; Indian Creek Pass; Arkansas Junction, near Leadville; Eldora to Baltimore; Empire.

28. GLYCYRRHIZA L. WILD LIQUORICE.

a. Glycyrrhiza lepidota Nutt. Among bushes and in rich meadows from Ont. and Wash. to N. Y. and Ariz.; also in Mex.-Alt. 4000-8000 ft.-Colorado Springs; Parlin, Gunnison Co, A Alamosa; Grand Junction; Huerfano Valley, near Gardner; Arboles; Ft. Collins; Walcott; Pueblo; Denver; Poudre Cañon; Rist Cañon; near Boulder.

\section{AMORPha L. False Indigo, Lead-plant.}

Tall shrub; leaflets $2-5 \mathrm{~cm}$. long; pods usually 2 -seeded.

Low shrubs; leaflets $5-1.5 \mathrm{~cm}$. long; pods I-seeded.

I. A. angustifolia.

Glabrous or nearly so; spike usually solitary at the ends of the branches.

Densely canescent; spikes usually clustered.

2. A. nana.

3. A. canescens.

I. Amorpha angustifolia (Pursh) Boynton. (A. fruticosa angustifolia Pursh; A. fruticosa James; not L.) Along streams from S. D. and Mont. to Fla. and Colo.-Alt. 4000-5000 ft.-Sterling, Logan Co.; river flats and plains east of Ft. Collins.

2. Amorpha nana Nutt. (A. microphylla Pursh) On dry prairies from Man. to Iowa and Colo.-Palmer Lake.

3. Amorpha canescens Pursh. Sand-hills and prairies from Ind and Man. to La., Tex. and Colo.-Along Platte River.

\section{PSORALEA I. POME Blanche, Indian Bread-RoOT.}

Flowers small, less than $8 \mathrm{~mm}$. long, in racemes or interrupted spikes; root not tuberous.

Flowers in racemes; leaves not silvery.

Racemes short and dense, elliptic or oblong; fruit globose. I. $P$. lanceolata. Racemes lax, more elongated; fruit ovoid.

$\begin{array}{ll}\text { Flowers in interrupted spikes; leaves silvery. } & 3 . P \text {. argophylla. }\end{array}$

Flowers large, over I cm. long, in dense head-like spikes; plant with a deep-seated tuberous, farinaceous root. 
Plants with long scattered hairs, not cinereous; leaflets linear to obovate.

4. P. hypogaea.

Plant cinereous, with short appressed pubescence; leaflets broadly obovate or rounded-spatulate.

5. P. mephitica.

I. Psoralea lanceolata Pursh. In sandy soil from Sask. to Colo. and Ariz. -Alt. 4000-7000 ft.-Colorado Springs; Wray; Manitou Junction; La Veta.

2. Psoralea tenuiflora Pursh. On dry plains and hills from S. D. and Mont. to Ark. and Ariz.-Alt. 4000-8000 ft.-Golden; Cucharas Valley, near La Veta; Cañon City; New Windsor, Weld Co.; Eads; Crow Creek; Cheyenne Cañon; Colorado Springs; Ft. Collins; plains and foot-hills near Boulder.

3. Psoralea argophylla Pursh. On plains and prairies from Wis. and Sask. to Mo. and N. M.-Denver.

4. Psoralea hypogea Nutt. On dry plains from Neb. and Colo. to Tex. and N. M.-Alt. 4000-6000 ft.-Denver; Colorado Springs.

5. Psoralea mephitica S. Wats. In arid soil from Colo. to N. M. and Calif.-Grand Junction.

Perennials.

\section{I. PAROSELA Car.}

Stem and leaves perfectly glabrous.

Stem herbaceous; bracts obovate, persistent, enclosing the calyx.

1. P. lasianthera.

Stem low, suffruticose, branched; spikes 2-6 flowered; bracts ovate, deciduous.

Stem and leaves more or less hairy.

2. P. formosa.

Spike dense, crowded; petals yellow, at least at first; plant herbaceous.

Leaves digitately tri-foliolate; plant low and cespitose. 3. P. Jamesii.

Leaves pinnately 3-7-foliolate.

Leaflets of the stem-leaves at least only 3 ; petals turning purplish; spike in fruit about ro $\mathrm{mm}$. thick.

4. P. elatior.

Leaflets $5-7$; petals not turning purple; spike in fruit about $15 \mathrm{~mm}$. thick.

Spike lax; petals purple.

5. P. aurea.

Leaves pinnately $3-\mathrm{I} 3$ foliolate; stem scarcely spinose.

Leaves uni-foliolate or none; plant very spiny.

Annual; leaves glabrous.

6. P. lanata.

7. P. spinosa.

8. P. Dalea.

I. Parosela lasianthera (A. Gray) Heller. (Dalea lasianthera A. Gray) In dry soil from Colo. to Tex. and N. M.-Reported from Colorado, but doubtful.

2. Parosela formosa (Torr.) Vail. (Dalea formosa Torr.) In dry soil from Colo, and Utah to Tex, and Ariz.-Platte River.

3. Parosela Jamesii (T. \& G.) Vail. (Dalea Jamesii T. \& G.; Parosela Porteri A. Nels.) In dry soil from Colo. to Tex. and N. M.-Alt. 40006000 ft.-Rocky Ford, Otero Co.; Walsenburg; Cañon City; Florence.

4. Parosela elatior (A. Gray) Vail. (Dalea nana elatior A. Gray; $D$. rubescens S. Wats.) Dry places from Colo. to Tex.- "Southeastern Colorado."

5. Parosela aurea (Nutt.) Britton. (Dalea aurea Nutt.) On plains from S. D. to Texas.- "Northeastern Colorado."

6. Parosela lanata (Spreng.) Britton. (Dalea lanata Spreng.) In dry soil from Kans. and Utah to Tex. and Ariz,; also in Mex.-On the Platte. 
7. Parosela spinosa (A. Gray) Vail. (Dalea spinosa A. Gray) In arid places from Colo. to Calif. and Ariz.; also Mex. - Colorado"; exact locality not given.

8. Parosela Dalea (L.) Britton. (Dalea alopecuroides Willd.) Prairies from Ill. and Minn, to Tex. and Mex.-Denver (Eastwood).

\section{Petalostemon Lam. Prairie Clover.}

Calyx glabrous; corolla white.

I. P. oligophyllus.

Calyx pubescent.

Corolla white or yellow; spike long and compact.

Corolla rose or purple, very rarely white.

Leaflets usually 5 .

Stem and leaves glabrous or sparingly hairy.

Stem rather densely short-hairy.

Leaflets $7-17$, oblong.

2. P. compactus:

1. Petalostemon oligophyllus (Torr.) Rydb. ( $P$. graciles oligophyllus Torr.) On plains from Ass. to Iowa, Colo. and Ariz.-Alt. 4000-7000 ft.Ft. Collins; east of Colorado Springs; Cañon City; New Windsor, Weld Co.; Cucharas Valley, near La Veta; Pueblo; Poudre River; Arkansas River; Fossil Creek; Dixon Cañon; Boulder.

2. Petalostemon compactus (Spreng.) Sweezy. (Dalea compacta Spreng.; $P$. macrostachyus Torr.) On dry plains from Neb. to Wyo, and Colo.Alt. 4000-5000 ft.-Denver; New Windsor, Weld Co.; near Timnath; Ft. Collins.

3. Petalostemon purpureus (Vent.) Rydb. (P. violaceus Michx.) On plains and prairies from Ind., Sask. and Alb. to Mo. and N. M.-Alt. 4000-7000 ft.-Colorado Springs; Boulder; La Porte, Larimer Co.; Sterling, Logan Co.; Cucharas Valley, near La Veta; Denver; Ft. Collins; Spring Cañon; Horsetooth Gulch; Boulder.

4. Petalostemon pubescens A. Nelson. Plains of Colo--Berwind.

5. Petalostemon villosum Nutt. In sandy soil from Sask, and Mont. to Mo. and Colo.-Alt. 4000-500o ft--Sterling, Logan Co.

\section{HEDYSARUM L.}

Calyx-teeth shorter than the tube; reticulations of the pod polygonal.

I. H. marginatum.

Calyx-teeth longer than the tube; reticulations of the pods transversely elongated, usually reaching from the middle to the margins, without cross-veins.

Leaflets elliptic-oblong, not fleshy; flowers I $2-15 \mathrm{~mm}$. long, purple; bracts lanceolate-subulate, 3-5 $\mathrm{mm}$. long; internodes of the fruit 3-5.

2. H. pabulare.

Leaflets linear-oblong, somewhat fleshy; flowers about Io $\mathrm{mm}$. long, rose-purple; bracts lanceolate, I.5-2 mm. long; internodes of the fruit I-3.

3. H. carnosulum.

1. Hedysarum marginatum Greene. ( $H$. uintahense A. Nels.) On wooded hillsides of Wyo. and Colo.-Alt. up to $9000 \mathrm{ft}$.-Near La Plata Post Office; Pagosa Springs; Hesperus.

2. Hedysarum pabulare A. Nelson. ( $H$. Bakeri Greene) On hills of Colo. and N. M.-Alt. 6000-7000 ft.-Mancos; Cimarron; Cañon City, Fremont Co.; Dolores; Palisades. 
3. Hedysarum carnosulum Greene. On dry hills from Colo. to N. M. and Ariz.-Cañon City; Cedar Hills.

\section{ONOBRYCHIS Scop. SAND-FOIN.}

1. Onobrychis Onobrychis (L.) Rydb. (O. sativa Lam.) Cultivated and occasionally escaped from Mont. to Colo.-Alt. about $8000 \mathrm{ft}$.-Walsenburg.

\section{VICIA L. VETCH.}

Racemes 3-40-flowered; flowers I-2.5 cm. long.

Leaves decidedly pubescent.

Stipules semi-sagittate, not toothed.

Stipules broadly semi-hastate, strongly toothed.

I. V. caespitosa.

Leaves glabrous or sparingly pubescent when young.

Leaflets linear or oblong to oval, not toothed.

Leaflets oblong or linear, rather thick and strongly veined.

Stipules narrowly semi-sagittate; often entire.

Leaflets elongated, narrowly linear; plant low.

3. V. sparsifolia.

Leaflets, at least the upper ones, oblong or linear-oblong; plant tall, climbing.

4. V. dissitifolia.

Stipules broadly semi-hastate or semi-orbicular in outline, sharply toothed.

Leaflets usually oval, thin and not strongly veined.

5. $V$. oregana.

6. $V$. americana.

Leaflets obovate-cuneate, truncate and toothed at the apex. $7 . V$. californica. Racemes I-2-flowered; flowers 5-6 mm. long.

8. V. producta.

I. Vicia caespitosa A. Nelson. In mountain valleys of Wyo. and Colo.Alt. 5000-750o ft.-Dixon Cañon Creek; Horsetooth Gulch; Cache la Poudre; Ft. Collins; Manitou; Colorado City.

2. Vicia trifida D. Dietr. In river valleys from Minn. and Mont. to Neb. and Colo--Alt. 4000-9000 ft.-Mesas near Pueblo; Cucharas River, below La Veta; Veta Pass; butte five miles southwest of La Veta; mesas near Colorado Springs; Ft. Collins; Routt Co.; Campton's ranch, North Poudre; Moon's ranch; Spring Cañon; Empire.

3. Vicia sparsifolia Nutt. (Lathyrus linearis Nutt.; $V$. linearis Greene) On prairies and in valleys from Man., Alb. and Ida. to Kans. and Calif.Alt. 4000-10,000 ft.-Florissant; Denver; Arboles; Turkey Creek and tributaries; Roswell; Grayback mining camps and Placer Gulch; Table Rock.

4. Vicia dissitifolia (Nutt.) Rydb. (Lathyrus dissitifolius Nutt.) In valleys of Neb. and Colo.-Alt. 4000-900o ft.-Lake City; Bob Creek, West La Plata Mountains; Colorado Springs; Mancos Cañon; Roswell; Green Mountain Falls; Walcott; New Windsor; Dillon Cañon, Trinidad; Empire.

5. Vicia oregana Nutt. ( $V$. Americana truncata Port. \& Cot1lt., in part.) On river banks from Minn., Sask, and Wash. to Kans, and Calif.-Alt. 4000ro,000 ft.-Palmer Lake; Denver; headwaters of Sangre de Cristo Creek; Upper La Plata Cañon; Mancos.

6. Vicia americana Muhl. On prairies and in rich river valleys from $\mathrm{N}$. B. and Ida. to Va. and Ariz.-Alt, 4000-I0,000 ft.-Cucharas River, below La Veta; North Cheyenne Cañon; Glenwood Springs; White River Plateau; Walsenburg; Walcott, Eagle Co.; Cerro Summit; southeast of Ouray; Big Creek Gulch; Empire.

7. Vicia californica Greene. In river valleys from Calif. and Wyo. to Colo.-Alt. about 7500 ft.-A doubtful specimen from Ridgeway. 
8. Vicia producta Rydb. On gravelly hills and sides of cañons from Colo. and Utah to N. M. and Ariz.-Alt. 7000-8000 ft.-Butte five miles southwest of La Veta; Brantly Cañon, Las Animas Co.; Spring Cañon.

\section{Lathyrus L. Velchling, Marsh Pea.}

Flowers less than $18 \mathrm{~mm}$. long; corolla white.

Leaflets oval to oblong.

Leaflets linear.

I. L. leucanthus.

Flowers about $2 \mathrm{~cm}$. or more.

Corolla purple.

Stipules large and broad, about half as long as the leaflets.

Stipules narrow, less than half as long as the leaflets.

3. L. utahensis.

Leaflets elliptic to oval; upper leaves at least with well deveoped tendrils.

4. L. decapetalus.

Leaflets linear or nearly so; tendrils reduced to cusps or small appendages. Plant glabrous or nearly so.

Plant decidedly villous-pubescent.

Corolla white or yellowish.

5. L. ornatus.

6. L. incanus.

7. L. laetivirens.

1. Lathyrus leucanthus Rydb. Hillsides, among bushes and open woods, in Colo. and N. M.-Alt. 8000-II,00o ft.-Empire; Veta Pass; Ojo; above Mancos; Boulder; Tennessee Pass, Lake Co.; Pass Creek; mountain near Veta Pass; Rico, Dolores Co.; West Indian Creek; Los Pinos (Bayfield); North Park, near Teller; Van Boxle's ranch, above Cimarron; Victoria; Leroux Creek; Michigan Fork; Spicer.

2. Lathyrus arizonicus Britton. On wooded hillsides from Colo. to Ariz.Alt. 8000-II,000 ft.-West Mancos Cañon; Mt. Hesperus; Grayback mining camps and Placer Gulch; Pass Creek; Iron Mountain; West Indian Creek.

3. Lathyrus utahensis Jones. In valleys of Utah and Colo.-Parrott; Durango.

4. Lathyrus decapetalus Pursh. On plains and table-lands from Colo. and Utah to N. M. and Ariz.-Alt. $7000-8000 \mathrm{ft}$-C Cato; Cucharas River, below La Veta; Calhan; Mancos; Palmer Lake; Robinson; Mancos Cañon; Swallows, between Pueblo and Cañon City; Gunnison; Sapinero.

5. Lathyrus ornatus Nutt. On prairies and plains, S. D. and Wyo. to Ind. Terr. and Colo.-Alt. 4000-8000 ft.-Mesas near Colorado Springs; Dillon Cañon; along Conejos River, north of Antonito; Dolores; Colorado City.

6. Lathyrus incanus (Rydb. \& Smith) Rydb. (L. ornatus incanus Rydb. \& Smith.) On sandy plains from Neb. and Wyo. to Colo. and Utah.-Alt. 4000-8000 ft.-Table Rock; Palmer Lake; Calhan.

7. Lathyrus laetivirens Greene. In the mountains of Colo.-Alt. about $8000 \mathrm{ft}$.-Cerro Summit; Steamboat Springs.

\section{Order 28. GERANIALES.}

Plants destitute of secreting glands or cells in the tissue.

Styles united around a central column from which they break at maturity.

Styles distinct or permanently united.

Fam. 72. Geraniaceae.

Styles distinct or partly united; the tips and the stigmas free.

Leaves simple; stamens 5 .

Leaves compound; stamens IO-I5.

73. LinaceaE.

74. OXAIIDACEAE.

Styles and stigmas permanently united. 75. ZYGOPHYLLACEAE.

Plants with secreting glands often in the leaves or only in the bark.

76. Rutaceae. 


\section{Family 72. GeraniaceaE J. St. Hill. Geranium Family.}

Leaves in ours digitately divided or lobed; tails of the ripening carpels dehiscent, merely arched, glabrous on the inner face. 1. Geranium.

Leaves pinnately dissected; tails of the ripening carpels, if dehiscent, twisted below and bearded on the inner face.

2. ERODIUM.

\section{r. Geranium L. Cranebili, Geranium.}

Petals $\mathrm{I}-2 \mathrm{~cm}$. long.

Plant erect, tall, scarcely cespitose; divisions of the leaves rhombic in outline; the terminal tooth much longer than the rest; petals white (sometimes slightly tinged with rose) and purple-veined.

Lower part of the stem glabrous or with scattered spreading villous or glandular hairs. I. G. Richardsonii.

Lower part of the stem with short reflexed and appressed hairs. Slender; leaves and calyx sparingly pubescent. 2. G. gracilentum. Stout; calyx and leaves densely pubescent, the latter almost grayish. Veins of the petals weak; calyx anly sparingly glandular.

Veins of the petals very strong; calyx densely glandular. 3. G. Cowenii. 4. G. nervosum.

Plant more or less cespitose; stems ascending or spreading; divisions of the leaves obovate-cuneate; the terminal tooth only slightly longer than the rest; petals purplish.

Petals broadly obovate to obcordate; light purple with darker veins. Stem glandular-villous with long spreading hairs.

Teeth of the leaves ovate to lanceolate, acute. 5. G. Parryi.

Teeth of the leaves broadly ovate, abruptly short-acuminate.

6. G. Pattersonii.

Lower part of the stem grayish-pubescent with reflexed hairs, not glandular.

Teeth of the leaves very short and broad; stem diffuse; petals obcordate. 7. G. Fremontii.

Teeth of the leaves elongated, lanceolate; stem more upright; petals obovate.

8. G. caespitosum.

Petals narrowly obovate, dark purple; plant not at all glandular.

Petals 5-7 mm. long.

9. G. atropurpureum. 10. G. Bicknellii.

I. Geranium Richardsonii Fish. \& Traut. In meadows from Sask. and B. C. to N. M. and Calif.-Alt. 8000-Io,000 ft.-Honnold; Rabbit-Ear Pass; Bob Creek, West La Plata Mountains; Four-Mile Hill, Routt Co.; camp on Grizzly near foot of Rabbit-Ear Range.

2. Geranium gracilentum Greene. In mountain valleys from Colo. to N. M. and Ariz.-Alt. 6000-I0,000 ft.-Headwaters of Clear Creek; Pike's Peak; Piedra; Mancos; 4 miles west of Cameron Pass; near Veta Pass; near La Plata Post Office; La Plata Cañon; Columbine, Middle Park; Box Cañon, west of Ouray; Bosworth's; Beaver Creek; bank of Elk River, Routt Co.; Trail Creek botton; Rico; Silverton; northwest of Dolores.

3. Geranium Cowenii Rydb. In the mountains of Colo--Alt. 6000-7000 ft.Hills, Larimer Co.; Horsetooth Gulch; Rist Cañon; La Veta.

4. Geranium nervosum Rydb. In the mountains of Wyo. and Ida. to Utah and Colo.-Alt. 8000-900o ft.-Pike's Peak; Grizzly Creek; Continental Divide, Routt Co.; Four-Mile Hill, Routt Co.; Steamboat Springs.

5. Geranium Parryi (Engelm.) Heller. (G. Fremontii Parryi Engelm.) In the mountains of Wyo. and Colo.-Alt. 6000-I0,000 ft.-Pike's Peak; head- 
waters of Clear Creek; Colorado Springs; Idaho Springs; Manitou; Platte Cañon; vicinity of Arthur's Rock; near Boulder.

6. Geranium Pattersonii Rydb. In the mountains of Colo--Alt. 8000-I2,000 ft.-Near Empire; Douglas Mountain, Empire; Gray's Peak; Ute Pass; North Cheyenne Cañon; Palmer Lake; near Narrows; Platte Cañon; Eldora to Baltimore.

7. Geranium Fremontii A. Gray. In the mountains of Colo-Alt, up to $9000 \mathrm{ft}$.-Sand Creek Pass.

8. Geranium caespitosum James. On hills and in dry mountain valleys from Wyo. and Colo.-Alt. 5000-10,000.-Grayback mining camps and Placer Gulch; foothills of Larimer Co.; Turkey Creek and tributaries; Sangre de Cristo Creek; Horsetooth Gulch; Dixon Cañon.

9. Geranium atropurpureum Heller. On hills from Colo. to N. M. and Ariz.-Alt. 7000-8000 ft.-Box Cañon, west of Ouray; Arboles; Ouray; Mancos; Horsetooth Gulch; Dixon Cañon Creek; Dolores.

ro. Geranium Bicknellii Britton. In waste places and on hillsides from N. S. and B. C. to N. Y. and Colo.-Alt. 4000-5000 ft.-Fish Creek Falls.

\section{ERODIUM L.}

1. Erodium cicutarium L. In waste places from N. S. and Ore. to N. J., Colo. and Calif.; also Mex. Introduced from Europe--Alt. 4000-7000 ft.Cucharas River, below La Veta; South Cheyenne Cañon; Colorado Springs; Brantly Cañon, Las Animas Co.; Deer River; Palisades; Hotchkiss; Ft. Collins; Boulder.

\section{Family 73. LINACEAE Dumont. Flax Family.}

I. LINUM L. FLAX.

Petals blue; sepals not glandular-ciliate.

Annuai.

Perennial.

Petals yellow; sepals usually glandular-ciliate.

Sepals long-acuminate-aristate, twice as long as the pod. 3. L. aristatum.

Sepals not more than half longer than the pod.

Petals less than I cm. long; sepals merely keeled or slightly wing-crested.

Stem glabrous or slightly and minutely puberulent.

Lateral veins of the sepals indistinct at least below; petals $6-7 \mathrm{~mm}$. long.

Lateral veins of the sepals strong; petals about $8 \mathrm{~mm}$. long.

4. L. australe.

Stem densely puberulent.

5. L. rigidum.

Petals over T cm. long; sepals strongly wing-crested.

6. L. puberulum.

7. L. arkansanum.

r. Linum usitatissimum L. In waste places, escaped from cultivation; native of Europe-Ft. Collins.

2. Linum Lewisii Pursh. (L. perenne of Coult. Man.; not L.) On dry plains and hills from Mackenzie and Yukon to Tex. and Calif.; also Mex.Alt. 5000-10,000 ft.-Cimarron; mesas near Pueblo; Ft. Collins; Los Pinos (Bayfield); Mancos; West Mancos Cañon; Veta Pass; New Windsor, Weld Co.; Palmer Lake; north of La Porte; Dixon Cañon; foot-hills, Larimer Co.; Spring Cañon; Hahn's Peak. 
3. Linum aristatum Engelm. In arid places from Colo. and Utah to Tex. and Ariz.- "Colorado"; exact locality not given.

4. Linum australe Heller. On dry plains and hills from Colo. to N. M. and Ariz.; also Mex.-Alt. 4000-8000 ft.-Arboles; La Veta; Mancos Cañon; Dixon Cañon; Durango.

5. Linum rigidum Pursh. On dry plains and hills from Sask. and Alb. to Mo. and Colo.-Alt. 4000-7000 ft.--Livermore, Larimer Co. ; foot-hills western Larimer Co.; Dillon; Durango.

6. Linum puberulum (Engelm.) Heller. (L. rigidum puberulum Engelm.) On dry plains and hills from Colo. and Nev. to Tex. and Calif.-Alt. 4000$6000 \mathrm{ft}$.-Grand Junction; Walsenburg.

7. Linum arkansanum Osterh. Sandy soil from Neb. and Colo. to Kans. and Tex.-Rocky Fork, Otero Co.

\section{Family 74. OXALIDACEAE Lindl. WoOd-SORRel FAmily.}

Plants acaulescent, perennial with bulb-like rootstock; corolla rose-violet.

1. Ionoxalis.

Plants caulescent, not succulent, annuals or perennials with slender rootstock; corolla yellow.

2. Xanthoxalis.

I. IONOXALIS Small. ViOLeT WOOD-SORREL.

1. Ionoxalis violacea (L.) Small. (Oxalis violacea L.) On prairies and in valleys from New England and Minn. to Fla. and Colo.-Glen Eyrie.

2. XaNThoXalis Small. Yellow Wood-Sorrei, Sourgrass.

Inflorescence umbellike; pods pubescent.

Inflorescence dichotomous-cymose; pods glabrous.
I. $X$. stricta.

4. $X$. coloradensis.

$\therefore$ Xantoxalis stricta (L.) Small. (Oxalis stricta L.) In woods, cultivated soil and roadsides, from N. S. and S. D. to Fla., Tex. and Colo.-Alt. 4000-8000 ft.-Boulder; Pagosa Springs; foot-hills, Larimer Co.; gulch west of Pennock's; mountains northeast of Dolores; Howe's Gulch; Redstone; Horsetooth Gulch.

2. Xantoxalis coloradensis Rydb. In gulches and in river valleys of Colo. and Black Hills of S. D.-Alt 5000-9000 ft.-Gulch in foot-hills, Larimer Co.; Sangre de Cristo Creek; New Windsor, Weld Co.; along Poudre; Redstone; Ft. Collins; Mason's river-front farm.

\section{Family 75. ZYgOPHYLlaCEAE Lindl. Caltrop Family.}

Herbs; albumen none; fruit not villous; carpels Io-12. Shrubs; albumen horny; fruit villous; carpels 5 .
I. Kalstroemia.

z. Covillea.

\section{RALSTROEMIA Scop.}

Sepals lanceolate, appressed-pubescent. Sepals linear-subulate, bristly hirsute.
1. K. maxima.

2. K. hirsutissima.

1. Iralstroemia maxima (L.) T. \& G. (Tribulus maximus L.) Waste places and sandy soil in the Gulf States.-Rocky Ford. 
2. Kalstroemia hirsutissima Vail. On plains and prairies from Kans. and Colo. to Tex. and N. M.; also Mex.-Cañon City; Pueblo.

2. Covillea Vail. Creosote Bush.

1. Covillea tridentata (DC.) Vail. (Larrea mexicana Moricand) Arid districts from Colo. and Utah to Tex. and S. Calif.- "So. Colo.," exact locality not given.

Family 76. RUTACEAE Juss. Rue Family.

Fuit a capsule; leaves unifoliolate; stamens $8 . \quad$ I. Thamnosma. Fruit an indehiscent samara; leaves 3 -foliolate; stamens $4-5$. 2. Ptelea.

I. Thamnosma Torr. \& Frem.

1. Thamnosma texanum Torr. Dry plains from Colo. to Tex. and N. Mex.; also in Mex.-Alt. up to $5400 \mathrm{ft}$.-Soda spring ledge, Cañon City (Brandegee).

2. ptelea l. Hop-tree, Water Ash.

Samara truncate at the apex.

Samara emarginate at the apex.

I. P. angustifolia. 2. P. crenulata.

1. Ptelea angustifolia Benth. Along streams from Colo. to Tex. and N. M. ; also in Mex.-Cañon City; Florence.

2. Ptelea crenulata Greene. Along streams from Colo. to N. M. and Calif. -Brantly Cañon, Las Animas Co.

\section{Order 29. POLYGALALES.}

Family 77. POLYGaLACEAE Reichenb. Milkwort Family.

I. POLYGALA L. MILKWORT:

Stems herbaceous, unarmed; keel with a fimbriate crest.

Perennial; leaves alternate.

Annual; leaves verticillate.

I. $P$. alba.

2. $P$. verticillata.

More or less spiny undershrubs; keel not crested, but with a beak.

Plant 5-I $5 \mathrm{~cm}$. high; flowers 7-Io $\mathrm{mm}$. long.

Plant 6-10 dm. high; flowers $3-4 \mathrm{~mm}$. long.

3. P. subspinosa.

4. P. acanthoclada.

I. Polygala alba Nutt. On plains from S. D. to Tex. and Ariz.-Exact locality not given.

2. Polygala verticillata $L$. On grassy places from Que. and Sask. to Fla. and Colo.-Clear Creek.

3. Polygala subspinosa S. Wats. On dry mesas from Colo and Nev. to N. M. and Ariz.-Alt. about $5000 \mathrm{ft}$.-Grand Junction; Gunnison Mesa.

4. Polygala acanthoclada A. Gray. In dry valleys from Colo. and Nev. to Ariz.-San Juan Valley.

\section{Order 30. EUPHORBIALES.}

Styles and stigmas distinct or mainly so, cleft or foliaceous; ovary 3-celled (rarely 2-celled); land-plants.

78. EuPHORBIACEAE.

Styles united by pairs; ovary 4-celled; small water- or mud-plants. 


\section{Family 78. EUPHORBIACEAE St. Hill. Spurge Family.}

Flowers not in an involucre; calyx of several sepals.

Petals present, at least in the staminate flowers.

Stamens 6 ; filaments distinct.

Stamens xo; filaments monadelphous.

Corolla wanting; stamens $\mathrm{I}-3$.

I. Croton.

2. Ditaxis.

3. Tragia.

Flowers in involucres; calyx represented by minute scales at the base of filamentlike pedicels.

Glands of the involucres with petal-like appendages; these however sometimes much reduced.

Leaves all opposite.

Glands of the involucres 4 ; leaves inequilateral, usually oblique at the base. 4. Chamaesyce.

Glands of the involucres 5 ; leaves equilateral, not oblique at the base.

5. ZYGOPHYLIIDIUM.

Leaves alternate or scattered, at least below the inflorescence; bracts petallike. 6. Dichrophyllum.

Glands of the inflorescence without petal-like appendages; entirely naked or with a crescent-like horn.

Stem topped by an umbel; stipules none; involucres in open cymes, each with 4 glands and entire or toothed lobes.

7. Tithymalus.

Stem not topped by an umbel; stipules gland-like; involucres in cluster-like cymes; each with a single gland or rarely with 4 glands and fimbriate lobes.

\section{CROTON L.}

8. Poinsettia.

I. Croton texensis (Klotzsch) Muell. Arg. In sandy soil from Ill. and Wyo. to Ala. and Ariz.; also in Mex.-Alt. 4000-6000 ft.-New Windsor; Crow Creek; Cañon City; Longmont; Boulder; La Salle.

\section{z. DITAXIS Vahl.}

I. Ditaxis humilis (Engelm. \& Gray) Pax. (Argythamnia humilis Muell.) On prairies from Kans. and Colo. to La. and Tex.- "Southern Colorado."

\section{TRAGIA.}

I. Tragia ramosa Torr. In dry soil from Mo, and Colo. to Tex. and Ariz.; also Mex.-Alt. 4000-6000 ft--Boulder; Denver; Castle Rock; Larimer Co.; Arboles; Walsenburg; Trinidad; Horsetooth Gulch; Spring Cañon; gulch west of Pennock's; Ute Creek; Pennoclk's; Spring Cañon.

Leaves entire.

\section{ChamaEsyce S. F. Gray. Spurge.}

Annuals or biennials.

Plants prostrate; leaf-blades nearly orbicular. $\quad$ I. C. serpens.

Plants more or less ascending or erect; leaf-blades linear or linear-lanceolate. Capsule less than $1.5 \mathrm{~mm}$. long.

2. C. revoluta.

Capsule about $2 \mathrm{~mm}$. Iong or more.

Appendages of the glands conspicuous, white. 3. C. petaloidea.

Appendages inconspicuous, greenish-white, or obsolete.

Perennials.

4. C. Alagelliformis.

Leaves glabrous.

Glands transversely oval; appendages fan-shaped, white, petalloid.

5. C. albomarginata. greenish.
6. C. Fendleri.

Leaves pubescent.

7. C. lata. 
Leaves toothed, but sometimes only at the apex.

Capsule, stem and leaves glabrous.

Seeds strongly transversely wrinkled.

Seeds pitted or irregularly and faintly wrinkled.

Seeds deeply and irregularly pitted.

8. C. glyptosperma.

Seeds faintly pitted or wrinkled.

9. C. rugulosa.

Leaves oblong; seeds usually with a white bloom.

Leaves linear; seeds brownish, usually without bloom.

Iо. C. serpyllifolia.

II. C. albicaulis.

Capsule, stem and leaves pubescent.

I2. C. stictospora.

1. Chamaesyce serpens (H. B. K.) Small. (Euphorbia serpens H. B. K.) On prairies from Ont. and S. D. to Fla. and Ariz.; also Mex.-New Windsor, Weld Co.

2. Chamaesyce revoluta (Engelm.) Small. (E. revoluta Engelm.) On hillsides from Tex. and Colo. to N. M.; also northern Mex.-Cañon City.

3. Chamaesyce petaloidea (Engelm.) Small. (E. petaloidea Engelm.) On prairies and hillsides, especially in sandy soils, from Iowa and Wyo. to Tex. and Colo.-Alt. 4000-7000 ft.-Boulder; La Veta; Crow Creek; Longmont; Boulder Cañon.

4. Chamaesyce flagelliformis (Engelm.) Rydb. (E. petaloidea Alagelliformis Engelm.; E. Aagelliformis Engelm.) In dry soil from Colo. to Tex. and N. M.- "Southwestern Colorado."

5. Chamaesyce albomarginata (T. \& G.) Small. (E. albomarginata T. \& G.) In dry soil from Colo. and Utah to Tex. and Calif.; also Mex.-Upper Platte.

6. Chamaesyce Fendleri (T. \& G.) Small. (E. Fendleri T. \& G.) On dry hills, in sandy soil, from Neb. and Wyo. to Tex. and Ariz.-Alt. 4000-6000 ft.-Foot-hills near Boulder; Trinidad; Cañon City; Black's Lake; Cedar Hills.

7. Chamaesyce lata (Engelm.) Small. (E. lata Engelm.) On plains and prairies from Kans. and Colo. to Tex. and N. M.- "Southwestern Colorado."

8. Chamaesyce glyptosperma (Engelm.) Small. (E. glyptosperma Engelm.) In sandy soil from Ont. and B. C. to Tex, and Mex.-Alt. 4000-7000 ft.Colorado Springs; Denver; Deer Run; Cañon City; Pueblo; Boulder; Fort Collins; Manitou; New Windsor; gulch west of Soldier Cañon; Miller's ranch, between Fort Collins and La Porte; Horsetooth Gulch.

9. Chamaesyce rugulosa (Engelm.) Rydb. (E. serpyllifolia rugulosa Engelm.) In sandy soil from Wyo. to N. M. and Calif.-Mountains between Sunshine and Ward; gulch west of Soldier Cañon; between Porter and Durango.

ro. Chamaesyce serpyllifolia (Pers.) Small. (E. serpyllifolia Pers.) In dry soil from Mich. and Wash. to Tex. and Calif.; also Mex.-Alt. 4000-8000 ft.-Antonito; Lyons; Arboles; Gunnison; Durango; Manitou; Parlin; Boulder Co.; Box Cañon west of Ouray; between Fort Collins and La Porte; Rocky Ford.

II. Chamaesyce albicaulis Rydb. (E. albicaulis Rydb.) In old fields and sandy soil from Neb. and Mont. to N. Mex.-Alt. 4000-5500 ft.-Foot-hills west of Fort Collins. 
I2. Chamaesyce stictospora (Engelm.) Small. (E. stictospora Engelm.) On prairies and plains from Kans, and Colo. to Mex, and Ariz.-Alt. 5000$7000 \mathrm{ft.}-$ Cañon City; Pueblo; south of Fort Collins.

\section{ZYGOPHYLLIDIUM Small.}

I. Zygophylliđium hexagonum (Nutt.) Small. (Euphorbia hexagona Nutt.) In river valleys from Iowa and Mont. to Tex. and Colo.-Plains near Denver.

6. DICHROPHYLLUM K1. \& Garcke. SNow-ON-The-mountain.

I. Dichrophyllum marginatum (Pursh) Kl. \& Garcke. (Euphorbia marginata Pursh) In pastures from Minn. and Mont. to Tex. and Colo.-Alt. 4000-7000 ft.-Rocky Mountains; Boulder; sources of the Platte; Fort Collins; New Windsor; Dry Creek, Larimer Co.; La Veta; Denver; Nepesta.

7. TITHYMALUS Kl. \& Garcke. SPURge.

Leaves entire; glands of the involucres with processes.

Plants perennial; processes short and blunt.

Stem-leaves linear; capsule rough; seeds smooth. $\quad$ I. T. Cyparissias.

Stem-leaves from oblong or oblanceolate to orbicular; capsule smooth; seeds pitted.

Bracts rhombic-ovate, cuspidate; stem rather slender. 2. T. montanus.

Bracts rhombic-reniform, mucronate; stem stout. 3. T. robustus.

Plants annual; processes of the glands long and horn-like; seeds pitted.

4. T. crenulatus.

Leaves distinctly serrulate; plants annual or biennial; glands without processes.

Upper stem-leaves merely sessile; bracts manifestly longer than broad.

5. $T$. arkansanus.

Upper stem-leaves with small basal lobes; bracts mostly broader than long.

6. T. missonriensis.

I. Tithymalus Cyparissias (L.) Lam. (Euphorbia Cyparissias L.) Escaped. from cultivation from Mass. and Colo. to Va.-Fort Collins.

z. Tithymalus montanus (Engelm.) Small. (Euphorbia montana Engelm.) On dry hills from Colo. and Utah to Tex and Ariz.-Alt. 6000-8000 ft.Cimarron; Buena Vista.

3. Tithymalus robustus (Engelm.) Small. (E. montana robusta Engelm.) On dry hills from Mont. and S. D. to Colo, and Ariz.-Alt. 4000-8000 ft.Cimarron; Cucharas River, La Veta; Colorado Springs; Alamosa; Larimer Co.; Gunnison; Arboles; Fort Collins; Longmont; Pike's Peak trail; Poudre River; Fort Collins; along Purgatory River; Fossil Creek; Rist Cañon; Colorado Springs.

4. Tithymalus crenulatus (Engelm.) Heller. (E. crenulata Engelm.) On hillsides from Colo. to Calif. and Ariz.-Mancos; Horsetooth Gulch.

5. Tithymalus arkansanus (Engelm. \& Gray) Kl. \& Garcke. (E. arkansana Engelm. \& Gray) In dry soil from Mo. and S. D. to Ala. and Ariz.-Alt. 4000-6000 ft.-Larimer Co.; Boulder; Horsetooth Gulch.

Tithymalus arkansanus coloradensis (Norton) Rydb. Floral leaves elliptical.-McEimo Cañon; Larimer Co.

6. Tithymalus missouriensis (Norton) Small. (Euphorbia dictyospermo Coulter; not F. \& M.; E. arkansana missouriensis Norton) In sandy soil from Iowa and Wash. to Kans. and N. M.-Denver. 


\section{PoInsettia Graham. Spurge.}

Seeds not prominently tubercled; glands of the involucre $3-4$; leaf-blades linear or linear-lanceolate.

I. P. cuphosperma.

Seeds prominentiy tubercled; gland of the involucre solitary; leaf-blades ovate to lanceolate (linear-lanceolate only in one variety).

2. P. dentata.

1. Poinsettia cuphosperma (Boiss.) Small. (Euphorbia cuphosperma Boiss.) In cañons and hillsides from S. D. and Wyo. to Tex. and Ariz.; also Mex.Alt. 5000-7000 ft.-Colorado Springs; Manitou; Cañon City.

2. Poinsettia dentata (Michx.) Small. (Euphorbia dentata Michx.) In moist soil from $\mathrm{Pa}$. and S. D. to La., Mex. and Utah.-Alt, 4000-6000 ft.Boulder; Fort Collins; New Windsor. A rare variety with nearly linear leaves.-Fort Collins.

Family 79. ,CALlitrichacEAE Lindl. Water Starwort Family. 1. Callitriche L. Water Starwort.

I. Callitriche palustris L. In shallow running water from N. S. and B. C. to Fla. and Calif.; also Europe, Asia and S. Am.--Leroux Parks, Delta Co.; Ft. Collins; Boulder.

\section{Order 3i. SAPINDALES.}

Low annual herbs; stamens twice as many as the sepals and petals.

8o. LIMNANTHACEAE.

Shrubs or trees; stamens usually as many as the petals or sepals.

Stamens opposite the sepals.

Plants with resiniferous tissue; fruit drupaceous; seeds without aril; leaves in ours compound.

8r. Spondiaceae.

Plants without resiniferous tissue; fruit a loculicidal capsule; seed with a fleshy aril; leaves simple.

82. Celastraceae.

Stamens alternate with the sepals; fruit a double samara; leaves opposite. 83. AcERAceae.

Family 8o. LimnanthaceaE Lindl. False Mermaid Family.

1. Floerkia Willd. False Mermaid.

r. Floerkia occidentalis Rydb. In wet soil from Wyo. and Wash. to Colo. and Utah.-Steamboat Springs; Gunnison Co.

Family 8r. SPONDIACEAE Kunth. Sumac Famiuy. Drupe with glabrous outer coat; stone ribbed; plants poisonous to touch. Drupe with pubescent outer coat; stone smooth; plants not poisonous.
I. RHUS.

2. Schmaltzia.

1. RHUS L. Poison OAK, PoIson Ivy.

1. Rhus Rydbergii Small. On plains, hills and among bushes from Mont. and B. C. to Nebr. and Colo.-Alt. $4000-5000$ ft.-Ft. Collins; foot-hills near Boulder. 


\section{SChMaltzia Desv. Sumac.}

Leaflets 9-3I; flowers appearing after the leaves. Leaflets $I-3$; flowers appearing before the leaves.

1. S. glabra.

2. S. trilobata.

I. Schmaltzia glabra (L.) Small. (Rhus glabra L.) Along streams, in thickets and on hills from N. S. and B. C. to Fla. and Ariz.-Alt. 4000-6000 ft.-Cheyenne Cañon, near Pike's Peak; Lower Boulder Cañon, Boulder Co.; foot-hills, Larimer Co.; vicinity of Arthur's Rock; gulch west of Pennock's.

2. Schmaltzia trilobata (Nutt.) Small. (Rhus trilobata Nutt.) On dry hills from Ass. and Wash. to Mo., Tex. and Calif.; also Mex.-Alt. 4000-8000 ft.-Boulder; Colorado Springs; Buena Vista; Trinidad; southeast of La Veta; Manitou; Ft. Collins; Cedar Hills; along Poudre; Rist Cañon; Horsetooth Gulch; gulch west of Soldier Cañon; Spring Cañon; Howe's Gulch.

\section{Family 82. CELASTRACEAE Lindl. Staff-tree Family.}

Petals, sepals and stamens 4 ; ovary 2-celled; each cell with 2 ovules; depressed or trailing evergreen shrubs, not spiny.

I. РACH YSTIMA.

Petals and sepals 5; stamens 5-Io; ovary I-celled with 2 ovules; small erect shrubs with angled, green, often spinescent branches.

2. Forsellesia.

\section{PACHYSTIMA Raf.}

I. Pachystima Myrsinites (Pursh) Raf. In woods from Mont. and B. C. to N. M. and Calif.-Alt. 6000-10,000 ft.-Headwaters of Clear Creek; near Empire; Mt. Ouray; Crystal Creek; East and West Indian Creek; near La Plata Post Office; Steamboat Springs; Glenwood Springs; Four-Mile Hill, Routt Co.; west and southeast of Ouray ; Rico; Big Creek Gulch, Routt Co.; Trapper's Lake; Black Cañon of Gunnison; Ragged Mountain, Gunnison Co.; mountains near Silverton; bank of Fish Creek; Hematite.

Stamens 5-7.

2. FORSELLESIA. Greene.

Stamens Io.

I. F. meionandra.

2. F. spinescens.

I. Forsellesia meionandra (Koehne) Heller. (Glossopetalon meionandrum Koehne) In arid regions of southern Colorado. Exact location not given. 2. Forsellesia spinescens (A. Gray) Greene. (Glossopetalon spinescens A. Gray) In desert regions from Ore. to Tex. and Calif.--Grand Junction; Hovensweep Castle (Brandegee).

Family 83. ACERACEAE J.. St. Hil. Maple Family.

Leaves with simple or rarely digitately divided blades; flowers polygamo-dioecious.

Leaves with pinnately compound blades; flowers dioecious.

r. ACER.

2. Rulac.

\section{ACER L. Maple.}

Flowers polygamous in racemes or corymbs; petals and sepals both present; disk well developed; lobes of the leaves toothed. 1. A. glabrum.

Flowers monoecious, in umbels; petals lacking; lobes of the leaves sinuate. 
I. Acer glabrum Torr. In cañons, on hillsides and along streams, from W. Neb. and Wyo. to N. M. and Utah.-Alt. 4000-g000 ft.-Headwaters of Clear Creek; Hinsdale Co.; Pike's Peak; near Pagosa Peak; near La Plata Post Office; Idaho Springs; foot-hills west of Ft. Collins; South Cheyenne Cañon; Colorado Springs; Wahatoya Cañon; Ute Pass; southeast of Ouray; along Uncompahgre River near Ouray; Rist Cañon; Dillon Cañon; gulch west of Pennock's; hills northwest of Soldier Cañon; Howe's Gulch; Baxter's ranch; Big Narrows on Poudre; Ft. Collins; Dolores; North Poudre River; Campton's ranch; Horsetooth Gulch; gulch west of Dixon Cañon; Redstone; mountains between Sunshine and Ward; Eldora to Baltimore.

x. Acer grandidentatum Nutt. In wooded valleys and cañons from Mont. to Tex. and Ariz.-Pike's Peak.

2. RULAC Adans. BoX-elder, Ash-LEaved Maple.

Twigs and petioles essentially glabrous; leaflets thin, coarsely toothed.

Twigs and petioles copiously pubescent; leaflets thick, lobed.

1. R. Negundo,

2. R. texana.

r. Rulac Negundo (L.) Hitchc. (Acer Negundo L.; Negundo aceroides Moench.) In low ground and along streams from Vt. and Ida. to Fla. and Tex.-Alt. 4000-7000 ft.-South Cheyenne Cañon; Colorado Springs.

2. Rulac texanum ( $\mathrm{Pax}$. ) Small. (Acer texanum Pax.) Along rivers from Sask. and Mont. to Mo. and Ariz.-AIt. 5000-8500 ft.-Southeast of Ouray; Cucharas Valley, near La Veta; Ft. Collins; Walsenburg; Cache la Poudre; foot-hills near Boulder.

\section{Order 32. RHAMNALES.}

Sepals manifest; petals involute; fruit capsular or drupaceous; ours shrubs or trees.

84. Frangulaceae.

Sepals minute or obsolete; petals valvate; fruit a berry; ours vines with tendrils. 85. VITACEAE.

\section{Family 84. FRANGULACEAE DC. BuCKthorn Family.}

Fruit pulpy; petals small, clawless or wanting; stigmas usually z.

Fruit dry : petals hooded and long-clawed; stigmas 3 . Rhamnus.

Fruit dry; petals hooded and long-clawed; stigmas $3 . \quad$ 2. Ceanothus.

I. RHAMNUS L. BuckthoRn.

Leaves broadly elliptic or ovate; flowers solitary in the axils; carpels 3 or 4 .

Leaves lanceolate; flowers 2 or 3 in each axil; carpels 2.

I. $R$. cathartica.

2. R. Smithii.

I. Rhamnus cathartica L. Cultivated for hedges and escaped; native of Europe.-Ft. Collins.

2. Rhamnus Smithii Greene. Along streams in Colo. and N. Mex.-Alt. about $7000 \mathrm{ft} .-$ Pagosa Springs.

2. Ceanothus L. New Jersey Tea.

Leaf-blades rounded-oval, often cordate at the base, very shining above; closely glandular-dentate.

1. C. velutinus.

Leaf-blades oblong to elliptic or ovate, glandular-serrate or sub-entire. 
Umbels mostly terminal; leaves dull beneath, glabrate or villous.

Umbels mostly axillary; leaves silky beneath.

2. C. pubescens.

Leaf-blades distinctly glandular-serrate; plant not spiny. 3. C. subsericeus. Leaf-blades obsoletely denticulate or entire; branches often ending in spines.

4. C. Fendleri.

1. Ceanothus velutinus Dougl. On hillsides from Mont. and B. C. to Colo. and Calif.-Alt. 6000-7000 ft.-Headwaters of Clear Creek; near Empire; Steamboat Springs; Walton Creek; Four-Mile Hill, Routt Co.; Sheephorn Divide; between Pallas and Sydney; Poudre Cañon; mountains between Sunshine and Ward; Pinkham Creek; Beaver Creek.

z. Ceanothus pubescens (T. \& G.) Rydb. (C. ovatus pubescens T. \& G.) In sandy soil from Mich. and S. D. to Mo. and Colo.-Alt. 4000-8000 ft.Foot-hills, Larimer Co.; Colorado Springs; Pennock's mountain ranch; Horsetooth Mountain; Monument; Boulder.

3. Ceanothus subsericeus Rydb. Foot-hills of Colo--Alt. about $6000 \mathrm{ft} .-$ Larimer Co.

4. Ceanothus Fendleri A. Gray. In woods and on hillsides from S. D. and Wyo. to N. M. and Ariz.-Alt. 5000-9000 ft.-Headwaters of Clear Creek; Denver to Idaho Springs; Sangre de Cristo Creek; Mancos; Pagosa Springs; Grayback mining camps and Placer Gulch; Boulder; west of Ouray; Mt. Harvard; southeast of Ouray; Rist Cañon; vicinity of Arthur's Rock, Larimer Co.; Leroux Creek; Horsetooth Gulch; Pennock's mountain ranch; Horsetooth Mountain; mountains between Sunshine and Ward.

Family 85. VitaceaE Lindl. Grape Family.

Hypogynous disk present; leaf-blades simple. I. VITIS. Hypogynous disk wanting or obsolete; leaf-blades digitately $5-7$-foliolate.

2. Parthenocissus.

\section{VITIS L. GRAPES.}

1. Vitis vulpina L. (Vitis riparia Michx.) Along streams from N. B. and N. D. to W. Va., Tex. and Colo.-Alt. 4000-9000 ft.-Walsenburg; Dixon Cañon, Larimer Co.; Ft. Collins; banks of Cache la Poudre; Rist Cañon; gulch west of Pennock's; Boulder.

\section{PARThenocissus Planch. Virginia Creeper, American Ivy.}

Aerial rootlets present; tendrils with disks.

Aerial rootlets lacking; tendrils without disks.

1. $P$. quinquefolia.

2. P. laciniata.

I. Parthenocissus quinquefolia (L.) Planch. In woods and on banks from Que. and Man. to Fla. and Tex.-Reported from Colorado (Meehan), but doubtful.

2. Parthenocissus vitacea Hitchc. ( $P$. quinquefolia laciniata Planch.; $P$. lacinata Small) On river banks and in woods from Mich. and Wyo. to Ohio and Ariz.-Alt. 4000-6000 ft.-Foot-hills, Larimer Co.; Cheyenne Cañon; Ft. Collins; North Cheyenne Cañon; Golden; vicinity of Arthur's Rock; near Boulder. 


\section{Order 33. MALVALES.}

\section{Family 86. MALVACEAE Neck. Mallow Family.}

Style-branches filiform, longitudinally stigmatose anteriorly; carpels numerous, indehiscent, containing a single ovule and a reniform seed.

Stamens simply monadelphous; flowers involucelled.

Petals notched at the apex; carpels beakless without internal processes.

I. MaLva.

Petals erose at the apex; carpels beaked, with an internal process above the seed.

2. Callikrhoe.

Stamens united in a double series; flowers without involucels.

Style-branches terminated by a capitate stigma.

3. Sidalcea.

Lower seed at least from an ascending ovule; calyx more or less bractioled.

Ovule and seed solitary, conformed to the rounded cavity of the carpel.

4. Malvastrum.

Ovules $I-3$ and seeds I-2; the cells of the carpels more or less extended and empty above.

5. Sphaeralcea.

Lower seed at least resupinate-pendulous; no involucels under the calyx, or these represented by $\mathrm{I}-3$ setaceous bractlets.

Carpels I-ovuled, the cell filled with the seed.

Carpels 3-9-ovuled, dehiscent apically and dorsally.

6. SIDA.

7. Abutilon.

\section{Malva L. Mallow.}

Calyx not reflexed in fruit.

Plant erect; leaves crisp.

Plant procumbent; leaves not crisp.

Calyx large, reflexed-spreading in fruit.

1. M. crispa.

2. $M$, rotundifolia.

3. M. parviflora.

1. Malva crispa L. In waste places, escaped from gardens, from N. S. and S. D. to N. J. and Colo.-Ft. Collins.

2. Malva rotundifolia L. In waste places, naturalized from Europe; from Mass. and Minn. to Ga. and Utah.-Alt. up to $7500 \mathrm{ft}$.-North of La Veta; Hotchkiss; near Boulder; Denver.

3. Malva parviflora L. In waste places, naturalized from Europe; from Mont. and B. C. to Fla., Tex. and Calif.-Hotchkiss.

\section{CALlirRHOE Nutt. Poppy Mallow.}

1. Callirrhoe involucrata (T. \& G.) A. Gray. On plains and in sandy soil from Mo. and Wyo. to Tex. and Utah.-Ft. Collins; Cheyenne Cañon; Yuma; Cclorado Springs.

\section{SIDALCEA A, Gray.}

Inflorescence and calyx densely stellate; corolla cream-colored.

Inflorescence and calyx sparingly hirsute; corolla purple or white.

$$
\text { 2. S. neo-mexicana. }
$$

1. Sidalcea candida A. Gray. Along streams and in wet meadows from Wyo. to N. M. and Utah.-Alt. 7000-13,000 ft.-Lake City; La Veta; Steamboat Springs; Parlin, Gunnison Co.; Grizzly Creek; Cameron Pass; above Dix Post Office; Wahatoya Creek; West Spanish Peak; Cucharas Valley; Michigan Hill. 
2. Sidalcea neo-mexicana A. Gray. (S. malvaefolia of Coult. Man.) In mountain valleys from Wyo. and Utah to N. M. arid southern Calif.; also Sonora.-Ait. 6000-10,000 ft.-Pitkin; La Veta; Parlin, Gunnison Co.; Grizzly Creek; Marshall Pass; Grayback mining camps and Placer Gulch; Sangre de Cristo Creek; Piedra; valley of Arkansas; Calhan; Buena Vista; Bear River, Routt Co.; North Park; Soda Spring near north fork of the Platte; Bear River at Steamboat Springs; Grizzly Creek I6 miles north of Walden; Elk River.

\section{Malvastrum A. Gray. False Mallow.}

Plant canescent with stellate hairs; leaves 3-5-divided with 2-3-cleft divisions. Plant low, I-2 dm. high; middle segment of the leaves slightly longer than the others; raceme crowded. 1. $M$. coccineum.

Plant tall, $3-4 \mathrm{dm}$. high; middle segment of the leaves usually half longer than the others; raceme elongated.

2. M. elatum.

Plant lepidote and silvery with scale-like peltate hairs; leaves 3 -parted with narrowly linear divisions or the upper simple and filiform. 3. M. leptophyllum.

1. Malvastrum coccineum (Pursh) A. Gray. On plains and in sandy valleys from Sask. and Ore. to Iowa, Tex. and Utah.-Alt, 4000-9000 ft.-Ft. Collins; Cimarron; Deer River; Manitou; Cañon City; Arboles; Cucharas River below La Veta; Sangre de Cristo Creek; mesas near Pueblo; Trinidad; along Platte River, Denver; Mancos; New Windsor, Weld Co.; Rocky Ford; Montrose; Lamar; Quimby; Ouray; Horsetooth Gulch; Grand Junction; Colorado City.

2. Malvastrum elatum (Baker) A. Nelson. ( $M$. coccineum elatum Baker) In dry valleys from southern Colo. and Utah to N. Mex.-Salida.

3. Malvastrum leptophyllum A. Gray. In dry places from western Texas to southern Utah.-Valley of San Juan and La Plata (Brandegee); McElmo Creek (Eastwood).

\section{SphaERalcea St. Hil. Globe-mallow.}

Carpels glabrous or canescent, not hirsute, lower part reticulated; leaves small, not maple-like.

Leaves lanceolate; fruit not depressed; carpels with cusp. 1. S. cuspidata.

Leaves round-ovate to reniform in outline; fruit depressed globose; carpels not cuspidate-tipped.

2. S. marginata.

Carpels thin, hirsute, the lower portion not reticulate; leaves large, maple-like.

Sepals lanceolate or ovate-lanceolate; bractlets subulate, three-fourths as long as the sepals or more.

3. A. Crandallii.

Sepals broadly triangular-ovate; bractlets scarcely more than half as long as the sepals.

Calyx and pedicels finely stellate; bractlets subulate; petals $2-2.5 \mathrm{~cm}$. long. 4. A. rivularis.

Calyx and pedicels hirsute with branched hairs; bractlets lanceolate; petals $3 \mathrm{~cm}$. or more long.

5. A. grandiflora.

I. Sphaeralcea cuspidata (A. Gray) Britton. (S. angustifolia cuspidata A. Gray; S. stellata T. \& G.; Sida stellata Torr.; not Cav.) In dry ground from Kans and Colo. to Tex. and Ariz.; also Sonora.-Cañon City; Pueblo; Rocky Ford.

2. Sphaeralcea marginata York. (Malvastrum Munroanum S. Wats., in part; not Malva Munroana Dougl.) In dry places in western Colo. and northern N. M,--Alt. up to $6000 \mathrm{ft}$--McElmo Cañon; Grand Junction. 
3. Sphaeralcea Crandallii Rydb. Mountains of Colo.-Alt. about $7000 \mathrm{ft}$ Steamboat Springs.

4. Sphaeralcea rivularis (Hook.) Torr. (Malva rivularis Hook.; Sphaeralcea acerifolia Nutt.) Along streams from Alb. and B. C. to S. D., Colo. and Nev.-Four-Mile Hill, Routt Co.; Ragged Mountain, Gunnison Co.; Buffalo Pass; Park Range; Fish Creek Falls.

5. Sphaeralcea grandiflora Rydb. Mountains of Colo.-Alt. 7000-9000 ft.Mesa Verde; west of Ouray.

\section{SIDA L.}

I. Sida sagittaefolia (A. Gray) Rydb. (Sida lepidota sagittaefolia A. Gray) Plains from Colo. to Tex. and Ariz.; also in Mex.-"Southern Colorado."

7. abdtilon Gaertn. Velvet-Leaf, Indian Mallow.

1. Abutilon parvulum A. Gray. In dry soil from Colo. to Tex. and Ariz. -Cañon City.

\section{Order 34. HYPERICALES.}

Styles wanting; stigma introrse; ours small water-plants. 87. ElATINACEAE. Styles present; stigmas capitate or nearly so.

Styles in ours distinct.

Sepals persistent, united into a tube; leaves not pellucid-dotted.

Sepals distinct; leaves pellucid-dotted.

88. FRAN KENIACEAE. Styles wholly united.

Corolla regular or nearly so; stamens 8.

Corolla irregular; one petal spurred; stamens 5 .

89. HY PERICACEAE.

9o. Cistacene.

9I. Violaceae.

Family 87. ELATINACEAE Lindl. WATER-wort FAMILy.

I. elatine L. Water-wort, Mud Purslane.

Leaves oblanceolate; flowers usually 3-merous.

1. E. triandra.

Leaves obovate; flowers 2 -merous.

2. E. americana.

I. Elatine triandra Schkur. In shallow water from Ills, and Wyo. to Colo. -Platte River.

2. Elatine americana Arn. In mud and shallow water from Que. and B. C. to Va., Colo. and Calif.-Platte River.

Family 88. FRANKENIACEAE.

I. FRANKENIA L.

I. Frankenia Jamesii Torr. On saline plains from Colo. to Tex. and Sonora.-BIuffs about Pueblo; Rocky Ford, Otero Co.; Cañon City.

Family 89. HYPERICACEAE Lindl. St. John's Wort Family.

I. HYPERICUM L. St. JoHN's WorT.

Petals more than twice as long as the sepals; both usually margined with black glands.

Petals slightly exceeding the sepals; black glands none.

I. H. fornosum.

2. H. majus. 
I. Hypericum formosum H. B. K. On hillsides and mountain valleys from Colo. and Utah to Mex. and S. Calif.-Alt. 6000-Io,000 ft.-South Park; Pagosa Springs; Colorado Springs; Mancos; Elk River, Garfield Co.; Marshall Pass; near Manitou, El Paso Co.; Chambers' Lake; Wahatoya Creek; Gypsum .Creek Cañon; Poudre Cañon.

2. Hypericum majus (A. Gray) Britton. In wet meadows from $\mathrm{Me}$. and B. C. to N. J. and Colo.-Alt. $4000-6000 \mathrm{ft}$-Foot-hills, near Boulder.

\section{Family 9o. CISTACEAE Lindl. Rock-Rose Family. 1. helianthemum Pers. Frostweed.}

I. Helianthemum majus (L.) B. S. P. (H. canadense Walkerae Evans) On hilisides from N. S. and S. D. to N. C. and Colo.-Douglas County.

\section{Family 9I. VIOLACEAE DC. Violet Family.}

Sepals more or less auricled at base.

Sepals not auricled at base.
1. VIOLA.

2. Calceolarta.

I. VIOLA L. VIOLET.

Acaulescent ; flowers scapose.

Plant stoloniferous, at least so after the flowering period.

Flowers pale blue or lilac.

1. V. palustris.

Flowers white.

Upper and lateral petals twice as long as broad; petioles not red-spotted. Leaves ovate, pointed, green; lateral petals veined with purple.

z. V. blanda.

Leaves reniform, not pointed, glaucous; lateral petals not veined.

3. V. Macloskeyi.

Upper and lateral petals three times as long as broad; petioles and scapes

red-spotted.

Plant not stoloniferous; flowers blue.

Leaf-blades divided into linear lobes.

Leaf-blades entire.

4. V. LeConteana.

Blade strongly decurrent upon the petiole; cleistogenes horizontal.

Blade not decurrent; cleistogenes erect or ascending.

Sepals lanceolate, pointed; leaves herbaceous. 7. V. cognata.

Sepals oblong, obtuse, 3 -nerved; leaves subcoriaceous.

Caulescent, leafy-stemmed.

8. V. nephrophylla.

Flowers yellow or tinged with brown.

Stems short or subacaulescent at flowering time.

Leaf-blades pedately divided into narrow segments; petals tinged with brown beneath.

9. V. Sheltonii.

Leaf-blades entire or merely toothed.

Blades lanceolate, tapering to a margined petiole, pubescent.

Io. $V$. Nuttallii.

Blades ovate to oblong-ovate, scarcely or not at all tapering to the petiole. I I. $V$. linguaefolia.

Stems erect or ascending, bearing scattered long-petioled orbicular leaves.

Flowers blue, purple or white.

I2. $V$. biflora.

Flowers white or tinged with purple beneath.

I3. $V$. canadensis.

Flowers blue.

Plant rough-pubescent, $\mathrm{I}-2 \mathrm{dm}$. high.

Plant glabrous, 2-6 cm. high.

I4. $V$. retroscabra.

I5. $V$. bellidifolia. 
1. Viola plustris L. Wet soil, Lab. and Alaska to N. Y. and Colo-Ait. 8500-10,000 ft.-Grayback mining camps; Beaver Creek; banks of Michigan River; Eldora to Baltimore.

z. Viola blanda Willd. Swamps and wet meadows, Newf. and B. C. to N. C. and Utah.-Alt. $8000-10,000 \mathrm{ft}$-Caribou; headwaters of Clear Creek; Columbine.

3. Viola Macloskeyi F. E. Lloyd. Subalpine situations, Mont. and Ore. to Colo. and Calif.-Alt. about $9000 \mathrm{ft}$.-North Park, Larimer Co.

4. Viola LeConteana G. Don. ( $V$. blanda amoena LeConte) Moist woodlands, N. S. and Ida. to N. C. and Colo.-Alt. about $9000 \mathrm{ft}$.-Chicken Creek.

5. Viola pedatifida G. Don. Prairies, Ill. to B. C. and Ariz.-Alt. about 8000 ft.-Wahatoya Cañon.

6. Viola retusa Greene. Woodlands and meadows, S. D. to Kans. and Colo. -Alt. about $5000 \mathrm{ft}$-New Windsor; Ft. Collins; Timnath, Larimer Co.

7. Viola cognata Greene. Wet meadows, Alb. and S. D. to N. M., Ariz., Utah and Calif.-Alt 5000-ro,000 ft.-Bob Creek, West La Plata Mountains; headwaters of Sangre de Cristo Creek; mountain near Veta Pass; West Indian Creek; Cucharas Valley near La Veta; Timnath, Larimer Co.; Lake City; Ft. Collins; plains and foot-hills near Boulder.

8. Viola nephrophylla Greene. Meadows and thickets, Ida. and Wyo. to Colo., Ariz. and Nev.-Los Pinos.

9. Viola Sheltonii Torr. Western Colo. to Calif.-Alt. 8000-9000 ft.-Grand Mesa; Cerro Summit.

ro. Viola Nuttallii Pursh. Prairies, plains and foot-hills, Man. and Mont. to Mo., N. M. and Ariz.-Alt. 4000-9000 ft.-Walsenburg; southeast of La Veta; Cucaras Valley and river near La Veta; Ft. Collins; southwest of La Veta; Rist Cañon, Larimer Co.; New Windsor, Weld Co.; plains near Denver; Grand Mesa; plains and foot-hills near Boulder.

II. Viola linguaefolia Nutt. ( $V$. vallicola A. Nels.; $V$. physalodes Greene) Foot-hilis and mountains, N. D. and Mont. to Colo. and Utah.-Ait. up to 7000 ft.-Between Meeker and Craig; mountains east of Steamboat Springs; Minturn, Eagle Co.; Cimarron; Dixon Creek; Trinidad.

I2. Viola biflora L. Mountains of Colo.; also in Europe and Asia.-Alt. 8000-10,000 ft.-Jack Brook; headwaters of Clear Creek and alpine ridges east of Middle Park; Argentine Pass; Eldora to Baltimore.

13. Viola canadensis L. The typical $V$. canadensis of the east is represented in Colorado by the following subspecies:

Viola canadensis Rydbergii (Greene) House. ( $V$. Rydbergii Greene) Radical leaves subreniform, as broad as long or broader, on elongated petioles; pubescent at least on the veins beneath. Rocky Mountains, Alb. and Ida. to S. D. and Colo.-Ait. 5000-9000 ft.-Ouray; Van Boxle's ranch above Cimarron; near Pagosa Peak; Mancos; Steamboat Springs; gulch of Bear River, Routt Co.; Cucharas Valley, near La Veta; Ft. Collins; Apex; Villa Grove; foot-hills, Larimer Co. ; Rico; Boulder.

Viola canadensis neo-mexicana (Greene) House. ( $V$. neo-mexicana Greene) Southern Colo. and N. M.-Alt. 7500-I2,000 ft.-Idaho Springs; Wahatoya Cañon; Mt. Abram; about Ouray; Rico; Eldora to Baltimore. 
Viola canadensis scopulorum A. Gray. (V. scopulorum Greene) Colo. and N. M. Low, tufted and spreading, more or less pubescent; the stipules very large, scarious.-Horsetooth Gulch.

I4. Viola retroscabra Greene. Mountains, Colo, and N. M. to southern Calif.-Alt. 6000-Io,00o ft.-Grayback mining camps; Cerro Summit; Cameron Pass; Cimarron; Mancos; along Uncompahgre River near Ouray; Breckenridge; Bob Creek; West Indian Creek; Pagosa Springs; Minturn, Eagle Co.; mountain near Veta Pass; Chambers' Lake; mountains of Estes Park, Larimer Co.

I5. Viola bellidifolia Greene. High mountains, Wyo, and Colo.-Alt. 8000I2,000 ft.-Marshall Pass; Slide Rock Cañon, West La Plata Mountains; Alpine Tunnel; Bob Creek Divide; Graymont; Cameron Pass; Columbine; mountains of Estes Park; Chambers' Lake; Red Mountain; Gunnison; source of Leroux, Delta Co.; Eldora to Baltimore; summit of North Park Range, Larimer Co, ; Rabbit-Ear Range, Routt Co.

\section{z. Calceolaria Loefl. Nodding Violet.}

I. Calceolaria verticillaria (Ortega) Kuntze. (Ionidium polygalaefolium Vent.; Ionidium lineare Torr.) Plains, Colo. and Kans. to Tex., Ariz. and Mex.-Brantly Cañon, Las Animas Co.; Cañon City.

\section{Order 35. OPUNTIALES.}

Sepals and petals 4 or 5 very unlike;* leaves ample; plants erect, not succulent, with rigid hairs.

92. LOASACEAE.

Sepals and petals nearly alike, at least the latter numerous; leaves typically and in all ours mere scales or wanting; succulent plants armed with spines.

93. Cactaceae.

\section{Family 92. LOASACEAE Reichenb. LoASA Family.}

Placentae with horizontal lamellae between the seeds; these in two rows, flat, more or less winged.

Placentae without lamellae; seeds usually prismatic.

Placentae slender, filiform; ovules in one row, 10-40; seeds minutely muricate, not striate; filaments free or nearly so. 2 . ACroLAsia.

Placentae broad, band-like; ovules in $\mathrm{I}-2$ rows, few; seeds distinctly striate, often rugose; filaments at the base united with the petals into a ring.

3. Mentzelia.

\section{TOUTEREA Eat. \& Wright.}

Upper leaves entire.

All leaves pinnatifid, lobed or toothed.

Petals obtuse, spatulate, $1-2 \mathrm{~cm}$. long.

Petals acute.

Petals greenish-yellow; seeds irregularly angled on the face.

I. T. multicaulis.

๘. T. multiflora.

Petals golden yellow to straw color; seeds not angular on the face.

Petals golden yellow, about $2 \mathrm{~cm}$. long or less.

Low, less than $3 \mathrm{dm}$. high; leaves less than $6 \mathrm{~cm}$. long.

Seeds merely margined.

Seeds winged.

4. T. chrysantha.

* Many species of Touterea have petaloid staminodia of which the outer 5 sometimes are as broad as the petals and resemble them. 
Leaves sinuately dentate or crenate; the lower oblanceolate-spatulate; the upper ovate-lanceolate.

5. T. integra.

Leaves mostly pinnately lobed; lobes of the leaves narrow, linear or lanceolate.

Tall, usually $4 \mathrm{dm}$. or more high; leaves often I dm. long.

Leaves divided to near the base into linear-oblong or lanceolate narrow lobes. . 7. T. laciniata.

Leaves sinuate or lobed half-way to the midrib or less; lobes triangular or ovate or broader.

Plant erect; leaves tapering at the base, acutely lobed.

8. T. speciosa.

Plant ascending or decumbent; leaves sinuately round-lobed, at least the upper cuneate or rounded at the base.

Petals straw-color.

9. T. sinuata.

Outer filaments dilated; petals $2-3 \mathrm{~cm}$. long.

Petals about $2 \mathrm{~cm}$. long; upper leaves with broad bases, long-acuminate. Io. T. Rusbyi.

Petals about $3 \mathrm{~cm}$. long; none of the leaves broad at the base.

Plant branched below; flowers subtended by single entire bracts. II. T. nuda.

Plants simple below; flowers subtended by several toothed bracts.

Filaments all filiform; petals $4-5 \mathrm{~cm}$. long.

I2. T. stricta.

I3. $T$. decapetala.

I. Touterea multicaulis Osterhout. On plains of Colo.-Wolcott, Eagle Co.

2. Touterea multiflora (Nutt.) Rydb. (Mentzelia multiflora A. Gray) On dry plains from Colo. to Tex. and Ariz.; also Mex.-Alt. 7000-9000 ft.Salida; Platte Cañon; Pine Grove; Artist Glen; Palmer Lake; Grayback mining camp and Placer Gulch.

3. Touterea lutea (Greene) Rydb. (Mentzelia lutea Greene) In dry soil in Colo.-Cañon City.

4. Touterea chrysantha (Engelm.) Rydb. ( $M$. chrysantha Engelm.) On hills, mesas and cañons from Colo. and Utah to Ariz.-Cañon City.

5. Touterea integra (Jones) Rydb. (Mentzelia multifora integra Jones) In arid soil of southern Utah and southwestern Colo.-Mesa across Gunnison from Grand Junction.

6. Touterea densa (Greene) Rydb. ( $M$. densa Greene) In gulches and cañons and on dry table-land of Colo. and N. M.-Alt. 7000-9000 ft.-Cañon City; Salida; Gunnison; gulch west of Palmer Lake; Smith's Fork Cañon, Delta Co.; Hotchkiss.

7. Touterea laciniata Rydb. On plains and in cañons of Colo.-Alt. 5000$7000 \mathrm{ft}$.-Durango; Pagosa Springs; Cañon City; Antonito.

8. Touterea speciosa Osterh. (Mentzelia speciosa Osterh.) On hills and in dry valleys from Wyo. to Colo.-Alt. 5000-I0,00o ft.-Estes Park, Larimer Co.; west of Loveland, Larimer Co.; Veta Pass; Idaho Springs; near Boulder; near Badito, between La Veta and Gardner; Turkey Creek and tributaries; Ute Pass; Dillon Cañon; Livermore; Arthur's Rock; Dixon Cañon; between Sunshine and Ward; Ft. Collins.

9. Touterea sinuata Rydb. In cañons of Colorado.-Boulder.

Io. Touterea Rusbyi (Wooton) Rydb. (Mentzelia Rusbyi Wooton) On plains and in valleys from Wyo. to N. M. and Ariz.-Alt. 5000-7000 ft.Wolcott; Glenwood Springs; Durango; Black Cañon; between Porter and Durango; Salida Cañon. 
II. Touterea nuda (Nutt.) Eat. \& Wr. (Mentzelia nuda Nutt.) On plains and hillsides from western Neb. and Wyo. to Colo.-Alt. 4000-7000 ft.Livermore, Larimer Co.; gulch west of Pennock's; Platte Cañon; valley of upper Arkansas River; Boulder.

12. Touterea stricta Osterh. (Hesperaster strictus Osterh.) On plains, hillsides and dry valleys from western Neb. and Wyo. to Kans, and Tex.Alt. 4000-7000 ft.-Colorado Springs; New Windsor, Weld Co.; Ft. Collins; near Manitou; Denver; Arboles; Pueblo; along the Poudre; Spring Cañon, Lyons; Boulder.

13. Touterea decapetala (Pursh) Rydb. (Bartonia decapetala Pursh; Mentzelia ornata Pursh) In cañons from S. Dak. and Alb. to Tex. and Nev. -Alt. 4000-7000 ft.-Ft. Collins; west of Loveland; Huerfano Valley, near Gardner; near Boulder.

\section{ACROLASLA.}

Sepals lanceolate-subulate, half as long as the petals or longer, acute; seed rather strongly muriculate.

Leaves ovate in outline, entire or merely coarsely toothed. 1. A. latifolia.

Leaves lanceolate in outline; stem-leaves, except the uppermost, pinnately divided or lobed.

Petals 5-7 mm. long, about twice as long as the sepals.

Leaves divided to near the midrib with ascending lobes; plant erect.

Leaves divided $1 / 2-2 / 3$ to the midrib, with divergent lobes; plant ascending or diffuse.

Petals $2-4 \mathrm{~mm}$. long.

3. A. ctenophora.

4. A. albicaulis.

Sepals linear-oblong, obtusish, only $x / 3$ as long as the petals, which are $3-4$ mm. long; seeds minutely muriculate (tubercles seen only by very strong magnifications); leaves entire or dentate; the upper broadly ovate.

Tall, 3-5 dm. high; capsules $z-3 \mathrm{~cm}$. long; lower leaves lanceolate or linearlanceolate, some of them usually toothed. 5. A. dispersa.

Low, less than $2 \mathrm{dm}$. high; capsules I2-I $5 \mathrm{~mm}$. Iong; leaves all ovate, entire. 6. A. compacta.

I. Acrolasia latifolia Rydb. On hillsides in Colo-Alt. $6000-8000 \mathrm{ft}$ Boulder; between Sunshine and Ward; Larimer County.

2. Acrolasia gracilis Rydb. (Trachyphytum gracilis Nutt.) In sandy soil from Wyo. and Ore. to Colo.-Alt. 5000-8000 ft.-Foot-hills, Larimer Co.; mesas near Pueblo; Salida; Tobe Miller's ranch.

3. Acrolasia ctenophora Rydb. On dry hills and on railroad banks in southern Colo.-Alt. 6000-7000 ft.-Walsenburg; Cucharas River below La Veta.

4. Acrolasia albicaulis (Dougl.) Rydb. (Mentzelia albicaulis Dougl.) On sandy soil from Neb., Mont. and B. C. to N. M. and Utah.-Alt. 4000-7000 ft. -Mesa, Gunnison River; Hotchkiss; Rist Cañon; near Boulder; Los Pinos; Mancos; Glenwood Springs; Sunset Cañon.

5. Acrolasia integrifolia ( $\mathrm{S}$. Wats.) Rydb. ( $M$. albicaulis integrifolia $\mathrm{S}$. Wats.; $M$. dispersa $\mathrm{S}$. Wats.) In sandy soil from Mont. and $\mathrm{B}$. C. to Colo. and Calif.-Alt. 6000-7000 ft.-Glenwood Springs, Garfield Co.; Horsetooth Gulch.

6. Acrolasia compacta (A. Nels.) Rydb. ( $M$. compacta A. Nels.) In sandy soil in Wyo, and Colo.-Steamboat Springs. 
3. MENTZELIA L.

I. Mentzelia oligosperma Nutt. On dry prairies, plains and hills from S. D. and Colo. to La. and Tex.; also in Mex.-Alt. 4000-6000 ft.-Foot-hills, Larimer Co.; southwest of Soldier Cañon.

\section{Family 93. CactaceaE H. B. K. Cactus Family.}

Stems continuous or not conspicuously jointed; leaves obsolete; spines not barbed; spine-bearing and flower-bearing areolas distinct.

Flowers not arising from the tubercles, but from their axils; ovary naked.

Flowers arising from the tubercles or ribs; ovary scaly.

Flowers nearly terminal, $i$. $e$, arising near the areolas which later develop spines; stem never jointed.

2. Echinocactus.

Flowers lateral, $i$. e., arising near the fully developed spine-bearing areolas. 3. Echinocereus.

Stems conspicuously jointed; leaves evident, but deciduous; spines barbed; flowers arising from spine-bearing areolas.

4. Opuntia.

\section{r. Cactus L. Ball-Cactus.}

Central spine usually solitary; corolla greenish.

Plant simple or nearly so; central spine robust, porrect. 1. C. missouriensis.

Plant cespitose; central spine often lacking.

2. C. similis.

Central spines $3^{-I 2}$; petals purple.

Plant usually cespitose, depressed-globose; central spines $3-4$.

Plant usually simple, ovate to cylindric; central spines $4-12$ (rarely 3 ).

viviparus.

4. C. radiosus.

I. Cactus missouriensis (Sweet) Kuntze. (Mamillaria missouriensis Sweet) On dry plains and hills from S. D. and Mont. to Kans. and Colo.Como.

๘. Cactus similis (Engelm.) Rydb. (Mamillaria similis Engelm.; $M$. missouriensis caespitosa S. Wats.) On dry hills from Kans, and Colo. to Tex.- "Colorado" (Greene).

3. Cactus viviparus Nutt. (Mamillaria vivipara Haw.) On dry hills and plains from Neb. and Mont. to Colo.-Ft. Collins.

4. Cactus radiosus (Engeim.) Coulter. On plains from Colo. and Utah to Tex. and Ariz. In Colorado it is only represented by the var. neomexicanus (Engelm.) Coulter, lower than the type and with more numerous central spines.- "Colorado"; Ft. Collins; Hermosa.

\section{2. echinocactus Link \& Otto. Hedgehog-thistle, Cactus.}

Stems with tubercles, resembling Cactus in habit.

Radiating spines $8-9$; central ones $r-3$.

Radiating spines about 20 ; central ones 8-ro.

Stems with definite ridges, scarcely tubercled.

1. E. glaucus.

2. E. Simpsoni.

3. E. Whipplei.

I. Echinocactus glaucus K. Sch. In dry places in Colo.-Alt. about 6000 ft.-Mesa Grande on Dry Creek; Gunnison.

2. Echinocactus Simpsoni Engelm. (Mamillaria Simpsoni M. E. Jones; M. Purpusi K. Sch.) On dry table-lands of Utah and Colo.-Alt. 7500-II,000 ft.-Clear Creek, Sangre de Cristo Pass; Veta Pass; Veta Mountain; Empire; Dolores. 
3. Echinocactus Whipplei Engelm. \& Big. On dry plains from Colo. and Utah to N. M. and Ariz. In Colorado has only been found the var. spinosior Engelm. with more numerous, 9-II, radiating spines.-La Plata Valley; Mesa Verde.

\section{ECHINOCEREUS Engelm. CereUS.}

Ribs about 13 ; corolla greenish or yellowish.

I. E. viridiflorus.

Ribs 5-I2; corolla red or purple.

Plant light green; corolla violet-purple; central spine 1 , terete, nearly black, curved above.

2. E. Fendleri.

Plant dark green; corolla scarlet (except perhaps in the first).

Ribs 5-7.

Central spine 0 ; radiating ones $3-5$, almost terete. 3. E. paucispinus.

Central spine $8 \mathrm{~cm}$. long, angled and grooved; radiating ones 6-8, strongly angled.

4. E. gonacanthus.

Ribs 9-1 I.

Central spines all terete; flowers $4^{-6} \mathrm{~cm}$. long, usually yellowish inside.

Lower central spines quadrangular; flowers $8-10 \mathrm{~cm}$. 10ng. 5. E. aggregatus.

6. E. Roemeri.

I. Echinocereus viridiflorus Engelm. (Cereus viridiflorus Engelm.) On high plains and hills from Wyo. to Tex, and N. M.-Alt. 5000-8000 ft.-Tobe Miller's ranch; Veta Mountain; Manitou; Colorado Springs; near Boulder.

z. Echinocereus Fendleri (Engelm.) Rümpl. (Cereus Fendleri Engelm.) On dry plains from Colo. and Utah to Tex. and Ariz.- "So. Colorado."

3. Echinocereus paucispinus (Engelm.) Rümpl. (Cereus paucispinus Engelm.) On rocks and limestone hills from Tex. to Colo.-Durango.

4. Echinocereus gonacanthus (Engelm. \& Big.) Lehm. (Cereus gonacanthus Engelm. \& Big.) On sandy bluffs in Colo. and N. M.-Florence; Arboles.

5. Echinocereus aggregatus (Engelm.) Rydb. (Mamillaria aggregata Engelm.; Cereus phoeniceus Engelm.) On plains and hillsides from Colo. to Tex. and Ariz.; also in Mex.-Alt. 5000-7500 ft.-La Veta; Badito.

6. Echinocereus Roemeri (Muhlenf.) Rydb. (Cereus Roemeri Muhlenf.; C. conoideus Big.) On plains from Colo. (?) to N. M. and Calif.- "So. Colorado."

\section{4. opuntia Mill. Prickly Pear.}

Internodes of stem short, more or less flattened.

Internodes of the stem oval or orbicular, decidedly flattened.

Fruit fleshy and juicy, spineless or nearly so.

Spines none, or a solitary strong one reflexed and I-2 small ones at its base, all white or gray. $\quad 1$. O. mesacantha.

Spines I-8, not very unlike in length.

Spines not twisted.

Spines I-3, brownish; internodes orbicular or obovate, II-I $5 \mathrm{~cm}$. wide. z. O. camanchica.

Spines 5-7, white or gray; internodes oblong, $5 \mathrm{~cm}$. long and $3.5 \mathrm{~cm}$. wide. 3. O. Schweriniana. Spines twisted, 3-5, white; internodes $I 3-17 \mathrm{~cm}$. long and about as wide.

Fruit dry and usually with spine-bearing areolas. 4. O. tortispina.

Corolla yellow.

5. O. polyacantha.

Corolla red. 
Filament red; fruit very prickly.

Filaments yellow; fruit scarcely prickly.
6. O. rhodantha.

7. O. xanthostemma.

Internodes oblong or nearly cylindrical, turgid and nearly terete, easily breaking off, $2-4 \mathrm{~cm}$. long.

Internodes of stem elongated, cylindric or prismatic.

Tubercles of the stem sharp and comb-like; erect shrub.

Tubercles neither prominent nor comb-like; plant decumbent.

8. $O$. fragilis.

9. O. arborescens.

1. Opuntia mesacantha Raf. (O. Rafinesqui Engelm.) On plains and prairies especially in sandy soil from Wisc, and Minn. to Ky. and Ariz.--Alt. 4000-5500 ft.-Fort Collins; Denver; Boulder.

2. Opuntia camanchica Engelm. On plains from Colo. to Tex. and Ariz.Alt. up to $6000 \mathrm{ft}$-Colorado Springs.

3. Opuntia Schweriniana K. Sch. In dry places in Colo.-Sapinero.

4. Opuntia tortispina Engelm. On plains from Neb. and Colo. to Ind. Terr. -Exact locality not given.

5. Opuntia polyacantha Haw. (O. missouriensis DC.) On plains and hills from N. D. and B. C. to Ind. Terr., N. M. and Ore.-Alt. $4000-7000 \mathrm{ft} .-$ Quimby; Ft. Collins; Denver; Walsenburg; North Cheyenne Cañon.

6. Opuntia rhodantha K. Sch. On plains of Neb. and Colo.-Alt. 4000-8000 ft.-."Colorado"; Grand Junction; Boulder.

7. Opuntia xanthostemma K. Sch. On plains of western Colo.-Mesa Grande.

8. Opuntia fragilis Haw. On prairies and plains from Wisc, and B. C. to Kans. and Colo.-Denver; Boulder.

9. Opuntia arborescens Engelm. On plains and hills from Colo. to Tex. and Ariz.-Alt. 4000-6000 ft.-Pueblo; Piedra.

ro. Opuntia Davisii Engelm. In dry soil from Colo. to Tex. and Calif.La Plata Valley, Mancos and McElmo (Brandegee).

\section{Order 36. THYMELIALES.}

\section{Family 94. ElaEAGNaCEAE Lindl, Oleaster Family.}

\section{LEPARgYRAEA Raf. Buffalo-Berky.}

Leaves ovate or oval, green above; shrub thornless.

Leaves oblong, silvery on both sides; shrub thorny.
I. L. canadensis.

2. L. argentea.

r. Lepargyraea canadensis (L.) Greene. (Shepherdia canadensis L.) In woods from Newf. and Alaska to N. Y., Colo. and Ore-Alt. 6500-12,000 ft. -Villa Grove, Black Cañon; Georgetown; Bear Creek Divide, West La Plata Mountains; southeast of Ouray; Box Cañon, west of Ouray; Chambers' Lake; Graham's Park; mountains of Larimer Co.; Stove Prairie Hill; Bosworth's ranch; Eldora to Baltimore.

2. Lepargyraea argentea (Nutt.) Greene. (Shepherdia argentea Nutt.) On sandy river banks and islands from Man., Sask. and Alb. to Kans., N. M. and Nev.-Alt. 4000-7000 ft.-Grand Junction; Cimarron; Mancos; La Porte, Larimer Co.; Wolcott; Hotchkiss; Dolores; Durango. 


\section{Order 37. MYRTALES.}

Styles present; mostly land-plants.

Hypanthium merely enclosing the ovary.

Hypanthium adnate to the ovary.

95. Lythraceae.

Styles wanting; stigma sessile; aquatics.

96. Epilobiaceae.

97. Gun Neraceae.

\section{Family 95. LYTHRACEAE Lindl. LoOSESTRIFE FAMILY.}

Hypanthium cylindric.

Hypanthium campanulate or hemispheric.

I. Lythrum.

2. AMMANiA.

\section{LYTHRUM L. LOOSESTRIFE.}

1. Lythrum alatum Pursh. In swamps from Mass, and S. D. to Ky. and Colo.-Alt. 5000-6000 ft.-Near Boulder.

\section{AMMANIA L.}

I. Ammania coccinea Rottb. In swampy places from Ind. to S. D., Fla. and Mex.; also S. Am.-Denver.

\section{Family 96. EPILOBIACEAE DC. Evening Primrose Family.}

Flowers 4-merous.

Fruit a many-seeded capsule, opening by valves.

Seeds with a tuft of silky hairs.

Hypanthium not prolonged beyond the ovary; flowers large.

1. Chamaenfirion.

Hypanthium somewhat prolonged beyond the ovary; flowers small.

Seeds without a tuft of silky hairs, naked or tuberculate.

2. Epilobium.

Hypanthium not produced beyond the ovary; flowers minute.

3. Gayophytum.

Hypanthium produced beyond the ovary into a long tube.

Stigma divided into 4 linear lobes.

Stamens equal in length; capsule terete or round-angled.

Ovules and seeds horizontal, inserted in 2 or rarely more rows, prismatic-angled; petals yellow.

4. Onagra.

Ovules and seeds ascending, in one row, not angled; buds drooping; petals white or pink.

5. ANOGRA.

Stamens unequal in length, the alternate longer; capsule crested or winged; plant acaulescent or low-stemmed.

Capsules with more or less distinct double crests on the angles; seed furrowed along the raphe. 6. PAchylophus.

Capsules winged or at least sharply angled on the angles.

Plants acaulescent, cespitose. 7. Lavauxia.

Plants caulescent with wiry diffuse stems. 8. GAURELIA.

Stigma discoid or capitate.

Stigma discoid; hypanthium-tube funnelform above.

Hypanthium-tube longer than the ovary; stigma entire.

9. Galpinsia.

Hypanthium-tube shorter than the ovary; stigma 4-toothed.

Stigma capitate.

io. Meriolix.

Plant acaulescent; capsules 4-winged; hypanthium-tube tubularcylindric.

I I. Taraxia.

Plant caulescent; capsules not winged; hypanthium-tube obconic or funnelform. 
Capsule linear, sessile, narrowed above.

i2. Sphaerostigma.

Capsule more or less clavate, pedicelled and obtuse.

Fruit indehiscent, nut-like.

I3. Chylisma.

Hypanthium-tube filiform; filaments unappendaged; ovary I-celled .

14. Stenosiphon.

Hypanthium-tube obconic: filaments with scales at the base; ovary 4-celled. 15. Gaura.

Flowers 2-merous; fruit indehiscent, obovoid and bristly with hooked hairs. 16. Circaea.

\section{CHAMAENERION Adans. Fire-WeEd.}

Style pubescent at the base; leaves lanceolate or linear-lanceolate with the lateral veins confluent in marginal loops.

I. C. angustifolium. Style glabrous; leaves ovate or ovate-lanceolate; lateral veins obsolete, not looped.

2. C. latifolium.

1. Chamaenerion angustifolium (L.) Scop. (Epilobium angustifolium L.) On hilis, in open woods and copses, especially on burnt areas from Greenl. and Alaska to N. C., Ariz. and Calif.-Alt. 6000-I0,000.-Caribou; foot-hills, Larimer Co.; Oro City; Estes Park, Larimer Co.; Pagosa Peak; near La Plata Post Office; La Plata Cañon; Marshall Pass; Cameron Pass; Pike's Peak; Red Mountain, south of Ouray; Jack's Cabin; Artist's Glen; Como; Larimie River at Sherwood's; Baxter's ranch; Bosworth's ranch, Stove Prairie; Boulder Cañon; mountains between Sunshine and Ward.

2. Chamaenerion latifolium (L.) Sweet. (E. latifolium L.) In wet ground from Greenl. and Alaska to Colo. and Wash.-Alt. 7500-Io,000 ft.-Graymont; Ruby; Gunnison; near La Plata Post Office; La Plata Cañon; Clear Creek; Empire.

\section{z. EPILOBIUM L. Willow-HERB.}

Perennials; stigma entire or merely notched.

Leaves oblong, oval, ovate, or lanceolate, usually dentate or denticulate.

Plants with rosettes or turions; leaves ovate or lanceolate, usually broadest below the middle and distinctly denticulate or dentate.

Stem pubescent throughout.

I. E. Palmeri.

Stem glabrous except sometimes the upper portion and the decurrent lines. Flowers 7-8 $\mathrm{mm}$. long; petals purple or dark pink; leaves ovatelanceolate.

Leaves sessile or nearly so; innovations by turions.

Seeds without apiculations; coma sessile. z. E. ovatifolium.

Seeds with a pale hyaline beak at the apex. 3. E. brevistylum.

Leaves short-petioled; innovations by rosettes. 4. E. occidentale.

Flowers 3-5 $\mathrm{mm}$. long.

Leaves all except the uppermost short-petioled.

5. E. adenocaulon.

Leaves all sessile or only the very earliest sometimes short-petioled. Leaf-blades rounded at the base, broadly lanceolate to ovate.

Petals purple, 5-8 $\mathrm{mm}$. long; leaf-blades usually ovate.

Petals white, $4 \mathrm{~mm}$. long; leaves lanceolate.

2. E. ovatifolium.

6. E. rubescens.

Leaf-blades acute at the base.

Leaf-blades ample, ovate or broadly lanceolate.

7. E. stramineum.

Leaf-blades narrow lanceolate, almost erect; plant slender, I-3 dm. high. $\quad$ 8. E. Drummondii.

Plants with stolons or soboles, low, I-2 (seldom 3) dm. high. 
Petals white; plant $\mathbf{I}-\mathbf{3} \mathrm{dm}$. high, stoloniferous.

Petals purple or pink.

Plant $\mathrm{I}-3 \mathrm{dm}$. high, soboliferous; flowers $5-7 \mathrm{~mm}$. long.

Io. E. Hornemannii.

Plant usually less than I dm. high, stoloniferous; flowers less than 5 $\mathrm{mm}$. long.

Flowers nodding in bud; pod cylindrical; seeds smooth.

II. E. anagallifolium.

Flowers ascending in bud; pod somewhat clavate; seeds papillose.

12. E. clavatum.

Leaves narrowly linear, entire; innovations of long subterranean shoots,

bearing at their ends ovoid turions; petals white; capsule cinereous.

Leaves and lower part of the stem glabrous. I3. E. wyomingense.

Leaves and stem crisp-pubescent.

I4. E. lineare.

Annuals with more or less sheddy, straw-colored bark; stigma 4-cleft.

Pedicels and pods sparingly glandular, the former long. I5. E. paniculatum.

Whole inflorescence densely glandular; pedicels very short, scarcely exceeding the bracts.

16. E. adenocladon.

1. Epilobium Palmeri Rydb. In wet places from Mont. and Ida. to Utah and Colo.-Tobe Miller's ranch.

2. Epilobium ovatifolium Rydb. In wet ground in Colo. and Utah.-Alt. 8000-13,000 ft.-Lake City; head of Bard Creek; mountains above Ouray; Bob Creek, west of Mt. Hesperus; headwaters of Sangre de Cristo Creek; near Pagosa Peak; Red Mountain, south of Ouray; Ironton Park, 9 miles south of Ouray; Columbine; west of Ouray; Grayback mining camps and Placer Gulch.

3. Epilobium brevistylum Haussk. Along streams from Mont. and Wash. to Colo. and Calif.-Alt. 8000-9000 ft.-Veta Pass; headwaters of Pass Creek; near Pagosa Peak; north of Steamboat Springs.

4. Epilobium occidentale (Trelease) Rydb. (E. adenocaulon occidentale Trelease) In wet ground from Mont, and Alb. to S. D. and Colo.-Alt. 5000-10,000 ft.-Caribou; Boulder; Van Boxle's ranch above Cimarron.

5. Epilobium adenocaulon Haussk. (E. coloratum Torr.; not Muhl.) In swamps and wet meadows from N. B. and Wash. to Pa., Colo. and Nev.Alt. 4000-10,000 ft.-Cheyenne Mountain; near Empire; Pagosa Springs; Mountain View; Engelmann Cañon; William's Cañon; Parlin, Gunnison Co.; North Cheyenne Cañon; Spring Cañon; foot-hills, Larimer Co.; South Park; Ft. Collins; Grizzly Creek; Dark Cañon, Pike's Peak; Durango; South Park; Boulder.

6. Epilobium rubescens Rydb. In wet places of Colo.-Alt. up to $9000 \mathrm{ft}$.Pagosa Springs; Middle Park; Engelmann Cañon.

7. Epilobium stramineum Rydb. In wet places of Colo. and Wyo.-Alt. 8000-1 I,000 ft.-Sangre de Cristo Creek; Chicken Creek, West La Plata Mountains; Bob Creek, west of Mt. Hesperus; Idaho Springs; near Pagosa Peak; Ruxton.

8. Epilobium Drummondii Haussk. Along brooks from Sask. and Wash. to S. D. and Colo.-Alt. 8000-9000 ft.-Headwaters of Clear Creek; South Park; Van Boxle's ranch, above Cimarron; Sargent's; headwaters of Sangre de Cristo Creek; Walton Creek, Routt Co.; summit of North Park Range, Larimer Co.

9. Epilobium alpinum L. On mountain sides in wet places from Greenl. and Alaska to N. H., Colo. and Calif.-Alt. 9000-II,000 ft.-Head of Bard 
Creek; mountains above Ouray; Cameron Pass; Front Range, Larimer Co.; Gore Pass; Chambers' Lake; Graymont.

10. Epilobium Hornemannii Reichenb. On mountain sides in wet places, from Greenl. and Alaska to N. H., Colo. and Calif.-Alt. 8000-10,000 ft.Near Empire; Mt. Harvard; head of Bard Creek; Marshall Pass; Cameron Pass; Grayback mining camps and Placer Gulch; Estes Park, Larimer Co.; Silver Plume; Beaver Creek; Buffalo Pass; summit of North Park Range, Larimer Co.

II. Epilobium anagallifolium Lam. In wet soil from Lab, and Alaska to Colo. and Nev.-Alt. I0,000-I2,000 ft.-Caribou; near Pagosa Peak; Silver Plume; west of North Park.

12. Epilobium clavatum Trelease. On alpine peaks from Mont. and B. C. to Colo.-Summit of North Park Range, Larimer Co.

13. Epilobium wyomingense A. Nels. (E. palustris albiflorum Hook.) In swamps from Sask. and Yukon to Colo.

14. Epilobium lineare Muhl. In swamps from N. B. and B. C. to Del., Ind. Terr. and Colo,--New Windsor.

I5. Epilobium paniculatum Nutt. In sandy soil from Alb. and B. C. to Colo. and Calif.-Alt. 5000-9000 ft.-Gregory Cañon; headwaters of Clear Creek; Ft. Collins; Doyle's; Marshall Pass; south of Ouray; Cimarron; Ruxton Park; Piedra; mountains, Larimer Co.; Horsetooth Gulch; between Porter and Durango; Gunnison Co.; gulch west of Soldier Cañon; Steamboat Springs; Boulder; Elk River, Routt Co.

16. Epilobium adenocladon (Haussk.) Rydb. (E. paniculatum adenocladon Haussk.) In sandy soil from S. D. and Wyo. to Colo. and Utah.-Alt. 5000$8500 \mathrm{ft}$-Boulder; southeast of Ouray; Horsetooth Gulch; Soldier Cañon; Cassel's.

\section{GAYOPHYTUM Juss.}

Capsules torulose, less than 3 times as long as the stipes, usually more or less clavate.

Petals I.5-2.5 mm. long, rose with yellow base; capsules 8-12 mm. long, nearly tiwce as long as the stipes.

Petals about I mm. long, rose or white.

Capsules decidedly clavate, rounded at the apex, seldom longer than the stipes, spreading or reflexed. $\quad$ 2. G. ramosissimum.

Capsules only slightly if at all clavate, narrow, ustually longer than the stipes and erect. 3 . G. Nuttallii.

Capsules neither torulose not clavate; stipes very short. 4. G. racemosum.

I. Gayophytum intermedium Rydb. On hillsides in sandy soil from Mont. and Wash. to Colo. and Calif.-Alt. 5000-Io,000 ft.-Caribou; near Empire; west of Ouray; Chambers' Lake; Grayback mining camps and Placer Guich; Veta Pass; Ward, Boulder Co.; between Sunshine and Ward; Boulder; North Park; Table Rock.

2. Gayophytum ramosissimum T. \& G. On hillsides, especially in sandy soil, from Mont. and Wash. to Colo., Ariz. and Calif.-Alt. 6000-Io,000 ft.Headwaters of Clear Creek; Lake City; Grayback mining camps and Placer Gulch; Mt. Harvard; Veta Pass; Turkey Creek and tributaries; Pagosa Springs; Calhan; Rabbit-Ear Pass; Los Pinos; Black Cañon; La Veta; Dillon; Valiey Spur; west of Ouray; Baxter's ranch; Chambers' Lake; Walton Creek; Table Rock; Dolores; gullch west of Soldier Cañon. 
3. Gayophytum Nuttallii T. \& G. On hillsides from S. D. and Wash. to Colo., Ariz. and Calif.-Alt. 6000-8000 ft.-Parlin, Gunnison Co.; foot-hills, Larimer Co.

4. Gayophytum racemosum T. \& G. In sandy soil from Wyo, and Wash. to Colo. and Calif.-Alt. 5000-12,000 ft.-Headwaters of Clear Creek; Veta Pass; above Mancos; along the Poudre.

\section{ONAgra Adans. Evening Primrose.}

Hypanthium slender, $2.5-5 \mathrm{~cm}$. long.

Petals I-2 cm. long, yellow; pubescence rarely hirsute.

Plant green; capsule $3-4 \mathrm{~cm}$. long.

Plant grayish strigose; capsule $2-3 \mathrm{~cm}$. long.

Petals $2-3.5 \mathrm{~cm}$. long, often pinkish; plant more or less hirsute.

Hypanthium stout, 6-I3 cm. long.

1. O. Oakesiana.

2. O. strigosa.

r. Onagra Oakesiana (A. Gray) Britton. (Oenothera Oakesiana A. Gray) In rich valleys from Que. and S. D. to N. Y. and Colo.-Alt. up to Io,00o ft.Salida; North Cheyenne Cañon; Valley Spur.

2. Onagra strigosa Rydb. In valleys and on plains from Minn. and Wash. to Kans, N. M. and Utah.-Alt. 4000-7000 ft.-Ft. Collins; Colorado Springs; Gunnison; Elk River, Routt Co.; Engelmann Cañon; Poudre Cañon; Gypsum; soldier Cañon.

3. Onagra Hookeri (T. \& G.) Small. (Oenothera Hookeri T. \& G.; $O$. biennis hirsutissima A. Gray) In valleys from Ida. to N. M. and Calif.; also Mex.-Alt. 6000-I0,00o ft.-Black Cañon of Gunnison; Cañon City, Fremont Co.; Pagosa Springs; Parrott Post Office; west of Ouray; Wahatoya Creek; Pike's Peak; Durango; along Conejos River north of Antonito.

4. Onagra Jamesii ( $T$. \& G.) Small. (Oenothera Jamesii T. \& G.) In dry soil from Oki. and Utah to Tex. and Ariz.-On Platte River (?).

\section{ANogra Spach. White Evening Primrose.}

Calyx in bud merely acutish; tips not free.

Capsule divergent or reflexed.

Capsule erect or ascending.

Calyx in bud acuminate or acute; tips free.

1. A. violacea.

2. A. albicaulis.

Capsule linear-cylindric; throat of the calyx glabrous.

Calyx sparingly long-hairy, glandular-puberulent or glabrous, not strigose. Leaves deeply pinnatifid.

Leaves subentire, dentate or short-lobed.

3. A. rhizomata.

Capsules strongly ascending, straight; leaves linear, entire or nearly so, strigose beneath.

4. A. Nuttallii.

Capsules divergent, usually curved upwards; leaves usually denticulate or sometimes lobed.

Leaves glabrous, except the margins. $\quad$ 5. A. Vreelandii.

Leaves pubescent on both sides.

Calyx and hypanthium densely grayish strigose; leaves cinerous.

6. A. cinerea.

7. A. latifolia.

Capsules oblong; throat of the calyx hairy; leaves deeply pinnatifid.

8. A. coronopifolia.

I. Anogra violacea A. Nels. In sandy soil of Wyo. and Colo.-Alt. 4000$5500 \mathrm{ft}$.-Deer River; Palisades; Hotchkiss. 
2. Anogra albicaulis (Pursh) Britton. (Oenothera pinnatifida Nutt.) On hillsides from N. D. and Mont. to Tex. and Sonora.-Alt. 4000-7000 ft.Denver; Ft. Collins; Rist Cañon; river-bluffs north of La Veta; Cucharas Valley near La Veta; Larimer Co.; McElmo Cañon; Purgatory River, Trinidad; Horsetooth Gt1lch; Palisades; Grand Junction, mesa across Gunnison River; Boulder; Ft. Collins.

3. Anogra rhizomata A. Nels. In sandy soil in Wyo. and Colo.-Alt. about $7500 \mathrm{ft}$-Gunnison.

4. Anogra Nuttallii (Lindl.) A. Nels. (O. Nuttallii Lindl.) In sandy soil from Minn. and Ida. to Colo,-Alt. 4000-900o ft.-Denver; La Porte; Fossil Creek, Larimer Co.; Grizzly Creek; Manitou; Table Rock; Baxter's ranch; Colorado Springs; Boulder; Buena Vista; Ivywild.

5. Anogra Vreelandii Rydb. In cañons of Colo.-Alt. about $6000 \mathrm{ft} .-$ McElmo Cañon.

6. Anogra cinerea Rydb. In dry soil from western Neb. and Wyo. to Colo.Denver; between Bent's Fort and Pueblo.

7. Anogra latifolia Rydb. (Oenothera pallida latifolia Rydb.) On sandy soil from Neb. to Colo. and Kans.-Alt. 4000-I0,000 ft.-Gunnison; Marshall Pass; Sterling, Logan Co.

8. Anogra coronopifolia (T. \& G.) Britton. On prairies and plains from S. D. and Wyo. to Kans. and N. M.-Alt. 4000-9000 ft.-Cheyenne Mountain; Moon's ranch, Larimer Co.; plains west of Ft. Collins ; Denver; Clear Creek Station; along the Platte; Pike's Peak; Idaho Springs; Piedra; Mancos; Cucharas River below La Veta; Gunnison; Manitou; Buena Vista; Palmer Lake; Grayback mining camps and Placer Gulch; North Park; Spring Cañon; Baxter's ranch; road to Soldier Cañon; vicinity of Pine Grove; Estes Park; Boulder; Como; Hayden.

\section{PACHYLOPHUS Spach.}

Plant glabrous.

2. P. caespitosus.

Plant more or less hairy.

Hypanthium, calyx and fruit glabrous, slightly strigose or with a few scattered long hairs.

Tube of the hypanthium $3-6 \mathrm{~cm}$. long; pubescence (except on the margins of the leaves) short and usually appressed.

Tube of hypanthium 6-I2 mm. long.

Plant acaulescent, cespitose; pod short conic-ovoid, with very thick ridges.

3. P. macroglottis.

Plant more or less caulescent; pod elongated conic-ovoid, with low ridges.

Hypanthium, calyx and fruit densely hirsute.

Pod stipitate.

Pod sessile.

4. $P$. caulescens.

Plant acaulescent; ridges of the fruit slightly tuberculate.

5. P. marginatus.

6. P. hirsutus.

Plant more or less caulescent; ridges of the fruit with lobed, more or less foliaceous crests.

7. P. exiguus.

r. Pachylophus caespitosus (Nutt.) Raim. (Oenothera caespitosa Nutt.) On dry hills from N. D. and Wyo. to Colo. and Utah.-Alt. $4000-9000 \mathrm{ft}$.Grizzly Creek; foot of Horsetooth Mountain. 
2. Pachylophus montanus (Nutt.) A. Nels. (Oenothera montana Nutt.) On dry hills from Ass. and Ida. to Colo. and Nev.-Alt. up to $7500 \mathrm{ft}$.Mancos; Palisade; mesa across Gunnison River from Grand Junction; Elk Cañon; Dillon Cañon, Trinidad.

3. Pachylophus macroglottis Rydb. On hillsides in Colo.-Alt. 5000-I0,000 ft.-Red Rock Cañon; Turkey Creek and tributaries; foot-hills, Larimer Co.; Horsetooth Gulch; gulch west of Pennock's; Narrows, Poudre Cañon; Pennock's mountain ranch; Dolores; Manitou; Hotchkiss; Pike's Peak; butte, 5 miles southwest of La Veta; Cerro Summit; Arboles; Boulder.

4. Pachylophus caulescens Rydb. On hillsides and river banks in Colo.Alt. 4500-9000 ft.-Palisade, bank of Grand River; Dolores.

5. Pachylophus marginatus (Nutt.) Rydb. (Onothera marginata Nutt.; $O$. idahoensis Mulford) On hills from Ida. and Ore. to Utah and Colo.Glenwood Springs.

6. Pachylophus hirsutus Rydb. On hillsides from Wyo. to N. M. and Utah. -Alt. 7000-10,000 ft.-Empire; above Como, South Park; Pennock's mountain ranch; Georgetown; South Park; Ruxton; near Mancos; Pike's Peak; mountains between Sunshine and Ward.

7. Pachylophus exiguus (A. Gray) Rydb. (Oenothera exigua A. Gray) On plains from Colo. to N. Mex.-Alt. 4000-5500 ft.-Rocky Ford, bank of Arkansas River; mesas near Pueblo; Garden of the Gods.

\section{I.AVAUXIA Spach.}

Leaves strigose-canescent.

Leaves green, glabrous or puberulent with ciliate margins.

1. L. brachycarpa.

2. L. flava.

I. Lavauxia brachycarpa (A. Gray) Britton. (Oenothera brachycarpa A. Gray) On plains from Kans. and Colo. to Tex. and N. M.-Alt. 4000-6000 ft.-Loveland; Denver; west of Ft. Collins; Ft. Collins; Fossil Creek; north of La Porte; Tobe Miller's ranch; Boulder.

z. Lavauxia flava A. Nels. (Oenothera triloba S. Wats., in part; not Nutt.) In valleys from Ass, and Ore. to Colo. and Calif.-Alt. 5000-I0,000 ft.Leadville; North Park; Arboles; Egeria Park; headwaters of Sangre de Cristo Creek; Grayback mining camps and Placer Gulch; near Parrott Post Office; Rabbit-Ear Range; Table Rock; Leroux Creek; Steamboat Springs; north of La Porte; Alamosa.

\section{GAURELLA Small.}

I. Gaurella guttata (Geyer) Small. (Oenothera canescens Torr.) On dry plains from Neb. and Colo, to Okl. and N. Mex.-Purgatory River.

\section{GALPINSIA Britton.}

x. Galpinsia lavandulaefolia (T. \& G.) Small. (Onoethera lavandulaefolia T. \& G.) On plains and prairies from Neb. and Wyo. to Tex. and Mex.Alt. 4000-5500 ft.-Mesas near Pueblo; Grand Junction. 
Io. MERIOLIX Raf.

Throat of the hypanthium dark-purple within.

1. M. melanoglottis. Throat of the hypanthium orange within, sometimes with a darker ring at the base of the stamens.

2. $M$. serrulata.

^. Meriolix melanoglottis Rydb. On plains from Tex. to Colo._"Colo.," exact locality not given.

2. Meriolix serrulata ( $\mathbb{N}$ utt.) Walp. (Oenothera serrulata Nutt.) On plains and hills from Man. and Sask. to Colo. and Ariz.-Alt. 400o-8000 ft.Boulder; Denver; first range of foot-hills, Larimer Co.; Ft. Collins; Palmer Lake; Ouray; Monument; Manitou Junction; Pennock's mountain ranch.

Leaves linear, silky-hirsute.

II. Taraxia Nutt.

Leaves oblanceolate, glabrous.

I. T. gracilifiora.

2. T. subacaulis.

I. Taraxia graciliflora ( $\mathrm{H}$. \& A.) Raim. Hillsides in California. One specimen collected by Fremont is labeled "Arkansas River, above Pueblo." This may have been a mistake in labeling, as the species is not known east of the Great Basin.

2. Taraxia subacaulis (Pursh) Rydb. (Jussiaea subacaulis Pursh; Oenothera heterantha Nutt.) In valleys from Mont. and Ida. to Colo. and Calif. -Steamboat Springs.

22. SPHAEROSTIGMA Nutt.

Corolla yellow, turning reddish or greenish; plant hirsutulous below; often glandular above.

1. S. pubens.

Corolla white or rose-color; plant stigulose or puberulent. 2. S. minutiflormm.

I. Sphaerostigma pubens (S. Wats.) Rydb. (Oenothera strigulosa pubens S. Wats.) In sandy soil from Ida. and B. C. to Colo. and Calif.-Arkansias River above Pueblo.

2. Sphaerostigma minutiflora ( $\mathrm{S}$. Wats.) Rydb. (Oenothera allysoides minutiflora S. Wats.) In sandy soil from Wyo. to Colo. and Nev.-Grand Junction.

\section{CHYLISMA Nutt.}

I. Chylisma scapoidea (Nutt.) Small. (Oenothera scapoidea Nutt.) In arid soil from Wyo. to Colo. and Utah.-Alt. 4500-7000 ft.-Palisade, bank of Grand River; Cimarron; Grand Junction; Hotchkiss; Cañon City.

\section{STENOSIPHON Spach.}

I: Stenosiphon linifolium (Nutt.) Britton. (S. virgatus Spach.) On prairies from Neb. and Colo. to Ark., Tex. and Mex.-Exact locality not given.

\section{I5. GAURA L.}

Anthers oval, attached near the middle; fruit fusiform, sessile, almost equally 8-ribbed.

I. G. parviflora.

Anthers linear or nearly so, attached near the base; fruit strongly 4-angled, at least above.

Fruit sessile, broadly fusiform; tall biennials.

Fruit prolonged below into a stipe-like base.

2. G. neo-mexicana. 
Stipe-like base slender; fruit fusiform; tall herbaceous plants.

Stipe-like base thick; body of the fruit pyramidal-ovoid; low plants with subligneous base.

Plants more or less pubescent.

Stem hirsute as well as strigose, at least below.

Stem merely strigose or glabrous below.

Leaves canescent, the lower usually oblong and sinuately toothed.

5. G. marginata.

Leaves sparingly strigose; all linear and entire. $6 \mathrm{G}$. parvifolia.

Plant glabrous or nearly so, except the strigose hypanthium.

7. G. glabra.

I. Gaura parviflora Dougl. In valleys from S. D. and Wash. to La. and Ariz.; also Sonora.-Alt. 4000-700o ft.-Colorado Springs; Cucharas Valley, near La Veta; Durango; Ft. Collins; William's Cañon; Deer River; along the Platte River; Boulder.

2. Gaura neo-mexicana Wooton. In valleys of Colo. and N. M.-Alt. about $7000 \mathrm{ft} .-$ Pagosa Springs; Piedra.

3. Gaura coloradensis Rydb. On hills of Colo.-Alt. about $5000 \mathrm{ft} .-\mathrm{Ft}$. Collins; east of Poudre and east of College.

4. Gaura coccinea Nutt. On plains and prairies from Mont. to Tex. and Ariz.-Alt. 4000-5500 ft.-Denver; Pike's Peak; New Windsor, Weld Co.; mesas near Pueblo; Ead's; Ft. Collins; Quimby; Ouray; Platte River.

5. Gaura marginata Lehm. On plains and prairies from Man., Sask. and Mont. to Kans. and Colo.-Alt. 4000-6000 ft.-Ft. Collins; Walsenburg.

6. Gaura parvifolia Torr. On dry plains of Colo. and N. M.-Alt. 40007000 ft.-Durango; Pueblo; Colorado Springs; Ft. Collins.

7. Gaura glabra Lehm. On plains from S. D. and Mont. to Colo. and Ariz. -Alt. 400o-8000 ft.-Trail Glen; Gunnison; Ft. Collins; Durango; Boulder.

\section{CiRCAEA L. Enchanter's Nightshade.}

Plant I-2 dm. high; leaves sharply dentate, usually cordate at the base

I. C. alpina.

Plant 3-6 dm. high; leaf-blades sinuately denticulate, usually truncate or rounded at the base.

2. C. pacifica.

I. Circaea alpina L. (C. pacifica Coulter; not Aschers, and Magn.) In moist woods from Lab. and Alaska to Ga. and Colo.-Alt. 7000-8000 ft.Green Mountain Falls; Estes Park, Larimer Co.; foot-hills, Larimer Co.; gulch, Soldier Cañon; vicinity of Pine Grove; Stove Prairie Hill; Rist Cañon; Bosworth's ranch, Stove Prairie.

2. Circaea pacifica Ach. \& Magn. In wet woods from Mont. and Wash. to Colo. and Calif.-Locality not given; probably doubtful.

\section{Family 97. GUNNERACEAE Endl. Water Milfoll Family.}

Stamen I; ovary I-celled; leaves entire.

Stamens 4-8; ovary 4-celled, splitting into 4 nutlets; at least the submerged leaves pinnatifid.

I. Hippurus.

2. MYRIOPHYLLUM. 
1. hippURUS L. Mare's-Tail, Bottle-Brush.

I. Hippurus vulgaris L. In water from Greenl. and Alaska to Mich., N. M. and Calif.-Alt. 7000-I0,000 ft.-Ironton Park, 9 miles south of Ouray; Gunnison; Laramie River near Colorado line; Wahatoya Creek; Hamor's Lake above Durango; Hotchkiss.

2. MYRIOPHYLLUM L. WATER-MILFOIL.

1. Myriophyllum spicatum L. In water from Newf., Sask, and Ida. to Fla. and Calif,--Alt. up to $8000 \mathrm{ft}$-Gunnison.

\section{Order 38. UMBELLALES.}

Fruit drupaceous or baccate; gynoecium x-several-carpellary; if 2-carpellary, stigmas introrse.

Ovule with a ventral raphe; leaves mostly alternate; blades lobed or compound. 98. Hederaceae.

Ovule with a dorsal raphe; leaves mostly opposite; blades entire or merely toothed.

Fruit dry, a cremocarp; gynoecium 2-carpellary; stigmas terminal. 99. CoRnaceaE. IOO. AMMIACEAE.

Family 98. HEDERACEAE L. IVY FAMILY.

I. ARALIA L. Wild Sarsaparilla.

1. Aralia nudicaulis L. In woods from Newf. and Ida. to N. C., Mo. and Colo.-Alt. 5000-9000 ft.-Mountains of Estes Park, Larimer Co.; mountains, Larimer Co.; north of Cheyenne Cañon; Engelmann's Cañon; Colorado Springs; Jack Brook; Boulder.

Family 99. CORNACEAE Link. Dogwood Family.

Flowers in open cymes, not subtended by an involucre; shrubs. I. 'SvidA. Flowers in a head or umbel subtended by a large white involucre; herbs.

1. SVIDA Opis. Dog-Wood, Cornel.

z. Cornella.

Young branches and inflorescence villous.

I. S. interior.

Young branches appressed strigose or nearly glabrous. 2. S, stolonifera riparia.

1. Svida interior Rydb. On river banks in Neb., S. D., Wyo. and Colo. -Alt. 4000-6000 ft.-Colorado Springs; Cañon City; Meeker; Walsenburg; gulch west of Pennock's.

2. Svida stolonifera riparia Rydb. On river banks from Man., Mackenzie and Alaska to Neb., Colo. and Ariz.-Alt. 4000-ro,000 ft.-Lake City; Ouray; 6 miles below Hot Sulphur Springs; Walsenburg; Minnehaha; Upper La Plata Cañon; Box Cañon, west of Ouray; Pass Creek; Ft. Collins; Crystal Creek; Redstone; Gunnison; Mancos; Turkey Creek and tributaries; Parlin, Gunnison Co.; gulch south of Rist Cañon; Bosworth's ranch; near Narrows of Cache la Poudre; gulch west of Pennock's; Stove Prairie.

2. CORNella Rydb. Bunch-Berry, DWARF Cornel.

1. Cornella canadensis (L.) Rydb. (Cornus canadensis L.) In woods from Lab. and Alaska to N. J., Minn., Colo. and Calif.-North Park. 


\section{Family roo. ammiaceae Presl. Carrot Family.}

Fruit bristly or spiny.

Fruit subglobose, covered with hooked spines; leaves palmately divided.

$$
\text { I. Sanicula. }
$$

Fruit linear or linear-oblanceolate, attenuate at the base, bristly on the angles;

leaves twice to thrice ternate.

2. WASHINGTONIA.

Fruit neither spiny nor bristly.

Fruit not strongly flattened dorsally, usually more or less laterally flattened.

Oil-tubes obsolete in the mature fruit, which is linear; leaves twice or thrice ternate.

3. Gly cosma.

Oil-tubes present.

Oil-tubes solitary in the intervals; petals white.

Stylopodium conical.

Divisions of the leaves linear to filiform; ribs of the fruit filiform.

4. CARUM.

Divisions of the leaves lanceolate; ribs of the fruit thick obtuse wings.

Stylopodium flat or wanting; petals yellow.

5. Cicuta.

Ribs broad and corky.

Dwarf cespitose alpine subacaulescent plants; fruit not tuberculate.

6. OREOXIS.

Tall plants, $3 \mathrm{dm}$. high or more; fruit tuberculate-roughened.

Ribs not corky.

7. Harbouria.

Tall and branching, leafy-stemmed plants with broad leaf-divisions; ribs inconspicuous.

8. ZIZIA.

Acaulescent and cespitose plants; ribs of the fruit prominent.

Oil-tubes more than one in the intervals.

9. Aletes.

Stylopodium conical.

Fruit round, with globose carpels and very slender inconspicuous ribs.

Fruit ovate or oblong, with prominent equal ribs. I0. BerUla.

Stylopodium flat or wanting.

I I. LigusticuM,

Seed-face suicate or decidedly concave.

Ribs filiform.

Ribs with broad thin wings.

Seed-face plane or but slightly concave.

Ribs all conspicuously winged.

Leaves pinnate with short crowded and more or less confluent segments; flowers usually purple or white.

14. Phellopterus.

Leaves ternate-pinnate with short linear and pungent segments; flowers usually yellow.

Ribs not winged.

I 5. PTERYXIA.

Lateral ribs thick and corky; the dorsal ones filiform.

Ribs all corky and equally prominent.

16. OROGENIA.

Plant tall and leafy; oil-tubes never present in the dorsal ribs.

I7. Sium.

Plant low, acaulescent; oil-tubes present in the dorsal ribs.

6. Oreoxis.

Fruit strongly flattened dorsally, with the lateral ribs more or less prominently winged.

Stylopodium present.

Stylopodium conical.

Plant glabrous with linear to lanceolate leaf-segments.

Sepals evident; leaves in our species simply pinnate; oil-tubes solitary in the intervals. 
Sepals obsolete; leaves in ours three to four times compound; oiltubes 2 or more in the lateral intervals. I9. ConIOSELINUM.

Plant villous; leaves ternate with rounded-cordate, lobed leaflets; sepals obsolete.

Stylopodium depressed.

Dorsal ribs prominent or winged.

Plant caulescent, branched; sepals mostly obsolete; petals white. 2I. ANGELICA.

Plant acaulescent or nearly so; sepals evident; petals in most yellow. 22. Cynomarathrum.

Dorsal wings filiform; petals yellow; sepals obsolete; plant caulescent. Stylopodium wanting; plant acaulescent or nearly so. 23. Pastinaca.

Lateral wings of the fruit thin.

Lateral wings of the fruit thick.

Dorsal ribs very prominent or winged.

24. Lomatium.

Dorsal ribs filiform.

Dwarf plants with pinnate or bipinnate leaves and conspicuous involucels.

26. CyMOPTERUS.

Tall and stout plants with three or four times compound leaves and involucels of small bractlets.

27. Leptotaenia.

\section{SANICULA L. SNAKE-ROOT.}

I. Sanicula marilandica L. In rich woods from Newf. and Wash. to Ga. and Colo.-Alt. 4000-6500 ft.-Pike's Peak; foot-hills, Larimer Co.; mouth of Cheyenne Cañon; Spring Cañon; Pennock's mountain ranch; Dixon Cañon.

\section{z. Washingtonia Raf. Sweet Cicely.}

Involucels of several bractlets.

Involucels lacking or of a single small bractlet.

1. W. longistylis. z. W. obtusa.

I. Washingtonia longistylis (Torr.) Britton. (Osmorrhiza longistylis Torr.) In woods and copses from N. Sc. and Ass. to Ga. and Colo--Alt. 4000-6000 ft.-Foot-hills, Larimer Co.; Horsetooth Gulch; Buckthorn Creek, Larimer Co.

2. Washingtonia obtusa C. \& R. (Osmorrhiza nuda Porter; not Torr.) In woods from Alb. to N. M. and Calif.-Alt. 600o-12,00o ft.-South Cheyenne Cañon; Rifle, Garfield Co.; headwaters of Pass Creek; four miles west of Cameron Pass; Cedar Edge; Jack Brook; Upper West Mancos Cañon; near La Plata Post Office; headwaters of Sangre de Cristo Creek; near Pagosa Peak; Wahatoya Cañon; Pennock's mountain ranch; gulch east of Stove Prairie; above Beaver Creek; Rabbit-Ear Range.

\section{GLYCOSMA Nutt.}

I. Glycosma occidentalis Nutt. (Osmorriza occidentalis Torr.) On hillsides and valleys from Alb. and Wash. to Colo. and Calif.-Alt. up to Io,00o ft.-Mountains north of Bear River below Steamboat Springs, Routt Co.; Bob Creek, West La Plata Mountains; Rabbit-Ears, Larimer Co.

4. CarUm L. Caraway.

Leaves twice pinnately divided.

1. C. Carui.

Leaves once pinnately divided.

2. C. Gairdneri.

1. Carum Carui L. Escaped from cultivation, in waste places from Newf. and Mont. to Pa. and Colo.-Alt. up to $9500 \mathrm{ft} .-\mathrm{Ft}$. Collins; mountains between Sunshine and Ward. 
2. Carum Gairdneri (H. \& A.) A. Gray. In valleys from Alb. and Wash. to Colo., Ariz. and Calif.-Steamboat Springs; near Bear River, above Hayden, Routt Co.

\section{5. cicuta l. Water Hemlock, Musquash Root.}

I. Cicuta occidentalis Greene. (C. maculata Coulter; not L.) In water and wet meadows from N. D. and Ida. to N. M. and Calif.-Alt. 5000-8000 ft. -Trinidad; Iola; Pagosa Springs; Ft. Collins; Wahatoya Creek.

Involucels linear, entire.

\section{OREOXIS Raf.}

Oil-tubes more than one in the intervals; plant glabrous. 1. O. humilis.

Oil-tubes solitary in the intervals; plant usually puberulent. $z$. O. alpina.

Involucels ovate or lanceolate, toothed.

3. O. Bakeri.

I. Oreoxis humilis Raf. On the higher peaks of Colo--Alt. II,000-I3,000 ft.-Pike's Peak; Bear Creek Divide; West La Plata Mountains; Mount Garfield.

2. Oreoxis alpina (A. Gray) C. \& R. (Cymopterus alpinus A. Gray) On the higher peaks of Colo. and Utah.-Alt. 10,000-12,000 ft.-Georgetown; headwaters of Clear Creek; Gray's Peak; mountains above Boreas; mountain near Veta Pass; Mount Ouray; Bob Creek Divide, West La Plata Mountains; above Beaver Creek; Cameron Pass; Berthoud Pass.

3. Oreoxis Bakeri C. \& R. On the higher peaks of Colo.-Alt. I0,000-13,000 ft.-Alpine Tunnel; Mt. Hayden; near Pagosa Peak; West Spanish Peak; Mount Ouray.

\section{HARBOURIA C. \& R.}

I. Harbouria trachypleura (A. Gray) C. \& R. (Cicuta trachypleura S. Wats.) In mountains from Wyo. to N. M.-Alt. 5000-I0,000 ft.-Foot-hills near Golden; Bosworth's ranch, Stove Prairie; foot-hills west of Ft. Collins; foot-hills, Larimer Co.; Horsetooth Gulch; Rist Cañon; Howe's Gulch ; gulch west of Pennock's; west of Soldier Cañon; mountains between Sunshine and Ward; Boulder; Empire.

\section{ZizIA Koch. Meadow Parsnip, Alexanders.}

I. Zizia cordata (Walt.) Koch. In wet meadows and woods from Conn., Sask. and Wash. to Ga., Ala. and Utah.-South Park; Pinkham Creek, Larimer Co.

\section{ALETES C. \& R.}

Peduncles longer than the leaves; branches of the umbels short.

Leaflets rounded-obovate in outline; their teeth ovate. r. A. obovata.

Leaflets rhombic-cuneate in outline, incised-toothed with lanceolate acuminate teeth.

2. A. acaulis.

Peduncies shorter than the leaves; branches of the umbels nearly as long as the peduncles. 3. A. humilis.

1. Aletes obovata Rydb. On the mountains of Colo.-Alt. about $7000 \mathrm{ft}$.Golden; Lower Boulder Cañon, Boulder Co.; near Morrison.

2. Aletes acaulis (Torr.) C. \& R. (Deweya acaulis Torr.; Carum Hallii

S. Wats.) In the mountains of Colo, and N. M.-Alt. up to Io,ooo $\mathrm{ft}$. $-\mathrm{Near}$ Morrison; South Table Mountain; Golden; gulch south of Boulder; mountains between Sunshine and Ward. 
3. Aletes humilis C. \& R. In the mountains of Colo--Dale Creek, Larimer Co.

10. BERULA Hoffm. Cut-leaved Water Parsnip.

2. Berula erecta (Huds.) Coville. (B. angustifolia Koch) In water from Ills., Minn. and B. C. to Tex. and Calif.-Alt. 4000-6000 ft.-Ft. Collins; Poudre flats; Boulder.

\section{LigUSTICUM L. Lovage, ANgelica.}

Leaves twice or thrice compound; first divisions ternate.

Stem leafy; divisions of the leaves not filiform.

Leaves thin, dark green.

Leaves thicker, pale green.

I. L. Porteri.

2. L. affine.

Plant subscapose or with a single leaf; ultimate divisions of the leaves linearfiliform.

Leaves once pinnate; plant scapose.

3. L. tenuifolitum.

4. L. Eastroodii.

I. Ligusticum Porteri C. \& R. In mountain woods from Wyo. to N. M. and Ariz.-Alt. 8000-I2,000 ft.-Lake City; near La Plata Post Office; Engelmann Cañon; Georgetown; headwaters of Pass Creek; headwaters of Sangre de Cristo Creek; Turkey Creek and tributaries; Veta Mountain; Mirror Lake; near Pagosa Peak; Columbine; Cerro Summit; Crested Butte; mountains west of. Steamboat Springs; mountains between Sunshine and Ward.

๘. Ligusticum affine A. Nels. Open, moist hillsides in Wyo. and Colo.Summit of North Park Range, Larimer Co.

3. Ligusticum tenuifolium S. Wats. In mountain woods from Ida. and Ore. to Colo.-Middle Park; South Park.

4. Ligusticum Eastwoodii C. \& R. In the mountains of Colo. and S. Wyo--Alt. I0,000-II,000 ft.-Mountains above Ouray; Bear Creek Divide; Pagosa Peak; Keblar Pass; La Plata Mountains.

\section{MUSENION Raf.}

Fruit glabrous or slightly puberulent.

Fruit strongly scabrous puberulent.
1. M. divaricatum.

2. $M$. angustifolium.

1. Musenion divaricatum (Pursh) C. \& R. In dry ground from Ass. and Alb. to S. D. and Colo.-Alt. 4000-6000 ft.-North Denver; outside of Dixon Cañon; north of La Porte; foot-hills, Larimer Co.; Spring Cañon; west of Loveland; Boulder.

z. Musenion angustifolium Nutt. In arid valleys in hard ground of Ass. and Alb. to Colo.-Alt. 4000-5000 ft.-Plains near Denver.

\section{I3. AULOSPERMUM C. \& R.}

Clusters of leaves and peduncles borne at the summit of a more or less elongated stem.

Corolla yellow.

Rachis of the primary leaf-segments dilated; secondary segments confluent, broad, toothed or merely cleft. I. A. longipes.

Rachis of the primary leaf-segments not dilated; secondary segments distinct, finely dissected into small oblong lobes.

Corolla purple.

Leaves clustered at the base; plant acaulescent.

2. A. angustum.

3. A. planosum.

4. A. purpureum. 
I. Aulospermum longipes (S. Wats.) C. \& R. (Cymopterus longipes S. Wats.) In dry soil from Wyo. to Colo. and Utah.-Yampa River.

2. Aulospermum angustum Osterhout. In dry places of Colo.-Steamboat Springs; Hayden.

3. Aulospermum planosum Osterhout. In dry places of Colo--Minturn; Steamboat Springs.

4. Aulospermum purpureum (S. Wats.) C. \& R. (Cymopterus purpureus S. Wats.) In dry places from Colo. and Utah to N. M. and Ariz.-Alt. 6000-7000 ft.-Mancos; Cimarron; Durango; Ridgway.

\section{I4. PHELLOPTERUS Nutt.}

Peduncles, even in fruit, shorter than the leaves; fruit $6-8 \mathrm{~mm}$. long.

I. P. montanus.

Peduncles, at least in fruit, equalling or exceeding the leaves; fruit over $8 \mathrm{~mm}$. long.

Involucels I- 3 -nerved.

Involucels 5-9-nerved.

z. P. purpurascens.

3. P. camporum.

I. Phellopterus montanus Nutt. (Cymopterus montanus T. \& G.) In dry places from S. D. and Wyo. to Ark. and Colo.-Alt. 4000-7000 ft.-Colorado Springs; Ft. Collins; Pueblo; New Windsor; Denver.

2. Phellopterus purpurascens (A. Gray) C. \& R. (Cymopterus montanus purpurascens A. Gray) In dry places from Colo. and Utah to Tex. and Ariz. -In Colorado it is represented only by the var. Eastwoodiae (Jones) C. \& R. which is more robust, with more open inflorescence and narrower wings to the fruit.-Alt. 6000-8000 ft.-Hermosa; Mancos; Cerro Summit.

3. Phelopterus camporum Rydb. Dry mesas of S. Colo.-Alt. about 5000 ft.-Mesas near Pueblo.

\section{I5. PTERYXIA Nutt.}

1. Pteryxia foeniculacea Nutt. (Cymopterus foeniculaceus T. \& G.) In dry places from Ida. and Wash. to Colo., Utah and Ore.-Alt. about $8500 \mathrm{ft}$.Columbine; Steamboat Springs.

I6. OROGENIA S. Wats. Turkey Pea.

I. Orogenia linearifolia S. Wats. On mountain ridges from Ida. and Wash. to Colo. and Ore.-Mancos; Rabbit-Ears, Routt Co.; Steamboat Springs.

17. SIUM L. Water Parsnip.

1. Sium cicutaefolium Gmelin. In water from Newf. and Mackenzie to Va. and Calif.-Alt. 4000-8000 ft.-Parlin, Gunnison Co.; Gunnison; San Luis Valley.

I8. OXYPOLIS Raf.

I. Oxypolis Fendleri (A. Gray) Heller. (Archemora Fendleri A. Gray) Along brooks and in springy places from Wyo. to N. M.-Alt. 8000-II,000 ft. -Headwaters of Clear Creek; Upper Corral Creek; Idaho Springs; Marshall Pass; Ruby; Robinson; near Pagosa Peak; East Indian Creek; mountain near Veta Pass; headwaters of Sangre de Cristo Creek; Grayback mining 
camps and Placer Gulch; Cameron Pass; headwaters of Pass Creek; Bob Creek; Gypsum Creek Cañon, Eagle Co.; Beaver Creek; Berthoud Pass; between Sunshine and Ward.

\section{CONIOSELINUm Hoof. Hemlock Parsnip.}

I. Conioselinum scopulorum (A. Gray) C. \& R. (Ligusticum scopulorum A. Gray) In mountain wood from Colo. to N. M. and Ariz.-Alt. 7000-II,000 ft.-Headwaters of Clear Creek; near Empire; Ironton Park, 9 miles south of Ouray; Robinson; Red Mountain road south of Ouray; Alpine Tunnel; Marshall Pass; mountains, Larimer Co.; Crested Butte; Cumbres; RabbitEar Pass; Palmer Lake; Breckenridge; cañon west of Palmer Lake; Elk Cañon; Ouray; Empire.

20. HERACLEUM L.

I. Heracleum lanatum Michx. In wet ground from Vt. and Alaska to N. C. and Calif.-Alt. 5000-Io,000 ft.-Ruxton Brook; west of Ouray; Gunnison; Pagosa Springs; north Cheyenne Cañon; Ft. Collins; Mancos; Baxter's ranch; along the Poudre; between Sunshine and Ward.

\section{ANGELICA L. ANgelica.}

Oil-tubes mostly solitary in the intervals, not continuous around the seed; rays of the umbels ascending.

Involucels of many-lanceolate, long-acuminate bractlets. I. A. Grayi.

Involucels none, or a few linear-subulate or filiform bractlets. 2 . $A$. pinnata. Oil-tubes continuous around the seeds; rays of the umbels widely spreading.

3. A. ampla.

I. Angelica Grayi C. \& R. In the mountains of Colo. and S. Wyo.-Alt. 9000-I3,000 ft.-Headwaters of Clear Creek; Pike's Peak; Silver Plume; near Pagosa Peak; Cameron Pass; Little Kate Basin, La Plata Mountains; Graymont; West Spanish Peak; Keblar Pass; Boreas; Beaver Creek.

2. Angelica pinnata S. Wats. In wet meadows from Alb. to N. M. and Utah.-Alt. 7000-8500 ft.-Gunnison Co.; Squaw Hill above Cimarron; Empire.

3. Angelica ampla A. Nels. In wet meadows of Wyo. and Colo.-Alt. about $7000 \mathrm{ft}$.-Cheyenne Mountain; north of Cheyenne Cañon; southeast of Jefferson, South Park.

22. CYNOMARATHRUM Nutt.

r. Cynomarathrum Eastwoodii C. \& R. Low plains of western Colo.Grand Junction; Mesa County.

23. PASTINACA L. Pars nip.

r. Pastinaca sativa L. Cultivated and escaped around dwellings from Vt. and Wash. to Fla. and Calif.-Boulder. 


\section{LOMATIUM C. \& R.}

Plants slender with thick rounded corms; corolla yellow. \&. L. leptocarpum. Plant generally stouter from a thickened root or rootstock, rarely corm-like.

Bractlets lanceolate, oblong or linear; corolla white.

Bractlets scarious-margined, as well as the whole plant puberulent or rarely glabrate.

Bractlets not scarious-margined, villous.

z. L. orientale.

3. L. inacrocarpum.

Bractlets of the involucels none or very few, linear or subulate; corolla yellow. Leaves finely dissected with numerous small divisions. 4. L. Grayi.

Leaves once to thrice ternate with comparatively large divisions.

5. L. platycarpum.

1. Lomatium leptocarpum (Nutt.) C. \& R. (Pencedanum leptocarpum Nutt.) On plains and hillsides from Ida. and Ore. to Colo. and Calif.Steamboat Springs.

2. Lomatium orientale C. \& R. (Peucedanum nudicaule Nutt., mainly) On dry plains from S. D., Mont. and Ida, to Kans., N. M. and Ariz.-Alt. 40008000 ft.-Plains near Denver; foot-hills west of Ft. Collins; mountains, Larimer Co.; Calhan; vicinity of Horsetooth; Horsetooth Gulch; Dixon Cañon; Empire.

3. Lomatium macrocarpum (Nutt.) C. \& R. (Pencedanum macrocarpum Nutt.) Dry hills and plains from Sask. and B. C. to Colo. and Calif.Egeria Park, Routt County.

4. Lomatium Grayi C. \& R. On dry plains and hills from Wyo. and Wash. to Colo. and Ore.-Alt. up to $7000 \mathrm{ft} .-$ Mancos; Durango; Los Pinos; Glenwood Springs.

5. Lomatium platycarpum (Torr.) C. \& R. (Peucedanum simplex Nutt.) On hillsides from Alb. and Wash. to Colo. and Ore--Alt. $6000-8000 \mathrm{ft}$.Above Mancos; Mancos; Cerro Summit; Glenwood Springs; Fort Lewis.

\section{PSEUDOCYMOPTERUS C. \& R.}

Plant more or less caulescent; leaves thin.

Petals yellow.

Ultimate divisions or teeth of the leaves short, ovate to lanceolate; leaves ovate in outline.

Ultimate divisions of the leaves linear, elongated.

Leaves ovate in outline, at least the basal ones.

Leaves, at least the basal ones, broadly rhombic in outline.

Plant slender; leave mostly twice compound with very long and few divisions.

Plant low; 1

lant low; leaves thrice pinnate with shorter, crowded numerous

Petals purple.

Plants acaulescent with thick or firm leaves.

4. P. multifidus.

5. P. purpureus.

Primary divisions of the leaves once or twice dissected with narrowly linear divisions.

6. $P$. anisatus.

Primary divisions broad, cuneate-flabellate, cleft and toothed with short ovate or lanceolate teeth.

7. P. aletifolius.

1. Pseudocymopterus montanus (A. Gray) C. \& R. (Ligusticun montanum B. \& H.) In mountain woods from Wyo. to N. M. and Ariz.-Alt. 8000-I2,500 ft.-Headwaters of Clear Creek; Clear Creek Cañon; Cumbres; Cumberland Basin, La Plata Mountains; Los Pinos; hills above Mancos; West Indian Creek; Sangre de Cristo Cañon; Cameron Pass; Alpine Tunnel; 
Idaho Springs; Larimer Co.; Ironton Park, 9 miles south of Ouray; mountain near Veta Pass; Pass Creek; Piedra; near Pagosa Peak; Gore Pass; Rico; Leroux Creek, Delta Co.

2. Pseudocymopterus sylvaticus A. Nels. In woods of Colo. and Wyo.Alt. 8000-12,000 ft.-Gulch, Mt. Harvard; Clear Creek Cañon near Georgetown; Keblar Pass; Pike's Peak; Veta Pass; Hahn's Peak; mountains, Larimer Co.; West Indian Creek; Turkey Creek and tributaries; Veta Mountain; Seven Lakes; Bosworth's; William's Cañon above Manitou; above Beaver Creek; Dillon Cañon; Empire; mountains between Sunshine and Ward.

3. Pseudocymopterus tenuifolius (A. Gray) Rydb. (Thaspium montanum tenuifolium A. Gray) In mountain woods from Colo. to N. M. and Ariz.Alt. 8000-To,000 ft.-Engelmann Cañon; William's Cañon; Minnehaha; East Indian Creek; Lake City; vicinity of Como.

4. Pseudocymopterus multifidus Rydb. ( $P$. montanus multifidus Rydb.) In mountain woods of Colo.-Alt. 800o-Io,000 ft.-Lake City; Ironton, San Juan Co.; Wahatoya Cañon; Ironton Park, 9 miles south of Ouray; Seven Lakes.

5. Pseudocymopterus purpureus (C. \& R.) Rydb. ( $P$. montanus purpureus C. \& R.) In the mountains of Colo., Utah, N. M. and Ariz.-Alt. about $1 \mathrm{I}, 500$ ft.-Mt. Ouray; Garfield.

6. Pseudocymopterus anisatus (A. Gray) C. \& R. (Cymopterus anisatus A. Gray) On mountains among rocks from Wyo. and Nev. to Colo. and Utah.Alt. 9000-I I,000 ft.-Headwaters of Clear Creek; Ute Pass, Colorado Springs; Silver Plume; Little Veta Mountain; West Spanish Peak.

7. Pseudocymopterus aletifolius Rydb. In the mountains of Colo. amorig rocks.-Alt. 6000-I0,000 ft.-Minnehaha; Cheyenne Mountain.; Pike's Peak; Ruxton; North Cheyenne Cañon; Manitou; South Cheyenne Cañon.

\section{CYMOPTERUS Raf.}

Umbels dense, globular; petals white; involucre wanting.

Ultimate divisions of the leaves linear or linear-oblong, acutish.

Ultimate divisions of the leaves short, broadly oblong, obtuse.

$$
\text { 1. C. acaulis. }
$$

2. C. Parryi.

Umbels open; petals yellow; involucre present, although often a mere vestige. Divisions of the leaves narrow.

Divisions of the leaves broad.

3. C. Fendleri.

4. C. Newberryi.

I. Cymopterus acaulis (Pursh) Rydb. (C. glomeratus DC.; C. campestris T. \& G.) In dry arid places from N. D. and Ass. to Ark. and Colo.-Alt. 4000-8000 ft.-Larimer Co.; Walsenburg; plains near Denver; mesas near Pueblo; Cucharas Valley near La Veta; butte 5 miles southwest of La Veta; Ft. Collins; Poudre River.

2. Cymopterus Parryi (C. \& R.) Jones, (Coloptera Parryi C. \& R.) In dry places from Mont. to Neb. and Colo.-McCoy's, Eagle Co.

3. Cymopteris Fendleri A. Gray. In dry places of Colo., Utah and N. M.-Westwater; Mancos; Grand Junction.

4. Cymopterus Newberryi (S. Wats.) Jones. In dry places of Colo., Utah and N. M.-Westwater. 


\section{LEPTOTAENIA Nutt.}

Fruit 8-1 $2 \mathrm{~mm}$. long, usually without oil-tubes; leaves finely dissected into linear divisions.

I. L. multifida.

Fruit I 5-18 mm. long, with oil-tubes; leaves less dissected into oblong divisions.

2. L. Eatoni.

r. Leptotaenia multifida Nutt. In rich soil from Alb. and Wash. to Colo. and Calif.-Near Dix Post Office; Durango; Glenwood Springs; Baldwin; Spicer.

2. Leptotaenia Eatoni C. \& R. In rich soil from Wyo. and Ida. to Utah and Colo.-Alt. 7000-8000 ft.-Los Pinos; Cerro Summit; Minturn.

\section{Order 39. ERICALES.}

Gynoecium superior; fruit usually capsular.

Herbaceous saprophytes without green leaves.

Herbs or shrubs with green leaves.

Corolla of essentially distinct petals; herbs with rootstocks.

Corolla of more or less united petals; shrubs.

I02. Pyrolaceae.

103. ERICACEAE.

Gynoecium inferior; fruit baccate or drupaceous.

I04. VACCINIACEAE.

Family roI. MONOTROPACEAE Lindl. Indian-PIPE Family.

I. Pterospora Nutt. Pine Drop, Giant Bird's-nest.

1. Pterospora andromedea Nutt. In rich woods from Que. and B. C. to Pa., Ariz. and Calif.-Alt. 4000-8000 ft.-Bosworth's ranch, Stove Prairie; mountains, Larimer Co.

Family io2. PYROLACEAE Agardh. Wintergreen Family.

Plants leafy-stemmed; flowers corymbose; style very short and covered by the peltate stigma; filament dilated and hairy at the middle.

1. Chimaphila.

Plants scapiferous with a basal rosette of leaves; flowers racemose or solitary; style evident; filaments subulate, naked.

Flowers solitary; petals spreading; valves of the capsule not cob-webby on the edges. $\quad 2$. Moneses.

Flowers racemose; petals more or less converging, concave; valves of the capsule cob-webby on the edges when opening.

3. Pyrola.

r. Chimaphila Pursh. Pipsissewa.

I. Chimaphila umbellata (L.) Nutt. In woods from N. S. and Alaska to Ga. and Calif.-Alt. 8000-I I,000 ft.-Estes Peak, Larimer Co.; North and South Boulder Peak; Bierstadt Lake; Beaver Creek.

2. MONESES Salisb. One-Flowered Wintergreen.

I. Moneses uniflora (L.)' S. F. Gray. In wet woods from Lab. and Alaska to Pa., Colo. and Ore.-Alt. 9000-12,000 ft.-Silverton; Marshall Pass; Front Range, Larimer Co.; Ruby; Caribou; Steamboat Springs; camp on Little Beaver Creek; Berthoud Pass. 


\section{PYROLA L. WintERgReEn.}

Flowers with a Io-lobed hypogynous disk; stigma peltate, 5-lobed; petals with a pair of tubercles at the base.

Flowers without hypogynous disk and petals without tubercles.

Style straight and short; stigma peltate; stamens equally connivent around the pistil.

2. P. minor.

Style and stamens declined; stigma much narrower than the concave apex of the style, which forms a collar or ring.

Leaves not mottled.

Petais pink or purplish.

Leaf-blades round-reniform.

Leaf-blades orbicular or round-ovate.

Petals white or greenish.

Leaves mottled.

3. P. asarifolia.

4. P. uliginosa.

5. P. chlorantha.

6. P. picta.

1. Pyrola secunda L. In damp woods from Lab. and Alaska to D. C. and Calif.-Alt. 6000-I2,000 ft.-Grand Lake; Mt. Abram, Ouray; Echo Cañon; Box Cañon, west of Ouray; Pagosa Peak; Steamboat Springs, Routt Co.; Mt. Harvard; Cheyenne Mountain; Beaver Creek; mountains between Sunshine and Ward; Fish Creek Falls.

2. Pyrola minor L. In woods from Greenl. and Alaska to Conn. and Calif.-Alt. 8000-I2,000 ft.-Headwaters of Clear Creek; Grand Lake; Marshall Pass; chaparral-covered hills southeast of Ouray; Artist's Glen, near Pike's Peak; Silver Plume; La Plata Cañon; Cameron Pass; Graymont; Beaver Creek.

3. Pyrola asarifolia Michx. In damp woods from N. B. and Alb. to N. Y. and Colo.-Alt. 9000-I2,000 ft.-West Spanish Peak; Graymont.

4. Pyrola uliginosa Torr. ( $P$. rotundifolia uliginosa A. Gray) In wet rich woods and swampy places from N. S. and B. C. to N. Y., Colo. and Calif.-Alt. 7000-12,000 ft.-Headwaters of Clear Creek; South Boulder Peak; Grand Lake; Marshall Pass; Ouray; Berthoud Pass, near Cozzens; Keblar Pass; Steamboat Springs; Beaver Creek.

5. Pyrola chlorantha Swartz. In woods from Lab. and B. C. to D. C., Colo. and Calif.; also in Europe.-Alt. 9000-I2,000 ft.-Marshall Pass; Hamor's Lake, north of Durango; 4 miles west of Cameron Pass; Cheyenne Mountains; Front Range, Larimer Co.; Gore Pass; swamp above Beaver Creek.

6. Pyrola picta Smith. In woods from Ida. and Wash. to Colo., Ariz. and Calif.-Alt. 8000-9000 ft.-Cañons and adjoining meadows west of Ouray.

\section{Family ro3. ERICACEAE DC. Heath Family.}

Fruit more or less fleshy or surrounded by a fleshy calyx or hypanthium; plants prostrate, evergreen; corolla without sacs.

Fruit a berry or drupe, not enclosed in the calyx. 1. Arctostaphyos.

Fruit a loculicidal capsule, enclosed in the accrescent fleshy calyx and hypanthium.

Fruit dry, a septicidal capsule; erect bog-shrubs.

Corolla saucer-shaped with so sacs for the anthers.

Corolla campanulate without sacs.

2. Gaultheria.

3. Kalmia.

4. Phyllodoce.

\section{ARCtOSTAPHYLOS Adans. BeAR-BerRy, Kinnikinic.}

1. Arcostaphylos uva-ursi (L.) Spreng. In woods, on hillsides and sandy soil from Lab. and Alaska to N. J., Colo. and Ore.-Alt. 5000-10,000 ft.- 
Arkansas Junction near Leadville; Dillon; Idaho Springs; South Cheyenne Cañon; mountains north of Cascade; West Mancos Cañon; mountains, Larimer Co.; Golden; west of Ft. Collins; Stove Prairie, Larimer Co.; Pike's Peak; Manitou; Eldora; mountains between Sunshine and Ward; Bear Creek Cañon.

\section{Gadltheria L. Creeping Wintergreen.}

1. Gaultheria humifusa (Graham) Rydb. (Vaccinium humifusum Graham; Gaultheria Myrsinitis Hook.) On wooded hillsides from Mont. and B. C. to Colo. and Calif.-Alt. about II,000 ft.-Buffalo Pass, Park Range; headwaters of Clear Creek; summit of North Park Range, Larimer Co.

\section{Kalmia. American o1 Swamp Laurel.}

.. Kalmia microphylla (Hook.) Heller. ( $K$. glauca microphylla Hook.) In mountain swamps from Alb. and Alaska to Colo. and Calif.-Alt. Io,000I, 000 ft.-Caribou; Long's Peak; Buffalo Pass; summit of North Park Range, Larimer Co.

\section{PHYLLODOCE Salisb.}

I. Phyllodoce empetriformis (Smith) Don. Swamps and mountain sides from Alaska to northern Calif., Colo. and Alb.-Alt. up to i I,000 ft.-Grizzly Gulch, near Gray's Peak.

\section{Family io4. VACCINIACEAE Lindl. Huckleberry Family.}

I. VACCINIUM L. Blue-berry, Huckleberry, Bilberry.

Branches not angled.

1.V. caespitosum.

Branches angled.

Fruit purplish-black; leaves over I cm. long. $\quad$ 2. $V$. oreophilum.

Fruit bright red; leaves usually less than I cm. long. 3. $V$. erythrococcum.

1. Vaccinium caespitosum Michx. In arctic and alpine regions from Lab. and Alaska to N. H., Colo. and Wash.-Alt. 8000-12,000 ft.-Headwaters of Clear Creek, near Empire; Middle Park; Mirror Lake; Tennessee Pass, 7 miles west of Leadville; Damfino Creek; Cameron Pass; Leroux Creek; Eldora to Baltimore; Buffalo Pass; summit of North Park Range, Larimer Co.

2. Vaccinium oreophilum Rydb. (V. Myrtillus A. Gray; not L.) In woods from Alb. and B. C. to N. M.-Alt. 8000-I2,000 ft.-Front Range, Larimer Co.; Bob Creek, West L.a Plata Mountains; near Pagosa Peak; Keblar Pass; East Indian Creek; mountain near Veta Pass; Valley Spur; Red Mountain, south of Ouray; head of Bear Creek; Beaver Creek.

3. Vaccinium erythrococcum Rydb. (V. Myrtillus microphyllum Hook.) On hillsides from Alb. and B. C. to Colo. and Calif.-Alt. 8500-I2,000 ft.Headwaters of Clear Creek, near Empire; Alpine Tunnel; Little Veta Mountain; Beaver Creek; above Cameron Pass; Baltimore; Buffalo Pass; summit of North Park Range, Larimer Co. 


\section{Order 40. PRIMULALES.}

\section{Family 105. PRIMULACEAE Vent. Primrose Family}

Corolla present.

Corolla-lobes erect or spreading; stamens distinct.

Corolla salverform or funnelform, its lobes imbricated; stamens included; plants scapiferous; leaves basal.

Corolla-tube equalling or exceeding the calyx; style filiform; flowers conspicuous. $x$. PrIMULA.

Corolla-tube shorter than the calyx; throat constricted; style very short; flowers minute. 2. ANDROSACE.

Corolla rotate, its lobes convolute or involute in the bud; stamens exserted; plants leafy-stemmed.

Flowers axillary, solitary; corolla-lobes broad, curved around the stamens; staminodia conspicuous. 3. Steironema.

Flowers in axillary short spikes; corolla-lobes long and linear; tube very short; staminodia tooth-like. - 4. NAuMBurgia.

Corolla-lobes reflexed; stamens more or less monadelphous; plants scapiferous.

5. DODECATHEON.

Corolla wanting; calyx with 5 petaloid lobes; flowers solitary, sessile in the axils of the opposite stem-leaves.

6. GLAUX.

\section{PRimula L. Primrose.}

Bracts of the involucre more or less gibbous at the base; lobes of the corolla deeply 2-cleft, $i . e_{0}$, at least one-fourth their length; leaves densely mealy beneath.

1. P. americana.

Bracts of the involucre not gibbous below; lobes of the corolla merely emarginate or notched, rarely entire; leaves not mealy.

Plant less than I dm. high, I-few-flowered; flowers less than $2 \mathrm{~cm}$. long.

Scape $1.5-5 \mathrm{dm}$. high, many-lowered; flowers over $2 \mathrm{~cm}$. long.

2. P. angustifolia.

3. P. Parryi.

I. Primula americana Rydb. ( $P$. farinosa Hook.; not L.) In swamps and wet meadows from Ass. and Alb. to Colo.-Alt. about 8000 ft.-Neat Lake John, North Park; Gunnison.

z. Primula angustifolia Torr. On alpine peaks of Colo.-Alt. 9000-I4,400 ft. -Saddle, Pike's Peak; Marshall Pass; Gray's Peak; Pike's Peak; Berthoud Pass near Georgetown; West Spanish Peak; Sierra Blanca; headwaters of Clear Creek.

3. Primula Parryi A. Gray. Along cool mountain streams from Mont. to Colo. and Ariz.-Alt. 9000-13,00o ft.-Bottomless Pit, Pike's Peak; Berthoud Pass, near Georgetown; Cameron Pass; Tennessee Pass, 7 miles west of Leadville; tributaries of South Fork of Cache La Poudre River, Larimer Co.; Elk Mountains; Gray's Peak; Slide Rock Cañon; timber line above Cameron Pass; mountains south of Ward, Boulder Co.; Carson; summit of Mt. Garfield; headwaters of Clear Creek; Lake City; Caribou; Graymont; Beaver Creek; Berthoud Pass.

\section{ANDROSACE L.}

Perennials, cespitose and proliferous; corolla 5-8 $\mathrm{mm}$. in diameter.

1. A. carinata.

Annuals, not cespitose-proliferous, or the last one may be perennial by rosettes; corolla 3-4 $\mathrm{mm}$. wide. 
Calyx-tube in fruit obpyramidal, its green teeth surpassing the capsule. Bracts of the involucre ovate or oblong. 九. A. occidentalis.

Bracts of the involucre lanceolate or subulate.

Calyx-teeth erect, lanceolate, usually shorter than the tube.

Peduncles, pedicels and calyx-lobes densely puberulent, the latter exceeding the fruit.

3. A. puberulenta.

Peduncles and pedicels sparingly puberulent or glabrous; calyx-lobes glabrous or nearly so, not exceeding the fruit.

Corolla longer than the calyx.

Peduncles $\mathrm{I}-2 \mathrm{dm}$. high, many times longer than the strongly ascending or suberect pedicels. 4. A. pinetorum.

Peduncles less than $3 \mathrm{~cm}$. high, often equalled or exceeded in length by the spreading pedicels. 5 . A. subumbellata. Corolla shorter than the calyx.

6. A. diffusa.

Calyx-teeth more or less spreading, ovate-triangular, foliaceous, equalling or exceeding the whitish tube; corolla shorter than the calyx.

7. A. sublifera.

Calyx-tube in fruit hemispherical; teeth broadly triangular.

8. A. fliformis.

I. Androsace carinata Torr. (A. Chamaejasne A. Gray; not Host.) On alpine peaks from Alb. to Colo.-Alt. 9000-I3,000 ft.-Mt. Evans; Pike's Peak; near the summit of the Rocky Mountains; Bottomless Pit; West Spanish Peak; Iron Mountain.

2. Androsace occidentalis Nutt. In dry soil from Ills., Man. and Mont. to Mo., Tex. and Calif.-Alt. 4000-8500 ft.-Mancos; foot-hills, Larimer Co.; Los Pinos (Bayfield); Empire.

3. Androsace puberulenta Rydb. On plains and hills from Man., Mackenzie River and Alb. to N. Mex.-Alt. 5000-I2,000 ft.-Plains near Boulder; Pike's Peak; Seven Lakes; Wahatoya Cañon; mountain near Veta Pass; headwaters of Sangre de Cristo Creek; Gentian Ridge; Veta Mountain; Ribbon Lake; Marshall Pass; Cucharas River, above La Veta; Little Veta Mountain; near Ironton, San Juan Co.; Mt. Hesperus; Bear Creek Divide, west of Mt. Hesperus; Iron Mountain; Carson.

4. Androsace pinetorum Greene. In the mountains from Mackenzie and Yukon to Colo. and Ariz. Scarcely distinct from A. septentrionalis L.Ait. 5000-8000 ft.-Los Pinos (Bayfield); Graham's Park; hills southeast of La Veta; Georgetown; Boulder; Soldier's Cañon; Dolores.

5. Androsace subumbellata (A. Nelson) Small. Along mountain streams from Mont. to Colo, and Ariz.-Alt. 9000-12,000 ft.-Berthoud Pass, near Georgetown; Ironton Park, 9 miles south of Ouray; Pike's Peak; Gore Pass; source of Leroux, above Graymont; Beaver. Creek; Cameron Pass; Grizzly Creek; Deep Creek.

6. Androsace diffusa Small. In the mountains mostly along rivers from Mackenzie and B. C. to N. M. and Ariz.-Alt. 6000-II,000 ft.-Massif de l'Arapahoe; Pike's Peak; Upper La Plata River; Veta Pass; North Park near Teller; along the Michigan; Van Boxle's ranch, above Cimarron; Silver Plume; foot-hills, Larimer Co.; Mancos; Georgetown; Mt. Harvard; on Turkey Creek and tributaries; Glenwood Springs, Garfield Co.; hills above Mancos; Pennock's mountain ranch; vicinity of Como; Bosworth's ranch, Stove Prairie; along Purgatory River, Trinidad; Rist Cañon; above Manitou; gulch west of Pennock's; Dolores. 
7. Androsace subulifera (A. Gray) Rydb. (A. septentrionalis subulifera A. Gray). In the mountains from Mont. to Colo.-Alt. 6000-10,000 ft.-Cascade; Minnehaha; Cameron Pass; Steamboat Springs; Cimarron; Beaver Creek; Mancos; Durango; Pennock's; Dillon Cañon, Trinidad.

8. Androsace filiformis Retz. (A. capillaris Greene) Along mountain streams from Wash. and Mont, to Colo.-Alt. up to Io,000 ft.-Gore Pass; Middle Park; Grand River, I2 miles below the lake; Steamboat Springs.

\section{Steironema Raf. Fringed Loosestrife.}

I. Steironema ciliatum (L.) Raf. In swamps and wet meadows from N. S. and Wash. to Ga. and Ariz.-Alt. 4000-8000 ft.-New Windsor, Weld Co. ; Alamosa; Wahatoya Creek; Ft. Collins; Mason's river-front farm; Rist Cañon; Horsetooth Gulch; La Porte; Boulder.

\section{NAUMBURgia Moench. Tufted Loosestrife.}

1. Naumburgia thyrsiflora (L.) Duby. In shallow water and swamps from N. S. and Alaska to Pa., Colo. and Ore.; also in Europe.-Alt. about $5000 \mathrm{ft} .-\mathrm{Ft}$. Collins.

\section{5. dodecatheon L. American Cowslip, Shooting Star.}

Anthers subsessile or nearly so ; tube of the filaments, if any, less than $0.5 \mathrm{~mm}$. long.

1. D. multiflorum.

Anthers not subsessile; filaments united into a distinct tube, $\mathrm{r}-3 \mathrm{~mm}$. long.

Anthers more than twice as long as the short filaments.

Leaves entire.

Leaf-blades oval or oblong; bracts oblong, mostly obtuse; plant slender; flowers I-3 (rarely 4-5). $\quad$ 2. D. philoscia.

Leaf-blades oblanceolate; bracts lanceolate, acute; plant usually stout and many-flowered.

Leaves sinuately dentate.

Anthers less than twice as long as the filaments.

3. D. radicatum.

4. D. sinuatum.

5. D. pauciflorum.

1. Dodecatheon multiflorum Rydb. In wet meadows of Colo. and Wyo.Alt. 8000-9000 ft.-Sangre de Cristo Creek.

2. Dodecatheon philoscia A. Nels. In wet meadows of Colo. and Wyo.Alt. 800o-Io,000 ft.-William's Cañon, near Pike's Peak; Walton Creek; Sargent's; Pike's Peak; Ft. Collins.

3. Dodecatheon radicatum Greene. In wet meadows from S. D. and Wyo. to Kans. and N. Mex.-Alt. 7000-II,000 ft.-Eldora to Baltimore; Berthoud Pass; Dark Cañon; Bear Creek Cañon; Grayback mining camps and Placer Gulch; Walden; below Colorado Springs; Idaho Springs; West Indian Creek; Veta Mountain; South Park; East Indian Creek; Lake City; Horsetooth Gulch; forks of Poudre and Big South; gulch west of Dixon Cañon; Pennock's mountain ranch; Hematite; Pike's Peak.

4. Dodecatheon sinuatum Rydb. (D. radicatum sinuatum Rydb.) Shady wet banks and wet meadows in Colo.-Alt. 5000-8000 ft.-Foot-hills, Larimer Co.; Buena Vista ; foothills west of Ft. Collins.

5. Dodecatheon pauciflorum (Durand) Greene. In wet meadows and along streams from Mackenzie and Sask, to Colo.-Alt. about $8500 \mathrm{ft}$.-Columbine. 
6. Glaux L. Sea Mrlkwort, Black Saltwort,

1. Glaux maritima $L$. On beaches and in salt marshes from Newf, and Alaska to N. J., Colo. and Ore--Alt. about 5000 ft.-New Windsor, Weld Co.; Ft. Collins; Cache la Poudre.

\section{Order 4I. OLEALES.}

Family ro6. OLEACEAE Lindl. Olive Family.

Fruit a samara.

I. Fraxinus.

Fruit a drupe.

4. Adelia.

1. FRAXINUS L. Ash.

I. Fraxinus anomala Torr. In cañons from western Colo. and Utah to Ariz.-Alt. 4500-5000 ft.-Grand Junction; Deer River; between Hotchkiss and Smith's Fork.

2. ADELIA P. Br.

1. Adelia neo-mexicana (A. Gray) Kuntze. (Forestiera neo-mexicana A. Gray; F. acuminata parvifolia A. Gray) On hills from Colo. to Tex. and N. M.-San Juan (Brandegee).

\section{Order 42. GENTIANALES.}

Corolla-lobes convolute or imbricated in the bud; leaves typically opposite and simple.

i 07. Gentianaceae.

Corolla-lobes induplicate-valvate in the bud; leaves alternate, in ours mostly basal and trifoliolate.

io8. Menyanthaceal.

\section{Family io7. GeNTIANACEAE Dumont. Gentian Family.}

Style filiform, mostly deciduous; anthers recurving or twisted at maturity.

Corolla small, red, rose or yellowish; tube surpassing the calyx; filaments spirally twisted.

1. ERYthraea.

Corolla large, blue, purple or white; tube much shorter than the calyx; stamens recurved.

Style stout and short or none, persistent.

Corolla without nectariferous pits, glands or scales.

Corolla campanulate, funnelform or salvershaped; calyx 4-5-lobed; stamens inserted in the corolla-tube.

Corolla without plaits or lobes at the sinuses; calyx without an intercalycine membrane; sepals imbricated.

Flowers 4-merous, rather large, usually over $3 \mathrm{~cm}$. long; corolla-lobes more or less fringed or toothed; inner sepals broader, membraneousmargined.

3. ANTHOPOGON.

Flowers small, 5-merous (seldom 4-merous), less than $2 \mathrm{~cm}$. long; outer sepals the broader; corolla-lobes never fringed, rarely toothed.

4. Amarella.

Corolla plicate in the sinuses; the plaits more or less extended into membraneous lobes or teeth; calyx with an intercalycine membrane; its lobes valvate.

Dwarf annuals or biennials; flowers solitary, terminal; anthers cordateversatile.

5. Chondrophylia.

Perennials; flowers short-peduncled, at least some of them axillary; anthers linear or oblong, extrorse. 6. Dasystephana.

Corolla rotate; calyx 4-5-parted to near the base; stamens inserted on the

base of the corolla. 7. Pleurogyne. 
Corolla with nectariferous glands, pits or scales.

Style none; leaves opposite, rarely alternate; corolla without a crown at the base.

8. Swertia.

Style manifest; leaves in ours verticillate; corolla with a crown at the base.

9. Frasera.

\section{r. erythraea Neck. Centaury, Canchalagua,}

1. Erythraea arizonica (A. Gray) Rydb. (E. calycosa arizonica A. Gray) In sandy soil from Colo. and Utah to Ariz.-Hotchkiss, Delta Co.

\section{EUSTOMA Salisb.}

1. Eustoma Russellianum (L.) Griseb. In wet meadows from Neb. and Colo. to La. and N. M.; also Mex.-Alt. 4000-5500 ft.--Tobe Miller's ranch; La Porte, Larimer Co.; Ft. Collins; Denver.

\section{ANThOpogon Neck. Fringed Gentian.}

Annuals or biennials; flowers on naked long peduncles terminating the branches, not bracteate. 1. A. elegans.

Perennials; flowers short-peduncled in the axils of two bract-like leaves.

2. A. barbellatus.

I. Anthopogon elegans (A. Nels.) Rydb. (Gentiana elegans A. Nels.) In wet places from Mackenzie to Colo. and Ariz.-Alt. 8000-I3,000 ft.-Goose Creek; Westcliffe; 4 miles west of Cameron Pass; White River Plateau; Twin Lakes; McCoy; Columbine; Keblar Pass; North Park; near Pagosa Peak; Grand Lake; Mt. Bartlett; Robinson; Mt. Harvard; North Park near Teller; Long's Peak; Medicine Bow Mountains; Chambers' Lake; South Park at Jefferson; Breckenridge.

2. Anthopogon barbellatus (Engeim.) Rydb. (Gentiana barbellata Engelm.; G. Moseleyi A. Nels.) In mountain meadows and in wet places on the peaks of Colo.-Alt. 9000-I2,000 ft.-Mt. Harvard; Pike's Peak; Gentian Dell; near Breckenridge; Gray's Peak; Vance Junction; Cameron Pass.

\section{4. amarella Gileb. Gentian.}

Flowers solitary on long peduncles; stems depressed, cespitose.

Flowers numerous, short-peduncled; stems erect, leafy, more simple.

Calyx-lobes very unequal; two of them large, foliaceous, ovate or oval, much broader than the rest and covering them.

Calyx-lobes somewhat unequal, but all oblong, lanceolate or linear.

Flowers numerous, crowded, very short-peduncled; the whole inflorescence dense and spike-like; leaves ustally equalling or exceeding the internodes. 3. A. strictiflora.

Flowers rather few, distinctly peduncled; middie internodes elongated and usually longer than the leaves.

Larger sepals usually half as long as the corolla or longer; plant stout, 2-4 dm. high; stem-leaves lanceolate. 4 4. A. scopulorum.

Sepals less than half as long as the corolla; plant slender, I-2, seldom 3 dm. high; stem-leaves usually ovate-lanceolate. 5. A. plebeja.

I. Amarella monantha (A. Nels.) Rydb. (Gentiana tenella A. Gray, in part; not Rottb.; G. monantha A. Nels.) In wet places of Colo.-Alt. 800012,000 ft.-Mirror Lake; headwaters of Clear Creek, near Empire. 
z. Amarella heterosepala (Engelm.) Greene. (Gentiana heterosepala Engelm.) In damp ground in Utah and Colo.-Alt. about $9000 \mathrm{ft}$.-Near Pagosa Peak; divide road to Steamboat Springs; western Gunnison Co.

3. Amarella strictiflora (Rydb.) Greene. (Gentiana amarella stricta S. Wats.; G. strictiflora Rydb.) On hillsides and damp places from Sask. and Alaska to Colo. and Calif.-Alt. 7500-I2,000 ft.-Empire; mountains between Sunshine and Ward; Gunnison; Lake John; North Park; Mt. Harvard; Ribbon Lake; Estes Park, Larimer Co.; Seven Lakes; Chambers' Lake; Bottomless Pit, Pike's Peak; headwaters of Clear Creek near Empire; Bergen Park; South Park, southeast of Jefferson; Baxter's ranch.

4. Amarella scopulorum Greene. (Gentianella Clenentis Rydb.) In damp places from Mont. and S. D. to Colo, and Ariz.-Alt. 9000-12,000 ft.Clear Lake; Idaho Springs; Palsgrove Cañon; Ruxton Dell; Minnehaha; Middle Park; below Half-way House, Pike's Peak; Graymont; Hamor's Lake above Durango; Artist's Glen near Pike's Peak; Pike's Peak; Silver Plume; headwaters of Clear Creek; Bosworth's ranch.

5. Amarella plebeja (Cham.) Greene. (Gentiana plebeja Cham.; $G$. Amarella acuta A. Gray; not Hook.) In wet places from Mackenzie and Alaska to Colo. and Calif. (?).-Alt. 8000-I0,000 ft.-Georgetown; Middle Park, near Cozzens; Marshall Pass; Grand Lake; Deep Creek Lake; north of Steamboat Springs; vicinity of Pine Grove.

Amarella plebeja Holmii (Wettst.) Rydb. (Gentiana plebeja Holmii Wettst.; G. Amarella nana Engelm.) A low alpine variety.-Alt. Io,oooI2,000 ft.-Caribou; Buffalo Pass; Breckenridge.

\section{CHONDROPHYLLA (Bunge) A. Nels.}

Leaves and calyx-lobes with broad scarious margins; the capsule long-stipitate and at last exserted from the corolla. 1. C. Fremontii. Leaves and calyx-lobes slightly scarious-margined; capsule short-stipitate, not exserted.

2. C. americana.

1. Chondrophylla Fremontii (Torr.) A. Nels. (Gentiana humilis Engelm.; not Stev.; G. Fremontii Torr.) On alpine wet brook-banks in Wyo. and Colo.-Alt. 7000-10,000 ft.-Gunnison; headwaters of Sangre de Cristo Creek; headwaters of Clear Creek; Georgetown; Como.

2. Chondrophylla americana (Engelm.) A. Nels. (Gentiana prostrata Hook.; not Henke.; var. Americana Engelm.) In wet places along streams from Alb. and Alaska to Colo.-Alt. I0,000-I2,000 ft.-Wilson, San Miguel Co.; "Colorado"; northeast of Boreas.

\section{DASYSTEPhana Adans. Ciosed Gentian.}

Testa of the seeds lamellose-rugose; the lamellae white, forming hexagonal areolas; basal leaf-rosette remaining at flowering time. I. D. Romanzovii.

Testa of the seeds smooth, but often produced into wings; basal rosette none.

Floral leaves more or less broadened and more or less scarious; seeds usually wingless.

Floral leaves narrow, not scarious; seeds winged.

2. D. Parryi.

Leaves all except the floral ones ovate, oblong or lanceolate.

Calyx-lobes well developed; calyx-tube truncate at the apex.

3. D. afinis.

Calyx-lobes none or minute; calyx-tube irregular, more or less lobed or cleft.

4. D. Forwoodii. 
Upper stem-leaves linear or lance-linear.

Flower-cluster dense; its branches and internodes very short.

Flower cluster lax, its branches and internodes elongated.

$$
\text { 5. D. Bigelovii. }
$$

6. D. interrupta.

I. Dasystephana Romanzovii (Ledb.) Rydb. (Gentiana Romanzovii Ledeb.; G. frigida A. Gray; not Haenke) On alpine peaks and in arctic regions from Mont. and Alaska to Colo. and Utah; also Asia.-Ait. I I,oooI4,000 ft.-Headwaters of Clear Creek; Gray's Peak; Gentian Ridge; Saddle Cliffs; Mt. Harvard; Alpine Tunnel; Mt. Ouray; Seven Lakes, near Pike's Peak; Georgetown; near Pagosa Peak; Dead Lake, near Pike's Peak; Devil's Causeway, White River Plateau; Cameron Pass; Berthoud Pass; Ethel Peak.

2. Dasystephana Parryi (Engelm.) Rydb. (Gentiana Parryi Engelm.) In the mountains from Wyo. to Colo. and Utah.-Alt. 8000-12,000 ft.-Trapper's Lake; Pike's Peak between Half-way House and Lake Mer; near Pagosa Peak; Westcliffe; Mt. Harvard; Artist's Glen near Pike's Peak; Georgetown; Seven Lakes; Marshall Pass; Ruxton Park; Grand Lake; Ironton Park, 9 miles south of Ouray; Red Mountain road, south of Ouray; Crested Butte; headwaters of Clear Creek; Red Mountain; Breckenridge; Sprague's, Estes Park; Leroux Parks, Delta Co.; Buffalo Pass; Empire; mountains between Sunshine and Ward.

3. Dasystephana affinis (Griseb.) Rydb. (Gentiana affinis Griseb.) In the mountain meadows from Sask, and Alb. to Colo.-Alt. 7000-12,000 ft. -Mountain meadows, Twin Lakes; Sand Creek Pass; Pike's Peak; Trail Glen; Crystal Park; Lake John, North Park; Colorado Springs; headwaters of Clear Creek, near Empire; between Porter and Durango; Sprague's, Estes Park; Medicine Bow Mountains.

4. Dasystephana Forwoodii (A. Gray) Rydb. (Gentiana Forwoodii A. Gray) On hills from Alb. to Colo.-Alt. 700o-I0,00o ft.-Gray's Peak; Sargent; Westcliffe; Twin Lakes; headwaters of Clear Creek near Empire; Pearl; Wolcott; Gunnison; Mt. Harvard; Lake City; Buena Vista; Gypsum Creek Cañon.

5. Dasytephana Bigelovii (A. Gray) Rydb. (Gentiana Bigelovii A. Gray) In the mountains from Colo. to N. M. and Ariz.-Alt: about 6000 ft.-Colorado Springs; Pike's Peak; Sprague's; Estes Park; west of Soldier Cañon.

6. Dasystephana interupta (Greene) Rydb. (Gentiana interupta Greene) In the mountains from Colo. to Nev.-Alt. about $8000 \mathrm{ft}$.-Kremmling; $\mathrm{Pa}-$ gosa Springs; Parlin, Gunnison Co.

\section{PLEUROGYNE Eschsch.}

I. Pleurogyne fontana A. Nels. ( $P$. rotata Hook., in part; not Griseb.; $P$. rotata tenuifolia Griseb.) In damp places from Hudson Bay and Alaska to Colo.-Alt. 8000-II,000 ft.-Twin Lakes; near Lake John, North Park; Jefferson, South Park; Caribou; headwaters of Clear Creek, near Empire; Beaver Creek.

\section{SWERTIA L.}

Flowers 4-merous.

1. S. scopulina.

Flowers 5-merous.

Inflorescence elongated; corolla-lobes linear or oblong. $\quad$ 2. S. palustris.

Inflorescence congested; corolla-lobes oval-elliptic.

3. S. congesta. 
1. Swertia scopulina Greene. In mountain meadows of Colo.-Alt. about I0,000 ft.-Keblar Pass.

2. Swertia palustris A. Nels. (S. perennis Am. auth.; not L.) In wet places from Mont. to Colo. and Utah.-Alt. 8000-I3,000 ft.-Pike's Peak; near Pagosa Peak; Stephen's Mine; 4 miles west of Cameron Pass; Crested Butte; Marshall Pass; near Ironton, San Juan Co.; Clear Lake; Gray's Peak; Artist's Glen near Pike's Peak; Georgetown; Hamor's Lake above Durango; Alpine Tunnel; Mt. Harvard; Ruxton Dell ; above timber line, Silver Plume; Breckenridge; headwaters of Clear Creek; Ragged Mountain, Gunnison Co.; Georgetown; Berthoud Pass; Buffalo Pass.

3. Swertia congesta A. Nels. In wet places in the alpine regions from Mont. to Colo. and Utah.-Alt. about I2,000 ft.-Seven Lakes.

\section{g. FRASERA Walt.}

Petals about $2 \mathrm{~cm}$. long, usually exceeded by the long sepals.

Plant glabrous; inflorescence simple with verticillate pedicels; basal leaves over I dm. wide.

1. F. macrophylla.

Plant puberulent; inflorescence compound; some branches simple, others again - branched; basal leaves about $5 \mathrm{~cm}$. wide.

Petals about $15 \mathrm{~mm}$. long or less; inflorescence compound.

Sepals narrowly linear, usually much exceeding the petals; floral leaves narrowly linear-lanceolate, very long.

3. F. sterosepala.

Sepals linear-lanceolate, scarcely equalling the petals; floral leaves similar to the upper stem-leaves, but smaller and narrower.

Stem-1eaves oblanceolate.

Stem-leaves linear-lanceolate.

4. F. speciosa.

5. $F$. angustifolia.

1. Frasera macrophylla Greene. On hills from Wyo. to Colo. and Utah.Alt. 9000-I0,000 ft.-Pagosa Springs; Keblar Pass; Ironton Park, 9 miles south of Ouray.

2. Frasera scabra (Jones) Rydb. (F. speciosa scabra Jones) On hills from Colo. to Ariz.-Alt. 8000-10,000 ft.-Bob Creek, West La Plata Mountains; Abiqua Peak.

3. Frasera stenosepala Rydb. On the hills from Wyo. to N. Mex.-Alt. 6000-9500 ft.-Foot-hills, Larimer Co.; Ward, Boulder Co.; The Crags, Pike's Peak; headwaters of Clear Creek, near Empire; Pike's Peak trail.

4. Frasera speciosa Doug1. On hills from S. D., Mont. and Ore. to Colo. and Calif.-Alt. 7000-I0,000 ft.-Sand Creek Pass; Manitou; Mt. Abram, Ouray; Cheyenne Mountain; Howe's Gulch; Bosworth's ranch, Stove Prairie; gulch west of Pennock's; Rist Cañon; Horsetooth Gulch; U.te Pass.

5. Frasera angustifolia Rydb. On dry hills from Mont. to Colo.-Mountains between Sunshine and Ward.

Family io8. MENYANThaCEAE G. Don. Buckbean Familx.

1. Menyanthes L. Buckbean, Marsh Trifoll.

1. Menyanthes trifoliata L. In water from Greenl. and Alaska to Pa. and Calif.; also in Europe and Asia.-Estes Park, Larimer Co. 


\section{Order 43. ASCLEPIADALES.}

Styles united; stamens distinct or gynandrous; pollen loosely granular. I09. ApoCYNACEAE.

Styles distinct; stamens monadelphous; pollen united into waxy masses or the grains in groups of 4 .

ito. Asclepiadaceae.

\section{Family rog. APOCYNACEAE Lindl. Dogbane Family.}

Anthers unappendaged at the base, not connected with the stigma; flowers without a disk; leaves alternate.

1. AmSONIA,

Anthers appendaged at the base, converging around the stigma and slightly adhering to it; calyx-tube partly attached to the gynoecium by the thick disk; leaves opposite.

2. APOCYNUM.

\section{AMSONIA Walt.}

1. Amsonia texana (A. Gray) Heller. (A. angustifolia texana A. Gray) In rocky places from Texas to Colo.-Grand Junction.

\section{APOCYNUM L. Dogbone, Indian Hemp.}

Corolla fully twice as long as the calyx; its lobes spreading in anthesis.

Leaves more or less pubescent beneath.

Sepals broadly lanceolate; corolla open campanulate; leaves thick, dark green, decidedly pubescent beneath.

Leaves oval, acute at both ends; plant usually tall.

1. A. androsemaefolium. plant low, diffuse. $\quad$ 2. A. scopulorum.

Sepals narrowly lanceolate; corolla narrower, almost cylindro-campanulate; leaves pale green, pubescent merely on the petioles and the veins beneath, the lower truncate, the upper acute at the base. 3. A. lividum.
Leaves perfectly glabrous.
4. A. anbigens.

Corolla less than twice as long as the calyx; its lobes erect or nearly so.

Leaves acute at the base, petioled.

5. A. cannabinum.

Leaves, at least those of the main stem, truncate or subcordate at the base and subsessile.

6. A. hypericifolium.

I. Apocynum androsemaefolium L. In copses and borders of woods from Anticosti and Ida. to Ga. and Ariz.-Alt. 7000-9500 ft.-Artist's Glen; Engelmann Cañon; Wahatoya Creek; mountains, Larimer Co.; Stove Prairie Hill; Horsetooth.

2. Apocynum scopulorum Greene. In the mountains from Sask. and Yukon to Colo--Alt. 5000-9000 ft.-Pagosa Springs; Mancos; Roger's, Gunnison watershed.

3. Apocynum lividum Greene. In the mountains of Colo.-Alt. 5000-8000 ft.-Black Cañon; mouth of Cheyenne Cañon; Mancos; Piedra; Palisade; Clear Creek Cañon; Ft. Collins.

4. Apocynum ambigens Greene. In the mountains from Mont. and Wash. to Colo. and Calif.-Alt. 6000-900o ft.-West of Ouray; Black Cañon; Boulder Cañon; Rist Cañon; Horsetooth Mountain; Montrose; Steamboat Springs.

5. Apocynum cannabinum L. On banks of streams from Anticosti and Wash. to Fla. and L. Calif.-Alt. 4000-5000 ft.-Deer River; New Windsor, Weld Co.; Boulder; along the Poudre; Ft. Collins.

6. Apocynum hypericifolium Ait. In sandy soil from Ont. and B. C. to Ohio and N. M.-Alt. 5000-6000 ft.-Plains and foot-hills near Boulder. 


\section{Family i o. ASCLEPIADACEAE Lindl. Milkweed Family.}

Corolla-lobes reflexed during anthesis.

Hoods of the crown crestless within or with an obscure crest-like midrib. Corolla-lobes erect-spreading during anthesis; hoods with a crest at least above.

\section{ACERATES Ell. Green Milkweed.}

Auricles of the hood, when present, concealed within; leaves oval to linearlanceolate.

I. A. viridiflora.

Auricles of the hoods conspicuously spreading; umbels lateral; leaves narrowly linear.

Hoods emarginate or truncate at the summit, crestless within; umbels distinctly peduncled.

2. A. auriculata.

Hoods trilobed at the summit with an internal crest-like midrib terminating in the middle lobe; umbels subsessile or on very short peduncles.

3. A. angustifolia.

1. Acerates viridiflora (Raf.) Eat. In dry or sandy soil from Mass. and Mont. to Fla. and N. M.-Alt. 4000-6000 ft.-Fossil Creek, Larimer Co.; Horsetooth Mountain; Boulder; Berkeley; Valverde.

.. Acerates auriculata Engelm. On dry plains from Neb. and Colo. to Tex. and N. M.-Alt. 4000-5000 ft.-Cañon City; Ft. Collins; Horsetooth Gulch; Denver; Valverde; Montclair.

3. Acerates angustifolia (Nutt.) Decaisne. (Asclepias stenophylla A. Gray) In sandy soil from S. D. and Colo. to Mo., Tex. and N. M.-Exact locality not given.

\section{ASClEpias L. Milkweed, Silkweed,}

Leaves orbicular to linear-lanceolate, opposite.

Follicles with soft spinulose processes, tomentose; leaves large and broad, tomentose, transversely veined, oval or ovate.

Follicles without processes.

Flowers very large; petals over I $\mathrm{cm}$. long; column none; horns included in the hoods; leaves almost orbicular, subcordate at the base.

2. A. cryptoceras.

Flowers middle-sized or small; petals much less than I cm. long; column usually present and horns exserted.

Leaves broadly oval or rectangular oval or nearly orbicular, obtuse or retuse at both ends; umbels sessile.

Plant puberulent when young, glabrate in age; column very short. 3. A. latifolia.

Plant tomentulose; column half as long as the anthers.

Leaves ovate or lanceolate, or rarely oval, acute.

4. A. arenaria.

Leaves ovate or ovate-lanceolate, more or less tomentose at least when young; hoods ovate-oblong to lanceolate, much exceeding the stamens. 5. A. Hallii.

Leaves linear-lanceolate; hoods truncate, little if any longer than the anthers.

Column short; leaves pale, tomentose or puberulent when young. Hoods about half as long as the anthers; umbels peduncled.

6. A. brachystephano

Hoods only slightly shorter than the anthers; umbels subsessile. 7. A. uncinalis.

Column more than half as long as the anthers; corolla purple; leaves glabrous.

8. A. incarnata. 
Leaves narrowly linear, verticillate or scattered.

Plant tall, 4-6 dm. high from a rootstock; leaves verticillate.

Hoods entire.

Hoods dorsally hastate-sagittate. Io. A. galioides.

9. A. verticillata.

Plant low, $1-2 \mathrm{dm}$. high, bushy from a ligneous base; leaves scattered.

I . A. pumila.

I. Asclepias speciosa Torr. On river bottoms and in fields from Man. and B. C. to N. M. and Calif.-Alt. $4000-8000^{\circ} \mathrm{ft} .-\mathrm{Ft}$. Collins; Mancos; Denver; Wahatoya Cañon; Piedra; Colorado Springs; Grand Junction; Boulder.

2. Asclepias cryptoceras S. Wats. In dry soil from Ida. and Ore. to Colo. -Grand Junction.

3. Asclepias latifolia (Torr.) Raf. ( $A$. obtusifolia latifolia Torr.; $A$. Jamesii Torr.) On plains from Colo. to Tex. and Ariz.-Hotchkiss; Cañon City.

4. Asclepias arenaria Torr. In sandy soil from Neb. and Colo. to Okl. and N. M.-Locality not given.

5. Asclepias Hallii A. Gray. In gravelly soil in Colo.-Alt. 7000-9000 ft.Calhan; Veta Pass; Gunnison; La Veta; Buena Vista; Arkansas River.

6. Asclepias brachystephana Engelm. In sandy soil from Wyo. to Tex. and Ariz.- "On the plains."

7. Asclepias uncialis Greene. In sandy soil from Wyo. to $N$. M. and Ariz.- "Colorado" (Hall \& Harbour).

8. Asclepias incarnata L. In swamps and wet meadows from N. B. and Man. to Fla. and N. M.-Alt. 4000-6000 ft.-Ft. Collins; Timnath, Larimer Co.; Denver; Cache la Poudre; Boulder.

9. Asclepias verticillata $L$. In dry fields and on hills from Me. and N. D. to Fla. and Ariz.--Rocky Ford; Paonia; Colorado Springs.

ro. Asclepias galioides H. B. K. In dry soil from Kans. and Colo. to Ark. and Ariz.; also Mex.-Exact locality not given.

II. Asclepias pumila (A. Gray) Vail. (A. verticillata pumila A. Gray) Dry plains and in sandy soil from S. D. and Mont. to Ark. and N. M.Alt. 4000-7000 ft.-Near Ft. Collins; East Park, Denver; headwaters of Clear Creek; Boulder; Colorado Springs; along Platte River, Denver; Ft. Collins; Manitou; gulch, Soldier Cañon; Boulder.

\section{ASCLEPIODORA A. Gray.}

I. Asclepiodora decumbens (Nutt.) A. Gray. In dry sandy soil from Kans. and Nev. to Ark., Tex. and Ariz.; also Mex.-Alt. $7000-8000 \mathrm{ft}$.-Near Badito, between La Veta and Gardner; Arboles; Hortense Springs; Durango; Walsenburg; Dolores.

\section{Order 44. POLEMONIALES.}

Stamens 5 , if only 4 , not didynamous.

Fruit a capsule or berry; ovary not 4-lobed.

Styles or stigmas usually distinct.

Parasitic twining plants with scale-like leaves. III. Cuscutaceae.

Plants not parasitic; leaves normal.

Inflorescence not scorpoid; flowers cymose or solitary; ovary z-3-celled; micropyle of the seed turned downward. 
Corolla plaited and the plaits convolute in the bud; flowers axillary, solitary or cymose-conglomerate; plants usually twining.

II 2. Convolvulaceae.

Corolla merely convolute in the bud, not plaited; flowers cymose; plants never twining. II3. Polemontaceae.

Inflorescence more or less distinctly scorpoid; ovary in ours I-celled or imperfectly 2-celled; micropyle of the seed turned upwards.

Styles and stigmas wholly united.

I I 4. HYDROLEACEAE.

Ovules few.

Ovules numerous.

Median axis of the gynoecium in the same plane as the axis of the stem; seeds mostly pitted. I I9. SOLAN ACEAE.

Median axis of the gynoecium not in the same plane as the axis of the stem; seed tuberculated (Verbascum). I 20. RHINANTHACEAE.

Fruit of $\mathrm{I}-4$ nutlets (in all our genera) ; ovary more or less distinctly 4 -lobed.

Style or stigma furnished with a glandular ring. in Helotropaceas.

Style or stigma not furnished with a glandular ring. II6. Boraginaceat.

Stamens 4 and didynamous, or 2 or $\mathrm{I}$.

Carpels ripening into 4 nutlets, an achene or a drupe.

Style apical on the lobeless ovary.

Style arising between the 4 lobes of the ovary.

II7. VERBENACEAE.

I I8. LAMINACEAE.

Carpels ripening into a capsule.

Placentae of the ovary axile.

Ovary 2-celled, rarely 3-5-celled; land-plants.

Ovary I-celled; ours submerged water-plants.

I20. RHINANTHACEAE.

i 21 . Pinguiculaceae.

Placentae of the ovary parietal.

Herbs parasitic on the roots of other plants; leaves scale-like, not green.

Herbs with green leaves; not parasitic.

I 22. Oroban chaceae.

I23. Martyniaceae.

\section{Family ir r. CUSCUTACEAE Dumont. Dodder Family.}

\section{CUSCUTA L. DODDER.}

Styles equal with elongated stigmas.

1. C. epithymun.

Styles unequal; stigma capitate.

Capsules circumscissile; calyx- and corolla-lobes acuminate; inflorescence umbel-like.

Capsule indehiscent or bursting irregularly.

Calyx gamosepalous, usually not bracted.

2. C. umbellata.

Corolla-lobes not incurved.

Scales of the corolla incurved upon the ovary; styles about half as long as the ovary or longer.

3. C. Gronovii.

Scales of the corolla appressed to the corolla-tube; styles $1 / 4-1 / 3$ as long as the ovary.

Corolla-lobes incurved at the apex.

4. C. curta.

Capsule $4 \mathrm{~mm}$. or less broad; inflorescence rather open.

Capsule 5-6 mm. broad; inflorescence globular clusters.

5. C. indecora.

6. C. megalocarpa.

Calyx of 5 almost distinct and overlapping sepals, subtended by 2 or more similar bracts.

7. C. cuspidata.

I. Cuscuta epithymum L. On clover, alfalfa, etc.; introduced from Europe.-Ft. Collins.

2. Cuscuta umbellata H. B. K. On low herbs, especially on Portulaca, from Colo. to Tex. and Ariz.; also in Mex.-Hovenweep Cañon (Brandegee).

3. Cuscuta Gronovii Willd. On low shrubs and coarse herbs from N. S. and Man. to Fla., Tex. and Colo.-Manitou. 
4. Cuscuta curta Engelm. (C. Gronovii curta Engelm.) On coarse herbs in sandy soil in Utah and Colo.-Alt. about $7000 \mathrm{ft}$-Dome Rock in Platte Cañon.

5. Cuscuta indecora Choisy. On herbs, mostly composites and leguminous plants, commonest on Ambrosia artemisiaefolia and Glycyrrhiza lepiota; from Ills. and Neb. to Fla, and Calif.-Alt. 4000-5000 ft.-Ft. Collins.

6. Cuscuta megalocarpa Rydb. On willows; in Colo. and Wyo.-Alt. about $7000 \mathrm{ft}$-Cucharas Creek near La Veta.

7. Cuscuta cuspidata Engelm. On Ambrosia, Iva and some leguminous plants from Mo. and Neb. to Tex. and Colo.-Alt. 4000-5000 ft.-Ft. Collins.

Family i 12 . CONVOLVULACEAE Vent. Morning-glory Family.

Styles distinct, each 2-cleft.

Styles united up to the stigmas.

Stigmas ovoid or subglobose.

Stigmas filiform to oblong-cylindric.
1. Evolvulus.

2. IPOMOEA.

3. Convozvulus.

\section{EVOLVULUS L.}

I. Evolvulus Nuttallianus R. \& S. (E. argenteus Pursh; not R. Br.; E. pilosus Nutt.; not Lam.) In sandy soils and on sterile plains from S. D. and Colo. to Tex. and Ariz.; also Mex.-Alt. 4000-6000 ft.-Cañon City; along Platte River, Denver; Fossil Creek, Larimer Co.; Trinidad; Ft. Collins ; near Boulder; Ouray; Dixon Cañon.

2. IPOMOEA L. MORNING-GLORY.

ז. Ipomoea leptophylla Torr. On plains and hillsides from S. D. and Wyo. to Tex. and N. M.-Alt. 4000-5000 ft.-Denver; Rocky Ford; bank of Arkansas River.

\section{Convolvulus L. Wild Morning-glory, Bindweed.}

Bracts small, remote from the calyx.

Plant not canescent; leaf-blades hastate, but otherwise entire.

Whole plant glabrous or nearly so.

Stem and lower surface of the leaves with scattered long hairs.

2. C. ambigens.

Plant more or less canescent; leaves usually lobed or dissected.

Main divisions of the leaf-blades ovate or oblong, obtuse, lobed.

3. C. hermannioides.

Main divisions of the leaf-blades linear, entire; the basal lobes usually cleft deeply.

Bracts large, close under the calyx and enclosing it.

Leaf-blades hastate; the basal lobes often sinuate-dentate, acute; stem and leaves glabrous or slightly hairy.

5. C. americanis.

Leaf-blades more sagittate; basal lobes rounded, entire; stem and leaves densely pubescent.

6. C. interior.

I. Convolvulus arvensis L. Naturalized from Europe, growing in fields and waste places from N. S. and Mont. to N. J. and Colo.-Durango.

2. Convolvulus ambigens House. In loose or sandy soil from Colo. to N. M. and Calif.-Alt. 5000-6000 ft.-Plains near Boulder; Ft. Collins. 
3. Convolvulus hermannioides A. Gray. Dry plains and in sandy soil from Neb. and Colo, to Tex.-Trinidad.

4. Convolvulus incanus Vahl. On dry plains from Colo. to Tex. and Ariz.; also Mex.-Alt. $4000-5500 \mathrm{ft}$-Cañon City; Brantly Cañon, Las Animas Co.; Trinidad.

5. Convolvulus americanus (Sims) Greene. (C. sepium americanus Sims) Among bushes from N. S. and Wash. to N. C. and N. M.-Alt. 4000-7000 ft.-Walsenburg; Cucharas Valley near La Veta; Colorado Springs; Denver; Ouray; Ft. Collins.

6. Convolvulus interior House. In sandy soil from Neb. and Colo. to Ind. Terr. and Ariz.-Ft. Collins.

\section{Family II3. POLEMONIACEAE Vent. Phlox Family.}

Calyx at length ruptured by the maturing capsule.

Calyx-tube more or less scarious between the lobes distended and then ruptured by the capsule.

Corolla strictly salver-shaped with a narrow throat; leaves proper opposite; seeds without spiracles.

Seeds not altered when wetted; our species all perennials with all the leaves opposite.

1. Phlox.

Seeds mucilaginous when wetted; annuals with floral leaves alternate. 2. Microsteris.

Corolla funnelform or tubular with an open funnelform throat; seeds mucilaginous when wetted.

Stem leafy; bracts not connate.

Leaves opposite; inflorescence cymose and dichotomously branched; seeds without spiracles. 3 . Linanthus.

Leaves alternate; inflorescence paniculate or capitate; seeds usually producing spiracles (spirally twisted threads) when wetted.

4. Gilia.

Stem without proper leaves, but with persistent connate cotyledons; bracts of the capitate inflorescence leaf-like and connate at the base.

5. Grmnosteris.

Calyx-tube not at all scarious, early splitting without being distended; lobes and leaves more or less spinulose-pointed; seeds without both spiracles and mucilage.

6. LEPTODAC'TYLON.

Calyx not ruptured by the capsule; leaves alternate; seeds with mucilage and spiracles when wetted.

Calyx-teeth spinulose-tipped; leaves pinnatifid; flowers capitate.

Calyx-teeth herbaceous, not spinulose-tipped.

7. NavarRetia.

Stamens straight; leaves simple, in ours entire.

8. Collomia.

Stamens declined; leaves pinnate.

9. Polemonium.

\section{Phlox L. Phlox.}

Intercostal portion of the calyx not replicate.

Leaves beset with cob-webby hairs; plants densely pulvinate-cespitose.

Leaves ovate to lanceolate, densely arachnoid-lanate, mucronate-tipped, but scarcely acerose.

Leaves subulate, acerose, sparsely arachnoid.
Leaves not cob-webby, except sometimes slightly so at the base.

I. P. bryoides.

Leaves glabrous, or merely cob-webby at the base, not glandulose.

Calyx over $8 \mathrm{~mm}$. long; its teeth longer than the tube.

Calyx and the bases of the leaves arachnoid-hairy.

Calyx and stem finely villous or glabrous; leaves not arachnoid. 
Calyx over I cm. long; leaves flat; margins not revolute; stem 5-10 $\mathrm{cm}$. high.

4. P. multiflora.

Calyx less than I $\mathrm{cm}$. long; leaves very narrow with revolute margins. 5. P. depressa.

Calyx less than $8 \mathrm{~mm}$. long; its lobes much shorter than the tube.

6. P. scleranthifolia.

Leaves hispid-ciliate on the margin, usually with more or less glandular hairs.

Leaves linear to subulate, not with thickened margins.

Leaves less than I $\mathrm{cm}$. long; plant densely pulvinate-cespitose; limb of corolla seldom over I $\mathrm{cm}$. broad.

Leaves almost erect, appressed; corolla-limb 6-8 $\mathrm{mm}$. wide.

$7 . P$. condensata.

Leaves ascending-spreading; corolla-limb about io mm. wide.

8. P. caespitosa.

Leaves over I $\mathrm{cm}$. long; plant cespitose, but not pulvinate; corolla-limb $12-20 \mathrm{~mm}$. wide.

9. P. Kelseyi.

Leaves oblong or broadly linear with a more or less thickened and cartilaginous margin.

Leaves linear, I-2 cm. long; margins not very thick; corolla-tube twice as long as the calyx; young stems white-angled. 9. $P$. Kelseyi.

Leaves oblong with very thick margins, $7-12 \mathrm{~mm}$. long; corolla-tube not twice as long as the calyx; young stems not white-angled.

Io. $P$. alyssifolia.

Intercostal portion of the calyx replicate.

Leaves long-attenuate, not thick; only upper portion of the plant glandular; corolla scarcely twice as long as the calyx. II. $P$. longifolia.

Leaves obtusish or abruptly acute, thick and firm; corolla-tube fully twice as long as the calyx; plant conspicuously glandular. I2. P. Stansburyi.

I. Phlox bryoides Nutt. On dry hills from Neb, and Wyo. to Colo. and Utah.-Livermore, Larimer Co.

2. Phlox canescens T. \& G. On dry hills from Mont. to Colo. and Calif.Colorado, according to Gray, but doubtful.

3. Phlox andicola Nutt. In sandy soil and on hills from S. D. and Ida. to Colo.-Pike's Peak; Ouray.

4. Phlox multiflora A. Nelson. In the mountains from Mont. to Colo.Alt. 5000-10,000 ft.-North Boulder Peak; mountain near Veta Pass; Jack's Cabin, Gunnison watershed; Columbine; west of Ft. Collins; Rist Cañon; North Park; Minturn; Beaver Creek.

5. Phlox depressa (E. Nels.) Rydb. (Phlox multiflora depressa E. Nels.) In the mountains from Mont. and Ida. to Colo.-_."Colorado."

6. Phlox scleranthifolia Rydb. On mountain sides from S. D. and Mont. to Colo.-Alt. I0,000-I3,000 ft.-West Spanish Peak.

7. Phlox condensata (A. Gray) E. Nelson. (P. caespitosa condensata A. Gray) In the mountains of Colo.-Alt. 12,000-I3,000 ft.-Uncompahgre Peak; headwaters of Clear Creek; Sierra Blanca; mountains above Como; Alpine Tunnel; northwest of Como; Boreas.

8. Phlox caespitosa Nutt. On rocky hills and mountains from Mont. and B. C. to Colo. and Ore.-Alt. I0,000-13,000 ft.-West Spanish Peak; Mt. Hesperus; northwest of Como.

9. Phlox Kelseyi Britton. In valleys from N. D. and Mont. to Colo.-Alt. up to I2,000 ft.-Little Kate Basin, La Plata Mountains.

Io. Phlox alyssifolia Greene. On hills from S. D. and Ass. to Colo.Exact locality not given (Hall \& Harbour). 
I1. Phlox longifolia Nutt. In valleys and on hills from Mont. and Wash. to Colo. and Ore.-Mancos; Leroux Creek, Delta Co.; Palisade, Mesa Co.; Minturn.

12. Phlox Stansburyi (Torr.) Heller. (P. speciosa Stansburyi Torr.) In dry regions from Colo. to N. M. and Calif.-Alt. 7000-8000 ft.-Los Pinos (Bayfield); Middle Park; Cerro Summit; Mancos; Hotchkiss; Cimarron; Palisades; Dolores.

\section{MICROSTERIS Greene.}

2. Microsteris micrantha (Kellogg) Greene. (Collomia micrantha Kellogg; C. gracilis A. Gray, in part) In sandy soil from Neb. and Wyo. to Colo. and Calif.-Alt. 4000-9000 ft.-Los Pinos (Bayfield); Veta Pass; headwaters of Sangre de Cristo Creek; west of Ft. Collins; southeast of La Veta; Mancos Cañon; Cedar Edge, Gunnison watershed; near Denver; Horsetooth Gulch; gulch west of Soldier Cañon; Trinidad; Boulder; Buena Vista.

\section{LINANTHUS Benth.}

I. Linanthus Harknessii (Curran) Greene. (Gilia Harknessii Curran; G. pharnaceoides A. Gray, in part) In sandy or loose soil from Mont. and B. C. to Colo. and Calif.-Middle Park; Steamboat Springs.

\section{GILIA R. \& P.}

Flowers capitately or spicately glomerate.

Perennials; flowers in dense heads or spikes.

Leaves entire.

Leaves at least some of them pinnatifid.

1. G. spergulifolia.

Plant branched only at the base or simple; stem or branches strict, with a single head-like or spike-like inflorescence.

Inflorescence spike-like, more or less interrupted; corolla greenishwhite, its lobes acute.

Inflorescence head-like; corolla white, its lobes obtuse.

2. G. spicata.

3. G. cephaloidea.

Plants branched above as well as the base; inflorescence of several heads, more or less corymbosely arranged.

Corolla-lobes about $2 \mathrm{~mm}$. long; calyx-teeth and bracts green with very short spine-tips; branches straw-color. 4. G. iberidifolia.

Corolla-lobes $4-5 \mathrm{~mm}$. long; calyx-lobes and bracts rose-tinged with long spine-tips; stems tinged with purple.

5. G. roseata.

Annuals, repeatedly branched, with small clusters of flowers in the axils of the leaves, more capitate at the ends of the branches.

Divisions of the leaves linear-filiform; floral leaves similar; corolla twice as long as the calyx. 6. G. pumila.

Divisions of the leaves very short, oblong; floral leaves broader and shorter, more entire; tube of the corolla slightly exceeding the calyx.

Flowers openly paniculate or thyrsoid-paniculate. 7. G. polycladon.

Leaves pinnately divided.

Corolla-tube over I cm. long; corolla salver-form; calyx-lobes lanceolate, attenuate and spine-tipped.

Inflorescence thyrsoid, narrow.

Corolla-lobes acute or acuminate; corolla ustally scarlet or pink. Calyx only slightly scarious at the angles; its lobes lanceolate-attenuate, longer than the tube. 
Calyx and inflorescence glandular-puberulent, not long-hairy.

8. G. aggregata.

Calyx and usually also the inflorescence with long white flat hairs as well as glandular-puberulent.

9. G. pulchella.

Calyx very scarious at the angles; its teeth shorter than the tube; corolla-lobes acute.

I0. G. scariosa.

Corolla-lobes rounded or obtuse at the apex; corolla white.

Inflorescence open and inclined to be flat-topped.

Corolla-tube $3-4 \mathrm{~cm}$. long; its lobes obtuse.

Corolla-tube $1.5-2.5 \mathrm{~cm}$. long; its lobes acute.

Corolla-tube less than I cm. long.

Stamens exserted; corolla salverform.

Divisions of the leaves all linear-filiform, not wider than the rachis; corolla about I cm. long. I4. G. polyantha.

Divisions at least of the lower leaves obovate or oblong, much broader than the rachis; corolla 5-7 $\mathrm{mm}$. long.

Stamens not exserted; corolla more or less funnelform.

Corolla 7-12 mm. long; plant leafy throughout.

Corolla-tube distinctly exserted from the calyx; leaves mostly basal or the stem-leaves reduced.

16. G. simuata.

Corolla-tube scarcely exserted from the calyx; plant more leafy.

17. G. inconspicua.

Corolla $4-5 \mathrm{~mm}$. long.

Plant leafy only at the base; divisions short and broad; corolla about twice as long as the calyx. I8. G. subacaulis.

Plant leafy throughout; divisions of the leaves narrow, filiform; corolla only slightly exceeding the calyx. I9. G. minutifora.

Leaves entire or the lower ones toothed or lobed.

Basal leaves toothed or lobed.

Flowers $\mathrm{r} \mathrm{cm}$. long or more.

Stem-leaves oblanceolate, often toothed; stem rather stout; capsule 5 mm. long, acute.

20. G. Crandallii.

Stem-leaves lanceolate-subulate, entire; stem very slender; capsule 3.5 $\mathrm{mm}$. long, obtuse.

Flowers less than I cm. long.

2I. G. Haydeni.

Flowers less than
Basal leaves entire.

Basal leaves oblanceolate or spatulate.

Leaves petioled; corolla much exserted.

22. G. leptomeria.

Leaves sessile, fleshy; corolla scarcely exserted. 24. G. sedifolia.

All leaves filiform or the lower 3-parted with filiform lobes.

I9. G. minutiflora.

I. Gilia spergulifolia Rydb. On dry hills in Wyo. and Colo. to Utah.Arboles.

2. Gilia spicata Nutt. On dry hills from Neb. and Wyo. to Colo. and Utah.-Alt. 4000-I0,000 ft.-Headwaters of Clear Creek; Livermore, Larimer Co.; Turkey Creek and tributaries; mesas near Pueblo; Ft. Collins; plains, Larimer Co.; Morrison; Tobe Miller's ranch; mountains between Sunshine and Ward.

3. Gilia cephaloidea Rydb. On dry hills from Mont. to Colo.-Alt. I I,000I2,000 ft.-Mountains above Como; above Boreas.

4. Gilia iberidifolia Benth. In "bad lands" and on dry hills from S. D. and Mont. to Colo. and Nev.-Alt. 5000-7500 ft.-Grand Junction; Dolores.

5. Gilia roseata Rydb. In arid soil, western Colo.-Grand Junction.

6. Gilia pumila Nutt. In dry soil from Wyo. to western Texas and Ariz.-Alt. 5000-7000 ft.-Mancos; Grand Junction; Apishipa Creek, Otero Co. 
7. Gilia polycladon Torr. In cañons from Colo. and Nev. to W. Tex.-Alt. 4000-5000 ft.-Cañon of Grand River; Grand Junction.

8. Gilia aggregata (Pursh) Spreng. In open glades and on hills from B. C. and Mont. to Colo. and Utah,-Alt. 7000-900o ft.-Black Cañon, Gunnison watershed; Larimer Co.; West Mancos Cañon; Rabbit-Ear Pass; Dolorẹs; Medicine Bow Mountains; Dillon Cañon, Trinidad; Hotchkiss; Sherwood; Steamboat Springs; Brant's Soda Springs.

9. Gilia pulchella Dougl. (G. aggregata attenuata A. Gray) On open hills and plains from Ida. to Colo. and Utah.-Alt. 8000-9000 ft.-Middle Park; Arboles; West Indian Creek; Grizzly Creek; Pinkham Creek; Rabbit-Ear Range, Routt Co.

ro. Gilia scariosa Rydb. On open hills in Colo.-Alt. 7000-9000 ft.-Headwaters of Clear Creek near Empire; Pike's Peak; Grizzly Creek; Garden of the Gods; Grayback mining camps and Placer Gulch; Minnehaha, Pike's Peak; Veta Pass; Mancos Cañon; divide between Colorado Springs and Denver; Empire; Table Rock; Denver; Palmer Lake.

II. Gilia candida Rydb. In open valleys of Colo.-Alt. 8000-10,000 ft.South Boulder Peak; Calhan; Veta Pass; Colorado Springs; mountains between Sunshine and Ward.

12. Gilia longiflora Don. In sandy soil and on plains from Neb. and Colo. to Tex. and Ariz.; also Mex.-Alt. 4000-5000 ft.-Sterling, Logan Co.; Alamosa; Ft. Collins; Pike's Peak; Salida.

13. Gilia laxiflora (Coult.) Osterh. (G. longiflora laxiflora Coult.) On plains from Colo. and Utah to N. M.-Alt. 5000-7000 ft.-New Windsor; Denver; Walsenburg; Cucharas Valley, near La Veta; Trinidad; Ft. Collins.

14. Gilia polyantha Rydb. (G. exserta A. Nels.) In dry places, in Colo.Pagosa Springs; Hotchkiss, Delta Co.

I5. Gilia pinnatifida Nutt. In sandy soil from Neb. and Wyo. to N. M. -Alt. 4000-r4,000 ft.-Headwaters of Clear Creek; Cheyenne Cañon, near Pike's Peak; Colorado Springs; Georgetown; Sangre de Cristo Creek; Indian Creek Pass; Middle Park; Calhan; Manitou; Boulder; cañon of the Cache la Poudre; west of Ouray; Mt. Harvard; Uncompahgre River near Ouray; Pike's Peak; Ouray; Colorado Springs; Marshall Pass; Gunnison; below Carson; Boreas; Palmer Lake; Manitou Junction; Table Rock; forks of Poudre and Big South; mountains between Sunshine and Ward; Boulder.

I6. Gilia sinuata Benth. In sandy soil from Colo. to N. M. and Calif.Alt. 5000-6000 ft.-Walsenburg; Arboles; foot-hills near Golden.

17. Gilia inconspicua Dougl. On hillsides from Colo. and Utah to Ariz.; also Mex.-Alt. $6000-8000$ ft.-Butte 5 miles southwest of La Veta; Wahatoya Cañon; Crystal Creek; Larimer Co.; Rist Cañon; Horsetooth Gulch; Spring Cañon; Boulder; Palmer Lake; Hotchkiss.

18. Gilia subacaulis Rydb. In sandy soil from Wyo. to Colo, and Utah.Gunnison River; Grand Cañon.

19. Gilia minutiflora Benth. On plains and in sandy soil, from Mont. and Ore. to Colo.-Steamboat Springs.

20. Gilia Crandallii Rydb. Sage plains from Colo. and Nev. to N. M.Alt. about $7000 \mathrm{ft.}-$ Durango; Mancos. 
2I. Gilia Haydeni A. Gray. Dry plains of Colo.-Plains of the Mancos; San Juan; Mesa Verde and El Late (Brandegee).

22. Gilia leptomeria A. Gray. In dry soil from Colo, and Utah to $N$. M. and Calif.-Alt. 4000-5000 ft.-Deer Run, Gunnison watershed; Grand Junction.

23. Gilia pentstemonoides M. E. Jones. On rocks in Colorado.-Cimarron.

24. Gilia sedifolia Brand. On mountains in Colo.-Sheep Mountain, Uncompahgre Range.

\section{GYMNOSTERIS Greene.}

1. Gymnosteris nudicaulis (H. \& A.) Greene. In sandy soil from Ore. to Nev, and Colo. (Gray).

\section{LEPTODACTYLON Nutt.}

Leaves alternate; stem woody throughout.

Leaves opposite; stem woody only at the base.

Leaves decidedly pungent; ovules numerous.

Leaves scarcely pungent; ovules $2-3$ in each cell.

1. L. pungens.

2. L. Watsonii.

3. L. Nuttallii.

I. Leptodactylon pungens (Torr.) Nutt. (Cantua pungens Torr.; Gilia pungens Benth.) In sandy valleys and on hillsides, Mont. and Wash. to Colo. and Calif.-Alt. 6000-9000 ft.-Black Cañon; Gunnison; New Windsor, Weld Co.; mountains, Larimer Co.; Walsenburg; headwaters of Sangre de Cristo Creek; Denver.

๘. Leptodactylon Watsonii (A. Gray) Rydb. (Gilia Watsonii A. Gray) Rocky hills in Utah and Colo.-Alt. up to $5000 \mathrm{ft}$.-Grand Junction; Glenwood Springs.

3. Leptodactylon Nuttallii (A. Gray) Rydb. (Gilia Nuttallii A. Gray) In the mountains from Wyo, and Wash. to Colo. and Calif.-Alt 900o-I I,000 ft.-Arkansas Junction, near Leadville; Robinson; Tennessee Pass, Lake Co.; near Pagosa Peak; Oro City; Continental Divide, Routt Co.; Rabbit-Ear Pass; La Plata Cañon; Ragged Mountain; Florence; Rabbit-Ears, Larimer Co.

\section{NAVARRETIA R. \& P.}

I. Navarretia minima Nutt. In dry soil from Sask. and Wash. to Neb., Ariz. and Calif.-Alt. 4000-9000 ft.-Steamboat Springs; Bear River; Delta Co.; Hebron.

\section{COLLOMIA Nutt.}

I. Collomia linearis Nutt. In dry and sandy soil from N. D. and B. C. to Neb. and Calif; also introduced in N. B. and N. Y.-Alt. 4000-9000 ft:Larimer Co.; Chicken Creek, West La Plata Mountains; Mancos; North Park, near Teller; Steamboat Springs; Poverty Ridge, near Cimarron; Ward, Boulder Co.; Jack's Cañon, Gunnison watershed; divide road tó Steamboat Springs; Parlin, Gunnison Co.; La Veta; Idaho Springs; Durango; headwaters of Pass Creek; Pagosa Springs; Grayback mining camips and Placer Gulch; Mt. Richtofen on the Michigan; Platte Cañon; Table Rock; the Narrows; Dolores; Rist Cañon; Horsetooth Gulch; Monument; Poudre River; Boulder. 


\section{POLEMONIUM L. JACOB'S LADDER.}

Corolla campanulate; filaments with pilose appendages at the base; inflorescence usually open; leaflets never verticillate.

Low, I-3 dm. high, cespitose; basal leaves numerous and stem-leaves few. Stem and leaves viscid-pubescent with long flat hairs.

Calyx-lobes broadly lanceolate; pedicels in anthesis shorter than the flowers. 1. P. scopulinum.

Calyx-lobes narrowly lanceolate; pedicels in anthesis usually equalling or exceeding the flowers.

Stem and leaves viscid-puberulent; the latter often glabrate.

$$
\text { 2. P. delicatum. }
$$

3. $P$. parviflorum.

Stem tall, leafy, usually solitary from the rootstock, 4-1o dm. high.

Inflorescence narrow, dense, thyrsoid.

Plants with a slender rootstock, not long-villous. $\quad 4$. P. occidentale.

Plants with a woody base; stem and leaves long-villous.

Inflorescence open and broad.

Corolla $2 \mathrm{~cm}$. high or nearly so; leaves glabrous. 5. P. grande.

Corolla 8-I $5 \mathrm{~mm}$. high; leaves pubescent.

Stem and inflorescence long-villous, scarcely at all viscid.

6. P. molle.

Stem and inflorescence short-hairy; the latter at least distinctly viscid. Corolla over I cm. long; inflorescence conical or obovoid in outline; main peduncle usually exceeding the branches.

Sepals oblong-lanceolate; flowers few. 7. P. Archebaldiae. Sepals lanceolate; flowers numerous. $\quad$ 8. $P$. robustum.

Corolla less than I cm. long; inflorescence flat-topped; main peduncle exceeded in length by the branches. 9. P. foliosissimum.

Corolla funnelform; filaments without appendages at the base; inflorescence dense, spiciform; leaflets (except in the first species) verticillate.

Corolla purple.

Leaflets not verticillate.

Leaflets more or less verticillate.

Iо. P. speciosum.

Corolla less than $2 \mathrm{~cm}$. long, campanulate-funnelform with a rather broad tube.

Corolla $2-3 \mathrm{~cm}$. long, funnelform with a narrow tube.

Corolla yellow, ochroleucous or greenish. II. P. Grayianum.

Corolla funnelform; stamens adnate to the middle of the corolla-tube. I3. P. inellitum.

Corolla almost tubular; stamens almost wholly adnate to the corolla-tube. 14. P. Brandegei.

I. Polemonium scopulinum Greene, $(P$. humile pulchellum A. Gray, in part) On mountain sides of Colo.-Alt. 8000-14,000 ft.-Lake City; headwaters of Clear Creek; Mt. Hesperus; Iron Mountain; Tennessee Pass, Lake Co.; Seven Lakes; Cameron Pass; Georgetown; Gray's Peak; Silverton; Mt. Abram, Ouray; Alpine Tunnel; Pike's Peak; Bob Creek; Mt. Baldy; Bottomless Pit; Cottonwood Lake; Red Mountain road, south of Ouray; Carson; near Pagosa Peak; near Ironton, San Juan Co.; Silver Plume; Grand Mesa, Gunnison watershed; above Graymont; Beaver Creek; Empire; Buffalo Pass; Eldora to Baltimore; mountains between Sunshine and Ward.

2. Polemonium delicatum Rydb. On high mountains in Colo. and $\mathbf{N}$. M. -Alt. I0,000-12,000 ft.-Marshall Pass (?); West Spanish Peak; Silver Plume; Bob Creek; Berthoud Pass.

3. Polemonium parviflorum Nutt. ( $P$. viscosum A. Gray, in part; not Nutt.) On hills from Mont. and Wash. to Colo, and Calif.- "Colorado." 
4. Polemonium occidentale Greene. ( $P$. coeruleum A. Gray, in part; not L.) In valleys and open woods from Ass, and Alaska to Colo. and Utah. -Alt. 6000-9000 ft.-Headwaters of Sangre de Cristo Creek; Chambers' Lake; Indian Creek Pass; Parlin, Gunnison Co.; Breckenridge; Gunnison; Ironton Park, 9 miles south of Ouray; Durango; Empire; Walden.

5. Polemonium grande Greene. In the mountains of Colo.-Alt. about 9000 ft.-Near Pagosa Peak.

6. Polemonium molle Greene. In the mountains of Colo.-Alt. 8000-9500 ft.-Piedra; near La Porte; Eldora to Baltimore.

7. Polemonium Archebaldiae A. Nels. Mountains of Colo,-Berwind.

8. Polemonium robustum Rydb. In the mountains of Colo, especially along streams.-Alt. 8000-10,000 ft.-Bob Creek, West La Plata Mountains; Keblar Pass; Veta Pass; Sangre de Cristo Creek; headwaters of Clear Creek at Dumont; Leroux Creek.

9. Polemonium foliosissimum A. Gray. In the mountains of Colo. and N. M.-Alt. 6000-II,000 ft.-Headwaters of Clear Creek; Estes Park, Larimer Co.; La Veta; Veta Pass; Oak Mesa, Delta Co.; Durango; Berthoud Pass; Empire; Willow Creek; Graymont; Sargent.

Io. Polemonium speciosum Rydb. On the highest peaks of Colo.-Alt. about I3,000 ft.-Pike's Peak; Mt. Garfield; Gray's Peak.

II. Polemonium Grayianum Rydb. On the higher peaks of Colo.-Alt. 9000-I3,000 ft.-Gray's Peak; Graymont; Central City.

I2. Polemonium confertum A. Gray. On the higher mountains among rocks in Wyo. and Colo.-Alt. 9000-I3,000 ft.-Mt. McClellan; Pike's Peak; Cameron Pass; Lake City; Gray's Peak; headwaters of Clear Creek; Sangre de Cristo Range; West Spanish Peak; Seven Lakes; near Pike's Peak; near Ironton, San Juan Co.; mountains above Boreas; Little Kate Basin, La Plata Mountains; Ragged Mountain; Gunnison Co.; Argentine Pass; tributaries of South Fork of Cache la Poudre River, Larimer Co.; Beaver Creek; Mt. Abram, Ouray; mountains near Mt. Harvard; Mt. Hesperus; Devil's Causeway; Graymont; Berthoud Pass; Spicer, Larimer Co.

13. Polemonium mellitum (A. Gray) A. Nels. ( $P$. confertum mellitum A. Gray) On the higher mountains from Wyo. and Nev. to Colo.-Alt. 80oo$9500 \mathrm{ft}$.-Eldora to Baltimore.

14. Polemonium Brandegei (A. Gray) Greene. (Gilia Brandegei A. Gray) On the higher peaks of Colo.-Alt. 6000-I2,000 ft.-Sierra Blanca; West Spanish Peak; Big Creek Gulch, Routt Co.; mountains between Sunshine and Ward; Wagon-wheel Gap.

Family I I 4. HYDROLEACEAE H. B. K. WATER-Leaf Family.

Ovary I-celled; style z-cleft; leaf-blades usually toothed, lobed or dissected.

Corolla-lobes convolute in the bud; placentae dilated.

Stamens exserted; calyx not enlarged in fruit; leaves alternate.

Stamens included.

I. HYDROPHYLLUM.

Calyx enlarged in fruit, not appendaged; leaves opposite.

2. Macrocalyx. 
Calyx not much enlarged in fruit with appendages in the sinuses.

3. Nemophila.

Corolla-lobes imbricated in the bud; placentae narrow.

4. Phacelia. Ovary imperfectly 2-celled; styles 2 , distinct; leaf-blades entire.

5. Marilaunidium.

\section{HYDROPHYLLUM L. WATERLEAF.}

Peduncles shorter than the petioles and mostly shorter than the flower-clusters; anthers oblong. I. H. capitatum. Peduncles longer than the petioles; anthers oblong-linear. z. H. Fendleri.

x. Hydrophyllum capitatum Dougl. In wet places on hillsides from Mont. and B. C. to Colo. and Calif.-Alt. about $9000 \mathrm{ft} .-$ Grand Mesa, Gunnison watershed; Rabbit-Ear Range, Routt Co.; Steamboat Springs.

2. Hydrophyllum Fendleri (A. Gray) Heller. ( $H$. occidentale Fendleri A. Gray) Along streams and among bushes from Wyo. and Ida. to Colo. and N. M.-Alt. 5000-I0,000 ft.-West of Ft. Collins; near Pagosa Peak; Apex; Van Boxle's ranch, above Cimarron; Villa Grove; Idaho Springs; Ojo; East Indian Creek; Pass Creek; Chicken Creek, West La Plata Mountains; Horsetooth Gulch; Rist Cañon; Dixon Cañon; mountains between Sunshine and Ward; Empire.

\section{MACROCALYX Trew.}

I. Macrocalyx Nyctelea (L.) Kuntze. (Ellisia Nyctelea L.) In damp places from Sask. and Mont. to Va. and Colo.-Alt. 5000-9000 ft.-Ft. Collins; New Windsor, Weld Co.; Cerro Summit, Gunnison watershed; Sangre de Cristo Creek; Cucharas River below La Veta; Horsetooth Gulch; Spring Cañon.

\section{NEMOPHILA Nutt.}

I. Nemophila breviflora A. Gray. In tich soil from Mont. and Ida. to Colo. and Ore.-Steamboat Springs.

\section{PHACELIA Juss.}

Leaves all simple and entire or some of the lower pinnately 3-5-divided with entire divisions; capsule acute; ovules 4 .

Plant densely whitish canescent.

Plant pubescent but not canescent.

I. P. leucophylla.

Plant decumbent or ascending, slender, I-3 dm. high; inflorescence open with a few branches. 2 2. P. alpina.

Plant erect or sometimes ascending, 3-5 dm. high, stout and more leafy; inflorescence dense with numerous short branches. 3. P. heterophylla.

Leaves from sinuate-crenate to twice-pannatifid.

Plant annual, not cespitose.

Corolla-lobes entire or merely sinuate-crenate.

Leaves sinuate-crenate to lobed half-way to the midrib.

Stem-leaves ovate, oval or elliptic in outline; edges and ridge of the seeds not with cross ridges. 4 4. $P$. integrifolia.

Stem-leaves oblong in outline; edges and salient ventral ridge of the $\begin{array}{ll}\text { seeds with rounded cross-ridges. } & \text { 5. } P \text {. corrugata. }\end{array}$

Leaves pinnately divided to the midrib.

Terminal divisions of the leaves large and obovate in outline.

6. P. splendens.

Terminal divisions of the leaves not much enlarged, ovate, lanceolate or oblong in outline.

7. P. glandulosa. 
Corolla-lobes distinctly dentate or erose.

Corolla white; stamens about twice as long as the corolla.

8. P. alba.

Corolla purplish or pink; stamens slightly exceeding the corolla.

9. P. neo-mexicana.

Plant perennial, cespitose; inflorescence spicate-thyrsiform.

Plant equally sericeous throughout; segments of the leaves narrowly linear.

Io. $P$. sericea.

Plant finely pubescent, hirsute-ciliate on the petioles; segments of the leaves oblong.

I1. P. ciliosa.

I. Phacelia leucophylla Torr. On dry hills from S. D. and Wash. to Colo. and Utah.-Alt. up to $8000 \mathrm{ft}$.-Horsetooth Gulch; mountains between Sunshine and Ward.

2. Phacelia alpina Rydb. On mountains from Mont. to Colo. and Nev.Alt. 7000-12,500 ft.-Steamboat Springs; Silver Plume; Mt. Harvard; near Ironton, San Juan Co.

3. Phacelia heterophylla Pursh. On hills from Mont. and Wash. to Colo. and Calif.-Alt. 6000-9000 ft.-Near Empire; Ironton Park, 9 miles south of Ouray; foot-hills, Larimer Co.; Narrows, Poudre Cañon; Howe's Gulch; Dixon Cañon; gulch west of Pennock's; Horsetooth Mountain; Rist Cañon; Rabbit-Ear Range, Routt Co.; Platte River; Colorado Springs; Eldora to Baltimore; Ft. Collins; Amelia; Table Rock; Ute Pass, near Pike's Peak; Pagosa Peak; Van Boxle's ranch, above Cimarron; Ouray; Upper West Mancos Cañon; Sangre de Cristo Creek; East Indian Creek; Lake Moraine; William's Cañon, near Pike's Peak; Trail Glen; Boulder; Rist Cañon; Ragged Mountain.

4. Phacelia integrifolia Torr. In gypsum soil from Colo. and Utah to western Tex. and Ariz.; also Mex.- "Southwestern Colorado."

5. Phacelia corrugata A. Nels. In dry soil from Colo. and Utah to western Tex. and N. M.-Alt. 4000-5000 ft.-Grand Junction; Rifle, Garfield Co.; Palisade.

6. Phacelia splendens Eastw. In dry ground in Colo. and Utah.-Alt. 5000-8000 ft.-Ouray; Cimarron; Hotchkiss, Delta Co.; Grand Junction; Lake City.

7. Phacelia glandulosa Nutt. In gravelly soil from Mont. to western Tex. and Ariz.-Alt. 6000-Io,000 ft.-Mt. Harvard; Cheyenne Cañon; West Spanish Peak; Walsenburg; Lake City ; Cumbres; foot-hills, Larimer Co. ; Howe's Gulch.

8. Phacelia alba Rydb. In valleys from Wyo. to N. M.-Alt. 8000-Io,000 ft.-Headwaters of Clear Creek; Sangre de Cristo Creek; La Veta; Placer; Doyle's; Georgetown; Marshall Pass; Graymont; Eldora to Baltimore.

9. Phacelia neo-mexicana Thurber. In sandy soil from Colo. to N. M.Alt. 4500-7500 ft.-Georgetown; between La Veta and Gardner, near Badito; Trinidad; Salida; La Porte, Larimer Co.; Dillon Cañon.

10. Phacelia sericea Hook. In the mountains from Mont. and B. C. to Colo. and Nev.-Alt. 9000-I3,000 ft.-Lake City; mountains south of Ward, Boulder Co.; Mt. Garfield; Tennessee Pass, 7 miles west of Leadville; Leadville, Lake Co.; Mt. Harvard; Larimer Co. ; Silverton; Medicine Bow Mountains; above Graymont; above Como; Beaver Creek; Larimer Co.; Eldora to Baltimore. 
II. Phacelia ciliosa Rydb. In the mountains from Alb. and B. C. to Colo. and Nev.-Alt. 8000-I2,000 ft.-Between Bald Mountain and Seven Lakes; near Pagosa Peak; Cameron Pass; Hahn's Peak; Clear Creek Cañon; mountains above Boreas; Berthoud Pass, near Georgetown; Little Kate Basin, La Plata Mountains; Carson; Silver Plume.

\section{MARILAUNIDIUM Kuntze.}

I. Marilaunidium angustifolium (A. Gray) Kuntze. (Nama dichotomum angustifolium A. Gray) In cultivated ground and waste places from Colo. to N. M.-Colorado Springs.

\section{Family i 5 . HeliotropaceaE Small. Heliotrope Family.}

Cone of the stigma penicillate-setose; fruit didymous; each of the two carpels splitting into two almost hemispherical nutlets. 1. Euploca.

Cone of the stigma not penicillate-setose; fruit in ours 4-lobed, splitting into four I-seeded nutlets.

2. Heliotropium.

\section{r. EUPLOCA Nutt.}

I. Euploca convolvulacea Nutt. (Heliotropium convolvulaceum A. Gray) Sandy plains from Neb. and Wyo. to Tex. and Calif.; also Mex.-Arkansas River; sandy plains of Platte.

\section{HELIOTROPIUM L. HeLiotrope.}

1. Heliotropium spathulatum Rydb. (H. Curassavicum Hook.; not L.) In river valleys from Ass. and Wash. to N. M. and Calif.-South of New Windsor, Weld Co.

\section{Family ir6. BORAginaceaE A. Gray. Borage Family.}

Nutlets with hooked prickles at least on the margin.

Nutlets unarmed or if prickly, the prickles not curved.

I. LAFpula.

Receptacle conic or elongated; the nutlets attached laterally.

Nutlets attached below the middle, with an oblique truncate back, which is surrounded by an entire or toothed margin; low pulvinate-cespitose perennials.

2. ERItrichium.

Nutlets attached at the middle or with an elongated scar reaching from the base to above the middle, not with a truncate margined back; plants not pulvinate-cespitose.

Pedicels and calyx persistent in fruit.

Calyx circumscissile; plants dichotomously branched.

Calyx not circumscissile; plants not dichotomously branched.

Calyx-lobes spreading in fruit; leaves alternate; perennials.

4. Oreocarya.

Calyx nearly closed in fruit; leaves proper opposite; annuals.

5. Allocarya.

Pedicels in fruit falling off with the calyx; the latter closed; branched but not dichotomous annuals. 6 6. CRYPTANThe.

Receptacle flat or merely convex.

Scar of the nutlets large and excavated, bordered by a prominent margin.

Scar of the nutlets small and marginless. 
Nutlets obliquely attached; flowers mostly bractless; corolla blue or white with funnelform throat.

8. Mertensia.

Nutlets attached by the very base.

Corolla salverform or funnelform; its lobes rounded and spreading.

Racemes not bracted; corolla in ours blue; its lobes convolute in bud.

9. Myosotis.

Racemes bracted; corolla yellow or yellowish; its lobes imbricated in bud.

Io. LITHOSPERMUM.

Corolla tubular; its lobes erect, acute, otherwise as in Lithospermum. II. ONOSMODIUM.

\section{LAPPULA Moench. StICK-SEed.}

Inflorescence leafy-bracted only at the base; bracts minute above; gymnobase short-pyramidal; scar of the nutlets ovate or triangular; perennials or biennials.

Corolla I.5-6 mm. wide, blue; stem very leafy.

Marginal prickles free to the base or nearly so.

Corolla $1.5-3 \mathrm{~mm}$. wide.

Corolla 4-6 $\mathrm{mm}$. wide (leaves firmer).

1. L. Besseyi.

Marginal prickles united for $1 / 3-1 / 2$ their length into a distinct wing.

Stem-leaves linear-lanceolate, densely strigose. 3 3. angistata.

Stem-leaves oblong-lanceolate, hispidulous; the hairs with papillose bases.

4. L. scaberrima.

Corolla 6-8 mm. wide, blue with white center; stem very leafy at the base.

5. L. gracilenta.

Inflorescence leafy; the floral leaves, although smaller, resembling those of the stem; annuals.

The annular margin connecting the bases of the prickles inconspicuous in all four nutlets.

Calyx-lobes more than twice as long as the fruit, reflexed-spreading; floral leaves broadly lanceolate.

6. L. calycosa.

Calyx-lobes less than twice as long as the fruit; floral leaves linear or linearlanceolate.

7. L. occidentalis.

The annular margin connecting the bases of the prickles at least in three of the nutlets broadened and forming a cup.

Plant diffusely branched, at flowering time without basal rosette.

8. L. cupulata.

Plant at flowering time with a basal rosette of spatulate leaves; stems more simple.

9. L. collina.

I. Lappula Besseyi Rydb. In wooded cañons of Colorado.-Alt. about $8000 \mathrm{ft}$.-Mouth of Cheyenne Cañon near Pike's Peak.

2. Lappula floribunda (Lehm.) Greene. (Echinospermum floribundum Lehm.) On hillsides and among bushes from Man. and Alb. to N. M. and Calif.-Alt. 5000-ro,000 ft.-Boulder Cañon; New Castle; Twin Lakes: La Veta; Gunnison; Valley Spur; Pagosa Springs; near Dix Post Office; Wahatoya Creek; mountains, Larimer Co.; Four-mile Hill, Routt Co. ; North Poudre; Empire; Poudre Cañon; Como.

3. Lappula angustata Rydb. Foot-hills of Colo. and Wyo.-Alt. 5000-6000 ft.-La Veta; foot-hills and plains near Boulder; Rist.Cañon; Hahn's Peak.

4. Lappula scaberrima Piper. In sandy soil from Wyo. and Neb. to Colo. -Cripple Creek; Idaho Springs.

5. Lappula gracilenta Eastw. In cañons of southwestern Colo.-Navajo Cañon; Mesa Verde.

6. Lappula calycosa Rydb. In waste places and fields in Colo.-Alt. 5000$6000 \mathrm{ft} .-$ Pike's Peak; Mancos; New Windsor, Weld Co.; Walsenburg; Glenwood Springs; Ft. Collins. 
7. Lappula occidentalis (S. Wats.) Greene. (Echinospermum Redoreskyi occidentalis S. Wats.) In sandy places and on dry plains from Sask. and Wash. to Mo. and N. M.-Alt. 4000-10,000 ft.-Twin Lakes; mesas near Pueblo; South Cheyenne Cañon; Colorado Springs; plains near Denver; Mancos; Cimarron; river-bluffs, north of La Veta; Mountain View; Antonito; Valley Spur; along Uncompahgre River near Ouray; Los Pinos; Ft. Collins; Howe's Gulch; bank of Arkansas River; Quimby; Spring Cañon; Manitou.

8. Lappula cupulata (A. Gray) Rydb. In river valleys from S. D. and Ida. to Tex. and Colo.-Alt. 4000-5500 ft.-New Windsor, Weld Co.; mesas near Pueblo; Hotchkiss, Delta Co.; Cañon City; Denver; Ft. Collins.

9. Lappula collina Greene. On dry hills from Colo. and Utah to Tex. and Ariz.-Palisades.

2. ERITRICHIUM Schrader. Mountain Forget-me-not.

Dorsal surface of the nutlets margined with a ridge-like ring, but not toothed. I. E. elongatum.

Dorsal surface of the nutlets with a toothed border; corolla 4-5 $\mathrm{mm}$. wide.

2. E. argenteum.

I. Eritrichium elongatum (Rydb.) White. (E. aretioides elongatum Rydb.) On high mountain tops from Mont. and Ore. to Colo.-Alt. I I,oooI2,000 ft.-Headwaters Clear Creek; above Beaver Creek.

2. Eritrichium argentum White. (Omphalodes nana aretioides A. Gray) On alpine peaks from Wyo. to Colo. and Utah.-Alt. II,000-14,400 ft.Gray's Peak; mountains above Como; mountains of Estes Park, Larimer Co.; Pike's Peak; Chicago Lake; Argentine Pass; Bald Mountain; Bush Creek, Custer Co.

\section{PIPTOCALYX Torr.}

I. Piptocalyx circumscissa Torr. (Krynitzkia circumscissa A. Gray) In dry soil from Ida. and Wash. to Colo., Ariz. and Calif.-Routt. Co., near Wyoming line.

\section{OREOCARYA Greene.}

Fruit depressed; nutlets at the margin separated by an open space.

Leaves appressed-canescent, not hispid; corolla $5-7 \mathrm{~mm}$. wide.

$$
\text { I. O. cinerea. }
$$

Leaves with a fine canescence intermixed with hispid hairs; corolla less than $5 \mathrm{~mm}$. wide.

Plant low, grayish, not yellowish-hispid above; racemes short, 2-ranked.

$$
\text { 2. O. suffruticosa. }
$$

Plant tall, yellowish-hispid above; racemes in fruit elongated, I-ranked.

Fruit conical or ovoid; nutlets touching each other.

3. O. multicaulis.

Corolla-tube not exserted.

Floral leaves long, many times longer than the short flower-clusters.

Floral leaves comparatively short, little if at all surpassing the flowerclusters.

Sepals ovate-lanceolate, only slightly exceeding the mature nutlets; inflorescence a panicle with rather few branches. 
Corolla 7-8 mm. broad; nutlets muricate and cross-ridged, but not honeycomb-crested.

Corolla 4-5 mm. broad; nutlets honey-comb-crested.

5. O. elata.

6. O. Bakeri.

Sepals lanceolate to linear, much exceeding the nutlets; inflorescence thyrsoid.

Inflorescence a broad open round-topped thyrsus; branches usually again branched.

Tall, 2-4 dm. high; nutlets with acute backs and sharply acute or slightly winged margins; tubercles united into more or less distinct cross-ridges.

Plant light yellowish-green; nutlets more or less distinctly winged; cross-ridges of the nutlets rather regular and uniting on the back.

7. O. hispidissima.

Plants dark green; nutlets merely acute-angled and irregularly cross-ridged. 8 . O. thyrsiflora.

Low, $\mathrm{r}-2 \mathrm{dm}$. high; nutlets with rounded backs and merely acutishmargined; muriculations united into almost star-shaped tubercles.

9. O. aperta.

Inflorescence, at least in flower, a narrow, almost spike-like thyrsus; if more open, branches simple.

Plant green, very hispid; only the basal leaves canescent; bristles with very conspicuous pustulate bases, much longer than the short strigose or tomentose pubescence.

Corolla 7-1o mm. wide; nutlets ovate, more than half as wide as long; basal leaves broadly spatulate densely canescent.

10. O. glomerata.

Corolla 5-7 mm. wide; nutlets lanceolate, less than half as wide as long; basal leaves broadly oblanceolate, somewhat canescent;

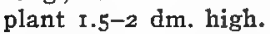

II. O. perennis.

Plant canescent; basal leaves at least with inconspicuous bristles, which are scarcely longer than the other pubescence; pustulate bases inconspicuous.

Plant stout, 3-4 dm. high, rather simple; corolla 7-10 mm. wide.

Plant low, less than I dm. high, densely cespitose.

12. O. argentea.

13. O. nana.

Corolla-tube long-exserted.

Corolla white.

Nutlets more or less distinctly rugose with irregular cross-ridges as well as muricate.

Ridges of the nutlets honey-comb-crested; inflorescence a narrow thyrsus; leaves canescent and hispid.

14. O. eulophus.

Ridges of the nutlets neither much interlacing nor crested.

Inflorescence at least in fruit open with elongated branches; stem stout.

Inflorescence narrow; stem slender.

I5. O. longiflora.

16. O. cristata.

Nutlets finely muricate; inflorescence at last more or less yellowish; leaves finely canescent.

Plant cespitose, low, I-I.5 dm. high; basal leaves $2-3 \mathrm{~cm}$. long, $3-7 \mathrm{~mm}$. wide.

17. O. fulvocanescens.

Plant 2-3 dm. high; basal leaves $4-8 \mathrm{~cm}$. long, 7-15 mm. wide.

Corolla yellow.

I8. O. nitida.

19. O. Alava.

I. Oreocary a cinerea Greene. On dry plains of Colo.-Alt 5000-7000 ft.Mesas near Pueblo; Cañon City; Arkansas River; Rocky Ford.

2. Oreocarya suffruticosa (Torr.) Greene. (Krynitzkia Jamesii A. Gray) On plains and foot-hills from S. D. and Wyo. to Colo--Alt. $4000-8000 \mathrm{ft}$ Plains and foot-hills near Boulder; Gunnison; Colorado Springs; Denver; 
Salida; on the Platte; headwaters of Clear Creek; Manitou Junction; Lasalle; Morrison; Pueblo; Ouray.

3. Oreocarya multicaulis (Torr.) Greene. (Eritrichium multicaule Torr.) In arid lands from Colo. to Tex. and Ariz.-Alt. $4000-6000 \mathrm{ft}$-Gunnison; Arboles.

4. Oreocarya virgata (Porter) Greene. (Krynitzkia virgata A. Gray) On dry hills in Wyo. and Colo.-Alt. 5000-9000 ft.-Plains and foot-hills near Boulder; Green Mountain Falls; Pike's Peak; Clear Creek Cañon; Larimer Co.; foot-hills near Golden; Ft. Collins; Manitou; headwaters of Clear Creek; Denver; Rist Cañon, Barnes' camp; Horsetooth Gulch; Soldier Cañon; North Cheyenne Cañon; Artist's Glen; Wood's ranch; Narrows.

5. Oreocarya elata Eastw. In arid places of western Colo.-Grand Junction.

6. Oreocarya Bakeri Greene. Sage plains of southern Colo--Mancos.

7. Oreocarya hispidissima (Torr.) Rydb. (Eritrichium glomeratum hispidissimum Torr.) In river valleys and on hills from Neb. and Wyo. to N. M. and Utah.-Alt. 5000-9000 ft.--Sangre de Cristo Creek; Calloway.

8. Oreocarya thyrsiflora Greene. On sandy hillsides from Neb. and Wyo. to Colo.-Alt. 5000-7000 ft.-Cripple Creek; Salida; Colorado Springs; Livermore; Badito; Platte bottom.

9. Oreocarya aperta Eastw. On arid hills of western Colo.-Grand Junction. 10. Oreocary a glomerata (Pursh) Greene. (Krynitzkia glomerata A. Gray) Dry hills from Sask. and Ida. to Utah. It has been reported from Colorado, but doubtful.

II. Oreocarya perennis (A. Nels.) Rydb. (O. affinis perennis A. Nels.) Dry rocks from S. D. and Ida. to Colo.-Cheyenne Mountain.

I2. Oreocarya argentea Rydb. On dry hills in Colo.-Rifle, Garfield Co.; Steamboat Springs.

13. Oreocarya nana Eastw. On dry table lands in western Colo.--Grand Junction.

I4. Oreocarya eulophus Rydb. On gravelly hills in Colo. and Utah.McCoy's, Eagle Co.; Dolores.

I5. Oreocarya longiflora A. Nels. On dry table-lands and plains of Utah and Colo.-Alt. about $5000 \mathrm{ft}$.-Hotchkiss; Grand Junction.

r6. Oreocarya cristata Eastw. On arid hills of western Colo.-Grand Junction.

17. Oreocarya fulvocanescens (A. Gray) Greene. (Krynitzkia fulvocanescens A. Gray) On hills from Wyo. to N. M.--Locality not given.

18. Oreocarya nitida Greene. On dry hills in Colo.-Alt. about $5000 \mathrm{ft}$.Deer River; Grand Junction.

I9. Oreocarya flava A. Nels. On hills from Wyo. to N. M. and Ariz.Grand Junction.

\section{ALlOCARYA Greene.}

1. Allocarya scopulorum Greene. (Krynitzkia californica A. Gray, in part) In sandy soil from Mont. and Wash. to Colo. and Nev.-Alt. 5000-9000 ft.Near Empire; Grizzly Creek; Calhan; Georgetown; Steamboat Springs, Routt Co.; Cerro Summit; Gunnison; Veta Pass; Alamosa; Hubbard Creek; Buena Vista; along the Conejos north of Antonito; Boulder; North Park. 
Nutlets not winged.

\section{CRYPTANTHE Lehm.}

Nutlets dissimilar, 3 of them tubercled, the fourth smooth or nearly so. Sepals in fruit strongly thickened on the back.

Sepals in fruit not strongly thickened on the back.

Plant I-2 dm. high; calyx in fruit $6-8 \mathrm{~mm}$. long.

Plant a few cm. high; calyx in fruit less than $5 \mathrm{~mm}$. long.

Nutlets all smooth.

1. C. crassisepala.

2. C. Kelseyana.

3. C. minima.,

Nutlets usually all four maturing.

No open areola between the forks of the groove of the acute nutlets.

4. C. Torreyana.

A distinct open areola between the forks of the groove of the lanceolate, acuminate nutlets.

Leaves spatulate or oblanceolate, or the upper sometimes linear.

Leaves narrowly linear.

Only one nutlet maturing.

Nutlets wing-margined.
5. C. Pattersonii.

6. C. Fendleri.

7. C. gracilis.

8. C. pterocarya.

I. Cryptanthe crassisepala (T. \& G.) Greene. (Krynitzkia crassisepala A. Gray) In loose soil, "prairie-dog towns" and waste places from Sask. and Mont. to Tex. and Utah; also Mex.-Alt. 4000-6000 ft.-Walsenburg; foot-hills west of Ft. Collins; Colorado Springs; Ft. Collins; Deer River; Trinidad; New Windsor, Weld Co.; Ouray; Boulder.

2. Cryptanthe Kelseyana Greene. In dry and sandy soil from Ass, and Mont. to Colo.-Alt. about $6000 \mathrm{ft}$.-Pike's Peak; Walsenburg.

3. Cryptanthe minima Rydb. In river valleys of Colo.-Alt. about $7000 \mathrm{ft}$. - Cucharas River above La Veta.

4. Cryptanthe Torreyana (A. Gray) Greene. On hillsides from Ida. and Wash. to Colo. and Calif.-Idaho Springs.

5. Cryptanthe Pattersonii (A. Gray) Greene. (Krynitzkia Pattersoni A. Gray) On hillsides in Wyo. and Colo.-Alt. 6000-7000 ft.-River-bluffs north of La Veta; South Cheyenne Cañon.

6. Cryptanthe Fendleri (A. Gray) Greene. (Krynitzkia Fendleri A. Gray) In river valleys and on sandy places, from Wyo. to N. M. and Ariz.-Alt. 5000-8000 ft.-Denver; Cheyenne Mountain; Antonito; Salida; Gunnison; Colorado Springs; Palmer Lake.

7. Cryptanthe gracilis Osterhout. In dry soil, in Colorado.-Glenwood Springs.

8. Cryptanthe pterocarya (Torr.) Greene. (Eritrichium pterocaryum Torr.) On plains and in dry places from Wash. to N. M.-Palisades; Grand Junction.

\section{ANCHUSA L.}

I. Anchusa officinalis L. Introduced from Europe in waste places.-Ft. Collins.

8. MERTENSIA Roth. LUNGWORT.

Filaments equalling or exceeding, and usually broader than the anthers.

Calyx-lobes rounded-ovate, shorter than the ample, campanulate tube.

Calyx-lobes longer than the short tube.

Calyx-lobes linear or oblong, obtuse.

BRACHYLOBAE.

Calyx-lobes triangular-lanceolate to linear-lanceolate, acute.

Ciliatae. 
Plant tall, usually over $4 \mathrm{dm}$. high; leaves distinctly veined, in most feather-veined, but in a few triple-veined with anastomosing veins.

Membranaceae.

Plant low, usually less than $4 \mathrm{dm}$. high; leaves with a strong midrib, without distinct lateral veins (except sometimes the basal leaves, which then, however, are thick and firm).

LANCEOLATAE.

Anthers subsessile or on very short narrow filaments inserted in the tube or the throat of the corolla; low plants, I-3 dm. high, of the habit of the lanceolata group.

ALPINAE.

\section{BRACHYLOBAE.}

One species.

\section{Ciliatae.}

1. M. brachyloba.

Corolla 9-1 $2 \mathrm{~mm}$. long; limb not longer than the tube.

Sepals thickened and pale on the back.

Sepals neither thickened nor pale on the back.

Corolla $12-15 \mathrm{~mm}$. long; limb longer than the tube.

Sepals oblong, I.5-2 mm. long.

Leaves dark green, rough with large muricate points; pedicels with larger white murication.

4. $M$. punctata.

Leaves more glaucous, smooth or with minute callous murication; pedicels almost smooth.

Sepals linear, $3 \mathrm{~mm}$. long.

2. M. picta.

3. M. ciliata.

Corolla I cm. or less long.

Corolla-tube over $4 \mathrm{~mm}$. wide; calyx bristly-ciliate.

5. M. polyphylla.

6. $M$. platensis.

\section{Membranaceae.}

Corolla-tube $2-3 \mathrm{~mm}$. wide.

Plant stout; pedicels bristly hispid with spreading hairs.

Plant slender; pedicels strigose.

7. M. cynoglossoides.

rolla about $1.5 \mathrm{~cm}$. long.

Calyx not white-hairy, about half as long as the tube of the white corolla.

9. $M$. alba.

Calyx densely white-hairy, especially near the margins of the lobes, $1 / 3$ as long as the blue corolla.

I o. M. pratensis.

\section{LANCEOLATAE.}

Pedicels distinctly strigose or hirsute.

Calyx and pedicels densely pubescent all over.

Stems from a more or less woody caudex or rootstock; leaves pubescent on both sides.

Leaf-blades linear or only the uppermost lanceolate. II. $M$. lateriflora.

Blades of the basal leaves ovate, lanceolate or spatulate.

Plant more or less grayish and densely pubescent throughout, especially on the calyx.

I2. M. Bakeri.

Plant green; pubescence long and loose, even on the stem.

Stems from a fusiform root; leaves glabrous beneath. I3. M. myosotifolia.

14. $M$. fusiformis.

Calyx externally glabrous except on the ciliate margins, and sometimes on the midveins and angles.

Leaves glabrous beneath.

Calyx-lobes ovate-lanceolate; inflorescence open. I5. M. viridula.

Calyx-lobes narrowly or linear-lanceolate; inflorescence dense.

Leaves narrowly linear.

Leaves oblong, lanceolate to ovate.

I6. $M$. lineariloba.

Stem-leaves lanceolate or oblanceolate; corolla-limb about equalling the tube.

17. M. Pary yi.

Stem-leaves ovate to ovate-lanceolate; corolla-limb shorter than the tube.

I8. $M$. ovata.

Leaves hairy on both sides. 
Leaves narrowly linear.

Leaves oblong or oblanceolate.

II. M. lateriflora.

I9. M. amoena.

Pedicels glabrous or pustulate; calyx glabrous except the ciliate-margined calyxlobes.

Upper surface of the leaves short-pubescent.

Upper surface of the leaves not hairy; merely pustulate.

\section{Alpinae.}

20. M. linearis.

21. M. lanceolata.

Calyx ciliate on the margins; leaves ovate, lanceolate or oblanceolate.

Corolla 5-7 mm. long.

Corolla over I cm. long.

Calyx villous-ciliate all over; corolla 7-8 mm. long. Leaves oblong or oblanceolate, glabrous beneath.

Leaves linear, densely hairy on both sides.

22. $M$. alpina.

23. M. perplexa.

24. $M$, brevistyla.

25. $M$. canescens.

1. Mertensia brachyloba Greene. On foot-hills of Colorado.-Alt. about $5500 \mathrm{ft}$.-West of Ft. Collins; Mt. Harvard.

2. Mertensia picta Rydb. In the mountains of Colo.-Alt. about I2,00o ft.Mt. Baldy; Estes Park.

3. Mertensia ciliata (Torr.) Don. (Pulmonaria ciliata Torr.) Along streams from Wyo. and Ida. to Colo. and Nev.-Alt. 6000-13,000 ft.-Headwaters of Clear Creek; Pike's Peak; South Park; North Cheyenne Cañon; Colorado Springs; Cascade; Green Mountain Falls; Peak Valley; Georgetown; Gray's Peak; Boreas; Cameron Pass; Michigan Hill; Beaver Creek; Campton's Ranch; Poudre River; summit of North Park Range, Larimer Co.

4. Mertensia punctata Greene. Along streams in the mountains of Colo.Alt. 9000-I0,000 ft.-Near Pagosa Peak; Chambers' Lake.

5. Mertensia polyphylla Greene. Along streams in the mountains of Wyo. and Colo.-Alt. 8000-I2,000 ft.-Near Pagosa Peak; mountains, Larimer Co.; Pike's Peak; near Ironton, San Juan Co.; headwaters of Pass Creek; Eldora to Baltimore; Hotchkiss; Cameron Pass; Marshall Pass; Van Boxle's ranch above Cimarron; Dark Cañon; Black Cañon; Ward, Boulder Co.; West Indian Creek.

6. Mertensia platensis Rydb. (Mertensia polyphylla platensis Rydb.) Along streams in mountains of Colo.-Alt. about ro,000 ft.-Bob Creek, West La Plata Mountains.

7. Mertensia cynoglossoides Greene. Along streams in Colo.-Alt, about $7000 \mathrm{ft}$.-Black Cañon.

8. Mertensia muriculata Greene. Along streams in Colo.-Alt. about 7000 ft.-Black Cañon.

9. Mertensia alba Rydb. Along mountain streams in Colo.-Alt. about I0,500 ft.-La Plata River.

ro. Mertensia pratensis Heller. In wet meadows and along streams from Colo. to N. M. and Ariz.-Alt. 7000-12,000 ft.-Cucharas River, above La Veta; Dolores; Mt. Hesperus; Bob Creek, West La Plata Mountains; Mancos; mountains above Ouray.

II. Mertensia lateriflora Greene. On hillsides in Colo.-Alt. 5000-I I,500 ft.-Near Empire; Ojo; Veta Mountain; Palsgrove Cañon; headwaters of Sangre de Cristo Creek; Carson; Estes Peak, Larimer Co.; South Park; Eldora to Baltimore; Estes Park; Cascade; Ruxton.

12. Mertensia Bakeri Greene. On the higher mountains of Colo.-Alt. II,000-I3,000 ft.-Horse-shoe Mountain; Marshall Pass; Hayden Peak; Carson; mountains above Como; Iron Mountain; Spicer. 
I3. Mertensia myosotifolia Heller. On mountains in Colo.-Red Cliff, Eagle Co.

I4. Mertensia fusiformis Greene. ( $M$. congesta Greene) On hillsides in Colo.-Alt. 7000-I0,000 ft.-Graham's Peak; Bob Creek, West La Plata Mountains; Cimarron; Minturn; Poverty Ridge.

I5. Mertensia viridula Rydb. Along mountain streams in Colo.-Alt. 6000-I2,000 ft.-Jack Brook; North Cheyenne Cañon; Cascade Cañon; Colorado Springs; Ruxton; West Spanish Peak.

16. Mertensia lineariloba Rydb. On hillsides in Colo.-Alt. $8000-9000 \mathrm{ft} .-$ West Indian Creek; near Empire.

I7. Mertensia Parryi Rydb. On the higher mountains of Colo-Alt. II,000-12,000 ft.-Alpine ridges east of Middle Park; Cameron Pass; Alpine Tunnel; Estes Park; Beaver Creek; Gray's Peak; Ethel Peak.

18. Mertensia ovata Rydb. On high mountains among rocks in Colo.-Alt. 9000-I0,000 ft.-West Spanish Peak; Anita Peak.

19. Mertensia amoena A. Nels. On hills in Wyo. and Colo.-Alt. 5000I0,000 ft.-Montezuma; Boulder; Eldora to Baltimore.

20. Mertensia linearis Greene. On dry hillsides from Ass. to Neb. and Colo.-Alt. 5000-9000 ft.-Cucharas Valley, near La Veta; Georgetown; plains near Denver; South Cheyenne Cañon, Colorado Springs; Platte Cañon; Manitou; El Paso Co.; Wahatoya Creek; near Livermore, Larimer Co.; Clear Creek Cañon; hills southeast of La Veta; Boulder; Malta station, near Leadville; Eldora to Baltimore.

2I. Mertensia lanceolata (Pursh) DC. On hills in damp places from Mont. to Colo.-Alt. 5000-I0,000 ft.-Foot-hills west of Ft. Collins; Howe's Gulch; north of La Porte; Rist Cañon; gulch west of Soldier Cañon; Eldora to Baltimore; Boulder; vicinity of Horsetooth.

22. Mertensia alpina (Torr.) Don. On alpine peaks of Colo.-Alt. II,000I4,000 ft.-Massif de l'Arapahoe; Pike's Peak; headwaters of Clear Creek; Argentine Pass; Garden of the Gods; Saddle cliffs.

23. Mertensia perplexa Rydb. On high mountains of Colo.-Mountains south of Ward, Boulder Co.

24. Mertensia brevistyla S. Wats. In the mountains of Utah, Wyo. and Colo.-Exact locality not given.

25. Mertensia canescens Rydb. On alpine peak of Colo.-Alt. I 1,000-12,000 ft.-Berthoud Pass; mountains southwest of Como.

\section{MYOSOTIS L. FORGET-ME-NOT.}

I. Myosotis alpestris Schmidt. In mountain meadows from Alb. and Alaska to Colo.-Devil's Causeway.

\section{io. Lithospermum L. Gromwell, Puccoon.}

Corolla-lobes neither fimbriate nor toothed; flowers all well developed.

Corolia greenish or pale yellow, I cm. or less long; crest in the throat obsolete.

Corolla-limb 3-5 mm. wide; tube not longer than the calyx; stem grayish strigose, but scarcely hispid.

r. L. Torreyi.

Corolla-limb $5-8 \mathrm{~mm}$. wide; tube longer than the.calyx; stem more or less hispid.

2. L. pilostim. 
Corolla bright yellow or orange, I2 $\mathrm{mm}$. or more long; crest of the tube prominent.

Floral leaves of the later flowers small, shorter than the flowers; limb of the corolla 6-8 $\mathrm{mm}$. wide.

3. L. multiflorum.

Floral leaves of the later flowers not reduced; limb of the corolla $8-20 \mathrm{~mm}$. wide.

Hispid pubescent; corolla-tube bearded at the base within.

Canescent; corolla-tube not bearded at the base within.

4. L. Gmelini.

5. L. canescens.

Corolla-lobes fimbriate or dentate; later flowers cleistogamous.

Corolla $2.5-3$ (rarely only 2 ) $\mathrm{cm}$. long; lobes distinctly fimbriate.

Corolla $2 \mathrm{~cm}$. or less long; lobes dentate.

6. L. linearifolium.

Corolla I 5-20 $\mathrm{mm}$. long; limb 8-20 mm. wide.

Corolla Io $\mathrm{mm}$. or less long; limb $6-8 \mathrm{~mm}$. wide.

7. L. mandanense.

8. L. breviflorum.

1. Lithospermum Torreyi Nutt. On hills and in cañons from Mont. and Ida. to Colo. and Utah.-Alt. $8000-8600 \mathrm{ft}$-Poverty Ridge, near Cimarron; below Parrott Post Office; Steamboat Springs.

2. Lithospermum pilosum Nutt. On hills from Alb. and B. C. to Colo, and Nev.-Leroux Creek, Delta Co.; Minturn; Denver.

3. Lithospermum multiflorum Torr. On hills and mountain sides and in cañons from Wyo. to N. M. and Ariz.; also in Mex.-Alt. 7000-10,000 ft.Thompson's Park, La Plata Mountains; Crystal Park; Colorado Springs; Estes Park, Larimer Co.; Grayback mining camps and Placer Gulch; mouth of Cheyenne Cañon; North Cheyenne Cañon; Artist's Glen; Como, South Park; Cañon City; southeast of Ouray; Piedra; above Mancos; Pike's Peak; headwaters of Clear Creek; Horsetooth Gulch; Table Rock; Northwest of Soldier Cañon; Hotchkiss; Rist Cañon; Seven Lakes; Empire.

4. Lithospermum Gmelini (Michx.) Hitchc. (L. hirtum Lehm.) In sandy places and dry plains from N. Y. and Mont. to Fla. and N. M.-Denver (Eastwood).

5. Lithospermum canescens (Michx.) Lehm. On plains and in open woods from Ont, and N. D. to Ala., Tex, and Colo--Alt. 4000-6000 ft.Bouider.

6. Lithospermum linearifolium Goldie. (L. angustifolium Michx.) On prairies and plains from Ill, Man. and B. C. to Tex. and Ariz.-Alt. 40007000 ft.-Mt. Harvard; Colorado Springs; river-bluffs, north of La Veta; mesas near Pueblo; Cucharas River below La Veta; Trinidad; plains near Denver; Ft. Collins; Lamar; Durango; Spring Cañon; Boulder.

7. Lithospermum mandanense Spreng. On dry plains from N. D. and Alb. to Tex. and Ariz,--Alt. 4000-5000 ft--Larimer Co.; Colorado City.

8. Lithospermum breviflorum Engelm. \& A. Gray. (L. albescens Greene) On dry plains from Ark. and Colo, to Tex. and N. M.; also Mex.-Alt. 4000-6000 ft.-Arboles; Boulder.

\section{I1. ONOSMOdIUM Michx. False Gromwell.}

I. Onosmodium occidentale Mackenzie. On plains and in sandy soil from Man. and B. C. to Mo., Tex. and Utah.-Alt. 3500-5000 ft.-Along Platte River, Denver; Ft. Collins; Boulder; Golden; Longmont. 


\section{Family i 7 7. VERBENACEAE St. Hil. Vervain Family.}

Flowers in terminal spikes; corolla-limb 5-lobed; nutlets 4. Flowers in axillary peduncled short spikes; corolla-limb 4-lobed; nutlets 2.

I. VERBENA.

2. Phyla.

\section{VERBENA L. VERVAIN.}

Anthers not appendaged; flowers in elongated spikes, less than $8 \mathrm{~mm}$ long.

Plant tall, erect, strict; leaves not pinnatifid, only sometimes lobed at the base in the first species.

Bracts shorter than the calyx.

1. V. hastata.

Bracts one-third longer than the calyx; pubescence dense, soft.

Plant low . MacDougalii.

pinnatifi bracts much longer than the calyx.

3. V. bracteosa.

Anthers of the longer stamens appendaged by a gland on the connective; corolla $8 \mathrm{~mm}$. long or more.

Calyx-lobes subulate.

Calyx-lobes setaceous.

3. $V$. ciliata.

5. V. ambrosifolia.

1. Verbena hastata L. In river valleys and moist meadows from N. S. and B. C. to Fla. and Calif.-Alt. 4000-7000 ft.-Timnath, Larimer Co.; foot-hills near Golden; Ft. Collins; Mason's river-front farm, Larimer Co.; Boulder.

2. Verbena MacDougalii Heller. In river valleys from Colo. to N. M. and Ariz.-Alt. about $7000 \mathrm{ft}$.-La Veta; Cucharas Valley, near La Veta; Arboles; Palmer Lake.

3. Verbena bracteosa Michx. ( $V$. rudis Greene) On prairies and plains and in waste places from Ill., Alb. and B. C. to Fla. and Calif.-Alt. 40007500 ft.-Colorado Springs; Manitou; Arboles; Walsenburg; Platte River; Ft. Collins; Deer River; Cimarron; Rist Cañon; Dixon Cañon; Boulder.

4. Verbena ciliata Benth. On plains from Colo. to Tex. and Ariz.; also Mex.-Alt. 4000-5500 ft.-Mesas near Pueblo; Durango; Trinidad.

5. Verbena ambrosifolia Rydb. On plains from S. D. and Colo. to Tex. and Ariz.; also Mex.--Alt. 4000-6000 ft.-Boulder; Walsenburg; Rocky Ford, Otero Co.; foot-hills, Larimer Co.; Boulder Co.; La Porte; Soldier Cañon; Florence; Quimby.

\section{PHYLA Lour.}

1. Phyla cuneifolia (Torr.) Greene. (Lippia cuneifolia Torr.) On plains from S. D. and Wyo., to Tex and Ariz.-Alt. 4000-6000 ft.-Greeley, Weld Co.; Ft. Collins; foot-hills, Larimer Co.; Boulder Cañon; banks of Arkansas at Pueblo; Rocky Ford; Boulder.

\section{Family i 18. LAMIACEAE Lindl. Miñ Family.}

Ovary of 4 united carpels; style not basal; nutlets laterally attached.

Flowers in small congested cymes, axillary to small bracts, and forming a raceme-like panicle; calyx-lobes shorter than the tube; leaves toothed.

I. TEUCHRIUM.

Flowers solitary in the axils of bracts similar to the leaves; calyx-lobes longer than the tube; leaves laciniate. 2. Melosmon.

Ovary of 4 distinct or nearly distinct carpels; styles basal; nutlets basally attached. Corolla bilabiate. 
Calyx 2-lipped; both lips entire; stamens 4.

3. Scuteliaria.

Calyx either 2-lipped and at least one of the lips toothed, or regularly 4-5 toothed.

Stamens included in the corolla-tube.

Stamens exserted.

4. Marrubium.

Upper lip of the corolla concave.

Anther-bearing stamens 4.

Upper stamens longer than the lower.

Calyx 5-toothed.

Anther-sacs parallel or nearly so; stamens divergent.

5. Agastache.

Anther-cells divaricate; anther approximate in pairs.

Calyx regularly 5-toothed; plants erect. 6. NePETA.

Calyx irregularly 5-toothed; plant trailing.

Calyx distinctly 2-lipped.

7. GLecoma.

Upper stamens shorter than the lower.

Calyx distinctly 2 -lipped, closed in fruit.

8. Dracocephalum.

Calyx 5-toothed, not 2-lipped, open in fruit.

Calyx membranous, inflated in fruit, faintly nerved.

io. Physostegia.

Calyx not membranous, not inflated in fruit, strongly 5-10nerved.

Nutlets 3-sided, truncate above.

Nutlets ovoid, nearly terete, rounded above.

I 1. LeONURUS.

Anther-bearing stamens 2.

12. Stachys.

Connective of the anthers very long, articulated to the filaments, bearing a perfect anther at the ascending end and a reduced one or none at the other; calyx 2-lipped. I3. Salvia.

Connective of the anther short; anther-cells confluent; calyx equally 5 -toothed.

I 4. Monarda.

Upper lip of the corolla flat.

Stamens curved, often converging.

Calyx regularly 5-toothed; anther-bearing stamens 2 .

Calyx 2-lipped or irregularly 5 -toothed.

Anther-bearing stamens 2.

Anther-bearing stamens 4 .

I5. Poliomintha.

(7). ClNOPODIUM.

Stamens straight, distant and diverging; calyx almost regularly 5toothed; anther-bearing stamens 4.

Corolla nearly regular, 4-5-toothed.

Anther-bearing stamens 2 .

Anther-bearing stamens 4 .

I9. LyCOPUS.

20. Mentha.

\section{TEUCRIUM L. Germander.}

I. Teucrium occidentale A. Gray. In thickets and among bushes in rich soil from Ont. and B. C. to Pa., Colo. and Calif.-Alt. $4000-6000 \mathrm{ft}$.-New Windsor, Weld Co.; Cañon City; Ft. Collins; Rocky Ford; Boulder.

\section{MELOSMON Raf.}

I. Melosmon laciniatum (Torr.) Small. (Teucrium laciniatum Torr.) On plains from Kans. and Colo. to Tex, and Ariz.-St. Charles River, Pueblo Co.; Walsenburg; Apishapa Creek, Otero Co.; Cañon City; Trinidad; Cedar Hills. 


\section{SCUTELLARIA L, Scullcap.}

Perennials with horizontal rootstock.

Leaf-blades lanceolate or ovate, more or less distinctly toothed, at least the lower ones.

Leaf-blades entire or nearly so, oval, oblong or linear. Perennials with a woody caudex.

I. S. galericulata.

2. S. Brittoni.

3. S. resinosa.

I. Scutellaria galericulata L. Along streams and in swamps from Newf. and Alaska to N. C. and Ariz.-Alt. 4000-8000 ft-Gunnison; near Ouray; along Poudre; Ft. Collins; Mason's river-front farm; Alamosa; Andrew's Shetland ranch; Gunnison; Boulder; Estes Park, Larimer Co.; Ft. Collins.

2. Scutellaria Brittoni Porter. On hillsides and river valleys from Wyo. to Colo.-Alt. 5000-10,000 ft.-Eldora to Baltimore; Boulder; Fossil Beds; foot-hills near Boulder; Pike's Peak; near Denver; Green Mountain Falls; near Pike's Peak; Cucharas River below La Veta; New Windsor, Weld Co.; Ft. Collins; Ute Pass; Howe's Gulch; Dillon Cañon, Trinidad; Manitou; Dixon Cañon; Horsetooth Gulch; Spring Cañon; Soldier Cañon; Cache la Poudre; Table Rock.

Scutellaria Brittoni virgulata (A. Nels.) Rydb. (S. virgulata A. Nels.) A luxuriant variety with larger and thinner leaves.-Veta Pass; West Spanish Peak; Dillon Cañon.

3. Scutellaria resinosa Torr. On plains and hills from Kans. and Colo. to Tex. and Ariz.- " Plains of Colorado."

\section{MARRUBIUM L. White HoARHOUND.}

I. Marrubium vulgare L. In waste places from Me. and B. C. to N. C. and Calif.; naturalized from Europe.-Ft. Collins.

\section{AgAStaChe Clayt. Giant-hyssop.}

Calyx-lobes ovate-lanceolate, acute.

Leaves glaucous beneath; calyx tinged with blue; stem glabrous.

I. A. anethiodora.

Leaves not glaucous beneath; calyx green, yellowish or rarely pinkish; stem puberulent. z. A. pallidiflora.

Calyx-lobes elongated lanceolate, acuminate, rose-tinged. 3. A. urticifolia.

x. Agastache anethiodora (Nutt.) Britton. (Lophanthus anisatus Benth.) Among bushes from Ont., Mackenzie River, and Alb. to Neb. and Colo.Alt. 3700-7000 ft.-Rist Cañon, Larimer Co.; Dome Rock in Platte Cañon; mountains, Larimer Co.; Bosworth's Ranch, Stove Prairie.

2. Agastache pallidiflora (Heller) Rydb. (Brittonastrum pallidiforum Heller; $B$. Greenei Briquet; $A$. montana Greene) In the mountains from Colo. to N. M. and Ariz.-Alt, up to $9000 \mathrm{ft}$.-Near Pagosa Peak.

3. Agastache urticifolia (Benth.) Kuntze. (Lophanthus urticifolius Benth.) On hillsides and valleys from Mont. and Wash. to Colo. and Calif.-Alt. 7000-8500 ft.-Four-mile Hill, Routt Co.; Glenwood Springs, Garfield Co.; Sierra Madre Range; Hamor's Lake, above Durango; Cerro Summit; Honnold; divide road to Steamboat Springs; Red Mountain road south of Ouray; Ouray; Steamboat Springs; summit of North Park Range, Routt Co. 


\section{Nepeta L. Catnip, Catmint.}

1. Nepeta Cataria L. In waste places and around dwellings from N. B. and Ore. to Va. and Utah; naturalized from Europe.-Alt. 5000-8000 ft.Along Uncompahgre River near Ouray; Ft. Collins; Boulder.

\section{GLECOMA L. Ground Ivy.}

1. Glecoma hederacea $L$. In waste places from Newf. and Minn. to Ga. and Colo.; introduced from Europe.-Boulder.

\section{DRACOCEPHALUM L. DRagon's-heAD.}

I. Dracocephalum parviflorum Nutt. On hillsides and in valleys from N. Y. and Alaska to N. M. and Ariz.-Alt. 5000-I0,000 ft.-Dry rocks, Cheyenne Mountain; mountain sides near Empire; Twin Lakes; Idaho Springs; foothills, Larimer Co.; Front Range, Larimer Co.; Mancos; Breckenridge; La Veta; Gunnison; Arboles; Sangre de Cristo Creek; Mt. Harvard; Palmer Lake; Grand Junction; Beaver Creek; Stove Prairie Hill; Empire; Boulder.

\section{PRUnella L. Self-heal, Heal-ali.}

I. Prunella vulgaris L. In woods, among bushes and in wet places; naturalized from Europe.-Alt. 4000-9000 ft.-Arboles; Colorado Springs; Sangre de Cristo Creek; Ft. Collins; Mancos; Palmer Lake; Sargent; Steamboat Springs; Boulder.

Io. PHYSOSTEgIA Benth. Lion's-heart, False Dragon's-head.

1. Physostegia parviflora Nutt. Among bushes from Minn, and B. C. to Colo. and Ore.-Exact locality not given.

\section{LEONURUS L. MOTHERWORT.}

I. Leonurus Cardiaca L. In waste places from N. S. and Mont. to N. C. and Colo.-Alt. 4000-8000 ft.-Cucharas Creek near La Veta; Lower Boulder Cañon, Boulder Co.

\section{I2. STAChys L. Hedge Nettle.}

Leaf-blades oblong-ovate or cordate; corolla I2-I5 mm. Iong; calyx-lobes almost equalling the calyx-tube.

r. S. teucrifolia.

Leaf-blades oblong-lanceolate; corolla Io-12 mm. long; calyx-lobes decidedly shorter than the calyx-tube.

2. S. scopulorum.

I. Stachys teucrifolia Rydb. In wet meadows in Colo. and Wyo.--New Windsor, Weld Co.; Colorado Springs; McCoy; Arboles.

2. Stachys scopulorum Greene. In wet meadows from Minn., Mackenzie River, and Alb. to N. M.-Alt. 4000-8500 ft.-Cucharas Valley, near La Veta; Grizzly Creek; Colorado Springs; South Park; Trimble Springs above Durango; Steamboat Springs, Routt Co.; Gunnison; Marshall Pass; Parlin, Gunnison Co.; along Conejos River north of Antonito; Dillon Cañon; Campton's ranch; Longmont; Ft. Collins ; Table Rock. 
13. Salvia L. Sage.

Corolla $15-30 \mathrm{~mm}$. long; tube exserted.

Corolla 8-I $2 \mathrm{~mm}$. long; tube included in the calyx.

1. S. Pitcheri.

2. S. lanceolata.

I. Salvia Pitcheri Torr. (S. azurea grandiflora Benth.) On prairies from Mo. and Neb. to Tex. and Colo.- "Eastern Colorado."

2. Salvia lanceolata Willd. On prairies, plains and hillsides from S. D. and Mont. to Tex. and Ariz.; also in Mex.-Alt. 4000-8500 ft.-Colorado Springs; hills about Box Cañon west of Ouray; Cucharas Valley, near La Veta; foot-hills west of Ft. Collins; Ft. Collins; Boulder.

\section{MONARda L. Horse-mint, Wild Bergamot.}

Heads solitary at the ends of the stem and branches; stamens conspicuously exceeding the acute upper lip of the corolla.

Petioles and stem more or less hirsute-villous or lanate, the latter especially so under the nodes.

Leaves hirsute; stem and petioles hirsute-ciliate. I. M. comata.

Leaves softly pubescent, especially below; stem, petioles and veins of the leaves lanate.

Whole plant finely strigose or puberulent.

Petioles seldom over $5 \mathrm{~mm}$. long.

Leaf-blades ovate-cordate; plant pale, more or less cinereous.

Leaves lanceolate with rounded or truncate base; plant green.

6. M. Ramaleyi.

$\begin{array}{ll} & \text { 3. } M \text {. stricta. } \\ \text { Petioles } I-3 \mathrm{~cm} \text {. long. } & \text { 4. } M \text {. mollis. }\end{array}$

Verticillate glomerules several in the upper axils of the leaves; stamens scarcely exceeding the emarginate or cleft upper lip. 5 . Mectinata.

I. Monarda comata Rydb. On hillsides in Colo.-Alt. 5000-8000 ft.-Pike's Peak; Wahatoya Creek; Ft. Collins; La Veta.

z. Monarda menthaefolia Benth. On hillsides and in valleys, especially among bushes from IIl., Man. and Ida. to Tex. and Colo.-Alt. 4000-9000 ft.-West Mancos Cañon; Pike's Peak; Hughes' Lake, Ouray; Cañon City; Redstone; Rist Cañon; Boulder; mountains between Sunshine and Ward.

3. Monarda stricta Wooten. On hillsides from Wyo. to N. M. and Ariz. -Alt. 5000-7000 ft.-Boulder; Durango; Piedra; Rist Cañon; Redstone.

4. Monarda mollis $L$. On prairies and among bushes from S. D. and Mont. to Ga. and Tex.-Alt. 4000-8500 ft.-Boulder; Four-mile Hill, Routt Co.

5. Monarda pectinata Nutt. ( $M$. citriodora Coulter; $M$. Nuttallii A. Nels.) On plains, especially in sandy soil from Colo. and Utah to Tex. and Ariz.Alt. 4000-6000 ft-Durango; New Windsor, Weld Co.; Denver; foot-hills, Larimer Co.; Soldier Cañon; Spring Cañon; Platte Cañon; Tobe Miller's ranch; vicinity of Horsetooth Mountain; Poudre Cañon, near Narrows; along Poudre River; Boulder.

6. Monarda Ramaleyi A. Nels. In sandy soil in Colo.-Boulder Creek, near Boulder.

\section{POLiomintha A. Gray.}

I. Poliomintha incana A. Gray. Dry places from western Tex, to southern Utah and Ariz.-San Juan Valley (Brandegee). 
16. hedeoma Pers. Pennyroyal.

Calyx-teeth about equal in length; floral leaves spreading or reflexed, hispid-ciliate. I. H. hispida.

Calyx-teeth of the lower lip much longer than those of the upper; floral leaves mostly erect, cinereous-hispidulous.

Floral leaves longer than the subtended calyces; plant $1.5^{-4} \mathrm{dm}$. high.

2. H. sancta.

Floral leaves scarcely exceeding the subtended calyces; plant I-I.5 dm. high.

3. H. nana.

I. Hedeoma hispida Pursh. In sandy soil from Ills. and Ass. to Ky and Colo.-Golden.

2. Hedeoma sancta Small. (H. Drummondii A. Gray, in part; not Benth.) On dry plains from Colo. to Tex. and N. Mex.-Alt. $4000-8000$ ft.-Durango; Manitou; Glen Eyrie; Dolores.

3. Hedeoma nana (Torr.) Greene. (H. dentata nana Torr.; H. Drummondii A. Gray, in part) On dry plains and hills from Colo. and Utah to Tex. and Ariz.-Alt. 5000-7000 ft.-Manitou; Fossil Creek; between Hotchkiss and Smith's Fork; Durango.

\section{CLINOPODIUM L. BASIL-WEED.}

I. Clinopodium vulgare L. In thickets from N. S. and Colo. to N. C. and N. M.-Alt. up to Io,000 ft.-Sierra Madre; Steamboat Springs.

I8. MADRONELLA Greene.

Bracts thin and pale, oval to orbicular.

I. M. parvifolia. Bracts thick, resembling the leaves, lanceolate or ovate-lanceolate, obtuse.

2. M. dentata.

1. Madronella parvifolia (Greene) Rydb. (Monardella parvifolia Greene) In cañons of Colo.-Alt. about $7000 \mathrm{ft}$-Black Cañon.

2. Madronella dentata Rydb. (Monardella dentata Rydb.) On mountains of Colo.-Gray's Peak.

\section{I9. LYCOPUS L. WATER HOAR-HOUND.}

Stem and lower surface of the leaves densely and finely pubescent, the former often velvety.

1. L. velutinus.

Stem sparingly and coarsely pubescent or glabrous; leaves glabrous or nearly so. Leaves merely coarsely serrate.

Leaves sinuately pinnatifid.

2. L. lucidus.

3. L. americanus.

1. Lycopus velutinus Rydb. In wet places among bushes from Ark. and Colo. to Tex.-Base of the Rocky Mountains.

2. Iycopus lucidus Turcz. In wet soil, especially in woods and thickets from Neb. and B. C. to Colo. and Calif.-Alt. $4000-5000$ ft.-Ft. Collins; Mason's river-front farm; Poudre flats.

3. Lycopus americanus Muh1. (L. sinuatus Ell.) In swamps and wet meadows from Newf. and B. C. to Fla. and Calif.-Alt. 4000-7000 ft.-Timnath, Larimer Co.; Cheyenne Mountain; New Windsor, Weld Co.; Table Rocks; Redstone; Ft. Collins; Poudre flats; Boulder. 


\section{2o. MENTHA L. MiNT.}

Whorls of flowers forming terminal spikes.

I. M. spicata.

Whorls of flowers axillary.

Leaf-blades thin, dark green, not strongly veined, tapering gradually into slender petioles, which equal or exceed the flower-clusters. 2 2. $M$. borealis.

Leaf-blades thick, strongly veined, abruptly contracted into short petioles, which are much shorter than the flower-clusters. 3. M. Penardi.

I. Mentha spicata L. ( $M$. viridis L.) Moist fields and waste places, from Me. and Minn. to Fla. and Colo. Introduced from Europe-North Denver (Eastwood).

2. Mentha borealis Michx. (M. canadensis glabrata Benth; not $M$. glabrata Vahl.) In wet places from N. B. and Mont. to Va. and Utah.-Alt. 6500-7500 ft.-Cimarron and Squaw Hill.

3. Mentha Penardi (Briq.) Rydb. (M. arvensis Penardi Briq.) In wet places, especially among bushes, from Neb., Mackenzie River and B. C. to Colo. and Utah.-Alt. 4000-8000 ft.-Cañon City; along Uncompahgre River, near Ouray; Durango; Montrose; Gunnison; Pagosa Springs; Cucharas Valley, near La Veta; Ft. Collins; Kremmling; Parlin, Gunnison Co.; Alamosa; Walsenburg; Boulder.

\section{Family i i 9. SOLANACEAE Pers. Night-shade Family.}

Fruit a berry.

- Corolla plicate; lobes usually induplicate; all our species herbs.

Calyx inflated and bladder-like in fruit.

Corolla open-campanulate, yellow or whitish, often with a dark center; seeds finely pitted; flowers nodding in anthesis. I. Prysalis.

Corolla rotate, violet or purple; seeds rugose-tuberculate; flowers erect in anthesis.

Calyx not inflated and bladder-like in fruit.

2. Quincula.

Calyx closely investing the berry.

Stamens alike, not declined; low unarmed perennials.

Stamens dissimilar, declined; prickly annuals.

Calyx not inclosing the berry.

Corolla little if at all plicate; its lobes valvate; shrubs.

Fruit a capsule.

Capsule circumscissile near the top, which separates as a lid; corolla irregular.

Capsule opening by valves; corolla regular.

Capsule prickly; seeds flat.

Capsule not prickly; seeds scarcely flattened.

3. Chamaesaracha.

4. ANdrocera.

5. Solanum.

6. LYCIUM.

\section{Physalis L. Ground-Cherry, Strawberry Tomato.}

Annuals with branching roots; fruiting calyx cordate-ovoid, acuminate, strongly 5 -angled.

Leaf-blades very oblique, cordate, sinuate-dentate.

s. P. pruinosa.

Leaf-blades orbicular or broadly ovate, sinuately crenate, scarcely cordate and scarcely oblique at the base.

2. P. neo-mericana.

Perennials with horizontal rootstock or rarely with woody caudices.

Pubescence if any not stellate, although in $P$. pumila with some branched hairs. Leaves and stem glabrous or the veins of the former and the upper part of the latter with scattered appressed hairs.

Leaf-blades ovate, ovate-lanceolate or oval.

Leaf-blades lanceolate, oblanceolate or linear.

3. P. subglabrata.

Leaves and stem more or less pubescent with spreading hairs. 
Pubescence sparse, consisting of flat, sometimes jointed hairs, scarcely viscid. Fruiting calyx ovoid, scarcely angled and scarcely sunken at the base; leaves thick, oblanceolate or spatulate to rhombic, subentire.

Leaves oblanceolate or spatulate; hairs all simple. Pubescence very short; leaves narrowly oblanceolate.
Pubescence long; leaves spatulate.
5. P. polyphylla.
6. P. lanceolata.

Leaves broader, often rhombic; hairs on the lower surface branched. 7. P. pumila.

Fruiting calyx pyramidal-ovoid, obtusely 5-angled and deeply sunken at the base; leaves ovate to lanceolate, generally more or less toothed.

8. $P$. virginiana.

Pubescence dense, viscid, partly of fine and short, partly of long flat jointed hairs.

Leaves large; blades over $5 \mathrm{~cm}$. long, more or less cordate; long flat hairs numerous. 9 9. P. heterophylla.

Leaves smaller; blades less than $5 \mathrm{~cm}$. long; long flat hairs few, mostly confined to the calyx.

Plant erect or ascending.

Leaf-blades reniform or rounded cordate, coarsely sinuately toothed.

I0. $P$. hederaefolia.

Leaf-blades rounded ovate or rhombic. II. $P$. comata.

Plant prostrate, diffuse; leaf-blades nearly orbicular.

I2. $P$. rotundata.

Pubescence fine, grayish, at least in part stellate.

I3. P. Fendleri.

1. Physalis pruinosa L. In cultivated soil, from Mass. and Iowa to Fla. and Mo.; introduced in Colo.-Ft. Collins.

2. Physalis neo-mexicana Rydb. ( $P$. pubescens Coult.; not L.) In loos soil from Colo. to N. M. and Ariz.-Alt. about 6000 ft.-Colorado Springs.

3. Physalis subglabrata Mack. \& Bush. In river valleys and cultivated grounds from Ohio and Mont. to $\mathrm{Pa}$. and Colo.-Alt. up to $7000 \mathrm{ft}$-Dome Rock in Platte Cañon.

4. Physalis longifolia Nutt. ( $P$. lanceolata laevigata A. Gray) In river valleys and rich soil from Iowa and Mont. to Ark. and Ariz.; also in Mex.Alt. $4000-8000$ ft.--Gunnison; Berkeley Lake, Denver; Pueblo; Ft. Collins; Boulder.

5. Physalis polyphylla Greene. On plains of Colorado.-Walsenburg; Piedra.

6. Physalis lanceolata Michx. On plains and prairies from Ills. and S. D. to S. C. and Ariz.; also in Mex.-Alt. 4000-6000 ft.-Ft. Collins; Colorado Springs / Boulder.

7. Physalis pumila Nutt. ( $P$. lanceolata hirta A. Gray) Prairies and river valleys from Mo. and Colo. to Tex.-Alt. 4000-7000 ft.-La Veta; Sulphur Spring, Soldier Cañon.

8. Physalis virginiana Mill. ( $P$. lanceolata A. Gray, in part; not Michx.) On prairies, in river valleys and cultivated ground from N. Y., Mich. and Mont. to Fla. and Tex.-Alt. $4000-8000$ ft.-Boulder Cañon; between Sunshine and Ward.

9. Physalis heterophylla Nees. ( $P$. virginiana A. Gray; not Mill.) In cultivated fields and sandy or loose soil from N. B. and Sask. to Fla., Tex. and Utah.-Alt. 4000-6000 ft.-Timnath, Larimer Co.; Red Rock Cañon; New Windsor, Weld Co.; foot-hills, Larimer Co.; gulch west of Pennock's; Dixon Cañon; Howe's Gulch; Ft. Collins; Boulder; Longmont. 
Io. Physalis hederaefolia A. Gray. On plains and rocky hills from Colo. to Tex. and Calif.-Exact locality not given.

II. Physalis comata Rydb. On hillsides from Neb. and Colo. to Tex.Alt. 4000-5500 ft.-New Windsor, Weld Co.

12. Physalis rotundata Rydb. On plains from N. D. and Colo. to Tex. and N. M.--Sandy valleys, Larimer Co.; along Poudre River.

x3. Physalis Fendleri A. Gray. On rocky hills and plains from Colo. and Utah to N. M. and Ariz.-Alt. 6000-8000 ft.-Cañon City; near Badito, between La Veta and Gardner; Piedra; Durango; Mancos; Walsenburg; Dolores.

\section{Quincula Raf. Puple Ground-cherry.}

I. Quincula lobata (Torr.) Raf. (Physalis lobata Torr.) On plains and river bluffs from Kans. and Colo. to Tex. and Ariz.; also in Mex.-Alt. 4000-6000 ft.-Rocky Ford; Cheyenne Cañon; Spring Cañon; Ft. Collins; Dixon Cañon; Boulder; Longmont.

\section{ChamaESARACHA A. Gray.}

Pubescence dense, hirsute as well as puberulent. I. C. conioides. Pubescence sparse, puberulent or stellate, hirsute if at all only on the calyx.

2. C. Coronopus.

I. Chamaesaracha conioides (Moric.) Britton. (C. sordida A. Gray) In clayey soil from Kans. and Colo. to Tex. and Ariz.; also in Mex.-Alt. ip to $5000 \mathrm{ft}$--Lamar; Pubelo.

2. Chamaesaracha Coronopus (Dunal) A. Gray. On clayey soil from Kans. and Colo. to Tex. and Ariz.-Alt. 4000-6000 ft.-Cañon City; McElmo Cañon; mesas near Pueblo; Walsenburg; Trinidad.

\section{ANDROCERA Nutt.}

I. Androcera rostrata (Dunal) Rydb. (Solanum rostratum Dunal; Androcera lobata Nutt.) On plains and in river valleys from N. D. and Wyo. to Tex. and N. M. ; also in Mex.; introduced eastward to N. H. and Fla.-Alt. 4000-6000 ft.-Colorado Springs; Golden; New Windsor, Weld Co.; Ft. Collins; Denver; foot-hills west of Ft. Collins; Boulder.

Annuals.

\section{Solandm L. Nightshade, Potato.}

Leaves pinnatifid.

Leaves sinuately dentate or entire.

1. S. triflorum.

Plant strigose or glabrous; berry black.

Leaves glabrous or nearly so; calyx-lobes obtuse. $\quad$ 2. S. nigrum.

Leaves decidedly strigose beneath; calyx-lobes abruptly acutish.

Corolla-lobes $3-4 \mathrm{~mm}$. long. 3 . S. interior.

Corolla-lobes 6-8 mm. long. $\quad$ 4. S. Douglasii.

Plant more or less viscid-villous; fruit greenish or yellowish.

Perennials.

5. S. villosum.

Plant green, glabrous or pubescent, but not stellate, never prickly; perennial with tubers.

6. S. Jamesii.

Plant silvery-white with stellate hairs; stem often prickly. 7. S. elaeagnifolium. 
1. Solanum triflorum Nutt. On prairies and waste places, and especially in "prairie-dog towns" from Ont. and Alb. to Kans. and Ariz.-Alt. 4000I0,000 ft.-Cucharas Valley, near La Veta; Colorado Springs; Durango; Ft. Collins; Walsenburg; Ouray; Mountain View; along Uncompahgre River, near Ouray; Rocky Ford; Boulder.

2. Solanum nigrum L. In waste places, from N. S. and Wash. to Fla. and Tex.; introduced from Europe-College lawn, Ft. Collins.

3. Solanum interior Rydb. In river valleys among bushes from $\mathrm{Neb}$. and Colo. to Tex. and Calif.-Alt. 4000-6000 ft.-Cañon City; Timnath, Larimer Co.; along the Platte River, Denver; Bent's Fort.

4. Solanum Douglasii Dunal. In valleys of Calif., Ariz. and northwestern Mex. A specimen collected by Fremont is labelled: "Probably from the sources of the Platte, near the mountains." This is probably an error and very likely the specimen came from California.

5. Solanum villosum (Mill.) Lam. (S. nigrum villosum Mill.) In sandy soil from Wyo. and B. C. to Colo, and L. Calif.-Alt. 5000-6000 ft.-Boulder.

6. Solanum Jamesii Torr. In the mountains from Colo. to Tex. and Ariz. -Alt. 4000-7000 ft.-La Veta; Trinidad; Ft. Collins.

7. Solanum elaeagnifolium Cav. On plains from Mo. and Colo. to Tex. and Calif.; also in Mex.-Pueblo; Brantly Cañon, Los Animas Co.

\section{LYCiUM L. Matrimony Vine.}

1. Lycium pallidum Miers. On arid hills from Colo. and Utah to N. M. and Ariz.; also in Mex.-McElmo Creek; San Juan Valley.

\section{Hyoscyamus L. Black Henbane, Hog's-bean.}

I. Hyoscyamus niger L. In waste places from N. S., Mich. and Mont. to N. Y. and Colo.; introduced and naturalized from Europe.-Alt. up to 8000 ft.-Along Uncompahgre River, near Ouray.

\section{DATURA L. ThORN-APPLE, JiMSON-WEED.}

Corolla $1.5^{-2} \mathrm{dm}$. long; capsule more or less fleshy, bursting irregularly.

Corolla about I $\mathrm{dm}$. long; capsule dry; 4-valved.

1. D. meteloides,

Capsule erect; plant glabrous.

Corolla white; lower prickles of the capsule shorter. 2. D. Stramonium.

Corolla violet; prickles all alike.

Capsule nodding; plant more or less cinerous.

3. D. Tatula.

4. D. discolor.

I. Datura meteloides DC. Along streams from Colo. to N. M. and Calif.; also in Mex.-Alt. 5000-6000 ft.-McElmo Cañon; Montezuma Co.; Hovenweep Cañon; Grand Cañon.

2. Datura Stramonium L. In waste places from N. S. and Minn. to Fla., Tex. and Colo.; naturalized from Asia.-Boulder Cañon; Denver; Cherry Creek; Golden.

3. Datura Tatula L. In waste places from Ont. and Minn. to Fla., Tex. and Colo.; naturalized from tropical America.-Ft. Collins.

4. Datura discolor Benth. In river valleys from Colo. to Ariz. and Calif.; also in Mex.-Colorado, according to Gray, no specimens seen. 


\section{NICOTIANA L. Tobacco.}

Leaves clasping at the base; flowers diurnal. 1. N. trigonophylla.

Leaves petioled, not clasping at the base; flowers nocturnal. 2. N. attenuata.

1. Nicotiana trigonophylla Dunal. In dry grounds from Colo. and Utah to Tex. and Calif.; also in Mex.- "Southern Colorado" (Parry).

2. Nicotiana attenuata Torr. In dry or sandy ground from Mont. and B. C. to N. M. and Calif.-Alt. 6000-7000 ft.-Gypsum, Eagle Co.; Black Cañon; Salida; Glenwood Springs, Garfield Co.; Montrose; McElmo Cañ_n; Hotchkiss; Rustic; mountains between Sunshine and Ward.

\section{Family i 20. RHINANTHACEAE St. Hil. Figwort Family.}

Anther-bearing stamens 5 .

Corolla rotate.

Corolla funnelform, 2-lipped. (Occasional forms of)

Anther-bearing stamens 4 or 2 .

Corolla spurred or saccate at the base on the lower side.

Corolla neither spurred nor saccate on the lower side.

Stamens 5, 4 anther-bearing, the fifth sterile and often rudimentary.

Sterile stamen rudimentary, represented by a scale or gland on the upper inside of the corolla-tube or throat; corolla short.

Corolla gibbous at the base on the upper side; ovules and seeds few or solitary ; annuals.

3. Collinsia.

Corolla not gibbous at the base, but more or less ventricose especially on the lower side; ovules and seeds numerous; perennials.

4. Scrophularia.

Sterile stamen elongated, filiform to spatulate; corolla-tube elongated, tubular or funnelform.

Inflorescence thyrsoid-paniculate; seeds not with an ariliform, cellularreticulate outer coat; corolla not gibbous at the base above; calyx deeply cleft.

Inflorescence racemose or spiciform; seeds with an ariliform, cellularreticulate outer coat, calyx obtusely 5 -lobed.

Stamens 4 or 2.

Upper lip or lobes of the corolla external in the bud.

Anther-bearing stamens 4 .

Corolla more or less bilabiate; sepals united into an angled tube; plants leafy-stemmed.

7. Mimulus.

Corolla nearly regular; flowers solitary on scape-like peduncles from the basal rosette of leaves; plant acaulescent. 8. Limosella.

Anther-bearing stamens 2 ; calyx of 5 , almost distinct sepals; sterile filaments short or wanting.

Lower lip or lobes of the corolla external in the bud.

Stamens 2 .

Corolla almost regularly 4 -lobed.

9. Gratiola.

Corolla none or 2-lipped, cleft to near the base; upper lip entire; lower irregularly cleft or toothed.

Stamens 4 .

Corolla slightly 2-lipped; stamens not ascending under the upper lip.

I 2. Gerardia.

Corolla distinctly 2 -lipped; stamens ascending under the upper lip. Anther-sacs dissimilar; the inner one pendulous by its apex; leaves mostly alternate.

Calyx gamosepalous, $i$. $\boldsymbol{c}$., all the sepals united below into a tube. Calyx deeply cleft in front and behind, less deeply so (sometimes not at all) on the sides; upper lip of the corolla much longer than the 3 -lobed lower one.

13. Castilleja. 
Calyx almost equally 4-cleft; upper lip of the corolla slightly if at all longer than the $I-3$ saccate lower one which is minutely or obsoletely toothed.

I4. ORThocarpus.

Calyx 2-phyllous, $i$, e., cleft to the base on the sides, or, by absence of the lower part, I-phyllous. I5. AdENoSTEGIA.

Anther-cells alike, parallel; leaves mostly opposite.

Calyx split below, or below and above, not inflated; capsule ovoid or oblong, oblique.

Galea prolonged into a filiform recurved beak; throat with a tooth on each side.

i6. ElePhantella.

Galea not prolonged into a beak or this not filiform, straight or incurved; throat without teeth.

i7. Pedicularis.

Calyx 4-toothed, inflated and veiny in fruit; capsule orbicular.

i8. Rhinanthus.

\section{VERBascum L. Mullen.}

Plant densely woolly; flowers in dense spikes.

Plant glabrous or sparingly glandular; flowers racemose.

1. V. Thapsus.

2. V. Blattaria.

I. Verbascum Thapsus L. In waste places and cultivated ground from N. S. and B. C. to Fla. and Calif. ; naturalized from Europe-Alt. 5000-6000 ft.-Boulder; I2 miles above mouth of Leroux Creek.

2. Verbascum Blattaria L. In waste places from Que. and B. C. to Fla. and Calif.; naturalized from Europe.-Boulder.

\section{LINARIA Mill. Butter-And-Eggs, ToAd-Flax.}

Corolla blue or white, I $2 \mathrm{~mm}$. long or less.

Corolla yellow, $2-3 \mathrm{~cm}$. long.

I. L. canadensis.

2. L. Linaria.

I. Linaria canadensis (L.) Dum. In dry soil from N. S. and Wash. to Fla. and Calif.-Alt. 4000-8000 ft.-Boulder; Table Rock; Loveland; Spring Cañon.

2. Linaria Linaria (L.) Karst. (L. vulgaris Mill.) In waste places and fields from Newf. and Man. to Va. and Colo.; naturalized from Europe.Gunnison; North Plattè.

\section{COLlinsia Nutt. Blue-Eyed-Mary.}

1. Collinsia parviflora Dougl. On shaded hillsides from Ont. and B. C. to Ariz. and Calif.-Alt. 5000-9000 ft.-Foothills, Larimer Co.; Veta Mountain; west of Ft. Collins; near Golden; Chicken Creek, West La Plata Mountains; Ward; Cimarron; North Boulder Peak; Palmer Lake; Rist Cañon; vicinity of Horsetooth; Beaver Creek; Trail Creek; Horsetooth Gulch; hills west of Soldier Cañon; Boulder.

\section{SCROPHULARIA L. FIg-WORT, HEAL-ALL.}

I. Scrophularia occidentalis (Rydb.) Bickn. In woods and among bushes from N. D. and Wash. to Ind. Terr. and Calif.-Alt. 4000-I0,000 ft.-Georgetown; South Cheyenne Cañon; Turkey Creek and tributaries; near Parrott, La Plata Mountains; Cache la Poudre; Baxter's ranch; Moon's ranch; Horsetooth Gulch; Pennock's mountain ranch; Rist Cañon; gulch west of Soldier Cañon; Trail Creek; Boulder. 


\section{PENTSTEMON Soland. Beard-TONGUe.}

Corolla blue, purple, white or yellowish, more or less funnelform or salverform. Anthers bearded.

I. GLABRI.

Anther glabrous or merely hirtello-ciliate along the line of dehiscence.

Plant not suffruticose at the base.

Leaves not linear-filiform.

Corolla decidedly funnelform, $i$. e., throat much wider than the tube.

Sterile stamen glabrous; plant tall, perfectly glabrous.

Sterile stamen bearded.

I. GLABri.

Plant perfectly glabrous, or slightly puberulent above.

Corolla strongly ventricose-gibbous; tube proper very short.

Corolla over $3 \mathrm{~cm}$. long; stem-leaves clasping; plant tall.

II. GRANDIFLORI.

Corolla about $2 \mathrm{~cm}$. long; leaves linear or oblanceolate, not clasping; plant low. III. HalitaNI.

Corolla not ventricose-gibbous; tube gradually dilated into a funnelform throat. IV. Acuminati.

Plant glandular at least on the inflorescence.

Stem glabrous below.

Stem glandular or puberulent.

V. Giauci.

VI. Cristatr.

Corolla-tube almost cylindrical or slightly widening upwards; corolla less than $2 \mathrm{~cm}$. long.

Stems several from a branching rootstock, low and weak.

VII. HaRbouriani.

Stems solitary or a few from a taproot or short caudex.

Leaves linear-filiform.

VIII. CONFERTI.

Corolla-limb not strongly oblique; sterile stamen bearded.

Corolla-limb strongly oblique; sterile stamen glabrous.

IX. LARICIFOLIT.

Plant suffruticose at the base.

X. Ambigui.

XI. Caespitosi.

Corolla red, almost tubular.

Anthers opening for nearly their whole length.

XII. Barbati.

Anthers opening only on their proximal part.

XIII. Bridgesiani.

\section{Glabri.}

Anthers bearded with long villous hairs.

Leaves and stem glabrous.
Calyx-lobes acute or obtuse.
1. P. strictus.

Calyx-lobes long-acuminate.

2. P. strictiformis.

Leaves and lower part of the stem densely and minutely puberulent.

Anthers glabrous or sparingly short-hirsute.

3. P. comarrhenus.

Anthers sparingly bearded.

Stem-leaves all narrowly lanceolate.

Calyx-lobes with narrow scarious margins, not auricled.

Corolla about $1.5 \mathrm{~cm}$. long; plant puberulent. 4 4. P. Fremontii.

Corolla about $2 \mathrm{~cm}$. long; plant glabrous.

5. P. utahensis.

Calyx-lobes with very broad scarious margins, forming erose auricles.

Stem and leaves glabrous. $\quad 6$. P. oreophilus.

Stem and leaves more or less puberulent. $\quad$ 7. $P$. alpinus.

Upper stem-leaves broadly ovate or cordate. $\quad 8$. P. Brandegei.

Anthers and sterile filaments glabrous.

9. $P$. unilateralis.

\section{Grandifloki.}

One species.

III. Halliani.

One species.

Io. $P$. grandiflorus.

II. P. Hallii. 


\section{Acuminati.}

Inflorescence interrupted; bracts except the lowermost shorter than the flowers; basal leaves spatulate or oblanceolate.

Bracts ovate to almost orbicular.

Bracts lanceolate to linear-lanceolate.

12. P. cyathophoris.

Calyx-lobes broadly obovate, scarious, erose, abruptly contracted into a very short acumination.

I3. P. Watsonii.

Calyx-lobes ovate or lanceolate, acute or gradually acuminate.

Calyx-lobes lanceolate; plant 3-4 dm. high.

Calyx-lobes ovate; plant $2 \mathrm{dm}$. high or less.

I4. P. secundiflorus.

I5. P. Fendleri.

Inflorescence dense; bracts large, long-acuminate, most of them exceeding the flowers; basal leaves linear or nearly so, narrower than the stem-leaves.

One species. $\quad$ V. GLauci.

16. $P$. angustifolius.

\section{Vi. Cristati.}

I 7. P. glaucus.

Corolla-tube decidedly gibbous-ventricose; sterile stamen densely yellow-villous; corolla purplish.

Basal leaf-blades obovate or spatulate or ovate, broader than the cauline leaves; corolla about $1.5 \mathrm{~cm}$. long.

18. P. Moffattii.

Basal leaf-blades linear to linear-oblanceolate, usually narrower than the upper cauline leaves; corolla $2-3 \mathrm{~cm}$. long.

19. P. Jamesii.

Corolla-tube funnelform, scarcely gibbous; sterile stamen sparingly yellow-villous; corolla white.

20. P. albidus.

VII. Harbouriani.

One species.

VIII. CONFERTI.

21. P. Harbourii.

Leaves more or less dentate.

Calyx-lobes elongated-lanceolate, not scarious; flowers ascending; stem-leaves linear-lanceolate or linear.

22. $P$. gracilis.

Calyx-lobes ovate-lanceolate, scarious-margined below and usually toothed; stem-leaves oblong-lanceolate or lanceolate. 23. P. humilis.

Leaves entire.

Calyx glabrous or puberulent, but not at all glandular; its lobes with very broad, erose, scarious margins and abrupt acumination.

Corolla over I cm. long; upper stem-leaves broadly lanceolate, often rounded at the base; plant $3 \mathrm{dm}$. high or more.

24. P. Rydbergii.

Corolla less than I cm. long; upper stem-leaves linear-lanceolate; plant seldom over $3 \mathrm{dm}$. high.

Calyx and inflorescence more or less glandular.

Plant glabrous or nearly so.

Plant decidedly puberulent.

25. P. procerus.

22. P. gracilis.

26. $P$. radicosus.

IX. LARICIFOLII.

One species.

X. Ambigui.

One species.

XI. Caespitosi.

27. P. laricifolius.

28. P. ambiguns.

Leaf-blades obovate, spatulate or broadly oblanceolate.

Leaves green and glabrous or slightly puberulent; calyx-lobes oblong-lanceolate.

29. $P$. suffrutescens.

Leaves densely grayish or whitish puberulent; calyx-lobes lanceolate.

Leaf-blades narrowly oblanceolate to linear or filiform.

3o. P. caespitosus.

Calyx-lobes scarcely scarious-margined, entire; inflorescence few-flowered;

floral leaves like the rest.

Leaves green and glabrate.

Leaves densely canescent-puberulent.

3I. P. xylus.

Caly $x$-lobes scarious-margined, dentat

32. P. teucrioides.

racemiform; floral leaves reduced.

many-flowered 
XII. Barbaty.

Lower lip bearded within.

Lower lip glabrous within.

Anthers glabrous; leaves usually glabrous.

Anthers long-bearded; leaves puberulent.

34. P. barbatus.

35. P. Torreyi.

36. $P$. trichander.

XIII. BRIDGESIANI.

One species.

37. P. Bridgesit.

1. Pentstemon strictus Benth. On hills from Wyo. to Colo. and Utah.Alt. 6000-9000 ft.-Cimarron; Chicken Creek, West La Plata Mountains; Elk River, Routt Co.; Cerro Summit ; La Plata River; Pearl ; Hotchkiss; between Porter and Durango; North Park; Walton; Steamboat Springs; Walden.

2. Pentstemon strictiformis Rydb. On hills and plains of Colo.-Alt. 7500-9000 ft.-Mesa Verde; hills about Box Cañon, west of Ouray; Arboles; Grayback mining camps and Placer Gulch; Mancos; Sangre de Christo Creek; Antonito; Redcliffe.

3. Pentstemon comarrhenus A. Gray. On dry hills in Colo, and Utah.Alt. 5000-7000 ft.-Mancos; Cedar Edge; Piedra.

4. Pentstemon Fremontii T. \& G. On dry hills from Wyo. to Colo. and Utah.-Meeker, Rio Blanco County.

5. Pentstemon utahensis (S. Wats.) A. Nels. ( $P$. glaber Utahensis S. Wats.) In the mountains from Wyo. and Ida. to Colo. and Utah.-Alt. up to Io,000 ft.-Hahn's Peak; Marshall Pass; Hotchkiss; Horsetooth Gulch; Leroux Creek; Anita Peak.

6. Pentstemon oreophilus Rydb. In the mountains of Colo.-Alt. 8000Io,000 ft.-Mountain sides near Empire; Bald Mountain; Halfway House; Larimer Co.; Manitou; South Cheyenne Cañon; Eldora to Baltimore; Bosworth's ranch; Horsetooth Mountain; Stove Prairie.

7. Pentstemon alpinus Torr. $(P$. glaber alpinus A. Gray; $P$. riparius A. Nels.) In the mountains of Colo. and Wyo., especially along streams.-Alt. 6000-10,000 ft.-Flagstaff Hill; mountain sides near Empire; Bosworth's ranch; Stove Prairie; Horsetooth Mountain; Ward; Empire.

8. Pentstemon Brandegei Porter. In the mountains from Mont. to Colo. -Alt. 6000-9000 ft.-Dry rocks, Cheyenne Mountain; Colorado Springs; Pueblo; Pike's Peak.

9. Pentstemon unilateralis Rydb. ( $P$. secundiflorus A. Gray; not Benth.) In the mountains from Wyo. to N. M.-Alt. 5500-I0,000 ft.-Near Empire; Georgetown; Douglass Co.; Sangre de Cristo Creek; Gunnison; Central City; Manitou; Ft. Collins; Golden; Idaho Springs; Como, South Park; Mt. Harvard; Colorado Springs; Leroux Creek; gulch west of Pennock's; Hayden's ranch; Clear Creek; Spring Cañon; Poudre River; La Porte; Empire; Eldora to Baltimore; Boulder.

I0. Pentstemon grandiflorus Nutt. On prairies and plains from Ills., Wisc. and Ore. to Ind. Terr. and Utah.-Gray's Peak.

II. Pentstemon Hallii A. Gray. On the higher mountains of Colo.-Alt. I0,000-14,000 ft.-Pike's Peak; Seven Lakes; Dead Lake; Mount Garfield; mountains above Como; Argentine Pass; Gray's Peak; above Boreas.

12. Pentstemon cyathophorus Rydb. In the mountains of Colo.-Alt. about 8500 ft.-Pearl; Grizzly Creek; North Park. 
13. Pentstemon Watsonii A. Gray. In the mountains from Colo. to Nev. and Ariz.-Glenwood Springs.

14. Pentstemon secundiflorus Benth. ( $P$. acuminatus A. Gray, mainly; not Dougl.) On dry plains and hills from Wyo. to N. Mex.-Alt. 5000-9000 ft. -Near Empire; Manitou; Colorado Springs; Ft. Collins; foothills, Larimer Co.; Denver; South Park; Crystal Park; North Park, near Teller; north of La Porte; Horsetooth Gulch; Wray; Platte Cañon; Dixon Cañon; Trail Creek; Camp Creek.

r. Pentstemon Fendleri A. Gray. On high plains of Colo. and to N. M. and Calif.-Arboles; Salida.

I6. Pentstemon angustifolius Pursh. ( $P$. coeruleus Nutt.) On plains from S. D. and Mont. to Colo.-Alt. 4000-6000 ft.-Ft. Collins; New Windsor; Redcliffe; Colorado Springs.

Pentstemon angustifolius caudatus (Heller) Rydb. ( $P$. caudatus Heller) A taller variety with broader leaves from Colo. and N. Mex.-Livermore; Cucharas River, below La Veta; Ojo; butte, 5 miles southwest of La Veta; Walsenburg; river-bluffs north of La Veta; mesas near Pueblo; Colorado College.

17. Pentstemon glaucus Graham. In the mountains from Wyo. and Utah to Colo. and Ariz.-Alt. 8000-12,000 ft.-Headwaters of Clear Creek; Halfmoon Creek; Dark Cañon, Pike's Peak; Chambers' Lake; mountains south of Ward, Boulder Co.; Berthoud Pass, near Georgetown; Pike's Peak; Silver Plume; Cameron Pass; near Graymont; near Pagosa Peak; Salida; Gore Pass; Anita Peak; Hahn's Peak; Red Mountain road, south of Ouray; near La Plata; Palsgrove Cañon; Marshall Pass; Argentine Pass; near Seven Lakes, Pike's Peak; Villa Grove; Silverton; Robinson; Alpine Tunnel; Gray's Peak; Little Kate Mine, La Plata Mountains; Steamboat Springs.

Pentstemon glaucus stenosepalus A. Gray. A variety with long-attenuate calyx-lobes.-Graymont; Ragged Mountain; Michigan Hill; Boreas; Beaver Creek; Gore Pass; Four-mile Hill, Routt Co.; Seven Lakes, Pike's Peak; Eldora to Baltimore; Chambers' Lake; Spicer.

18. Pentstemon Moffattii Eastw. On dry table-lands of western Colo.Mancos.

I9. Pentstemon Jamesii Torr. On plains and dry valleys in Colo. and S. D. -Alt. 5000-9000 ft.-Cucharas Valley, near La Veta; Swallows, between Pueblo and Cañon City; mesas near Pueblo; near Badito; Sangre de Cristo Creek; Walsenburg; Rocky Ford.

20. Pentstemon albidus Nutt. On prairies and plains from Ass. and Ida. to Kans. and Colo.--Near Denver; Eads; Sterling; Grand Junction.

2I. Pentstemon Harbourii A. Gray. On the higher peaks of Colo.-Alt. 9000-I3,000 ft.-Rock-slide at the foot of Mt. McClellan; Kelso Valley; Little Kate Basin, La Plata Mountains; West Spanish Peak; mountains above Ouray; Mt. Richtofen.

22. Pentstemon gracilis Nutt. On plains and prairies from Man. and Sask. to Tex. and Colo.-Alt. 4000-8000 ft.-Divide west of salt-works, South Park; north of Cheyenne Cañon; Wahatoya Creek; Brantly Cañon; Table Rock; Dillon Cañon, Trinidad; Palmer Lake.

23. Pentstemon humilis Nutt. On plains and hills from Mont. and Alb. to Colo. and Nev.-Alt. 5000-I0,000 ft.-South Park; near Denver; headwaters 
of Clear Creek; Crystal Park; Cheyenne Mountain; North Cheyenne Cañon; Turkey Creek and tributaries; Wahatoya Cañon; near Georgetown; foothills west of Ft. Collins; foot-hills below Colorado Springs; Dale Creek, Larimer Co.; Dixon Cañon; Rist Cañon; gulch west of Pennock's; gulch south of Boreas; Horsetooth Gulch; gulch south of Boulder; Platte Cañon; Empire; Eldora to Baltimore; Camp Creek.

24. Pentstemon Rydbergii A. Nels. (P. erosus Rydb.) In the mountains from Wyo. and Wash. to Colo.-Alt. 7000-10,000 ft.-Steamboat Springs; Rabbit-Ears, Larimer Co.; South Park; Sargent's; Gunnison; Marshall Pass; Chicken Creek, West La Plata Mountains; Pitkin; Columbine; Parlin, Gunnison Co.; Robinson; Sheephorn Divide, Middle Park; Rabbit-Ears Pass; Salida; Walton Creek; Como; Mt. Richtofen on the Michigan; Big South; Eldora to Baltimore.

25. Pentstemon procerus Dougl. On hills and mountains from Sask. and B. C. to Colo. and Calif.-Alt. 8000-I I,000 ft.-Headwaters of Clear Creek; Bard Creek Valley, near Empire; Chambers' Lake; North Park; Mt. Harvard; Twin Lakes; Como; between Como and Boreas; Walden.

26. Pentstemon radicosus $A$. Nels. On plains from Ida. and Mont. to Colo. -Pinkham Creek.

27. Pentstemon laricifolius H. \& A. On dry hills from Wyo: and Ore. to Colo.-Medicine Bow Mountains, Larimer Co.

28. Pentstemon ambiguus Torr. On plains from Colo. and Utah to Tex. and Ariz.; also in Mex.-Rocky Ford; Sterling.

29. Pentstemon suffrutescens Rydb. ( $P$. caespitosus suffruticosus A. Gray; $P$. procumbens Greene) On dry hills and mountains of Colo. and Utah.Alt. up to $10,000 \mathrm{ft}$--Keblar Pass; Ridgway.

30. Pentstemon caespitosus Nutt. On dry hills from Wyo., Utah and Colo. -McCoy's, Eagle Co.; north of Craig.

3I. Pentstemon xylus A. Nelson. In the mountains of Colo.-Alt. 6500ı0,000 ft.-Cimarron; South Cottonwood Gulch, Chaffee Co.; Como; Mancos; Gunnison.

32. Pentstemon teucrioides Greene. On dry hills in Colo--Alt. about 7250 ft.-Sapinero.

33. Pentstemon linarioides A. Gray. (P. Coloradoensis A. Nels.) On dry hills and plains from Colo. and Utah to N. M. and Ariz.; also in Mex.Alt. 6500-7500 ft.-Dolores; Mancos Cañon; Durango.

34. Pentstemon barbatus Nutt. In the mountains from Colo. to Ariz.; also in Mex.- "Mountains of Colorado."

35. Pentstemon Torreyi Benth. ( $P$. barbatus Torreyi A. Gray) On hillsides in the mountains from Colo. to N. M. and Ariz.; also in Mex.-Alt. 7000-10,000 ft.-Lake City; Artist's Glen; Placer; mesas near Buena Vista; Sangre de Cristo Creek; Salida; North Cheyenne Cañon; Black Cañon; Dillon Cañon.

36. Pentstemon trichander (A. Gray) Rydb. ( $P$. barbatus trichander A. Gray) In the mountains of Colo.-Alt. 7000-10,000 ft.-Mesa Verde; Piedra; Buena Vista; Durango.

37. Pentstemon Bridgesii A. Gray. Rocky banks from Colo. to Ariz. and Calif.-Alt. $6000-8000$ ft.-El Late (Brandegee). 


\section{CHIONOPHILA Benth.}

1. Chionophila Jamesii Benth. In the higher mountains of Colo. and Southern Wyo.-Alt. II,000-I4,000 ft.-Mt. .Hayden; near Pagosa Peak; Pike's Peak; Gray's Peak; mountains above Boreas; Massif de l'Arapahoe; Douglass Mountain, Georgetown; Beaver Creek; Mt. Bartlett; Mt. Robinson; Red Mountain; Ethel Peak.

\section{MIMULUS L. MONKEY-FLOWER.}

Calyx oblique, decidedly inflated in fruit; upper tooth much larger than the rest; corolla yellow.

Calyx-teeth acute; stem neither rooting at the nodes nor floating.

Perennials, usually tall and erect, $3^{-6} \mathrm{dm}$. high; corolla $2-3 \mathrm{~cm}$. long; calyx-teeth not much unequal.

Leaves glabrous; stem pubescent only above. $\quad$ I. M. Langsdorfii.

Leaves and stem pubescent throughout.

2. M. puberulus.

Annuals, slender or low; corolla $2 \mathrm{~cm}$. or less long; upper calyx-tooth much elongated.

Corolla $1.5^{-2} \mathrm{~cm}$. long, at least twice as long as the calyx.

3. M. nasutus.

Corolla 5-8 mm. long, about half longer than the calyx. 4. M. Hallii.

Calyx-teeth obtuse; stem decumbent or floating, rooting at the nodes.

Calyx neither oblique nor inflated; its lobes nearly equal.

5. M. Geyeri.

Perennials; flowers $1-4 \mathrm{~cm}$. long; sepals linear-lanceolate.

Tall, with erect stem, 3-Io dm. high; corolla crimson or rose.

Low or slender, weak; corolla yellow.

6. M. Lewisii.

7. M. moschatus.

Annuals; flowers $0.5-1 \mathrm{~cm}$. long; sepals ovate, triangular or broadly lanceolate. Leaves petioled; blades cordate to ovate-lanceolate.

Leaves sessile, oblong, lanceolate or linear.

8. $M$. floribundus.

9. M. gratioloides.

1. Mimulus Langsdorfii Sims. ( $M$. luteus A. Gray; not L.; $M$. minor A. Nels.) In swamps and along streams, especially in muddy places, from Ass. and Alaska to N. M. and Calif.; also in Mex.-Alt. 8000-12,000 ft.-Hahn's Peak; Chambers' Lake; Van Boxle's ranch, above Cimarron; Grayback mining camps and Placer Gulch; Manitou; headwaters of Sangre de Cristo Creek; Ouray; Twin Lakes; bank of Michigan; Cameron Pass; Twin Lakes; Four-mile Hill; Gypsum Creek Cañon; Berthoud Pass; Empire; between Sunshine and Ward; Gray's Peak; Veta Pass; Silver Plume.

2. Mimulus puberulus Greene. In wet places in the mountains of Colo.Alt. 7500-I0,000 ft.-Four miles west of Cameron Pass; Villa Grove, Steele Cañon; Breckenridge; Dix; Bob Creek, West La Plata Mountains; Red Mountain; Pagosa Springs; west of Ouray.

3. Mimulus nasutus Greene. In wet places in the mountains from Ida. and B. C. to Colo. and Calif.-Alt. 9000-Io,000 ft.-Rico; Ouray; Horsetooth Gulch ; Pennock's.

4. Mimulus Hallii Greene. In wet places in the mountains of Colo-Alt. up to $8500 \mathrm{ft}$.-Georgetown; Piedra; Horsetooth Gulch; gulch west of Pennock's.

5. Mimulus Geyeri Torr. ( $M$. Jamesii T. \& G.) In water from Mich. and N. D, to Ills. and Colo.-Alt. 4000-7000 ft.-Boulder; Colorado Springs; Cucharas Valley, near La Veta; Montrose; Spring Cañon; New Windsor.

6. Mimulus Lewisii Pursh. Along streams from Minn., Mont. and B. C. to Colo., Ariz. and Calif.-North Park. 
7. Mimulus moschatus Dougl. In wet places from Ont. and B. C. to Colo. and Calif.-Alt. up to $9000 \mathrm{ft}$.-Continental Divide, Routt Co.; Steamboat Springs.

8. Mimulus floribundus Dougl. In wet places, especially in sandy soil, from Mont. and B. C. to Ariz. and Calif.-Alt. 5000-8000 ft.-Boulder; Lower Boulder Cañon; Cimarron; Black Cañon; Golden; mountains, Larimer Co.; Ft. Collins; west of Soldier Cañon; Horsetooth Gulch; Cache la Poudre; mountains between Sunshine and Ward.

9. Mimulus gratioloides Rydb. On hillsides in southern Colo.-Alt. 70008000 ft.-Butte, 5 miles southwest of La Veta; Crystal Creek.

\section{LimOSELLA L. MUDWORT.}

I. Limosella aquatica $L$. In shallow water and mud from Lab. and B. C. to Colo. and Calif, ; also in Europe and Asia.-Alt. 4000-8000 ft.-Ft. Collins; Denver; North Platte, below Hebron; Parlin; Estes Park.

\section{GRatiola L. Hedge Hyssop.}

I. Gratiola virginiana L. In wet places, especially around springs, from Que. and B. C. to Fla. and Calif.-Alt. $5000 \mathrm{ft}$-Garland; Boulder; Ft. Collins; Alamosa.

\section{io. Veronica L. Speedwell, Brooklime.}

Flowers in axillary racemes.

Leaves all short-petioled; leaf-blades ovate, oblong or oval.

Leaves of the flowering shoots at least sessile, lanceolate to linear.

I. V. americana.

2. V. Anagallis.

ilowers in terminal spikes or racemes, or solitary in the axils of the leaves.

Perennials; flowers in terminal spikes or racemes; bracts reduced and unlike the leaves.

All leaves sessile, ovate or ovate-oblong; capsules obovate or oval, merely emarginate.

3. V. Wormskjoldii.

Lower leaves petioled; blades rounded-oval or the upper oblong; capsule obcordate.

4. V. serpyllifolia.

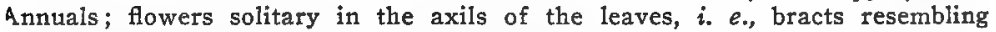
the other leaves and only slightly reduced.

Peduncles shorter than the oblong to linear stem-leaves. 5. $V$. xalapensis.

Peduncles longer than the ovate stem-leaves.

6. V. Buxbaumii.

1. Veronica americana Schwein. In water from Anticosti and Alaska to Pa., Colo. and Calif.-Alt. 4000-12,000 ft.-Headwaters of Sangre de Cristo Creek; headwaters of Pass Creek; Mancos; Ft. Collins; Green Mountain Falls; Van Boxle's ranch, above Cimarron; La Veta; Red Mountain; Horsetooth Gulch; Twin Lakes; Trail Creek; Poudre Cañon; Gore Pass; gulch west of Pennock's; Howe's Gulch; Boulder.

Veronica americana crassula Rydb. ( $V$. crenatifolia Greene) A low variety with fleshy entire leaves. From S. D. and Mont. to Colo. and Utah. -Red Mountain.

2. Veronica Anagallis L. In water from N. S. and B. C. to N. C. and Ariz.-Alt. 5000-8000 ft.-Wahatoya Creek; Ft. Collins.

3. Veronica Wormskjoldii R. \& S. ( $V$. alpina A. Gray, in part; not L.) In wet places from Greenl. and Alaska to N. H., Colo. and Ariz.-Alt. 9000- 
12,000 ft.-Summit of North Park Range, Routt Co.; four miles west of Cameron Pass; Silver Plume; Little Kate Basin, La Plata Mountains; Trappers' Lake; near Pagosa Peak; Seven Lakes; Marshall Pass; Tennessee Pass; Mirror Lake; Alpine Tunnel; Silverton; Beaver Creek; Leroux Creek; Berthoud Pass.

4. Veronica serpyllifolia L. In fields, thickets and open woods from Lab. and Alaska to Ga., Colo. and Calif.; also in Europe and Asia.-Alt. 8000I1,000 ft.-Caribou; Marshall Pass; Red Mountain, south of Ouray; Grayback mining camps and Placer Gulch; headwaters of Sangre de Cristo Creek; Bob Creek, West La Plata Mountains; Silverton; Beaver Creek; Hotchkiss; Gore Pass.

5. Veronica xalapensis H. B. K. (V. peregrina A. Gray, in part; not L.) In sandy soil from Sask. and B. C. 'to Tex. and Calif.-Alt. 5000-8500 ft.Ft. Collins; Table Rock; Manitou; foothills, Larimer Co.; Mancos; Pagosa Springs; Ft. Collins; Idaho Springs; Cerro Summit; Veta Pass; Boulder; Grizzly Creek.

6. Veronica Buxbaumii Tenare. In waste places from N. S. and N. Y. to Colo.; adventive from Europe and Asia.-Boulder.

Corolla present.

\section{BESSEYA Rydb.}

Flowers not reflexed; calyx-lobes 3-4.

Upper lip of the purple corolla twice as long as the calyx; plant I-I.5 $\mathrm{dm}$. high.

I. S. alpina.

Upper lip of the corolla only slightly longer than the calyx; plant I.5-3 dm. high.

Corolla purple or pink, not ciliate; divisions of the lower lip obtuse.

2. S. plantaginea.

Corolla white or yellowish, ciliate on the margin; divisions of the upper lip acute.

Flowers refiexed; calyx-lobes 2 ; corolla greenish-white. Corolla lacking.

3. S. Ritteriana.

4. S. reflexa.

5. S. gymnocarpa.

I. Besseya alpina (A. Gray) Rydb. (Synthyris alpina A. Gray) On the higher mountains of Wyo. and Colo.-Alt. Io,000-I4,000 ft.-Mt. Harvard; West Spanish Peak; Gray's Peak; Massif de l'Arapahoe; headwaters of Clear Creek; Ethel Peak.

z. Besseya plantaginea (Benth.) Rydb. (Synthyris plantaginea Benth.) On hillsides and mountains from Wyo. to N. M. and Ariz.-Alt. 6000-I3,500 ft.-Mountain near Veta Pass; Pike's Peak; mountains above Ouray; hills southeast of La Veta; mesas near Colorado Springs; South Cheyenne Cañon; butte, 5 miles southwest of La Veta; Wahatoya Cañon; Manitou; Gray's Peak; Minnehaha; Cascade; Artist's Glen; Mt. Garfield; headwaters of Clear Creek; Como; Bear Creek Cañon.

3. Besseya Ritteriana (Eastw.) Rydb. (Synthyris Ritteriana Eastw.; $S$. favescens A. Nelson) On the higher mountains of Colo.-Alt. 7000-12,000 ft.--Red Mountain; Bear Creek Divide, West La Plata Mountains; Cimarron; Cumberland Basin.

4. Besseya reflexa (Eastw.) Rydb. (Synthyris reflexa Eastw.) On the mountains of Colo.-Kendall Basin, near Silverton.

5. Besseya gymnocarpa (A. Nels.) Rydb. (Wulfenia gymnocarpa A. Nels.; Synthyris rubra A. Gray, in part; not Benth.) On hills from S. D. and Alb. to Colo. and Utah.-Wood's ranch. 


\section{I2. GERARDIA L.}

1. Gerardia Besseyana Britton. On prairies and river bottoms from Iowa and Wyo. to La. and Colo.-Alt. 4000-5000 ft.-Boulder; Platte River, Denver; Ft. Collins; Longmont; along the Poudre; Longmont; Cherry Creek.

\section{i3. Castilleja Mutis. Painted Cup, Painter's Brush.}

Annuals or biennials.

I. Stenanthae.

Perennials.

Galea several times longer than the very short lip, usually at least $2 / 3$ as long as the corolla-tube; bracts in most species tinged with scarlet, crimson or rose.

Calyx cleft much deeper in front than behind.

Calyx about equally cleft in front and behind.

Stem villous-canescent; bracts entire, or trilobed with broad, rounded middle lobe.

III. INTEGRAE.

Stem glabrous or pubescent, but not canescent.

Leaves entire or the uppermost rarely slightly 3 -lobed; corolla-lip very short and callous.

Bracts usually entire and obtuse, oblong to obovate, if 3 -lobed with a broad middle lobe.

IV. RHEXIFOLIAE.

Bracts 3 -cleft with lanceolate lobes, if entire very acute.

V. LANCiFoliae.

Leaves, at least the upper, pinnately cleft; bracts also cleft; lower corollalip not callous, larger.

VI. HisPidAE.

Galea less than 3 times as long as the lip, rarely half as long as the corollatube; bracts in most species tinged with yellow or brown.

Leaves entire; bracts also entire or slightly 3 -lobed. VII. Pallidae.

Leaves pinnately divided, at least the upper ones.

Whole plant white-woolly.

Plant not white-woolly.

Corolla $1.5-3 \mathrm{~cm}$. long, slightly exceeding the calyx.

Corolla 4-5 cm. long, almost twice as long as the calyx.

VIII. Lineatae.

IX. Brachyanthae.

X. Sessiliflorae.

I. Stenanthia.

One species.

II. LINARIIIFOLIAE.

I. C. exilis.

Bracts crimson or pink.

Leaves all narrowly linear. $\quad$ 2. C. linaricefolia.

Upper leaves lanceolate.

Bracts yellow.

III. Integrae.

3. C. Crista-galli.

4. C. cognata.

Leaves entire.

Bracts oblong. $\quad$ 5. C. integra.

Bracts obovate. $\quad 6$. C. gloriosa.

Leaves pinnatifid.

7. C. Lindheimeri.

IV. RheXifoliae.

Upper stem-leaves at least broadly lanceolate or oblong-ovate.

Leaves all narrowly lanceolate.

8. C. rhexifolia.

Bracts acute and usually deeply cleft, scarlet or crimson. 9. C. confusa.

Bracts rounded at the apex, entire or with a short tooth on each side.

Bracts brownish or yellowish; leaves lanceolate, acute, densely puberulent. Io. C. brunnescens.

Bracts crimson or rose-color; leaves linear-lanceolate, acuminate, glabrous or nearly so at maturity.

II. C. lauta. 


\section{Lancifoliae.}

Calyx and upper part of the stem densely white-woolly. I2. C. trinervis.

Calyx and upper part of the stem sparingly hirsute-villous.

Plant growing more or less in clumps, with a short caudex.

Stems solitary from a horizontal or ascending rootstock.

$$
\text { 9. C. confusa. }
$$

3. C. lancifolia.

\section{Hispidae.}

Galea longer than the corolla-tube.

Galea shorter than the corolla-tube.

14. C. chromosa.

Bracts or their middle lobe very broad and rounded; calyx-lobes very short and rounded at the apex.

Bracts with narrow, lanceolate, oblong, or linear lobes. Plant glabrous up to the inflorescence, $I-2 \mathrm{~cm}$. high. Plant more or less pubescent, 3-6 dm. high.

Lobes of calyces, bracts and leaves narrowly linear; bracts brick-red.

I7. C. linearis.

Lobes of bracts and calyces broader, lanceolate or oblong; bracts crimson.

18. C. hispida.

ViI. Pallidae.

Plant 5-I $5 \mathrm{~cm}$. high, densely villous above; corolla less than $2 \mathrm{~cm}$. long; bracts varying from brownish-crimson to greenish-yellow. I9. C. occidentalis.

Plant z-4 dm. high, slightly if at all villous; corolla usually $2 \mathrm{~cm}$. long or more. Stems solitary from a creeping rootstock; plant darkening in drying.

20. C. huteovirens.

Stems growing in clums with a short caudex; plant rarely darkening in drying.

Upper leaves broadly lanceolate; all 3-ribbed; plant glabrous up to the inflorescence.

$2 \mathrm{I}$. C. sulphurea.

All leaves linear, I-ribbed or the uppermost linear-lanceolate and indistinctly 3-ribbed; plant puberulent.

22. C. wyomingensis.

\section{Lineatae.}

One species.

23. C. lineata.

\section{BrachyanthaE.}

Lower lip of the corolla fully half as long as the galea; plant less than I dm. high.

Lower lip $1 / 5-1 / 3$ as long as the galea; plant $3-4 \mathrm{dm}$. high.

Lower lip about $1 / 3$ as long as the galea; its lobes lanceolate, acuminate. 24. C. puberula.

Lower lip $1 / 5-1 / 4$ as long as the galea; its lobes ovate, acute.

25. C. brachyantha.

26. C. Alava.

\section{Sessiliflorae.}

One species.

27. C. sessilithora.

r. Castilleja exilis A. Nels. (C. stricta Rydb.; not DC.) In wet ground from Mont. and Wash. to Colo. and Nev.-Las Animas; Hotchkiss.

2. Castilleja linariaefolia Benth. In the mountains from Wyo. to N. M. and Calif.; also in Mex.-Alt. 6000-9000 ft.-Pike's Peak; near Empire; North Boulder Peak; headwaters of Clear Creek; southeast and west of Ouray; Parlin; Honnold; north of Mancos; Jack's Cabin; Cascade Cañon; Cerro Summit; West Indian Creek; Elk River, Routt Co.; Chicken Creek, West La Plata Mountains; Idaho Springs; Çucharas Valley, near La Veta; Twin Lakes; Veta Pass; Sangre de Cristo Creek; Pagosa Springs; La Veta ; Soldier Cañon; Hotchkiss; Gypsum Creek Cañon; Baxter's ranch; Steam- 
boat Springs; Narrows; Dolores; Beaver Creek; Horsetooth Gulch; Durango; Rist Cañon; Trapper's Lake; Graymont; Grand Lake; Poudre Cañon, Larimer Co.; Silverton; Empire.

3. Castilleja Crista-galli Rydb. In the mountains from Mont. to Colo.Alt. 7000-10,000 ft.-Green Mountain Falls; South Cheyenne Cañon; Grayback mining camps and Placer Gulch; Eldora to Baltimore.

4. Castilleja cognata Greene. In the mountains of Colo.-Alt, about 8280 ft.-Jack's Cabin.

5. Castilleja integra A. Gray. Dry ground from Colo. to N. M. and Ariz.; also Mex.-Alt. 5000-10,000 ft.-Colorado Springs; Trail Glen; La Veta; Red Rock Cañon; Ojo; river-bluffs north of La Veta; Calhan; butte, 5 miles southwest of La Veta; hills southeast of La Veta; Piedra; Salida; near Denver; Como; Purgatory River, Trinidad; Palmer Lake; Table Rock; Cheyenne Cañon; Eldora to Baltimore; Colorado City.

6. Castilleja gloriosa Britton. In dry places from Colo. to Ariz.-Brantly Cañon.

7. Castilleja Lindheimeri A. Gray. In dry places from Colo. to Tex.Alt. 4000-7000 ft.-Mancos; Grand Junction.

8. Castilleja rhexifolia Rydb. In the mountains from Alb. and Alaska to Colo--Alt. 7000-I4,000 ft.-Mt. Hesperus; Cameron Pass; Echo Creek, near La Veta; Marshall Pass; Mt. Hayden, La Plata Mountains; Mt. Harvard; Berthoud Pass.

9. Castilleja confusa Greene. In the mountains of Wyo, and Colo-Alt. 6000-II,000 ft.-Georgetown; Red Mountain, south of Ouray; Bob Creek, west of Mt. Hesperus; Ruxton Park; Colorado Springs; Pike's Peak; Elk River, Routt Co.; Chicken Creek, west of Mt. Hesperus; Como; Little Veta Mountain; Upper La Plata River; Minnehaha; Little Kate Basin; mountains above Ouray; Beaver Creek; Rico; Michigan Hill; gulch east of Stove Prairie; Bosworth's ranch; Steamboat Springs; Empire; Eldora to Baltimore; Rabbit-Ears, Larimer Co.

xo. Castilleja brunnescens Rydb. In the mountains of Colo. and Wyo.Alt. 9000-II,000 ft.-Bush Creek, Custer Co.; Gray's Peak; Mancos; Red Mountain, south of Ouray; Pike's Peak; Taylor River; Cameron Pass; Hahn's Peak.

rx. Castilleja lauta A. Nelson. (C. oreopola subintegra Fernald.) In the mountains from Mont. and Ore. to Colo.-Alt. 9000-I2,000 ft.-Marshall Pass; Mt. Hesperus; Little Kate Basin; Cameron Pass; Alpine Tunnel; Graymont; Beaver Creek; Rico; Anita Peak.

12. Castilleja trinervis Rydb. In the mountain woods of Colo.-Alt. 8500Io,000 ft.-Columbine; headwaters of Pass Creek; headwaters of Sangre de Cristo Creek; Grayback mining camps and Placer Gulch.

13. Castilleja lancifolia Rydb. In mountains from Mont. and Alaska to Colo. and Ore.-Alt. 8000-12,000 ft.-Near Ironton, San Juan Co.; near Pagosa Peak; mountains between Sunshine and Ward; Berthoud Pass.

14. Castilleja clisomosa A. Nelson. (C. Stokesii Brand.) In the mountains of Wyo. to Colo. and Calif.-Alt. about 8000 ft--Cerro Summit.

15. Castilleja obtusiloba Rydb. In the mountains of Colo.-Alt. about 9000 ft.-Leroux Parks, Delta Co. 
I6. Castilleja Haydeni (A. Gray) Cockerell. (C. pallida Haydeni A. Gray) On the higher mountains of Colo.-Alt. about 12,300 ft.-Cumberland Mine, La Plata Mountains.

17. Castilleja linearis Rydb. In the mountains of Colo.-Alt. 8500-12,000 ft.-Gibb's Peak, Custer Co.; West Spanish Peak.

I8. Castilleja hispida Benth. On hills and mountains from Mont. and Wash. to Colo. and Utah.-Alt. about $7500 \mathrm{ft}$-CMountains, Larimer Co.; Dolores; Cimarron; Pinkham Creek.

Ig. Castilleja occidentalis Torr. (C. pallida occidentalis A. Gray) On the higher mountains from Alb. and B. C. to Colo.-Alt. II,000-I4,000 ft.Near Empire; Pike's Peak; Gray's Peak; Ward; Mt. Ouray; Alpine Tunnel; Cameron Pass; Mt. Garfield; Berthoud Pass; Beaver Creek; Ethel Peak; summit of North Park Range, Routt Co.

20. Castilleja luteovirens Rydb. In mountain meadows from Wyo. and Colo.-Alt. 7000-9000 ft.-Headwaters of Clear Creek; Seven Lakes, near Pike's Peak; Veta Pass; Hamor's Lake, north of Durango; Chicken Creek, west of Mt. Hesperus; Sangre de Cristo Creek; Wahatoya Creek.

21. Castilleja sulphurea Rydb. In the mountains from S. D. and Wyo. to Colo. and Utah.-Alt. 7000-I0,000 ft.-Rabbit-Ears, Larimer Co.; Mt. Harvard; Georgetown; Andrews' Shetland ranch; Grayback mining camps and Placer Gulch; Steamboat Springs; Cameron Pass; Columbine; Denver; Gunnison; Chambers' Lake; Ward; Ruxton Dell; North Park; Empire; Lake Moraine, Pike's Peak; Silver Plume; Graymont; Rico; Twin Lake; Walton Creek; Leroux Creek.

22. Castilleja wyomingensis Rydb. In the mountains from Mont. to Colo. and Utah.-Alt. 7500-9000 ft.-Wahatoya Creek; Red Mountain road, south of Ouray.

23. Castilleja lineata Greene. In the mountains of Colo--Alt. 9000-10,000 ft.-West Spanish Peak; Pagosa Springs.

24. Castilleja puberula Rydb. In the mountains of Colo.-Alt. 8000-12,000 ft.- "Colorado"; Empire; Berthoud Pass.

25. Castilleja brachyantha Rydb. (C. breviflora A. Gray) In the mountains of Wyo. and Colo.-Alt. 8000-10,000 ft.-Headwaters of Cleat Creek; North Park, near Teller; Grizzly Creek.

26. Castilleja flava S. Wats. In dry valleys from S. D., Mont. and B. C. to Colo. and Utah.-Alt, about $8000 \mathrm{ft}$--Upper Laramie River; Pinkham Creek.

27. Castilleja sessiliflora Pursh. On dry plains from Ills. and Ass. to Mo., Tex. and Ariz.-Ait. 4000-7000 ft.-Table Rock; Ft. Collins; Colorado Springs; near Pueblo; Tobe Miller's ranch; Colorado City.

\section{I4. ORTHOCARPUS Nutt.}

Corolla yellow; spike densely flowered; seeds costate. 1. O. luteus.

Corolla white, turning rose-purple; spike lax; seeds with a logse reticulate coat. 2. O. purpureo-albus.

I. Orthocarpus luteus $\mathrm{Nutt}$. On dry plains and in sandy soil from Sask. and Wash. to Colo. and Nev.-Alt. 4000-Io,000 ft.-Grizzly Creek; South Park; Georgetown; foot-hills, Larimer Co.; Pagosa Springs; Trimble 
Springs, above Durango; Veta Mountain; Villa Grove; Garland; Silverton; Ruxton Dell; near Steamboat Springs; La Veta, west of Ouray; Gunnison; Table Rock; Middle Park; Horsetooth Gulch; Long Gulch; west of Soldier Cañon; Empire; between Sunshine and Ward.

2. Orthocarpus purpureo-albus A. Gray. In dry places from Colo. and Utah to N. M. and Ariz.-Durango; Piedra; La Plata and Mancos.

15. ADENOSTEgIA Benth.

1. Adenostegia Kingii (S. Wats.) Greene. (Cordylanthus Kingii S. Wats.) Dry ridges from Nev. to Colo.-Alt. $5500 \mathrm{ft}$.-San Juan Valley (Brandegee).

\section{ElephaNtella Rydb. Little Red Elephant.}

I. Elephantella groenlandica (Retz.) Rydb. (Pedicularis groenlandica Retz.) In swamps and wet meadows from Greenl. and B. C. to Colo. and Calif.-Alt. 8000-12,000 ft.-Headwaters of Clear Creek; Cameron Pass; Silver Plume; Gray's Peak; Hamor's Lake, above Durango; Trapper's Lake; Seven Lakes; Central City; headwaters of Sangre de Cristo Creek; near Pagosa Peak; Pike's Peak; Alpine Tunnel; Cabin Cañon; Mirror Lake; Veta Pass; Mt. Harvard; Gore Pass; Eldora to Baltimore; Van Boxle's ranch, above Cimarron; Beaver Creek; summit of North Park Range, Routt Co.

\section{PEDICULARIS L. LOUSEWORT.}

Galea produced into a distinct beak.

Beak long, strongly incurved; lip very broad, meeting or inclosing the tip of the beak. 2. P. racemosa.

Beak short and straight; lip narrower and not meeting the tip of the galea. 2. P. Parryi.

Galea not produced into a distinct beak; but often with two lateral teeth near the apex.

Leaves pinnately divided or lobed.

Leaves divided to the midrib or nearly so into narrow, acute, dentate, serrate or incised divisions.

Galea toothless; plant $4-10 \mathrm{dm}$. high; lip not reaching the tip of the galea.

Galea with two lateral teeth. 3. P. bracteosa.

Plant tall, 3-I5 dm. high; corolla sordid yellow, $3-3.5 \mathrm{~cm}$. long; lip almost reaching the tip of the galea.

4. P. Grayi.

Plant lower, I-4 dm. high; corolla purple, $2-2.5 \mathrm{~cm}$. long; lip not reaching the tip of the galea.

5. P. scopulorum.

Leaves pinnately lobed (two-thirds to the midrib or less) with broadly oblong or rounded, obtuse and crenate lobes. $\quad 6$. P. canadensis.

Leaves merely crenate.

7. P. crenulata.

1. Pedicularis racemosa Dougl. On wooded mountain sides from Mont. and B. C. to Colo. and Calif.-Alt. 8000-12,000 ft.-Headwaters of Clear Creek; Cameron Pass; Trapper's Lake; Berthoud Pass; Douglass Mountain, Georgetown; near Pagosa Peak; Marshall Pass; Mt. Abram, Ouray; Beaver Creek; Boreas; bank of Michigan; Leroux Park; Eldora to Baltimore; Buffalo Pass; Anita Peak; Rabbit-Ear Range.

2. Pedicularis Parryi A. Gray. On the higher mountains from Wyo. to Colo. and Utah.-Alt. 8000-12,000 ft.-South Park; Pike's Peak; headwaters of Clear Creek; Empire; North Park near Teller; Como, South Park; Little 
Kate Basin, La Plata Mountains; Seven Lakes; Cameron Pass; Marshall Pass; Alpine Tunnel; Beaver Creek; Berthoud Pass.

3. Pedicularis bracteata Benth. In wet places in the mountains from Alb. and B. C. to Colo. and Utah.-Alt. 9000-12,000 ft.-Marshall Pass; Cameron Pass; near Pagosa Peak; Tennessee Pass, 7 miles west of Leadville; Mt. Hesperus; Leroux Parks, Delta Co.; Upper La Plata River; Beaver Creek; Berthoud Pass; summit of North Park Range, Larimer Co.

4. Pedicularis Grayi A. Nels. ( $P$. procera A. Gray) In wooded ground in the mountains of Wyo. and Colo.-Alt. 8000-r3,000 ft.--Near Empire; Cameron Pass; headwaters of Clear Creek; Andrews' Shetland ranch; Bear Lake Cañon; Georgetown; Silver Plume; Upper La Plata Cañon; Como; South Park; West Spanish Peak; near Pagosa Peak; Bear Creek Cañon, near Colorado Springs; Buena Vista; Veta; Pike's Peak; Hamor's Lake; Ruxton Park; gulch south of Steamboat Springs; Hotchkiss; Bosworth's ranch; Stove Prairie; Empire.

5. Pedicularis scopulorum A. Gray. On the higher peaks of Colo.-Alt. Io,000-13,000 ft.-South Park; Mt. Abram, Ouray; Gray's Peak.

6. Pedicularis canadensis $\mathrm{L}$. In mountain meadows and moist woodlands from N. S., Man. and Wyo. to Fla. and N. M.-Alt. 6000-9000 ft.-Pike's Peak; North Cheyenne Cañon; headwaters of Sangre de Cristo Creek; Crystal Park; Veta Pass; Cucharas River, below La Veta; Table Rock.

7. Pedicularis crenulata Benth. In meadows and parks of Wyo. and Colo. -Alt. 7000-Io,000 ft.-Gunnison; Sapinero; Parlin; South Park; Westcliffe; Buena Vista; Como, South Park; Sand Creek Pass; Walden.

\section{RHINANTHUS L. YeLLOW-RATTLE.}

I. Rhinanthus Crista-galli L. On wooded hills and in meadows from Lab. and Alaska to N. Y., N. M. and Ore.; also in Europe.-Pagosa Springs.

Family izr. PINGUiCUlaceat Dumort. Bladderwort Family.

\section{UTRICULARIA L. BIADDERWORT.}

Leaves 2-3 times pinnately divided with long divisions; corolla about $12 \mathrm{~mm}$. wide; spur prominent, elongated-conical, curved.

I. U. vulgaris.

Leaves dichotomously divided with very short divisions; corolla 4-6 mm. wide; spur a mere protuberance.

2. U. minor.

x. Utricularia vulgaris $L$. In water from Newf. and Alaska to Fla. and Calif.; also in Europe.-Alt. 8000-I2,000 ft.--Rio Grande, Alamosa; Parlin; Seven Lakes; Estes Park.

ะ. Utricularia minor L. In water from Greenl. and B. C. to N. J., Colo. and Calif.; also in Europe--Near Grand Lake.

Family I22. OROBANChaCEAE Lindl. Broom-Rape Family.

Flowers subtended by bractlets.

Flowers without bractlets.
I. Myzorrhiza.

2. Thalesia. 
I. MYZORRHIZA Philippi. BrOOM-RAPE.

Corolla 20-25 mm. long; anthers woolly. Corolla I 5-18 mm. long; anthers glabrous.

1. M. multiflora.

2. M. Ludoviciana.

1. Myzorrhiza multiflora (Nutt.) Rydb. (Orobranche multiflora Nutt.; Aphyllon multiflorum A. Gray) In sandy soil from Colo. and Utah to Tex. and Ariz.-Along the McElmo; Dixon Cañon.

2. Myzorrhiza ludoviciana (Nutt.) Rydb. (O. Ludoviciana Nutt.; Aphyllon Ludovicianum A. Gray) In sandy soil from Ills. and Wash. to Tex. and Calif.-North Denver, near Argos (Eastwood).

\section{¿. THALESIA Raf. CANCER-root.}

I. Thalesia fasciculata (Nutt.) Britton. Parasitic on Composites, especially Artemisia frigida, from Ind. and Yukon to Colo. and Calif.; also Mex. -Alt. 4000-II,000 ft.-Near Boulder; Silver Plume; West Spanish Peak; Como, South Park; Salida; Garden of the Gods; Table Mountain; Golden; Arboles; Ft. Collins; Dolores; Table Rock; Fossil Creek; Quimby; Soldier Cañon.

\section{Family iz3. MARTYNiACEAE Link. Unicorn-plant Family.}

I. MARTYNIA L. UNICORN-PLANT; RAM'S-HORN.

I. Martynia Louisiana Mill. ( $M$. proboscoidea Glox.) In waste places from Me. and Iowa to N. C. and Colo.-Ft. Collins; Cañon City.

\section{Order 45. PLANTAGINALES.}

Family I 24. PLANTaginaceae Lindl. Plantain-Family.

I. Plantago l. Plantain.

Flowers all perfect; corolla not closed over the fruit; stamens 4.

Leaves lanceolate to ovate; neither leaves*nor spike silky-pubescent; stamens in all the flowers long-exserted.

Spike cylindrical; seeds not concave on the faces.

Leaves ovate, abruptly contracted at the base; seeds more than 2 in each cell.

Pyxis dehiscent at the middle, rounded-ovoid, obtusish; leaves usually thick and the dense spike obtuse.

I. P. major.

Pyxis dehiscent far below the middle, elongated-ovoid, very acute; leaves thin and the lax spike acute. $\quad$ 2. $P$. asiatica.

Leaves lanceolate, gradually tapering into the petioles; seed not more than 2 in each cell.

Leaves thin; plant not woolly at the base. 3. P. Trueedyi.

Leaves thick; plant with red or brown wool at the base.

4. P. eriopoda.

Spike short, oblong, $1-3 \mathrm{~cm}$. long; seeds concave on the faces; leaves narrowly lanceolate.

5. P. lanceolata.

Leaves linear; leaves and peduncles pubescent with long silky hairs; anther in the more fertile flowers included; seeds solitary in each cell; concave on the faces.

6. P. Purshii.

Flowers subdioecious or polygamo-dioecious; corolla in the fertile plant remaining closed or early closing over the capsule; stamens 2 ; leaves filiform.

7. $P$. myosuroides. 
I. Plantago major L. In waste places and around dwellings from Newf. and B. C. to Fla. and Calif.; naturalized from Europe-Georgetown; along Uncompahgre River, near Ouray; Ft. Collins.

2. Plantago asiatica $\mathrm{L}$. In waste places and sandy soil from Ass. and B. C. to Colo.; also Eastern Asia.-Ait. 5000-8000 ft.-Parlin; Arboles; Ft. Collins.

3. Plantago Tweedyi A. Gray. On grassy slopes from Mont. to Colo. and Utah.-Alt. up to Io,00o ft.-Chambers' Lake; Rabbit-Ears Pass; Buffalo Pass; Gore Pass.

4. Plantago eriopoda Torr. ( $P$. retrorsa Greene) In saline soil from Que. and Mont. to Colo. and Nev.-Alt. $4000-8500 \mathrm{ft}$.-La Porte; Doyle's; bank of Canadian River.

5. Plantago lanceolata $\mathrm{L}$. In waste places and around dwellings from N. B. and Wash. to Fla. and Calif.; naturalized from Europe, but rare in the Rocky Mountain region.-Alt. up to $5000 \mathrm{ft}$. Ft. Collins.

6. Plantago Purshii R. \& S. On piains, prairies and in river valleys, especially in sandy or poor soil from Ont., Ass. and Wash. to Mo., Tex. and Ariz.-Alt. 4000-Io,000 ft.-Golden; Ft. Collins; Colorado Springs; Monument Park; Denver; Trinidad; West Spanish Peak; Veta Pass; Walsenburg; New Windsor; Pueblo; Quimby; Wray; Table Rock; Grand Junction.

7. Plantago myosuroides Rydb. In sandy soil from Ass. and S. D. to Neb. and Utah.-Grand Junction.

\section{Order 46. RUBIALES.}

Stamens as many as the corolla-lobes.

Leaves with stipules (in ours leaf-like and usually regarded as leaves) adnate to the stem between the leaf bases. I 25. RUBIACEAE.

Leaves without stipules or if present these adnate to the petioles. 126. CAPRIFOLIACEAE.

Stamens twice as many as the corolla-lobes; low herbs with ternately dissected leaves. 127. ADOXACEAE.

\section{Family i 25. RUBIACEAE Juss. Madder Family.}

\section{GaLiUm L. Benstraw.}

Flowers perfect; fruit hirsute with uncinate hairs or glabrous.

Annuals.

Stem coarse, reclining; leaves (i. $e$., leaves and stipules), 6-8 in the whorls. Leaves linear or oblanceolate.

Leaves $2-7 \mathrm{~cm}$. long; nutlets when ripe $3-5 \mathrm{~mm}$. in diameter; flowers white.

I. G. Aparine.

Leaves $0.5-2 \mathrm{~cm}$. long; nutlets when ripe $2-3 \mathrm{~mm}$. in diameter; flowers ochroleucous.

Leaves elliptic.

z. G. Vaillantii.

9. G. Alaviflorum.

Stem slender, erect or ascending; leaves 4 in the whorls.

Leaves ovate or oblong, 5-7 mm. long; fruit nearly sessile. peduncled.

3. G. proliferum.

\section{Perennials. \\ Leaves not cuspidate-pointed.}

Stem stout; leaves thick, 3-nerved.

Stem very slender; leaves I-nerved.

G. bifolium.

5. G. boreale. 
Leaves obovate to broadly oblong-obovate, somewhat fleshy. Petals almost I mm. long; pedicels and generally also stem glabrous. 6. G. Brandegei.

Petals about $0.5 \mathrm{~mm}$. long; pedicels and stem more or less scabrous.

Leaves linear-oblong or linear-oblanceolate. $\quad$ 8. G. trifidum.

Leaves cuspidate-pointed.

Stem retrorse-bristly; pedicels scarcely exceeding the bracts.

9. G. Aavifiorum.

Stem glabrous or sparingly hirsute; pedicels much exceeding the small bract.

Flowers in ours dioecious; fruit with long hairs, not uncinate; perennials. Io. G. triflorum. II. G. coloradense.

I. Galium Aparine L. In shady places from N. B. and Alaska to Fla. and Calif, ; also in Europe and Asia.-Alt. 4000-6000 ft.-Horsetooth Gulch; Rist Cañon; Ft. Collins; foot-hills, Larimer Co.

2. Galium Vaillantii DC. (G. Aparine Vaillantii Koch.) Among bushes and in shady places from Mont. and B. C. to Mex.-Alt. 5000-8000 ft.Spring Cañon; Rist Cañon; butte, 5 miles southwest of La Veta.

3. Galium proliferum A. Gray. On stony hills from Colo. to Tex. and N. M.; also Mex.-Locality not given.

4. Galium bifolium S. Wats. In wet places in the mountains from Mont. and Wash. to Colo, and Calif.-Alt. about $7500 \mathrm{ft} .-$ Honnold; Steamboat Springs.

5. Galium boreale L. On rocky banks and hillsides, especially among bushes, from Que. and Alaska to N. J., Mo., Colo. and Calif.-Alt. 4000IO,000 ft.-Rist Cañon; foot-hills, Larimer Co.; Hotchkiss; Baxter's ranch; Barnes' Camp; Table Rock; Ft. Collins; Stove Prairie Hill; gulch west of Pennock's; Pike's Peak; west of Ouray; Dillon; Veta Pass; Parlin; Gunnison; Minnehaha; Pagosa Springs; Grayback mining camps and Placer Gulch; Narrows; Andrews' Shetland ranch; Four-mile Hill, Routt Co. ; Mancos; Golden; Clear Creek Cañon; North Cheyenne Cañon; Bear Creek Cañon; Cumbres; Moon's ranch; Glenwood Springs; between Sunshine and Ward; Fish Creek Falls.

6. Galium Brandegei A. Gray. In moist ground from Wyo, to N. M. and Calif.-Alt. 6000-I0,000 ft.-Columbine; twelve miles below Grand Lake; Steamboat Springs; Chambers' Lake.

7. Galium subbiflorum (Wieg.) Rydb. (G. trifidum subbiflorum Wieg.) In cold bogs and wet places from Minn. and Ida. to Colo. and Calif.-Alt. 8000-10,000 ft.-Beaver Creek; Empire.

8. Galium trifidum L. In swamps and wet meadows from Newf. and Ida. to Colo. and Utah.-Alt. up to $8000 \mathrm{ft}$.-Parlin; Beaver Creek.

9. Galium flaviflorum Heller. In cañons of Colo. and N. M.-Alt. 7500$8500 \mathrm{ft} .-$ Box Cañon, west of Ouray.

ıo. Galium triflorum Michx. In open woods from Newf. and Alaska to Ala. and Calif.-Alt. 6000-9000 ft.-Boulder Cañon; Red Mountain road, south of Ouray; Ruxton Brook; headwaters of Pass Creek; near Pagosa Peak; Columbine; vicinity of Pine Grove; Bosworth's ranch; Four-mile Hill; Ouray.

II. Galium coloradense Wright. (G. Mathewsii A. Gray, in part) On arid grounds in southern Colo.-Alt. 7000-8000 ft.-Black Cañon; Mesa Verde; Mancos; Glenwood Springs. 


\section{Family I 26. CAPRIFOLIACEAE Vent. Honeysuckle Family.}

Style deeply 3-5-cleft; shrubs or trees with compound cymose inflorescence and drupaceous fruit.

Leaves pinnate; ovary $3-5$-celled, each cell with I ovule. 1. Sambucus.

Leaves simple; ovary I-celled and I-ovuled.

Style slender, undivided; stigma capitate.

Trailing evergreen herb; flowers long-peduncled, geminate; stamens 4, didynamous.

Shrubs; stamens generally 5.

3. Linnaea.

Corolla rarely gibbous at the base, regular or nearly so. 4. Symphoricarpos. Corolla gibbous at the base, irregular and bilabiate. 5. Distegra.

\section{SAMBUCUS L. Elder.}

Cyme not flat-topped, thyrsoidrpaniculate; the axis continuous.
Fruit red or rarely yellow.
Fruit black.
I. S. microbotrys.
2. S. melanocarpa.

Cyme flat-topped, umbelliform, 4-5-rayed; the rays again variously compound; fruit blackish.

3. S. neo-mexicana.

I. Sambucus microbotrys Rydb. On hillsides from S. D. and Wyo. to Colo. and Ariz.-Alt. 7500-I2,000 ft.-Gore Pass; above Beaver Creek; Marshall Pass; Bob Creek, West La Plata Mountains; Jack Brook; west of Ouray; Ironton Park, nine miles south of Ouray; Front Range, Larimer Co.; Ojo; Villa Grove; Halfway House; Pike's Peak; Gray's Peak; Little Veta Mountain; East Indian Creek; Bottomless Pit, Pike's Peak; Lake City; Red River, Franklin Co.; between Sunshine and Ward.

2. Sambucus melanocarpa A. Gray. In cañons and ravines from Alb. and Ida. to Colo. and Ore.-Alt. about $9000 \mathrm{ft}$.-Headwaters of Pass Creek; Clear Creek Cañon; Fish Creek Falls; Pinkham Creek.

3. Sambucus neo-mexicana Woot. In the mountains of Colo, $\mathrm{N}$. Mex. and Ariz.-Silver Plume.

\section{VIBURNUM L. Arrow-wood, Snow-balls.}

Leaves palmately veined, usually 3-lobed; fruit red. 1. $V$. pauciflorum. Leaves pinnately veined, not lobed; fruit blue or black. 2. V. Lentago.

I. Viburnum pauciflorum Pylaie. In woods from Lab. and Alaska to Pa., Colo. and Wash.-Alt. about $8000 \mathrm{ft}$.-Grand Lake; Minnehaha; Clear Creek.

2. Viburnum Lentago L. In wood and on banks of streams from $\mathrm{Me}$. and Man. to Ga. and Colo.-Guich south of Boulder.

\section{LiNNaEA Gron. Twin-flower, Ground-vine.}

I. Linnaea americana Forbes. (L. borealis Michx.; not L.) In cold woods from Greenl. and Alaska to N. J., Mich., Colo. and Utah.-Alt. 8000I3,00o ft.-Beaver Creek; Graymont; Grand Lake; Chambers' Lake; Gray's Peak; West Spanish Peak; Front Range, Larimer Co.; South Boulder Peak.

\section{SYMPHORICARPOS L. SNOW-BERRY, CORAL-BERry.}

Corolla short; open-campanulate.

Fruit red; style bearded.

Fruit white; style glabrous.

Style and stamens somewhat exserted; leaves thick.

Style and stamens not exserted; leaves rather thin.

Corolla elongated, oblong-campanulate to salverform.

I. S. Symphoricarpos.

2. S. occidentalis.

3. S. pauciflorus. 
Corolla oblong-campanulate, $6-8 \mathrm{~mm}$. long.

Leaves decidedly pubescent; stem puberulent; leaves rounded-oval, obtuse or rounded at the apex.

Leaves glabrate or slightly pubescent.

Leaves rounded-ovate or rounded-oval, $3-4 \mathrm{~cm}$. long.

Leaves oval, acute, $\mathrm{I}-2 \mathrm{~cm}$. long.

Corolla tubular-funnelform, 8-12 $\mathrm{mm}$. long.
4. S. rotundifolius.

I. Symphoricarpos Symphoricarpos (L.) MacM. (S. vulgaris Michx.) Along rivers and in rocky places from N. Y. and Wyo. to Ga., Tex. and Colo.-Manitou.

2. Symphoricarpos occidentalis Hook. Hillsides from Mich., Mackenzie and B. C. to Mo. and Colo.-Alt. 4000-8000 ft.-Poudre Cañon; Baxter's ranch; Ft. Collins; Stove Prairie Hill; Pueblo; Cañon City; Denver; Ft. Collins; Livermore; Echo Creek; Colorado Springs; Boulder; between Sunshine and Ward.

3. Symphoricarpos pauciflorus (Robbins) Britton. (S. racemosus pauciflorus Robbins) In rocky places and on hillsides from Vt. and B. C. to Pa., Colo. and Calif.-Gypsum; Howe's Gulch; Horsetooth Mountain; North Cheyenne Cañon; west of Ft. Collins; Middle Park; Dillon Cañon.

4. Symphoricarpos rotundifolius A. Gray. In the mountains from Wyo. and Ida. to N. M.-Spicer, Larimer Co.

5. Symphoricarpos utahensis Rydb. On hillsides from Wyo. and Ida. to Colo. and Utah.-Alt. about $8000 \mathrm{ft}$.- Van Boxle's ranch, above Cimarron.

6. Symphoricarpos vaccinioides Rydb. On hillsides from Mont. and Wash. to Colo. and Nev.-Alt. about 7000 ft.-Wolcott, Eagle Co.; Cimarron.

7. Symphoricarpos oreophilus A. Gray. In the mountains from Colo. and Utah to N. M. and Ariz.-Alt. 7500-I0,000 ft.-Divide road to Steamboat Springs; near Ouray; Pitkin; southeast of Ouray; Durango; Georgetown; West Mancos Cañon; Grayback mining camps and Placer Gulch; on Turkey Creek and tributaries; near Pagosa Peak; Gunnison; Wolcott, Eagle Co.; Clear Creek; Eldora to Baltimore.

\section{DISTEGIA Raf.}

I. Distegia involucrata (Richardson) Rydb. (Lonicera involucrata Banks) In wet woodlands from Que. and Alaska to Mich., Colo. and Calif.; also Mex.-Alt. 7000-9000 ft.-Gulch south of Rist Cañon; Mancos; Gunnison; Mt. Hesperus; Los Pinos (Bayfield); near Pagosa Peak; Glenwood Springs; foot-hills, Larimer Co.; Andrews' Shetland ranch; Wahatoya Cañon; East Indian Creek; South Park; near Ironton, San Juan Co.; Sapinero; Gunnison; Parlin; Box Cañon, west of Ouray; Red Mountain road, south of Ouray; Veta Pass; Eldora to Baltimore; mountains between Sunshine and Ward; Beaver Creek.

Family I 27. ADOXACEAE Fritch. Moschatel Family.

x. ADOXa L. Musk-root, Moschatel.

r. Adoxa Moschatellina L. In shady, wet, rocky places from Arctic America to Wisc. and Colo.-Alt. 7000-12,000 ft.-Carson; Seven Lakes; Gentian 
Ridge; Pike's Peak; West Spanish Peak; Bottomless Pit, Pike's Peak; near Pagosa Peak; Tennessee Pass, seven miles west of Leadville; Front Range, Larimer Co.; Mt. Hesperus; Clear Creek; Boulder Cañon.

\section{Order 47. CAMPANULALES.}

Endosperm wanting; flowers monoecious or dioecious; plant mainly vines with tendrils. I28. Cucurbitaceae.

Endosperm present; flowers perfect; plants (at least ours) not vines.

Corolla regular.

Corolla split on one side and more or less irregular. I29. Campanulaceae. i 30. Lobeliaceae.

\section{Family I 28. CUCURBITACEAE Juss. Gourd Family.}

Ovary I-celled with 3-5 placentae; ovules numerous; corolla campanulate; fruit fleshy, indehiscent. I. Cucurbita.

Ovary 2-celled; ovules few; fruit opening at the top; corolla rotate, small.

1. cucurbita L. Gourd, Pumpkin.

2. Micrampeis.

I. Cucurbita foetidissima H. B. K. (C. perennis A. Gray) On plains from Mo, and Neb. to Tex. and Calif.-Bank of Arkansas River.

\section{MiCRampelis Raf. Balsam Apple; Mock Apple.}

I. Micrampelis lobata (Michx.) Greene. (Echinocystis lobata T. \& G.) On river banks among shrubs from $\mathrm{Me}$. and Mont. to $\mathrm{Va}$. and Colo.-Ft. Collins; Cache la Poudre; Platte River, near Denver.

\section{Family i 29. CAMPANULACEAE Juss. Bellflower Family.}

Corolla campanulate or funnelform; inflorescence racemose or paniculate; flowers complete throughout.

1. Campanula.

Corolla rotate; inflorescence spicate; flowers of two kinds; the earlier cleistogamous.

2. Specularia.

\section{Campanula L. Bellflower, Bluebel, Harebell.}

Flowers over I $\mathrm{cm}$. long; plant simple or with erect or ascending branches.

Capsule erect, opening by pores near the summit, just below the base of the sepals.

Hypanthium and pod club-shaped, constricted just below the sepals, often hairy; leaves entire; sepals obtuse.

1. C. uniflora.

Hypanthium and pod turbinate, not constricted; sepals acuminate.

Capsule nodding, opening by pores near the base.

2. C. Parryi.

Flowers 5-8 mm. long; stem retrorse-hispid with divaricate branches.

3. C. petiolata.

4. C. aparinoides.

x. Campanula uniflora L. In arctic-alpine localities from Greenl. and Alaska to Lab., Colo, and Utah.-Mountains of Estes Park.

2. Campanula Parryi A. Gray. In mountain valleys from Wyo. and Utah to N. M. and Ariz.-Alt. 8000-I2,00o ft.-Table Rock; Sand Creek; Como and vicinity; Happy Hollow; Beaver Creek; Clear Creek, near Elizabethtown; Hematite; Eldora to Baltimore; Empire. 
3. Campanula petiolata DC. (C. rotundifolia American authors, in part; not L.) On hills and mountains from Mackenzie and Wash. to N. M. and Utah.-Alt. 5000-12,000 ft.-Gunnison Co.; Gray's Peak; Rist Cañon; Breckenridge; Narrows; near Ft. Collins; Horsetooth Gulch; Palmer Lake; Dillon Cañon; Trinidad; Howe's Gulch; gulch west of Soldier Cañon; Boulder.

4. Campanula aparinoides Pursh. In wet meadows from N. B. and Sask. to Ga. and Colo.-Along Platte, near Denver (Eastwood.).

\section{SPECULARIA Heist. Venus' Looking-glass.}

Leaves cordate-clasping; capsule oblong.

I. S. perfoliata.

Leaves linear or linear-lanceolate; capsule linear-cylindric. 2. S. leptocarpa.

I. Specularia perfoliata (L.) A. DC. On hillsides from Me. and B. C. to Fla., Ariz. and Ore. also in Mex.-Spring Cañon; Howe's Gulch; Horsetooth Gulch; Platte River.

2. Specularia leptocarpa (Nutt.) A. Gray. In dry soil from Mo. and Mont. to Tex. and Colo.-Locality not given.

\section{Family i 30 . LOBELIACEAE Dumort. Lobelia Family.}

\section{LOBElia L. Lobelia, Cardinal-Flower.}

1. Lobelia syphilitica L. In wet places from Me. and S. D. to Ga., La. and Colo. West of the Missouri River it is only represented by the smaller var. Ludoviciana A. DC.-Vicinity of Ft. Collins; hills north of La Porte; Denver.

\section{Order 48. VALERIANALES.}

\section{Family I3I. VALERIANACEAE Batsch. VALERIaN Family.}

\section{VALERIANA L. VALERIAN.}

Leaves thick, entire or with linear, entire divisions; veining almost parallel. Fruit and ovaries pubescent; bracts in the staminate plant linear-lanceolate. I. V. edulis.

Fruit glabrous, scurfy, muricate or rugose.

Basal leaves oblanceolate; fruit broadly ovate; corolla of the staminate plant 2.5-3 mm. wide; root thick.

Basal leaves narrowly linear-oblanceolate; fruit narrowly ovate; corolla of the staminate flowers less than $2 \mathrm{~mm}$. wide; root rather slender.

Leaves thin; the cauline ones pinnate; veining distinctly pinnate. 3. V. furfurascens.

\section{Ovary and fruit at least when young pubescent.}

4. V. micrantha.

Ovary and fruit glabrous.

Basal leaf-blades ovate-cordate.

5. V. ovata.

Basal leaf-blades spatulate, oval or lanceolate, tapering at the base.

Lateral leaflets or lobes of the stem-leaves small, linear-lanceolate, acuminate. 6. V. acutiloba.

Lateral leaflets of the stem-leaves ample, ovate to lanceolate, acute. 7. V. occidentalis.

1. Valeriana edulis Nutt. On hillsides and dry meadows from Ida. and Mont. to Colo. and Utah.-Alt. up to I I,000 ft.-Berthoud Pass; Continental Divide; Columbine; Conejos River, north of Antonito. 
z. Valeriana trachycarpa Rydb. In the mountains of Colo, and N. M.Alt. 8000-Io,000 ft.-Red Mountain; Alpine Tunnel; Marshall Pass; RabbitEars Pass.

3. Valeriana furfurascens A. Nelson. On hillsides and mountains of Wyo. and Colo.-Alt. 7000-10,000 ft.-Bosworth's ranch; Narrows; Pike's Peak; Ruxton Dell; Indian Pass Creek.

4. Valeriana micrantha A. Nelson. In the mountains from Mont. and Ida. to Colo. and Utah.-Alt. about gooo ft.-West Mancos Cañon; Rabbit-Ears, Larimer Co.

5. Valeriana ovata Rydb. In the mountains of Colo. and N. Mex.-Alt. up to $9500 \mathrm{ft}$.-Cameron's Cone.

6. Valeriana acutiloba Rydb. ( $V$. oreophila Greene) In the mountains from Wyo. and Utah to N. M. and Ariz.-Alt. 8000-I3,500 ft.-Silverton; Beaver Creek; mountains about Ouray; mountains above Graymont; Ragged Mountains; Cameron Pass; Pike's Peak; Clear Creek; mountain near Veta Pass; near Pagosa Peak; Bear Creek Cañon; Mt. Hesperus; Mt. Abram, Ouray; Ruxton Dell; Gray's Peak; Carson; Grayback mining camps and Placer Gulch; Salida; Boreas; Mt. Richtofen.

7. Valeriana occidentalis Heller. In wet places in the mountains from Ida. and Mont. to Colo. and Utah.-Cañon of Cache la Poudre; Poverty Ridge, above Cimarron; Anita Peak; Beaver Creek.

\section{Order 49. CARDUALES.}

Flowers all with tubular corollas or none, or only the ray-flowers with ligulate corollas.

Stamens distinct; flowers unisexual.

Stamens united by the anthers, or if distinct (in Kuhnia) the flowers hermaphrodite.

Flowers all with ligulate corollas.

132. AMBRosiaceae. i 33. Carduaceae.

I34. Cichoriaceae.

\section{Family 132. AMBROSIACEAE Reich. Ragweed Family.}

Staminate and pistillate flowers in the same heads; the latter few (rarely solitary or none), at the margins.

Achenes turgid, ovoid or pear-shaped, marginless.

Involucres of 5 dilated ovate, rigidly acuminate bracts; achenes with a large terminal areola, surrounded by a disk. I. OXYTENiA.

Involucres not with dilated rigidly acuminate bracts; terminal areola minute. 2. Iva.

Achenes flattened, wing-margined; involucres of 5 ovate or oblong herbaceous bracts and within them I-2 large scarious bracts subtending the pistillate flowers.

3. Dicoria.

Staminate and pistillate flowers in different heads; the latter I-4, without corolla, and enclosed in a nut-like or burr-like involucre.

Involucres of the staminate heads with united bracts; receptacles low; rudimentary styles peniciliate or fimbriate at the apex.

Spines or tubercles of the I-flowered pistillate heads in a single row.

Spines of the I-4-flowered pistillate heads in more than one row.

$$
\text { 4. Ambrosta. }
$$

5. Gaertineria.

Involucres of the staminate heads with distinct bracts; receptacle cylindraceous; spines of the 2 -flowered pistillate heads in several rows, uncinate. 
I. OXYTENIA Nutt.

1. Oxytenia acerosa Nutt. On dry plains from Colo. to N. M. and Ariz.Alt. about $4500 \mathrm{ft}$.-San Juan Valley.

\section{IVA L. MARSH ELDER}

Heads paniculate; leaves ovate, canescent beneath. Heads axillary; leaves obovate or oblong, green.

1. I. xanthifolia.

2. I. axillaris.

1. Iva zanthifolia Nutt. In moist soil, along streams and in waste places from Mich., Sask and Wash. to Neb. and N. M.-Alt. 4000-7000 ft.-Sunset Cañon; Cheyenne Mountain; Ft. Collins; Huerfano Valley, near Gardner ; Poudre River.

2. Iva axillaris Pursh. In alkaline or saline meadows from Sask. and B. C. to Ind. Terr. and Calif.-Alt. 4000-7000 ft.-Gunnison; near Greeley; Grand Junction; Calhan; Ft. Collins ; Lamar.

\section{DICORIA T. \& G.}

I. Dicoria Brandegei A. Gray. On sandy bottoms from Colo. and Utah to Ariz.-San Juan River; between McElmo and Recapture Creeks.

\section{AMBROSIA L. RAG-WEed, Hog-WEED.}

Involucres of the staminate heads 3 -ribbed; leaves palmately 3-5-cleft or entire.

Involucres of the staminate heads not ribbed; leaves once to thrice pinnatifid.

Annual; fruit with acute teeth.

Perennial; fruit with blunt teeth or unarmed.

2. A. artemisifolia.

I. Ambrosia trifida L. In moist soil from Que. and Ass, to Fla. and Colo. -Alt. 4000-5000 ft.-East of Windsor; Ft. Collins; Dixon Cañon; Poudre Cañon.

Ambrosia trifida integrifolia (Muhl.) T. \& G. A variety with entire leaves. Together with the species.-Cache la Poudre River.

2. Ambrosia artemisifolia L. In dry soil, waste places and fields from N. S. and B. C. to Fla. and Colo.-Alt. 4000-5000 ft.-Ft. Collins; banks of the Poudre.

3. Ambrosia psilostachya DC. On prairies and plains from Ills., Sask, and Ida. to La. and Calif.; also in Mex.-Alt. 4000-7000 ft.-Golden; New Windsor; Garden of the Gods; Pagosa Springs; Boulder; Lyons; Ft. Collins.

\section{GAERTNERIA Med.}

Leaves twice or thrice pinnately dissected.

Leaves regularly pinnate with linear or oblong divisions.

Staminate involucres cleft below the middle; root mostly annuals.

Staminate involucres not cleft to the middle; perennials.

1. G. acanthocarpa.

Divisions of the leaves oblong or oblong-linear, acute.

Divisions of the leaves linear, obtuse.

Leaves interruptedly pinnate; divisions ovate or triangular.

2. G. tenuifolia.

3. G. linearis.

Leaves simply pinnate or simple.

4. G. tomentosa.

5. G. Grayi. 
1. Gaertnoria acanthocarpa (Hook.) Brilton. (Franscria Hookeriana Nutt.) On plains and in sandy valleys from Sask, and B. C. to Tex. and Calif.-Alt. 4000-8000 ft.--Colorado Springs; Denver; Hucríano Valley, near Gardncr; Istena Vista; Grand Junction; Delia; Rocky Ford; Grand River.

2. Gaertneria tenuifolia ( $\Lambda$. (iray) Kunn\%(. (Franseria l'nttifolia $\Lambda$. Gray) In moist fround from Kans. and Colo, to 'T'x. and (alif.; also in Mex.Fixict locality not given.

3. Gaertneria linearis Rydb. Dry plains of Colo--Alt, about $7000 \mathrm{ft}$ Calhan.

4. Gaertneria tomentosa (Nutt.) Ileller, (Ambrosia tomentosa Nutt.; Franseria discolor Nutt,) In dry soil from S. D. and Wyo. to Kans, and N. M.-Alt, 4000-6000 It.--I'latte River; lit. Collins; New Windsor; Boulder.

5. Gaertnoria Grayl Jieller. (Frauseria tomentosa A. Gray) Rivel valleys in Kánt., Neb. and Eastem Colo,-Exact locality not given.

\section{XANTHIUM 1. COCKLEBUR.}

I. Xanthium commune Britton. In valleys from Que, and N. Y. to Utah and Ari,. - Ft. Collins.

\section{liamily i33. CARDUACEAE Necker. Thister Family.}

Stigmatic lines at the base of the stigmas or below the middle; heads always discold, never yellow or brown; anthers not caudate at the base.

Stigma filiform or subulate, hispidulous.

Tribe I. VERNONIAE.

Stigmas more or less clavate, papillose-puberulent. Tribe z. Eupatoriat.

Stigmatic lines extending to the tips of the stigmata or to the appendage thereof, if present.

Anther-sacs not triled at the base; heads most commonly radiate and with yellow or brown disk-flowers.

Stigmata of the perfect flowers with more or less distinct appendages; these ustully strongly hairy outside, glabrous inside, but never with a ring of longer hairs.

Tribe 3. Asterian.

Stigmatia of the perfect flowers without appendages; or if with appendages, thence hitiry on bolls sides and with a ring of longer hairs.

Pappus never capillary; stigma rarely appendaged.

Brncts of the involucres herbnceous or foliaceous.

Receptacle with chaffy scales, subtending the flowers.

Tribe 5. Heilantileat.

lien'ntacle naked, or in Gaillardia with bristles, but not chaffy-bracted.

Bracts of the involucres dry and scarious.

Tribe 6. HRLINIAL.

Pappus capillnry; stigmn often appendaged.

Tribe 7. Anthemideas.

Tribe 8. Senteronear.

Anther-sncs citulate at the base; heads never radiate and corollas yellow only fn a few species of Cardurs.

Anthers not appendaged at the top; heads heterogamous or dioecious; pistillnte flowers will filiform corollas.

Tribe 4, Gnaphaliar.

Anther with elongated cartilnginous, mostly caudate appendages at the top; flowers all hermaphrodite ur the marginal ntulral; corolla not filiform.

Tribe 9. Cynareal.

\section{TuH: I. VERNONTAT.}

One kenus.

\section{TRIDE 2. EUPATORIAE.}

Achenes 5-ankled without intervening ribs; pappus of wholly capillary bristles, mostly uniserial. s. EUSATORIUM.

Achenes 8-10-ribbed or 8- ro-striate. 
Bracts of the involucre herbaceous or partly colored, not striate.

Bracts of the involucres not herbaceous, striate-nerved.

$$
\text { 5. Laciniaria. }
$$

Pappus-bristles plumose; anthers distinct; bracts few.

3. KuHNiA.

Pappus-bristles scabrous or barbellate; anther united; bracts usually many.

4. Coleosanthus.

\section{TRIBE 3. ASTEREAE.}

A. Plants not dioecious.

I. Marginal pistillate flowers, if present, ligulate.

a. Ray-flowers yellow or none.

I. Pappus consisting of scales or awns or lacking, never of numerous capillary bristles.

Heads small, not over $4 \mathrm{~mm}$. high, few-flowered; pappus more or less paleaceous.

6. Gutierrezia.

Heads large, many-flowered; involucre in all except one species viscid; pappus of a few deciduous awns.

7. GRINDELia.

2. Pappus at least in part of numerous capillary bristles.

a. Pappus double, the inner of capillary bristles; the outer of scales or short bristles; involucres many-flowered, hemispherical with narrow imbricated bracts.

b. Pappus wholly of capillary bristles.

* Heads discoid.

Involucres narrowly turbinate; its bracts more or less chartaceous, keeled, arranged in definite (usually 5) vertical ranks; achenes elongated-linear; stigma-tips subulate-filiform.

9. Chrysothamnus.

Involucres broadly turbinate to hemispherical; its bracts more or less imbricated, but not in definite vertical ranks; achenes scarcely elongated-linear.

Stigma-tips obtuse; involucral bracts narrow, poorly imbricated. (Rayless species of) 3I. ERIGeron.

Stigma-tips acute; bracts either broad or well imbricated or both. Achenes truncate at the top, gradually tapering towards the base, usually cinereous-pubescent; bracts neither broad nor abruptly acuminate.

Appendages or tips of the styles filiform; undershrubs with white-tomentulose stems and glandular-hairy foliage; leaves entire-margined.

15. MACRONEMA.

Appendages or tips of the stigmas subulate to ovate.

Leaves with spinulose-tipped teeth; corolla-tube slender. (Rayless species of) ir. Sideranthus.

Leaves not spinulose, in ours entire-margined; corollatube dilated above.

Io. Isocoma.

Achenes elongated, obovoid, i. e., tapering at both ends, but more so below, multi-striate, glabrous or slightly hairy; bracts of the involucres broad and abruptly acuminate; appendages of the stigmas ovate to short-subulate.

* Heads radiate.

I3. Oonopsis.

Leaves pinnately cleft or toothed; lobes or teeth spinulose-tipped.

Pappus of the fertile achenes deciduous in a ring; annuals, equally leafy throughout; bracts more or less foliaceous.

Pappus persistent.

I4. Prionopsis.

Bracts chartaceous, not foliaceous, merely with green tips; plants annual or perennial with a caudex, equally leafy throughout; pappus in age more or less spreading; achenes turbinate and densely silky. it. Sideranthus.

Bracts more or less foliaceous, at least above; plants perennial with taproots, large basal leaves and few and rather small 
stem-leaves; pappus not spreading; achenes oblong, glabrous or sparingly pubescent. I 2. Pyrrocoma.

Leaves entire or toothed, but teeth not spinulose-tipped.

Bracts not longitudinally striate.

Bracts abruptly acuminate; stems leafy up to the sessile heads.

Bracts not abruptly acuminate.

I3. OONOPSIS.

Appendages of the stigma filiform, much longer than the stigmatic portion; low shrubs with whitish bark and foliaceous outer bracts.

I 5. Macronema.

Appendages of the stigmas ovate or triangular, not longer than the stigmatic portion.

Plants low cespitose evergreen undershrubs with more or less evergreen leaves and solitary peduncled heads.

i6. Stenotus.

Plants with wholly herbaceous stem, if at all woody only at the caudex; leaves not evergreen.

Bracts, at least the outer, foliaceous or with foliaceous tips.

Disk-flowers tubular; plants with a taproot.

12. Pyrrocoma.

Disk-flowers more or less widened upwards; plants with rootstock or short caudex.

Heads corymbiform-cymose; rays small and few; plants leafy.

I7. OREOCHRYSUM.

Heads solitary; rays numerous; plants dwarf.

I8. TONEstus.

Bracts of the inflorescence not at all foliaceous or merely with green tips.

Rays not more numerous than the disk-flowers; receptacle alveolate.

Inflorescence racemose or paniculate; bracts not in vertical rows. Ig. Solidago.

Inflorescence corymbiform; bracts in distinct vertical rows. 20. Petradoria.

Rays more numerous than the disk-flowers; receptacle fimbriolate; heads corymbose.

2I. EUthamia.

Bracts of the involucres longitudinally striate; heads in congested corymbs.

22. OLIGONEURON.

b. Ray-flowers blue, pink or white.

I. Pappus a mere crown or of a few scales or awn-like bristles.

2. Pappus of numerous capillary bristles.

23. TOWNSENDIA.

a. Rays only slightly if at all exceeding the pappus; all annual.

Bracts in $2-3$ series, the outer foliaceous; stigma-tips acute.

24. Brachyactis.

Bracts in $I-2$ series, narrow, not foliaceous; stigma-tips obtuse.

32. LEPTILON.

b. Rays conspicuous, longer than the pappus, ustually equalling or exceeding the width of the disk.

Stigma-tips lanceolate or oblong to filiform.

Perennials with a rootstock or caudex.

Bracts acuminate, as well as the leaves tipped with callous points or spines; plants with cespitose caudices and solitary heads at the ends of the stems or branches.

25. XYLORRHIZA.

Bracts not acuminate, or if long-attenuate, with soft tips.

Pappus dilated at the apex; bracts narrow, more or less keeled.

Pappus not dilated at the apex.

26. UNAMIA. 
Bracts broad with a distinct keel or mid-vein, not at all foliaceous.

27. EUCEPHALUS.

Bracts usually narrow, when broad neither keeled nor with a prominent mid-vein. 28. Aster.

Annuals or biennials, or if short-lived perennials, not with rootstocks; bracts in many series, with herbaceous spreading or reflexed tips; stigma-tips linear to filiform.

29. Machaeranthera.

Stigmá-tips triangular or ovate, obtuse or rarely acutish; bracts not foliaceous.

Involucres turbinate; bracts well imbricated in several rows. 30. LeUCELENe.

Involucres hemispherical or broader; bracts in $\mathrm{I}-3$ series. 31. ERIGERON.

II. Marginal pistillate flowers not ligulate, reduced to a filiform or narrow short tube.

33. ESCHENBACHIA.

B. Heads unisexual, dioecious, discoid; pappus of the staminate flowers with clavate tips.

Tribe 4. GNAPhaliaE.

Shrubs; bracts coriaceous ; receptacle naked; pistillate flowers numerous; corolla reduced to a short slender tube; hermaphrodite flowers few and sterile; their pappus with clavate tips. 35. Berthelotia.

Herbs, if at all shrubby only at the base; bracts more or less scarious.

Receptacle chaffy; stigmas of the hermaphrodite sterile flowers not truncate. 36. Filago.

Receptacle not chaffy; stigmas of the hermaphrodite flowers mostly truncate.

Plants dioecious, or the pistillate heads with a few hermaphrodite flowers in the center.

Pappus-bristles of the pistillate flowers falling off in a ring; those of the staminate flowers clavellate or apically barbellate, crisp; central hermaphrodite flowers none. 37. Antennaria.

Pappus-bristles of the pistillate flowers falling off separately; those of the staminate flowers scarcely clavellate; central hermaphrodite flowers present in the pistillate heads.

Plants not dioecious; flowers fertile throughout the heads.

\section{Tribe 5. HELIANTHEAE.}

39. Gnaphalium.

A. Bracts not enclosing the achenes of the rays; plants not glandular-viscid.

I. Disk-flowers hermaphrodite but sterile.

Marginal pistillate flowers with conspicuous rays; involucres of very dissimilar sets of bracts.

40. Melampodium.

Marginal pistillate flowers reduced to a truncate or obliquely cleft tube; the ligule, if any, reduced to 2 or 3 small teeth. 4I. PARTHENICE.

II. Disk-flowers fertile.

a. Ray-flowers fertile, with very short tube, persistent on the achenes and becoming papery in texture.

Achenes of the disk compressed; leaves entire. 42. Crassina.

Achenes obtusely 4-angled; leaves toothed. 43. HeLIOPSIs.

b. Ray-flowers deciduous from the achenes or wanting.

I. Pappus a crown or none, or of a few scales on the angles of the achenes and rarely minute ones between.

u. Achenes of the disk-flowers not obcompressed (except in RATIBIDA); chaffs usually more or less concave and clasping.

Receptacle conic, subulate or columnar.

Achenes 4-angled.

44. BRAUneria.

Achenes quadrangular-compressed; apex of the achenes covered by the base of the corolla-tube.

Achenes nearly equally 4-angled; apex not covered by the base of the corolla.

Achenes flattened, broad-margined or winged.

46. RUDBECKIA.

47. Ratibida. 
Receptacle from flat to convex.

Achenes of the disk neither sharp-angled, margined nor winged.

Rays fertile; their achenes commonly 3 -angled or obcompressed; plants with thick balsamiferous tap-roots.

Pappus none; stem scapiform or with reduced leaves.

48. BALSAMORRHIZA.

Pappus a lacerate chaffy crown or of distinct chaffs; stem low but leafy.

49. Wyethia.

Rays sterile or wanting; plants not with fleshy tap-root.

Pappus none or a minute ring. 45. GYMNolomia.

Pappus of 2 scarious awns. 50. HeLIANTiUs.

Achenes of the disk thin-edged, margined or winged.

Ray-flowers neutral; achenes scarcely winged.

Ray-flowers fertile; achenes winged. 52. Ximiantieledenta.

$b$. Achenes obcompressed; chaffs flat or hardly concave; involucres distinctly double.

Bracts of the involucres distinct or nearly so.

Pappus in ours of small teeth, a mere border, or wanting.

Pappus of 2-4 barbed or hispid awns.

53. Coreopsis.

54. BIDENS.

Bracts of the inner involucre united at least to near the middle.

55. Thelesperma.

2. Pappus of 5-many, linear to lanceolate scales with thickened axis and hyaline margins.

74. GaIllardia.

B. Bracts of the involucres uniserial, partly or wholly enclosing the achenes of the fertile ray-flowers; plants glandular-viscid. 56. Madia.

\section{TRIBE 6. HELENIAE.}

A. Plant-tissues without oil-glands.

I. Ligules persistent and becoming papery on the striate achenes; plants more or less woolly.

II. Ligules deciduous or none.

57. Psilostrophe.

a. Achenes flat with only marginal nerves; disk-corollas 4-toothed.

b. Achenes angled, not flat, nerved or striate.

58. Pericome.

1. Receptacle naked.

a. Bracts of the involucres pale or colored, at least the margins and tips scarious.

Corolias of the disk-flowers with reflexed or spreading lobes; bracts of the broadly campanulate involucres obovate or broadly oblong.

Heads discoid.

59. HyMENOPAPPUS.

Heads radiate; ligules obscurely toothed, yellowish or white.

60. LEUCAMPYX.

Corolla of the disk-flowers with linear, erect lobes; bracts of the turbinate involucres spatulate to linear-oblanceolate in two series; heads in our species radiate; ligules deeply cleft, purple.

61. POLYPTERis.

$b$. Bracts of the involucres neither colored nor scarious.

Achenes 4-angled.

Foliage impressed punctate; leaves, at least the lower, opposite.

Perennials, suffruticose at the base; leaf-segments oblong to linear. 6z. Picradeniopsis.

Annuals; leaf-segments filiform or nearly so.

Foliage not impressed-punctate; leaves alternate.

63. Achyropappus.

Bracts obovate, cuneate or oblanceolate.

Perennials with a woody caudex; leaves entire; pappus of 10 scales.

Annuals; leaves dissected; pappus in our species wanting.

Bracts linear.

65. BAHIA.

66. ChaENACj's. 
Achenes 5-Io-ribbed.

Bracts of the involucre erect, not spreading nor reflexed.

Involucres many-flowered; pappus present; achenes tapering below. Bracts of the involucres nearly equal and similar, all distinct.

Leaves simple; stem scapiform or with a few small leaves; heads long-peduncled.

Corollas yellow; bracts numerous; leaves linear to oblong. 67. TETRANEURis.

Corollas fiesh-colored; bracts about I2; leaf-blades from orbicular to oblong.

68. Chamaechaenactis.

Leaves dissected into linear lobes; stem low but leafy. 69. RYDBERGIA.

Bracts of the involucres unequal; the outer united at the base. 70. Hymenoxys.

Involucres few-flowered; pappus wanting; achenes linear, 8-10striate.

Bracts of the involucres spreading or reflexed.

Leaves not decurrent on the stem; tubes of the disk-flowers moderately long. 72. Dugaldia.

Leaves decurrent on the stem; tubes of the disk-corollas very short or reduced to a ring. ¿. Receptacle with bristle-like chaffs.

73. Helenium.

74. Gaillardia.

B. Plant-tissues, especially the leaves and involucres with oil-glands; plants heavy-scented.

Bracts of the involucres more or less united; stigmas of the disk-flowers elongated.

Bracts of the involucres united only at the base; stigmas with conical tips. 75. BOEBERA.

Bracts of the involucres united into a cup; stigmas obtuse.

76. LowelliA.

Bracts of the involucres distinct; stigma very short, obtuse, without an appendage.

77. Pectis.

\section{TRIBE 7. ANTHEMIDEAE.}

Receptacle chaffy.

Achenes terete, at least not flattened; involucres hemispherical, large.

78. ANTHEMIS.

Achenes flattened; involucres campanulate or obovoid, small.

Receptacle naked or merely pubescent.

Heads radiate.

79. ACHILIEA.

Heads discoid.

Plants spiny; achenes and corollas cobwebby.

Plants not spiny; achenes not cobwebby.

8o. Chrysanthemum.

8i. Picrothamnus.

82. Artemisia.

\section{Tribe 8. SENECIONEAE.}

Plants scapiferous, dioecious or nearly so, with large basal leaves appearing after flowering; hermaphrodite flowers usually sterile. 83. Petasites.

Plants not scapiferous, not dioecious; disk-flowers hermaphrodite, fertile.

Involucres of many or several bracts.

Involucres of commonly much overlapping or unequal bracts.

84. Haploestes.

Involucres of connivent erect herbaceous equal bracts, with or without smaller calyculate ones below.

Leaves mostly opposite; pappus of a single series of rigid bristles.

Leaves alternate; pappus of numerous soft bristles.

85. ArNica.

86. Senecio.

Involucres of 4-6, firm, concave, erect and strongly overlapping bracts; shrubs with alternate leaves and discoid heads.

87. Tetradymia. 
One genus.

88. Carduus.

Tribe 1. VERNONIAE.

I. VERNONIA Schreb. IRON WEED.

I. Vernonia Jamesii T. \& G. ( $V$. marginata (Torr.) Britton) On plains from Neb. and Colo. to Ark. and Tex.- "On the Arkansas."

\section{Tribe 2. EUPATORIAE.}

2. EUPATORIUM L. JoE-Pye WeEd, Thorough-WORT.

Leaves verticillate in whorls of threes.

Leaves ovate, acute.

Leaves lanceolate, acuminate.

Leaves opposite.

I. E. maculatum.

2. E. Bruneri.

3. E. texense.

1. Eupatorium maculatum L. In moist soil from N. Y. and B. C. to Ky. and N. M.-Along river east of Ft. Collins.

2. Eupatorium Bruneri A. Gray. (Eupatorium Rydbergii Britton) In moist soil from Iowa, Sask. and B. C. to Colo. and Utah.-Alt. 4000-5000 ft.Cañon City; Ft. Collins; La Poudre near La Porte.

3. Eupatorium texense (T. \& G.) Rydb. (E. ageratifolium texense T. \& G.; E. ageratifolium A. Gray, mainly; not DC.) Rocky hills from Colo. to Tex, and Ariz.-Alt. 7000-8500 ft.-Cañon City; Box Cañon, west of Ouray; Trail Glen.

\section{KUHNIA L.}

Leaves oblong or lanceolate, 3 -ribbed, more or less toothed.

Bracts narrowly linear, acuminate.

Bracts linear, abruptly acute.

Leaves linear, I-ribbed, entire.

I. K. Hitchcockii.

z. K. glutinosa.

3. K. Goodingii.

r. Kuhnia Hitchcockii A. Nelson. Plains of Kans. and Colo.-Alt. 4000$5000 \mathrm{ft}$.-Denver.

2. Kuhnia glutinosa Ell. (K. eupatorioides corymbulosa T. \& G.) On dry prairies and plains from Ills. and Mont. to Ky. and Colo.-Alt. about 5000 ft.-Boulder; New Windsor; Ft. Collins; Spring Cañon.

3. Kuhnia Goodingii A. Nels. On rocky hills and plains from Colo. to Tex. and Ariz.-Alt. 4000-7000 ft.-Engelmann Cañon; Granite; Manitou; Durango; Hotchkiss; Pagosa Spring.

\section{Coleosanthus Cass.}

Leaf-blades ovate or deltoid.

Leaves slender-petioled, not spinulose-toothed; bracts thin, $2 \mathrm{~mm}$. or less wide. Heads 30-50-flowered.

Leaves thin, minutely puberulent; teeth usually broadly triangular, acute; peduncles usually longer than the heads.

I. C. grandiflorus.

Leaves thick, densely scabrous-pubescent, very veiny; teeth rounded-ovate, obtuse or mucronate; peduncles shorter than the subumbellate heads.

Heads Io-25-flowered.

2. C. umbellatus. 
Tips of the bracts not spreading; leaf-blades $2-4 \mathrm{~cm}$. long.

3. C. albicaulis.
Tips of the bracts spreading, squarrose; leaf-blades less than $\mathrm{I} \mathrm{cm}$. long 4. C. scaber.

Leaves subsessile or very short-petioled, spinulose-toothed; bracts firm, 3-6 mm. wide. $\quad$ 6. C. atractyloides. Leaves linear or oblong, sessile.

5. C. linifolius.

I. Coleosanthus grandiflorus (Hook.) Kuntze. (Brickellia grandiflora Nutt.) In cañons, "bad-lands" and draws from Mont. and Wash. to Colo. and Ore.-Alt. 4000-8000 ft.-Columbine; Trappers' Lake; cañon north of Palmer Lake; bank of Poudre, La Porte.

2. Coleosanthus umbellatus Greene. (Brickellia grandiflora minor A. Gray; Coleosanthus congestus A. Nels.) On hillsides and in cañons from Wyo. to N. M. and Ariz.-Alt. 5000-10,000 ft.-Colorado Springs; near Empire; Boulder Cañon, Boulder Co.; Pike's Peak; foot-hilis, Larimer Co.; Georgetown; Trout Creek; Jefferson Co.; Golden; Cañon City; near Pagosa Peak; southeast of Ouray; Black Cañon; Idaho Springs; La Poudre; Redstone; mountains between Sunshine and Ward; Steamboat Springs; Elk Cañon; Powder River; Table Rock; Hayden; Roaring Fork, Larimer Co.

3. Coleosanthus albicaulis Rydb. (Brickellia Wrightii Gray, in part.) In cañons and on foot-hills from Colo. and Utah to N. M.-Alt. 5000-8000 ft.Lower Boulder Cañon; Trail Glen; Manitou; Golden; Mt. Harvard; foothills, Larimer Co.; near Boulder; Spring Cañon; Glenwood Springs.

4. Coleosanthus scaber Greene. On dry soil in Colo.-Alt. about $4700 \mathrm{ft}$.Deer River; Mesa Verde.

5. Coleosanthus linifolius (D. C. Eaton) Kuntze. (Brickellia linifolia D. C. Eaton; C. humilis Greene.) In arid soil from Colo. and Nev. to Calif-Alt. 4000-7000 ft.-Arboles; Grand Junction; cañon of Smith's Fork; between Porter and Durango.

6. Coleosanthus atractyloides (A. Gray) Kuntze. (Brickellia atractyloides A. Gray.) In desert regions from Colo. and Nev. to Ariz. and Calif.Southwestern Colo.

\section{LACINIARIA Hill. Blazing Star.}

Pappus plumose; leaves strongly punctate.

I. L. punctata.

Pappus merely barbellate.

Heads in a short raceme-like inflorescence; bracts obovate with dark rosepurple, laciniate apices.

2. L. ligulistylis.

Heads in a long raceme-like inforescence; bracts spatulate or obovate-oblanceolate with pale, merely erose apices.

3. L. scariosa.

1. Laciniaria punctata (Hook.) Kuntze. (Liatris punctata Hook.) On dry plains and hills from Iowa, Sask. and Mont. to Tex. and Ariz.-Alt. 4000-9000 ft.-Miller's ranch; north slope of Cheyenne Mountain; Ft. Collins; Boulder; Denver; Pike's Peak; dry plains northwest of Denver; Westcliffe; Manitou; Livermore, Larimer Co.; Cucharas Valley, near La Veta; New Windsor; Gunnison; mountains between Sunshine and Ward; Table Rock; Poudre Cañon; Ft. Collins; Golden; Colorado Springs; Salida.

2. Laciniaria ligulistylis A. Nels. On hills from Sask. to Colo.-Alt. 4000$8000 \mathrm{ft}$--Head of Redstone; Table Rock; La Veta; Alamosa; Twin Lakes; Pagosa Springs; Larimer Co.; Parlin, Gunnison Co.; Westcliffe; Jack's Cabin; Trout Creek; Sugar Loaf Mountain. 
3. Laciniaria scariosa (L.) Hill. (Liatris scariosa Willd.) On prairies from Me. and S. D. to Fla. and Kans. It has been reported from Colorado, but all specimens seen so named belong to the preceding.

\section{Tribe 3. ASTEREAE.}

\section{GUTIERREZIA Lag.}

Disc- and ray-flowers in each head $3-7$ each.

Surface of the leaves marked with large dots, each bordered by a hyaline scale.

Surface of the leaves not lepidote, either puberulent or glabrous. I. G. lepidota.

Axils of the leaves with fasciculate branches.

2. G. fasciculata.

Axils of the leaves without fasciculate branches.

Plant shrubby.

Involucres elongated, clavate-turbinate, $2-3 \mathrm{~mm}$. wide; bracts oblong or lanceolate.

3. G. longifolia.

Involucres campanulate, only slightly turbinate at the base, $3-4 \mathrm{~mm}$. wide; bracts ovate or obovate. 4. G. linearis.

Plant ligneous only at the short persistent caudex.

Leaves linear, usually $1.5-4 \mathrm{~mm}$. wide.

Involucres oblong-turbinate, over $5 \mathrm{~mm}$. long; outer bracts lanceolate; stems 3-4 dm. high. 5. G. scoparia.

Involucres campanulate, somewhat turbinate only at the base; bracts ovate; stems I-2 dm. high.

Leaves linear-filiform, less than I $\mathrm{mm}$. wide.

6. G. diversifolia.

Ligules of the rays fully as long as the involucre. 7. G. filifolia.

Ligules of the rays about half as long as the involucre.

Heads usually peduncled and solitary at the ends of the branches.

8. G. divaricata.

Heads usually subsessile in clusters of $3-4$ at the ends of the branches.

Plant low, $\mathrm{x}-2 \mathrm{dm}$. high; branches green; leaves $\mathrm{I}-2 \mathrm{~cm}$. long.

9. G. juncea.

Plants 3-4 dm. high; branches with straw-colored bark; leaves $3-4 \mathrm{~cm}$. long.

Disc- and ray-flowers in each head only $\mathrm{I}-2$ each.

Jo. G. Sarothrae.

I I. G. glomerella.

I. Gutierrezia lepidota Greene. On dry plains of western Colo.-Grand Junction.

2. Gutierrezia fasciculata Greene. On dry plains in western Colo.-Grand Junction.

3. Gutierrezia longifolia Greene. On dry hills and plains from Colo. and Utah to N. M.-Alt. 4000-5500 ft.-Cañon City; Westcliffe; Boulder.

4. Gutierrezia linearis Rydb. On plains from Neb. and Colo. to Kans. and N. M.-Alt. 6000-8000 ft.-Gunnison; Red Rock Cañon, near Pike's Peak.

5. Gutierrezia scoparia Rydb. On dry plains from Wyo. to Colo.-Alt. 5000-7000 ft.-Colorado Springs; Manitou; Boulder.

6. Gutierrezia diversifolia Greene. On plains from Sask, and Mont. to N. M. and Utah.-Alt. 5000-8000 ft.-Upper Larimer River; Ft. Collins; Gunnison; Muddy River, Middle Park; Parlin; Manitou; west of Loveland; La Veta; Timnath.

7. Gutierrezia filifolia Greene. On dry plains from Ida. to N. M. and Nev,-Alt. about $7000 \mathrm{ft}$-C Cucharas Valley, near La Veta.

8. Gutierrezia divaricata Nutt. On plains from Wyo. to Tex. and Utah.San Juan Co. 
9. Gutierrezia juncea Greene. On dry hills and plains from Okl. and Colo. to Ariz.-Alt. 7000-I0,000 ft.--Garden of the Gods; Twin Lakes; Westcliffe.

ro. Gutierrezia Sarothrae (Pursh.) B. \& R. (G. Euthaniae T. \& G.) On plains from Neb. and Wyo. to Kans. and Utah.-Alt. 4000-7000 ft.-Colorado Springs; Salida.

11. Gutierrezia glomerella Greene. On dry plains from Colo. to N. M.Alt. about $4700 \mathrm{ft}$.-Deer Run.

\section{GRINdelia Willd. Gum Plant, Resin-weed.}

Tips of the outer bracts spreading; none reflexed.

1. G. decumbens.

Tips of the bracts squarrose; those of the outer ones strongly reflexed.

Heads radiate.

Pappus-awns apparently smooth; barbules seen only under a compound microscope.

Stem-leaves oval, ovate, or ovate-oblong with a broad base.

Leaves bluish-green, spinulose-dentate; heads very broad and flat; its bracts broad and even the squarrose tips flattened. 2. G. texana.

Leaves yellowish-green, merely dentate; heads hemispherical; its bracts narrow and with terete squarrose tips.

3. G. squarrosa.

Stem-leaves oblanceolate, rarely oblong.

Leaves all finely serrate, dentate or subentire.

Leaves finely and closely serrate.

Leaves rather remotely dentate or subentire.

4. G. serrulata.

5. G. perennis.

Leaves coarsely toothed; the basal ones sub-laciniate. 6. G. subincisa.

Pappus-bristles distinctly barbellate; barbules distinctly seen with a common pocket-lens.

Stem tall, 4-6 dm. high, usually solitary; stem-leaves broadly oblong or obovate; bracts broad, only the outer ones squarrose-reflexed.

7. G. erecta.

Plant low, about $3 \mathrm{dm}$. high; usually several stems from the base; stemleaves oblanceolate or oblong; all bracts squarrose. 8. G. subalpina.

Heads discoid.

Stem-leaves oval or obovate.

Stem-leaves oblanceolate or oblong.

Outer bracts strongly recurved; inner not squarrose. Io. G. fastigiata.

All bracts squarrose.

II. G. aphanactis.

1. Grindelia decumbens Greene. On plains from Kans. and Colo. to N. M. -Alt. 4000-7000 ft.-Durango; Ignacio; Pagosa Springs; Mancos; Cimarron.

2. Grindelia texana Scheele. ( $G$. grandiflora Gray, in part; not Hook.) On plains from Colo. to Tex. and N. Mex.-Alt. about $5000 \mathrm{ft}$-Lower Boulder Cañon.

3. Grindelia squarrosa (Pursh) Dunal. On prairies and plains from Iowa and Wyo. to Kans. and Ariz.-Alt. up to $6000 \mathrm{ft}$.-Colorado Springs.

4. Grindelia serrulata Rydb. On plains and hills from Wyo. and Colo.Alt. about $5000 \mathrm{ft}$--Denver; Ft. Collins.

5. Grindelia perennis A. Nels. On plains and hills from Sask. and Ida. to Colo.-Alt. 5000-6000 ft.-New Windsor; Boulder; Ft. Collins.

6. Grindelia subincisa Greene. On hills from Colo. and N. M.-Durango.

7. Grindelia erecta A. Nels. In the mountains of Wyo. and Colo.-Alt. 7000-10,000 ft.-Near Empire; Georgetown; Huerfano Valley, near Gardner; Cerro Summit; mountains between Sunshine and Ward.

8. Grindelia subalpina Greene. In the mountains from Mont. to Colo. and Utah.-Botilder; head of Lone Pine Creek.

9. Grindelia inornata Greene. In the mountains of Colo.-Cañon City. 
10. Grindelia fastigiata Greene. On dry hills of western Colo,-Alt. about $4600 \mathrm{ft} .-\mathrm{Grand}$ Junction.

11. Grindelia aphanactis Rydb. In sandy soil in southwestern Colo.Durango.

\section{CHRYSOPSIS Nutt. GoLden Aster.}

Leaves at least when young appressed canescent.

Stem-leaves, except the lower ones sessile or nearly so.

Stem-leaves oblong to lanceolate, decidedly acute.

1. C. hirsutissima.

Stem-leaves obovate or obovate-lanceolate, mostly obtuse and mucronate or more seldom acutish.

Leaves usually less than $3 \mathrm{~cm}$. Iong; those of the branches short, $1-\mathrm{r} .5$ cm. long; heads small; involucres seldom I $\mathrm{cm}$. broad, usually subtended by leaves.

2. C. foliosa.

Leaves $3-6 \mathrm{~cm}$. long; those of the branches not reduced; heads larger; involucres over I $\mathrm{cm}$. broad.

Inner bracts with subulate usually brownish and spreading tips; heads sessile.

3. C. caudata.

Inner bracts merely acute.

Heads peduncled, naked or subtended by I-2 small linear or oblong leaves; leaves neither cordate nor truncate at the base.

4. C. villosa.

Heads sessile, subtended by ample oval leaves; upper stem-leaves cordate or truncate at the base.

5. C. amplifolia.

Leaves all except the uppermost petioled, oblanceolate, obtuse or acutish.

Heads short-peduncled or sessile.

Stem 3-5 dm. high; heads peduncled.

Stems low, scarcely over I dm. high; heads sessile.

Heads long-peduncled; peduncles $3-7 \mathrm{~cm}$. long.

6. C. Bakeri.

7. C. alpicola.

8. C. pedunculata.

Leaves hispid or hirsute with a spreading pubescence.

Leaves copiously hairy, only slightly viscid.

Leaves obovate, broadly oblanceolate or rarely oblong, subsessile except the lower; pubescence short.

9. C. horrida.

Leaves oblanceolate, all except the uppermost distinctly petioled.

Plant tall, 3-4 dm. high; heads more or less peduncled.

Plant densely cespitose; but stems simple to near the top.

Plant profusely branched.

Plant low, I-2 dm. high; heads sessile.

Leaves sparingly hairy, decidedly viscid.

Upper leaves obovate, sessile, obtuse; lower oblanceolate, petioled.

Involucres over I $\mathrm{cm}$. broad, subtended with obovate or oblong leaves.

13. C. resinolens.

Involucres less than I $\mathrm{cm}$. broad, naked or subtended by small linear leaves.

Leaves all oblanceolate, acute.

I4. C. viscida.

I5. C. hispida.

1. Chrysopsis hirsutissima Greene. In sandy soil from Sask. and N. D. to Colo. and Ariz.-Alt. 7000-9000 ft.-Arboles; Veta Pass; Mancos.

2. Chrysopsis foliosa Nutt. In sandy soil from Minn. and Wash. to Kans. and Colo.-Cheyenne' Mountain; Red Rock Cañon; Spring Cañon; North Cheyenne Cañon.

3. Chrysopsis caudata Rydb. On hills and mountains of Colorado.-Alt. 5000-10,000 ft.-Ruxton Dell; near Boulder.

4. Chrysopsis villosa (Pursh) Nutt. (C. imbricata A. Nels. ?) On dry hills from Minn. and Ida. to Tex. and N. M.-Alt. 4000-10,000 ft.-Mt. Harvard; Tennessee Pass, Lake Co.; Trail Glen; Chambers' Lake; New Windsor; mountains, Larimer Co.; Pike's Peak; Clear Creek; Middle Park; Steamboat Springs. 
5. Chrysopsis amplifolia Rydb. In the mountains of Colo.-Alt. 5000-7000 ft.-Ward; Longmont; Manitou.

6. Chrysopsis Bakeri Greene. (C. incana Greene; C. compacta Greene) On hills from Mont. and Ida. to N. M.-Alt. 4000-10,000 ft.-Columbine; Montrose; Jack's Cabin, Gunnison watershed; Box Cañon, west of Ouray; Redcliffe; Big Creek Gulch; Marshall Pass; Lone Pine Creek, Larimer Co.; Red Mountain road, south of Ouray; Sangre de Cristo; Deer River; Black Cañon; Cedar Edge; Rogers; near Pagosa Peak; Tennessee Pass, Lake Co.; Rist Cañon; Graymont.

7. Chrysopsis alpicola Rydb. On the higher peaks of Wyo. and Colo.Alt. II,000-I3,000 ft.-Clark's Peak; South Park; Gray's Peak; Graymount.

8. Chrysopsis pedunculata Greene. On hills in Colo.-Pagosa Springs.

9. Chrysopsis horrida Rydb. On hills from Neb. and Colo. to Tex.-Alt. about $5000 \mathrm{ft} .-\mathrm{New}$ Windsor.

1o. Chry sopsis arida A. Nels. On dry hills from Kans, and Mont. to N. M. and Ariz.-Alt. 5000-12,000 ft.-Twin Lakes; Mount Ouray; Boulder.

II. Chrysopsis floribunda Greene. In sandy soil in Colo.-Alt. 5000-7000 ft.-New Windsor; Black Cañon.

12. Chrysopsis pumila Greene. In cañons of Neb. and Colo.-Alt. Io,000 I I,000 ft.-Near Empire.

13. Chrysopsis resinolens A. Nels. In sandy soil of Wyo. and Colo.-Alt. 5000-6000 ft.-Chambers' Lake; Boulder.

Chrysopsis resinolens obtusata A. Nels. Alt. 8000-10,000 ft.-Mountains between Sunshine and Ward.

14. Chrysopsis viscida (A. Gray) Greene. (C. villosa viscida A. Gray) In the mountains from Colo. to Tex. and Ariz.-Manitou; Breckenridge; summit of North Park Range.

15. Chrysopsis hispida (Hook.) Nutt. (C. villosa hispida A. Gray) In sandy river valleys from Sask. and Alb. to N. M. and Ariz.-Black Cañon of the Gunnison.

\section{CHRYSOTHAMNUS Nutt. RABBIT-BRUsh.}

Bracts of the involucre acuminate.

Achenes glabrous.

Leaves oblanceolate or spatulate, puberulent; plant less than $2 \mathrm{dm}$. high.

Leaves narrowly linear, slightly tomentulose or glabrous.

Bracts thick, strongly carinate, glabrous. $\quad$ z. C. pulchellus.

Bracts thin, not strongly carinate, arachnoid-ciliate. 3. C. Bigelovii.

Achenes pubescent.

Bracts $4-6$ in each vertical row.

Bracts $2-3$ in each vertical row.

2. C. pulchellus.

Outer bracts long-acuminate, produced and more or less foliaceous. Leaves linear, more or less distinctly 3-nerved. 4. C. Parryi. Leaves very narrowly linear, r-nerved.

Leaves mostly erect; the upper reduced, not exceeding the heads. 5. C. Newberryi.

Leaves arcuate-spreading; the upper longer than the heads.

6. C. Howardi.

Outer bracts short, neither produced nor foliaceous.

Heads 5-8 mm. high; bracts thin, glabrous; leaves filiform. 
Leaves $2-3 \mathrm{~cm}$. long, over I $\mathrm{mm}$, wide, light green.

Leaves $\mathrm{I}-2 \mathrm{~cm}$. long, less than I mm. wide, dark green.

7. C. Greenei.

Heads about I cm. long; bracts thicker, arachnoid-ciliate.

8. C. Alifolius.

Leaves $\mathrm{I}-2 \mathrm{~cm}$. long; involucres lanate as well as arachnoid.

9. C. collinits.

Leaves 3-4 cm. long; involucres somewhat viscid, merely arachnoidciliate on the margin.

Bracts not acuminate.

Achenes pubescent; bracts acute or obtuse.

Branches at least when young more or less whitened with a pannose tomentum; style-appendages longer than the stigmatic portion; corolla 7-Io $\mathrm{mm}$. long.

Bracts and mature leaves perfectly glabrous.

Bracts ovate, or the outer triangular; involucre about half as long as the flowers.

I I. C. virens.

Bracts lanceolate to linear; involucre more than half as long as the flowers.

Lobes of the corollas lanceolate, mostly acute, in age spreading. Leaves nearly erect or strongly ascending, straight, $1-2 \mathrm{~mm}$. wide.

12. C. graveolens.

Leaves spreading or reflexed, more or less falcate, about I mm. wide. I3. C. patens.

Lobes of the corolla ovate, obtuse, about $0.5 \mathrm{~mm}$. long, erect in age. Leaves about $0.5 \mathrm{~mm}$. wide.

Leaves about $2 \mathrm{~mm}$. wide.
Bracts erose-ciliate on the margin, or tomentose, or both.

Leaves I mm. or less, spreading.

14. C. pinifolizs.

15. C. confinis.

Leaves $\mathrm{I}-2.5 \mathrm{~mm}$. wide.

Bracts narrow, linear-lanceolate, strongly carinate, almost glabrous, except the erose-ciliate margins.

16. C. plattensis.

$\begin{array}{ll}\text { except the erose-ciliate margins. } & \text { I } 7 \text {. C. pulcherrimus. }\end{array}$

as well as ciliate. $18 . C$. frigidus.

Branches green, without tomentum; style-appendages shorter than the stigmatic portion; corolla $5-7 \mathrm{~mm}$. long.

Leaves and stem glabrous or nearly so, except the hispidulous-ciliate margins of the former.

Leaves narrowly linear, $1-2 \mathrm{~mm}$. wide, strongly twisted.

19. C. elegans.

Leaves linear to lance-linear or oblanceolate, 2-8 mm. wide, not twisted.

Bracts linear, oblong, or lanceolate.

Bracts at least the outer ones with thick green tips.

20. C. linifolius.

Bracts comparatively thin, not green-tipped. 21. C. serrulatus.

Bracts ovate, oval or the inner broadly elliptic.

Leaves and stem decidedly puberulent.

Leaves 3-6 $\mathrm{mm}$. wide, rarely twisted.

Leaves $1-2.5 \mathrm{~mm}$. wide, usually twisted.

Achenes glabrous; bracts rounded at the apex.

22. C. latifolius.

23. C. lanceolatus.

24. C. puberulus.

25. C. Vaseyi.

r. Chrysothamnus depressus Nutt. (Bigelovia depressa A. Gray) Plains of Utah, Colo. and N. M.-Alt. 4000-8000 ft.-Gunnison; Squaw Creek, above Cimarron.

2. Chrysothamnus pulchellus (A. Gray) Greene. (Bigelovia pulchella A. Gray) On dry hills from Colo. and Utah to Tex. and N. M.; also in Mex. -Exact locality not given. 
3. Chrysothamnus Bigelovii (A. Gray) Greene. (Bigelovia Bigelovii A. Gray) On dry plains from Colo. and Utah to Tex. and N. M.-Alt. about 7000 ft.-Huerfano Co.; mesas, La Veta; Buena Vista.

4. Chrysothamnus Parryi (A. Gray) Greene. (Bigelovia Parryi A. Gray) On hills and in dry valleys from Wyo. to Colo.-Alt. 7500-10,000 ft.-Gray's Peak; Georgetown; South Park; near Empire; Lake City; southeast of Ouray; North Fork; Pitkin; mesa, Yampa ; Parlin; Cottonwood Lake; Twin Lakes; Steamboat Springs; Marshall Pass; Cerro Summit; Cumbres; Mt. Harvard; on Grizzly Creek; near Empire; Middle Park; Black Cañon of the Gunnison; Little Muddy, Gunnison Co.; Breckenridge; Hayden.

5. Chrysothamnus Newberryi Rydb. On dry hills of N. M. and Colo.Mesa Verde.

6. Chrysothamnus Howardi (Parry) Greene. (Bigelovia Howardii A. Gray) On dry hills from Neb. and Wyo. to Colo.-Middle Park; Greene, North Park; near Walden.

7. Chrysothamnus Greenei (A. Gray) Greene. (Bigelovia Greenei A. Gray; C. scoparius Rydb.) On plains of Colo.-Alt. 5000-7500 ft.-Huerfano Co.; La Veta; Hugo.

8. Chrysothamnus filifolius Rydb. On plains of Colo.-Antonito; Granite.

9. Chrysothamnus collinus Greene. On hills of Wyo, and Colo.-Westcliffe.

10. Chrysothamnus wyomingensis A. Nelson. On dry plains of Wyo. and Colo.-South Park at Jefferson.

II. Chrysothamnus virens Greene. Plains of southern Colo.-Pike's Peak; Cañon City.

I2. Chrysothamnus graveolens (Nutt.) Greene. (Bigelovia graveolens A. Gray) In cañons, on "bad-lands," and dry hills from Neb. and Mont. to N. M. and Utah.-Alt. $4000-8000$ ft.-New Windsor; Golden; Grand Junction; near Denver; Grizzly Creek; Cañon City; Idaho Springs; Egeria Park; Breckenridge; Ft. Collins; Boulder; Delta; Jefferson Co.

13. Chrysothamnus patens Rydb. On dry plains and hills in Colo.-Alt. 4600-7500 ft.-Grand Junction; Alamosa; Manitou; Iola.

14. Chrysothamnus pinifolius Greene. On dry hills and plains in Colo.Alt. 7000-13,000 ft.-Gunnison; Doyles; Mt. Abram.

I5. Chrysothamnus confinis Greene. On arid plains of Colo. and N. M.Alt. 4000-8000 ft.-Grizzly Creek; Huerfano Valley, near Gardner.

I6. Chrysothamnus plattensis Greene. On plains of Wyo, and Colo.-Alt. 4000-5000 ft.-Denver; New Windsor; near Hebron; Ft. Collins.

17. Chrysothamnus pulcherrimus A. Nels. On plains from Mont. to Colo. -North Park; Pagosa Springs; near Hebron; Grand River, near State Bridge; Trimble Springs; Poudre Cañon; forks of Poudre and Big South; Gypsum.

18. Chrysothamnus frigidus Greene. On plains from Ass. to Colo.-Alt. $8000 \mathrm{ft}$-Buena Vista.

I9. Chrysothamnus elegans Greene. On plains of Colo.-Alt. 7500-8500 ft.-Gunnison; Doyles; South Park.

20. Chrysothamnus linifolius Greene. On dry plains of Wyo. and Colo.Alt. 4000-5000 ft.-Deer Run; Grand Junction; Hotchkiss, Delta Co.; Olathe. 
2I. Chrysothamnus serrulatus (Torr.) Rydb. (Bigelovia Douglasii serrulata A. Gray; C. glaucus A. Nels.) On dry plains of Wyo. and Utah to Colo.-Alt. 5000-8000 ft.-Gypsum; road to Steamboat Springs; Cottonwood Lake; South Park, near Jefferson; North Park; headwaters of Clear Creek; Twin Lakes; Middle Park.

22. Chrysothamnus latifolius (D. C. Eaton) Rydb. (Bigelovia Douglasii latifolia A. Gray) On dry plains from Mont. and Wash. to Colo.

23. Chrysothamnus lanceolatus Nutt. (Bigelovia Douglasii lanceolata A. Gray) On dry plains and hills from Mont. and Wash. to Colo.-Alt. 70008500 ft.-Cottonwood Lake; Grizzly Creek; Black Cañon; Cerro Summit; North Park, near Walden; Hayden, Routt Co.

24. Chrysothamnus puberulus (D. C. Eaton) Greene. (Linosyris viscidiflora puberula D. C. Eaton) On dry plains and hills from Mont. and Wash. to Colo. and Utah.-Alt. 8000-9500 ft.--Pitkin; Parlin; South Park, southeast of Jefferson.

25. Chrysothamnus Vaseyi (A. Gray) Greene. (Bigelovia Vaseyi A. Gray) In the mountains of Wyo., Colo. and Utah.-Alt. about 7500 ft.-Middle Park; Greene, North Park; Gunnison; Squaw Hill, above Cimarron.

\section{Iо. ISOCOMA Nutt.}

Bracts acute, linear-lanceolate.

Bracts obtuse or obtusish, linear, oblong or oblanceolate.

1. I. pluriflora.

2. I. Wrightii.

I. Isocoma pluriflora (T. \& G.) Greene. (Bigelovia plurifiora A. Gray) On plains of Colo.- "On the Arkansas."

2. Isocoma Wrightii (A. Gray) Rydb. (Bigelovia Wrightii A. Gray) On banks and in saline soil from Colo. to Tex. and Ariz.-Alt. 4000-5000 ft.San Juan Valley (Brandegee).

\section{SIDERANTHUS Nutt.}

Leaves spinescently toothed, not pinnatifid.

Heads discoid; perennial with woody caudex. 1. S. grindelioides.

Heads radiate; annual.

Leaves pinnatifid at least the lower ones.

Stem more or less floccose or cinereous, especially when young.

Plant cinereous-pubescent, more or less glandular. 3 . S. australis.

Plant more or less floccose, not at all glandular. $\quad 4$. S. spinulosus.

Plant neither floccose nor cinereous.

Plant glabrous or slightly glandular-puberulent. $\quad$ 5. S. glaberrimus.

Plant decidedly pubescent.

Plant finely puberulent.

Plant hispid-strigose.

6. S. puberulus.

7. S. gracilis.

I. Sideranthus grindelioides (Nutt.) Britton. (Aplopappus Nuttallii T. \& G.) On dry plains and hills from Ass. and Nev. to Neb. and Ariz.-Alt. 4000-5500 ft.-Grand Junction; Rifle; Hotchkiss.

2. Sideranthus annuus Rydb. (Aplopappus rubiginosus A. Gray; not $\mathrm{T}$. \& G.) On sandy soil from Neb. and Colo. to Kans. and Tex.-Alt. 4000$5000 \mathrm{ft} .-P l a t t e$ Valley, Julesburg; New Windsor; Ft. Collins.

3. Sideranthus australis (Greene) Rydb. (Aplopappus australis Greene) On dry soil from Colo. to Tex. and N. M.; also in Mex.-Alt. about $4700 \mathrm{ft}$. -Deer Run. 
4. Sideranthus spinulosus (Pursh) Sweet. (Aplopappus spinulosus DC.) On dry plains and prairies from Minn., Sask. and Mont. to Tex. and Ariz.Alt. 400o-7000 ft.-Cheyenne Mountain; Denver; Arboles; Manitou; Ft. Collins; Cucharas Valley, near La Veta; Greeley; Cañon City; New Windsor; Spring Cañon; Hotchkiss; Boulder; roadside near Rocky Ford; Ft. Collins; Wray; Raton Range.

5. Sideranthus glaberrimus Rydb. On dry plains from S. D. and Wyo. to Ind. Terr. and Colo.-Table Rock.

6. Sideranthus puberulus Rydb. On dry hills in Colo.-Alt. up to $8000 \mathrm{ft}$. -Salida; Buena Vista.

7. Sideranthus gracilis (Nutt.) Rydb. (A. gracilis A. Gray) On dry hills from Colo. and Utah to Tex. and Ariz.; also in Mex.-Alt. about 6700 ft.-Durango; between Porter and Durango; Mancos.

\section{PYRROCOMA Nutt.}

Bracts except the innermost obtuse, obovate or oblong.

Bracts mostly acute or acuminate.

Heads large; disk $2 \mathrm{~cm}$. or more in diameter; bracts in about 3 series.

Upper part of stem and involucre decidediy villous; bracts wholly foliaceous. 2. P. Clementis.

Stem and involucre almost glabrous; bracts chartaceous at the base, with foliaceous tips.

Heads smaller; disk less than $2 \mathrm{~cm}$. in diameter.

Bracts in $2-3$ unequal series. Stem and bract more or less white-woolly. 4. P. lagopus. Stem and bracts glabrous or nearly so. $\quad$ 5. P. Vaseyi.

Bracts nearly of the same length. Plant villous.

Plant, except the upper parts, glabrate in age.

6. P. inuloides.

7. P. uniflora.

1. Pyrrocoma crocea (A. Gray) Greene. (Aplopappus croceus A. Gray) In the mountains from Wyo, to N. M. and Ariz.-Alt. 5000-8000 ft.-Doyle's; Cerro Summit; North Park; La Plata Cañon; Steamboat Springs; between Pallas and Sydney; Egeria Park; Little Muddy; Gunnison Co.; Walton Creek; Boulder; North Park, along the Michigan; Willow Creek, Routt Co.

2. Pyrrocoma Clementis Rydb. In the mountains of Wyo. and Colo.Tennessee Pass; Robinson; Mt. Harvard.

3. Pyrrocoma integrifolia (Porter) Greene. (Aplopappus integrifolius Porter) In the mountains from Sask. and B. C. to Colo.-Rabbit-Ear Range.

4. Pyrrocoma lagopus Rydb. On dry plains and alkali flats in Wyo. and Colo.-North Park.

5. Pyrrocoma Vaseyi (Parry) Rydb. (Aplopappus lanceolatus Vaseyi Parry) In the mountains from Wyo. to Colo, and Utah.-Alt. tp to 9000 ft.-Middle Park; Lake John, North Park; North Fork, Larimer Co.

6. Pyrrocoma inuloides (Hook.) Greene. (Aplopappus inuloides Nutt.) Plains from Mont. and Ida. to Colo.-North Park, near edge of Wyoming.

7. Pyrrocoma uniflora (Hook.) Greene. (Aplopappus uniflorus Nutt.) In river valleys from Sask. and Mont. to Colo. and Utah.

\section{OONOPSIS Greene.}

Dwarf; stem less than I dm. high; heads 6-1o dm. high. I. O. Engeimannii. Plant robust, I.I-3 dm. high; heads $15-20 \mathrm{~mm}$. high. 
Heads several.

Head solitary.

2. O. foliosa.

3. O. monocephala.

I. Oonopsis Engelmannii (A. Gray) Greene. (Bigelovia Engelmannii A. Gray) On dry plains from Kans. to Colo.- Hugo Station.

2. Oonopsis foliosa (A. Gray) Greene. (Aplopappus Fremontii A. Gray) On mountains of Colo.-Alt. 5000-7000 ft.-Pueblo; Fremont Co.; Cañon City; Florence; Rocky Ford.

3. Oonopsis monocephala A. Nelson. Only known from the type locality at Berwind, Colorado.

\section{I4. PRIONOPSIS Nutt.}

I. Prionopsis ciliata Nutt. (Aplopappus ciliatus DC.) On hillsides and banks from Mo. and Colo. to Tex.-Exact locality not given.

\section{I5. MACRONEMA Nutt.}

Outer bracts oblong, acute.

Outer bracts broadly oblong, obtuse.

I. $M$. discoideum.

2. M. obiusum.

1. Macronema discoideum Nutt. (Aplopappus Macronema A. Gray) On the mountains from Colo. and Utah to Calif.-Alt. up to 12,000 ft.-Georgetown; Marshall Pass; Mt. Harvard; Sangre de Cristo; Mt. Ouray.

2. Macronema obtusum Rydb. In the mountains of Colo.-Alt. about 8000 ft.-South Cottonwood Gulch, Chaffee Co.; Twin Lakes.

\section{Iб. STENOTUS Nutt.}

Bracts lanceolate, acute.

Bracts oval or oblong, very obtuse.

1. S. acaulis.

2. S. armerioides.

I. Stenotus acaulis Nutt. (Aplopappus acaulis A. Gray) On hills from Sask. and Wash. to Colo. and Calif.-Meeker, Rio Blanco Co.

2. Stenotus armerioides Nutt. On dry hills and "bad lands" from Man. and Ass. to N. M.-Alt. up to $7000 \mathrm{ft}$.-Cimarron.

\section{I7. OREOCHRYSUM Rydb.}

1. Oreochrysum Parryi (A. Gray) Rydb. (Aplopappus Parryi A. Gray; Solidago Parryi Greene) On mountains from Wyo. to N. M. and Ariz.Alt. 7000-12,000 ft.-Villa Grove; Silver Plume; southeast of Ouray; Cameron Pass; Ruby; Marshall Pass; Minnehaha; Buffalo Pass, Park Range; Cottonwood Lake; Grizzly Creek; Pagosa Peak; Devil's Causeway, White River Plateau; Berthoud Pass; Georgetown; Silverton; Mt. Harvard; mountains between Sunshine and Ward; Vance Junction; Bitter Creek; Gray's Peak; Lake City; Clear Creek.

\section{I8. TONESTUS A. Nelson.}

Bracts acute; plant viscid-puberulent.

s. T. Lyallii.

Bracts obtuse; plant soft-pubescent or glabrate, scarcely viscid. 2. T. pygmaeus.

I. Tonestus Lyallii (A. Gray) A. Nelson. (Aplopappus Lyallii A. Gray; Pyrrocoma Lyallii Rydb.) On high mountains from Mont. and Wash. to Colo.-Clear Creek. 
z. Tonestus pygmaeus (T. \& G.) A. Nels. (Aplopappus pygmaeus A. Gray; Macronema pygmaeum Greene) On mountains of Wyo. and Colo.Alt. I0,000-I3,000 ft.-Clear Creek; Gray's Peak; Little Kate Mine, La Plata Mountains; Mt. Princeton; Cameron Pass, Larimer Co.; Pike's Peak; Bald Mountain; Silver Plume; Mt. Garfield; near Pagosa Peak; Beaver Creek; Raton Range; Middle Park.

\section{I9. SOLIDAgO L. Golden RoD.}

Leaves glabrous or slightly pubescent along the veins and on the margins.

Leaves not triple-veined; branches of the inflorescence not recurved-spreading; heads not secund.

Bracts of the inflorescence lanceolate or linear-lanceolate, acute or acuminate. Leaves ciliate at the base.

Leaves not ciliate at the base.

I. VirgaureaE.

Bracts of the inflorescence oblong or linear-oblong, obtuse. Leaves, at least the basal ones, toothed; stem-leaves few; plants I-4 dm. high.

II. HuMiLes.

Leaves all entire; stem very leafy, 4-8 dm. high.

III. Speciosae,

Leaves triple-veined; heads more or less secund on recurved-spreading branches.

Plants slender, not very leafy, 2-4 dm. high; stem-leaves narrowly oblanceolate or linear.

IV. Glaberrimae.

Plant tall, leafy, 4-io dm. high; stem-leaves lanceolate. V. SERotinAE.

Leaves densely canescent.

Leaves lanceolate; bracts narrowly linear-lanceolate.

Leaves, at least the lower ones, oblanceolate or obovate.

VI. Serotinae.

VII. IncanaE.

\section{VIRGAUREAE.}

Plant low and slender, I-3 dm. high; inflorescence corymbiform; branches with a single or a few corymbose heads.

Heads 7-9 $\mathrm{mm}$. high; inner bracts linear-lanceolate, of about the same length as the flowers and pappus; plant 2-3 dm. high.

I. S. scopulorum.

Heads 5-7 mm. high; bracts lanceolate; the inner shorter than the flowers and the pappus; plant usually less than $2 \mathrm{dm}$. high. 2. S. ciliosa.

Plants stout, $3-4 \mathrm{dm}$. high; inflorescence paniculate; branches racemiform; heads 7-9 mm. high.

Basal leaves broadly oblanceolate, acute; stem pubescent.

3. S. rubra.

Basal leaves narrowly oblanceolate, obtuse; stem glabrous up to the inflorescence.

4. S. laevicaulis.

\section{Humiles.}

Plant low, I-I.5 dm. high; inflorescence with few heads, short, congested.

Plant taller, 2-4 dm. high; inflorescence with many heads, elongated.

5. S. decumbens.

Leaves not ciliate; bracts oblong; inflorescence usually narrow.

Leaves ciliate at the base; bracts linear; inflorescence open.

6. S, oreophila.

7. S. dilatata.

III. Speciosae.

One species.

8. S. pallida.

\section{Glaberrimae.}

Heads less than $5 \mathrm{~mm}$. high; stem slender.

Inflorescence decidedly viscid; leaves indistinctly triple-veined.

Inflorescence not viscid; leaves distinctly triple-veined.

9. S. viscidula. 
Inflorescence narrow, scarcely secund; bracts linear-lanceolate.

Io. S. nissouriensis.

Inflorescence ustrally open and more or less secund; bracts oblong-lanceolate.

Heads 6-7 mm. high; stem stout. II. S. glaberrima. I2. $S$. concinna.

V. Serotinae.

Leaves green, sparingly pubescent or glabrous; pubescence scabrous, mostly confined to the margins and the veins.

Stem usually glabrous up to the inflorescence; heads $5 \mathrm{~mm}$. high or more; leaves glabrous except on the margins and on the mid-veins.

Stem more or less pubescent.

I3. S. Pitcheri.

Heads $5 \mathrm{~mm}$. or more high; leaves pubescent; plant stout.

Heads about $4 \mathrm{~mm}$. high; plant comparatively slender.

Leaves pubescent at least on the veins. 15. S. canadensis.

Leaves glabrous, except the scabrous-ciliolate margins.

Leaves densely canescent, especially beneath.

Leaves usually broadly lanceolate, scabrous above. 17. S. scabriuscula.

Leaves linear-lanceolate, finely and rather softly canescent on both sides, more or less yellowish-gray.

18. S. gilvocanescens.

VII. InCANAE.

Plants low, 1-2 dm. high; inflorescence corymbiform; branches not secund.

19. S. nana.

Plants tall, 2-6 dm. high; inflorescence narrow, or if open with distinctly secund branches.

Bracts oblong of linear, obtuse; stem-leaves scarcely triple-veined; inflorescence usually narrow.

Stem-leaves oblanceolate.

Stem-leaves spatulate or elliptic.
Bracts lanceolate or ovate, acute; stem-leaves distinctly triple-veined; in-

20. S. pulcherrima. florescence usually more open.

Stem-leaves oblanceolate or elliptic; bracts lanceolate.

Stem-leaves obovate, thick; bracts ovate.

22. S. trinervata.

23. S. mollis.

I. Solidago scopulorum (A. Gray) A. Nels. (S. multiradiata scopulorum A. Gray) On hills and mountains from Alb. and B. C. to Colo. and Utah. -Alt. 8000-I0,000 ft.-Bard Creek, near Empire; Lake City; Grizzly Creek; White River Plateau; Robinson; Mt. Harvard; Big South; Gore Pass.

2. Solidago ciliosa Greene. In the higher mountains from Alb. to Colo. and Ariz.-Alt. up to 13,000 ft.-Ironton, San Juan Co. ; Seven Lakes; Gray's Peak.

3. Solidago rubra Rydb. In the mountains of Colo.-North Park; Grizzly Creek, Larimer Co.

4. Solidago laevicaulis Rydb. In the mountains of Colo. and Wyo.-Alt. up to II,000 ft.-North Park; Berthoud Pass.

5. Solidago decumbens Greene. (S. humilis nana A. Gray) On the higher mountains of Wyo. and Colo.-Alt. ro,000-13,000 ft.-Gray's Peak; near Empire; Mt. Harvard; Mt. Garfield; near Pagosa Peak; Bottomless Pit; Cameron Pass; Berthoud Pass.

6. Solidago oreophila Rydb. (S. humilis A. Gray, in part; S. humilis Pattersonii Gandoger) In the mountains from Mackenzie to Colo.-Alt. 7000I I,000 ft.-Clear Creek; near Empire; near Pagosa Peak; Minnehaha; Estes 
Park; Grizzly Creek; Villa Grove; Bear Creek Cañon; Crystal Park; Willow Creek; La Plata Cañon; Cripple Creek road; Marshall Pass; Cottonwood Lake; Chambers' Lake; Twin Lakes; South Park; Mount Baldy; Ruxton Dell; The Crags; Steamboat Springs; Baxter's ranch; Table Rock; between Sunshine and Ward; Palmer Lake; Beaver Creek; Bosworth's ranch; Stove Prairie.

7. Solidago dilatata A. Nels. In the mountains of Wyo. and Colo.-Alt. 8000-9500 ft.-Mountains between Sunshine and Ward.

8. Solidago pallida (Porter) Rydb. (S. spectabilis Coulter; not A. Gray; S. speciosa pallida Porter) On hills from N. D. to Neb. and Colo.-Alt. 5000-6500 ft.-Lower Boulder Cañon; Manitou; Bosworth's ranch, Stove Prairie; Bergen Park.

9. Solidago viscidula Rydb. In the mountains of Colo.-Grand Lake.

10. Solidago missouriensis Nutt. (S. Tolmieana A. Gray) On hills and mountains from Wyo. and Ida. to Colo.-Clear Creek; North Park; Middle Park.

II. Solidago glaberrima Martens. (S. Missouriensis A. Gray; not Nutt.) On plains and hills from Mich., Alb. and Ida. to Mo., Tex. and Ariz.-Alt. 4000-9000 ft.-Pike's Peak; New Windsor; Cheyenne Mountain; Durango; near Empire; Mt. Harvard; Boulder; Ft. Collins; Long Gulch; Horsetooth Mountain; Georgetown; falls of Poudre River; Stove Prairie Hill.

12. Solidago concinna A. Nels. (S. Missouriensis extraria A. Gray) In the mountains from Alb. and B. C. to Colo.-Alt. 5000-900o ft.-Pike's Peak; Ft. Collins; New Windsor; Gunnison; Iola; North Park; Minnehaha; Crystal Park; Ruxton Park; Durango; Dillon; Englemann Cañon; Breckenridge; Soldier Cañon.

I3. Soliđago Pitcheri Nutt. (S. serotina A. Gray, in part) Along streams from Minn. and Wash, to Ark. and Colo.-Alt. 4000-6000 ft.-New Windsor; Lower Boulder Cañon; La Porte, Larimer Co.; North Cheyenne Cañon; Colorado Springs; Williams' Cañon; Ft. Collins; Soldiers' Cañon; Pleasant Valley; Poudre Flats; La Porte; Denver.

I4. Solidago polyphylla Rydb. (S. Canadensis procera A. Gray, in part) Along streams from B. C. to N. M. and Wash.-Alt. about $7000-8000 \mathrm{ft}$. Englemann Cañon; Gunnison; Cañon City.

I5. Solidago canadensis L. Among bushes from Lab. and Mackenzie to Colo.-Alt. 4000-8000 ft.-Gypsum, Eagle Co.; Parlin; Dillon; Denver; Chester; Twin Lakes; Gunnison; Gunnison Co.; North Park; Gypsum Creek Cañon; Elk River; Ft. Collins.

16. Solidago serra Rydb. Along streams, Wyo. and Colo--Yampa.

17. Solidago scabriuscula (Porter) Rydb. ( $S$. Canadensis scabriuscula Porter; var. scabra T. \& G., in part) In dry soil from N. D. and Wyo. to Mo. and Tex.-Alt. $5000 \mathrm{ft} .-F$ t. Collins.

18. Solidago gilvocanescens Rydb. (S. Canadensis gilvocanescens Rydb.) In sandy soil from Minn. and N. D. to Neb. and Colo.-Alt. $4000-5000 \mathrm{ft}$. Ft. Collins; Redstone.

19. Solidago nana Nutt. On high, dry plains from Mont. to Colo. and Ariz. Alt. up to $9000 \mathrm{ft}$.-Pagosa Springs; source of Leroux Creek.

20. Solidago pulcherrima A. Nels. ( $S$. nemoralis A. Gray, in part; not Ait.) Dry plains from Minn. and N. D. to Colo, and Ariz.-Alt. 6000-I0,000 
ft.-Pike's Peak; Bosworth's ranch, Stove Prairie; mountains between Sunshine and Ward; Soldier Cañon.

A variety with linear bracts was collected in Sheep Cañon.

2r. Solidago radulina Rydb. In the mountains of Utah and Colo.-Alt. 6000-8000 ft.-Meadow Park; Gunnison Co.

22. Solidago trinervata Greene. On dry plains and hills from S. D. and Wyo. to Colo. and Ariz.-Alt. 7000-9500 ft.-Lower Boulder Cañon; Idaho Springs; east of Laramie River; New Windsor; along Bear River, below Steamboat Springs; Durango; near Mancos; Iola; southeast of Ouray; Wolcott; west of Ouray; between Porter and Durango; Elk Cañon; Ft. Collins; Poudre River; Black Cañon of the Gunnison.

23. Solidago mollis Bartl. (S. nemoralis incana A. Gray) On plains from N. D. and Mont. to Colo. and Tex.-Alt. 7000-8000 ft.-Ft. Collins; New Windsor; Cucharas Valley, near La Veta.

\section{PETRADORIA Greene.}

1. Petradoria pumila (T. \& G.) Greene. (Solidago pumila T. \& G.) On high mountains from Wyo. and Nev. to Tex. and Ariz.-Alt. 5000-8000 ft.Durango; Grand Junction; Cerro Summit.

\section{EUTHAMrA Nutt.}

1. Euthamia occidentalis Nutt. (Solidago occidentalis Nutt.) In moist ground from Mont. and Wash. to N. M. and Colo.-Alt. 4000-5000 ft.Hotchkiss, Delta Co.; Sterling; Deer Run; Olathe, Delta Co.; Hotchkiss; Delta.

\section{OLIGONEURON Small.}

I. Oligoneuron canescens Rydb. (Solidago rigida humilis Porter) On prairies and river valleys from Sask. and Mont. to Neb. and Colo.-Pagosa Springs; Hayden.

\section{TOWNSENDIA Hook.}

Bracts acuminate.

Stems low with spreading basal branches, which surpass it in length.

Stems erect or nearly so, wholly simple below.
Involucre about $1.5 \mathrm{~cm}$. broad, naked.

Involucre about $2-3 \mathrm{~cm}$. broad, generally subtended by leaves.

I. T. grandiflora.

Bracts acute or obtuse.

3. T. Vreelandii.

Stems evident, leafy.

Stems $5-20 \mathrm{~cm}$. high; annuals and biennials.

Bracts of the involucre 3-ranked; pubescence of the stem appressed; leaves linear. $\quad$ 4. T. Fendleri.

Bracts 2-ranked; pubescence of the stem not strictly appressed; earlier leaves spatulate.

5. T. strigosa.

Stem usually evident, but short, I-5 $\mathrm{cm}$. long; perennials.

Leaves more or less cinereous.

Pappus of the rays consisting of bristles $1 / 3-1 / 2$ as long as those of the $\begin{array}{ll}\text { disk-flowers. } & \text { 6. T. incana. }\end{array}$

Pappus of the rays reduced to a crown of short squamellae.
Leaves glabrous or nearly so.
7. T. glabella.

5. T. strigosa. 
Plant acaulescent; heads sessile among the rosulate leaves.

Plant glabrate, cinereous only when young; leaves oblanceolate or spatulate. Bracts broadly lanceolate, tinged with red.

Bracts obtuse; ray-flowers with a very short pappus.

8. T. Rothrockii.

Bracts acute; pappus of disk-and ray-flowers alike. 9. T. Wilcoxiana. Bracts narrowly lanceolate, mostly green. Io. T. intermedia.

Plant permanently cinerous; leaves linear or linear-oblanceolate.

II. T. exscapa.

1. Townsendia grandiflora Nutt. On plains and hills from S. D. and Wyo. to Ind. Terr. and Colo.-Alt. 4000-1 I,000 ft.-Morrison; Manitou; South Table Mountain; Ft. Collins; Larimer Co.; Red Rock Cañon; Garden of the Gods; Spring Cañon; Boulder; Horsetooth Gulch; Pennock's mountain ranch; Soldier Cañon.

2. Townsendia eximia A. Gray. On mountain sides from Colo. to Tex. and Ariz.- "Colorado."

3. Townsendia Vreelandii Rydb. In mountain sides and in valleys of southern Colo.-Alt. 8000-I0,000 ft.-Veta Pass; Veta Mountain; West Spanish Peak.

4. Townsendia Fendleri A. Gray. Gravelly hills in N. M. and Colo.Roubadeaux Pass; Salida; Arkansas River, near Poncha Pass.

5. Townsendia strigosa Nutt. On gravelly hills from Wyo. to N. M. and Ariz.-Alt. 7000-10,000 ft.-Silver Plume; Mancos; Hotchkiss.

6. Townsendia incana Nutt. Mountains and hills from Wyo. and Utah to N. M. and Ariz.-Alt. 4000-5000 ft.-Grand Junction; Rifle; Palisades.

7. Townsendia glabella A. Gray. ( $T$. Bakeri Greene) On dry hillsides of Colo.-Alt. about $8500 \mathrm{ft}$.-La Pagosa; Dix; Los Pinos (Bayfield).

8. Townsendia Rothrockii A. Gray. On mountains of southern Colo.Alt. up to I3,000 ft.-South Park.

9. Townsendia Wilcoxiana Wood. On dry plains and hills from Ind. Terr. to Colo.-San Louis Range.

ro. Townsendia intermedia Rydb. On dry plains and hills from Neb. and Wyo. to Kans. and Ariz.-Alt. about 5000 ft.-Lake City; Ft. Collins; South Park; Colorado City.

II. Townsendia exscapa (Richardson) Porter. ( $T$. sericea Hook.) On dry plains from Sask, and Mont. to Tex. and N. M.-Alt. $4000-8000 \mathrm{ft}$ Uncompahgre Mountains, near Los Pinos; Denver; New Windsor; Central City; butte five miles southwest of La Veta; mesas near Colorado Springs; La Veta; Ft. Collins; Los Pinos (Bayfield); plains near Denver; Dixon Cañon; hills near Arthur's Rock; Horsetooth Gulch.

\section{BRACHYACTIS Ledeb.}

Bracts oblong or oblong-linear, obtuse.

Bracts narrowly linear, acute.

I. B. frondosa.

2. B. angusta.

I. Brachyactis frondosa (Nutt.) A. Gray. (Aster frondosus T. \& G.) Along streams and pools from Wyo. and Ida. to Colo. and Calif.-Hotchkiss, Delta Co.

2. Brachyactis angusta (T. \& G.) Britton. (Aster angustus T. \& G.) In wet saline soil from Ills., Sask. and Alb. to Mo., Colo. and Utah.-Blue River, above Kremmling; New Windsor; Hotchkiss. 
25. XYLORRHIZA Nutt.

Leaves not spinulose-toothed.

Leaves spatulate, cuspidate.

1. X. venusta.

Leaves linear-oblanceolate, acute.

2. $X$. villosa.

Leaves spinulose-toothed.

Ligules 8-10 $\mathrm{mm}$. long.

Ligules I 5-20 $\mathrm{mm}$. long.

3. X. coloradensis.

4. X. Brandegei.

x. Xylorrhiza venusta (Jones) Heller. (Aster venustus Jones) In dry places in Colo. and Utah.-Alt. about $7000 \mathrm{ft}$.-Cimarron; Hotchkiss.

2. Xylorrhiza villosa Nutt. (Aster Xylorrhiza T. \& G.) In rocky places and clayey soil in Wyo. and Colo.-North of Craig, Routt Co.

3. Xylorrhiza coloradensis (A. Gray) Rydb. (Aster coloradensis A. Gray) In the higher mountains of Colo.-South Park.

4. Xylorrhiza Brandegei Rydb. On high peaks in southern Colo.-Alt. 12,000 ft.-San Juan Pass.

26. UNAMIA Greene.

I. Unamia ptarmicoides (Nees) Greene. (Aster ptarmicoides T. \& G.) On rocky banks and bluffs from Mass. and Sask. to N. Y. and Colo.-Alt. 4000-7000 ft.-Cañon on east side of Cheyenne Mountain; Horsetooth Mountains; Soldier Cañon; Table Rock.

\section{EUCEPHALUS Nutt.}

Bracts all thin and acute, villous-ciliate on the margins; style-appendages subulate. I. E. Engelmannii.

Bracts firmer, merely ciliolate; the outer obtuse; style-appendages obtuse.
Inner bracts acute.
2. E. glaucus.
All bracts obtuse or mucronate.
3. E. formosus.

1. Eucephalus Engelmannii (A. Gray) Greene. (Aster Engelmannii A. Gray) In the mountains from Mont. and B. C. to Colo. and Wash.-Alt. 6000-I0,000 ft.--Sierra Madre; Steamboat Springs; Crested Butte; Four-mile Hill, Routt Co.; between Pallas and Sydney; MacIntyre Creek, Larimer Co.; Ruby; Fish Creek Falls; summit of North Park Range, Routt Co.

2. Eucephalus glaucus Nutt. (Aster glancus T. \& G.) In the mountains of Wyo., Colo. and Utah.-Alt. 7000-I0,000 ft.-Headwaters of Clear Creek; Gray's Peak; Bosworth's ranch; Black Cañon; Durango; chaparral-covered hills southeast of Ouray; about Ouray; Grand Lake; Home; Pagosa Springs; mountains between Sunshine and Ward; Roaring Fork, Larimer Co.

3. Eucephalus formosus Greene. In the mountains of Colo-Alt. about $9500 \mathrm{ft}$.-Near Pagosa Peak.

\section{ASTER L.}

Involucres and peduncles glandular.

Bracts narrowly linear, almost equal in length. I. CAMPESTRES.

Bracts thick, oblanceolate, well imbricated.

II. OBLONGIFOLII.

Involucres and peduncles not glandular.

Outer bracts neither foliaceous nor equalling or surpassing the inner.

Bracts more or less pubescent on the back.

Bracts not bristle-pointed.

Heads solitary; plant less than $3 \mathrm{dm}$. high; leaves oblanceolate or the upper linear.

III. Alpini.

Heads corymbose or paniculate. 
Plants less than I $\mathrm{dm}$. high, glabrous up to the villous inflorescence. IV. ANDINI.

Plants z-6 dm. high; pubescence of the stem and leaves hirsute or strigose, ustrally scant.

Bracts bristle-pointed.

V. Grisei.

VI. Multiflori.

Bracts glabrous, except the ciliate margins.

Bracts linear, oblong or lanceolate, all acute or acutish.

Lower leaves long-petioled; blades cordate or ovate (rarely broadly

lanceolate), usually more or less serrate.

VII. Sagitififolit.

Lower leaves oblanceolate, linear, or lanceolate.

Plants perfectly glabrous throughout.

Bracts whitish-coriaceous below and with a distinctly rhombic green tip above; upper leaves auriculate-clasping.

VIII. LAEVES.

Bracts linear-subulate, green throughout; leaves narrowly linear, not clasping.

IX. PORTERIANi.

Upper part of the stem and peduncles with at least pubescent lines.

Heads usually numerous in a leafy panicle or compound corymb. Stem only with pubescent lines.

Bracts narrowly oblanceolate with rhombic tips; leaves thickish, the lower often triple-nerved.

X. Subracemosi.

Bracts linear to subulate with narrow linear-oblanceolate green backs or the outer wholly green; leaves thin, never triplenerved.

XI. SaLICIFOLII.

Stem at least above pubescent on all sides. XII. LONCHOPHYLLI.

Heads few in a naked small corymb.

Bracts oblanceolate, the outer obtuse.
for bracts foliaceous, equalling or surpa

XIII. Occidentales.

XIV. AdSCEndentes.

Outer bracts foliaceous, equalling or surpassing the inner.

Heads rather numerous in an open leafy panicle. XV. FulCRATI.

Heads few, in a usually simple, racemose or corymbose inflorescence with nearly erect branches.

XVI. FoliaceI.

\section{Campestres.}

Leaves oblong to linear-lanceolate.

Leaves linear.

\section{ObLONGIFOLII.}

1. A. Novae-Angliae.

z. A. campestris.

Leaves oblong or lanceolate.

Leaves scabrous-hirsutulous, mostly spreading or reflexed.

Leaves glabrous, except the bristly-ciliate margins, ascending.

3. A. Kumleinii.

Leaves linear or the lower ones oblanceolate.

4. A. Fendleri.

5. A. pasciflorus.

III. Alpini.

One species.

6. A. alpinus.

IV. ANDINI.

One species.

\section{Grisei.}

7. A. andinus.

Leaves rather copiously and permanently appressed-hirsutulous.

Plant 3-4 dm. high; stem retrorse-hirsute below. 8. A. griseus.

Plant I-1.5 dm. high; hairs of the stem not retrorse. 9. A. griseolis.

Leaves sparingly strigose and glabrate in age, or perfectly glabrous, except the hispidulous-ciliate margins.

Bracts with green tips and mid-veins.

Stem stout; leaves oblanceolate.

Stem slender; leaves narrowiy linear-oblanceolate or linear.

Leaves firm; bracts with thick tips.

Leaves and bracts thin.

Outer bracts green almost throughout.

Iо. A. Underzuoodii.

I I. A. vallicola.

I2. A. Nelsonii.

I3. A. violacers. 


\section{Multiflori.}

Pubescence of the stem spreading or reflexed.

Heads less than $5 \mathrm{~mm}$. high.

I4. A. exiguus.

Heads $6-8 \mathrm{~mm}$. high.

I 5. A. crassulus.

Pubescence of the stem appressed or ascending.

Bracts very unequal in length, well imbricated, the outer much shorter.

Bracts narrowly oblanceolate, acutish, especially the inner.

Bracts broadly oblanceolate or the outer spatulate, very obtuse.

I6. A. multiflorus.

I7. A. polycephalus.

Bracts almost equal in length or the outer sometimes longer; heads few or solitary at the ends of the branches.

Bracts thick, very squarrose; leaves thick, densely strigose.

18. A. commutatus.

Bracts thin, not squarrose; leaves sparingly strigose, in age often glabrate. I9. A. falcatus.

\section{Sagittifolit.}

One species.

20. A. Lindleyanus.

VIII. Laeves.

Green tips of the bracts broadly rhombic; leaves of the branches much reduced. 21. A. laevis.

Green tips of the bracts narrowly rhombic or rhombic-oblanceolate; leaves of the branches gradually but not conspicuously reduced. 22. A. Geyeri.

iX. Porteriani.

One species.

23. A. Porteri.

\section{Subracemosi.}

Inflorescence falsely racemose; leaves linear to oblanceolate.

24. A. subracemosus.

XI. Salicifolit.

Inflorescence elongated, not flat-topped.

Heads numerous in a much branched panicle; bracts not with white mid-ribs. Leaves distinctly toothed.

Disk of the head about I $\mathrm{cm}$. high and broad; leaves thickish.

$\begin{array}{ll}\text { Disk 6-8 } \mathrm{mm} \text {. high and broad; leaves thin. } & \text { 25. A. salicifolius. }\end{array}$

Leaves entire, rarely denticulate.

All bracts narrowly linear; branches ascending; rays purplish.

Bracts almost linear-filiform, more or less squarrous.

Bracts linear, erect.

27. A. hesperizts.

28. A. coerulescens.

Outer bracts broader than the inner, oblanceolate; branches more divergent.

Rays usually white.

Rays purple.

Heads fewer; bracts with white mid-ribs.

29. A. Osterhoutii.

30. A. fuviatilis.

3I. A. laetevirens.

Inflorescence more or less flat-topped.

Leaves lanceolate to linear-lanceolate, firm; heads numerous.

Leaves narrowly linear, thin; heads few.

32. A. corymbiformis. 33. A. longulus.

\section{LONCHOPHYLII.}

One species.

XIII. Occidental.es.

One species.

34. A. lonchophyllus.

35. A. Fremontii. 


\section{Adscendentes.}

Heads few in a simple corymb, less than I $\mathrm{cm}$. high; upper leaves much reduced; stem 2-3 dm. high, slender.

Heads many in a leafy panicle.

Heads about I cm. high; stem-leaves thick, lanceolate or oblanceolate. 37. A. Treedyi.

Heads less than I cm. high; stem-leaves linear or narrowly linear-oblanceolate.

Lower leaves oblanceolate; bracts glabrous, except the ciliate margins; plant $\mathrm{I}-3 \mathrm{dm}$. high.

Lower leaves narrowly linear-oblanceolate.

Plant low, 2-3 dm. high, with a ligneous caudex; bracts usually hairy on the back.

II. A. vallicola.

Plant $3^{-6} \mathrm{dm}$. high, from a more or less branched rootstock.

Bracts more or less hairy on the back.

Bracts glabrous except the ciliate margins.

12. A. Nelsonii.

39. A, Nuttallii.

XV. Fulcrati.

Outer bracts much exceeding the disk; some twice as long.

Outer bracts seldom exceeding the disk.

40. A. fulcratus.

4I. A. Eatonii.

XVI. Foliosi.

Plant tall, 4-8 dm. high.

Bracts mainly linear or linear-lanceolate.

Outer bracts broadly lanceolate or oblanceolate.

Outer bracts mostly acute.

Outer bracts mostly obtuse.

Plant low, 1-2 dm. high.

42. A. frondeus.

43. A. Canbyi.

44. A. Burkei.

45. A. apricus.

1. Aster Novae-Angliae L. Low ground from Canada to S. C., Colo. and Sask.-Cañon City.

2. Aster campestris Nutt. In valleys from Mont. and Wash. to Colo, and Ore.-Alt. up to $9000 \mathrm{ft}$.-Breckenridge; Dillon; Manitou; Laramie River, Larimer Co.

3. Aster Kumleinii Fries. (A. oblongifolius rigidulus A. Gray) On dry plains and prairies from Minn. to S. D.-Alt. 4000-7000 ft.-Near Bent's Fort; Cucharas Valley, near La Veta.

4. Aster Fendleri A. Gray. On plains and sandhills from Kans. and Colo. to N. M.-Alt. up to $7000 \mathrm{ft}$.-Arkansas River, above Cañon City.

5. Aster pauciflorus Nutt. Wet saline soil from Sask. to S. D., N. M. and A riz.-Warm soda springs in Animas Valley.

6. Aster alpinus L. In arctic and alpine places from Mackenzie and Alaska to Colo.-Alt. 12,000 ft.-Berthoud Pass.

7. Aster andinus Nutt. On alpine peaks from Mont, to Colo.--Gray's Peak; Mt. Harvard.

8. Aster griseus Greene. In the mountains of Colo.-Alt. about $8000 \mathrm{ft}$.Doyles.

9. Aster griseolus Rydb. On the higher mountains of Colo--Mt. Harvard; Twin Lakes; Breckenridge.

ro. Aster Underwoodii Rydb. On high mountains of Colo. and Wyo.Alt. 8000-I0,000 ft.-Ironton Park, nine miles south of Ouray; Eldora and Baltimore.

II. Aster vallicola Greene. In the mountains from Wyo. and Nev. to Colo. -Alt. 7000-8500 ft.-Alamosa; Sargent; Pagosa Springs; southeast of Ouray.

I2. Aster Nelsonii Greene. In the mountains of Colo. and Wyo.-Alt. 7000$8000 \mathrm{ft}$--Iola; Buena Vista. 
13. Aster violaceus Greene. In the mountains of Colo.-Mt. Harvard.

14. Aster exiguus (Fern.) Rydb. (A. ciliatus Muhl.) On prairies and plains from Vt. and Wash. to $\mathrm{Pa}$. and Ariz.; also in Mex.-Ft. Collins; Olathe; Gypsum; Sunset Cañon.

15. Aster crassulus Rydb. On plains from N. D. and Ida. to Colo. and Calif. (?)-Alt. 4000-8000 ft.-Near Denver, Platte River; La Veta; Gunnison; Parlin, Gunnison Co.; Seldon; along Bear River, below Steamboat Springs; Pagosa Springs; Gypsum; Ft. Collins; Hotchkiss.

16. Aster multiflorus Ait. On prairies and sterile ground from $\mathrm{Me}$. and Mont. to Ga. and Mex.-Alt. 4000-5000 ft.-Near Bent's Fort; Ft. Collins.

17. Aster polycephalus Rydb. (A. scoparius D. C.; not Nees) On plains and hills from Alb. and Neb. to Tex. and Ariz.-Alt. 4000-7000 ft.-Colorado Springs; McCoy; Twin Lakes; Ft. Collins; Trail Glen; Westcliffe; Salida; Olathe; Poudre River; Baxter's ranch; Poudre Cañon.

18. Aster commutatus A. Gray. On plains and river banks from Minn. to Wyo., to Kans. and Nev.-Alt. 4000-7000 ft.-Colorado Springs; Gunnison; Westcliffe.

I9. Aster falcatus Lindl. In valleys from Mackenzie and Alaska to Colo. -Alt. about 8000 ft.-Doyles; Gunnison Co.; near Colorado City.

2o. Aster Lindleyanus T. \& G. In valleys from Lab. and B. C. to N. H. and Colo.-Poudre near La Porte.

21. Aster laevis L. In open woodlands from Ont. and Sask. to La. and N. M.-Westcliffe; Tobe Miller's ranch; Poudre River; Ft. Collins; Ruxton Dell.

22. Aster Geyeri (A. Gray) Howell. (A. laevis Geyeri A. Gray) Valleys from Alb. and Wash. to Colo--Alt. 6000-800o ft.-Cheyenne Mountain; North Cheyenne Cañon; Parlin, Gunnison Co.; mountains, Larimer Co.; near Pagosa Peak; Engelmann Cañon; Box Cañon, west of Ouray; Ft. Collins; Redstone; Poudre River; Bosworth's ranch; Palmer Lake.

23. Aster Porteri A. Gray. In the mountains of Colo.-Alt. 5000-I0,000 ft. -Golden; Lower Boulder Cañon; Minnehaha; Idaho Springs; North Cheyenne Cañon; Ft. Collins; Boswarth's ranch; Cheyenne Mountain; between Sunshine and Ward; cañon west of Palmer Lake.

24. Aster subracemosus Rydb. In valleys from Mont. and Colo.-Alt. 7500$8500 \mathrm{ft}$.-Southeast of Ouray; North Park.

25. Aster salicifolius Lam. On wooded banks from Me. and Ass. to Fla., Tex. and Colo.-New Windsor; North Park; Ft. Collins.

26. Aster paniculatus Lam. On wooded banks from N. B. and N. D. to Va., Kans. and Colo.-Gypsum.

27. Aster hesperius A. Gray. Along streams from Colo. to N. M. and Calif. -New Windsor.

28. Aster coerulescens DC. ( $A$. salicifolius coerulescens A. Gray) On rocky banks from Wyo. to Tex. and Colo.-New Windsor; Ft. Collins; Olathe, Montrose Co.; Gypsum; Pondre River; Home.

29. Aster Osterhoutii Rydb. Along ditches in northern Colo.-New Windsor.

30. Aster fluviatilis Osterhout. Along streams in Colo.-New Windsor.

31. Aster laetevirens Greene. Along streams in Colo. and Wyo.-Home; Dale Creek, Larimer Co. 
32. Aster corymbiformis Rydb. In meadows in Colo.-Alt. 5000-8000 ft.Parlin, Gunnison Co.; Ft. Collins; Westcliffe; Denver.

33. Aster longulus Sheldon. In wet meadows from Minn. and Alb. to Neb. and Colo.-Twin Lakes; Westcliffe.

34. Aster lonchophyllus Greene. In the mountains of Colo.-Alt. 8000I0,000 ft.-Crested Butte; Gore Pass.

35. Aster Fremontii A. Gray. In valleys from Mont. to Colo--Alt. 9000I2,000 ft.-Cameron Pass; Breckenridge; Michigan; Trappers' Lake; Ironton Park, nine miles south of Ouray; Sherwood's; Laramie River; Robinson; Twin Lakes; Marshall Pass; Ruxton Park; Lake City.

36. Aster armeriaefolius Greene. In the mountains of Wyo. and Colo.Alt. 8000-10,000 ft.-Doyles; Marshall Pass; Laramie River, Larimer Co.; Grizzly Creek; Bosworth's ranch, Stove Prairie.

37. Aster Tweedyi Rydb. In valleys of Wyo. and Colo.-Alt, about 5000 ft.-Near Laramie River, Larimer Co.

38. Aster adscendens Lindl. In valleys from Ass. to Colo. and Nev,-Alt. 8000-I0,000 ft.-Near Empire; mountains between Sunshine and Ward; Ft. Collins; Grizzly Creek.

39. Aster Nuttallii T. \& G. (A. orthophyllus Greene) In the mountains from Wyo. to Colo. and Calif.-Alt. 5000-8000 ft.-Gunnison; Ft. Collins; Cerro Summit; Montrose.

40. Aster fulcratus Greene. In valleys of Colo.-Alt. about $9000 \mathrm{ft}$.-Near Pagosa Peak.

41. Aster Eatonii (A. Gray) Howell. (A. foliaceus Eatonii A. Gray; Brachyactis hybrida Greene) In the mountains from Mont. and B. C. to Colo. and Calif.-Alt. about 5000-8000 ft.-Poudre River; Gunnison; Upper Arkansas; Cheyenne Cañon.

42. Aster frondeus (A. Gray) Greene. (A. foliaceus frondeus A. Gray; Aster glastifolius Greene) In the mountains from Ida. and B. C. to Colo. and Nev.-Alt. 8000-10,000 ft.-Empire; near Laramie River, Larimer Co.; Ruxton Dell; near Pagosa Peak; Mt. Harvard.

43. Aster Canbyi Vasey. In the mountains of Colo.-Alt. 8000-II,000 ft.Crested Butte; McCoy; near Grand Lake; Mt. Harvard; mountains between Laramie River and North Park; Gypsum; Berthoud Pass; cañon west of Palmer Lake.

44. Aster Burkei (A. Gray) Howell. (A. foliaceus Burkei A. Gray) In the mountains from Wyo. and Wash. to Colo. and Ariz.-Robinson; Steamboat Springs; Hotchkiss.

45. Aster apricus (A. Gray) Rydb. (A. foliaceus apricus A. Gray) On alpine peaks from Mont. and B. C. to Colo. and Ore.-Alt. 8000-12,000 ft.Gray's Peak; Twin Lakes; Westcliffe; Boreas; Buffalo Pass; Empire; Berthoud Pass; Grizzly Creek.

\section{MACHAERANTHERA Nees.}

Leaves twice pinnatifid; root annual; achenes terete.

I. M. tanacetifolia.

Leaves spinulose-toothed; plant perennial or biennal; achenes compressed.

Bracts linear-subulate; green tips of most of them longer than the strawcolored lower portion, squarrose-reflexed.

Stem and inflorescence distinctly viscid. 
Stem-leaves lanceolate or oblong, usually distinctly triple-veined.

Leaves thin, coarsely but not saliently toothed; bracts over I mm. wide. 2. M. Bigeloriti.

Leaves thick with salient teeth; plant very glandular; bracts less than I $\mathrm{mm}$. wide.

Achenes glabrous or minutely pubescent; stem glabrous below.

Achenes strigose; stem glandular hispid throughout.

$$
\text { 3. M. varians. }
$$

Stem-leaves linear or oblanceolate, $\mathrm{s}$-veined.

$$
\text { 4. M. aspera. }
$$

Plant $2-5 \mathrm{dm}$. high; heads numerous or several in a panicle or raceme. Basal leaves spatulate, coarsely but not saliently toothed or entire; inflorescence divaricate.

5. $M$. viscosa.

Basal leaves narrowly oblanceolate, saliently toothed; inflorescence narrow; plant about $2 \mathrm{dm}$. high. 6 . M. viscostla.

Plant $\mathrm{I}-2$ (seldom 3) $\mathrm{dm}$. high; heads solitary or few; basal leaves broadly spatulate, toothed.

Stem strigose-puberulent; involucre slightly if at all viscid. 7. M. Pattersonit.

8. $M$. rubricaulis.

Bracts linear with lanceolate or rhombic green tips, which are usually much shorter than the straw-colored lower portion.

Leaves cinereous.

Bracts canescent, scarcely at all viscid or glandular.

Bracts densely viscid or glandular, especially the tips.

9. M. canescens.

ı. M. pulverulenta.

Leaves glabrous, or glandular-hispid or scabrous, not cinereous.

Stem puberulent or glabrate, glandular only on the inflorescence.

Bracts slightly if at all squarrose.

Stem slender with strongly ascending branches; leaves subentire. I I. $M$. glabrella.

Stem divaricately branched; lower leaves sharply toothed.

Bracts strongly reflexed-squarrose.

12. M. ramosa.

Leaves all, except those of the smaller branches, toothed.

Leaves all entire.

13. M. Selbyi.

14. M. spectabilis.

Stem densely glandular-hispid.

Bracts more or less glandular-pubescent and with squarrose tips.

Bracts grayish puberulent; tips not squarrose.

15. M. cichoriacea.

16. M. Fremontii.

1. Machaeranthera tanacetifolia ( $\mathrm{H}$. B. K.) Nees. (Aster tanacetifolius H. B. K.) In moist sandy soil from S. D. and Mont, to Tex, and Ariz.Denver; Wyoming line; foothills, west of Ft. Collins; New Windsor; Pueblo; Rocky Ford; Spring Cañon.

z. Machaeranthera Bigelovii (A. Gray) Greene. (Aster Bigelovii A. Gray) On plains and foot-hills of Colo. and N. Mex.-Alt. $5000-6000$ ft.-Boulder.

3. Machaeranthera varians Greene. On plains and mountains of Colo. and N. M.-Alt. 6000-8000 ft.-Hinsdale Co.; Colorado Springs; near Pagosa Peak; Bottomless Pit, Pike's Peak.

4. Machaeranthera aspera Greene. On the mountains of Colo.-Alt. 8000I0,000 ft.-Manitou; Ute Pass; Hinsdale Co. ; Colorado Springs ; Pike's Peak; Engelnann Cañon; Como; Georgetown; mountains between Sunshine and Ward.

5. Machaeranthera viscosa (Nutt.) Greene. (Aster canescens viscosus A. Gray) On dry hills and plains from Wyo. to Colo. and Calif. (?)-Alt. 6000-10,000 ft.-Colorado Springs; Sangre de Cristo Creek; Rogers; Grecian Bend, Pike's Peak; Trail Glen; Twin Lakes; Mt. Harvard; Table Rock. 
6. Machaeranthera viscosula Rydb. On plains and mountains of Colo.Veta Pass; South Park; southeast of Jefferson.

7. Machaeranthera Pattersonii (A. Gray) Greene. (Aster Pattersonii A. Gray) In moist places in the mountains of Colo.-Alt. I0,000-I4,000 ft.Caribou; Gray's Peak and vicinity; Silver Plume; Berthoud Pass.

8. Machaeranthera rubricaulis Rydb. On plains, table lands and hills of Colo.-Alt. 5000-7000 ft.-Platte River; Denver; Colorado Springs; La Veta; mountain above Andrews' ranch; south of Antonito.

9. Machaeranthera canescens (Pursh) A. Gray. (Aster canescens Pursh) On sterile ground and sandy banks from Sask. and B. C. to Colo.-North Park; Honnold.

Io. Machaeranthera pulverulenta (Nutt.) Greene. On dry plains from Mont. to Colo.-Gypsum; North Fork, Larimer Co.

II. Machaeranthera glabella Greene. In the mountains of Colo.-Alt. 7000Io,ooo ft.-Black Cañon; Gunnison; southeast of Ouray; White River Plateau; Parlin; Cerro Summit.

12. Machaeranthera ramosa $\mathrm{A}$. Nels. In the mountains of Wyo. and Colo. -Alt. 8000-9500 ft.-Pitkin; Grizzly Creek; Gypsum.

13. Machaeranthera Selbyi Rydb. In cañons and meadows in Colo.-Alt. 7500-9500 ft.-West of Ouray; Mt. Harvard.

14. Machaeranthera spectabilis Greene. In the mountains of Colo--Alt. up to Io,ooo ft.-Marshall Pass; Gypsum.

15. Machaeranthera cichoriacea Greene. On hills and mountains from Wyo. to N. M.-Alt. $4500-7500$ ft.-Trail Glen; Westcliffe; Ft. Collins; Twin Lakes; Deer Run.

I6. Machaeranthera Fremontii Rydb. In black soil of river bottoms, Colo. - "Platte Waters."

\section{LEUCELENE Greene.}

Upper leaves strigose, slightly glandular and not conspicuously hispid-ciliate.

Lower leaves broadly spatulate; upper linear-subulate; branches long and slender.

Leaves all linear-spatulate; branches short.

Upper leaves conspicuously hispid-ciliate, copiously glandular.

Upper leaves linear-oblanceolate; the lower spatulate.

1. L. arenosa.

Upper leaves linear-subulate; the lower linear or linear-oblanceolate.

Leaves of the branches $6-12 \mathrm{~mm}$. long.

Leaves of the branches $2-5 \mathrm{~mm}$. long.

2. L. serotina.

1. Leucelene arenosa Heller. (Aster ericaefolius tenuis A. Gray) On dry hills from Colo. to Tex. and Ariz.; also Mex.-Alt. 4000-7000 ft.-Cimarron; Hotchkiss.

2. Leucelene serotina (Greene) Rydb. On arid hills from Colo. and Utah to Tex. and Ariz.-Cañon City.

3. Leucelene hirtella (A. Gray) Rydb. (Aster cricaefolius hirtella A. Gray) On dry hills from Wyo. and Utah to Tex. and Ariz.-Arboles; Leroux Creek; mountain above Manitou; Palisades; Grand Junction.

4. Leucelene alsinoides Greene. On dry hills from Colo. to Tex. and N. M. -Alt. up to $8000 \mathrm{ft}$.-Salida; Rocky Ford, Otero Co.; Walsenburg.

5. Leucelene ericoides (Torr.) Greene. (Asier ericaefolius Rothr.) On dry hills from Colo. to Tex. and N. M.- "Colorado" (James). 


\section{I. ERIGERON L. FLEABANE.}

Bracts of the involucre in $1-2$ series of almost equal length, not thickened on the back.

Rays inconspicuous, erect or ascending, usually involute and incurved, numerous; often inside them a series of rayless pistillate flowers; leaves entire.

I. ACRES.

Rays conspicuous, spreading, flat; no rayless pistillate flowers inside.

Plant without runners.

Perennials.

Leaves dissected or deeply cleft. II. Mulrifidr.

Leaves entire or merely toothed.

Stens low, less than $2 \mathrm{dm}$. high, scapiform, usually bearing only one head; stem-leaves usually reduced.

Involucres and peduncles villous with many-celled hairs; bracts comparatively broad.

III. UNTFLORI.

Involucres and peduncles hirsute to glandular-puberulent or glabrate, not long-villous.

IV. Radicati.

Stem leafy, $z-10 \mathrm{dm}$. high, if lower bearing several heads; stemleaves ample.

Stems densely cespitose from a thick tap-root; heads small; disk rarely over I $\mathrm{cm}$. wide.

Pappus double; stem hirsute.

Pappus simple; stems strigose.

V. Pumiri.

VI. Decumbentes.

Stems usually solitary from the ends of distinct (sometimes branched) rootstocks; heads large; disk over I $\mathrm{cm}$. wide.

Bracts loose with reflexed tips; rays broad; pappus simple; lower leaves broadly oblanceolate, the upper often reduced.

Bracts villous.

Bracts glandular-puberulent or glabrous.

VII. Elatiores.

Viti. Salsuginosi.

Bracts appressed, except the very tips; rays narrow; pappus double.

Upper stem-leaves ample, ovate to lanceolate, not much smaller than the lower, which are more or less distinctly 3-nerved; peduncles usually short, ascending. IX. MAcranthI.

Upper stem-leaves reduced, linear-lanceolate; none of the leaves 3-nerved; peduncles long and erect.

Annuals or biennials.

X. Glabellit.

Stem-leaves not cordate-clasping.

Stems rather simple with a few large heads; disks about $\mathrm{I} \mathrm{cm}$. or more broad.

X. Glabelli.

Stems much branched, leafy, with numerous small heads; disk 6-9 mm. broad.

Stems strigose, except at the base; pappus-bristles of the rays usually lacking.

XI. Ramosi.

Stems and leaves densely short-pubescent with spreading hairs; pappus-bristles of the rays present.

Annuals; pappus scant and simple. XIII. Bellidiastra.

Biennials (rarely perennials); pappus double, the outer of short subulate squamellae. XIV. Divergentes.

Stem-leaves broad, cordate-clasping. XII. Philadel.Phicr.

Plants first with a scapiform, naked peduncle, later producing lateral runnerlike branches.

XV. Flagellares.

Bracts of the involucre in 3-4 series, more or less imbricated, thickened on the back; the outer usually successively shorter.

Achenes terete or nearly so, several-nerved.

Achenes flattened or quadrangular, 2-4-nerved.

XVI. Cani.

XVII. Caespitosi. 
I. ACRES.

Bracts of the involucre linear, abruptly acute, never glandular; inflorescence racemiform with almost erect branches.

Low, I-2 dm. high; stem-leaves sessile; peduncles short.

Taller, 3-6 dm. high, lower stem-leaves petioled; basal leaves oblanceolate; peduncles elongated.

z. E. lonchophyllus.

Bracts of the inflorescence linear-subulate, long-attenuate, and more or less glandular-puberulent; inflorescence inclined to be corymbiform or paniculate; branches ascending.

Bracts glandular-puberulent, rarely with a few hairs. 3. E. droebachiensis.

Bracts hirsute or both hirsute and glandular-puberulent.

Plant tall, 3-6 dm. high, apparently only biennial; heads numerous.

$\begin{array}{ll}\text { Plant low, I-3 dm. high, perennial; heads few. } & \text { 4. E. yellowstoner. jucundus. }\end{array}$

II. Multifidi.

Leaves pinnately divided.

Leaves once to thrice ternately divided.

Leaves twice or thrice ternate.

Ultimate divisions of the leaves narrowly linear; peduncles with long linear leaves.

7. E. compositus.

Ultimate divisions of the leaves spatulate or broadly oblanceolate: peduncles naked above or with very short leaves.

Leaves once ternate or quinate.

8. E. multifidus.

9. E. trifidus.

III. UNIFLORI.

Involucres and peduncles with black-purple hairs.

Involucres and peduncles white-hairy.

Plant 5-8 cm. high; disk I0-1 $2 \mathrm{~mm}$. wide.

Plant I dm. high or more; disk I3-I $5 \mathrm{~mm}$. wide.

Iо. E. melanocephalus.

II. E. uniforus.

I2. E. leucotrichus.

\section{Radicati.}

Involucre glandular-puberulent or glabrate, not hirsute.

Stem and leaves glabrous or nearly so.

Stem and leaves pubescent and somewhat glandular.

I3. E. leiomeris.

36. E. viscidus.

Involucre more or less hirsute or strigose; in some also slightly glandularpuberulent.

Leaves and stem glandular-scabrous as well as hirsute.

Leaves and stem hirsute or strigose, not glandular.

14. E. glandulosus.

Stem I dm. or more high, appressed-pubescent; disk over I $\mathrm{cm}$. wide: branches of the caudex rather slender, purplish.

Leaves narrowly linear-oblanceolate, I-3 mm. wide, strigose.

23. E. Engelmannii.

Leaves oblanceolate to linear-oblanceolate, $3-8 \mathrm{~mm}$. wide, glabrous above except the margins.

15. E. ursintis.

Stem 4-7 cm. high; disk less than I $\mathrm{cm}$. wide; caudex and its branches stout and short, not purplish.

Leaves linear-oblanceolate to spatulate.

Stem with appressed hairs.

Stem with more or less spreading hairs.

Leaves linear-filiform.

I6. E. Peasei.

I7. E. retensis.

18. E. nematophyllus.

\section{Pumier.}

Rays present.

Ray-flowers white; the auter pappus of small inconspicuous bristles. I9. E. pumilus.

Ray-flowers blue or purplish; outer pappus conspicuous and squamellate.

Rays wanting. 20. E. concinnus.

21. E. aphanactis. 


\section{Decumbentes.}

Leaves I-nerved, linear-oblanceolate; the lower usually obtusish.

Plant 1.5-2 dm. high; pubescence of the leaves sparse, loose.

22. E. simulans.

Plant I dm. high or less, usually monocephalous; pubescence dense and appressed. 23. E. Engelnannii.

Leaves 3-nerved, at least at the base, equally long-acuminate at both ends. 24. E. microlonchus.

\section{Elatiores.}

Bracts very densely villous; leaves entire.

Bracts sparingly villous; leaves usually dentate.

25. E. elatior.

26. E. Coulteri.

\section{Salsugtnosi.}

One species.

27. E. salsuginosus.

\section{iX. Macranthi.}

Basal leaf-blades broadly obovate-spatulate, often denticulate; stem-leaves distant, shorter than the internodes, not ciliate on the margins; bracts glandularpuberulent, seldom with a few hairs. 28. E. superbus.

Basal leaf-blades oblanceolate, entire; stem-leaves usually longer than the internodes, ustrally ciliate on the margins.

Bracts glandular-puberulent, not at all hirsute; leaves glabrous.

Leaves linear-lanceolate, dark bluish green and shining, minutely ciliolate. 29. E. salicinus.

Leaves not dark-green, dull, strongly hirsute-ciliate. 30. E. macranthus.

Bracts more or less hirsute.

Stem and leaves glabrous or nearly so; the latter ciliate only on the margins and the veins below; bracts glandular-puberulent and with scattered hairs. 3 I. E. speciosus.

Stem and leaves hairy; bracts hirsute or both hirsute and glandular. Leaves hirsute.

Pubescence scant; that of the stem long; leaves linear-lanceolate.

32. E. conspicuus.

Pubescence of the leaves and the involucres dense; that of the stem short. Plant tall, green; upper stem-leaves ovate or ovate-lanceolate, distinctly triple-nerved.

Plant low, canescent; upper stem-leaves lanceolate, scarcely triplenerved.

Leaves glandular-puberulent.

33. E. subtrinervis.

34. E. incanescens.

35. E. Vreelandii.

\section{Glabelli.}

Involucres glandular-puberulent, sparingly if at all hairy.

Stem with long white hairs; the upper portion glandular-hirsute.

Lower leaves hairy; stem low, stout.

Leaves merely ciliate; stem slender.

36. E. viscidus.

37. E. eximius.

Stem glabrous; upper portion glandular-puberulent; leaves glabrate.

Involucre densely hirsute or strigose.

38. E. Snithii.

Bracts hirsute.

Leaves glabrate; plant evidently a perennial. 39. E. glabellus.

Leaves more or less hairy; plant in most cases apparently only biennial.

Bracts strigose; basal leaves linear-oblanceolate, denticulate.

40. E. consobrinus.

4I. E. strigulosis.

XI. Ramosi.

One species.

42. E. ramosils.

One species.

Xit. Philadelphici.

43. E. philadelphicus. 
XiII. Bellidtastra.

One species.

XIV. Divergentes.

Stem simple below.

Stem branched at the base.
44. E. Bellidiastrum.

45. E. Wootonii.

46. E. divergens.

XV. Flagellares.

Leaves and stem appressed-hairy.

47. E. Aagellaris.

Leaves and stem densely short-pubescent with spreading hairs.

Basal leaves oblanceolate, entire, or 3-lobed at the apex; leaves of the stolons linear; plant gray. 48. E. cinereus.

Basal leaves obovate-spatulate, entire, or with several lateral lobes or teeth; leaves of the stolons oblanceolate; plant greener. 49. E. nudiflorus.

XVI. Cani.

Disk of the heads fully I cm. high and about $1.5 \mathrm{~cm}$. wide; basal leaves spatulate, obtuse. 50. E. argentatus.

Disk of the heads $7-8 \mathrm{~mm}$. high and about I cm. wide; basal leaves oblanceolate, mostly acutish. 5I. E. canus.

XVII. Caespitosi.

Stem erect, about $3 \mathrm{dm}$. high, usually with several heads; stem-leaves linear. 52. E. subcanescens.

Stem decumbent at the base, $1-2 \mathrm{dm}$. high, with $1-3$ (seldom more) heads; stem-leaves oblong.

53. E. caespitosus.

I. Erigeron minor (Hook.) Rydb. (E. armeriacfolius A. Gray, in part; not Turcz.) In damp places in the mountains from Sask. and B. C. to Colo. and Utah.-Alt. 7000-I0,000 ft.-Lake City; Democrat Mountain; Georgetown; South Park; Twin Lakes; Westcliffe; Red Mountain road, south of Ouray; Gunnison ; Palsgrove Cañon; Clear Lake; Grand River, above Kremmling; Grizzly Creek; Pagosa Springs; Buena Vista; Buffalo Pass; near Como; Trappers' Lake.

2. Erigeron lonchophyllus Hook. (E. armeriaefolius A. Gray, in part) In wet places in the mountains from Sask. and Mont. to Colo. and Nev.-Alt. 8000-900o ft.-Parlin; Ruxton Park, Pike's Peak; Higho; Table Rock; Gypsum Creek; Buena Vista; Grizzly Creek; Twin Lakes.

3. Erigeron droebachiensis Muell. (E. acris Droebachiensis Blytt) In dry woods from N. B. and Alaska to Colo.-Breckenridge; Mt. Harvard; Anita Peak.

4. Erigeron yellowstonensis A. Nels. (E. acris A. Gray, in part; not L.) In the mountains from Mont. to Colo.-Alt. 9000-Io,000 $\mathrm{ft}$.-Breckenridge; Chambers' Lake; Beaver Creek.

5. Erigeron jucundus Greene. (E. acris dcbilis A. Gray; E. debilis Rydb.) In wet places, especially in the mountains, from Hudson Bay and B. C. to Colo. and Utah.-Alt. 8000-I I,000 ft.-Massif de l'Arapahoe; Mt. Baldy; headwaters of Clear Creek; Georgetown; Eldora to Baltimore.

6. Erigeron pinnatisectus (A. Gray) A. Nels. (E. compositus pinnatisectus A. Gray) On the higher peaks of Wyo. and Colo.-Alt. I0,000-I3,500 ft.Hahn's Peak; Cameron Pass; Pike's Peak; near Ironton, San Juan Co.; Gray's Peak; Mt. Garfield; Mt. Harvard; south of Ward, Boulder Co.; above Boreas; Bottomless Pit; Bald Mountain; Little Kate Mine, La Plata Mountains; near Pagosa Peak; Westcliffe; Devil's Causeway; Beaver Creek. 
7. Erigeron compositus Pursh. On the mountains from Mont. and Yukon to Colo. and Wash.-Alt. 8000-9000 ft.-Mountains between Sunshine and Ward.

8. Erigeron multifidus Rydb. On the higher mountains from Ass. and B. C. to Colo. and Calif.-Alt. 5000-12,500 ft.-Headwaters of Clear Creek; Hinsdale Co.; West Indian Creek; west of Ft. Collins; Calhan; foot-hills, Larimer Co.; Marshall Pass; Sierra Blanca; Mt. Abram; Ouray; Pike's Peak; Stove Prairie; Eldora to Baltimore; Rist Cañon; Barnes' Camp; gulch east of Stove Prairie; Beaver Creek; Spicer.

9. Erigeron trifidus Hook. On high mountains from Alb. and B. C. to Colo.-Table Rock; Spicer, Larimer Co.

ro. Erigeron melanocephalus A. Nels. (E. oreocharis Greene) On high mountains of Wyo. and Colo.-Alt. I I,000-12,000 ft.-Massif de l'Arapahoe; Caribou; headwaters of Clear Creek; Little Kate Mine, La Plata Mountains; near Pagosa Peak; Sierra Blanca; Mt. Harvard; Cameron Pass; Berthoud Pass; Argentine Pass; summit of North Park Range, Routt Co.

II. Erigeron uniflorus L. (E. simplex Greene) In arctic regions and on the higher peaks from Mont. to Colo. and Calif.-Alt. ro,000-I3,000 ft.Mt. McClellan, near Gray's Peak; West Spanish Peak; Bottomless Pit, Pike's Peak; Gray's Peak; above Cameron Pass; Marshall Pass; Seven Lakes; South Park; Alpine Tunnel; mountain northeast of Boreas.

12. Erigeron leucotrichus Rydb. On the higher mountains of Wyo. and Colo.-Alt. 9000-I2,000 ft.-Caribou; headwaters of Clear Creek; Pike's Peak Valley; Cameron Pass; Seven Lakes; Graymont; Berthoud Pass; Beaver Creek.

13. Erigeron leiomeris A. Gray. (E. spathulifolius Rydb.) On alpine peaks from Wyo. to N. M. and Utah.-Alt. 10,000-I2,000 ft.-Mt. Kelso; near Gray's Peak; Lake City; Redcliffe, Eagle Co.; mountains above Cameron Pass; Gray's Peak; Little Kate Mine, La Plata Mountains; Ragged Mountain, Gunnison Co.; Four-Mile Hill, Routt Co.; Hahn's Peak; Rabbit-Ears, Larimer Co.

14. Erigeron glandulosus Porter. On the mountains of Wyo. and Colo.Alt. 6000-12,500 ft.-Hinsdale Co. ; South Park; Alpine Tunnel; Georgetown; southeast of La Veta; east slope of Pike's Peak; Manitou; Garden of the Gods; near Colorado Springs; Palmer Lake; Cheyenne Cañon; Lake City; Empire; Colorado City.

15. Erigeron ursinus D. C. Eaton. On the mountains from Mont. and Ida. to Colo. and Utah.-Alt. 8000-10,000 ft.-Continental Divide, Routt Co.; Columbine; summit of North Park Range, Larimer Co.; Rabbit-Ears, Larimer Co.

I6. Erigeron Peasei Rydb. In alpine regions of Colo.-Lake City.

i7. Erigeron vetensis Rydb. On high, dry mountains of southern Colo.Alt. 8000-ro,000 ft.-Mountain near Veta Pass; Ojo; West Spanish Peak; Veta Mountain; North Cheyenne Cañon.

18. Erigeron nematophyllus Rydb. On rocky hills of Colo. and Wyo.Near Dale Creek, Larimer Co.

Ig. Erigeron pumilus Nutt. On the plains from N. D. and Wash. to Kans. and Utah.-Alt. 4000-7000 ft.-Moon's ranch; Cucharas River, La Veta; Ft. Collins; Antonito; New Windsor; Mancos; Palisades; Gypsum; Quimby; Wray. 
20. Erigeron concinnus (H. \& A.) T. \& G. On arid plains and hills from Mont. and B. C. to N. M. and Calif.-Alt. 4000-7000 ft.-Mancos; Grand Junction; Los Pinos (Bayfield); Durango; Dolotes.

2I. Erigeron aphanactis (A. Gray) Greene. (E. concinnus aphanactis A. Gray) On dry plains from Colo. and Nev. to Calif.-Antonito; Grand Junction.

22. Erigeron simulans Greene. (E. Engelmannii arenicola A. Nels.) On .dry hills and sandy flats from Mont. to Colo. and Utah.-Alt. 6000-8000 ft.Glenwood Springs; Cimarron; Gunnison; Salida; Buena Vista.

23. Erigeron Engelmannii A. Nels. On dry plains of Wyo. and Colo.Gunnison; Gypsum; Table Rock.

24. Erigeron microlonchus Greene. On dry plains from Wyo, to Colo. and Ariz.-Alt. about $7000 \mathrm{ft}$.-Cimarion.

25. Erigeron elatior (A. Gray) Greene. (E. grandiflorum elatior A. Gray) In wet places in the mountains of Wyo. and Colo.-Alt. 8000-12,000 ft.-Red Mountain; Silver Plume; Mt. Baldy; near Pagosa Peak; east side of Bald Mountain; Georgetown; Rabbit-Ear Pass; White River Plateau; Steamboat Springs; near Teller, North Park; Ruby; Villa Park; Boreas; Leroux Park; Rabbit-Ear Range, Routt Co.; near Empire; headwaters of Clear Creek; Robinson; Red Mountain; Silver Plume; Berthoud Pass.

26. Erigeron Coulteri Porter. In damp places in the mountains of Colo. and Utah.-Alt. 9000-12,000 ft.-Lake City; Hinsdale Co.; Bard Valley, near Empire; Bob Creek, west of Mt. Hesperus; Rabbit-Ear Pass; La Plata Cañon; Leroux Creek, Delta Co.; East River; near Pagosa Peak; Red Mountain, about Ouray; Ironton. San Juan Co.; Mt. Harvard; Ironton Park, nine miles south of Ouray; Silverton; Berthoud Pass.

27. Erigeron salsuginosus (Richardson) A. Gray. In wet ground from Alb. and Alaska to Colo, and Calif.-Alt. 9000-I2,000 ft.-Middle Park; Chambers' Lake; Georgetown; near Pagosa Peak; Minnehaha; Lake Moraine; Cameron Pass; Marshall Pass; mountains above Ouray; Hahn's Peak; Mt. Harvard; Red Mountain; Ruby; Ruxton Park, Pike's Peak; Silver Plume; Beaver Creek; Trappers' Lake; Berthoud Pass; Buffalo Pass; Gray's Peak; between Como and Boreas; Twin Lakes; Devil's Causeway; summit of North Park Range, Larimer Co.; Hahn's Peak.

Erigeron salsuginosus glacialis (Nutt.) A. Gray. In the higher mountains from Wyo. to N. M. and Utah.-Alt. 9000-I2,000 ft.-High Mountains, near Empire; Caribou; Veta Pass.

28. Erigeron superbus Greene. In the mountains of Colo.-Alt. 7500-12,000 ft.-Mountains near Empire; near Pagosa Peak; Minnehaha; Breckenridge; Villa Grove; Idaho Springs; Artist's Glen and Halfway House, Pike's Peak; Box Cañon, west of Ouray; Baxter's ranch ; chaparral-covered hills southeast of Ouray; mountains between Sunshine and Ward; Stove Prairie Hill; Marshall Pass.

29. Erigeron salicinus Rydb. In the mountains of Colo.-Alt, up to Io,000 ft.-Pagosa Springs; Keblar Pass; Narrows.

30. Erigeron macranthus Nutt. In the mountains from Mont. and B. C. to Colo, Utah and Ore.-Alt. 7000-10,000 ft.-Lake City; Platte River; West of Ouray; Jack's Cabin; Steamboat Springs; Keblar Pass; Durango; Cerro Summit; mountains, Larimer Co.; La Veta; La Plata Cañon; Mancos; Sun- 
set, Boulder Co.; Four-mile Hill, Routt Co.; Andrews' Shetland ranch; Mt. Abram, Ouray; southeast of Ouray; Veta; Bosworth's ranch; Poudre Cañon, near Narrows; Table Rock; Little Muddy; Hotchkiss; Eldora to Baltimore; Stove Prairie; Redstone; Cheyenne Cañon; Palmer Lake; Bosworth's ranch, Stove Prairie; gulch west of Soldier Cañon; Vance Junction; Hahn's Peak; Willow Creek; Steamboat Springs.

3I. Erigeron speciosus (Lindl.) DC. In the mountains from Mont. and Wash. to Colo., Utah and Ore.-Alt. 7500-9000 ft.-Castle Cañon; Minnehaha; chaparral-covered hills southeast of Ouray; mountains between Sunshine and Ward; Cheyenne Cañon.

32. Erigeron conspicuus Rydb. In mountain meadows from Mont. and Wash. to Colo.-Deep Creek Lake; Pine Grove; North Park, along the Michigan.

33. Erigeron subtrinervis Rydb. (E. glabellus mollis A. Gray, in part) Wooded mountain sides and dry places in the valleys from S. D. and Wyo. to N. M.-Alt. 7000-10,000 ft.-Near Empire; Gray's Peak; Grizzly Creek; North Park; Twin Lakes; Dark Cañon; North Cheyenne Cañon; Steele Cañon; Villa Grove; Echo Creek; Empire; Pine Grove.

34. Erigeron incanescens Rydb. (E. glabellus mollis A. Gray, in part) High mountains of Colo.-Alt. 9000-I0,000 ft.-West Spanish Peak; Sargent.

35. Erigeron Vreelandii Rydb. In wet meadows of southern Colo.-Alt. $7500 \mathrm{ft} .-W$ Whạtoya Creek.

36. Erigeron viscidus Rydb. On mountain ridges in Colo.-Alt. 8500-12,000 ft.-Piedra; Grayback mining camps and Placer Gulch; Ruxton Dell; Poudre River; Berthoud Pass; Boreas.

37. Erigeron eximius Greene. In the mountains of Colo.-Alt. 8000-10,000 ft.-Piedra; Poudre Cañon, above Rustic; Eldora to Baltimore; Poudre flats.

38. Erigeron Smithii Rydb. In rich meadows of Colo.-Alt. 7000-10,000 ft. _-Parlin, Gunnison Co.; Gunnison; Antonito; Sargent; Villa Grove; Arkansas Junction.

39. Erigeron glabellus Nutt. On mountains and hills from Sask. and Mackenzie to Wisc. and N. M.-Alt. 5000-12,000 ft.-Hinsdale Co.; McCoy ; Marshall Pass; Ft. Collins; Ribbon Lake; Clear Creek, below Georgetown; east bank of Poudre River, near Ft. Collins; Gypsum Creek Cañon; bank of Elk River.

40. Erigeron consobrinus Greene. (E. fraternus Greene) In mountain valleys of Colo.-Alt. 7000-10,000 ft.-Villa Grove; Gunnison; Cucharas River, below La Veta; Sangre de Cristo Creek; Wahatoya Creek; Alamosa; Garland; Parlin, Gunnison Co.; Estes Park, Larimer Co.; Cerro Summit: Como; vicinity of Como; Walton Creek; Conejos River; Steamboat Springs.

41. Erigeron strigulosus Rydb. In meadows of Colo.-Antonito.

42. Erigeron ramosus (Walt.) B. S. P. (E. strigosus Muhl.) In dry places from N. S. and B. C. to Fla. and Calif.-Alt. 5000-6500 ft.-Foot-hills, Larimer Co.; Boulder; Rist Cañon; Horsetooth Mountain; Arthur's Rock; Redstone.

43. Erigeron philadelphicus L. In wet fields and woodlands from Lab. and B. C. to Fla. and Calif.-Piedra; Poudre Cañon.

44. Erigeron Bellidiastrum Nutt. In low grounds from S. D. and Wyo. to Kans. and Ariz.-Alt. about $9000 \mathrm{ft}$-McElmo Cañon. 
45. Erigeron Wootonii Rydb. (E. cinereus var. $\gamma$ A. Gray) In sandy soil from Colo, to N. M. and Ariz.-Alt. up to $7000 \mathrm{ft}$.-Walsenburg; Antonito; Grand Lake; Garden of the Gods.

46. Erigeron divergens T. \& G. Low plains and river banks from Mont. and Wash. to N. M. and Calif.-Alt. 5000-8500 ft.-Golden City; Steamboat Springs; Durango; Mancos; Arboles; Ouray; Cedar Edge; Sargent; Honnold; Hotchkiss; Big Creek Gulch; Empire; Boulder; Buena Vista; Colorado Springs.

47. Erigeron flagellaris A. Gray. (E. stolonifer Greene) On banks of streams and river valleys from S. D. and Wyo. to N. M. and Utah.-Alt. 5000-I, $000 \mathrm{ft}$.-Durango; Ft. Collins; southeast of Ouray; Cucharas River, below La Veta; Arboles; Mancos; headwaters of Sangre de Cristo Creek; Bob Creek, west of Mt. Hesperus ; Como; Calhan ; Red Rock Cañon ; Boulder ; Middle Park; Veta Pass; Sargent; Columbine; Boulder; Castle Cañon; Walsenburg; Como; Trappers' Lake; Poudre, near the Narrows; Eldora to Baltimore; bank of Purgatory River, near Trinidad; Moon's ranch; Poudre Cañon; Horsetooth Gulch; Quimby; Howe's Gulch.

48. Erigeron cinereus A. Gray. (E. divergens cinereus A. Gray) On river bluffs from Colo. and Utah to Tex. and Ariz.-Alt. 6500-7500 ft.-Manitou; river bluffs north of La Veta; Los Pinos (Bayfield); Arboles.

49. Erigeron nudiflorus Buckl. Hills and river bluffs from Colo. to Tex. and Ariz.-Alt. 7000-8000 ft.-Ft. Collins; butte, five miles southeast of La Veta; Quimby; Horsetooth Mountain; Horsetooth Gulch.

50. Erigeron argentatus A. Gray. On dry plains from Mont. and Wash. to Col. and Nev.-Grand Junction.

5I. Erigeron canus A. Gray. On dry plains from S. D. and Wyo. to Neb. and N. M.-Alt. 4000-9000 ft.-Near Empire; Colorado Springs; Sunset Cañon; Lake City; Sangre de Cristo Creek; Grayback mining camps and Placer Gulch; Mancos; Almelia.

52. Erigeron subcanescens Rydb. On dry plains from Mont. and Alb. to Colo.-North Park.

53. Erigeron caespitosus Nutt. On dry plains from Sask., Yukon and B. C. to Colo.-Alt. about $9500 \mathrm{ft}$-Chambers' Lake.

\section{Leptilon Raf. Horseweed, Canada Fleabane.}

I. Leptilon canadense (L.) Britton. (Erigeron Canadense L.) In waste places and dry soil from Lab. and B. C. to Fla. and Calif.; also in W. Ind. and Mex. and introduced in Europe.-Alt. 4000-8000 ft.-Gunnison; Minnehaha; Box Cañon, west of Ouray; Ft. Collins; North Cheyenne Cañon.

\section{ESCHENBACHIA Moench.}

I. Eschenbachia Coulteri (A. Gray) Rydb. (Conyza Coulteri A. Gray) On river bottoms from Colo. to Tex, and Calif.-Cañon City (Brandigee).

34. Baccharis L. Grounsel Tree, Pencil Tree.

Pappus copious, in fruit elongating and surpassing the styles.

Pappus-bristles in several series; plant $3^{-6} \mathrm{dm}$. high, herbaceous with a woody base. 
Pappus-bristles in one series; plants $\mathrm{r}-5 \mathrm{~m}$. high, shrubby.

Fertile heads hemispherical, 5-Io $\mathrm{mm}$. broad; bracts all acute.

2. B. salicina.
.

Fertile heads deeply campanulate, 3-5 $\mathrm{mm}$. broad; outer bracts obtuse.

3. B. Emoryi.

Pappus scant, little if at all elongating, in fruit not exceeding the styles.

4. B. glutinosa.

1. Baccharis Wrightii A. Gray. In saline soil from Kans. and Colo. to Tex. and Ariz.; also in Mex.-Brantly Cañon, Las Animas Co.; Soda Spring ledge, Fremont Co.

2. Baccharis salicina T. \& G. In saline soil from Kans, and Colo. to Tex. and N. M.-Alt. 4000-5000 ft.-Rocky Ford, Otero Co.; Grand Junction; Cañon City.

3. Baccharis Emoryi A. Gray. Along rivers, especially in saline ground, from Colo. to N. M. and Calif.-Alt. about $4600 \mathrm{ft}$.-Grand Junction.

4. Baccharis glutinosa Pers. Along streams from Colo. to Tex. and Calif.; also in Mex.-Grand Junction; Grand Cañon; Peoria Creek.

\section{Tribe 4. GNAPHALIAE.}

\section{BERTHELOTIA DC.}

1. Berthelotia sericea (Nutt.) Rydb. (Polypappus sericeus Nutt.; Pluchea borealis A. Gray) On sandy banks of streams from Colo. and Utah to Tex. and Calif.; also in Mex.-Grand Cañon.

\section{FILAGO L.}

I. Filago prolifera (Nutt.) Britton. (Evax prolifera Nutt.) On dry ground from S. D. and Colo. to La. and Tex.-Plains near Greeley; New Windsor.

\section{ANTENNaria Gaertn. Cat's-foot, Everlasting.}

Pappus-bristles of the staminate heads with clavate or scarious-dilated tips.

Plants surculose-proliferous with leafy stolons.

Plant caulescent.

Bracts of the involucres with green or brown upper portion.

Bracts dark; leaves not yellowish.

Bracts of the heads lanceolate, acute.

Bracts oblong or oval, obtuse. (Pistillate heads of) 1. A. media.

Bracts very dark, almost black at the base, but often with white tips.

(Staminate heads of) r. A. media.

Bracts moderately dark, umber-colored throughout.

Bracts isabel-colored; leaves yellowish-white.

Inner bracts not rose-colored. 3. A. flavescens.

Inner bracts rose-colored. 4. A. concinna.

Bracts of the involucres with white or pink upper portion.

Heads $5-8 \mathrm{~mm}$. high.

Bracts usually with bright pink upper portion.

Leaves narrowly oblanceolate, acute. $\quad 5 . \mathrm{A}$. rosea.

Leaves spatulate, obtuse.

5. A. rosea.
6. A. imbricata.

Bracts with white upper portion. 
Leaves of the stolons narrowly oblanceolate, $1.5-5 \mathrm{~cm}$. long; bracts with dark spots. 7. A. nardina.

Leaves of the stolons spatulate, $0.5-3 \mathrm{~cm}$. long; bracts not with dark spots.

Leaves of the stolons $5^{-15} \mathrm{~mm}$. long, rhombic-spatulate; tomentum very fine, appressed and silky. $\quad 8$. A. microphylla.

Leaves of the stolons spatulate, usually rounded at the apex, I $5-30 \mathrm{~mm}$. long; tomentum looser.

Bracts of the pistillate heads obtuse; plant I--2 dm. high.

Bracts of the pistillate heads acute.

9. A. viscidula.

Inflorescence and upper leaves glanduiar-hairy; leaves of the inflorescence large, scarcely smaller than the upper stemleaves; bracts greenish. Io. A. bracteosa.

Infiorescence and upper leaves not glandular; the latter reHeads 8-i 2 mm. high. duced; bracts brownish. II. A. oxyphylla.

Leaves tomentose on both sides.

Plant tall, 2-3 dm. high; heads usually peduncled.

Leaves less than $2 \mathrm{~cm}$. long and $5-8 \mathrm{~mm}$. wide, usually not triplenerved; heads $7-9 \mathrm{~mm}$. high.

I I. A. oxyphylla.

Leaves over $2 \mathrm{~cm}$. long, 7-IO $\mathrm{mm}$. wide, triple-nerved; heads about I cm. high. I2. A. obovala.

Plant low, usually less than I dm. high; heads subsessile.

Leaves glabrous above. I3. A. aprica. 14. A. marginata.

Plant acaulescent; heads subsessile among the rosettes of the basal leaves. Bracts with white upper portion; leaves white on both sides.

Bracts with brown upper portion; leaves glabrate above. 15. A. rosulata.

I6. A. Sierrae-Blancae.

Plants not surculose-proliferous.

Heads 4-5 $\mathrm{mm}$. high; bracts nearly glabrous, scarious throughout; leaves silky-tomentose. 17. A. oblanceolata.

Heads 6-10 mm. high; bracts tomentose at the base; only tips scarious; leaves villous-tomentose.

Bracts with a large dark spot; those of the pistillate heads ovate to lanceolate, acute; those of the staminate heads ovate or oval, obtuse or acutish; pistillate heads about 8-ro mm. high, turbinate at the base.

18. A. pulcherrina.

Bracts with small dark spots or none; bracts of both staminate and pistillate heads with oblong or oval, obtuse tips; those of the staminate heads slightly broader. 19. A. anaphaloides.

-Pappus-bristles of the staminate heads not clavate; achenes puberulent; hairs bifurcate at the apex; plant low and densely cespitose. 20. $A$. dimorpha.

I. Antennaria media Greene. On the higher peaks from Mont. and B. C. to Colo. and Calif.-Alt. I0,000-I3,00o ft.-Massif de l'Arapahoe; Little Kate Basin, La Plata Mountains; Alpine Tunnel; West Spanish Peak; near Pagosa Peak; Bottomless Pit; Silver Plume; mountain southeast of Cameron Pass.

2. Antennaria umbrinella Rydb. On the higher mountains from Mont. and Ida. to Colo.-Alt. 7500-13,000 ft.-Ruxton Deil; Alpine Tunnel; Sierra Blanca; Little Kate Basin; divide road to Steamboat Springs; Gunnison; Ironton, San Juan Co.; Berthoud Pass.

3. Antennaria flavescens Rydb. On dry hills from Mont. and Wash. to Colo.-Alt. up to I0,500 ft.-Hahn's Peak; Spicer.

4. Antennaria concinna E. Nels. On mountain ridges of Colo. and Utah.Alt. about $9000 \mathrm{ft}$.-Palsgrove Cañon. 
5. Antennaria rosea (D. C. Eaton) Greene. (A. parviflora Rydb.; not Nutt.) In meadows from Alb. and Yukon to Colo. and Calif.-Alt. 6000-II,000 ft.Lake City; Empire City; North Boulder Peak; Pike's Peak; Mt. Hesperus ; headwaters of Pass Creek; Crested Butte; Mt. Abram, Ouray; Upper La Plata River; gulch west of Pennock's; Eldora to Baltimore; Horsetooth Motntain.

6. Antennaria imbricata E. Nels. On hillsides from Mont. to Colo. and Utah.-Alt. 6000-I0,00o ft.-West Mancos Divide; Palsgrove Cañon; Ruxton Dell; Rist Cañon; Chambers' Lake.

7. Antennaria nardina Greene. (A. corymbosa E. Nels.) In meadows from Mont. and Ore. to Colo.-Alt. up to I2,000 ft.-Lake City; Seven Lakes.

8. Antennaria microphylla Rydb. (A. parvifolia Greene; not Nutt.; A. formosa Greene) On dry plains and hills from Sask. and B. C. to Neb. and N. M.-Alt. 4000-II,000 ft.-Pike's Peak; Empire City; Lake City; Wahatoya Creek; Gunnison; Dark Cañon; Piedra; Seven Lakes; Wolcott, Eagle Co.; Alamosa; Parlin; Boulder; Ft. Collins; south of Walden; Ruxton Dell.

9. Antennaria viscidula A. Nels. On mountains of Wyo. and Colo.-Alt. 9000-13,000 ft.-West Spanish Peak; Cabin Cañon.

10. Antennaria bracteosa Rydb. In mountain meadows from Mont. to Colo. -Alt. 8000-9000 ft.-Colorado Springs; Mt. Hesperus; Sangre de Cristo Creek.

I I. Antennaria oxyphylla Greene. On hills and mountains from S. D. and Mont. to Neb. and Colo.-Alt. up to II,000 ft.-Mt. Abram, Ouray; gulch west of Pennock's.

12. Antennaria obovata E. Nels. On hills and mountains from S. D. to Colo.-Soldier Cañon; Palmer Lake.

r3. Antennaria aprica Greene. ( $A$. dioica Hook.; not Gaert.) On hills and mountains from S. D. and Alb. to N. M. and Utah.-Alt. 5000-r2,000 ft.-Lake City; Pike's Peak; Van Boxle's ranch, above Cimarron; Los Pinos; Veta Mountain; Turkey Creek and tributaries; Wahatoya Cañon; West Indian Creek; Sangre de Cristo Creek; East Indian Creek; north of La Veta; Ojo; Cucharas River, below La Veta; southeast of La Veta; Palmer Lake; Howe's Gulch; North Cheyenne Cañon; La Plata Cañon; Mancos; Chicken Creek, west of Mt. Hesperus; near Denver; Grayback mining camps and Placer Gulch; Mt. Hesperus; Horsetooth Gulch; Howe's Gulch; Horsetooth* Mountain; Eldora to Baltimore; Beaver Creek.

I4. Antennaria marginata Greene. On the mountains of Colo., N. M. and Ariz.-Alt. I0,000-I I,000 ft.-Little Veta Mountain.

I5. Antennaria rosulata Rydb. In mountain valleys of Colo. and Ariz.Alt. 7000-8000 ft.-Wahatoya Creek; Los Pinos (Bayfield).

I6. Antennaria Sierrae-Blancae Rydb. On alpine peaks of Southern Colo. -Alt. 12,000-13,000 ft.--Sierra-Blanca.

7. Antennaria oblanceolata Rydb. On mountain sides from Mont. and B. C. to Colo. and Calif.-Alt. up to ro,000 ft.-Mountains west of North Park; Buffalo Pass; Park Range; Walton Creek, Routt Co.

18. Antennaria pulcherrima (Hook.) Greene. (A. Carpatica pulcherrima Hook.) On hillsides from Sask, and Yukon to Colo. and Wash.-Alt. up to $9000 \mathrm{ft}$.-Hamor's Lake. 
I9. Antennaria anaphaloides Rydb. On hillsides from Mont. to Colo. and Ore.-Alt. 8000-II,000 ft.-Engelmann's Cañon; Massif de l'Arapahoe; Crystal Park; Iron Mountain; near Veta Pass; Marshall Pass; Manitou; Artists' Glen; West Indian Creek; Green Mountain Falls; Soldier Cañon; Howe's Gulch; gulch west of Pennock's; Stove Prairie.

20. Antennaria dimorpha T. \& G. On dry hills from Mont. and B. C. to Neb., Colo. and Nev.-Alt. about $7000 \mathrm{ft}$-Cimarron.

\section{ANAPhalis D. C. Pearly Everlasting.}

I. Anaphalis subalpina (A. Gray) Rydb. (A. margaritacea subalpina A. Gray) In open mountain woods from S. D. and B. C. to Colo. and Calif.Alt. 8000-II,000 ft.-Empire City; Middle Park; Cameron Pass; La Plata Cañon; near Pagosa Peak; Red Mountain road, south of Ouray; Sangre de Cristo; Ruby; Stove Prairie Hill; Empire; between Sunshine and Ward; Ft. Collins; Fish Creek Falls.

\section{GNaphalium L. Cudweed, Everlasting.}

Heads not leafy-bracted; involucres well imbricated; its bracts scarious, white or tinged with brownish, rose or yellow; plants mostly tall.

Leaves tomentose on both sides; plants little if at all glandular.

Leaves narrowed at the base, not at all decurrent.

I. G. Wrightii.

Stem-leaves not narrowed at the base, more or less decurrent, or at least auricled.

2. G. sulphurescens.

Leaves on the upper surface green and decidedly glandular, decurrent.

3. G. decurrens.

Heads leafy-bracted; involucres little imbricated; its bracts brown or greenish; plant low.

Plants loosely floccose; leaves broad, spatulate, oblong or oblanceolate.

4. G. palustre.

Plants appressed-tomentose; leaves except the lowest narrowly oblanceolate or linear.

Stem diffusely branched; glomerules crowded, cymosely disposed. Upper leaves narrowly oblanceolate. Upper leaves narrowly linear.

Stem mostly simple, erect; glomerules spicately disposed.

5. G. uliginosum.

6. G. angustifolium.

7. G. strictum.

I. Gnaphalium Wrightii A. Gray. On dry ground from Colo. to N. M. and Calif.; also in Mex.-Meadow Park; Lyons.

z. Gnaphalium sulphurescens Rydb. In sandy soil from northern Wyo. and Wash. to Tex. and N. M.-Alt. 5000-6000 ft.-Poudre, near La Porte; Ft. Collins; Boulder; New Windsor.

3. Gnaphalium decurrens Ives. In open ground from N. S. and Ida. to Pa. and Colo.-Alt. 6000-10,000 ft.-Greeley; Marshall Pass; Ouray; Box Cañon, west of Ouray; Horsetooth Gulch; Steamboat Springs.

4. Gnaphalium palustre Nutt. In wet places from Mont. and B. C. to Colo. and Calif.-Alt. 5000-7500 ft.-Alamosa; twenty miles below Steamboat Springs; along Bear River; Gunnison; Hotchkiss.

5. Gnaphalium uliginosum L. In wet places from Newf. and B. C. to Va., Colo. and Ore.-Twin Lakes.

6. Gnaphalium angustifolium A. Nels. In wet places in Wyo. and Colo.Alamosa; Honnold; North Platte River, near Hebron. 
7. Gnaphalium strictum A. Gray. In wet places from Wyo. to Colo. and Ariz.-Alt. 5000-ro,00o ft.-Buena Vista; Ruxton Dell; below Hot Sulphur Springs; near Pagosa Peak; Denver; Empire; Ft. Collins; Bosworth's ranch; Poudre River; Twin Lakes; Ft. Garland; Georgetown.

\section{Tribe 4. HELIANTHEAE.}

40. MELAMPODIUM L.

I. Melampodium leucanthum T. \& G. ( $M$. cinereum A. Gray, in part; not DC.) On dry plains from Colo. to Tex. and Ariz-Alt. 5000-8000 ft. -Rocky Ford, Otero Co.; Cañon City; near Badito; Walsenburg; Pueblo; Florence.

\section{I. PARTHENICE A. Gray.}

1. Parthenice mollis A. Gray. On hillsides along the stream from Colo. to Ariz.- " Southern Colorado."

42. CRASSINA Scepin. Zinnia.

Ligules of the rays large, much longer than the disk. $\quad$.. C. grandiflora. Ligules of the rays scarcely longer than the disk.

2. C. anomala.

I. Crassina grandiflora (Nutt.) Kuntze. (Zinnia grandiflora Nutt.) Plains from Colo. to Tex. and Ariz.-Alt. 5000-6000 ft.-Pueblo; Trinidad; Walsenburg; Arkansas River; Raton Range.

2. Crassina anomala (A. Gray) Kuntze. (Zinnia anomala A. Gray) On plains from Colo. to Tex. and Mex.-Pueblo.

\section{HELIOPSIS Pers. OX-Eve.}

I. Heliopsis scabra Dunal. On dry soil and river banks from Me. and B. C. to N. M.-Alt. 7000-8000 ft.-Wahatoya Creek; La Veta.

44. BRAUNeria Necker. Purple Cone-flower.

I. Brauneria angustifolia (DC.) Heller. On prairies from Minn. and Mont. to Tex.-Exact locality not given.

45. GYMNOLOMIA H. B. K.

I. Gymnolomia multiflora (Nutt.) B. \& H. On plains and banks of streams from Mont. and Nev. to N. M. and Ariz.-Alt. 6000-I0,000 ft.-Colorado Springs; Hahn's Peak; Veta Pass; southeast of Ouray; Ironton Park, nine miles south of Ouray; Manitou; Marshall Pass; Chester; Four-Mile Hill, Routt Co.; Golden; near Pagosa Peak; Lower Boulder Cañon, Boulder Co.; Cerro Summit; Big Creek Gulch; between Sunshine and Ward; Palmer Lake; Hotchkiss; Cimarron and Squaw Hill; La Veta; Ute Pass; Steamboat Springs.

46. RUDBECKIA L. Cone-Flower, Black-eyed Susan.

Heads radiate; disk in fruit spherical or oblong.

Leaves entire or merely toothed; plant hispid. 1. R. flava.

Leaves except the uppermost 3-5-cleft or pinnatifid; plant glabrous or nearly so. Basal leaves and lower stem-leaves pinnately 5-7-divided. 2. $R$. laciniata. Basal leaves and lower stem-leaves palmately ternate. 3. $R$. ampla. Heads discoid; disk in fruit cylindraceous.

4. R. montana. 
I. Rudbeckia flava Moore. ( $R$. hirta A. Gray, in part; not L.) On hillsides from N. D. and Wyo. to Colo.-Alt. 5000-I0,000 ft.-Pike's Peak; Gunnison; Idaho Springs; South Park; Ruxton Dell; Engelmann Cañon; Sangre de Cristo Creek; North Cheyenne Cañon; mountains, Larimer Co.; Georgetown; Parlin; Baxter's ranch; Bosworth's ranch; Stove Prairie; Moon's ranch; Ute; Pingree Hill; Poudre River; Laramie River; Rist Cañon.

2. Rudbeckia laciniata $L$. In wet places from Que. and Ida. to Fla. and Ariz.-Alt. 4000-9500 ft.-Durango; Williams' Cañon; mountains, Larimer Co.; Pagosa Springs; along Uncompahgre River, near Ouray; Ouray; Parlin, Gunnison Co.; Boulder; Ft. Collins; Big Creek Gulch; Bosworth's ranch, Stove Prairie; Elk Cañon; Long Gulch.

3. Rudbeckia ampla A. Nels. On river banks in Wyo. and Colo.-Baxter's ranch; Poudre River flats; Ft. Collins.

4. Rudbeckia montana A. Gray. In the mountains of Colo.-Wolcott, Eagle Co.; Gunnison Co.; Elk Mountains.

\section{RATIBIDA Raf. CONE-FLOWER.}

Disk in fruit oblong, about I cm. long; pappus of $I$ or 2 awn-like teeth without intermediate squamellae.

I. R. Tagetes.

Disk in fruit cylindraceous, $2-4 \mathrm{~cm}$. long; pappus with a series of squamellae.

4. R. columnaris.

1. Ratibida Tagetes (James) Barnhart. (Lepachys Tagetes A. Gray) On plains from Kans. and Colo. to Tex. and Ariz.; also in Mex.-Alt. 40007500 ft.-Cañon City; Iola; Cheyenne Wells.

2. Ratibida columnaris (Sims) D. Don. (Lepachys columnaris T. \& G.) On plains from Sask. and B. C. to Tenn., Tex. and Ariz.; also in Mex.-Alt. 4000-6000 ft.-Ute Pass, near Pike's Peak; Ft. Collins; Denver; Piedra; New Windsor, Weld Co.; Boulder; Horsetooth Gulch.

Ratibiaa columnaris pulcherrima (DC.) D. Don. Rays at least partly purple.-Ft. Collins.

\section{BALSAMORRHIZA Hook. BALSAM-ROOT.}

1. Balsamorrhiza sagittata (Pursh) Nutt. On hillsides from Alb. and B. C. to Colo. and Calif.-Alt. 7000-8000 ft.-Cerro Summit; Cimarron.

49. WYETHIA Nutt.

Involucral bracts nearly equal, in $2-3$ series; stem not white.

Plant glabrous.

Plant densely pubescent.

1. W. anplexicaulis. Involucral bracts unequal, the outer much shorter in 5-6 series; 2 . arizonica.

$$
\text { 3. W. scabra. }
$$

I. Wyethia amplexicaulis Nutt. In mountain valleys from Mont. and B. C. to Colo. and Nev.-Alt. about $9000 \mathrm{ft}$--Rogers; divide road to Steamboat Springs; Honnold; Continental Divide, Routt Co.; Arapahoe Pass; Camp Creek; Spicer.

2. Wyethia arizonica A. Gray. Near mountain streams from Colo, and Utah to Ariz.-Alt. 7000-8000 ft.-Mancos; Cerro Summit; Rifle, Garfield Co.; Los Pinos (Bayfield); Chicken Creek, west of Mt. Hesperus; Dolores; Gunnison Co. 
3. Wyethia scabra Hook. Dry plains from Wyo. to N. M. and Utah.Alt. about $5000 \mathrm{ft}$.La Plata Valley; base of Carisa (Brandegee).

\section{HELIANTHUS L. SUN-FLOWER.}

Annuals; leaves broad, ovate or cordate or lanceolate; disk purple.

Bracts ciliate, hispid, ovate or obovate, abruptly acuminate.

Lower leaves, at least, ovate or cordate, distinctly toothed.

Leaves lanceolate or narrowly deltoid, minutely toothed or entire.

I. H. lenticularis.

2. $H$. aridus.
3. $H$.

Bracts not ciliate, canescent-strigose, lanceolate. $\quad 3$. $H$. petiolaris. Perennials.

Disk dark brown or purple.

Leaves linear.

Leaves rhombic-ovate.

Disk yellow or light brownish.

Bracts broadly lanceolate, acute, appressed. 6 6. Humilus.

Bracts narrowly lanceolate, acuminate, more or less spreading or squarrose. Stem more or less scabrous or hispid; the upper leaves subsessile. Leaves and stem very scabrous. $\quad 7 . H$. Maximiliani.

Leaves scabrous above, hirsute beneath; stem more or less hirsute.

8. H. giganteus.

Stem, except the upper portion, glabrous and glaucous (rarely hirsute with few hairs); leaves mostly all petioled.

Leaves coarsely toothed; bracts hirsute-ciliate. 9. H. grosseserratus.

Leaves distantly and minutely denticulate or subentire; bracts not ciliate or ciliate merely at the base.

Io. H. fascicularis.

1. Helianthus lenticularis Dougl. (H. annus A. Gray, in part; not L.) On plains and in alluvial soil from N. D. and Ida. to Tex. and Ariz.-Alt. 4000$7000 \mathrm{ft} .-$ Cañon City; Valley Spur; Black Cañon; Ft. Collins; valley of Upper Arkansas River; Huerfano Valley, near Gardner; Boulder; Pennock's mountain ranch.

2. Helianthus aridus Rydb. In arid soil from Mont. to Neb. and N. Mex. -Alt. 4000-7000 ft.-Manitou.

3. Helianthus petiolaris Nutt. On dry plains and in waste places from Minn., Sask., Mont. and Ore. to Tex. and Calif.-Alt. 4000-Io,00o ft.-Colorado Springs; Ft. Collins; Boulder; Eldora to Baltimore; Wray.

4. Helianthus orgyalis DC. On plains from Mo. and Colo. to Tex.Southeastern Colorado.

5. Helianthus subrhomboideus Rydb. (H. rigidus A. Gray, in part) On plains from Man., Sask, and Mont. to Colo, and Neb.-Alt. 4000-8000 ft.La Pagosa; mountains, Larimer Co.; near Pagosa Peak; Cheyenne Mountain; Bosworth's ranch, Stove Prairie; Botlder; cañon west of Palmer Lake; Horsetooth Mountain.

6. Helianthus pumilus Nutt. On plains and mountains of Wyo. and Colo. -Alt. 5000-7500 ft.-Idaho Springs; Cañon City; New Windsor; Golden; Trail Glen; Horsetooth Gulch; Boulder; Harden's ranch; foot-hills, Dixon Cañon; hill south of Horsetooth Mountain; Bosworth's ranch, Stove Prairie; gulch west of Pennock's; Spring Cañon.

7. Helianthus Maximiliani Schrad. On prairies and in river valleys from Man. and Wyo. to Tex.-Alt. 4000-7000 ft.-Sterling, Logan Co.; Black Cañon of the Gunnison. 
8. Helianthus giganteus L. In moist ground from Me. and Sask. to Fla., La. and Colo.-Mt. Harvard.

9. Helianthus grosseserratus Martins. On plains and prairies from N. Y. and Wyo. to Pa., Tex. and Colo.-Ft. Collins.

ı. Helianthus fascicularis Greene. ( $H$. giganteus utahensis D. C. Eaton; H. utahensis A. Nelson) In mountain valieys from Ass. and Alb. to Colo. and Ariz.-Alt. 5000-8000 ft.-Gunnison; Parlin, Gunnison Co.; McCoy; Cañon City; Ft. Collins; mountains, Larimer Co.; Cache la Poudre; Boulder.

\section{I. HELIANTHELLA T. \& G.}

Chaffs of the receptacle soft and scarious.

Rays conspicuous; disk-flowers yellowish.

Disk $2-3 \mathrm{~cm}$. in diameter; leaves ovate to lanceolate, thin, not strongly reticulate.

I. $H$. quinquenervis.

Disk less than $2 \mathrm{dm}$. wide; leaves oblanceolate to lineaf, strongly reticulate.

Rays few and scarcely surpassing the dark-purple disk-fiowers. 2. H. Parryi.

Chaffs of the receptacle firm-chartaceous.

4. H. microcephala.

3. H. uniflora.

I. Helianthella quinquenervis A. Gray. Along mountain streams from S. D. and Ida. to Colo.-Alt. 7000-ro,000 ft.-Robinson; Cerro Summit; Mt. Harvard; Moon's ranch; mountains, Larimer Co.; North Park, near Teller; Steamboat Springs; Leroux Park; Buffalo Pass; Four-mile Hill; foot of Michigan Hill; east slope of Rabbit-Ear Range; Bosworth's ranch; Mt. Abram, Ouray; Villa Grove; South Park; near Ironton, San Juan Co.; West Spanish Peak; Marshall Pass; Eldora to Baltimore; Berthoud Pass; Spicer.

2. Helianthella Parryi A. Gray. In the mountains of Colo, N. M. and Ariz.-Alt. 8000-I0,000 ft.-Lat. $39^{\circ}-4 I^{\circ}$; Veta Pass; Ruxton Dell; Artists' Glen; Green Mountain Falls; Marshall Pass.

3. Helianthella microcephala A. Gray. Dry plains of Southern Colo., N. M. and Utah.-Alt.,4500 ft.-San Juan Valley.

4. Helianthella uniflora (Nutt.) T. \& G. On hills and mountains from Mont. and Ida. to N. M. and Utah,-Table Rock.

\section{XIMENESIA Cav.}

I. Ximenesia exauriculata (Rob. \& Greenm.) Rydb. (Verbesina encelioides exauriculata Rob. \& Greenm.) In mountain valleys from Mont. to Tex. and Ariz.-Alt. 5000-9000 ft.-Pass Creek; Cañon City; Colorado Springs; Rocky Ford; Ft. Collins; Pueblo; Mancos; Hotchkiss, Delta Co. ; Huerfano Valley, near Gardner; Salida; Gunnison; Manitou; Boulder; Lafayette; Montrose; Palmer Lake; Buena Vista; Timnath.

53. COREOPSIS L. TICK-SEED.

Leaves once or twice pinnately divided.

Leaves simple.

r. C. tinctoria.

2. C. lanceolata.

1. Coreopsis tinctoria Nutt. Low ground from Man. to Va., Tex., Ariz. and Alb.-Along Platte River, near Denver.

2. Coreopsis lanceolata L. In rich soil from Ont. and Colo, to Fla. and La.-Ft. Collins. 


\section{BIDENS L. Beggar-ticks; Bur-Mlarigold; Spanish Needles.}

Achenes flat, obovate or cuneate; leaves or segments broad.

Leaves pinnately 3-5-foliolate.

Outer bracts $4-8$; achenes nearly black.

Outer bracts I0-I6; achenes brown.

Leaves simple.

Heads discoid, erect; corolla 4-toothed.

Heads radiate, nodding; corolla 5 -toothed.

1. B. frondosa.

2. B. vulgata.

Outer bracts not much longer than the inner; achenes not corky on the angles.

Outer bracts surpassing the rays; achenes with corky angles.

3. B. comosa.

5. B. glaucescens.

Achenes linear, tetragonal; leaf-segments small.

Divisions of the leaves oblong or lanceolate.

Divisions of the leaves linear.

6. B. Bigelovii.

7. B. tenuisecta.

1. Bidens frondosa L. In wet soil from N. B. and Neb. to Fla., Tex. and Colo.-Alt. 4000-5000 ft.-Ft. Collins; Cache la Poudre.

2. Bidens vulgata Greene. In wet ground from Ont. and B. C. to N. C. and Calif.-Alt. 4000-5000 ft.-Ft. Collins.

3. Bidens comosa (A. Gray) Wiegand. (B. connata comosa A. Gray) In wet ground from Mass, and Nebr. to N. J. and Colo-Along Poudre.

4. Bidens prionophylla Greene. In shallow water and wet ground from Ills. and Mont. to Colo.-Alt. about $5000 \mathrm{ft} .-$ Poudre.

5. Bidens glaucescens Greene. (B. chrysanthemoides and B. cernua A. Gray, in part) In wet ground and shallow water from Sask. and Mont. to Kans. and Colo.-Alt. $4000-6000 \mathrm{ft}$-Denver; Colorado Springs; river flats east of Ft. Collins; Poudre River; Table Rock; Tobe Miller's ranch.

6. Bidens Bigelovii A. Gray. Along streams from Colo. to Tex. and Ariz. -Alt. up to $7500 \mathrm{ft}$-Manitou; Engelmann Cañon; Como; Ute Pass.

7. Bidens tenuisecta A. Gray. Along streams from Colo. and Ida. to Tex. and Ariz.; also in Mex.-Alt. 4000-8000 ft.-Engelmann Cañon; Colorado Springs; Buena Vista; Palmer Lake; Ute Creek; Cimarron.

Heads radiate.

\section{THELESPERMA Lể.}

Leaf-segments linear-filiform, I mm. or less wide.

Annual or biennial; outer bracts subulate-linear, more than half as long as the inner.

I. T. trifidum.

Perennial from a root-stock; outer bracts linear-lanceolate, half as long as the inner or less.

Leaf-segments linear, over I $\mathrm{mm}$. wide; plant perennial.

Plant with tap-root, leafy throughout.

2. T. tenue.

Plant with horizontal root-stock, leafy only at the base. 4. T. subrudun.

Heads discoid; perennials with root-stock or woody caudex. 5. T. gracile.

I. Thelesperma trifidum (Lam.) Britton. ( $T$. filifolium A. Gray) On dry plains from Neb. and Colo. to Kans., Tex. and N. M.-Alt. 4000-6000 ft.Colorado Springs; Denver, along Platte River.

2. Thelesperma tenue Rydb. On plains and in mountain valleys of Colo. -Alt. 5000-9000 ft.-Veta Pass; "the plains."

3. Thelesperma intermedium Rydb. On plains, in dry or sandy soil, from Neb. and Wyo. to Colo--Alt. 4000-8000-ft.-Cañon City; Wahatoya Cañon; La Veta. 
4. Thelesperma subnudum A. Gray. On dry plains of Colo, Utah, N. M. and Ariz.-Alt. 4500-7000 ft.-Brantly Cañon, Las Animas Co.; Grand Junction; Cedar Hills; Walsenburg; dry hills about Antonito.

5. Thelesperma gracile A. Gray. On dry plains from Neb. and Colo. to Tex. and Ariz.-Alt. 4000-ro,000 ft.-Colorado Springs; near Boulder; Manitou; New Windsor; Denver; Ft. Collins; between Sunshine and Ward; Fossil Creek; Wray; Raton Range; Poudre River.

56. MAdia Molina. TAR-WeEd.

I. Madia glomerata Hook. In open dry places in the mountains from Sask. and B. C. to Colo.-Alt. 6500-9000 ft.-Valley near Empire; Rabbits-Ear Pass; Cerro Summit; Pagosa Springs; Gunnison Co.; Hubbard Creek; Dale Creek; Steamboat Springs; between Pallas and Sydney; Hotchkiss; Hayden.

\section{Tribe 5. HELENIAE.}

\section{PSILOSTROPHE DC.}

Scales of the pappus one-third as long as the disk-corollas, mostly obtuse; leaves broadly spatulate; rays $8-12 \mathrm{~mm}$. long, indistinctly nerved. I. P. Bakeri.

Scales of the pappus one-half as long as the disk-corollas, acute or acuminate; rays $5^{-8} \mathrm{~mm}$. long, distinctly veined.

2. P. tagetina.

I. Psilostrophe Bakeri Greene. (Riddellia tagetina pumila Jones; P. pumila A. Nels.) On dry plains and hills in Colo. and Utah.-Alt. $5500 \mathrm{ft}$-Uncompahgre Mountains, near Los Pinos; Rifle, Garfield Co.; Grand Junction; Delta Co.; Montrose; Hotchkiss; Palisades.

2. Psilostrophe tagetina (Nutt.) Greene. (Riddellia tagetina Nutt.) On dry plains from Colo. to Tex. and Ariz.-Sources of the Platte.

\section{PERICOME A. Gray.}

I. Pericome caudata A. Gray. In cañons and river valleys from Colo. to Tex. and N. M.; also in Nex.-Alt. 5000-8000 ft.-North Cheyenne Cañon; Manitou; Engelmann Cañon; Colorado Springs; Marshall Pass; Ute Pass.

\section{HYMENOPAPPUS L'Her.}

Throat of the corolla I-I.5 mm. long, not over twice as long as the lobes.

Pappus not hidden by the hairs of the achenes.

Stem permanently densely white-tomentose; achenes silky.

I. H. arenosus.

Stem sparingly grayish-tomentose, glabrate in age; achenes loosely villous. Pappus hidden by the hairs of the achenes, or sometimes none. z. H. cinereus.

Throat of the corolla 3-4 times as long as the lobes. 3. H. filifolites.

Pappus shorter than the corolla-tube; throat of corolla 3-4 mm. long ; plant tall.

Pappus equalling the corolla-tube; throat about $I .5 \mathrm{~mm}$. long; plant dwarf. 5. H. parvulus.

1. Hymenopappus arenosus Heller. On dry hills and plains from Colo. and Utah to N. M.-Alt. 5000-7000 ft.-Arboles; Dolores; hills above Trinidad; Grand Junction; Mancos; Florence. 
2. Hymenopappus cinereus Rydb. ( $H$. ochroleucus Greene) On dry hills and plains of Colo.-Alt. 5000-II,000 ft.-West of Loveland, Larimer Co.; Twin Lakes; Rifle, Garfield Co.; Cimarron; Durango; Walsenburg; mesas near Pueblo; Cucharas Valley, near La Veta; Garden of the Gods; Trinidad; Palmer Lake; across Gunnison River, Grand Junction; mountains about Manitou; Florence; Buena Vista; Colorado Springs.

3. Hymenopappus filifolius Nutt. On dry plains from Sask. and Mont. to Neb., Colo. and Ore.-Alt. 4000-600o ft.-Grand Junction; Apishapa Creek, Otero Co. ; foot-hills, Larimer Co. ; Fit. Collins ; Fossil Creek.

4. Hymenopappus macroglottis Rydb. On dry hills and plains from Colo. to Tex. and Ariz.-Exact locality not given; specimens collected by Fremont.

5. Hymenopappus parvulus Greene. On dry hills of western Colo.-Alt. about 7500 ft.-Gunnison.

6o. LEUCAMPYX A. Gray.

I. Leucampyx Newberryi A. Gray. In cañons of Colo, and N. M.-Alt. 6000-9000 ft.-Pagosa Springs; West Indian Creek; Cimarron.

\section{I. POLYPTERIS Nutt.}

1. Polypteris Hookeriana (T. \& G.) A. Gray. On plains from Neb. and Colo. to Tex.-Alt. $4000-6000 \mathrm{ft} .-$ Golden; Ft. Collins.

\section{PICRADENIOPSIS Rydb.}

I. Picradeniopsis oppositifolia (Nutt.) Rydb. (Bahia oppositifolia Nutt.) In alkaline soil from S. D. and Mont. to Tex. and Ariz.-Alt. 4000-7000 ft. -Foot-hills, Colorado Springs; La Veta; New Windsor; Ft. Collins; Iola; foot-hills west of Ft. Collins; Denver; Cucharas Valley, near La Veta; Gunnison; Boulder; Rocky Ford; Pueblo; near Timnath.

\section{ACHYROPAPPUS H. E. $\mathrm{K}$.}

1. Achyropappus neo-mexicanus A. Gray. (Bahia neo-mexicana A. Gray) In sandy soil from Colo. to N. M. and Ariz, ; also Mex.-Alt. about $8000 \mathrm{ft}$. -Buena Vista; Alamosa.

64. PLATYSCHKUHRIA (A. Gray) Rydb.

Stem scapiform or nearly so; leaves firm, oval to lanceolate. I. P. integrifolia. Stem leafy; leaves thin, oblong.

2. P. oblongifolia.

1. Platyschkuhria integrifolia (A. Gray) Rydb. (Bahia nudicaulis A. Gray; Schkuhria integrifolia A. Gray) In arid regions of Wyo. and Colo.Alt. 4000-5000 ft.-Deer Run; Grand Junction.

2. Platyschkuhria oblongifolia (A. Gray) Rydb. (Bahia oblongifolia A. Gray) In arid regions of Colo. and Utah.-Valley of San Juan.

\section{BAHIA Lag.}

I. Bahia dissecta (A. Gray) Britton. (B. chrysanthemoides A. Gray) Along streams from Wyo. to N. M. and Ariz.-Alt. 6000-9000 ft.-Bosworth's 
ranch; Stove Prairie; Granite; Ouray; Ruxton Park; foot of Mt. Harvard; hills about Box Cañon, west of Ouray; mountains, Larimer Co.; North Cheyenne Cañon; mountains between Sunshine and Ward; Durango; Horsetooth Mountain; foot-hills, Larimer Co.; Elk Cañon; Idaho Springs; Empire; Gray's Peak; Lake City; headwaters of Clear Creek.

\section{CHAENACTIS DC.}

Annuals.

Perennials.

Heads corymbose, short-peduncled; caudex short, erect. 2. C. Douglasii.

Heads solitary, rather long-peduncled; caudex with spreading branches.

Bracts equalling the disk, only slightly tinged with purple. 3. C. pedicularia.

Bracts much shorter than the disk, purplish.

4. C. alpina.

I. Chaenactis stevioides $\mathrm{H}$. \& A. In arid places from Ida. and Nev. to N. M. and Ariz.-Alt. 4000-6000 ft.-Hotchkiss; Rifle; McElmo Cañon; Grand Junction; Delta Co.; Palisades.

2. Chaenactis Douglasii $\mathrm{H}$. \& A. In sandy and rocky places from Mont. and Wash. to Colo. and Calif.-Alt. 6000-9000 ft.-High rocks, Middle Park; North Park; Leroux, Delta Co.; Twin Lakes; Doyle's; Cimarron; headwaters of Sangre de Cristo Creek; Grand River Cañon; piñon belt, north of Mancos; Grayback mining camps and Placer Gulch; Palisades; Elk River, Routt Co.

3. Chaenactis pedicularia Greene. On high mountains of Colo.-Alt. about I ,500 ft.-Como; Little Kate Mine, La Plata Mountains.

4. Chaenactis alpina (A. Gray) Jones. (C. Douglasii alpina A. Gray) On high mountains from Mont, ,to Colo. and Utah._- Colorado."

\section{TETRANEURIS Greene.}

Flowering stems scapiform, leafless.

Leaves densly appressed silky, at least when young.

Leaves not strongly 3 erved on the broadened bases.

Leaves spatulate or oblanceolate, $2-4 \mathrm{~cm}$. long; scape $2-12 \mathrm{~cm}$. high.

Leaves linear or linear-oblanceolate; scape I $2-20 \mathrm{~cm}$. high.

$$
\text { I. T. acaulis. }
$$

2. T. simplex.

Leaves strongly 3 -nerved on the broadened bases, narrowly oblanceolate.

Leaves loosely villous or glabrate.

3. T. trinervata.

Leaves, scapes and involucres decidedly long-villous.

Leaves glabrous or sparingly villous; scape finely pubescent (long-villous only in $T$. Torreyana).

Branches of the caudex copiously villous at the ends, with long, at first white, but later brownish hairs.

Pappus-scales lanceolate, acute; bracts oblong.

Crowns of the caudex copiously villous; scape 5-10 $\mathrm{cm}$. long.

5. T. Torreyana.

Crowns of the caudex not copiously villous; scape $\mathrm{I}-2 \mathrm{~cm}$. high.

Pappus-scales oval, awned.

6. $T$. brevifolia.

Leaves oblanceolate, hairy.

Leaves linear-oblanceolate, or linear-oblong, glabrate

Bracts oval.

7. T. arizonica.

Bracts linear-oblong.

8. T. pilosa.

9. T. Crandallii. 
Branches of the caudex not copiously villous.

Bases of the leaves not broader than the oblanceolate or almost linear blades; branches of the caudex short and stout.

Leaves oblanceolate; bracts slightly shorter than the disk; rays not strongly veined.

Iо. T. glabriuscula.

Leaves linear or oblanceolate-linear; bracts one-fourth shorter than the disk; rays strongly nerved. II. T. angustifolia.

Bases of the leaves $2-4$ times as wide as the linear leaf-blades; branches of the caudex elongated; bases of the leaves and involucres sparingly silky villous.

Stems 2-3 dm. high with 2-4 leaves.

Outer bracts oval or ovate, purple.

Outer bracts linear-oblong or lanceolate, green. I2. T. stenophylla.

I3. T. leptoclada. I4. T. intermedia.

1. Tetraneuris acaulis (Pursh) Greene. (Actinella acaulis Nutt.) On hills and dry plains from Neb., Mont. and Ida. to N. M.-Alt. 4000-6000 ft.Rocky Ford, Otero Co.; Bartlett; mesas near Pueblo; Trinidad; Colorado City.

2. Tetraneuris simplex A. Nelson. On dry hills from S. D. and Ida. to Neb. and Colo.-Crow Creek; Monument.

3. Tetraneuris trinervata Greene. On dry hills from Colo. to Tex.-On the Platte.

4. Tetraneuris lanata (Nutt.) Greene. (Actinella lanata Nutt.) On the mountains of Wyo. and Colo.-Alt. 6000-13,000 ft.-Mountain near Veta Pass; Seven Lakes; Como; West Indian Creek; west slope of Bald Mountain ; Pike's Peak; Central City; Mt. Garfield; mesas near Colorado Springs; Berthoud Pass; Sangre de Cristo Pass; north of La Porte; Pine Grove; James' Peak.

5. Tetraneuris Torreyana (Nutt.) Greene. (A. Torreyana. Nutt.) On rocky hills of Wyo., Colo. and Utah.-Alt. 4000-6500 ft.-Near northern State line.

6. Tetraneuris brevifolia Greene. Exposed mountains near Pike's Peak, Colo.

7. Tetraneuris arizonica Greene. On dry hills from Colo. to Ariz.-Trinidad; Colorado Springs.

8. Tetraneuris pilosa Greene. On dry hills and mountains from Colo. to Ariz.-Alt. about $7000 \mathrm{ft}$. -Los Pinos (Bayfield); Manitou.

9. Tetraneuris Crandallii Rydb. On dry hills of Colo.-Alt. 4000-5000 ft.Grand Junction; McCoy's, Eagle Co. ; Cimarron.

ı. Tetraneuris glabriuscula Rydb. ( $T$. glabra Greene; not Actinella glabra Nutt.) On dry hills from Colo. and Nev. to N. M.-Alt. about $6000 \mathrm{ft}$.Ft. Collins; Cañon City; Red Rock Cañon, near Pike's Peak.

II. Tetraneuris angustifolia Rydb. On dry rocky hills from Colo. to Tex. and N. M.-Alt. up to $7000 \mathrm{ft}$.-Table Rock; Mancos; Ft. Lyon; Arkansas River.

12. Tetraneuris stenophylla Rydb. On dry plains from Kans. and Colo. to Tex.; also Mex.-Banks of Cimarron.

13. Tetraneuris leptoclada (A. Gray) Greene. (Actinella leptoclada A. Gray; T. Mancosensis A. Nels.) On dry hills of Colo. and N. M.-Alt. up to $9000 \mathrm{ft} .-$ Mancos; Leroux Creek, Delta Co.

I4. Tetraneuris intermedia Greene. On dry hills of southern Colo.-Alt. 6500-7000 ft.-Cimarron; Pagosa Springs. 
68. CHAMAECHAENACTIS Rydb.

r. Chamaechaenactis scaposa (Eastw.) Rydb. (Chaenactis scaposa Eastw.) In arid regions of Utah and Colo.-Grand Junction.

\section{RYDBERGIA Greene.}

Involucres densely white-woolly at the base; basal leaves more or less doubly pinnatifid.

Involucres darker, short-villous at the base; leaves simply pinnatifid with few divisions.

2. R. Brandegei.

I. Rydbergia grandiflora (T. \& G.) Greene. (Actinella grandiflora T. \& G.) On high mountain sides from Mont. to N. M. and Calif.-Alt. 9000-I3,500 ft.-Alpine Tunnel; Pike's Peak; Ironton, San Juan Co.; Gray's Peak; Mt. Harvard; Mt. Abram, Ouray; Seven Lakes; mountains south of Ward, Boulder Co.; Little Kate Mine, La Plata Mountains; near Pagosa Peak; Floral Mountain, near Georgetown; mountains above Como; Carson; Cameron Pass; Berthoud Pass; Beaver Creek; mountain northwest of Como; mountains about Graymont; Massif de l'Arapahoe; Hinsdale Co. ; headwaters of Clear Creek; Ethel Peak.

2. Rydbergia Brandegei (A. Gray) Rydb. (Actinella Brandegei A. Gray; Rydbergia glabrata Greene) On high peaks of southern Colo. and N. M.Alt. 9000-I3,000 ft.-West Spanish Peak; Sierra Blanca.

\section{Hymenoxys Cass. Colorado Rubber Plant.}

Plant low, perennial with a multicipal caudex.

Heads mostly solitary at the ends of the branches.

Rays $12-18 \mathrm{~mm}$. long; plant $\mathrm{I}-3 \mathrm{dm}$. high.

Rays 5-8 mm. long; plant less than I dm. high.

Heads mostly corymbose.

Rays orange, broadly cuneate.

Rays yellow, oblong or somewhat cuneate.

ı. H. macrantha.

2. H. pumila.

3. H. Earlei.

4. H. Aloribunda. few stems from a tap-root.

Stem simple below; leaves pinnate or simple; disk over I $\mathrm{cm}$. wide.

5. H. helenioides.

Stem diffusely branched; leaves once to thrice ternate; disk $5-8 \mathrm{~mm}$. wide.

6. H. multiflora.

I. Hymenoxys macrantha (A. Nels.) Rydb. (Picradenia macrantha A. Nels.; H. Richardsonii macrantha Cockerell) In dry soil from Wyo. to Utah and Colo.-Como; South Park.

2. Hymenoxys pumila (Greene) Rydb. (Picradenia pumila Greene; $H$. Richardsonii pumila Cockerell) Very dry hills from Ass, to Colo. and Utah. -North Park.

3. Hymenoxys Earlei Cockerell. In the piñon belt of Colo--Mancos.

4. Hymenoxys floribunda (A. Gray) Cockerell. (Actinella Richardsonii foribunda A. Gray; Picradenia floribunda Greene) In dry or gravelly soil from Colo. to N. M. and Ariz.-Alt. 4000-I0,000 ft.-Como; Buena Vista; Marshall Pass; Placer; Westcliffe; Twin Lakes; Mancos; Gunnison; Sangre de Cristo Creek; Turkey Creek and tributaries; Mt. Harvard; dry plains south of Antonito; Dillon Cañon; Nepesta; Colorado Springs. 
5. Hymenoxys helenioides (Rydb.) Cockerell. (Picradenia helenioides Rydb.) In river valleys of southern Colo.-Alt. $8000-9000 \mathrm{ft}$.-Sangre de Cristo Creek.

6. Hymenoxys multiflora (Buckley) Rydb. (Phileozera multiflora Buckley; Picradenia multiflora Greene) Dry plains from Kans. and Colo. to Tex. and Ariz.; also northern Mex. In Colorado represented by var. Osterhoutii (Cockerell) Rydb. (H. chrysanthemoides Osterhoutii Cockerell).-Apishapa Creek, Otero Co.

7r. FLAVERIA Juss.

I. Flaveria angustifolia (Cav.) Pers. In alkaline soil from Colo. to Tex. and N. M.; also Mex.-Alt. about $4600 \mathrm{ft}$.-Grand Junction.

\section{DUGALDIA Cass.}

I. Dugaldia Hoopesii (A. Gray) Rydb. (Helenium Hoopesii A. Gray) In mountain valleys from Wyo. to N. M. and Calif.-Alt. 7000-I2,000 ft.Mountains above Ouray; Crested Butte; Leroux Creek; Red Mountain; Breckenridge; Veta Pass; Westcliffe; Ironton Park, nine miles south of Ouray; Sangre de Cristo Creek; Grayback mining camps; Ironton, San Juan Co.; along carriage road to Pike's Peak; near Pagosa Peak; Trappers' Lake; Cripple Creek; La Plata Cañon; Gore Pass; Mancos; Leroux Creek delta; Hahn's Peak; Lake City.

\section{HELENIUM L. SNEEZE-WEED.}

I. Helenium montanum Nutt. ( $H$. autumnale A. Gray, in part; not L.) In meadows from Minn., Sask. and Wash. to Miss. and Colo.-Kremmling.

\section{GAILLARDIA Foug.}

Lobes of the disk-corollas acutc.

Lobes of the disk-corollas short and broad, obtuse.

1. G. aristata.

2. G. pinnatifida.

1. Gaillardia aristata Pursh. On hills and plains from Sask. and B. C. to Colo. and Ore.-Ait. 4000-8000 ft.-Glenwood Springs; Larimer Co.; Horsetooth Gulch; Rist Cañon; Westcliffe; Veta Pass; Idaho Springs; foot-hills west of Ft. Collins; Empire; Boulder; Soldier Cañon; Monument; hill northwest of Soldier Cañon; Spring Cañon; Redstone; forks of the Poudre and Big South; Dixon Cañon; Stove Prairie Hill; Narrows; Table Rock.

z. Gaillardia pinnatifida Torr. On dry plains from Colo. to Tex. and Ariz. -Alt. 4000-6000 ft.-Deer Run; Durango; Walsenburg; Grand Junction.

75. BOEBera Willd. Fetid Marigold.

1. Boebera papposa (Vent.) Rydb. (Dysodia chrysanthemoides Lag.) On prairies, river valleys, roadsides and waste places from Ohio and Mont. to Ark. and Ariz.; also Mex.-Alt. 4000-7000 ft.-Cucharas Valley, near La Veta; Ft. Collins; Minnehaha; Boulder; Lyons; Colorado Springs; North Cheyenne Cañon.

\section{LOWELLIA A. Gray.}

1. Lowellia aurea A. Gray. (Hymenatherum aureum A. Gray) On plains from Colo. to Texas.-Rocky Ford, Otero Co.; Cañon City; Pueblo; Huerfano; Colorado Springs; Denver. 


\section{PECTIS L.}

I. Pectis angustifolia Torr. In "sand-draws" and on sandy hillsides from Neb. and Colo. to Tex. and Ariz.-Alt. 4000-I I,00o ft.-Pueblo; Rocky Ford; Little Veta Mountain; Cañon City.

\section{Tribe 6. ANTHEMIDEAE.}

\section{8. anthemis L. May-weed, Fetid Camomile.}

1. Anthemis Cotula L. In fields and waste places from Newf. and Yukon to Fla, and Calif.-Alt, about $5000 \mathrm{ft} .-\mathrm{Ft}$. Collins; Hotchkiss.

\section{ACHILlEA L. YARROW.}

Bracts with light brownish margins.

Bracts with dark brown, nearly black margins.

I. A. lanulosa.

2. A. alpicola.

1. Achillea lanulosa Nutt. On plains and mountains from western Ont. and Yukon to Ind. Terr. and Calif. ; also Mex.-Alt. 4000-I2,000 ft.-Ft. Collins; Arboles; Sangre de Cristo Creek; Cucharas River, below La Veta; Ironton Park, nine miles south of Ouray; along Uncompahgre River, near Ouray; Dark Cañon; Ruxton Brook; Seven Lakes; Gunnison; Cerro Summit; mountains between Sunshine and Ward; Raton Range; Dillon Cañon, Trinidad; Pike's Peak; Steamboat Springs.

2. Achillea alpicola Rydb. (A. lanulosa alpicola Rydb.) On high mountains from Mont. to Colo.-Alt. I I,000-I2,000 ft.-Little Kate Mine, La Plata Mountains; Seven Lakes; Mt. Ouray.

\section{CHRYSANTHEMUM L. OX-Eye Daisy.}

r. Chrysanthemum Leucanthemum L. Naturalized from Europe from Lab. to Fla., Colo. and Mont.-Along Platte River, near Denver.

\section{PICROTHAMNUS Nutt.}

I. Picrothamnus desertorum Nutt. (Artemisia spinescens D. C. Eaton) On arid hills from Mont. and Ida. to N. M. and Calif.-Alt. $4000-6000 \mathrm{ft}$ Palisades, Mesa Co.; Hotchkiss; Grand River Cañon, above Palisades; Delta Co.

\section{ARTEMISIA L. WORMWOOD, SAGE-BrUSH.}

Heads heterogamous, i. e., flowers unlike; disk-flowers hermaphrodite; marginal ones pistillate, truncate, $2-3$-toothed.

Disk-flowers sterile; their styles mostly entire, penicillate; ovary abortive.

Disk-flowers fertile; their styles two-cleft.

I. Dracunculoides. Receptacle with long villous hairs.

Receptacle glabrous.

Annuals or biennials, tall. III. ANNuAe.

Perennials.

Plants not shrubby, except at the base; leaves not cuneate with 3toothed apex.

Plant not at all tomentose; plant low, $\mathrm{x}-3 \mathrm{dm}$. high.

IV. ARCTICAE.

Plant more or less tomentose, at least on the lower surface of the leaves.

Involucres densely tomentose. 
Leaves all entire or the lower merely toothed.

V. Gnaphaloides.

Leaves at least the lower ones pinnately divided or lobed.

Divisions of the leaves not narrowly linear or filiform; margins scarcely revolute.

VI. Diversifoliae.

Divisions of the leaves narrowly linear to filiform; margins revolute.

VIT. Stenophyllae.

Involucres in age glabrous, only slightly tomentose when young.

Plant shrubby; leaves cuneate, 3 -toothed at the apex. VIII. VulGares.

iX. Bigelovianae.

Heads homogamous; $i$.. ., flowers all alike, hermaphrodite and fertile; plants shrubby.

X. Tridentatae.

\section{Dracunculoides.}

Plants frutescent only at the base; heads rather many-flowered, hemispherical, over $1.5 \mathrm{~mm}$. in diameter.

Plants glabrous, at least in age; leaves all, except the lower ones, simple and linear.

Leaves and bracts dark green; heads $3-4 \mathrm{~mm}$. wide; flowers $30-40$, brown.

I. A. aronatica.

Leaves and bracts lighter; heads $2-3.5 \mathrm{~mm}$. wide; flowers yellow or light brown, about 20 . 2. A. dracunculoides.

Plant pubescent; leaves nearly all pinnatifid.

Heads $2-3 \mathrm{~mm}$. wide; bracts glabrous; stem appressed-hairy or glabrate; flowers yellow.

Stem-leaves with $\mathbf{I}-2$ pairs of lateral divisions close at the base, or entire grayish canescent. 3. A. glauca.

Stem-leaves pinnatifid or bipinnatifid with distant divisions, mostly green at least in age.

Stem tall, 5-Io dm. high, very leafy, in age nearly glabrous; divisions of the leaves linear-filiform. 4. A. Scouleriana.

Stem lower, 2-6 dm. high; divisions of the basal leaves linear-oblanceolate, more or less canescent.

5. A. Forwoodii.

Heads 4-5 mm. wide; bracts and stem at least when young with long silkyvillous loose hairs; flowers brown.

Plant shrubby; heads few-flowered, I-I.5 mm. in diameter; divisions of the leaves filiform.

\section{Frigidae.}

Heads numerous, 4-5 mm. wide; bracts light brown; plants usually comparatively tall, 3-8 dm. high. 8 . A. frigida.

Heads few, 6-12 mm. in diameter; bracts with dark brown or blackish margins; plant low, I-2 dm. high.

Heads several, spicately or racemosely disposed; corolla pubescent; basal leaves and lower stem-leaves bipinnatifid.

9. A. scopulorum.

Heads solitary or $2-4$ in a close cluster; corolla glabrous or nearly so; basal leaves pinnatifid with short divisions.

ı. A. Pattersonii.

\section{Annuae.}

One species.

IV. ARCTICAE.

Plant pubescent.

Plant glabrous.

V. Gnaphaloines.

Leaves in age glabrate above.

Leaves permanently tomentose on both sides.

II. A. biennis.

Heads erect, peduncled, 4-5 mm. wide; flowers brown. 15. A. natronensis.

Heads nodding or spreading, $4 \mathrm{~mm}$. or less wide. 
Heads distinctly pedicelled, nodding, on lax racemiform branches.

Heads subsessile, conglomerate on short branches.

Heads 3-4 mm. wide; flowers dark or purplish brown.

Heads $z-3 \mathrm{~mm}$. wide; flowers light brown.

I7. A. rhizomata.

Leaves lanceolate.

Leaves linear or nearly so.

18. A. gnaphaloides. 19. A. pabularis.

Vi. Diverstfoliae.

Leaves in age greenish and more or less glabrate above.

Lower leaves more or less cuneate-oblanceolate, lobed above the middle with lanceolate lobes; upper leaves entire; plant usually cespitose.

20. A. ludoviciana.

Leaves nearly all deeply pinnatifid, with linear or linear-lanceolate lobes. 21. A. Underwoodii.

Leaves permanently and almost equally white-tomentose on both sides.

Lower leaves cuneate or cuneate-oblanceolate, 3-lobed (more seldom 5-lobed) above the middle with lanceolate lobes. 22. A. Brittonii.

Lower leaves deeply pinnatifid with long linear or linear-lanceolate lobes. 23. A. diversifolia.

\section{Vit. Stenophyilae.}

Leaves in age glabrate above; inflorescence lax.

Heads erect; divisions of the leaves filiform.

Heads nodding; divisions of the leaves narrowly linear.

24. A. Wrightii.

25. A. Bakeri.

Leaves permanently white-tomentose on both sides; heads crowded.

Leaves, at least the lower ones, with linear rather short divisions.

Leaves with filiform divisions. 26. A. coloradensis. 27. A. kansana.

VIII. Vulgares.

Divisions of the leaves broad, lanceolate or oblong.

Leaves, except the uppermost, twice pinnatifid with obtusish lobes, glabrous or minutely appressed canescent beneath.

28. A. fraserioides.

Leaves, except sometimes the lowermost, once pinnatifid, with acute or acutish lobes, or the upper entire, white-tomentose beneath.

Tall, 6-1o dm. high; upper leaves entire; the rest simply pinnatifid.

29. A. elatior.

Lower, 2-6 dm. high; all leaves pinnatifid; the lower often twice pinnatifid.

Divisions of the leaves narrowly linear-lanceolate or linear.

3o. A. incompta.

\section{Bigelovianae.}

3. A. discolor.

One species.

\section{Tridentatae.}

32. A. Bigelovii.

Leaves nearly all trifid or tridentate at the apex.

Divisions of the leaves mostly long, narrowly linear, sometimes almost filiform; heads about $2 \mathrm{~mm}$. wide.

Divisions or teeth of the leaves short, ovate or oblong.

Heads $2-3 \mathrm{~mm}$. wide.

Bracts densely tomentose; inflorescence rather congested.

Shrub tall; inflorescence much branched; heads about $2 \mathrm{~mm}$. wide. 34. A. tridentata.

Shrub dwarf; inflorescence rather simple and spike-like; heads $3 \mathrm{~mm}$. wide.

35. A. arbuscula.

Bracts of the involucres almost glabrous; inflorescence lax, racemiform. 36. A, nova. 
Heads about $5 \mathrm{~mm}$. wide; outer bracts only tomentose; inflorescence racemeor spike-like. 37. A. spiciformis.

Leaves all linear, entire, acute, or rarely a few of them 3 -cleft at the apex; heads $3-4 \mathrm{~mm}$. wide in a compact inflorescence.

Leaves permanently canescent, not viscid.

Leaves, at least in age, glabrate, more or less viscid. 39. A. viscidula.

1. Artemisia aromatica A. Nels. In mountain valleys from Alb. and Wash. to Colo.-Alt. up to 9000 ft.-Breckenridge; Ironton Park, nine miles south of Ouray.

2. Artemisia dracunculoides Pursh. On prairies and plains from Mont. and Ida. to Tex. and Calif.-Alt. 5000-8000 ft.-Below Hot Sulphur Springs; Middle Park; Ft. Collins; Iola; Huerfano Valley, near Gardner; Table Rock; Elk River; Democrat Mountain.

Artemisia dracunculoides Wolfii Rydb. Heads larger with lanceolate bracts. In mountain valleys of Wyo. and Colo.-Alt. 7000-9000 ft.-Hamor's Lake, north of Durango; Grizzly Creek; Honnold; Twin Lakes; Colorado Springs.

3. Artemisia glauca Pall. On plains from Man. and Ass. to Nebr. and Colo.-Golden.

4. Artemisia Scouleriana (Besser) Rydb. (A. desertorum Scouleriana Besser) In valleys from B. C. to Colo.-Alt. 5000-10,000 ft.-New Windsor; Ruxton Dell; Denver.

5. Artemisia Forwoodii S. Wats. (A. desertorum Besser, in part; A. Canadensis A. Gray, in part; not Michx.) On plains and hills from Ass. and Mont. to N. M.-Alt. 5000-7500 ft.-Iola; Mt. Harvard; Baxter's ranch; Redstone; foot-hills, Larimer Co.; Boulder; Pine Grove; Ft. Collins; Cipango Hill; Lake City; Cheyenne Mountain; South Park.

6. Artemisia spithamaea Pursh. (A. borealis A. Gray, in part; not Pall) On alpine peaks and in arctic regions from Lab. to Alaska and Colo--Alt. II,000-I2,500 ft.-Cameron Pass; Gray's Peak; mountains about the headwaters of Clear Creek; Cumberland Mine, La Plata Mountains; Berthoud Pass; near Empire.

7. Artemisia filifolia Torr. On plains from Neb. and Wyo. to Tex. and Ariz.; also Mex.-Alt. 4000-5500 ft.-Cheyenne Wells; New Windsor; near Denver; near Timnath; plains of the Platte.

8. Axtemisia frigida Willd. On dry hills from Hudson Bay to Alaska, Tex. and Utah.-Alt. 4000-I0,000 ft.-Chambers' Lake; Pagosa Springs; Boulder; Graymont; Bosworth's ranch, Stove Prairie; Iola; Mt. Harvard; Cucharas Valley; near La Veta; Denver; Colorado Springs; mountains of Larimer Co.; dry hills, Lake John, North Park; Manitou; Gunnison; Twin Lakes; Middle Park; Ft. Collins; Golden; Lake City.

9. Artemisia scopulorum A. Gray. On high mountain peaks from Wyo. to Colo. and Utah--Alt. II,000-I4,000 ft.-Near Ironton, San Juan Co.; headwaters of Clear Creek; Pike's Peak; Seven Lakes; Gray's Peak; Cumberland Mines, La Plata Mountains; mountains above Como; mountains south of Ward; Mt. Garfield; Alpine Tunnel; Franklin; Beaver Creek; Boreas.

ro. Artemisia Pattersonii A. Gray. On alpine peaks of Colo.-Alt. I I,000I3,500 ft.-Summit of Mt. Garfield; west slope of Bald Mountain; Bottomless Pit; Seven Lakes; Saddle, Pike's Peak; Gray's Peak.

II. Artemisia biennis Willd. In wet places from N. S. to Mackenzie, 25 
Pa. and Calif.-Alt. 5000-9000 ft.-Honnold; Higho; Ft. Collins; Cucharas Valley, near La Veta; Middle Park; Poudre River.

12. Artemisia saxicola Rydb. (A. Chamissoniana saxatilis Besser; $A$. Norvegica A. Gray; not Fries) On the higher rockies of Colo. and Wyo.Alt. II,000-I3,000 ft.-Gray's Peak; Silver Plume; Long's Peak; Cameron Pass; Mt. Harvard; Berthoud Pass; headwaters of Clear Creek; Empire; Ethel Peak.

13. Artemisia Parryi A. Gray. On alpine peaks of Colo.-Sangre de Cristo Pass.

14. Artemisia silvicola Osterh. In the mountains of Colo. and N. M.Alt. about 8000 ft.-McIntyre Creek, Larimer Co.; near Pagosa Peak.

15. Artemisia natronensis A. Nels. In valleys of Wyo. and Colo-Alt. 7000 ft.-Cucharas Valley, near La Veta.

16. Artemisia pudica Rydb. On dry ground in the mountains of Colo.Alt. about $7700 \mathrm{ft}$-Gunnison.

17. Artemisia rhizomata A. Nels. In valleys from Alb. and Ida. to Colo. -Alt. 8000-10,000 ft.-Ruxton Park; Ruxton Dell; Columbine; Pitkin; Bosworth's ranch, Stove Prairie.

18. Artemisia gnaphaloides Nutt. On prairies and river banks from N. D. and Wyo. to Ark, and Colo.; also introduced eastward to Ont. and N. Y.Alt. 4000-9000 ft.-Gunnison; on Grizzly Creek; Trail Glen; Ft. Collins; Bosworth's ranch, Stove Prairie; above Poudre; Middle Park; Denver; New Windsor; Larimer Co.; Colorado Springs.

19. Artemisia pabularis (A. Nels.) Rydb. (A. rhizomata pabularis A. Nels.) In dry valleys from Neb. and Wyo. to Colo.

20. Artemisia ludoviciana Nutt. On prairies and in cañons from Mo. and Wyo. to Tex. and Ariz.-Alt. 4000-8000 ft.-Idaho Springs; Engelmann Cañon; Manitou; between Porter and Durango; near Empire.

21. Artemisia Underwoodii Rydb. On chaparral-covered hills and mountain sides in Colo.-Alt. 7500-9000 ft.-Ouray; Georgetown.

22. Artemisia Brittonii Rydb. Dry hills and plains of Colo. and Utah.Alt. 5000-9000 ft.-Boulder; Empire; Golden; Poudre River flats.

23. Artemisia diversifolia Rydb. In valleys from Ida. and B. C. to Colo. and Wash.-Pike's Peak.

24. Artemisia Wrightii A. Gray. On dry plains of Colo. and N. M.Southern Colorado; exact locality not given.

25. Artemisia Bakeri Greene. On dry plains and in cañons from Colo. to N. M. and Ariz.-Alt. up to $7000 \mathrm{ft}$-Black Cañon; between Porter and Durango.

26. Artemisia coloradensis Osterh. In mountain valleys from Colo. to Ariz.-Alt. 7000-10,000 ft.-Dale Creek, Larimer Co.; Marshall Pass; Pine Grove; Rustic; Soldier Cañon; San Luis Valley; Lake City.

27. Artemisia kansana Britton. (A. stenoloba Rydb.) On dry plains from Kans. and Colo. to N. M.-Alt. 4000-7000 ft.-Cucharas Valley, near La Veta.

28. Artemisia fraserioides Greene. In the mountains from Colo. to N. M. and Mex.-Alt, about gooo ft.-Near Pagosa Peak; Roubadeaux Pass; Lake City.

29. Artemisia elatior (T. \& G.) Rydb. In mountain valleys from Macken- 
zie and Alaska to Colo.-Alt. about $8000 \mathrm{ft} .-$ Red Mountain, south of Ouray. 30. Artemisia incompta Nutt. Hillsides from Mont. to northern Colo.Anita Peak.

3I. Artemisia discolor Dougl. In the mountains from Alb. and B. C. to Colo., Utah and Wash.-Lake City.

32. Artemisia Bigelovii A. Gray. On dry plains from Colo. to Tex, and Ariz.-Arkansas River.

33. Artemisia tripartita Rydb. (A. trifida Nutt.) On plains and hills from Mont. and Wash. to Colo. and Ore-Exact locality not given.

34. Artemisia tridentata Nutt. On dry plains (sage plains) from Neb., Mont. and B. C. to Colo. and Calif.-Alt. 4000-9500 ft.-Grand River, Sheepshorn road; Grand River, near State Bridge; Montrose; Pitkin; Gunnison; Steamboat Springs; near Empire; Upper Laramie River; Cimarron; Durango; Sangre de Cristo Creek; Hotchkiss; Breckenridge.

35. Artemisia arbuscula Nutt. On dry mountains and high plains from Wyo. and Ore. to Colo, and Calif.-Hayden flats, Routt Co.

36. Artemisia nova A. Nels. On high plains of Colo. and Wyo.-Alt. about $7700 \mathrm{ft}$-Gunnison.

37. Artemisia spiciformis Osterh. On dry plains of Colo. and Utah.-Alt. about $9000 \mathrm{ft}$.-West side of North Park; Crested Butte.

38. Artemisia cana Pursh. On dry plains and hills from Sask, and Mont. to Colo.-Alt. 4000-Io,000 ft.-Breckenridge; Marshall Pass; west of Hebron ; Hayden flats, Routt Co.; Timnath.

39. Artemisia viscidula (Osterh.) Rydb. (A. cana viscidula Osterh.) On dry plains of Wyo. and Colo.-Steamboat Springs.

\section{Tribe 7. SENECIONEAE.}

\section{PETASites Tourn. Sweet Coltsfoot.}

1. Petasites sagittata (Pursh) A. Gray. In wet ground from Lab. and Alaska to Minn. and Colo.-Alt. 8000-10,000 ft.-Eldora to Baltimore; Georgetown.

\section{HAPLOESTES A. Gray.}

I. Haploestes Greggii A. Gray. On dry plains from Kans. and Colo. to Tex. and N. M.--Southeastern Colorado; exact locality not given.

\section{ARNICA L.}

Heads radiate.

Basal leaves and lower stem-leaves with cordate or broadly ovate blades and slender petioles.

Achenes glabrous or glandular puberulent; rarely with a few silky hairs above.

Achenes densely hirsute or strigose.

I. A. platyphylla.

Blades of the leaves broadly oval; the basal ones with short petioles.

2. $A$. silvatica.

Basal and lower stem-leaves with long petioles and usually cordate bases; involucres and peduncles more or less villous, slightly glandular.

Plant $I_{-2} \mathrm{dm}$. high; leaves thick, usually entire. 3. A. pumila.

Plant 2-4 dm. high; leaves thin, usually toothed. 4. A. cordifolia.

Basal leaves with spatulate, oblanceolate or lanceolate blades. 
Stem leafy and usually with several heads; stem-leaves not much reduced.

Leaves grayish, densely villous or tomentulose.

Pubescence of the leaves soft and villous.

Leaves broadly oblanceolate or lanceolate.

Leaves linear or linear-lanceolate.

5. A. rhizomata.

Pubescence of the leaves very short and fine; leaves linear-lanceolate.

Leaves green, not densely pubescent.

Plant sparingly hirsute or glabrate; leaves usually broad.

Involucres and peduncles pilose or villous, not at all glandular or viscid. Stem tall, 4-6 dm. high; involucres hemispherical.

8. A. macilenta.

Stem low, 1.5-3 dm. high, few-leaved; involucre turbinate or campanulate.

Involucres and peduncles hirsute and glandular.

Bracts oblanceolate.

Bracts linear-lanceolate

Plant minutely glandular puberulent; leaves linear-lanceolate.

9. A. Rydbergii.

II. A. coloradensis.

I2. A. subplumosa.

13. A. longifolia.

Stem with a few more or less reduced leaves and usually a single head.

Basal leaves not with a tuft of brown hairs at the bases.

Involucres turbinate, as well as the peduncles densely villous, scarcely at all glandular; stem glabrous or nearly so below.

Leaves strongly 3-nerved.

Leaves faintly 3 -nerved.

9. A. Rydbergii.

I0. A. tenuis.

Involucres hemispherical, as well as the peduncles more or less glandular; stem pubescent throughout.

Involucres densely hirsute and glandular.

Stem-leaves linear.

Stem-leaves ovate-lanceolate.

Involucres glandular-puberulent.

Basal leaves with a dense tuft of brown hairs at their bases.

Leaves linear.

Leaves oblong, lanceolate or oblanceolate.

Heads discoid.

I4. A. fulgens.
II. A. coloradensis.
7. A. celsa.

I5. A. pedunculata.

16. A. monocephala.

I7. A. Parryi.

i. Arnica platyphylla A. Nels. In the mountains of Mont. and Ida. to Colo.-Ragged Mountain.

2. Arnica silvatica Greene. On wooded mountains from Mont. to Colo.Alt. 9000-12,000 ft.-Ruby; Mt. Bartlett; Robinson.

3. Arnica pumila Rydb. (A. parvifolia Greene) On the mountains from Wyo. to Colo. and Utah.-Alt. 8000-Ir,000 ft.-Westcliffe; hills about Box Cañon, west of Ouray; Red Mountain, south of Ouray; Veta Pass; Valley Spur; Mt. Hesperus; Marshall Pass; Gray's Peak.

4. Arnica cordifolia Hook. On wooded hills from Mont. and B. C. to Colo. and Calif.-Alt. 6000-II,00o ft.-Rist Cañon; mountains about Ouray; foothills, Larimer Co.; Bear Creek divide, west of Mt. Hesperus; Silver Plume; near Pagosa Peak; Wahatoya Cañon; mountain near Veta Pass; East Indian Creek; Chambers' Lake; foot-hills west of Ft. Collins; Silverton; Lake Moraine; Cañon City; Tennessee Pass, Lake Co.; Carson; Villa Grove; Eldora to Baltimore; Berthoud Pass; between Sunshine and Ward; Stove Prairie Hill; Horsetooth Gulch; Long Gulch; Clear Creek Cañon; Massif de l'Arapahoe; near Denver; Lake City.

5. Arnica rhizomata A. Nels. (A. lanulosa Greene) In valleys from Mont. and Ida. to Colo.-Alt. 8000-Ir,000 ft.-Banks of Elk River, Routt Co.; on Grizzly Creek; Marshall Pass; Robinson; below Grand Lake; Twin Lakes; Crested Butte. 
6. Arnica foliosa Nutt. In valleys from Mont. to Colo-Alt. 8000-10,000 ft.-Silverton; alkali meadow, Higho; Sargent; Parlin.

7. Arnica celsa A. Nels. In valleys from Wyo. to Colo.--Estes Park, Larimer Co.; Iola; Grizzly Creek.

8. Arnica macilenta Greene. In valleys of Wyo. and Colo.-Alt. about 8000 ft.--Steamboat Springs; Andrews' Shetland ranch.

9. Arnica Rydbergii Greene. On hills from Mont. to Colo.-Alt. 8000-12,000 ft.-Lula Pass, Larimer Co.; Silver Plume; Cameron Pass; Eldora to Baltimore; Hahn's Peak; summit of North Park Range.

Io. Arnica tenuis Rydb. In the mountains of Colo. and Wyo.-Alt. 900012,000 ft.-Beaver Creek.

II. Arnica coloradensis Rydb. In the mountains of Colo.-Exact locality not given.

12. Arnica subplumosa Greene. (A. Chamissonis longinodosa A. Nels.) In meadows from Mont. to Colo.-Alt. I0,000-I2,000 ft.-Mountains above Ouray; Marshall Pass; mountains east of North Park; Silver Plume; Breckenridge; Mt. Harvard; Berthoud Pass; Buffalo Pass; Chambers' Lake; Gray's Peak; Fish Creek Falls.

13. Arnica longifolia D. C. Eaton. ( $A$. polycephale A. Nels.) In meadows from Mont. and Wash. to Colo. and Calif.-Alt. Io,00o ft.-Keblar Pass; Ethel Peak.

14. Arnica fulgens Pursh. On hills from S. D., Alb. and B. C. to Colo. and Calif.-Alt. 8500 ft.-Empire; Pinkham Creek.

I5. Arnica pedunculata Rydb. On hills from N. D. and Wash. to Colo. and Calif.-Alt. 6000-10,000 ft.-Vicinity of Como; Clear Creek; Estes Park; Horsetooth Gulch; foot-hills, Larimer Co.; gulch south of Boulder; Table Rock; Dixon Cañon; Rist Cañon.

r6. Arnica monocephala Rydb. On hills from Mont. and Ida. to Colo.Alt. 6000-12,000 ft.-Dale Creek, Larimer Co.; Horsetooth Mountain; Berthoud Pass.

I7. Arnica Parryi A. Gray. ( $A$. eradiata (A. Gray) Heller) In the mountains from Mont. and B. C. to Colo. and Wash.-Alt. 9000-13,500 ft.Gore Pass; sources of Leroux Creek; continental divide, Routt Co.; Little Kate Mine, La Plata Mountains; Cameron Pass; Mt. Harvard; Silverton; Silver Plume; Rogers; Buffalo Pass; Berthoud Pass; Caribou; headwaters of Clear Creek; Rabbit Ears, Larimer Co. ; Hahn's Peak.

\section{SENECIO L.}

Heads more or less nodding.

Heads discoid.

Heads radiate.

I. Pudicr.

II. Amplectentes.

Heads not nodding.

Heads over I $5 \mathrm{~mm}$. high and $20 \mathrm{~mm}$. broad, solitary (seldom $2-3$ ).

Heads less than $15 \mathrm{~mm}$. high and broad.

II. AMPLECTENTES.

Plants equally leafy throughout.

Leaves or their divisions not narrowly linear or filiform.

Leaves merely toothed and entire, not pinnatifid.

Leaf-blades oval, elliptic or obovate, usually obtusish; heads few.

III. Occidentales.

Leaf-blades triangular or ovate to linear-lanceolate, distinctly acute; heads usually many. 
Leaf-blades at least the lower ones triangular or cordate.

Leaf-blades neither triangular nor cordate. Plant tall, 5-I5 dm. high; heads numerous.

Plant low, 2-4 dm. high; heads few. Heads radiate. Heads discoid.

Leaves pinnatifid.

Leaves or their divisions linear-filiform.

IV. Triangulares.

lants with the stem-leaves more or less reduced upwards.

Rootstock very short, erect, of short duration, with numerous fleshyfibrous roots; leaves dentate or entire.

Tall bog-plant, 5-I $5 \mathrm{dm}$. high; basal leaves long-petioled.

VIII. HYDROPHILI.

Meadow or wood plants, $2-5 \mathrm{dm}$. high; basal leaves comparatively shortpetioled.

Leaves sharply and densely dentate.

VI. Crassuli.

Leaves entire-margined or denticulate, seldom sinuate-dentate.

Rootstock better developed, horizontal or ascending, woody.

IX. INTEGERRIMI.

Stem leafy, more than $2 \mathrm{dm}$. high.

Stem stout; rootstock not cespitose; leaves callous denticulate or saliently dentate.

Heads discoid; leaves saliently dentate.

Heads radiate; leaves callous denticulate. Leaves glabrous.

Leaves tomentose.

VII. RapifoliI.

$\mathrm{X}$. Glaucentes.

XI. Atrati.

Stem slender; rootstock usually more or less cespitose; leaves neither callous-denticulate nor saliently and closely dentate; stem-leaves in the larger forms usually pinnatifid.

Basal leaves entire, more or less white-tomentose.

XII. Cani.

Basal leaves, at least most of them, toothed or pinnatifid.

Leaves and stem more or less loccose, tardily becoming glabrate.

XIII. TOMENTOSI.

Leaves and stem glabrous or slightly floccose when young.

Stem subscapose, less than $2 \mathrm{dm}$. high. XIV. AUREI.

XV. ANDicolae.

\section{Pudici.}

Heads $12-20 \mathrm{~mm}$. high, broadly campanulate.

Mid-vein of the leaves long-villous.

Mid-vein of the leaves not villous.

Involucre green; plant more or less hairy.

Involucres purple; plant glabrous.

Heads 8-10 mm. high, narrowly campanulate.
I. S. scopulinus.
2. S. chloranthus.
3. S. contristatus.
4. S. pudicus.

\section{Amplectentes.}

Stem-leaves clasping; stem over $15 \mathrm{~cm}$. high.

Stem-leaves not clasping, usually short-petioled.

Stem $3 \mathrm{dm}$. or more high, leafy.

Stem less than $2 \mathrm{dm}$. high.

Basal leaves gradually tapering into the petioles.

Plant glabrous or nearly so; leaves dentate; bracts oblong.

Plant arachnoid; leaves runcinate; bracts narrowly lanceolate.

5. S. amplectens.

6. S. pagosanus.

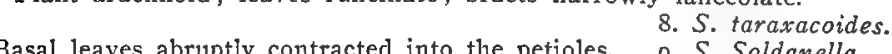

Basal leaves abruptly contracted into the petioles. 9. S. Soldanella. 


\section{iII. Occidentales.}

Plant 2-3 dm. high; stem-leaves obovate or oblong, clasping.

Plant very leafy; involucres about $2 \mathrm{~cm}$. broad, short-peduncled or subsessile; achenes strigose. Io. S. carthamoides.

Plant less leafy; involucres about I $5 \mathrm{~mm}$. broad, distinctly peduncled; achenes glabrous.

I I. S. blitoides.

Plant about I $\mathrm{dm}$. high; stem-leaves spatulate or ovate, not clasping. 12. S. invenustus.

IV. TRIangulares.

One species. 13. S. triangularis.

\section{Serrae.}

Heads I 2-I $5 \mathrm{~mm}$. high; disk 8-I $5 \mathrm{~mm}$. broad; whole plant dark green. 14. S. admirabilis.

Heads 8-Io mm. high; disk 5-6 mm. broad; plant light green. I5. S. serra.

\section{Vi. Crassuli.}

Stem-leaves linear or linear-lanceolate.

Stem-leaves ovate or ovate-lanceolate.

Leaves-firm; bracts thick and fleshy.

Leaves thin; bracts not very thick.
16. S. lapathifolium.

I7. S. crassulus.

18. S. semiamplexicaulis.

\section{RAPIFOLII.}

One species.

VIII. HydRophili.

Onę species.

19. S. rapifolius.

20. S. hydrophilus.

\section{INTEGERRIMI.}

Bracts without black tips; leaves entire-margined.

Bracts usually black-tipped; leaves more or less dentate or denticulate.

Bracts of the involucres narrowly linear-lanceolate, long attenuate.

Leaves thick; basal ones obovate, dentate. 22. S. Hookeri.

Leaves thin; basal ones oblanceolate or spatulate, merely denticulate.

23. S. dispar.

Bracts of the involucres linear or oblong, rather abruptly acute, with lanceolate or triangular tips.

Basal leaf-blades orbicular to broadly oval, rather abruptly contracted into the petioles.

24. S. Flintii.

Basal leaf-blades spatulate to linear-oblanceolate or rarely lanceolate, gradually tapering into the petioles.

Inflorescence even in age a flat-topped corymb; leaves more or less dentate.

25. S. coiumbianus.

Inflorescence with a short-peduncled terminal head and the lateral ones usually very long-peduncled; leaves merely callous denticulate.

Basal leaves thick; their petioles shorter than the blades.

26. S. perplexus.

Basal leaves thin; their petioles usually longer than the blades.

$$
\text { 23. S. dispar. }
$$

\section{Giaucentes.}

One species.

27. S. anacletus.

\section{Atrati.}

Bracts broadly linear, abruptly acute.

Bracts narrowly linear, long-acute.
28. S. atratus.

29. S. milliflorus.

XII. Cani.

Heads 7-8 mm. high.

Heads $\mathrm{I} \mathrm{cm}$. or more high. 3o. S. Purshianus.

3I. S. Harbourii. 


\section{XiII. Tomentosi.}

Basal leaves mostly dentate or crenate.

Basal leaves obovate or spatulate.

Lower stem-leaves acute; plant dark green.

Lower stem-leaves obtuse; plant yellowish-green.

Basal leaves lanceolate or oblanceolate.

Basal leaves narrowly oblanceolate, serrate.

Basal leaves lanceolate, sinuate-dentate.

32. S. plattensis.

53. S. flavulus.

33. S. salicinus.

34. S. canovirens.

Some of the basal leaves entire or dentate, the rest pinnatifid or pinnately lobed.

Plant conspicuously rosulate-stoloniferous; stem-leaves sinuately round-lobed.

35. S. rosulatus.

Plant not stoloniferous; stem-leaves pinnatifid with toothed lobes.

All leaves pinnatifid with toothed segments.

32. S. plattensis.

Caudex subligneous; plant tomentose; bracts shorter than the disk.

Leaves mostly flat and deeply pinnatifid.

Leaves very crisp with short-rounded lobes.

36. S. Fendleri.

Caudex not subligneous; plant glabrate.

37. S. lanatifolius.

38. S. multilobatus.

XIV. AureI.

Basal leaves pinnatifid.

Basal leaves not pinnatifid.

Heads radiate.

Leaves thick, more or less fleshy.

Basal leaves narrowly oblanceolate.

Plant low, less than $2 \mathrm{dm}$. high, often with several stems from the base; basal leaves short-petioled.

Cyme dense; upper leaves generally pinnatifid with narrow lobes.

39. S. condensatus.

Cyme more open; stem-leaves entire or merely crenate.

Basal leaves subentire or 3 -toothed at the apex.

Basal leaves crenate.

Plant 3-6 dm. high; basal leaves I dm. or more.

40. S. tridenticulatus.

4I. S. oblanceolatus.

42. S. longipetiolatus.

Basal leaves cuneate, spatulate, broadly oblanceolate or orbicular, subentire at the base.

Lower stem-leaves spatulate with a broad-winged petiole; upper ones sessile and with much enlarged bases. 43. S. crocatus.

Stem-leaves neither broad-winged nor with much enlarged bases.

All leaves large, broadly obovate, coarsely toothed.

44. S. oodes.

Upper stem-leaves reduced, either pinnatifid or very narrow.

Basal leaves crenate above the middle.

Basal leaves sharply dentate or serrate above the middle.

Leaves thin.

46. S. subcuneatus.

Earliest basal leaves cordate or reniform, rarely ovate.

Basal leaves entire or merely wavy.

Stem-leaves pinnatifid with dilated auricled bases; rays orange or red.

47. S. pyrrochrous.

Stem-leaves entire or nearly so, not auricled; rays yellow.

Basal leaves serrate or crenate.

48. S. Tracyi.

Basal leaves usually coarsely serrate; heads 8-ro mm. high.

Basal leaves small, crenate; heads $8 \mathrm{~mm}$. or less high. 50. S. Hartianus.

Basal leaves obovate or oval, crenate or sinuate-dentate. 
Stem-leaves lanceolate or oblanceolate in outline, with narrow segments. 53. S. Havulus.

Stem-leaves spatulate or oblanceolate in outline, with short and broad Heads discoid. segments. $5 \mathrm{I}$. S. mutabilis.

First basal leaves reniform.

None of the leaves reniform.

Plant yellowish or light green, 3-5 dm. high.

Plant dark green, about I.5 dm. high. XV. Andicolae.

52. S. nephrophyllits.

53. S. flavulus.

54. S. fedifolius.

Blades of the basal leaves reniform, orbicular, obovate or cuneate; toothed at least at the apex, obtuse.

Rays golden yellow.

55. S. petrocallis.

Rays pale-yellow.

Involucre hemispherical to campanulate.

Flowering stems about $2 \mathrm{dm}$. high; heads 9-10 $\mathrm{mm}$. high; basal leaves crenate-serrate, except at the very base.

56. S. cognatus.

Flowering stems less than $1.5 \mathrm{dm}$. high; heads $10-12 \mathrm{~mm}$. high.

Heads several; leaf-blades obovate or ovate, slightly tomentose.

57. S. pentodontus.

Heads solitary; leaf-blades reniform, glabrous. 58. S. Porteri. Involucre turbinate.

59. S. turbinatus.

Blades of the basal leaves elliptical to linear, entire or very rarely some of them 3-toothed at the apex, actute.

Leaves elliptic; heads about I cm. high.

6o. S. perennans.

Leaves narrowly oblanceolate; heads $7-8 \mathrm{~mm}$. high or the central one rarely I $\mathrm{cm}$.

6I. S. zerneriaefolius.

\section{ERIMOPHILI.}

One species.

62. S. MacDougalii.

XVII. LONGILOBI.

Plant more or less permanently tomentose.

Plant glabrous, at least in age.

63. S. filifolius.

Leaves, except those of the branches, pinnately divided.

Heads campanulate; bracts I2-I 5 .

Heads almost cylindrical; bracts 8-10.

64. S. Riddellii.

65. S. multicapitatus.

Leaves entire, linear-filiform or some rarely with a pair of filiform lobes.

66. S. spartioides.

I. Senecio scopulinus Greene. (S. Bigelovii Hallii A. Gray) In the mountains of Colo. and Wyo.-Alt. 8000-I0,000 ft.-North Park; Parlin; Veta Pass; Yampa; Empire; Steamboat Springs; Grizzly Creek.

2. Senecio chloranthus Greene. In the mountains of Colo.-Alt. 9000-I I,000 ft.-Coffee Pot Springs; White River Plateau; Marshall Pass; near Pagosa Peak; Ruxton Dell; La Plata River; Alpine Tunnel; Bald Mountain; Vance Junction; Medicine Bow Range; Twin Lakes.

3. Senecio contristatus Greene. In the mountains of Colo.-Alt. about Io,000 ft.-Keblar Pass.

4. Senecio pudicus Greene. (S. cernuus A. Gray; not L.) In the mountains of Colo.-Alt. 7000-12,000 ft.-Clear Creek; Georgetown; Mt. Harvard; Como; Mt. Ouray; Black Cañon; Bear Creek Cañon, near Pike's Peak; Ute Pass; Cheyenne Cañon; Pike's Peak; Twin Lakes; west of Ouray; between Pallas and Sydney; Grand Lake; Minnehaha; Empire; between Sunshine and Ward; Como; Marshall Pass; Lake City.

5. Senecio amplectens A. Gray. In alpine and subalpine regions of Colo.Alt. 9000-I3,000 ft.-Peak near White House; Silverton; Mt. Harvard; Gray's 
Peak; near Pagosa Peak; Ruby; mountains above Ouray; Berthoud Pass; headwaters of Clear Creek.

6. Senecio pagosanus Heller. (S. lactucinus Greene of 1900; not of I893) In the mountains of Colo.-Alt. I0,000-I2,000 ft.-Little Kate Mine, La Plata Mountains; near Pagosa Peak; mountains above Ouray; Mt. Harvard.

7. Senecio Holmii Greene. On alpine peaks of Colo.-Alt. 10,000-14,000 ft. -Ragged Mountain; Keblar Pass; Mt. Princeton; near Pagosa Peak; Mt. Harvard; Cameron Pass; mountains above Boreas.

8. Senecio taraxacoides (A. Gray) Greene. (S. amplectens taraxacoides A. Gray) On alpine peaks of Colo.-Alt. I0,000-I3,000 ft.-Cameron Pass; Mt. Garfield; Pike's Peak; Mt. Harvard; Bottomless Pit, near Pike's Peak; West Spanish Peak; Gray's Peak.

9. Senecio Soldanella A. Gray. On alpine peaks of Colo.-Alt. II,000-14,000 ft.-Mt. Princeton; Cameron Pass; Boreas; Cumberland Mine, La Plata Mountains; mountains above Cameron Pass; South Park.

Io. Senecio carthamoides Greene. (S. Fremontii A. Gray, in part; not T. $\&$ G.) In rocky wet places on alpine peaks of Colo. and Wyo.-Alt. gooor3,000 ft.-Ragged Mountain; mountains of Estes Park; Gray's Peak; West Spanish Peak; Pike's Peak; Silver Plume; Mt. Harvard; summit of Mt. Garfield; near Pagosa Peak; Upper La Plata River; Keblar Pass; Berthoud Pass; Chambers' Lake; headwaters of Clear Creek; Massif de l'Arapahoe.

Ir. Senecio blitoides Greene. (S. Fremontii A. Gray, in part; not T. \& G.) In wet rocky places on the higher mountains of Colo.-Alt. $8000-12,000 \mathrm{ft}$.Mountains above Ouray; Crested Butte.

12. Senecio invenustus Greene. On the higher peaks of Colo.-Alt. about I2,000 ft.-Near Pagosa Peak; Pike's Peak.

13. Senecio triangularis Hook. In wet places, especially along mountain streams, from Alb. and Alaska to Colo. and Calif.-Alt. 8000-I I,000 ft.Mt. Harvard; Ruby; Upper La Plata River; Steamboat Springs; Cameron Pass; headwaters of Pass Creek; Delta Co.; near Pagosa Peak; Mt. Ouray; Marshall Pass; Red Mountain road, south of Ouray; between Sunshine and Ward; Buffalo Pass; Berthoud Pass; Hematite; Gore Pass; Beaver Creek; Michigan Creek; Breckenridge; headwaters of Clear Creek; summit of North Park Range.

14. Senecio admirabilis Greene. In the mountains of Colo. and Wyo.Alt. 7500-10,000 ft.-Twin Lakes; Four-mile Hill, Routt Co.; Trappers' Lake; Breckenridge; Box Cañon, wesi of Ouray; Mt. Harvard; Keblar Pass; Marshall Pass; Empire; Vance Junction.

15. Senecio serra Hook. In valleys from Mont. and Wash. to Colo. and Ore.-Gunnison Co.; Grizzly Creek.

I6. Senecio lapathifolium Greene. In the mountains of Colo.-Alt. about I2,000 ft.-Mountains above Ouray; Mt. Harvard.

17. Senecio crassulus A. Gray. In the mountains from Mont. and Ida. to Colo. and Utah.-Alt. 8000-13,000 ft.-Silver Plume; Ward, Boulder Co.; Trappers' Lake; Cameron Pass; mountains above Ouray; North Park; mountain sides near Empire; Little Kate Mine and Cumberland Mine, La Plata Mountains; near Pagosa Peak; Eldora to Baltimore; head of the Red River, Franklin; mountain northeast of Boreas; Gray's Peak; Boreas; headwaters 
of Clear Creek; Rabbit-Ears, Larimer Co.; summit of North Park Range, Routt Co.

18. Senecio semiamplexicaulis Rydb. In meadows from Mont. and Ida. to Colo. and Utah.-Foot of Mt. Richtofen on the Michigan; Chambers' Lake.

19. Senecio rapifolius Nutt. In the mountains from S. D. and Ida. to Colo.-Alt. 7500-8500 ft.-Andrews' Shetland ranch; Bosworth's ranch, Stove Prairie; mountains, Larimer Co.

20. Senecio hydrophilus Nutt. In shallow water and swampy ground from Mont. to Colo. and Nev.-Alt. about 8000 ft.-Grizzly Creek, North Park; Montrose; six miles above Wolcott; swampy places near Yampa; Upper Laramie River; North Fork, Larimer Co.

2I. Senecio integerrimus Nutt. In valleys from S. D. to Neb. and Colo.Alt. 5000-10,000 ft.-Wolcott, Eagle Co.; mountain near Veta Pass; headwaters of Sangre de Cristo Creek; Owl Cañon, Larimer Co.

22. Senecio Hookeri A. Gray. In the mountains from Alb. and B. C. to Colo.-Alt. 8500-9500 ft.-Eldora to Baltimore.

23. Senecio dispar A. Nels. In mountain valleys of Wyo. and Colo--Steamboat Springs.

24. Senecio Flintii Rydb. Hills of southwestern Colo.-Exact locality not given.

25. Senecio columbianus Greene. ( $S$. lugens A. Gray, mainly; not Richardson; S. atriapiculatus Rydb.) In valleys from Sask. and Alaska to Minn. and Colo.-Alt. 5000-I3,000 ft.-Hills southeast of La Veta; Calhan; Ojo; Tennessee Pass; Veta Mountain; Sangre de Cristo Creek; Rist Cañon; Horsetooth Guich; gulch west of Soldier Cañon; Horsetooth Mountain; Gray's Peak; headwaters of Clear Creek; Los Pinos.

26. Senecio perplexus A. Nels. In mountain valleys from Wyo. and Ida. to Colo.-Alt. 8000-10,500 ft.-Robinson; Ojo; Chicken Creek, west of Mt. Hesperus; Mt. Harvard; Veta Mountain; headwaters of Sangre de Cristo Creek; Bob Creek, west of Mt. Hesperus; Cimarron; Eldora to Baltimore; Boulder; Horsetooth Gulch; Horsetooth Mountain; Gore Pass; Lake City.

27. Senecio anacletus Greene. ( $S$. Toluccanus microdontus A. Gray; $S$. microdontus Heller) In valleys from Colo. to N. M. and Ariz.; also in Mex. -Alt. 8000-II,000 ft.-Mt. Harvard; Veta Mountain; Dolores; Redcliffe; headwaters of Pass Creek; Tennessee Pass; Little Kate Mine, La Plata Mountains; Hematite; mountains north of Dolores; Leroux Parks; Silverton; Beaver Creek; headwaters of Clear Creek.

28. Senecio atratus Greene. (S. lugens foliosus A. Gray) In the mountains of Colo.-Alt. 7500-13,000 ft.-West of Ouray; Red Mountain road, south of Ouray; Ragged Mountain; vicinity of Como; West Spanish Peak; La Plata Cañon; Ward; mountains above Ouray; Marshall Pass; Como, South Park; Georgetown; Mt. Princeton; Mt. Harvard; Eldora to Baltimore; between Sunshine and Ward; Berthoud Pass; Marshall Pass; Clear Creek Cañon, above Georgetown; Como; Silverton; mountain sides near Empire; Lake City.

29. Senecio milliflorus Greene. In the mountains of Colo.-Pagosa Springs.

30. Senecio Purshianus Nutt. (S. canus A. Gray, in part; not Hook.) In the mountains from Sask. and B. C. to Tex. and Utah.-Alt. 6000-13,000 ft.Mountain northeast of Boreas; Rabbit-Ears, Larimer Co. 
3r. Senecio Harbourii Rydb. Mountains of Colorado.-Alt. 9000-I3,000 ft. - Silver Plume; mountains south of Ward, Boulder Co.; mountains between Sunshine and Ward; Boreas.

32. Senecio plattensis Nutt. On prairies and in river valleys from western Ont. and S. D. to Tex. and Colo.-Alt. 4000-7000 ft.-Cache la Poudre River; Ft. Collins; New Windsor; Boulder; Horsetooth Gulch; Cimarron; Florence.

33. Senecio salicinus Rydb. In the mountains of Colo.-Alt. 5000-6000 ft. -Foot-hills, Larimer Co. ; Veta Pass; Owl Cañon, Larimer Co.

34. Senecio canovirens Rydb. In the mountains of Colo. and N. M.-Alt. 6000-I0,000 ft.-Florence; Williams Cañon; Colorado Springs; Manitou; Georgetown; Pike's Peak; Buckhorn Creek.

35. Senecio rosulatus Rydb. On hills and mountains of Colo-Alt. 5000I3,000 ft.-Cameron Pass; Dillon Cañon; Trinidad; Pike's Peak; foot-hills west of Ft. Collins; Georgetown; Chambers' Lake; Gray's Peak; Sangre de Cristo Creek; Manitou; Grayback mining camps; Artists' Glen, near Pike's Peak; Green Mountain Falls; North Cheyenne Cañon; mountain sides near Georgetown; Silver Plume; New Windsor; Marshall Pass; Dark Cañon; Horsetooth Gulch; dry hills near Wood's ranch; near Narrows; Howe's Gulch; Rist Cañon; Baxter's ranch; above Beaver Creek; Caribou; Cheyenne Mountain; mountain sides near Golden; Bottomless Pit; Twin Lakes; Cañon City; Empire; Boulder; between Sunshine and Ward.

36. Senecio Fendleri A. Gray. On mountains from Colo, to Utah and N. M. -Alt. 8000-I3,000 ft.-Manitou; Mt. Ouray; Bottomless Pit; Ojo; hills north of Cascade; mountains near Colorado Springs; Grayback mining camps; Clear Creek; Hematite.

37. Senecio lanatifolius Osterhout. (S. Fendleri lanatus Osterhout) In the mountains of Colo.-Wolcott, Eagle Co.

38. Senecio multilobatus T. \& G. On dry plains of Colo. and Utah.-Alt. about $7000 \mathrm{ft}$--Dolores; Cañon of the Grand, above Palisades; Steamboat Springs; Grand Junction; Mancos; Minturn.

39. Senecio condensatus Greene. (S. aureus compactus A. Gray; S. compactus Rydb.) On dry plains and in sandy soil in Neb. and Colo.-Trinidad; Table Rock; Colorado Springs.

40. Senecio tridenticulatus Rydb. On dry plains from Colo. to Tex.-Alt. 7000-8000 ft.-Cottonwood Creek, Buena Vista; hills southeast of La Veta.

41. Senecio oblanceolatus Rydb. On dry plains and hills from Wyo. to Tex. -Alt. 4000-Io,000 ft.-Arboles; Los Pinos; Pike's Peak; Calhan; Como, South Park; El Paso Co.; mesas near Colorado Springs; Cucharas Valley, near La Veta; plains near Denver; Sangre de Cristo Creek; Turkey Creek and tributaries; Cottonwood Creek, near Buena Vista; Quimby; hills about Trinidad; Como; Clear Creek.

42. Senecio longipetiolatus Rydb. In valleys of Wyo. and Colo.-Alt. up to $9000 \mathrm{ft} .-$ Medicine Bow Range; Hamor's Lake, north of Durango.

43. Senecio crocatus Rydb. (S. aureus croceus A. Gray; S. dimorphophyllus Greene; S. heterodoxus Greene) On the higher mountains of Wyo. and Colo.-Alt. I0,000-I4,000 ft.-Pike's Peak Valley; Mt. Harvard; near Pagosa Peak; Cameron Pass; summit of mountains west of North Park; Little Kate Mine, La Plata Mountains; Alpine Tunnel; South Cottonwood Gulch, Chaffee Co.; Long's Peak; Red Mountain; Berthoud Pass; Grass Creek; Red River; Beaver Creek; Gray's Peak; summit of North Park Range, Larimer Co. 
44. Senecio oodes Rydb. Mountains of Colo.-Mt. Harvard; Robinson.

45. Senecio cymbalarioides Nutt. ( $S$. aureus borealis T. \& G.) In meadows from the Mackenzie to Colo. and Utah.-Alt, 7000-r3,000 ft.-West Spanish Peak; Marshall Pass; Rabbit-Ear Range; Mt. Harvard; Redcliffe; peak near White House; Hematite; Mancos.

46. Senecio subcuneatus Rydb. In meadows of Colo. and Wyo.-Alt. 70008500 ft.-Arboles; Grizzly Creek; Hamor's Lake; Mancos; Lake City.

47. Senecio pyrrochrous Greene. In wet meadows of Wyo. and Colo.Alt. 8000-9500 ft.-Mt. Harvard; Hamor's Lake, north of Durango; Sargents; Marshall Pass; Medicine Bow Range; Sheephorn Divide, Middle Park; Jack's Cabin; Rico; Silverton.

48. Senecio Tracyi Rydb. Mountains of Colo.--Alt. I0,500 ft.-Bob Creek, west of Mt. Hesperus.

49. Senecio pseudaureus Rydb. In wet meadows from the Mackenzie and B. C. to N. M. and Nev.-Alt. 7000-13,000 ft.-Mancos; Long's Peak; Grizzly Creek.

50. Senecio Hartianus Heller. In wet meadows from Colo. to N. M. and Ariz.-Alt. 7000-9000 ft.-Minturn, Eagle Co.; Cucharas River, below La Veta; headwaters of Sangre de Cristo Creek; Veta Pass; along the Conejos River, north of Antonito.

51. Senecio mutabilis Greene. ( $S$. aurellus Rydb.) In valleys of Colo.Alt. 5000-9000 ft.-Hotchkiss; Cimarron; Lake John, North Park; La Plata Cañon; Sapinero; Cucharas River, below La Veta; Arboles; Mancos; Los Pinos; Rico; Hotchkiss; Florence; Colorado Springs.

52. Senecio nephrophyllus Rydb. In wet meadows from Mont. to Colo.Near Lake John, North Park.

53. Senecio flavulus Greene. (S. flavovirens Rydb.) In wet meadows from Mont. and Ida. to Colo.-Alt. 5000-7000 ft.-Gypsum Creek Cañon; Walton Creek, Routt Co.; Dolores ; Laramie Plains; La. Veta ; New Windsor; Arboles; Sapinero; Black Cañon; Brant's Soda Spring; Walton Creek; Horsetooth Gulch; Walden.

54. Senecio fedifolius Rydb. Wet places in alpine regions of Colo.-South Park.

55. Senecio petrocallis Greene. ( $S$. petraeus Klatt) On alpine peaks of Colo.-Alt. II,000-I3,000 ft.-Near Pagosa Peak; mountains above Ouray; Gray's Peak; Lake City.

56. Senecio cognatus Greene. On high mountains of Colo.-Piedra.

57. Senecio pentodontus Greene. On alpine mountains of Wyo. and Colo. -Alt. ro,000-I2,000 ft.-Upper La Plata Cañon; West Spanish Peak; Carson; Lake City; Chicken Creek, west of Mt. Hesperus.

58. Senecio Porteri Greene. (S. renifolius Porter) Alpine regions of Colo. -Alt. I3,000 ft.-White House Mountain.

59. Senecio turbinatus Rydb. Mountains of Colo.-Lake City.

6o. Senecio perennans A. Nels. On the higher mountains of Wyo, and Colo.-Alt. 8000-I0,500 ft.-Grayback mining camps; Hahn's Peak; Redcliffe; Silver Plume.

6r. Senecio werneriaefolius A. Gray. On the peaks of Colo-Alt. 8000ro,ooo ft.-Empire; Cameron Pass.

62. Senecio MacDougalii Heller. (S. eremophilus A. Gray, mainly; not 
Richardson) In wet wooded places from N. D. and Mont. to N. M. and Ariz.-Alt, 6000-I0,000 ft.-Four-Mile Hill, Routt Co.; Pandora; Ute Pass; Chambers' Lake; mesa near Yampa; Green Mountain Falls; Parlin; Ruxton Park; Parrott City; Gunnison; near Pagosa Peak; Steamboat Springs; near Colorado Springs; Sangre de Cristo Creek; Silver Plume; La Veta; Ward; Spring Cañon; Georgetown; above Beaver Creek; cañon west of Palmer Lake; Hotchkiss; headwaters of Clear Creek.

63. Senecio filifolius Nutt. ( $S$. Douglasii A. Gray, in part; not DC.) In valleys from Colo. and Utah to Tex. and Ariz.; also in Mex.-Florence; Westcliffe; Estes Park, Larimer Co.; Cañon City; Pueblo.

64. Senecio Riddellii T. \& G. (S. filifolius Fremontii T. \& G.; A. Douglasii A. Gray, in part; S. Fremontii Rydb. ; not T. \& G.) On plains and in valleys from Neb. and Colo. to Tex. and N. M.-Alt. 4000-6000 ft.-Brantly Cañon; Boulder; Ft. Collins; Cimarron and Squaw Hill.

65. Senecio multicapitatus Rydb. On plains and in valleys from Colo. to N. M. and Ariz.-Alt. 7000-II,000 ft.-Huerfano Valley, near Gardner; Mt. Princeton Station.

66. Senecio spartioides T. \& G. (S. Douglasii A. Gray, in part) On plains and in valleys from Neb. and Wyo, to Tex. and Ariz.-Alt. $4000-9500 \mathrm{ft}$. Ft. Collins; Idaho Springs; Engelmann Cañon; along the Uncompahgre River, near Ouray; Gunnison; Salida; Cucharas Valley, near La Veta ; Pike's Peak; Antonito; Empire; mountains between Sunshine and Ward; Rist Cañon; Cache la Poudre River; Buena Vista; Golden; Colorado Springs.

Shrub not spiny.

87. TETRADYMIA DC.

Primary leaves oblanceolate.

Primary leaves linear.

Shrub spiny.

I. T. inermis.

2. T. linearis.

3. T. spinosa.

I. Tetradymia inermis Nutt. Dry hills from Mont. to Colo. and Nev.Alt. 4000-9000 ft.-Gunnison; North Park, Larimer Co.; La Veta; Cerro Summit; Leroux Creek; North Fork, Larimer Co.

2. Tetradymia linearis Rydb. On dry hills and plains of Colo. and Utah.Alt. about $7700 \mathrm{ft}$-Gunnison; La Veta.

3. Tetradymia spinosa H. \& A. On dry hills and plains from Mont. and Ore. to Colo. and Nev.-Alt. 4500-7000 ft.-Mancos; near Wyoming line, Routt Co.; Hotchkiss; Mancos Cañon; Grand Junction; Palisades.

\section{Tribe 9. CYNAREAE.}

\section{CARDUUS L. Thistle.}

Bracts of the involucres conspicuously arachnoid-pubescent, neither reflexed nor spreading, except the tips.

Inner bracts with conspicuously dilated tips.

Inner bracts long-attenuate, rarely slightly dilated.

I. VIRIDIFLORI.

Bracts of the involucres not arachnoid or only slightly so on the margins,

Bracts not with a dorsal glandular ridge.

Bracts, except the outermost, with dilated fimbriate tips.

Bracts, except the innermost, not with dilated tips.

III. Carlinoides.

Bracts not squarrose, except the spines or the loose tips. 
Innermost innocuous bracts not conspicuously elongated; their tips usually crisp or twisted, sometimes erose or laciniate.

IV. Scartosi.

Innermost innocuous bracts conspicuously elongated and more or less reddish, straight, neither dilated, crisp, twisted, nor erose.

Bracts squarrose or the lower reflexed.

V. Pulchell.

IX. NEO-MEXICANI.

Bracts with glandular dorsal ridge.

Flowers perfect.

Leaves tomentose on both sides.

Leaves glabrate above.

Flowers dioecious.

VI. Undulati.

VII. Altissimi.

VIII. Arvenses.

I. ViridiFLORI.

One species.

1. C. Parryi.

II. ERIOCEPHALI.

Anthers glabrous.

Lobes at least of the larger leaves elliptic or ovate, obtuse; spines of the bracts stout.

2. C. Osterhoutii.

Lobes of the leaves triangular or lanceolate, acute; spines of the bracts slender, yellow.

Stem tomentose or glabrous.

Involucres densely arachnoid.

Outer bracts with longer spines, almost equalling the inner; flowers red.

3. C. Hookerianus.

Outer bracts much shorter than the inner; flowers whitish.

Involucres sparingly arachnoid.

Stem arachnoid hairy.

Anthers pubescent.
4. C. araneosus.

5. C. oreophilus.

6. C. scopulorum.

7. C. hesperius.

\section{Carlinoides.}

Bracts all linear-lanceolate, not very unlike in length, with long stout flat spines.

8. C. griseus.

Bracts with short weak spines; the outer ovate or ovate-lanceolate; the inner with broad dilated tips.

Flowers ochroleucous; bracts not at all glandular ridged.

Heads campanulate; tips of the bract fimbriate. 9. C. Centaureae.

Heads hemispherical; tips of the bracts erose. Io. C. erosus.

Flowers red; bracts with a more or less distinct glandular ridge.

II. C. perplexans.

\section{SCARIOSI.}

Plants acaulescent or nearly so.

Bracts all with short spines.

I2. C. acaulescens.

Bracts, at least the middle ones, with long spines equalling the disk.

Plants distinctly caulescent.

13. C. americanus.

Tips of the inner bracts usually more or less dilated; at least the terminal head 3-4 $\mathrm{cm}$. wide.

Bracts thin and flat, greenish or brownish. I4. C. foliosus.

Bracts thick and firm, yellowish, only the tips brownish, more or less rounded or carinate on the back, ovate.

Divisions of the leaves broad, ovate. I5. C. coloradensis.

Divisions of the leaves narrow, linear-lanceolate. I6. C. scariosus.

Tips of the inner bracts usually not at all dilated; heads $2-2.5 \mathrm{~cm}$. in diameter.

Bracts narrowly lanceolate, usually arachnoid-hairy, gradually tapering to long, flat spines.

5. C. oreophilus.

Bracts broadly lanceolate, scarcely arachnoid with a very short spine. 


\section{Pulcheli.}

Leaves not white-tomentose beneath.

Leaves sparingly floccose when young, or glabrate.

Leaves glabrous, the lower twice pinnate.

Leaves white-tomentose beneath.

18. C. truncatus.

19. C. bipinnatus.

2o. C. pulchellus.

\section{Undulati.}

Flowers ochroleucous; bracts very viscid, with broad glandular dorsal ridges.

Tips of the inner bracts more or less dilated and crisp; involucre of the terminal head $4-5 \mathrm{~cm}$. in diameter. 2I. C. plattensis.

Tips of the inner bracts linear-lanceolate, neither dilated nor crisp; involucres usually $3 \mathrm{~cm}$. wide or less. 22. C. Tracyi.

Flowers rose or purple, rarely white; glandular ridge not so prominent.

Involucres less than $3 \mathrm{~cm}$. wide.

Spines of the middle bracts 5-10 $\mathrm{mm}$. long, erect or ascending.

23. C. canescens.

Spines of the middle bracts $5 \mathrm{~mm}$, or less long, weak and spreading.
Leaves entire or slightly lobed.
24. C. oblanceolatus.

Leaves pinnately divided or deeply lobed.

Leaves deeply pinnatifid with narrow, linear-lanceolate lobes; plant often yellowish.

25. C. Flodmanii.

Leaves with triangular or ovate-lanceolate lobes.

Bracts with a very inconspicuous glandular ridge, not at all viscid.

26. floccosus.

Bracts with a conspicuous glandular ridge, surrounded by a viscid area.

Involucres $4^{-6} \mathrm{~cm}$. in diameter.

27. C. undulatus.

Spines of the involucral bracts scarcely over $5 \mathrm{~mm}$. long; leaves very broad.

28. C. megacephalus.

Spines of the involucres $I \mathrm{~cm}$. long; leaves narrow. 29. C. ochrocentrus.

\section{Altissimi.}

One species.

ViII. Arvenses.

One species.

IX. NEO-MEXICANI.

One species.

30. C. filipendulus.

3.. C. arvensis.

32. C. neo-mexicanus.

1. Carduus Parryi (A. Gray) Greene. (Cnicus Parryi A. Gray) In the mountains of Colo., Utah and N. M.-Alt. 5000-II,000 ft.-Marshall Pass; La Veta; along the Uncompahgre River, near Ouray; Steele Cañon, Villa Grove; Redcliffe; Marshall Pass; Echo Creek, near La Veta; Veta Pass; near Pagosa Peak; Boulder; near Empire; Twin Lakes.

2. Carduus Osterhoutii Rydb. In the mountains of Colo.-Redcliffe; Tennessee Pass.

3. Carduus Hookerianus (Nutt.) Heller. (Cnicus Hookerianus A. Gray) In the mountains from Alb. and B. C. to Colo.-Alt. II,000-I2,000 ft.-Berthoud Pass.

4. Carduus araneosus Osterhout. Mountains of Colo.-Redcliffe.

5. Carduus oreophilus Rydb. In wooded valleys of Colo.-Alt. 6000-I2,000 ft.-Banks of Larimer Co.; Silver Plume; Georgetown; Pagosa Springs; Steamboat Springs; Boreas; Garland.

6. Carduus scopulorum Greene. (Cnicus eriocephalus A. Gray) In the mountains of Colo.-Alt. 9500-12,000 ft.-Ward; Mt. Harvard; head of Beaver Creek; Ruxton Dell; Mt. Baldy, Pike's Peak; Cameron Pass; Berthoud Pass. 
7. Carduus hesperius (Eastw.) Heller. (Cnicus hesperius Eastw.) In mountains of Colo., above timber line--Mt. Hesperus.

8. Carduus griseus Rydb. In the mountains of Colo.-Alt. up to I2,000 ft. -Trappers' Lake; Bosworth's ranch, Stove Prairie; Steamboat Springs; Happy Hollow; Ward; Marshall Pass; Telluride.

9. Carduus Centaureae Rydb. (Cnicus Americanus A. Gray, in part) In the mountains of Wyo. and Colo.-Alt. 7000-ro,000 ft.-Bosworth's ranch; Stove Prairie; mountains, Larimer Co.; Four-mile Hill, Routt Co.; Penn's Gulch; Steamboat Springs; mountains between Sunshine and Ward; Hinsdale Co.

Io. Carduus erosus Rydb. In the mountains of Southern Colo.-Alt. about $7500 \mathrm{ft}$.-Durango.

II. Carduus perplexans Rydb. In the mountains of Colo--Alt. about 7000 ft.-Cimarron.

12. Carduus acaulescens (A. Gray) Rydb. (Cnicus Drummondii acaulescens A. Gray) In the mountains of Colo--Alt. 8000-10,000 ft.-Banks of Laramie River; on Grizzly Creek; Parlin, Gunnison Co.; Columbine; Marshall Pass; Empire.

13. Carduus americanus Rydb. (Cirsium acaule Americanum A. Gray) In mountain valleys of Colo.--Alt. about ı,000 ft.-Silver Plume; Como; South Park.

I4. Carduus foliosus Hook. (Cnicus foliosus Gray) In the mountains from S. D. and B. C. to Colo.-Dillon.

15. Carduus coloradensis Rydb. (Cnicus Drummondii A. Gray, in part) In the mountains of Colo.-Alt. about $7500 \mathrm{ft}$-Pagosa Springs; Gunnison; Wolcott.

I6. Carduus scariosus (Nutt.) Heller. (Cnicus scariosus A. Gray) In the mountains of Wyo., Utah and Colo.-Alt. about $8500 \mathrm{ft} .-$ Columbine.

17. Carduus spathulatus Osterhout. Hills of Colorado.-North Park.

18. Carduus truncatus Greene. On sage plains of Southern Colo.-West of Mancos.

Ig. Carduus bipinnatus (Eastw.) Heller. (Cnicus bipinnatus Eastw.) In cañons of southwestern Colo. It is scarcely distinct from the preceding.Johnston Cañon, near Mancos River.

2o. Carduus pulchellus Greene. In the mountains of Colo.-Piedra.

2I. Carduus plattensis Rydb. On sand hills of Neb. and Colo.-New Windsor, Weld Co.; Wray.

22. Carduus Tracyi Rydb. On dry fields of Colo.-Alt. 5000-7000 ft.Green Mountain Falls; Mancos; Ft. Collins and La Porte.

23. Carduus canescens Nutt. On dry plains and hills of Wyo. and Colo.Alt. $7500-8500 \mathrm{ft}$.-Box Cañon, west of Ouray.

24. Carduus oblanceolatus Rydb. In the mountains of Wyo. and Colo.Twin Lakes.

25. Carduus Flodmanii Rydb. (Cnicus undulatus canescens A. Gray, mainly; not Cirsium canescens Nutt.; Carduus canescens Pammel) In river valleys from Minn. and Mont. to Iowa and Colo.-Alt. 4000-5000 ft.-Cache la Poudre; Ft. Collins; La Porte; Westcliffe; New Windsor, Weld Co.

26. Carduus floccosus Rydb. In the mountains of Colo.-Wolcott, Eagle Co.

27. Carduus undulatus Nutt. (Cnicus undulatus A. Gray) On dry plains 
and hills from Mich., Ass. and Mont. to Tex. and Utah.-Alt. 4000-7000 ft.Georgetown; near Grand Junction; Durango; Wolcott; Golden.

28. Carduus megacephalus Nutt. (Cnicus undulatus megacephalus A. Gray) On prairies, plains and hills from S. D. and Ida. to Mo., Tex. and Colo.Alt. 4000-7500 ft.-Idaho Springs; Boulder; Cucharas Valley, near La Veta; Ft. Collins; Spring Cañon; Turkey Creek.

29. Carduus ochrocentrus (A. Gray) Greene. (Cnicus ochrocentrus A. Gray) On plains from Neb. and Colo. to Tex. and Ariz.-Alt. 4000-5000 ft. -Ft. Collins; New Windsor.

30. Carduus filipendulus (A. Gray) Rydb. (Cirsium filipendulum Engelm.; Cnicus altissimus flipendulus A. Gray) On prairies, valleys and waste places from Colo. to Tex.-Clear Creek Valley; Ft. Collins.

3r. Carduus arvensis (L.) Robs. (Cnicus arvensis Hoffm.) In fields and waste places; an introduced weed from Europe and naturalized from Newf. and Ida. to N. J. and Colo.-Alt. 4000-5000 ft.-Livingstone; Ft. Collins.

32. Carduus neo-mexicanus (A. Gray) Greene. (Cnicus Neo-Mexicanus A. Gray; C. leucopsis Greene) On plains from Colo. to N. M. and Ariz.Alt. 4000-6000 ft.-.Grand Junction; Arboles; Rifle, Garfield Co.

\section{Family i34. CICHORIACEAE Reich. Chicory Family.}

I. Pappus of plumose bristles, often more or less paleaceous at the base. Achenes truncate at the apex, not beaked.

Flowers yellow; simple plants with fusiform roots. 2. Ptilocalais.

Flowers pink, rose or white; branched plants with rush-like stems.

2. Ptiloria.

Achenes with long beaks; simple plants with fistulose leaves.

3. Tragopogon.

II. Pappus not plumose.

A. Pappus consisting, at least partly, of chaffs or these reduced and united into a crown.

Involucres simple and naked, $i$. e., without smaller calyculate bracts below; pappus of both chaffs and bristles; flowers yellow. 4. Adopogon.

Involucres double, either imbricated or with smaller calyculate bracts below; flowers blue.

5. CICHORIUM.

B. Pappus of capillary bristles, not plumose, slightly if at all broadened below.

1. Achenes not flattened.

$u$. Pappus-bristles promptly deciduous, mainly together; only a few of the stouter ones in some species remaining.

6. Malacothrix.

$b$. Pappus persistent, tardily falling off separately, or together only by the breaking off of the beak.

Beaks of the achenes none or a mere attenuation.

Flowers rose or purplish.

Stems rush-like and striate; leaves narrowly linear or reduced; achenes tapering at the summit.

7. LXGODESMIA.

Stems not rush-like; leaves ample; achenes tapering to the base.

Annuals; heads 4-5-flowered; achenes with 4-5 strong ribs.

8. Prenanthelia.

Perennials; heads 8-30-flowered (rarely less); achenes terete or 4-5-angled.

Flowers yellow or white.

Heads several, rarely solitary; stem leafy.

Achenes tapering upwards; pappus white; bracts in fruit more or less thickened at the base or on the mid-rib.

io. Crepis.

Achenes not tapering upwards; pappus in ours sorded or reddish; bracts not thickened.

I I. HIERACIUM. 
Heads solitary on leafless scapes.

I2. Nothocalais.

Beaks of the achenes distinct and slender; plants scapiferous.

Achenes Io-ribbed.or 1o-nerved, not spinose-muricate; involucres more or less imbricated.

I3. Agoseris.

Achenes 4-5-ribbed, muricate-spinulose at least near the apex; involucres of a single series of principal bracts and several or numerous calyculate ones below.

I4. TARAXACUM.

$z$. Achenes flattened; leafy-stemmed plants with paniculate heads.

Achenes narrowed at the top or beaked; pappus-bristles falling separately; involucres cylindraceous.

I5. LACTUCA.

Achenes truncate at the top; pappus-bristles falling off more or less in connection; involucres hemispherical or campanulate.

I6. Sonchus.

\section{PTILOCALAIS Greene.}

1. Ptilocalais nutans (Geyer) Greene. (Microseris nutans A. Gray) Wet meadows from Mont. and Wash. to Colo. and Calif.-Alt. 8000-10,000 ft.Minturn, Eagle Co.; Cerro Summit; Silver Plume.

\section{«. PTILORIA Raf.}

Perennials.

Pappus plumose to the base, white; leaves, at least the lower ones, broad, oblanceolate in outline and runcinate.

I. $P$. ramosa.

Pappus merely scabrous at the base, brown; leaves often runcinate, but narrow.

Annuals or biennials.

2. P. pauciflora.

Pappus plumose to the base, not paleacous-dilated; plant strict, virgate; leaves entire or sinuate. 3. $P$. virgata.

Pappus plumose above the middle, dilated and paleaceous at the base; leaves pinnatifid or bipinnatifid or the upper bract-like.

4. P. exigua.

I. Ptiloria ramosa Rydb. On dry plains and in "bad-lands" from Neb. and Mont. to Colo.-Alt. 4000-6000 ft.-New Windsor; Boulder.

2. Ptiloria pauciflora (Torr.) Raf. (Stephanomeria runcinata Nutt.) On plains and hills from Colo. and Nev. to Tex. and Ariz.-Alt, 4500-8000 ft.Btuena Vista; Villa Grove; Mancos; Ft. Collins; Grand Junction; Deer Run; New Windsor; near Boulder; Hotchkiss; Cucharas Valley, near La Veta; Cañon City; between Sunshine and Ward; Boulder.

3. Ptiloria virgata (Benth.) Greene. (Stephanomeria virgata Benth.) In arid places from Colo. and Nev. to Calif.-Alt. about $4500 \mathrm{ft}$.-Grand Junction.

4. Ptiloria exigua (Nutt.) Greene. Dry places from Wyo. to N. M., Calif. and Nev.-Grand Junction (Eastwood).

\section{TRagopogon L. Salsify, Oyster Plant.}

Flowers yellow; involucral bracts equalling or shorter than the ligules.

Flowers purple; involucral bracts much longer than the ligules.

$$
\text { I. T. pratense. }
$$

2. T. porrifolius.

1. Tragopogon pratensis L. In fields and waste places from N. B. and Man. to N. J. and Colo. ; naturalized from Europe--Ft. Collins; Boulder.

2. Tragopogon porrifolius L. In fields and waste places from Ont. and Minn. to N. C. and Colo. Escaped from cultivation.-Ft. Collins; Colorado Springs. 


\section{ADOPOGON Necker. GOAT'S BEARD.}

1. Adopogon virginicum (L.) Kuntze. (Krigia amplexicaulis Nutt.) In moist woods and meadows from Ont. and Man. to Ga. and Colo.-Alt. 600o$8500 \mathrm{ft}$-Colorado Springs; mouth of Cheyenne Cañon; near Pike's Peak; North Cottonwood Creek.

\section{CICHORIUM L. CHICKORY.}

1. Cichorium Intybus L. On roadsides, fields and waste places from N. S. and Minn. to N. C. and Colo. Naturalized from Europe.-Ait. about 5000 ft.-Ft. Collins; La Porte, Larimer Co.; Denver.

\section{MALACOTHRIX DC.}

1. Malacothrix sonchioides T. \& G. On plains from Neb. and Nev. to Kans. and Calif.-Alt. 4500-8000 ft.-Grand Junction; McCoy's, Eagle Co.

\section{Perennials.}

\section{LYGODESMIA D. Don.}

Involucres $15-25 \mathrm{~mm}$. high, 6-10-flowered.

Involucres about to mm. high, usually 5 -flowered; upper leaves reduced.

Annuals; leaves narrowly linear; involucres $10-15 \mathrm{~mm}$. high. 3 . L. juncea.
rostrata.

I. Lygodesmia grandiflora T. \& G. On gravelly hills from Wyo. and Ida. to Colo. and Ariz.-Alt. up to $7000 \mathrm{ft}$.-Mancos; Glenwood Springs; Hotchkiss; Grand Junction; Gypsum, Eagle Co.

2. Lygodesmia juncea (Pursh) D. Don. On prairies and plains from Minn., Sask, and Alb. to Mo. and N. M.-Alt. 4000-I2,000 ft.-Gunnison; New Windsor; Ft. Collins; Denver; Pueblo; West Spanish Peak; Pagosa Springs; Table Rock; Fossil Creek; Manitou; Colorado Springs.

3. Lygodesmia rostrata A. Gray. In cañons and on sandy plains from S. D. and Sask. to Kans. and Colo.-New Windsor; Greeley.

8. PRENANTHELLA Rydb.

I. Prenanthella exigua (A. Gray) Rydb. (Lygodesmia exigua A. Gray) On stony hills from Colo. and Utah to Tex. and Ariz.-Grand Junction.

\section{NABALUS Cass. Rattlesnake-Root.}

^. Nabalus racemosus (Michx.) DC. (Prenanthes racemosa Michx.) In moist ground from N. B. and Sask. to N. J. and Colo.-Alt. 5000-9500 ft.Westcliffe; Estes Park, Larimer Co.; Cabin Cañon, near Pike's Peak.

\section{Io. CREPIS L. HAWK'S-BEARD.}

Achenes not discoid-dilated at the insertion of the pappus; plants tall.

Plants neither canescent nor furfurascent; heads hemispherical to turbinate.

Involucres glabrous or tomentulose when young; neither hirsute nor giandular. Involucres and peduncles tomentulose, at least when young.

Involucres glabrous or slightly puberulent when young.

1. O. tomentulosa.

$$
\text { 2. C. glauca. }
$$


Involucres and peduncles hirsute or glandular or both.

Leaf-blades oblanceolate or oblong to linear-oblanceolate.

Leaves long-petioled; petioles one-half as long to fully as long as the blades, not winged.

Blades of the basal leaves broadly oblanceolate; stem usually with $1-2$ leaves; involucres over I $\mathrm{cm}$. high.

3. C. petialata.

Blades of the basal leaves narrowly linear-lanceolate or linear-oblanceolate; stem scapiform; involucres less than I cm. high.

Leaves subsessile or with short, winged petioles.

4. C. glaucella.

Leaves glabous; involucres with a few short hairs.

Leaves and involucres hairy.

5. C. perplexa.

6. C. runcinata.

Leaf-blades obovate; involucres and peduncles densely glandular hispid with long hairs.

Involucres over I cm. high; leaves hairy, 1.5-2 dm. long.

Involucres I $\mathrm{cm}$. high or less; leaves glabrous or nearly so.

7. C. riparia.

8. C. denticulata.

Plant more or less canescent or furfurascent, especially the leaves.

Involucres glabrous, 5-7-flowered.

9. C. acuminata.

Involucres canescent.

Involucres and peduncles without black hairs.

Principal bracts of the involucres $5-8$; flowers of the same number.

Blade proper broadiy lanceolate; lobes usually directed downward.

Io. C. internedia.

Blade proper narrowly lanceolate to almost linear; lobes curved upwards.

II. C. angustata.

Principal bracts of the involucres $9-\mathrm{I}_{4}$; flowers $10-20$; plant low.

I2. C. pumila.

Involucres and peduncles with some black hairs intermixed with the tomentum; principal bracts 9-10.

Hairs glandular.

Hairs not glandular.

I3. C. occidentalis.

I4. C. scopuloritm.

Achenes with a more or less dilated disk bearing the deciduous pappus; plant dwarf, less than I dm. high.

I5. C. nana.

I. Crepis tomentulosa Rydb. In the mountains near Pike's Peak, Colo.Alt. nearly Io,000 ft.-Ruxton Dell.

ะ. Crepis glauca (Nutt.) T. \& G. (C. lancifolia Greene ?) In valleys from Mont. to Colo. and Nev.-Alt. 4500-10,000 ft.-Clear Creek, below Georgetown ; Ft. Collins; Doyle's; Garland; Wahatoya Creek; Eagle River.

3. Crepis petiolata Rydb. In the mountains of Wyo. and Colo.-Alt. $7000-$ $9000 \mathrm{ft} .-$ Along Bear River, five miles east of Hayden; Georgetown.

4. Crepis glaucella Rydb. In wet meadows from Mont. to Colo.-Alt. about $7500 \mathrm{ft} .-$ Wahatoya Creek.

5. Crepis perplexa Rydb. In valleys from N. D. and Alb. to Neb. and Colo. -Alt. 5000-9000 ft.-Sterling, Logan Co.; Garland; Parlin; Sangre de Cristo Creek; South Park; Pagosa Springs; Empire; Bosworth's range; La Porte; Georgetown; Moon's ranch; Table Rock; Beaver Creek; Tobe Miller's ranch; Walden.

6. Crepis runcinata T. \& G. In valleys from N. D. and Alb. to Colo.Westcliffe.

7. Crepis riparia A. Nels. On river banks of Neb. and Colo. and Utah.Yampa; Steamboat Springs.

8. Crepis denticulata Rydb. In the mountains of Colo., Wyo. and Utah.Near Lake John, North Park. 
9. Crepis acuminata Nutt. On hillsides from Mont. and Wash. to Colo. and Calif.-Alt. $7000-8000$ ft.-Van Boxle's ranch, above Cimarron; Middle Park; near Manitou; Deadman Cañon; Mancos.

Io. Crepis intermedia A. Gray. On hillsides from Mont. and Wash. to Colo, and Calif.-Alt. about 7000 ft.-Big Creek Gulch, Routt Co.; Ragged Mountain, Gunnison Co.; Mancos; Cedar Edge.

II. Crepis angustata Rydb. On hillsides from Mont. and Wash. to Colo. and Oregon.-Alt. about 8000 ft.-North Park; Howe's Gulch.

12. Crepis pumila Rydb. On hillsides from Mont. and Ida. to Colo. and Calif.-Soda Springs.

13. Crepis occidentalis Nutt. On plains and hillsides from Mont. and Wash. to Colo. and Calif.-Alt. 5000-8000 ft.-Denver; Dolores; Thompson's Park, east of Mancos; Boulder; McCoy's, Eagle Co.; Mancos.

14. Crepis scopulorum Coville. In the mountains from Mont. to Colo. and Utah.-Alt. about $8000 \mathrm{ft}$.-Cerro Summit.

15. Crepis nana Richardson. Arctic-alpine localities from Lab. to Colo., Calif, and Alaska.-Mt. Lincoln.

\section{HIERACIUM L. HAWK-WEED.}

Achenes cylindrical.

Flowers yellow.

Plant 4-Io dm. high, leafy. $\quad$ I. H. cynosuroides.

Plant low, I-3 dm. high, with I-3 stem-leaves and a few heads.

Flowers white or ochroleucous.

Achenes tapering gradually upwards.

z. H. gracilis.

3. H. albiflorum.

4. H. Fendleri.

r. Hieracium cynosuroides Arvet. On hillsides and in valleys from Mont. and B. C. to Colo--Breckenridge.

2. Hieracium gracile Hook. In the mountains from Mont. and Alaska to Colo. and Calif., especially along streams.-Alt. 9000-12,000 ft.-Cameron Pass; Chambers' Lake; Caribou; Silver Plume; high mountains about Empire; Gray's Peak; Marshall Pass; Berthoud Pass; above Beaver Creek; bank of Michigan; headwaters of Clear Creek; Anita Peak.

3. Hieracium albiflorum Hook. Open woods from Yukon to Colo. and Calif.-Alt. 8000-10,000 ft.-Keblar Pass; Continental Divide, Routt Co.; Steamboat Springs; Mt. Harvard; Cameron Pass; mountain between Sunshine and Ward; Buffalo Pass; mountains near Empire; Fish Creek Falls.

4. Hieracium Fendleri Schultz Bip. In woods from the Black Hills of S. D. to N. M. and Ariz.-Alt. 6000-10,000 ft.-Soldier Cañon; Horsetooth Mountain; Upper La Plata River; headwaters of Pass Creek; foot-hills, Larimer Co.; mountain above Little South; headwaters of Clear Creek.

\section{NOTHOCALAIS Greene.}

I. Nothocalais cuspidata (Pursh) Greene. (Troximon cuspidatum Pursh) On prairies from Ills. and S. D. to Mo. and Colo.-Alt. 4000-8000 ft.-Trinidad; Howe's Gulch; foot-hills, Larimer Co.; hills southeast of La Veta; plains near Denver; South Cheyenne Cañon; New Windsor; Horsetooth Gulch; Colorado City. 


\section{I3. AGOSERIS Raf.}

Beak short, scarcely more than half as long as the body of the achenes, striate throughout.

Leaves decidedly pubescent, even in age.

Outer bracts lanceolate, obtuse.

Outer bracts ovate or ovate-lanceolate, acuminate.

I. A. pubescens.

Leaves in age glabrate and glaucous.

Bracts villous-ciliate, at least on the margins.

Inner bracts long-acuminate; plant less than $2 \mathrm{dm}$. high.

Inner bracts merely acute.

2. A. inaculata.

Leaves obtuse or acute, entire or rarely toothed.

Outer bracts much broader than the inner, often obtusish; plant generally low and leaves short, obtuse.

4. A. pumila.

Outer bracts usually not much broader than the inner; plant 3-5 $\mathrm{dm}$. high; leaves long and acute.

5. A. scorzoneraefolia.

Leaves acuminate, more or less pinnatifid, lobed or toothed.

Leaves deeply pinnatifid; flowers turning purplish.

6. A. agrestis.

Leaves less deeply pinnatifid; flowers not turning purple.

7. A. Leontodon.

Bracts glabrous; involucres if at all hairy, only tomentose at the very base.

Leaves entire or toothed.

Outer bracts oval or ovate, obtusish; leaves $2-3 \mathrm{dm}$. long, oblanceolate;

flowers rose-color. 8 . A. roseata.

Bracts all linear-lanceolate, acute or acuminate; flowers yellow.

Leaves linear-oblanceolate. 9. A. glauca.

Leaves narrowly linear.

I0. A. parviflora.

Leaves pinnatifid with narrow lobes; flowers yellow, turning purple.

Bracts with loose spreading tips; heads broadly campanulate.

iI. A. rosea.

Bracts appressed; heads more or less turbinate. 12. A. laciniata.

Beak long, about as long as or longer than the body of the achene, scarcely striate at the middle.

Bracts all broad, ovate to ellipitical, abruptly acuminate.

3. A. montana.

Bracts, at least the inner ones, linear or linear-lanceolate, acute.

Involucres more or less regularly imbricated; beak about equalling the body of the achenes.

Leaves densely pubescent.

Plant low; Howers purple. I4. A. arachnoidea.

Plant tall; flowers yellow. I5. A. elata.

Leaves glabrous or nearly so.

Flowers reddish-brown or deep orange, changing into purplish.

Bracts with purplish blotches; leaves glaucous.

Bracts not with purplish blotches, if at all purplish only along the mid-rib.

Leaves narrowly linear, glaucous, usually pinnatifid with linear lobes. I7. A. Greenei.

Leaves oblanceolate, usually entire, rarely with short broad lobes or teeth.

All bracts narrowly linear and acute.

Plant tall, slender, $3-5 \mathrm{dm}$. high; leaves erect; heads $2-3 \mathrm{~cm}$. high.

I8. A. gracilens.

Plant low, I-3 dm. high; leaves spreading; heads $1.5-2 \mathrm{~cm}$. high. I9. A. humilis.

Outer bracts oblong or lanceolate, often obtuse. 20. A. aurantiaca.

Flowers light yellow, but often turning pinkish; inner bracts elongated in age. 
Involucres $1-1.5 \mathrm{~cm}$. in diameter; plant tall and stout, scarcely glaucous. I 5. A. elata.

Involucres less than $\mathrm{I} \mathrm{cm}$. in diameter; plant slender, glaucous.

21. A. arizonica.

Involucres of two distinct sets of bracts; the inner narrowly linear, 2 to 3 times as long as the ovate or oval outer ones; beak $3-4$ times as long as the body of the achenes.

22. A. rostrata.

1. Agoseris pubescens Rydb. On hillsides of Wyo. and Colo.-Platte Cañon; Marshall Pass.

2. Agoseris maculata Rydb. In the mountains of Colo.-Alt. 10,000-I3,000 ft.-Silver Plume; Tennessee Pass.

3. Agoseris attenuata Rydb. In the mountains of Colo.-Alt. near Io,000 ft.-Mountains west of North Park.

4. Agoseris pumila (Nutt.) Rydb. (Troximon pumilum Nutt.) On hills from Mont. to Colo.-Alt. up to I2,300 ft.-Red Mountain; Silver Plume.

5. Agoseris scorzoneraefolia (Schrad.) Greene. (Troximon glaucum dasycephalum T. \& G.) On hillsides from Mont. and Alb. to Colo.-Alt. 4000$8000 \mathrm{ft}$--Divide road to Steamboat Springs; Gunnison; Four-mile Hill, Routt Co.; Marshall Pass; Gypsum Creek Cañon.

6. Agoseris agrestis Osterh. On hills of Colo-Alt. 7000-r2,000 ft.-Estes Park, Larimer Co.; Ojo; butte, five miles southwest of La Veta; Berthoud Pass.

7. Agoseris Leontodon Rydb. On hills from Mont. and S. D. to Colo. and Ariz.-Alt. 7000-I0,000 ft.-Georgetown; Cripple Creek road, near Pike's Peak; Van Boxle's ranch, above Cimarron; Marshall Pass; Gunnison; Fourmile Hill; Walton Creek; Bear Creek.

8. Agoseris roseata Rydb. On hills in Colo.-Bear River, twenty miles below Steamboat Springs.

9. Agoseris glauca (Pursh) Greene. (Troximon glaucum Nutt.) On prairies and in meadows from Sask. and Wash. to Colo. and Utah.-Alt. 4000-10,000 ft.-Pitkin; near Teller, North Park; Stove Prairie; Bosworth's ranch; Ruxton Dell; Wahatoya Creek; Mancos; mountains, Larimer Co.; swamp above Beaver Creek; Dolores; Elk River; Conejos River, north of Antonito.

Io. Agoseris parviflora (Nutt.) Dietr. (Troximon glucum parviflorum A. Gray) In meadows from N. D. and Alb. to Colo.-Alt. $4000-8000 \mathrm{ft}$.Chambers' Lake; Gunnison; Parlin; Steamboat Springs; Mt. Harvard; Boulder.

II. Agoseris rosea (Nutt.) Dietr. (Troximon roseum Nutt.) In valleys of Colo.-Alt. about $8000 \mathrm{ft}$-Ojo.

12. Agoseris laciniata (Nutt.) Greene. (Stylosanthus laciniatus Nutt.; not Troximon laciniatum A. Gray) In meadows and valleys from Wyo. and Ida. to Colo. and Calif.-Alt. 5000-9500 ft.-Minturn, Eagle Co. ; Cerro Summit; Los Pinos; Durango; Seven Lakes, near Pike's Peak; Grayback mining camps; river bluffs north of La Veta; butte, five miles southwest of La Veta; headwaters of Sangre de Cristo Creek; Boulder.

13. Agoseris montana Osterh. In the mountains of Colo. and Wyo.-Alt. 9000-II,500 ft.-Mountains west of North Park, along road to Steamboat Springs; Buffalo Pass; mountainsides near Empire.

14. Agoseris arachnoidea Rydb. In valleys of southern Colo.-Alt. 7000$9500 \mathrm{ft}$.-Grayback mining camps; La Veta. 
15. Agoseris elata (Nutt.) Greene. (Troximon Nuttallii A. Gray) In rich low ground from Mont. and B. C. to Colo. and Calif.-Alt. 7000-10,000 ft.-Glenwood Springs; La Veta; Veta Pass; Cameron Pass; Horsetooth Gulch.

I6. Agoseris purpurea (A. Gray) Greene. (Troximon auranthiacum purpureum A. Gray) In the mountains of Colo. and N. M.-Alt. about 9ooo ft.-Table Rock; Minnehaha; near Pagosa Peak; Rogers.

17. Agoseris Greenei (A. Gray) Rydb. (Troximon gracilens Greenei A. Gray) In meadows from Alb. and B. C. to Colo.-Alt. about 8000 ft.-Minnehaha; Chicken Creek.

18. Agoseris gracilens (A. Gray) Greene. (Troximon gracilens A. Gray) In meadows and on hillsides from Mont. and B. C. to Colo. and Utah.-AIt. 8000-12,000 ft.-Steamboat Springs; West Indian Creek; Bear River, Routt Co.; Pike's Peak; Bob Creek; mountain near Veta Pass; Red Mountain; between Cheyenne Mountain and Seven Lakes; West Mancos Cañon; Grayback mining camps; Pass Creek; Mt. Harvard; North Fork of Cache la Poudre River; Buffalo Pass; Anita Peak; summit of North Park Range, Routt Co.

19. Agoseris humilis Rydb. In the mountains of Colo. and Wyo.-Alt. about $9000 \mathrm{ft}$.-Ironton Park, nine miles south of Ouray; Breckenridge; Tennessee Pass.

20. Agoseris aurantiaca (Hook.) Greene. (Troximon aurantiacum Hook.) In mountain meadows and on banks of streams from Mont. and B. C. to Colo.-Alt. 6000-13,000 ft.-Steamboat Springs; Pike's Peak; Tennessee Pass; Delta Co.; near Teller, North Park; Mt. Hesperus; near Ironton, San Juan Co.; Franklin.

21. Agoseris arizonica Greene. ( $A$. elongata Greene) In the mountains of Colo., N. M. and Ariz.-Alt. 7000-900o ft.-Grayback mining camps; Black Cañon; near Pagosa Peak; Piedra.

22. Agoseris rostrata Rydb. In the mountains of Colo.-Alt. $8000-9000 \mathrm{ft}$. -Lower Boulder Cañon; mountains between Sunshine and Ward; Bear Creek.

\section{TARAXACUM Hall. Dandelion, Blowball.}

Outer bracts (calyculum) more or less squarrose.

Outer bracts reflexed from the base; leaves deeply runcinate with triangular teeth.

Bracts numerous; leaves broad and the terminal lobe large.

$$
\text { B. T. Taraxacum. }
$$

Bracts few; leaves narrow and the terminal lobe small. 2. T. mexicanum.

Outer bracts or most of them appressed at the base and with spreading or reflexed tips; leaves with short lobes or sinuate.

Bracts conspicuously corniculate; the outer about two-thirds as long as the inner; achenes spinulose-toothed above and tuberculate on some of the ribs to near the base.

3. T. dumetorum.

Bracts, at least the outer ones, not corniculate; these about half as long as the inner; achenes merely tuberculate above, smooth below; leaves dark green.

Outer bracts wholly appressed, short.

Plant not dwarf; scape $5-20 \mathrm{~cm}$. high; involucres $15 \mathrm{~mm}$. high or more.

5. T. montanum.

Plant dwarf; scape $2-5 \mathrm{~cm}$. high; involucres $6-8 \mathrm{~mm}$. high and about $5 \mathrm{~mm}$. wide.

6. T. scopulorim. 
1. Taraxacum Taraxacum (L.) Karst. ( $T$. officinale Weber.) Around dwellings, in fields and on roadsides from Lab. and Wash. to S. C. and Calif.; naturalized from Europe.-Alt. 4000-7000 ft.-Minturn, Eagle Co.; La Veta; Ft. Collins.

2. Taraxacum mexicanum DC. In mountain valleys from Colo. to Mex. -Alt. 7000-9000 ft.-Pass Creek; Ouray; headwaters of Sangre de Cristo Creek; hills southeast of La Veta; along Uncompahgre River, near Ouray.

3. Taraxacum dumetorum Greene. (T. oblanceolatum A. Nels.) In mountain valleys from Ass. to Colo.-Alt. 7000-I0,000 ft.-Columbine; mountain near Veta Pass; Cucharas River, below La Veta; Mancos; Seven Lakes; Ft. Collins; Halfway House, Pike's Peak.

4. Taraxacum leiospermum Rydberg. In the mountains of Colo.-Alt. about Io,000 ft.-Tennessee Pass; Seven Lakes; Cripple Creek.

5. Taraxacum montanum Nutt. ( $T$. officinale alpinum A. Gray, in part) In the mountains from Mont. to Colo.-Alt. about $9500 \mathrm{ft}$.-Chambers' Lake; source of Leroux; Camp Creek.

6. Taraxacum scopulorum (A. Gray) Rydb. (T. officinale scopulorum A. Gray) On the higher peaks in damp places from B. C. to Utah, Colo. and Mont.-A1t. I0,000-I3,000 ft.-West Spanish Peak; Mt. Hesperus.

\section{I5. LACTUCA L. Lettuce.}

Achenes with a slender beak; pappus white.

Outer bracts (calyculum) not more than half as long as the bracts proper; flowers yellow, rarely tinged with blue.

Heads 6-8-flowered; achenes several-nerved, not rugose; leaves spinulose on the ribs.
I. L. virosa.

Heads I 2-20-flowered; achenes I-3-nerved, transversely rugose.
Involucres about I cm. high.
2. L. canadensis.

Involucres $1.5-2 \mathrm{~cm}$. high.

Leaves obovate or oblanceolate in outline with broad lobes, often spinu$\begin{array}{ll}\text { lose on the mid-ribs beneath. } & \text { 3. L. ludoviciana. }\end{array}$

Leaves linear or linear-lanceolate in outline, entire or with narrow lobes,

never spinulose.
4. L. graminifolia.
Outer bracts gradually increasing inwards; a distinct calyculum therefore not

evident; flowers blue. 5 5. L. pulchella.

Achenes beakless; pappus tawny or brown.

6. L. spicata.

I. Lactuca virosa L. In waste places and fields from Me. and N. D. to Ga. and Calif.; introduced from Europe--Alt. $5000 \mathrm{ft} .-\mathrm{Ft}$. Collins; Poudre flats.

2. Lactuca canadensis $L$. In moist open places from N. S. and Sask. to Fla. and Colo.-Alt. 4000-6500 ft.-La Porte, Larimer Co.; Hotchkiss; gulch west of Soldier Cañon.

3. Lactuca ludoviciana DC. River banks and moist places from Minn. and Mont. to Mo. and Tex.-Alt. 4000-8000 ft.-New Windsor; between Sunshine and Ward; Denver.

4. Lactuca graminifolia Michx. In rich soil from N. C. and Colo. to Fla. and Ariz.-Alt. up to $7500 \mathrm{ft}$.-Along the Uncompahgre River, near Ouray.

5. Lactuca pulchella DC. In wet meadows from Sask. and Wash. to Mo., N. M. and Calif.-Alt. 4000-8000 ft.-Cucharas Valley, near La Veta; Ft. Collins; Durango; Clear Creek; Gunnison; Parlin, Gunnison Co.; McCoy; Walsenburg; Montrose; Boulder; Gypsum; Table Rock; Fortification, Routt Co. 
6. Lactuca spicata (Lam.) Hitchk, (L. leucophaea A. Gray) In moist ground from Newf. and Man. to N. C. and Colo.-Boulder; Steamboat Springs.

16. SONChUS L. Sow-Thistle; Milk-thistle.

Involucres glandular-pubescent; heads about $25 \mathrm{~mm}$. high.

I. S. arvensis. Involucres glabrous; heads about $15 \mathrm{~mm}$. high.

Auricles of the leaves acute; achenes transversely wrinkled. 2. S. oleraceus. Auricles of the leaves rounded; achenes not transversely wrinkled.

3. S. asper.

I. Sonchus arvensis L. In fields from Newf. and Minn. to N. J. and Colo.; also on the Pacific Coast; introduced from Europe.-Walsenburg.

z. Sonchus oleraceus L. In fields and waste places from N. S. and Wash. to Fla. and Calif.; introduced from Europe--Alt. $5000 \mathrm{ft}$-Ft. Collins.

3. Sonchus asper (L.) All. In waste places and fields from N. S. and B. C. to Fla. and Calif.; introduced from Europe.-Alt. $4000-8000 \mathrm{ft}$--Along Uncompahgre River, near Ouray; Cerro Summit; Glenwood Springs. 
Number of Genera and Species Listed in Each Family and Order.

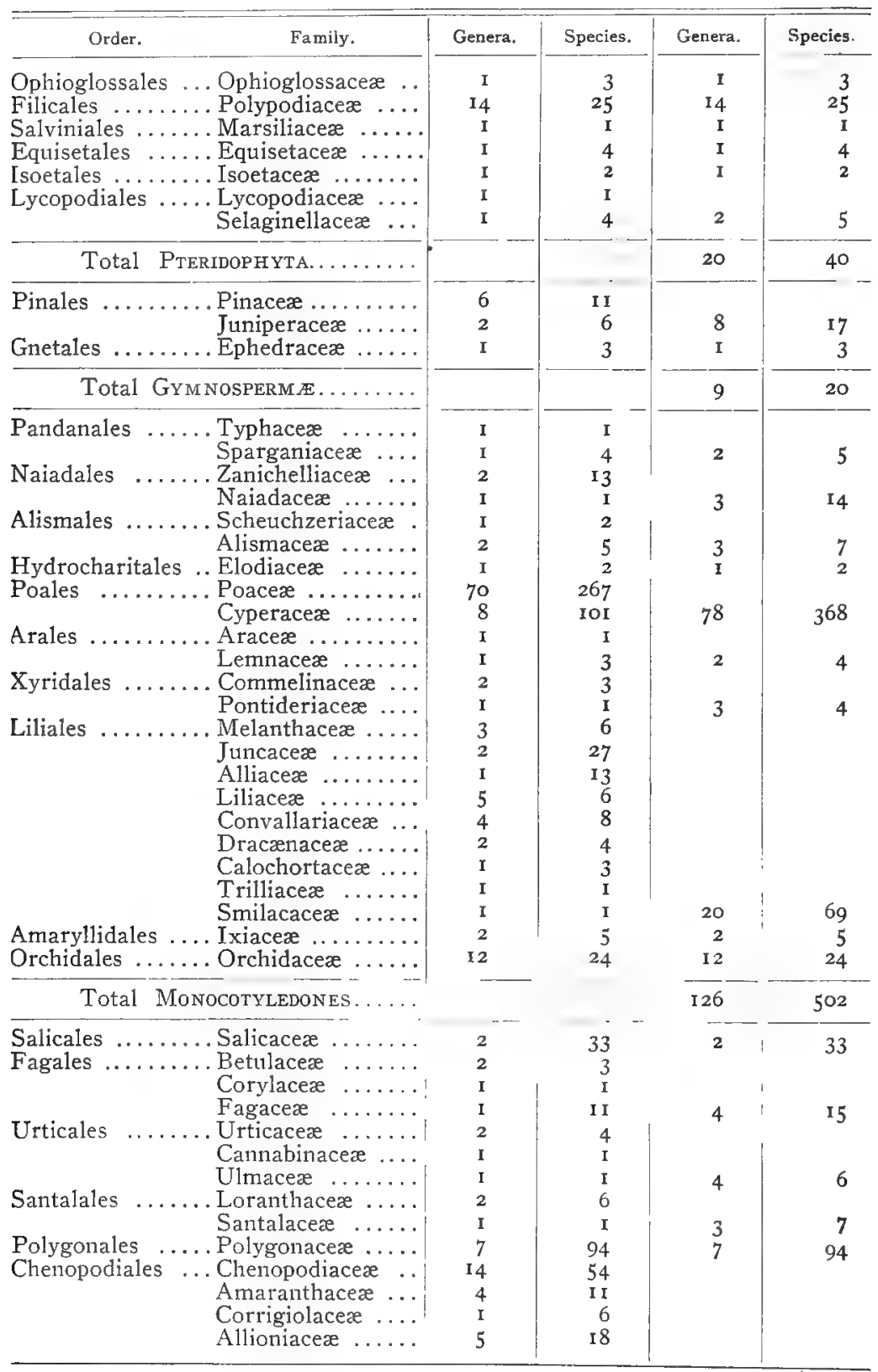


Number of Genera and Species Listed in Each Family and Order.

(Continued.)

\begin{tabular}{|c|c|c|c|c|c|}
\hline Order. & Family. & Genera. & Species. & Genera. & Species. \\
\hline & Tetragoniaceæ & I & I & & \\
\hline & Portulacaceæ .... & 8 & 14 & & \\
\hline & Alsinacæ $\ldots \ldots \ldots$ & 7 & $4 \mathrm{I}$ & & \\
\hline & Caryophyllaceæ .. & 3 & I 4 & 43 & I59 \\
\hline \multirow[t]{4}{*}{ Ranales } & Ceratophyllaceæ .. & $\mathbf{I}$ & l & & \\
\hline & Ranunculacex .... & I 7 & 92 & & \\
\hline & Nymphæaceæ .... & I & I & & \\
\hline & Berberidaceæ .... & 2 & 3 & $2 I$ & 97 \\
\hline \multirow[t]{3}{*}{ Papaverales } & Papaveracez .... & 2 & 4 & & \\
\hline & Fumariaceæ $\ldots$... & 2 & 4 & & \\
\hline & $\begin{array}{l}\text { Brassicacea } . . . \\
\text { Capparidacea }\end{array}$ & 27 & $\begin{array}{r}144 \\
8\end{array}$ & 35 & 160 \\
\hline \multirow{10}{*}{ Rosales ... } & Crassulaceæ ...... & $\begin{array}{l}4 \\
4\end{array}$ & $\begin{array}{l}8 \\
5\end{array}$ & & \\
\hline & Saxifragaceæ ... & 12 & 28 & & \\
\hline & Parnassiaceæ .... & I & 3 & & \\
\hline & Hydrangeaceæ ... & 3 & 5 & & \\
\hline & Grossulariaceæ ... & $\mathbf{I}$ & I 2 & & \\
\hline & Rosaceæ ........ & $2 I$ & 89 & & \\
\hline & Malaceæ ......... & 4 & I4 & & \\
\hline & $\begin{array}{l}\text { Amygdalaceæ } \ldots . . \\
\text { Mimosaceæ }\end{array}$ & I & 4 & & \\
\hline & $\begin{array}{l}\text { Mimosaceæ } . . . . . \\
\text { Cassiaceæ } . . . . .\end{array}$ & $\begin{array}{l}2 \\
2\end{array}$ & $\begin{array}{l}2 \\
3\end{array}$ & & \\
\hline & $\begin{array}{l}\text { Cassiaceæ } . . . . . . \\
\text { Fabaceæ ........ }\end{array}$ & 36 & 185 & 87 & $35^{\circ}$ \\
\hline \multirow[t]{5}{*}{ Geraniales . } & Geraniaceæ ..... & 2 & II & & \\
\hline & Linacer ........ & I & 7 & & \\
\hline & Oxalidacez ...... & 2 & .3 & & \\
\hline & Zygophyllaceæ ... & 2 & 3 & & \\
\hline & Rutaceæ ........ & 2 & 3 & 9 & 27 \\
\hline Polygalales . & Polygalaceæ ..... & I & 4 & I & 4 \\
\hline \multirow{2}{*}{ Euphorbiales } & Euphorbiaceæ .... & 8 & 25 & & \\
\hline & Callitrichaceæ ... & I & I & 9 & 26 \\
\hline \multirow{3}{*}{ Sapindales . } & Limnanthaceæ ... & $\mathbf{I}$ & I & & \\
\hline & $\begin{array}{l}\text { Spondiaceæ } \\
\text { Celastraceæ }\end{array}$ & $\begin{array}{l}2 \\
2\end{array}$ & 3 & & \\
\hline & & 2 & $\begin{array}{l}3 \\
4\end{array}$ & 7 & I I \\
\hline \multirow[t]{2}{*}{ Rhamnales .. } & Frangulacez ..... & 2 & 6 & & \\
\hline & Vitaceæ ......... & 2 & 3 & 4 & 9 \\
\hline Malvales ... & Malvaceæ ....... & 7 & 16 & 7 & 16 \\
\hline \multirow{5}{*}{ Hypericales } & Elatinacea $\ldots \ldots$ & I & 2 & & \\
\hline & Frankeniaceæ .... & I & $\mathbf{I}$ & & \\
\hline & Hypericacea ..... & I & 2 & & \\
\hline & Cistaceæ ........ & I & I & 6 & 22 \\
\hline & Violaceæ ........ & 2 & $\begin{array}{l}16 \\
20\end{array}$ & 0 & 22 \\
\hline \multirow{2}{*}{ Opuntiales } & Loasacer ........ & 3 & $\begin{array}{l}20 \\
23\end{array}$ & & \\
\hline & Cactaceæ ....... & 4 & $\begin{array}{r}23 \\
2\end{array}$ & $\begin{array}{l}7 \\
1\end{array}$ & 43 \\
\hline \multirow{3}{*}{ Myrtales ... } & 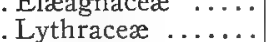 & $\begin{array}{l}\mathbf{I} \\
2\end{array}$ & $\begin{array}{l}2 \\
2\end{array}$ & & \\
\hline & Epilobiaceæ ..... & 16 & 62 & & \\
\hline & Gunneraceæ ..... & 2 & 2 & 20 & 66 \\
\hline \multirow{3}{*}{ Umbellales . } & Hederaceæ ..... & I & I & & \\
\hline & Cornaceæ ........ & 2 & 3 & & \\
\hline & Ammiacea ....... & 27 & $5^{8}$ & 30 & 62 \\
\hline \multirow[t]{4}{*}{ Ericales } & Monotropaceæ ... & $\mathbf{I}$ & $\mathrm{I}$ & & \\
\hline & Pyrolacea ...... & 3 & 8 & & \\
\hline & Ericacea ........ & 4 & 4 & & \\
\hline & Vacciniacex ..... & I & 3 & 9 & 16 \\
\hline
\end{tabular}


Number of Genera and Species Listed in Each Family and Order. (Continued.)

\begin{tabular}{|c|c|c|c|c|}
\hline Family. & Genera. & Species. & Gepera. & Species. \\
\hline Primulales .......Primulace & 6 & 19 & 6 & 19 \\
\hline Oleales .......... Oleacex ........ & 2 & 2 & 2 & 2 \\
\hline Gentianales ..... Gentianaceæ .... & 9 & 26 & & \\
\hline Menyanthaceæ ... & $\mathbf{I}$ & $\mathbf{I}$ & IO & 27 \\
\hline .. Apocynaceæ ..... & 2 & 7 & & \\
\hline Asclepiadaceæ ... & 3 & 15 & 5 & 22 \\
\hline Polemoniales .... Cuscutaceæ ..... & I & 7 & & \\
\hline Convolvulaceæ ... & 3 & 8 & & \\
\hline $\begin{array}{l}\text { Polemoniaceæ .... } \\
\text { Hydroleaceæ .... }\end{array}$ & $\begin{array}{l}9 \\
5\end{array}$ & $\begin{array}{l}58 \\
16\end{array}$ & & \\
\hline Heliotropaceæ ... & 2 & 2 & & \\
\hline Boraginaceæ ..... & II & 76 & & \\
\hline Verbenaceæ ...... & 2 & 6 & & \\
\hline Lamiaceæ ........ & 20 & 38 & & \\
\hline Solanaceæ ....... & 9 & $3 \mathbf{I}$ & & \\
\hline Rhinanthaceæ .... & I 8 & 106 & & \\
\hline Pinguiculaceæ ... & I & 2 & & \\
\hline $\begin{array}{l}\text { Orobanchaceæ } \ldots . \\
\text { Martyniaceæ }\end{array}$ & 2 & 3 & 84 & \\
\hline Plantaginaceæ .... & I & 7 & I & $\begin{array}{r}304 \\
7\end{array}$ \\
\hline Rubiales ......... Rubiaceæ ....... & I & I I & & \\
\hline Caprifoliaceæ .... & 5 & $I_{4}$ & & \\
\hline Adoxaceæ ....... & I & I & 7 & 26 \\
\hline Campanulales .... Cucurbitaceæ .... & 2 & 2 & & \\
\hline Campanulaceæ ... & 2 & 6 & & \\
\hline Lobeliaceæ ...... & I & I & 5 & 9 \\
\hline Valerianaceæ ..... & I & 7 & I & 7 \\
\hline $\begin{array}{l}\text { Ambrosiaceæ } \\
\text { Carduaceæ }\end{array}$ & $\begin{array}{r}6 \\
88\end{array}$ & $\begin{array}{r}13 \\
568\end{array}$ & & \\
\hline Cichoriaceæ ...... & I6 & 71 & I IO & 652 \\
\hline Total Dicotyledones......... & & & 547 & $2,35^{\circ}$ \\
\hline
\end{tabular}

Summary.

\begin{tabular}{|c|c|c|c|c|}
\hline & Orders. & Families. & Genera. & Species. \\
\hline $\begin{array}{l}\text { Pteridophyta ............. } \\
\text { Spermatophyta: } \\
\text { Gymosperma ........ } \\
\text { Angiospermæ: } \\
\text { Monocotyledones... } \\
\text { Dicotyledones ..... }\end{array}$ & $\begin{array}{l}6 \\
2 \\
10 \\
3 I\end{array}$ & $\begin{array}{r}7 \\
3 \\
24 \\
100\end{array}$ & $\begin{array}{r}20 \\
9 \\
126 \\
547\end{array}$ & $\begin{array}{r}40 \\
20 \\
502 \\
2,350\end{array}$ \\
\hline & 49 & r 34 & $70 \dot{2}$ & 2,912 \\
\hline
\end{tabular}




$$
\text { . }
$$


Contour Map of Colorado, Showing Counties, County Seats and Principal Streams.

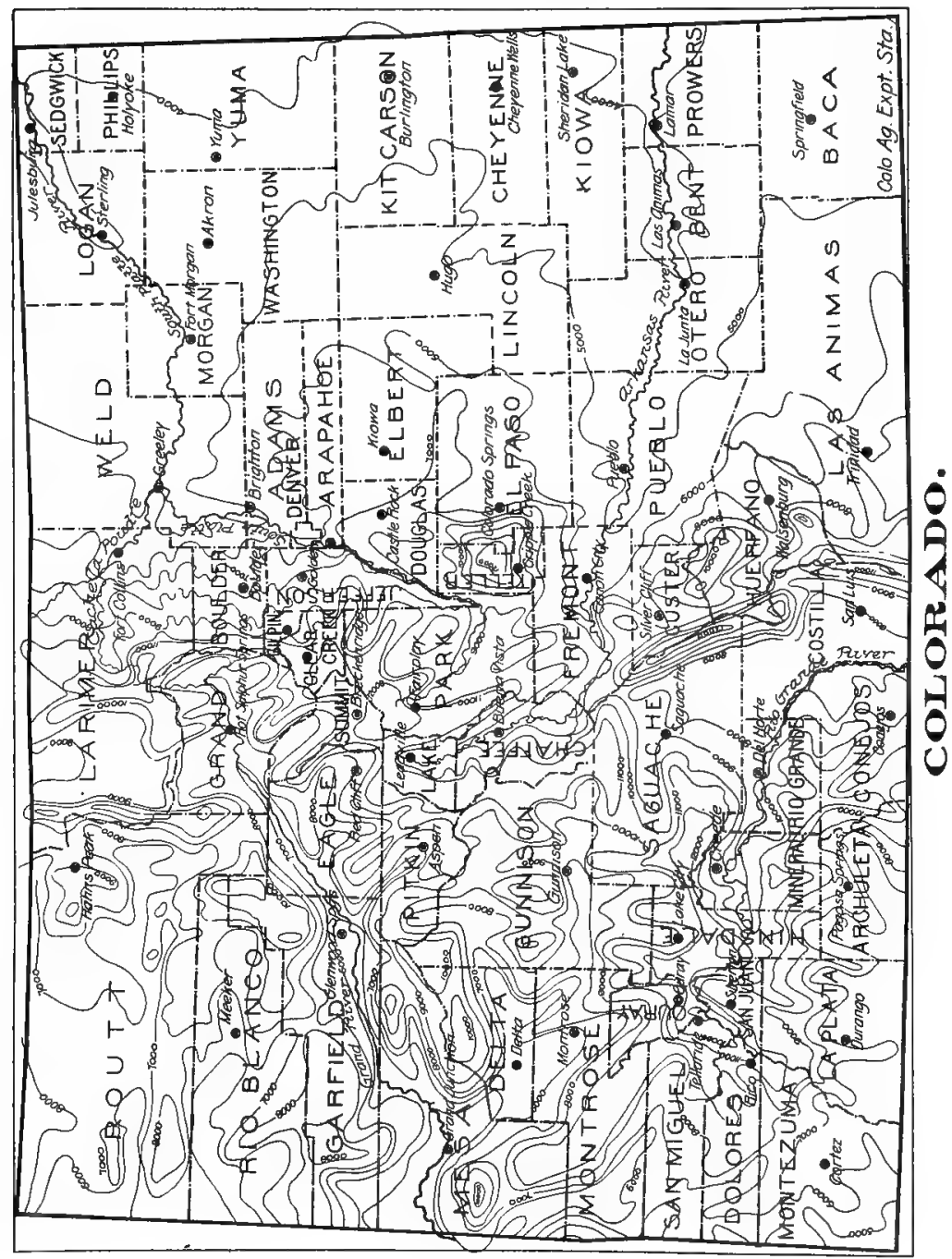




\section{GAZETTEER OF LOCALITIES MENTIONED GIVING LOCATION AND ELEVATIONS.}

The variation of elevation in Colorado from 3,350 to 14,483 feet at the highest peaks, introduces a corresponding range in climate and consequently great differences in flora. Within a short distance there may be a change in elevation which entirely changes the character of the flora, or alters the season of the year. The elevation becomes, therefore, often a more important guide than latitude.

Accordingly pains have been taken to give the elevations of the localities. The names are so often local, frequently changing, that it was thought best to identify them so far as possible, and to give the elevation. This list is therefore not a gazetteer of the State, but intended to give only the localities mentioned in the Flora. Where there are several localities of the same name, as is frequently the case, the ones where collections were made are intended to be given. The extreme elevations of streams are usually given, though not always.

The State has an area of I04,500 square miles, an area nearly as large as the six states of New England and the State of New York in addition. Speaking broadly, the eastern half forms part of the Great Plains. The rise from the eastern border of the State is steady but gentle to the foothills, where there is an abrupt rise, and the remaining half of the State may be considered mountainous, broken by numerous parks. The larger parks, as North Park, Middle Park, South Park and the San Luis Valley, are of considerable size, the latter being nearly 4,000 square miles, and at an elevation of about 7,000 to 8,000 feet. There are many other parks, as Estes Park, Egeria Park, and hundreds of moderate size. In general, timber line is found at about II,500 feet, variations of 500 feet above or below being found, due to local conditions. The local configuration influences the direction and amount of wind, the upward movement of the air, and consequently the amount and distribution of rainfall, therefore the flora. Hence these elements are important, if not controlling, and necessary to take into consideration. In addition the irrigated sections introduce important modifications. Irrigation occurs principally along the flanks of the mountain ranges, in the mountain valleys, and extending in tongues along the principal streams like the Platte and Arkansas, with small patches in other places where water is available.

The range of climate represents as great extremes as between Charleston, S. C., and Spitzbergen. In parts of the State snow rarely falls nor remains for any length of time, while in the high altitudes snow falls in every month and lasts throughout the year. With these conditions it is not surprising that there is a great number of species.

A map of the State is given showing the contours at intervals of 1,000 feet, all points on the same line being at the same elevation. From this map the general configuration of any part of the State, as well as the elevation of any portion may be closely estimated. The counties as they now exist, the principal streams, and county seats are also shown.

Much more labor was required to identify localities than was anticipated. Collectors have often used names for localities almost impossible to identify, especially where these names depend on ephemeral characters, as the name of an owner. Frequently places have changed names, as South Park was known to Fremont as Bayou Salade. Other names once common are now disused or displaced, and sometimes migrated to other localities.

The elevations are given in most cases, and are hoped to be essentially correct.

L. G. C. 
Alamosa, Conejos Co., San Luis Valley; alt. 7,550 ft.

Alpine Tunnel, at Alpine Pass, on C. \& S. R. R., Chaffee Co.; alt. II,608 ft. Anchor, Clear Creek Co.; alt. 10,450 ft.

Andrezes' Ranch and

Andrews' Shetland Ranch, on Cache la Poudre; alt. 7,700 ft.

Anita Peak, Elk Head Mountains, Routt Co.; alt. I0.66I ft.

Antonito, station on D. \& R. G. R. R., Conejos Co.; alt. $7,888 \mathrm{ft}$.

Apex, Gilpin Co.; alt. 9,858 ft.

Apishapa River, a tributary of Arkansas River, near Rocky Ford; heads near the Spanish Peaks; alt. from 4,300 to I2,000 $\mathrm{ft}$.

Arapahoe Pass, between Boulder and Grand counties; alt. approx. 12,00o ft. Arapahoe Peak, Front Range, Boulder Co.; alt. 13,520 ft.

Arboles, station on D. \& R. G. R. R., Archuleta Co.; alt. $5,998 \mathrm{ft}$.

Argentine Pass, between Clear Creek and Summit counties; alt. I3, Ioo ft.

Arkansas Cañon, commonly restricted to portion above Cañon City; alt. 5,500 to $6,000 \mathrm{ft}$.

Arkansas Junction, three miles west of Leadville; alt. Io, $185 \mathrm{ft}$.

Arthur's Rock (local), six miles southwest of Fort Collins; alt. 7,000 ft.

Artist's Glen, Pike's Peak; alt. 7,000 to 9,000 ft.

Aspen, Pitkin Co.; alt. 7,874 ft.

Aztec, on Aztec Creek, a tributary to San Juan river. (Some of the plants listed were perhaps collected at Aztec, N. M., which is not far from the Colorado line.)

Badito, on Huerfano River, below Gardner; alt. about 6,500 ft.

Bahia Salada, Spanish name of South Park; see Bayou Salade.

Bald Mountain (a very common local name), eight miles west of Loveland; alt. $7,200 \mathrm{ft}$. See Mt. Baldy.

Baldwin, Gunnison Co., south of Crested Butte; alt. 8,720 ft.

Baltimore, northern Gilpin Co., on Boulder Creek; alt. 8,9I4 ft.

Bard Creek Valley, near Empire, Clear Creek Co.; alt. 8,300 to I2,000 ft.

Barlow Ranch, Larimer Co., near Livermore; alt. about 6,500 ft.

Barnes' Camp, near junction of Beaver Creek with Little South Poudre; alt. about $7,200 \mathrm{ft}$.

Basin Creek, tributary to San Miguel in Montrose Co.; alt. 6,000 to 8,000 ft.

Battlement Crag, Pike's Peak; alt. about 9,000 ft.

Baxter's Ranch, west of Fort Collins; ait. 6,500 to $6,800 \mathrm{ft}$.

Bayfield, see Los Pinos.

Bayou Salade, name of South Park by early French trappers; alt. 8,000 to I0,000 $\mathrm{ft}$.

Bear Creek Cañon, near Ouray; alt. 8,722 ft.

Bear Creek (a very common name), near Pike's Peak, enters the Fountain at Colorado City; alt. 5,500 to I2,000 $\mathrm{ft}$.

Bear River, a tributary of Yampa River, Routt Co.; alt. 6,500 to I2,000 ft.

Beaver Creek (a very common name), Larimer Co.; enters Little South; alt. $6,800-$ II, $900 \mathrm{ft}$.

Routt Co.; flows into Willow Creek; alt. 8,200-ro,000 ft.

San Miguel Co.; flows into San Miguel River; alt. 7,500 to $12,500 \mathrm{ft}$.

Collections were made on all the above streams.

Beaver Park (also common), El Paso and Fremont counties; alt. 9,000 to I0,000 ft.

Larimer Co., Estes Park, above James's Hotel; alt. 8,500 ft.

Teller Co., northeast of Cripple Creek; alt. about $9.500 \mathrm{ft}$.

Bellevue, Larimer Co., eight miles northwest of Fort Collins; alt. 5,2I I ft.

Bent's Fort, on Arkansas River, eight miles west of Lamar to I852. then west of Las Animas; alt. 3,700 to $4,000 \mathrm{ft}$.

Bergen Park, Jefferson Co., southwest of Golden; alt. 7,643 ft.

Berkeley Lake, Jefferson Co., near Denver; alt. 5,400 ft.

Berthoud Pass, near Georgetown; alt. II,349 ft.

Berwind, Huerfano Co.; alt. about $6,500 \mathrm{ft}$.

Bierstadt Lake, near Flat Top trail, Estes Park; alt. about $10,500 \mathrm{ft}$.

Big 'Creek Gulch, Routt Co.; alt.' about 8,000 ft. 
Big Muddy, western Gunnison Co.; alt. about 8,000 to Ir,000 ft.

Big South, fork of Cache la Poudre; alt. 8,000 to I I,000 ft.

Big Thompson Creek, Larimer Co., from Estes Park to South Platte, near Denver; alt. 4,600 to $12,000 \mathrm{ft}$.

Bijou Basin, on the plains, El Paso Co., west fork of Bijou Creek, a tributary of South Platte.

Bingham Fill, five miles northwest of Fort Collins; alt. 6,000 ft.

Bitter Creek, Rio Blanco Co., a tributary of White River, below Coyote Basin ; alt. 5,800 to $9,000 \mathrm{ft}$.

Black Cañon of the Gunnison, Gunnison River below Sapinero; alt. about $7,000 \mathrm{ft}$.

Black's Lake, now forms part of Terry Lake Reservoir, two miles north of Fort Collins; alt. 5,200 ft.

Blue River, a tributary to Grand River, Summit and Grand counties; alt, 7,000 to $12,000 \mathrm{ft}$.

Bob Creek, west of Mt. Hesperus, La Plata Mountains; alt. 8,00o to Io,00o ft.

Boreas, on Breckenridge Pass, on C. \& S. R. R., between Breckenridge and Como; alt. II,482 ft.

Bosworth's Ranch, Stove Prairie; alt. 8,000 ft.

Bottomless Pit, Pike's Peak; alt. 13,000 ft.

Boulder, Boulder Co.; alt. $5.347 \mathrm{ft}$.

Boulder Cañon (Lower); alt. about $5,500 \mathrm{ft}$.

Boulder Creek, Boulder Co., a tributary of the Platte through the St. Vrain; alt. 4,800 to summit of range.

Box Cañon, west of Ouray; alt. 7,000 to 9,000 ft.

Brant's Soda Spring, near North Platte River, Larimer Co.; alt. about $8,800 \mathrm{ft}$.

Brantly Cañon, Las Animas Co.; alt. about 5,000 ft.

Breckenridge, Summit Co.; alt. about 9,700 ft.

Brush Creek, Custer Co.; alt. 7,000 to I2,000 ft.

Brush Creek, Gunnison Co., tributary to East River; ait. 9,000 to 13,000 ft.

Buckhorn Creek, Larimer Co., a tributary of Big Thompson Creek; alt. about 5,200 to $8,000 \mathrm{ft}$.

Buena Vista, Chaffee Co., on the Arkansas River; alt. 7,967 ft.

Buffalo Pass, Routt Co. and Larimer Co., across Park Range, between North Platte and Bear Rivers; alt. 10,650 ft.

Cabin Cañon, near Pike's Peak; alt. 5,000 to I0,000 ft.

Cache à la Poudre, now commonly written.

Cache la Poudre River, Larimer Co., outlet of Chamber's Lake, tributary to South Platte River near Greeley; alt. 4,500 to 9, I00 ft.

Calhan, El Paso Co., station on the C., R. I. \& P. R. R.; alt. $6.508 \mathrm{ft}$.

Calloway Hill, Larimer Co., near Livermore; alt. about 7,000 ft.

Cameron's Cone, near Pike's Peak; alt. Io,605 ft.

Cameron Pass, Medicine Bow range, between Cache la Poudre and Michigan Creek, Larimer Co.; alt. 10,300 ft.

Camp Creek, North Park; alt. 6,000 to 8,000 ft.

Camp Creek, Routt Co., Buffalo Pass; alt. 6,700 to 1o,600 ft.

Camp Creek, south of Gunnison; alt. 7,400 to 10,000 ft.

Camp Hardinge, near Pike's Peak.

Campton's, on the North Poudre, Larimer Co.; alt. about 7,800 ft.

Cañon City, Fremont Co.; alt. $5,343 \mathrm{ft}$.

Caribou, Boulder Co.; alt. 9,9I2 ft.

Carisa,

Carriso, in the Navajo settlements; alt. 8,000 to 9,000 $\mathrm{ft}$.

Carlton Lake, Grand Co., near Grand Lake; alt. about 8,100 ft.

Carson, Hinsdale Co., northeastern part (high).

Cascade Cañon, Pike's Peak; alt. 7,409 ft.

Cascade, seven miles west of Colorado Springs, E1 Paso Co., on Colorado Midland R. R.; alt. 7,000 ft.

Cassell's, northern part of Park Co.; alt. about 9,000 ft.

Castle Cañon, Castle Gulch, east of Jamestown; alt. 6,800 to 8,000 ft.

Castle Rock, Douglas Co.; alt. 6,219 ft. 
Cedar Creek, Logan Co., tributary to Horsetail Creek.

Montrose Co., tributary to Uncompahgre River; alt. 6,000 ft.

Cedar Edge (Cedaredge), north central Delta Co.; alt. about 7,000 ft.

Cedar Hills, northern part of Las Animas Co.; alt. about 6,ooo ft.

Central City, Gilpin Co., on U. P. D. \& G. R. R.; alt. 8,5I5 ft.

Cerro Summit, Montrose Co., between Cimarron and Montrose; alt. 7,964 ft.

Chamber's Lake, head of Poudre River, Larimer Co, ; alt. 9, Ioo ft.

Cherokee Hill, near Livermore, Larimer Co.; alt. 7,000 to 8,000 ft.

Cherry Creek, tributary of South Platte, near Denver, on Divide between Platte and Arkansas Rivers; alt. 5,000 to 7,700 ft.

Cherry Creek, Montezuma Co., tributary to Rio de la Plata.

Chester, Saguache Co., station on the D. \& R. G. R. R., between Salida and Gunnison; alt. 9,397 ft.

Cheyenne Cañon, see North' and South Cheyenne Cañons, Pike's Peak; alt. about 6,000 to $9,000 \mathrm{ft}$.

Cheyenne Mountain, southeast of Pike's Peak; alt. 9,407 ft.

Cheyenne Wells, Cheyenne Co., on the U. P. R. R.; alt. 4,279 ft.

Chicago Lakes, six miles southeast of Georgetown, north slope of Mt. Evans; alt. I $\mathrm{t}, 500 \mathrm{ft}$.

Chicken Creek, west of La Plata Mountains, Montezuma Co.; alt. 7,000 to $9,000 \mathrm{ft}$.

Cimarron Creek, see Little Cimarron River; alt. 6,900 to $14,000 \mathrm{ft}$.

Cimarron River, a tributary of Arkansas River, flowing through southeastern Colorado; alt. about 3,600 to $7,500 \mathrm{ft}$. Most references are to the Little Cimarron, or Cimarron Creek.

Cimarron Station, on the D. \& R. G. R. R., at the junction of the Little Cimarron and the Gunnison; alt. 6,906 ft.

Cipango Hill, Larimer Co., west of Stove Prairie; alt. about 8,000 ft.

Clark's Peak, Larimer Co., near Chamber's Lake; alt. $13,800 \mathrm{ft}$. Sometimes locally called Cameron Peak from neighboring Cameron Pass.

Clcar Creek, a tributary of the South Platte River, at Denver; alt. 5,000 to I $2,000 \mathrm{ft}$. A common name.

Clear Creek Cañon, cañon of Clear Creek, above Golden.

Clear Lake, three miles south of Georgetown; alt. 9,870 ft.

Cochetopa Pass, Saguache Co., between Cochetopa Creek and Saguache River; alt. $10,032 \mathrm{ft}$.

Coffee Pot Spring, Coffee Pot Gulch, southeast Garfield Co.; alt. above I0,600 ft.

Colorado City, El Paso Co., between Colorado Springs and Manitou; alt. 6, i io ft.

Colorado College, Colorado Springs; alt. about 6,200 ft.

Colorado Springs, El Paso Co., near Pike's Peak; alt. 6,098 ft.

Columbine, Routt Co., near Hahn's Peak; alt. 8,000 ft.

Columbine, Larimer Co., northern part of Estes Park; alt. about 8,000 ft.

Como, Park Co., South Park; alt. $9,787 \mathrm{ft}$.

Conejos River, a tributary of the Rio Grande del Norte; alt. from 7,300 to summit of range.

Corral Creek, Grand Co., a tributary of the Grand River.

Cottonwood Creek, Fremont Co., a tributary of the Arkansas River.

Cottonwood Creek, near Buena Vista, Chaffee Co. A very common name.

Cottonwood Lake, near Buena Vista; alt. $9,977 \mathrm{ft}$.

Cowdry, formerly Pinkhampton, North Park; alt. 8,200 ft.

Cozzens, near Berthoud Pass, Middle Park.

Craig, Routt Co., on Beaver River; alt. 6,050 ft.

Crags, The, northwest of Pike's Peak; alt. 10,500 ft.

Crested Butte, Gunison Co.; alt. 8,896 ft.

Cripple Creek Road, Teller Co. (to Colorado Springs); alt. 6,098 to 9,400 $\mathrm{ft}$.

Cripple Creek, Teller Co.; alt. 9,400 ft.

Crow Creek, Weld Co., a plains tributary of South Platte River from north of Cheyenne; alt. 4,500 to $6,000 \mathrm{ft}$.

Crystal Creek, north of Glen Eyrie, near Manitou; probably 6,000 to 8,000 ft.

Crystal Creek, near Ouray; alt. 7,000 to 9,000 ft. 
Crystal Park, between Manitou and Bear Creek Cañon; alt. about 8,500 ft.

Cucharas River, a tributary of Huerfano River; alt. 5, Ioo to summit of range.

Cumberland Mine, east La Plata Mountains; alt. about I2,300 ft.

Cumbres, Conejos Co., on the D. \& R. G. R. R., between Alamosa and Durango at the summit of the San Juan Range; alt. Io,oI5 ft.

Custer Butte; alt. about 9,000 $\mathrm{ft}$.

Dale Creek, northern Larimer Co.; alt. 7,500 ft.

Damfino Creek, tributary of Encampment Creek, northwest North Park; alt. about Io,000 $\mathrm{ft}$.

Dark Cañon, near Pike's Peak.

Dark Cañon, Gunnison Co., south of Ragged Mountain; alt. 8,500 ft.

Dead Lake, Pike's Peak, on divide between Beaver and Bear Creeks, southeast of summit; alt. Io,800 ft.

Deadman's Cañon, south of Cheyenne Mountain; alt. about 6,500 ft.

Deep Creek Lake, Garfield Co.; alt. about I0,000 ft.

Deep Creek Lake, Routt Co.; alt. about $9,000 \mathrm{ft}$.

Deep Creek, Routt Co., a tributary of Williams' Fork of Yampa River.

Deep Creek, San Juan Co.; alt. I0,000 to I2,500 ft.

Deer River; alt about $4,700 \mathrm{ft}$.

Deer Creek. exceedingly common name.

Deer Rur, Mesa Co., station on D. \& R. G. R. R. between Delta and Grand Junction; alt. 4,697 ft.

Delta, near mouth of Uncompahgre River; alt. $4,980 \mathrm{ft}$.

Democrat Mountain, northwest of Georgetown; alt. II,400 ft.

Denver, alt. $5,198 \mathrm{ft}$.

Devil's Causeway, on the headwaters of Yampa River; alt. 6,182 ft.

Dillon Cañon, Trinidad Co.; alt. about 7,000 ft.

Dillon, Summit Co.; alt. 8,859 ft.

Dix, La Plata Co.; alt. 7,500 ft.

Dixion Cañon, near Fort Collins; alt. 5,500 to $6,500 \mathrm{ft}$.

Dolores, Montezuma Co.; alt. 6,957 ft.

Dome Rock, Platte Cañon; alt. 6,21 I ft.

Dome Rock Valley, near Platte Cañon; alt. about 6,000 ft.

Douglas Mountain, Clear Creek Co.; alt. $9,552 \mathrm{ft}$.

Doyle, Gunnison Co., station on D. \& R. G. R. R.; alt. 8,047 ft.

Doyle's Ranch, on Huerfano River; alt. 4.7I5 ft.

Dry Creek, Larimer Co.; alt. 5,000 to 7,000 ft. Locally applied to any intermittent stream with storm flow. Very common.

Dumont, Clear Creek Co., between Georgetown and Idaho Springs; alt. $7,938 \mathrm{ft}$.

Durango, La Plata Co.; alt. 6,520 ft.

Eads, Kiowa Co., on the Mo. Pac. R. R.; alt. 4,707 ft.

Eagle Cliff, head of Park Hill, Estes Park, Larimer Co.; alt. 8,300 ft.

Eagle River, a tributary of the Grand; alt. 6, I00 to 10,000 ft.

East Indian Creck, a tributary of Cucharas River, Huerfano Co.; alt. 7,000 to $10,500 \mathrm{ft}$.

East River, Gunnison Co,, a tributary of Taylor River.

East River, Teller Co.
Echo Cañon, Lake Co., west of Twin Lakes; alt. about ro,00o ft.

Echo Creek, near La Veta, a tributary of Cucharas River.

Echo Creek, west of La Plata Mountains; alt. 9,500 to I I,000 ft.

Egeria Park, on Egeria Creek, Routt Co.; alt. 8,000 to 10,000 ft.

Eldora, Boulder Co.; alt. $8.543 \mathrm{ft}$.

Elizabeth, Elbert Co.; alt. 6,300 ft.

Elk Cañon, on Elk River, Routt Co.; alt. 8,000 ft.

Elk River, Routt Co., a tributary of Bear River.

El Late, see Sierra el Late, Montezuma Co.; alt. 9,840 ft.

Empire, Clear Creek Co.; alt. 8,603 ft.

Empire Pass, between Georgetown and Empire; alt. about same as Empire.

Encampment Meadow, northwest of North Park, on Grand Encampment Creek; ait. 8, I7 I ft. 
Engelmann Cañon, near Pike's Peak; alt. about 8,000 ft.

Engineer Mountain, San Juan Co.; alt. I3, I90 ft.

Estes Park, Larimer Co.; alt. 7,500 and tipward to 8,500 ft.

Ethel Peak, Larimer Co., Park Range; alt. II,976 ft.

Fish Creek, North Park, Larimer Co.; also near Virginia Dale, Larimer Co.

Fish Creek, Routt Co., a tributary of Bear River. Common name.

Fish Creek Falls, on Fish Creek, Routt Co.; alt. about 9,000 ft.

Flat Top Mountain, Routt Co., also west of Estes Park; alt. I3,000 ft.

Floral Mountain, northeast of Berthoud Pass; alt. $12.378 \mathrm{ft}$.

Florence, Fremont Co., on the Arkansas River; alt. 5,I99 ft.

Florissant, Teller Co.; alt. 8,I77 ft.

Fontaine qui Bouille River, tributary of Arkansas, at Pueblo; alt. 4,700 to $9,000 \mathrm{ft}$.

Fontaine qui Bouille Valley, from Colorado Springs south to Pueblo; alt. 4,600 to $6,000 \mathrm{ft}$.

Forester's Ranch, Larimer Co., on La Garde Creek, near Wyoming line; alt. $7,500 \mathrm{ft}$.

Fort Collins, Larimer Co.; alt. (Agr'1. College) 4,994 ft.

Fort Garland, San Luis Valley; alt. 7,937 ft.

Fortification Peak, near Craig, Routt Co.; alt. 7,668 ft.

Fort Lyon (near Las Animas), Bent Co.; alt. about 3,9lo ft.

Fort Morgan, Morgan Co.; alt. 4,3I9 ft.

Fossil Beds, Fremont Co., south of Cripple Creek; alt. 6,000 ft.

Fossil Creek, Larimer Co., four miles south of Fort Collins; alt. 4,800 to $6,000 \mathrm{ft}$.

Four-Mile Hill, Routt Co., near Four-Mile Creek; alt. 7,500 to 9,000 ft.

Franklin, Las Animas Co., north of Trinidad; alt. 6,272 ft.

Garden of the Gods, north of Manitou; alt. 6,500 to 7,000 ft.

Gardner, Huerfano Co., on Huerfano River; alt. about 7,000 ft.

Garland, five miles from Fort Garland, Costilla Co.; alt. 8, II2 ft.

Gato, on D. \& N. W. R. R., Boulder Co.; alt. 8,000 ft.

Gato Creek, west side San Luis Valley, Conejos Co.; alt. 8,000 to Io,000 ft.

Gentian Ridge, Pike's Peak.

Georgetown, Clear Creek Co.; alt. 8,488 ft.

Gibbs' Peak, Custer Co.; alt. I2,200 ft.

Glen Eyrie, five miles from Manitou, north of Garden of Gods; alt. about $6,500 \mathrm{ft}$.

Glen Mountain Falls, near Pike's Peak.

Glenwood Springs, Garfield Co.; alt. $5,758 \mathrm{ft}$.

Golden, Jefferson Co., on Clear Creek; alt. 5,667 ft.

Goose Creek, Mineral Co., tributary to Rio Grande; alt. about 9,00o ft.

Gore Pass, across Gore Mountains, border between Grand and Routt Co.. east of Egeria Park; alt. about 9,600 ft.

Graham's Park, on D. \& R. G. R. R. ; alt, 10,605 ft.

Granada, Prowers Co.; alt. 3,493 ft.

Grand Cañon, Cañon of the Arkansas River; alt. 5,500 to 6,000 ft.

Grand Lake, Middle Park; alt. 8.I53 ft.

Grand Mesa, table land between Mesa and Delta counties; alt. 9,000 to Io,000 $\mathrm{ft}$.

Grand Junction, Mesa Co., on Grand River, at the junction of the Gunnison; alt. 4,594 ft.

Grand River, the principal river of western Colorado, forming, with the Green, the Colorado River of the West; alt. 4,500 to Ir,ooo ft.

Granite, station on the D. \& R. G. R. R., in Chaffee Co.; alt. 8,930 ft.

Grant Lake (probably Clear Lake, south of Georgetown).

Grayback Mining Camps, near Grayback, Sangre de Cristo Range, east of Sierra Blanca; alt. 9,000 to Io,000 ft.

Graymont, Clear Creek Co.; alt. 9,783 ft.

Gray's Peak, Front Range, Clear Creek Co.; alt. I4,34I ft.

Grecian Bend, Pike's Peak.

Greeley, Weld Co., on Poudre River; alt. about 4,600 ft. 
Grecn, North Park; alt. 8,200 ft.

Greenhorn Mountains, Pueblo and Fuerfano counties; alt. I2,340 ft.

Green Mountain Falls, on the Midland R. R., E1 Paso Co., northwest of Pike's Peak; alt. 7,70o ft.

Green River, northwest Colorado, unites with the Grand; alt. in Colorado about $5,000 \mathrm{ft}$.

Gregory Cañon (Gregorio River, San Luis); alt. 8,500 ft.

Grizzly Creek, Larimer Co., in North Park, a tributary of the North Platte; alt. $9,500 \mathrm{ft}$.

Grizzly Creek, also five miles up the Grand from Glenwood Springs.

Grizzly Gulch, west side North Park; alt. about 8,500 ft.

Gunnison, Gunnison Co.; alt. 7,683 ft.

Gypsum, Eagle Co., station on D. \& R. G. R. R.; alt. 6,3Io ft.

Gypsum Creek Cañon, Eagle Co., a tributary of Eagle River; alt. about $6,000 \mathrm{ft}$.

Halfmoon Creek, Lake Co., a tributary of the Arkansas River, southwest of Leadville; alt. 9,600 to I2,000 $\mathrm{ft}$.

Halfway House, on Pike's Peak Cog Road; alt. 8,400 ft.

Hamor's Lake, north of Durango; alt. about 9,000 ft.

'Hahn's Peak, Park Range, Routt Co.; alt. Io,906 ft.

Happy Hollow, fifteen miles west of Fort Collins; alt. about 6,500 ft.

Hardin's Ranch, north of Manhattan, Larimer Co.; alt. about 7,800 ft.

Hayden, Routt Co.; alt. 7,500 ft.

Hayden's Ranch, Lake Co., station on the D. \& R. G. R. R.; alt. 9,14I ft.

Hebron, Larimer Co., North Park; alt. 8,200 ft.

Hematite (Hematite Gulch, San Juan Co., east of Silverton) ; alt. I0,000 to I2,500 ft.

Hermosa, La Plata Co., between Durango and Silverton; alt. 6,630 ft.

Hill's Ranch, McElmo Creek, Montezuma Co.; alt. 5,000 to 8,000 ft.

Higho, Larimer Co., near Lake John, North Park.

Holdredge Meadow, or Ranch, on Michigan River, North Park; alt. about $8,400 \mathrm{ft}$.

Home P. O., Zimmerman's Ranch, Larimer Co., on Cache la Poudre; alt. about 7,500 ft.

Honnold, Routt Co., on Little Snake River, near Wyoming line; alt. 9,I58 ft.

Horseshoe Mountain, Summit Co., southeast of Leadville; alt. I3,912 ft.

Horsetooth Gulch, near Horsetooth Mountain; alt. 5,500 to 6,500 ft.

Horsetooth Mountain, seven miles southwest of Fort Collins; alt. 7,160 ft.

Hortense Springs, Chaffee Co., near Mt. Princeton; alt. 7,700 ft.

Hotchkiss, Delta Co., between Delta and Paonia; alt. 5,369 ft.

Hot Sulphur Springs, Grand Co., Middle Park; alt. 7,800 ft.

Hovenreep Cañon, Montezuma Co., cañon of Yellow Jacket or Hovenweep Creek; alt. 6,300 ft.

Hovenzeep Castle, Montezuma Co.; alt. 5,239 ft.

Howe's Gulch, Larimer Co., west of Fort Collins; alt. 5,500 to 7,000 ft.

Hubbard Creek, Delta Co.

Huerfano, Huerfano Co., on Huerfano River; alt. 5,662 ft.

Huerfano Valley, upper part of Huerfano River, between the Greenhorn Mountains and the Sangre de Cristo Range; alt. about 8,300 ft.

Hughes' Lake, Ouray Co.; alt. 7,500 ft.

Hugo, Lincoln Co.; alt. 5,068 ft.

Idaho Springs, Clear Creek Co.; alt. 7,550 ft.

Ignacio, La Plata Co.; alt. 6,437 ft.

Indian Creek Pass, Culebra Range, from East Indian Creek to West Indian Creek; alt. 9,803 ft.

Iola, Gunnison Co., station on D. \& R. G. R. R.; alt. 7,434 ft.

Iron Mourtain, east of Sierra Blanca, Huerfano Co. ; alt. I I,000 ft.

Ironton Park, nine miles south of Ouray; alt. about 9,500 ft.

Ivywild, Pike's Peak Cog Road; alt. about 7,500 ft.

Jack Brook, Pike's Peak; alt. 8,500 to Io,000 ft.

Jack's Cabin, Gunnison watershed, station on D. \& R. G. R. R., between Gunnison and Crested Butte; alt. 8,294 ft. 
James' Peak, Gilpin Co., Front Range; alt. 13,283 ft. (Name originally given to Pike's Peak.)

Jefferson, Park Co., South Park; alt. $9.502 \mathrm{ft}$.

Johnston Cañon, Mesa Verde, near Mancos River; a1t. 4,000 to 8,000 ft.

Julesburg, Sedgwick Co., on South Platte River; alt. 3,458 ft.

Kebler Pass, Gumnison Co.; alt. about Io,000 ft.

Kelso Mountain, southwest of Georgetown; alt. 13,423 ft.

Kendall Basin, near Silverton.

Kremmling, Grand Co., near Grand River; alt. 7,150 ft.

Lafayette, Boulder Co.; alt. 5,300 ft.

Lake City, Hinsdale Co.; alt. 8,686 ft.

Lake John, North Park; alt. 8,200 ft.

Lake Moraine, on Ruxton Creek, Pike's Peak, east of summit; alt. Io,268 ft.

Lamar, Prowers Co., on Arkansas River; alt. $3,592 \mathrm{ft}$.

Lamb's Ranch, now Mills's, Long's Peak Inn, near Long's Peak; alt. 9, Ioo ft.

La Plata Mountains, Montezuma Co. and La Plata Co.; alt. up to I4,342 ft.

La Plata Peak, Saguache Range, Chaffee Co.; alt. I4,302 ft.

La Plata River, Montezuma Co., a tributary of the San Juan; alt. 4,700 to I3,000 ft.

La Porte, six miles northwest of Fort Collins; alt. about 5,200 ft.

Laramie Plains, between Big Laramie River and Poudre tributaries; alt. 7,000 to $9,000 \mathrm{ft}$.

Laramie River, Larimer Co.; alt. (from Wyoming line to Clark's Peak) 7,500 to $10,000 \mathrm{ft}$.

La Pagosa, see Pagosa Springs.

La Salle, Weld Co., on South Platte River; alt. 4,665 ft.

Las Animas Perdidas, La Plata Co., a tributary of the San Juan.

Las Animas Cañon, cañon of Rio de las Animas; alt. I I,000 ft.

La Veta, Huerfano Co., on Cucharas River; alt. 7,024 ft.

Leadville, Lake Co.; ait. Io,200 ft.

Lee's Lake, three miles west of Fort Collins; alt. 5, I00 ft.

Leroux Creek, Delta Co., flows into North Fork of Gunnison River; alt. 5,300 to II,O0O ft.

Leroux Park, Delta Co. ; alt. 5,300 to $8,000 \mathrm{ft}$.

Little Beaver Creck, Larimer Co., flows into South Fork of Poudre River; alt. 8 ,00o ft.

Little Cimarron River, flows into the Gunnison River; alt. 6,900 to I4,000 ft.

Little Kate Basin, Basin Creek; alt, about 10,500 ft.

Little Kate Mine, La Plata Mountains; alt. about same as above.

Little South, a tributary of the Cache la Poudre, below the Rustic, Larimer Co.; alt. 6,500 to I I,000 ft.

Little Veta Mountains, west of Veta Mountain, Huerfano Co.; alt. about ro,o00 ft.

Livermore, Larimer Co., on North Poudre; alt. 6,00o ft.

Lone Pine Creek, Larimer Co., tributary of North Poudre; alt. 6,000 to $9,000 \mathrm{ft}$.

Long Gulch, Larimer Co.; also Boulder Co., on the St. Vrain; a frequent name; alt. about $7,500 \mathrm{ft}$.

Longmont, Boulder Co.; alt. 4,947 ft.

Long's Peak, Front Range, between Boulder and Larimer counties; alt. I4,27I ft.

Los Pinos, Conejos Co., on D. \& R. G. R. R.; alt. 9,622 ft.

Loveland, Larimer Co., on Big Thompson; alt. 4,984 ft.

Lulu Pass, Larimer Co., east of Mt. Richtofen; alt. about 12,000 ft.

Lyons, Boulder Co. ; alt. about 6,500 ft.

McCoy, Eagle Co., on Grand River; alt. about 8,000 ft.

McElmo Cañon, Montezuma Co., Cañon of McElmo Creek, a tributary of San Juan River; alt. of creek at head, 7,000 ft.; at mouth, 4,566 ft.

McIntyre Creek, Larimer Co.; alt. 7,000 to $10,000 \mathrm{ft}$.

Mancos, Montezuma Co.; alt. 7,008 ft.

Manitou, east base of Pike's Peak; alt. 6,3I8 ft. 
Marshall Pass, D. \& R. G. R. R., between the Arkansas and Gunnison watersheds; alt. Io,856 ft.

Mason's River Front Farm, near Fort Collins, Larimer Co.; alt. about 5,000 ft. Massif de l'Arapahoe, Arapahoe Peak; alt. I3,520 ft.

Meadow Park, near Lyons, Boulder Co.; alt. about 6,500 ft.

Medicine Bow Mountains, range east of North Park, Larimer Co. Highest peak is Clark's Peak; alt. I3,800 ft.

Meeker, Rio Blanco Co.; alt. 6,I82 ft.

Mesa Verde, Montezuma Co., table land; alt. 6,500 to 8,500 ft.

Michigan River, North Park, a tributary of the North Platte River; alt. 8,000 to $\mathrm{I}$ I, $000 \mathrm{ft}$.

Middle Park, between the Front Range and Park Range and drained by Grand River.

Miller's Ranch, see Tobe Miller; alt. about 5,300 ft.

Minnehaha, on Ruxton Creek, near Pike's Peak; alt. about 8,400 ft.

Minturn, Eagle Co., station on D. \& R. G. R. R.; alt. 7,825 ft.

Montclair, Arapahoe Co., Denver suburb; alt. 5,400 ft.

Monte Vista, Rio Grande Co., San Luis Valley; alt. 7,665 ft.

Montezuna, Summit Co.; alt. I0,295 ft.

Montrose, Montrose Co., on Uncompahgre River; alt. $5,8 \mathrm{ir} \mathrm{ft}$.

Monument, station on D. \& R. G. R. R., El Paso Co.; alt. 6,974 ft.

Monument Park, El Paso Co., near Edgerton Station; alt. about 8,000 ft.

Moon's Ranch, west of Fort Collins; alt. 7.500 ft.

Moraine, Sprague's, Estes Park; alt. 8.000 ft.

Morrison, Jefferson Co., on Bear Creek; alt. 5,765 ft.

Mosquito Pass, east of Leadville; alt. I3,700 ft.

Mt. Abram, near Ouray; alt. I2,790 ft.

Mountain View, on Pike's Peak Cog Road; alt. about Io,00o ft.

Mt. Antero, Saguache Range, Chaffee Co.; alt. I4,245 ft.

Mt. Baldy, or Bald Mountain (a common local name), Larimer Co., west of Loveland; alt. 7,000 ft.

Larimer Co., east of Laramie River; alt. II,250 ft.

Boulder Co.; alt. II,470 ft.

Delta Co.; alt. 10,632 ft.

Near Pike's Peak; alt. about I2,300 ft.

Sangre de Cristo Range, near Sierra Blanca; alt. I4,I76 ft.

Mt. Bartlett, Park Range, Summit Co.; alt. about I3,500 ft.

Mt. Bross, Middle Park, Park Range; alt. I4, Ioo ft.

Mt. Elbert, Saguache Range, Lake Co.; alt. I4,436 ft.

Mt. Evans, west of Denver; alt. I4,260 ft.

Mt. Garfield, near Pike's Peak; alt. 13,500 ft.

Mt. Harvard, Saguache Range, Chaffee Co.; alt. I4,375 ft.

Mt. Hayden, near Ouray; alt. I3, Ioo ft.

Mt. Hesperus, La Plata Mountains, Montezuma Co.; alt. I3,376 ft.

Mt. La Plata, or La Plata Peak, Saguache Range, Chaffee Co.; alt. I4,302 ft.

Mt. Lincoln, Park Range, Park Co.; alt. I4,297 ft.

Mt. McClellan, Front Range, near Gray's Peak; alt. r3,423 ft.

Mt. Massive, Saguache Range, Lake Co.; alt. I4,27I ft.

Mt. Ouray, Saguache Range, Chaffee Co.; alt. 14,055 ft.

Mt. Princeton, Saguache Range, Chaffee Co.; alt. I4,I99 ft.

Mt. Richthofen, Medicine Bow Range, south of Cameron Pass, Larimer Co.; alt. about I3,800 ft.

Mt. Robinson, Summit Co., near Robinson; alt. Io,760 ft.

Muddy River, Middle Park, flows into Grand River; alt. 7,100 to 9,000 ft.

Narrores, Cache la Poudre River, Larimer Co.; alt. about 6,500 ft. Name given to a short box cañon.

Navajo Cañon, on Navajo Creek, a tributary of the Huerfano River; alt. $8,600 \mathrm{ft}$.

Nepesta, Pueblo Co., on Arkansas River; alt. 4,394 ft.

New Castle, Garfield Co., on Grand River; alt. 5,562 ft.

New Windsor, western Weld Co.; alt. 4,800 ft. 
North Cheyenne Cañon, foot of Cheyenne Mountain, east of Pike's Peak; alt. 6,000 to II,000 ft.

North Park, between Park Range and Medicine Bow Range, drained by North Platte River; alt. 8,000 to 9,000 ft.

North Park Range, between Larimer and Routt counties.

Notch Mountain, part of Mt. Richtofen; alt. about I3,000 ft.

Also near Mt. of the Holy Cross.

Oak Mesa, Delta Co.

Ojo, at the foot of Veta Mountain, Huerfano Co, ; alt. about 8,000 ft.

Olathe, Montrose Co.; alt. 5,352 ft.

Oro City, southeast of Leadville; alt, about Io,800 ft.

Ouray, Ouray Co.; alt. $7,721 \mathrm{ft}$.

Owl Cañon, Cañon of Owl Creek, North Park.

Also at head of Hook and Moore Glade, near Fort Collins; alt. about $5,600 \mathrm{ft}$.

Pagosa Peak, San Juan Range, Mineral Co.; alt. I2,674 ft.

Pagosa Springs, A rchuleta Co.; alt. 7,I08 ft.

Palisade, Mesa Co.; alt. about $4,723 \mathrm{ft}$.

Pallas, near southeast corner of Routt Co., on Bear River; alt. 8,700 ft.

Palmer Lake, summit of Divide between Arkansas and South Platte watershed, El Paso Co.; alt. 7,237 ft.

Palsgrove Cañon; alt. about 9,000 ft.

Pandora, San Miguel Co., southeast of Telluride; alt. 9,000 ft.

Paonia, Delta Co., on North Fork of Gunnison River; alt. about 5,500 ft.

Park Range, west of North Park; also divide between South Park and Arkansas River.

Parlin, Gunnison Co., between Marshall Pass and Gunnison; alt. 7,937 ft.

Parrott City, La Plata Co., between Durango and Mancos; alt. 8,633 ft.

Pass Butte, near southeast corner Routt Co. ; alt. 8,265.

Pass Creek, near Veta Pass; alt. from 7,000 to $9,000 \mathrm{ft}$.

Pass Creek, Saguache Co., flows into Cochetopa Creek; alt. 8,000 to 10,000 ft.

Paxton Ranch, near Mancos; alt. about 7,000 ft.

Pearl, North Park; alt. about 8,50o ft.

Pennock's (Pennock's Ranch), about eight miles west of Fort Collins; alt. about $5,500 \mathrm{ft}$.

Pennock's Monntain Ranch, off Rist Cañon Road; alt. about 8,000 ft.

Penn's Gulch (Pennsylvania Gulch) (?), east of Greorgetown.

Peoria Creek; alt. about 6,00o ft.

Piedra, Archuleta Co., on Rio Piedra; alt. 6,520 ft.

Pike's Peak, E1 Paso Co.; alt. I4,108 ft.

Pine Grove, on South Platte, Douglass Co.; alt. 6,738 ft.

Piney Creek, Eagle Co., a tributary of Eagle River; alt. about 7,500 ft.

Pingree Hill, Larimer Co., near Manhattan; alt. 7,000 to 8,200 ft.

Pinkham Creek, Larimer Co., North Park; alt. 8,400 ft.

Pinkhampton (now Cowdry), Larimer Co., North Park; alt. 8,400 ft.

Pitkin, Gunnison Co.; alt. 9,192 ft.

Placer, Costilla Co., on Sangre de Cristo Creek; alt. about 8,000 ft.

Pleasant $V$ alley, northeast of Greeley; alt. $4.800 \mathrm{ft}$.

Pleasant Valley, also northwest of Fort Collins; alt. about $5,200 \mathrm{ft}$.

Poncha Pass, between the Arkansas River and the San Luis River, D. \& R. G. R. R.; alt. 8,945 ft.

Porter, La Plata Co., near Durango; alt. 7,009 ft.

Poudre Cañon, Cañon of Cache la Poudre River, Larimer Co.; alt. 6,000 to $7,000 \mathrm{ft}$.

Poudre River, see Cache la Poudre River.

Poverty Ridge, near Cimarron; alt. about 8,500 ft.

Pueblo, Pueblo Co.; alt. 4,672 ft.

Purgatoire, or Purgatory River, or Las Animas River, a tributary of the Arkansas River, Las Animas, Otero and Bent counties; alt. 3,800 to $6,000 \mathrm{ft}$.

Quail Creek, near Steven's Mine, Graymont, Clear Creek Co.; alt. up to I I,000 ft. 
Queen's Cañon, near William's Cañon, Manitou.

Quimby, Arapahoe Co., north of Denver; alt. about 5,000 ft.

Rabbit Ear Pass; alt. about 9,00o ft.

Rabbit Ear Range, portion of Continental Divide, south of North Park.

Rabbit Ears, peaks southwest part North Park, Larimer Co.; alt. Io,7rg ft.

Ragged Mountain, Gunnison Co.; alt. II,70o ft,

Raton Mountains, southeast of Trinidad; alt. 9,600 ft.

Recapture Creek, Montezuma Co. ; alt. 4,446 ft. at mouth.

Redcliff, Eagle Co.; alt. 8,608 ft.

Red Dirt Divide (near Middle Park), Routt Co.; alt. about 8,ooo ft.

Red Mountain, south of Ouray; alt. I2,865 ft.

Red Mountain Road, south of Ouray; alt. 8,0000 to $\mathrm{x} 2,300 \mathrm{ft}$.

Red River, northern part Larimer Co., near Laramie River; alt. 7,100 ft.

Red Rock Cañon, Las Animas Co.; alt. 5,00o ft.

Red Rock Cañon, Dolores River; alt. 6,900 to 8,700 ft.

Red Rock Cañon, near Pike's Peak; alt. 4,000 to 9,000 ft.

Redstone, Larimer Co.; alt. 5,500 to $6,000 \mathrm{ft}$.

Redstone, Pitkin Co., near Carbondale.

Rico, Dolores Co.; alt. 8,737 ft.

Ridgeway, or Ridgway, Ouray Co.; alt. 7,500 ft.

Ritle, Garfield Co.; alt. 5,3Io ft.

Rio Blanco, Archuleta Co., flows into the San Juan; alt. 7,500 to II,500 ft.

Rio Florido, La Plata Co.; alt. 6, I00 to I I,000 ft.

Rio Grande, or Rio Grande del Norte, rises in San Juan Mountains; alt. in Colorado, 7,300 to $\mathrm{I} 2,400 \mathrm{ft}$.

Rist Cañon, west of Fort Collins; alt. 5,000 to 6,800 ft.

Roaring Fork, Larimer Co., flows into Cache la Poudre; alt. 7,800 to 10,000 ft.

Robinson, Summit Co., near Fremont Pass; Fremont Pass is alt. II,330 ft.

Robinson, Bent Co.; alt. 4,007 ft.

Rocky Ford, Otero Co.; alt. 4,I80 ft.

Rogers, Rogers Mesa, Gunnison Co., station between Crested Butte and Florence.

Also station between Delta and Paonia; alt. 5,443 ft.

Roubideau Pass, northwest of Sangre de Cristo Pass, from Huerfano Park to San Luis Valley; alt. about 8,000 ft.

Rosita, Custer Co.; alt. 8,500 ft.

Roswell, El Paso Co., north of Colorado Springs; alt. 6,073 ft.

Royal Gorge, narrowest and deepest part of the Cañon of the Arkansas River; alt. 5,500 to $6,000 \mathrm{ft}$.

Ruby, Gunnison Co., above Crested Butte; alt. Io,500 ft.

Ruby, Mesa Co, west of Grand Junction; alt. about $4,500 \mathrm{ft}$.

Rustic, Larimer Co., on the Poudre, foot of Pingree Hill; alt. $7,000 \mathrm{ft}$.

Ruxton Dell, on Ruxton Creek, Pike's Peak; alt. about 9,000 ft.

Ruxton Park, on Ruxton Creek, Pike's Peak; alt. about 9,00o ft.

Ruxton Ridge, Pike's Peak; alt. about 9,000 ft.

Saddle, on Pike's Peak Cog Road; alt. I3,00o ft.

Saddle Mountain, Park Co.; alt. I0,8I5 ft.

Saguache, Saguache Co.; alt. 7,723 ft.

Saguache Creek, or River, a tributary of San Luis River, Saguache Co.; alt. 7,500 to $\mathrm{I} 3,000 \mathrm{ft}$.

Saguache Range, separating the Arkansas from the Grand River and Gunnison watersheds; extending from Tennessee Pass to near Salida; alt. to 'I4,400 $\mathrm{ft}$.

Salida, Chaffee Co.; alt. 7,050 ft.

Sand Creek Pass, Larimer Co., between North Park and Laramie watersheds; alt. about $7,400 \mathrm{ft}$.

Sangre de Cristo Creek, a tributary of Trinchera River, Costilla Co., near Veta Pass; alt. about 9,00o ft.

Sangre de Cristo Range, separates San Luis Valley from Arkansas Valley; alt. to I4,400 ft.

San Juan Pass; alt. I2,000 ft. 
San Juan Valley, Montezuma Co.

San Luis Valley, around San Luis River and the upper Rio Grande; alt. 7,500 to $8,000 \mathrm{ft}$.

Sapinero, Gunnison Co., between Gunnison and Montrose; alt. 7,240 ft.

Sargent's, Saguache Co., on D. \& R. G. R. R., between Marshall Pass and Gunnison; alt. 8,462 ft.

Seven Lakes, near Pike's Peak; alt. Io,80o ft.

Sheep Creek, Larimer Co., empties into North Fork Cache la Poudre; alt. about 8,500 ft.

Sheephorn Divide, southwest of Middle Park; alt. 6,900 ft.

Sheephorn Divide, North Park.

Sherwood, Eagle Co.; alt. 6,900 ft.

Sherwood's Ranch, (Glen Eyre) Larimer Co., on the Laramie; alt. about $7,800 \mathrm{ft}$.

Sierra Blanca, Sangre de Cristo Range, Costilla and Huerfano counties; alt. $\mathrm{I} 4,483 \mathrm{ft}$.

Sierra Madre Range, name given by Fremont to Main Range from Georgetown south.

Sierra Sangre de Cristo, or Sangre de Cristo Range, separates the San Luis from the Huerfano and Arkansas watersheds, Saguache Co. Many high peaks, the highest $14,483 \mathrm{ft}$.

Silver Plume, Clear Creek Co.; alt. 9,188 ft.

Silverton, San Juan Co.; alt. 9,20I ft.

Slide Rock Cañon, west of La Plata mountains, north of Mt. Hesperus, alt. Io,000 to $\mathrm{I} 2,000 \mathrm{ft}$.

Smith's Fork. Delta Co., tributary of the Gunnison; alt. 7,000 ft.

Soda Creek, Routt Co., a tributary of Bear river.

Soldier Cañon, west of Fort Collins; alt. $5,000 \mathrm{ft}$.

South Boulder Cañon, near Boulder; alt. 5,600 ft. upward.

South Cheyenne Cañon, foot of Cheyenne Mountain, southeast of Pike's Peak; alt. 6,000 to $10,000 \mathrm{ft}$.

South Cottonwood Gulch, Chaffee Co, near Buena Vista; alt about 1o,500 ft.

South Park, between the Park Range and the Front and Rampart ranges, drained by South Platte river.

South Table Mountain, southeast of Golden; alt. 6,250 ft.

Spanish Peaks, Huerfano Co., two isolated peaks near Culebra Range; alt. west Spanish Peak, I3,620; east Spanish Peak alt., I2,720 ft.

Spicer, Larimer Co., on Grizzly Creek; alt. about 9,000 ft.

Sprague's, Moraine P. O., Estes Park; alt. about 8,000 ft.

Squaw Hill, Montrose Co. ; above Cimarron; alt. 7,000 to 8,500 ft.

State Bridge, Costilla Co., east of Antonito, Rio Grand; alt. 7,348 ft.

State Bridge, Grand River, east of Delta; alt. about 5,000 ft.

Steamboat Springs, Routt Co.; alt. 6,500 ft.

Steele Cañon, near Villa Grove.

Stephen's Mine, near Gray's Peak, at timberline; alt. II,500 ft.

Sterling, Logan Co.; alt. 3,922 ft.

Stove Prairie, Larimer Co., beyond Rist Cañon; alt. 7,600 ft.

Stove Prairie Hill, head of Rist Cañon; alt. about $8,000 \mathrm{ft}$.

St. Vrain Cañon, Cañon of St. Vrain Creek, Boulder Co.; a tributary of the South Platte River.

Sugar Loaf Mountain, Eagle and Summit counties; alt. $12,556 \mathrm{ft}$.

Sulphur Springs, Grand Co.; many in various parts of the state.

Sunset Cañon, near Sunset, Botulder Co.; alt. at Sunset, 7,707 ft.

Sunshine, Boulder Co.; alt. I2,945 ft.

Swallows, on Arkansas River, between Pueblo and Cañon City; alt. 4,863 ft. Sydney, or Sidney, Routt Co., on Bear River.

Table Rock, east of Palmer Lake; alt, 7,150 ft.

Taylor River, Gunnison Co.; alt. 8,000 to I I,000 $\mathrm{ft}$.

Teller, an abandoned mining camp, south of North Park; alt, about 9,000 ft.

Telluride, San Miguel Co.; alt. 8,756 ft. 
Tcnnessee Pass, near Leadville, between the watersheds of the Arkansas and Eagle rivers; alt. Io, $240 \mathrm{ft}$.

Thompson's Cañon, Long's Peak, drained by Thompson Creek; alt. 5,500 to $6,000 \mathrm{ft}$.

Thompson's Park, west of Dix, La Plata Co.; alt. $7,576 \mathrm{ft}$.

Tie Siding, upper waters of Fish Creek, Wyoming, near Larimer Co. line; alt. $7,800 \mathrm{ft}$.

Timnath, Eastern Larimer Co.; alt. $4,875 \mathrm{ft}$.

Tobe Miller's Ranch, near La Porte, Larimer Co.; alt. about 5,300 ft..

Tomichi River, tributary to Gunnison River; alt. 7,600 to about II,000 ft.

Trail Creek, Larimer Co., a tributary of North Poudre; alt. 6,500 to 7,500 ft.

Trail Creek, on Pike's Peak, El Paso Co.

Trail Glen, Pike's Peak; alt. about 9,000 ft.

Trapper's Lake, Garfield Co.; alt. II,00o ft.

Trimble Hot Springs, La Plata Co., near Durango; alt. 7,000 ft.

Trinidad, Las Animas Co.; alt. 5,994 ft.

Troublesome, Grand Co., near Troublesome Creek; alt. about 7,300 ft.

Troublesome Creek, Grand Co., a tributary of the Grand River; alt 7,300 $\mathrm{ft}$. to II,500 $\mathrm{ft}$.

Turkey Creek, a tributary of Huerfano River.

Turkey Creek, also a tributary of Arkansas River west of Pueblo, south of Mt. Rosa; alt. 5,000 to II,000 ft.

Trulve Mile Creek, Park Co., east of Weston Peak.

Twin Lakes, Lake Co.; alt. 9,367 ft.

Uncompahgre Mountains, between Gunnison and Hinsdale counties.

Uncompahgre Peak, Uncompahgre Mountains; alt. I4,4I9 ft.

Uncompahgre River, a tributary of the Gunnison River; alt. 4,000 to $7,000 \mathrm{ft}$.

Ute Creek, Hinsdale Co., a tributary of the Rio Grande.

Ute Creek, Costilla Co., a tributary of Trinchera River.

Ute Pass, west from Manitou, followed by Colorado Midland P. R.; alt. 9, I00 ft.

Valley Spur, east of Pitkin, Gunnison Co., station on the C. \& S. R. R.

Valmont, Boulder Co.; alt. 5,200 feet.

Valverde, Arapahoe Co., Denver suburb; alt. 5,212 ft.

Van Boxle's Ranch, above Cimarron; alt. 4,000 to $8,000 \mathrm{ft}$.

Vance Junction, San Miguel Co., near Telluride; alt. 8, IoI ft.

$V$ eta, see La Veta.

Veta Mountains, Huerfano Co.; alt. II,I76 ft.

Veta Pass, between Cucharas and Trincheras watershed, Culebra Range; alt. $9,242 \mathrm{ft}$.

Victoria, Larimer Co.; alt. 8,000 to 9,000 $\mathrm{ft}$.

Villa Grove, Saguache Co.; alt. $7,972 \mathrm{ft}$.

Wagon Wheel Gap, Mineral Co., on the Rio Grande; alt. 8:449 ft.

Wahatoya Cañon, between the two Spanish Peaks, Huerfano Co.; alt. 6,489 ft.

Walden, North Park, Larimer Co., on Coal Creek; alt. 8,050 ft.

Walsenburg, Huerfano Co.; alt. 6,187 ft.

Walton Creek, Eastern Routt Co.; alt. 6,800 ft.

Ward, Boulder Co., on "Switzerland Trail;" alt. 9,2I7 ft.

Webster, Park Co., on C. \& S. R. R.; alt. 8,979.

West Cliff, or Westcliffe, Custer Co.; alt. 7,86I ft.

West Indian Creek, Costilla Co.

West Mancos Cañon, cañon of the Rio Mancos, Montezuma Co.

Weston Pass, south southeast of Leadville; alt. II,930 ft.

West Spanish Peak, see Spanish Peaks.

$W$ estwater, Utah line, just west of Grand Junction.

Whitehouse Mountain, west of Ouray; alt. I3,496 ft.

White River Plateau, divide between White and Grand rivers; alt. II,000.

William's Cañon, near Manitou; alt. about 7,500 ft.

Willis Gulch, Gilpin Co., near Central City; alt. about 8,800 ft.

Willow Creek, Routt Co.

Willow Creek, Teller Co., souhwest of Cripple Creek. 
Windy Point, Pike's Peak Cog Road; alt. I2,300 ft. Wolcott, Eagle Co.; alt. 7,000 ft.

Wood's Ranch, on Trail Creek, Larimer Co.; alt. about 7,500 ft. Wray, Yuma Co.; alt. 3,512 ft.

Yampa, Routt Co.; alt. about $7,000 \mathrm{ft}$.

Yuma, Yuma Co.; alt. 4,I38 ft.

Zada, or Zola, Routt Co., near Pass Butte (?)

Zimmerman's, see Home P. O. 


\section{INDEX.}

The English names are given in common small letters, the Latin generic names in italic, and the names of Tribes, Families, Orders, and the higher divisions, in small capitals.

Abies, 9

Abronia, I 22

Abutilon, 23I

Acer, 226

ACERACE 2,226

Acerates, 270

Achillea, 382

Achyropappus, 377

Acnida, I2I

Aconite, I 39

Aconitum, I 39

Acorus, 74

Acroanthes, 89

Acrolasia, 236

Actca, 135

Actinella, 379, 380

Acuan, I 94

Adder's Mouth, 89

Adder's-torigue, 83

Adder's-Tongue Family, I

Adelia, 264

Adenostegia, 3 I 8

Adopogon, 404

Adoxa, 324

ADOXACEE, 324

AEgilops, 55

Agastache, 296

Agoseris, 407

Agrimonia, I89

Agrimony, 189

Agropyron, 52

Agrostidex, 23

Agrostis, 30

Alder, 97

Aletes, 252

Alexanders, 252

Alfalfa, 202

Alfilaria (Erodium)

Alisma, 14

Aismace 8 , I 4

Alismales, 13

Alkali-grass (Distichlis)

Alliace 2,81

Allionia, I 23

Allioniacese, I 22

Allioniella, 123

Allium, $8 \mathrm{I}$

Allocarya, 288

Alnus, 97
Alopecurus, 28

AlSINACE 2 , I 27

Alsine, I 27

Alsinopsis, $13 \mathbf{I}$

Alum-root, I 72

Alyssum, I6 I

Amaranth, 120

AmaranthaCE压, 120

Amaranth Family, I 20

Amaranthus, $\mathrm{I} 20$

Amarella, 265

Amarylliddales, 86

Ambrosia, 328

Ambrosiace 2,327

Amelanchier, I9I

American Cowslip, 263

American Ivy, 228

American Laurel, 260

Ammania, 240

AMMIACE $E, 250$

Amorpha, 2I 3

Amphiophis, I9

Amsonia, 269

AMYGDALACE $E, ~ I 93$

Anaphalis, 370

Anchusa, 289

Androcera, 302

Andropogon, 19, 20

Andropogonece, 19

Androsace, 26I

Anemone, 140

Anemone, 140

Angelica, 255

Angelica, 253, 255

Angiosperm $\mp$, II

Anisolotus, 202

Anogra, 244

Antennaria, 367

Anticlea, 76

Anthemidex, 382

Anthemis, 382

Antheropogon, 36

Anthopogon, 265

Aphyllon, 320

Apinus, 8

Aplopappus, 343, 346

APocynacese, 269

Apocynum, 269

Apple Family, I9I 
Aquilegia, I 36

Arabis, I64, I 66

Arace $\overline{4}, 74$

Aragallus, 212

Arales, 74

Aralia, 249

Archemora, 254

Arctostaphylos, 259

Arenaria, I30, I32

Argemone, 148

Argentina, 186

Argythammia, 222

Aristida, 23

Arnica, 387

Arrow-head, I4

Arrow-grass, I 4

Arrow-grass Family, I 4

Arrow-leaf (Balsamorrhiza)

Arrow-wood, 323

Artemisia, 382

Arum Family, 74

AsCLEPIADACE 270

Asclepiadales, 269

Asclepias, 270

Asclepiodora, 27 I

Ash, 264

Ash, Mountain, I93

Ash, Water, 22I

Ash-leaved Maple, 227

Aspen, 9 I

Asplenium, 4, 5

Aster, 351

Aster, 350, 351, 357

Astere.2, 337

Astragalus, 203-2I 2

Atelophragma, 205

Athyrium, 4

Atragene, I 4 I

Atriplex, I I 6

Aulospermum, 253

Avena, 34

Avenex, 33

Avens, 187

Avens, Mountain, I 88

Bacharis, 366

Bahia, 377

Ball-cactus, 237

Balsam Apple, 325

Balsam Fir, 9

Balsamorrhiza, 372

Balsam-root, 372

Balsams, 9

Bane-berry, I35

Barbarea, I6o

Barberry, I 48

Barberry Family, I 48

Barnyard-grass, 21

Barley, 55

Bartonia, 236
Basil-weed, 299

Bastard Toad-flax, Ior

Batrachium, 142

Bear-berry, 259

Beard-grass, 20, 30

Beard-tongue, 306

Beckmannia, 35

Bedstraw, 32I

Beech Family, 97

Beech-Fern, 2

Beggar-ticks, 375

Bell-flower, 325

Bell-flower Family, 325

Bell-rue, I 4 I

Belvisia, 5

Bent-grass, 30

BERBERIDACE I I 48

Berberis, ${ }_{4} 8$

Bergamot, Wild, 298

Berthelotia, 367

Berula, 253

Besseya, 3 I 3

Betula, 96

Betulacese, 96

Bidens, 375

Bigelovia, 341, 343

Bilberry, 260

Bindweed, 273

Birch, 96

Birch Family, 96

Bird's-foot Trefoil, 202

Bistort, I I 2

Bistorta, I I 2

Bitter-cress, I 63

Bitter-root, I 26

Blackberry, I80

Black Grama, 20

Black Henbane, 303

Black-eyed Susan, 37 I

Black Pine, 8

Black Saltwort, 264

Bladder-Fern, 3

Bladder-pod, I 54

Bladder-pod, Double, I 54

Bladderwort, 3 I9

Bladderwort Family, 3 Ig

Blanket-flower (Gaillardia)

Blazing Star, 336

Blepharineuron, 28

Blite, Sea, I I9

Blite, Strawberry, Ir 6

Blitum, I 6

Blowball, 409

Bluebell, 325

Blue-berry, 260

Blue Flag, 86

Blue-grass, 40

Blue-eyed Grass, 86

Blue-eyed Mary, 305*

Blue Flag (Iris) 
Blue-joint, 3 I

Blue Spruce, 8

Blue-stem, 20

Blue Tulip (Pulsatilla)

Babera, 381

Bog Orchid, 88

Borage Family, 284

BoraginaCE: 284

Botrychium, I

Bottle-brush, 249

Bouteloua, 36

Boykinia, I 73

Box-elder, 227

Brachyactis, 350

Bracken, 3

Bramble, i 80

Brassica, I6o

BRASSICACER, I 50

Brauneria, 37 I

Bread-root, Indian, 2I 3

Brickellia, 336

Brier, Igo

Brittonastrum, 296

Briza, 40

Bromus, $5 \mathbf{I}$

Brooklime, 3 I2

Broom-grass, I9, 5 I

Broom-rape, 320

Broom-rape Family, 319

Buchloe, 37

Buckbean, 268

Buckbean Family, 268

Buckthorn, 227

Buckthorn Family, 227

Buckwheat, False, II 3

Buckwheat Family, Ior

Buffalo Beans, 202

Buffalo-berry, 239

Buffalo-grass, 37

Buffalo-grass, False, 37

Bug-seed, I 19

Bulbilis, 37

Bull Pine, 7

Bull-rush, 58

Bunch-berry, 249

Bunch-flower Family, 76

Bunch-grass, I 9, 40

Bur-grass, 22

Bur-marigold, 375

Bur-reed, II

Bur-reed Family, Ix

Bursa, 553

Butter-and-eggs, 305

Butter-cup, 142

Cabbage, I60

CACTACE.XE, 237

Cactus, 237

Cactus Family, 237

Calamagrostis, 3 I
Calanovilfa, 32

Calamus, 74

Calceolaria, 234

Callirrhoë, 229

Callitrichacese, 225

Callitriche, 225

CALOCHORTACEE, 85

Calochortus, 85

Caltha, I 35

Caltrop Family, 220

Calypso, 89

Calypso, 89

Camass, Death, 77

Camass, Poison, 77

Campanula, 325

Campanulacex, 325

Campanulates, 325

Campion, 132

Canada Fleabane, 366

Canary-grass, 22

Cancer-root, 320

Cane-grass (Phragmites)

Canchalagua, 265

Cannabi nacex, ioo

Cantua, 279

Caper Family, I68

Capnoides, 149

CAPPARIDACEE, I 68

CAPRIfOLIACEA, 323

Caraway, 25I

Cardamine, 163

Cardaria, I 5 I

Cardinal-flower, 326

Carduacexe, 329

Carduales, 327

Carduus, 398

Carex, 60

Carpet-weed (Chamasyce)

Carpet-weed Family, I 24

Carrion-flower, 86

Carrot Family, 250

Carum, 25I, 252

CARYoPh YLLACER, I 32

Caryopitys, 8

Cassia, I94

Cassiace 2904

Castilleja, 3I 4

Catabrosa, 39

Catchfly, I 32

Catch-fly Grass, 22

Catnip, 297

Cat's-eye (Pulsatilla)

Cat's-foot, 367

Catmint, 297

Cat-tail, I I

Cat-tail Family, II

Ceanothus, 227

Cedar, Red, 9

Cedar, Rocky Mountain Red, to

Celastraces, 226 
Celtis, Ioo

Cembra Pines, 8

Cenchrus, 22

Centaury, 265

Cerastium, 128

Cerasus, 193

Ceratophyllace $\bar{~}$ I I 34

Ceratophyllum, I 34

Cercocarpus, 189

Cereus, 238

Chenactis, 378,380

Chatochloa, 2 I

Chamechanactis, 380

Chamacrista, 194

Chamanerion, 24I

Chamarhodos, 187

Chamesaracha, 302

Chamcsyce, 222

Cheat (Bromus)

Cheilanthes, 3

Cheiranthus, I 59

ChenopodiACEE, II 3

Chenopodiales, I I 3

Chenopodium, I I4

Cherries, I93

Chess, 5 I

Chick-weed, I 27

Chick-weed, Mouse-ear, I 28

Chick-weed Family, I27

Chicory, 404

Chicory Family, 402

Chinnaphila, 258

Chionophila, 3 I I

Chives, 8 I

Chloridex, 35

Chondrophylla, 266

Chrysanthemum, 382

Chrysopogon, 20

Chrysopsis, 339

Chrysosplenium, I7 I

Chrysothammis, 340

Chylisma, 247

CICHORIACE $\mathrm{E}, 402$

Cichorium, 404

Cicuta, 252

Cinna, 30

Cinquefoil, I80

Cinqufoil, Shrubby, 187

Circaa, 248

Cirsium, $40 \mathrm{I}$

Cistacese, 232

Cladothrix, I 21

Claytonia, I25, I 26

Clematis, I4I, I42

Cleome, I 68

Cleomella, I 68

Clementsia, 170

Clinopodium, 299

Cloak-Fern, 4

Closed Gentian, 266
Clover, 200

Clover, Prairie, 2 I 5

Clover, Sweet, 202

Clubmoss, 6

Clubmoss Family, 6

Clubmoss, Little, 6

Club-rush, 58

Cnemidophacos, 207

Cnicus, 400

Cockle (Vaccaria)

Cocklebur, 329

Cock-spur, 22

Cockspur-grass, 2 I

Cologlossum, 87

Coleogyne, 189

Coleosanthus, 335

Collinsia, 305

Collomia, 276, 279

Coloptera, 257

Colorado Rubber Plant, 380

Coltsfoot, Sweet, 387

Columbine, I 36

Comandra, I 01

Commelina, 75

COMMELINACE $\approx, 75$

Cone-flower, 37x, 372

Conioselinum, 255

Conringia, 166

Convallariacea

Convolvulaces, 273

Convolvulus, 273

Conyza, 366

Coral-berry, 323

Corallorrhiza, 90

Coral-root, 90

Cord-grass, 35

Coral-vine (Cuscuta)

Cordylanthus, 318

Coreopsis, 374

Coriospermum, II

Cornace $x, 249$

Cornel, 249

Cornella, 249

Cornus, 249

CorriglolaceE, I 2 I

Corydalis, 149

Corylacese, 97

Corylus, 97

Cotton-grass, 58

Cottonwood, 9 I

Cotton-weed (Epilobium)

Covillea, $22 \mathrm{I}$

Cow-bane, (Cicuta)

Cow Cabbage (Heracleum)

Cow Cockle (Vaccaria)

Cow-herb, I 34

Cow Parsnip (Heracleum)

Cowslip, American, 263

Crab-grass, 20

Crab-grass, Wild, 36 
Cranebill, 2 I 8

Crassina, $37 \mathrm{I}$

Crassulaceæ, I 69

Cratagus, Igz

Creeper, Virginia, 228

Creeping Juniper, Io

Creeping Wintergreen, 260

Creosote Brush, 22 I

Crepis, 404

Cristatella, I 68

Crocus (Pulsatilla)

Croton, 222

Crowfoot, $\mathrm{I}_{42}$

Crowfoot Family, I34

Crunocallis, I 26

Cryptanthe, 289

Cryptogramma, 3

Ctenophyllum, 207

Cucurbita, 325

Cucurbitace 2,325

Cudweed, 370

Currant, 176

Cuscuta, 272

Cuscutace 2,272

Cut-grass, Rice, 22

Cut-leaved Water Parsnip, 253

Cycloloma, I I 6

Cymopterus, 252, 254, 257

Cynarex, 398

Cynomarathrum, 255

Cyperaceer, 57

Cyperus, 58

Cypripedium, 87

Cyrtorrhyncha, 146

Cystium, 204

Cystopteris, 3

Cytherea, 89

Dactylis, 40

Daisy (Erigeron, Townsendia)

Daisy, Ox-eye, 282

Dalea, 2 I 4

Dandelion, 409

Danthonia, 35

Death Camas (Toxicoscordion)

Dasiphora, I 87

Dasyochloa, 37

Dasystephana, 266

Datura, 303

Day-flower, 75

Delphinium, I37

Deschampsia, 33

Desmanthus, 194

Deweya, 252

Dew-flower, 75

Deyeuxia, 31, 32

Dichrophyllum, 224

Dicoria, 328

Dicotyledones, 9 I

Diholcos, 207
Diplachne, 38

Disporum, 84

Distegia, 324

Distichlis, 40

Ditaxis, 222

Dithyrea, I 54

Dock, I07

Dodder, 272

Dodder Family, 272

Dodecatheon, 263

Dogbane, 269

Dogbane Family, 269

Dog-tooth Violet, 83

Dog-wood, 249

Dog-wood Family, 249

Dondia, I I

Double Bladder-pod, I54

Douglas Spruce, 8

Draba, I6I

DRACANACEAE, 85

Dracocephalum, 297

Dragon's-head, 297

Dropseed, 29

Dryas, 189

Drymocallis, 187

Dryopteris, 2

Duck-weed, 74

Duck-weed Family, 74

Dugaldia, $38 \mathrm{I}$

Dulichium, 58

Dwarf Cornel, 249

Dysodia, 38I

Eatonia, 39

Echinocactus, 237

Echinocereus, 238

Echinochloa, $2 \mathrm{I}$

Echinocystis, 325

Echinospermum, 285

Edwinia, I 76

ELAagnacex, 239

Elatinaces, 23 I

Elatine, 231

Elder, 323

Elder, Marsh, 328

Eleocharis, 59

Elephantella, 318

Elephant's Head (Elephantella)

Ellisia, 282

Elm Family, ı oo

ELODIACE 2 , I 5

Elymus, 56

Elyna, 60

Enchanter's Nightshade, 248

Engelmann Spruce, 8

Ephedra, ro

Ephedrace※, Io

EPILOBIACEx, 240

Epilobium, 241

Epipactis, 88

Equisetaces, 5 
Equisetales, 5

Equisetum, 5

Eragrostis, 38

ERICACER, 259

ERICALES, 258

Erigeron, 359, 366

Eriocoma, 25

Eriogonum, 101

Erioneuron, 37

Eriophorum, 58

Eritrichium, 286-289

Erodium, 219

Erocallis, 126

Erysimum, I 59

Erythrea, 265

Erythronium, 83

Eschenbachia, 366

Eucephalus, 35 I

Euklisia, 166

Eupatoriex, 335

Eupatorium, 335

Euphorbia, 223-225

EUPHORBIACEA, 222

EUPHORBIALES, 221

Euploca, 284

Eurotia, II 8

Eustoma, 265

Euthamia, 349

Evax, 367

Evening Primrose, 244

Evening Primrose Family, 240

Everlasting, 367,370

Evolvulus, 273

FABACERE, I94

FAGACE 2,97

FaGales, 96

Fairy Pink (Orthocarpus)

Fallugia, 188

False Buckwheat, I I 3

False Buffalo-grass, 37

False Dragon's-head

False Gromwell, 293

False Indigo, $2 \mathrm{I}_{3}$

False Mallow, 230

False Mermaid, 225

False Mermaid Family, 225

False Oats, 33

False Solomon's Seal, 84

Fame-flower, I 25

Fendlera, 176

Fern Family, I

Fern-worts, I

Fescue-grass, 48

Festuca, 48

FestuCEA, 37

Fetid Camomile, 382

Fetid Marigold, $38 \mathrm{I}$

Fig-wort, 305

Figwort Family, 304
Filago, 367

FILICALES, I

Filix, 3

Fimbristylis, 60

Fire-weed, 24I

Fir, Balsam, 9

Fir, Red, 8

Fir, White, 9

Firs, 9

Fish-weed (Potamogeton)

Five-finger, I 80

Flag, Blue, 86

Flag, Sweet, 74

Flaveria, 38I

Flax, 2I9

Flax Family, 2I9

Fleabane, 359

Fleur-de-Lis, 86

Florkia, 225

Forestiera, 264

Forget-me-not, 292

Forget-me-not, Mountain, 286

Forsellesia, 226

Four-o'clock, I 23

Four-o'clock Family, I22

Fox-tail, 28

Fox-tail Grass, 21

Fox-tail Pine, 7

Fragaria, 186

Frangulacese, 227

Frankenia, 23I

FRANKENIACEX, 23 I

Franseria, 329

Frasera, 268

Fraxinus, 264

Fringed Gentian, 265

Fringed Loosestrife, 263

Fritillaria, 83

Fritillary, 83

Froelichia, I 21

Frostweed, 232

Fumaria, I 49

Fumariace $x$, r 49

Fumitory, 149

Fumitory Family, I49

Gertneria, 328

Gaillardia, 38I

GaLEGE,x, I95

Galingale, 58

Galium, 321

Galpinsia, 246

Garlic, 8I

Gaultheria, 260

Gaura, 247

Gaurella, 246

Gayophytum, 243

Genistex, I95

Gentian, 265

Gentiana, 265-267 
Gentianace.E, 264

Gentranales, 264

Gentianella, 266

Gentian Family, 264

Geoprumnon, 202

GERANIACE $E, 218$

Geraniales, 2 I 7

Geranium, 218

Geranium, 218

Geranium Family, 2 I 8

Gerardia, 3 I 4

Germander, 295

Geum, I87, 188

Giant Bird's-nest, 258

Giant-hyssop, 296

Gilia, 276, 279

Glass-wort, I I

Glaux, 264

Glecoma, 297

Globe-flower, I 35

Globe-mallow, 230

Glossopetalon, 226

Glyceria, 48

Glycosma, $25 \mathrm{I}$

Glycyrrhiza, 2 I 3

GLYCYRRHIZEX, I96

Graphaliex, 367

Gnaphalium, 370

Gnetales, Io

Goat's Beard, 404

Golden Aster, 339

Golden Rod, 346

Golden Saxifrage, I7I

Goodyeara, 89

Gooseberry, I 76

Gooseberry Family, I76

Goosefoot, II4

Goosefoot Family, I I 3

Goose-tansy, I 86

Gourd, 325

Gourd Family, 325

Grama, 36

Grama, Black, 20

Grape Family, 228

Grapes, 228

Grapes, Oregon, 148

Graphephorum, 34, 38

Gratiola, 3 I 2

Grass Family, I5

Grass-of-Parnassus, I75

Grass-of-Parnassus Family, I75

Grayia, I 18

Grease-wood, I I9

Green Milkweed, 270

Grindelia, 338

Gromwell, 292

Gromwell, False, 293

Grossulariace 2 , 176

Ground-cherry, 300

Ground Ivy, 297
Ground Plums, 202

Ground-vine, 323

Gum Plant, 338

Grounsel Tree, 366

GUNNERACEF, 248

Gutierrezia, 337

Gymnolomia, $37 \mathrm{I}$

GYMNOSPERM

Gymnosteris, 279

Gyrostachys, 89

Habenaria, 88

Hackberry, I 00

Hair-grass, 30, 33

Halerpestes, 146

Hamosa, 204

Haploestes, 387

Harbouria, 252

Harebell, 325

Hawk-weed, 406

Hawk's beard, 404

Hawthorn, I 92

Hazel-nut, 97

Hazel-nut Family, 97

Heal-all, 297, 305

Heath Family, 259

Hedeoma, 299

HEderaCe

Hedgehog-thistle, 237

Hedge Hyssop, 312

Hedge Mustard, I57

Hedge Nettle, 297

HEDYSAREA, I96

Hedysarum, 215

HELENIE $\mathbb{E}, 376$

Helenium, $38 \mathrm{I}$

Heliant HEx, $37 \mathrm{I}$

Helianthella, 374

Helianthemum, 232

Helianthus, 373

Heliopsis, $37 \mathrm{I}$

HeLIOTROPACE⿸厂 284

Heliotrope, 284

Heliotrope Family, 284

Heliotropium, 284

Hellebore, White, 76

Helleborine, 88

Hemlock Parsnip, 255

Hemp Family, 100

Hemp, Indian, 269

Hemp, Water, I 2 I

Henbane, Black, 303

Heracleum, 255

Herb-Sophia, I57

Herd-grass, 30

Hesperaster, 236

Heteranthera, 75

Heuchera, I 72

Hickory Pine, 7

Hieracium, 406 
Hierochloe, 23

Hilaria, 20

Hippurus, 249

Hoffmanseggia, 194

Hog's-bean, 303

Hogs' Potatoe, 77

Hog-weed, 328

Holly-Fern, 2

Holodiscus, I 88

Holy Grass, 23

Homalobus, 208

Homalocenchrus, 22

Honey Clover (Melilotus)

Honeysuckle Family, 323

Hop-tree, $22 \mathrm{I}$

Hops, too

Hoarhound, Water, 299

Hoarhound, White, 296

HORDEX, 52

Hordeum, 55

Horkelia, 185

Horse-mint, 298

Horseweed, 366

Horsetail, 5

Horsetail Family, 5

Hosackia, 202

Huckleberry, 260

Huckleberry Family, 260

Humulus, too

Hungarian Grass, 21

HYNDRANGEACE 8 , I 75

Hydrangea Family, I 75

HYDROCHARITALES, I 5

HYDROLEACEN, 28I

Hydrophyllum, 282

Hymenatherum, 38I

Hymenopappus, 376

Hymenoxis, 380

Hyoscyamus, 303

HYPERICACE.X, $23 I$

HYPERICALES, 231

Hypericum, 23I

Hyssop, Hedge, 31 2

Ibidium, 89

Indian Bread-root, 2I 3

Indian Hemp, 269

Indian Mallow, 23I

Indian Millet (Eriocoma)

Indian-pipe Family, 258

Indian Grass, 20

Indigo, False, $2 \mathrm{I} 3$

Ionoxalis, 220

Ionidium, 234

Ipomea 273

Iris, 86

Iris, 86

Iris Family, 86

Iron Weed, 335

Isocoma, 342
ISOETACE $E, 5$

IsOETALES, 5

Isoetes, 5

Italian Millet, 2 I

Iva, 328

Ivy, American, 228

Ivy, Poison, 225

Ivy Family, 249

IXIACE.E, 86

Jacob's Ladder, 280

Jamesia, I 76

Jimson-weed, 303

Joe-Pye Weed, 335

Johnson Grass, 20

Joint-firs, ro

Joint-fir Family, Io

Jonesiella, 206

JUNCACEE, 77

Iuncoides, 80

Juncus, 77

June-berry, I9I

June-grass, 38

JUNIPERACEE, 9

Juniper, Creeping, so

Juniper, Low, 9

Juniper, Mountain, 9

Juniper Family, 9

Junipers, 9

Juniperus, 9, 10

Jussicea

Kalmia, 260

Kalstramia, 220

Kentrophyta, 208

Kinnikinick, 259

Kitten-tails (Besseya)

Knot-weed, rog

Kobresia, 60

Kochia, I 19

Koeleria, 38

Krynitzkia, 286-289

Kuhnia, 335

Kunzia, 189

Laciniaria, 336

Lactuca, 410

Ladies' Slipper, 87

Ladies' Tresses, 89

Lady-Fern, 4

Lady's Thumb, III

Lamb's Quarters, II 4

LAMIACE $E, 294$

Lappula, 285

Larkspur, 137

Larrea, 22I

Lathyrus, 216, 217

Laurel, American or Swamp, 260

Lavauxia, 246

Lead-plant, 2 I 3 
Leather-flower, I $4 \mathbf{I}$

Leek, 8I

Lemna, 74

LEMNACER, 74

Leonurus, 297

Lepachys, 372

Lepargyrcea, 239

Lepidium, $15 \mathrm{I}$

Leptasea, I74

Leptilon, 366

Leptochloa, 37

Leptodactylon, 279

Leptotenia, 258

Lesquerella, I 54

Lettuce, 4I

Leucampyx, 377

Leucelene, 358

Leucocrinum, 83

Levisia, I 26

Liatris, 336

Ligusticum, 253, 255, 256

LiLIACEA, 82

LILIALES, 76

Lilium, 83

Lily, 83

Lily, Mariposa, 85

Lily, Sego, 85

Lily, Tiger, 83

Lily Family, 82

Lily-of-the-valley Family, 83

LIMNANTHACEN, 225

Limnia, 126

Limnorchis, 88

Limosella, 3I 2

LINACE.X, 219

Linanthus, 276

Linaria, 305

Linnea, 323

Linum, 219

Lion's-heart, 297

Lip-Fern, 3

Lippia, 294

Liquorice, Wild, 213

Listera, 89

Lithophragma, I7I

Lithospermum, 292

Little Clubmoss, 6

Little Red Elephant, 3I 8

Lloydia, 83

LOASACEA, 234

Loasa Family, 234

Lobelia, 326

LOBELIACE $A, 326$

Lobelia Family 326

Loco Weed, 203

Locust-tree, 202

Lodge Pole Pine, 8

Lolium, 57

Lomatium, 256

Long-bracted Orchis, 87
Lonicera, 324

Loosestrife, 240

Loosestrife Family, 240

Loosestrife, Fringed, 263

Loosestrife, Tufted, 265

Lophanthus, 296

LORANTHACE $E$, IOO

LOTEA, I 95

Lousewort, 3 I 8

Lovace, 253

Love-vine (Cuscuta)

Lowellia, $38 \mathrm{I}$

Low Juniper, 9

Lucerne, 202

Lungwort, 289

Lupine, I97

Lupinus, 197

Luzula, 80

Lychnis, $\mathrm{I} 33$

Lycium, 303

LYCOPODIACEX, 6

LYCOPODIALES, 6

Lycopodium, 6

Lycopus, 299

Lycurus, 28

Lygodesmia, 404

Lyme-grass, 56

LYTHRACE 240

Lythrum, 240

Lysiella, 88

Macharanthera, 356

Macrocalyx, 282

Macronema, 345, 346

Madder Family, 32I

Madia, 376

Madronella, 299

Malacese, IgI

Malacothrix, 404

Male-Fern, 2

Mallow, 229

Mallow, Faise, 230

Mallow, Indian, 23I

Mallow Family, 229

Malva, 229, 23I

Malvace 2,229

Malvales, 229

Malvastrum, 230

Mamillaria, 237

Manna-grass, 48

Maple, 226

Maple Family. 226

Mare's-tail, 249

Marigold (Tetraneuris)

Marilaunidium, 284

Mariposa Lily, 85

Mariposa Lily Family, 85

Marsh Elder, 328

Marsh-grass, 35

Marsh-marigold, I 35 
Marsh Pea, 2 I7

Marsh Spike-grass, 40

Marsh Trifoil, 268

Marsilia, 5

Marsiliacex, 5

Marsilia Family, 5

Martynia, 320

MARTYNIACEIE, 320

Marubium, 296

Matrimony Vine, 303

May-flower (Pulsatilla)

May-weed, 382

Meadow-gowan, I 35

Meadow-grass, 40,48

Meadow-grass, Reed, 48

Meadow Parsnip, 252

Meadow-Rue, I 47

Medic, 202

Medicago, 202

Melampodium, 37 I

Melanthace正, 76

Melica, 39

Melic-grass, 39

Melilotus, 202

Melosmon, 295

Mentha, 300

Mentzelia, 235-237

Menyanthaces, 268

Menyanthes, 268

Mereolix, 247

Mermaid, False, 225

Mertensia, 289

Mesquite, 20

Mesquite-grass, 36

Micrampelis, 325

Micranthes, 173

Microphacos, 207

Microseris, 403

Microsteris, 276

Milfoil (Achillea)

Milfoil, Water, 249

Milk-thistle, 4 I I

Milk Vetch, 203

Milkweed, 270

Milkweed Family, 270

Milkwort, $22 \mathrm{I}$

Milkwort, Sea, 264

Milkwort Family, 22 I

Millet, 2 I

Millet, Indian (Eriocoma)

Millet, Italian, 2 r

Mimosace $\approx, 193$

Mimosa Family, I93

Mimosa, Prairie, I94

Mimulus, 3 I I

Mint, 300

Mint Family, 294

Mirabilis, 123

Mistletoe Family, roo

Mitella, I71, I72
Mitre-wort, I7I, I72

Mock Apple, 325

Mock Orange, I 76

Mahringia, 130

Monarda, 289

Monardella, 299

Moneses, 258

Monkey-flower, 3 I I

Monk's-hood, r 39

MONOCOTYLEDONES, I I

Monolepis, II 6

Monotropace 258

Moonwort, I

Morning-glory, 273

Morning-glory Family, 273

Morongia, I94

Moschatel, 324

Moschatel Family, 324

Motherwort, 297

Mountain Ash, I93

Mountain Avens, I 88

Mountain Forget-me-not, 286

Mountain Juniper, 9

Mountain Laurel (Ceanothus)

Mountain Mahogany, I89

Mountain Rice, 25

Mountain Sorrel, rog

Mouse-ear Chick-weed, I 28

Mouse-tail, I42

Mud-purslane, 23 I

Mudwort, 3 I 2

Muhlenbergia, 25

Mullen, 305

Munroa, 37

Muscaria, 173

Musenion, 253

Musk-root, 324

Musquash Root, 252

Mustard, Hedge, I 57

Mustard, White, 160

Mustard, Wild, I6o

Mustard, Tansy, I 57

Mustard Family, I50

Myosotis, 292

Myosurus, I 42

Myriophyllum, 249

Myrtales, 240

Myzorrhiza, 320

Nabalus, 404

Natadacese, I 3

NaIAdALES, I 2

Naias, I 3

Naias Family, I 3

Nama, 284

Nasturtium, I56

Naumburgia, 263

Navarretia, 279

Nemexia, 86

Nemophila, 282 
Nepeta, 297

Nettle, 99

Nettle Family, 99

New Jersey Tea, 227

Nicotiana, 304

Nigger-head (Rudbeckia)

Night-shade, 302

Night-shade, Enchanter's, 248

Night-shade Family, 300

Nine-bark, I 79

Nodding Violet, 234

Nolina, 85

Nothocalais, 406

Notholana, 4

Nut-grass, 58

Nut Pines, 8

Nymphøa, I 47

NYMPHAACE 147

Oak, 97

Oak, Poison, 225

Oat-grass, 23, 34

Oat-grass, Wild, 35

Oats, 34

Oats, False, 33

Oats, Wild, 23

Odostemon, 148

Enothera, 244-247

Oleaces, 264

Oleates, 264

Oleaster Family, 239

Oligoneuron, 349

Olive Family, 264

Omphalodes, 286

Onagra, 244

One-flowered Wintergreen, 258

Onion, 8I

Onion Family, 8I

Onobrychis, 216

Onosmodium, 293

Oonopsis, 344

OPHioglosSACEx, I

OPHIOGLOSSALES, I

Ophrys, 89

Opulaster, 179

Opuntia, 238

Opuntiales, 234

Orache, 116

Orchard-grass, 40

ORCHIDACEA, 87

Orchidales, 87

Orchid Family, 87

Orchid, Bog, 88

Orchid, Long-bracted, 87

Oregon Grapes, I 48

Oreobatus, 180

Oreobroma, I 26

Oreocarya, 286

Oreochrysum, 345

Oreoxis, 252
Orobanchaceie, 3 I 9

Orobanche, 320

Orogenia, 254

Orophaca, 2 I I

Orpine, I 70

Orpine Family, I6g

Orpine, Red, I 70

Orthocarpus, 317

ORYZEA, 22

Oryzopsis, 25

Osmorrhiza, 251

Oxalmide $\mathbb{E}, 220$

Oxalis, 220

Ox-eye, $37 \mathrm{I}$

Ox-eye Daisy, 382

Oxybaphus, I 24

Oxypolis, 254

Oxyria, I09

Oxytenia, 328

Oxytrope, 212

Oxytropis, $2 \mathrm{I} 2$

Oyster Plant, 403

Ozomelis, 172

Pachylophus, 245

Pachystima, 226

Painter's Brush, 3 I 4

Painted Cup, 3 I 4

Pandanales, 11

Panice 20

Panic-grass, 2 I

Panicularia, 48

Panicum, 2I

Papaver, I 48

Papaverace 148

PapaVerales, 148

Papyrus, 58

Parietaria, 99

Parnassia, 175

PARNASSIACE 175

Paronychia, I 2 I

Parosela, 214

Parsley-Fern, 3

Parsnip, 255

Parsnip, Meadow, 252

Parthenice, 37 I

Parthenocissus, 228

Pasque Flower, I 40

Pastinaca, 255

Pea, Marsh, 2 I $7_{7}$

Pea, Turkey, 254

Pea Family, I 94

Pearly Everlasting, 370

Pearl-wort, I 30

Pectiantia, I 7 I

Pectis, 382

Pedicularis, 3 I 8

Pellaa, 3, 4

Pellitory, 99

Penny-grass, I 52 
Pennyroyal, 299

Pencil Tree, 366

Pentstemon, 306

Pepper-grass, I 5 I

Peramium, 89

Peraphyllum, I92

Pericone, 376

Peritoma, I 68

Persicaria, I I I

Petalostemon, 215

Petasites, 387

Peteria, 202

Petradoria, 349

Peucedanum, 256

Phaca, 205-210

Phacelia, 282

Phacopsis, 206

Phalaridere, 22

Phalaris, 22

Phegopteris, 2

Phellopterus, 254

Philadelphus, I 76

Phileozera, $38 \mathrm{I}$

Philotria, I5

Phippsia, 28

Phleum, 28

Phlox, 274

Phlox, 274

Phlox Family, 274

Phoradendron, 100

Phragmites, 37

Phyla, 294

Phyllodoce, 260

Physalis, 300

Physaria, I 54

Physocarpus, I 79

Physostegia, 297

Picea, 8

Pickerell-weed Family, 75

Picradenia, 380

Picradeniopsis, 377

Picrothamnus, 382

Pigmy-weed, I 69

Pig-weed, I I4, I 20

Pinacea, 7

Pinales, 7

Pine Drop, 258

Pine Family, 7

Pines, 7, 8

Pinguiculace 3 I 9

Pink Family, I32

Piñons, 8

Pinus, 7, 8

Piperia, 88

Pipsissewa, 258

Piptocalyx, 286

Plantaginacere, 320

Plantaginales, 320

Plantago, 320

Plantain, 320
Plantain, Rattlesnake, 89

Plantain Family, 320

Platyschkuhria, 377

Pleurogyne, 267

Pluchea, 367

Plum Family, I93

Plums, I 93

Poa, 40, 50

POACEA, I 5

Poades, I 5

Podalyriese, I95

Poison Camass, 77

Poison Ivy, 225

Poison Oak, 225

Poinsettia, 225

Polanisia, I68

Polemoniacese, 274

Polemoniales, 271

Polemonium, 280

Poliomintha, 298

Polygala, 22I

Polygalace 2 , 221

Polygalaies, 22 I

Polygonacex, IOI

Polygonales, io I

Polygonatum, 85

Polygonum, I09, III-II 3

Polypappus, 367

Polypodiace. I

Polypodium, 2

Polypody, 2

Polypogon, 30

Polypteris, 377

Polystichum, 2

Pome Blanche, 2I 3

Pond-weed, I 2

Pond-weed Family, I 2

Pontederiacese, 75

Poplar, 9 I

Poppy, I 48

Poppy, Prickly, I 48

Poppy Family, 148

Poppy Mallow, z29

Populus, 9I

Porcupine Grass, 23

Portulaca, I 26

Portulacacese, I 25

Potamogeton, I 2

Potato, 302

Potatoe, Hogs', 77

Potentilla, I80, I86, 187

Poverty Grass, 23, 29

Powder-horn, I 28

Prairie Bean (Thermopsis)

Prairie Clover, 2I 5

Prairie-grass, 38

Prairie Mimosa, I94

Prenanthella, 404

Prenanthes, 404

Prickly Pear, 238 
Prickly Poppy, I 48

Primrose, 26I

Primrose Family, 26I

Primula, $26 \mathrm{r}$

Primulacese, 26I

Primulales, 26 I

Prionopsis, 345

Prosartes, 84

Prunella, 297

Prunus, 193

Pseudocymopterus, 256

Pseudotsuga, 8

Psilostrophe, 376

Psoralea, 2I 3

Psorale

Ptelea, 221

Pteridium, 3

Preridophyta, 1

Pteris, 3

Pterospora, 258

Pteryxia, 254

Ptilocalais, 403

Ptiloria, 403

Puccinellia, 48

Puccoon, 292

Pulsatilla, 140

Pumpkin, 325

Purple Cone-flower, 37 I

Purple Ground-cherry, 302

Purple Virgin's Bower, I4I

Purshia, I89

Purslane, I 26

Purslane Family, r 25

Pussley, I 26

Pyrola, 259

Pyrolaces, 258

Pyrrocoma, 344

Pyrus, 193

Quack-grass, 52

Quaking-grass, 40

Quamoclidion, I 23

Quercus, 97

Quillwort, 5

Quillwort Family, 5

Quincula, 302

Rabbit-brush, 340

Rag-weed, 328

Rag-weed Family, 327

Ram's-horn, 320

RANALES, I 34

RANUNCULACEE, I 34

Ranunculus, 142,146

Raspberry, I 80

Raspberry, Flowering, 180

Ratibida, 372

Rattle-snake Plantain, 89

Rattlesnake-root, 404

Razoumofskya, I 00
Red Cedars, 9

Redfieldia, 38

Red Fir, 8

Red Orpine, I 70

Red-top, 30

Red Willow (Svida)

Reed, 37

Reed-grass, 3 I, 32

Reed-grass, Wood, 30

Reed Meadow-grass, 48

Resin-weed, 338

Ribes, 176

Rib-grass (Plantago)

Rice Cut-grass, 22

Rice, Mountain, 25

Riddellia, 376

RhamnaLes, 227

Rhamnus, 227

RhinanthaCEX, 304

Rhinanthus, 3 I9

Rhodiola, I70

Rhus, 225, 226

Robinia, 202

Rock-brake, 4

Rock-cress, I 64

Rock Rose (Pachylophus)

Rock-rose Family, 232

Rocky Mountain Red Cedar, Io

Rocky Mountain White Pine, 8

Rocky Mountain Yellow Pine, 7

Roripa, I 55

Rosa, I90

ROSACE.A, I 78

ROSALES, I 69

Rose, 190

Rose Family, I78

Rose-root, 170

Rose-wort, I70

Rubacer, I80

Rubber Plant, Colorado, 380

RUBIACE.E, 321

RUBIALES, $32 \mathrm{I}$

Rubus, 180

Rudbeckia, 37I

Rue Family, 22I

Rulac, 227

Rumex, 107

Running Pine, 6

Rush Family, 77

Rushes, 77

Russian Thistle, I 20

RUTACEE, 221

Rydbergia, 380

Rye, Wild, 56.

Rye-grass, 57

Sabina, 9

Sage, 298

Sage, White, I 18

Sage, Winter, I 8 
Sage-brush, 382

Sagina, I 30

Sagittaria, I4

SALICACER, 9 I

Salicales, 9 I

Salicornia, II 9

Salix, 92

Salmon-berry, I80

Salomonia, 85

Salsify, 403

Salsola, 120

Salt-grass, 40

Salt-wort, I 20

Salt-wort, Black, 263

Salvia, 298

SALViniales, 5

Sambucus, 323

Sandal-wood Family, I I I

Sand-bur, 22

Sand-foin, 216

Sand-grass, 32, 37

Sand Lily (Touterea)

Sand Puffs (Abronia)

Sand-spur, 22

Sand Spurry, I 32

Sandwort, I 30, I 3 I

Sanicula, $25 \mathrm{I}$

SANTALACEE, IOI

Santalales, 100

SAPINDALES, 225

Saponaria, 134

Sarcobatus, II 9

Savastana, 23

Savins, 9

Savin, Trailing, 10

Saxifraga, I73-I75

Saxifragacese, I70

Saxifrage, I73

Saxifrage, Golden, I $7 \mathrm{I}$

Saxifrage Family, I zo

SCHEUCHZERIACEX, I 4

Schedonardus, 36

Schizachyrium, I9

Schkuhria, 377

Schleropogon, 37

Schmaltzia, 226

Schonocrambe, I 57

Schrankia, 194

Scirpus, 58

Scorpion-weed (Phacelia)

Scrophularia, 305

Scullcap, 296

Scurvy-grass, I60

Scutellaria, 296

Sea Blite, I 9

Sea Milkwort, 264

Sea-purslane, I 24

Sedge, 60

Sedge Family, 57

Sedurn, 170
Seed-bearing Plants, 7

Sego Lily, 85

Selaginella, 6

SELAGINELLACE

Selaginella Family, 6

Self-heal, 297

Senecio, 389

Senecionidee, 387

Senna Family, 194

Sensitive-brier, 194

Service-berry (Amelanchier)

Sessuvium, I 24

Setaria, 22

Shepherdia, 239

Shepherd's Purse, I 53

Shooting Star, 263

Shrubby Cinquefoil, I 87

Sibbaldia, 187

Sida, 231

Sidalcea, 229

Sideranthus, 343

Sieversia, I 88

Silene, 132

Silkweed, 270

Silver-leaf, I 86

Silver Plant (Eriogonum)

Sinapis, I60

Sisymbrium, I 57

Sisyrinchium, 86-159

Sitanion, 55

Sium, 254

Skeleton-weed (Lygodesmia)

Skunk-cabbage, 76

Skunk-grass, 38

Skunk-weed (Polemonium)

Slough-grass, 35

Smart-weed, I I I

Simelowskia, I 53

Smilacacese, 86

Smilacina, 84

Smilax, 86

Smilax, 86

Smilax Family, 86

Snake-root, $25 \mathrm{I}$

Snapdragon (Mimulus)

Sneeze-weed, $38 \mathrm{I}$

Snow-ball, 323

Snow-berry, 323

Snow-on-the-mountain, 224

Soap-weed ( $Y u c c a)$

SolANACE $x, 300$

Solanum, 302

Solidago, 346

Solomon's Seal (Salomonia), 85

Solomon's Seal, False, 84

Sonchus, 4II

Sophia, I 57

Sophora, 196

SOPHORE, I9, I9

Sorbus, 193 
Sorghastrum, 20

Sorghum, 20

Sorrel, I07

Sorrel, Mountain, I09

Sourgrass, 220

Sow-thistle, 4 I I

Spanish Bayonet, 85

Spanish Lettuce, 126

Spanish Needles, 375

Sparganiacez, i I

Sparganium, I I

Spartina, 35

Spatularia, I 74

Specularia, 326

Speedwell, 3 I 2

SPERMatophyta, 7

Spheralcea, 230

Spharostigma, 247

Spiderwort, 75

Spiderwort Family, 75

Spike-grass, Marsh, 40

Spikenard, Wild, 84

Spike-rush, 59

Spiraa, 189

Spiranthes, 89

Spleenwort, 4

Spondiace 2,25

Sporobolus, 27, 28, 29

Spring Beauty, I 25

Spring Beauty, Water, I 26

Spring Lily (Leucocrinum)

Spruces, 8

Spurge, 222, 224

Spurge Family, $22 z$

Squaw root (Carum)

Squirrel-grass, 55

Stachys, 297

Staff-tree Family, 226

Stanleya, I67

Star of Bethlehem (Leucocrinum)

Starwort, I 27

Starwort, Water, 225

Steironema, $26_{3}$

Stenophragma, I 59

Stenosiphon, 247

Stenotus, 345

Stephanomeria, 403

Stick-seed, 285

Stink-grass, 38

Stipa, 23

Stitchwort, I 27

St. John's Wort, 23 I

St. John's Wort Family, 23I

Stone-crop, I 70

Strawberry, 186

Strawberry Blite, I I 6

Strawberry Tomato, 300

Streptanthus, I 66

Streptopus, 84

Suada, I 20
Suckleya, I 8

Sugar Corn, 20

Sullivantia, 173

Sumac, 226

Sumac Family, 225

Sun-flower, 373

Svida, 249

Swamp Laurel, 260

Swamp Potato (Sagittaria)

Sweet Cicely, 25 I

Sweet Clover, 202

Sweet Coltsfoot, 387

Sweet Flag, 74

Swertia, 267

Switch-grass, $2 \mathrm{I}$

Symphoricarpos, 323

Syntherisma, zo

Synthyris, 31 3

Syringa, I 76

Talinum, 125

Tansy-mustard, I 57

Tape-grass Family, I 5

Taraxacum, 409

Taraxia, 247

Tar-weed, 376

Telesonit, I73

Tellima, I $7 \mathbf{I}$

Tetradymia, 398

TETRAGONIACE $x, 124$

Tetraneuris, 378

Teucrium, 295

Thalesia, 320

Thalictrum, 147

Thamnosma, 22 I

Thaspium, 257

Thelypodium, I 66

Thelesperma, 375

Thermopsis, 197

Thistle, 398

Thistle, Russian, 20

Thistle Family, 329

Thlaspi, 52

Thorough-wort, 335

Thorn-apple, 303

ThyMeliales, 239

Tickle-grass, 30

Tick-seed, 374

Tiger Lily, 83

Tillae, 169

Tillaastrum, 169

Timothy, 28

Tiniaria, I I 3

Tiorin, 30

Tissa, I32

Tithymalus, 224

Tium, 204

Toad-flax, 305

Toad-flax, Bastard, I o I

Tobacco, 304 
Tonestus, 345

Touterea, 234

Torensendia, 349

Toxicoscordion, 77

Trachyphytum, 236

Tradescantia, 75

Tragia, 222

Tragopogon, 403

Trailing Savin, Io

Tribulus, 220

Trichachne, $2 \mathrm{I}$

Tridens, 38

Trifoil, Birdsfoot, 202

Trifoil, Marsh, 268

Trifoliex, I95

Trifolium, 200

Triglochin, 14

TrILliacese, 86

Trillium, 86

Trillium Family, 86

Triodia, 37,38

Triplasis, 37

Trisetum, 33, 34

Trollius, 135

Troximon, 406, 408, 409

Tufted Loosestrife, 263

Turkey Pea, 254

Turnips, $x 60$

Turritis, 157

Twayblade, 89

Twin-flower, 323

Twisted-stalk, 84

Typha, II

TYPHACEA, I I

ULMACEX, I 00

UMBELLALES, 249

Umbrella-wort, I 23

Unamia, 35I

Unicorn-plant, 320

Unicorn-plant Family, 320

Urtica, 99

URTICACEN, 99

URTICALES, 99

Utricularia, 319

Vaccaria, 134

VACCINIACE $E, 260$

Vaccinium, 260

Vagnera, 84

Valerian, 326

Valeriana, 326

VALERIANACE $E, 326$

VALERIANALLES, 326

Valerian Family, 326

Vanilla Grass, 23

Vase-vine, I4I

Velvet-leaf, $23 \mathrm{I}$

Venus' Looking-glass, 326

Venus' Slipper (Cytherea)
Veratrum, 76

Verbascum, 305

Verbena, 294

VERBENACE 294

Verbesina, 374

VERNONIE.E, 335

Vernonia, 335

Veronica, 3 I 2

Vervain, 294

Vervain Family, 294

Vesicaria, 155

Vetch, 216

Vetchling, 217

Viburnum, 323

Vicia, 216

VICICE, I96

Vilfa, 27

Viola, 232

VIOLACEX, 232

Violet, 232

Violet, Dog-tooth, 83

Violet, Nodding, 234

Violet Family, 232

Violet Wood-sorrel, 220

Viorna, I $4 \mathrm{I}$

Virginia Creeper, 228

Virgin's Bower, I4I

Virgin's Bower, Purple, I 4I

VITACE 2,228

Vitis, 228

Wake-robin, 86

Water Ash, 22I

Water-cress, $\mathrm{r} 55$

Water-crowfoot, White, 142

Water Hemlock, 252

Water Hemp, I 2 I

Water Hoarhound, 299

Water-leaf, 282

Water-leaf Family, 28 r

Water Lily, Yellow, 147

Water-lily Family, I 47

Water Milfoil, 249

Water Milfoil Family, 248

Water Parsnip, 254

Water Parsnip, Cut-leaved, 253

Water-plantain, I4

Water-plantain Family, 14

Water Spring Beauty, I 26

Water Starwort, 225

Water Starwort Family, 225

Water-weed, 15

Water-wort, $23 I$

Water-wort Family, 23I

Water Whorl-grass, 39

Washingtonia, $25 \mathrm{I}$

Wedelia, 124

Wheat-grass, 52

White Evening Primrose, 244

White Fir, 9 
White Hellebore, 76

White Hoarhound, 296

White Mustard, I60

White Sage, I 8

White Spruce, 8

White Water-crowfoot, I 42

Whitlow-grass, I6I

Whitlow-wort, I2I

Whitlow-wort Family, I 2 I

Whorl-grass, Water, 39

Wild Bergamot, 298

Wild Crab-grass, 36

Wild Liquorice, 2 I 3

Wild Morning-glory, 273

Wild Mustard, 160

Wild Oat-grass, 35

Wild Oats, 23

Wild Rye, 56

Wild Sarsaparilla, 249

Wild Spikenard, 84

Willow, 92

Willow Family, 9I

Willow-herb, 24I

Wind-flower, I40

Winter-cress, I60

Wintergreen, 259

Wintergreen, Creeping, 259

Wintergreen, one-flowered, 258

Wintergreen Family, 258

Winter Sage, I 8

Wire Grass, 23, 29

Witch-grass, 21

Wood-Fern, 2

Wood Reed-grass, 30
Wood-rush, 80

Woodsia, 2

Wood-sorrel, Violet, 220

Wood-sorrel, Yellow, 22o

Wood-sorrel Family, 220

Wormwood, 382

Wulfenia, 3І3

Wyethia, 372

Xanthium, 329

Xanthoxalis, 220

Ximenesia, 374

$X y l o p h a c o s, 206$

Xylorrhiza, 351

XYRIDALES, 75

Yard-grass (Polygonum)

Yarrow, 382

Yellow-rattle, 319

Yellow Water-lily, I47

Yellow Wood-sorrel, 220

Yucca, 85

Yucca, 85

Yucca Family, 85

Zanichellia, $\mathrm{I}$

ZaNiCHELLIACEE, I 2

Zinnia, $37 \mathbf{1}$

Zizia, 252

ZOYSIEA, 20

Zygadenus, 76, 77

ZYGOPH YLLACEX, 220

Zygophyllidium, 224 


\section{ERRATA.}

Page 2, line I5, Northolaena read Notholaena.

Page 55, Ageliops, read Aegilops.

Page 120, lines 5, 7, 10, I3, "Swaeda," read "Suaeda."

Page I3I, line I8 "Callian," read "Calhan."

Page I50, lines I9 and 20 go out, and the numbers for Roripa, Turritis, Schoenocrambe and Sisymbrium become 9, IO, II, and 12 respectively.

Page I55-I67, the numbers of Roripa and the following genera of BRASSICACEAE should be changed to agree with the numbers in the key.

Page I7I, Pectianthia, read Pectiantia.

Page 189, line 2I, "Mountain Holly," read "Mountain Mahogany."

Page I90, The numbers in the key to Rosa should be changed to agree with those in the list following.

Page I92, The first five localities under Amelanchier alnifolia belong to $A$. oreophila instead.

Page 20I, Trifolium pratensis read Trifolium pratense.

Page 202, line 30 "Bird's-foot Treefoil" read Bird's-foot Trefoil.

Page 208, Numbers in the key of Kentrophyta should be changed to correspond with those of the following list.

Page 216, The number of Vicia should be 35 instead of 33 and on

Page 217, that of Lathyrus 36 instead of 34 . 





